Szegedi Tudományegyetem Bölcsészettudományi Kar

Történelemtudományi Doktori Iskola

Antikvitás Program

Széll Gábor

\title{
Küzdelem barbárok és eretnekek ellen Hydatius Chronicájában
}

\author{
Doktori $(\mathrm{PhD})$ értekezés
}

Témavezető: Dr. Székely Melinda tanszékvezető egyetemi docens

Szeged

2019 


\section{TARTALOMJEGYZÉK}

BEVEZETÉS 1

1. AZ 5. SZÁZADI VILÁGKRÓNIKÁK KIALAKULÁSA .....................................9

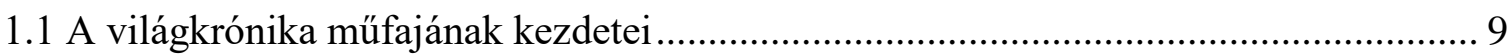

1.1.1 Formai és kronológiai követelmények ............................................................. 9

1.1.2 Az apologetikus történetírás kezdete ......................................................... 11

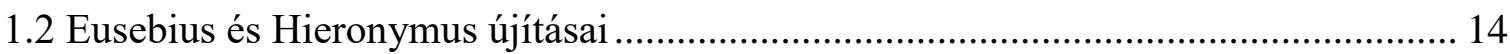

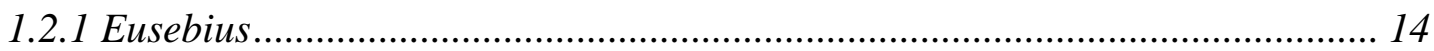

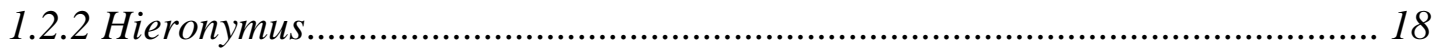

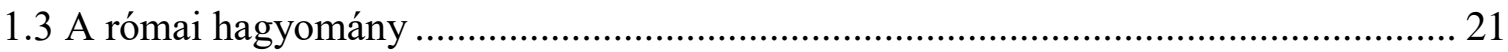

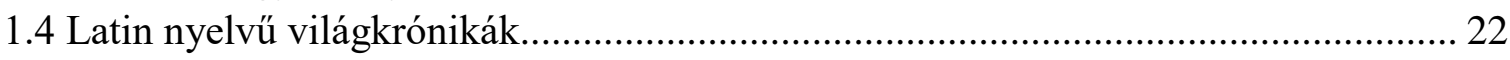

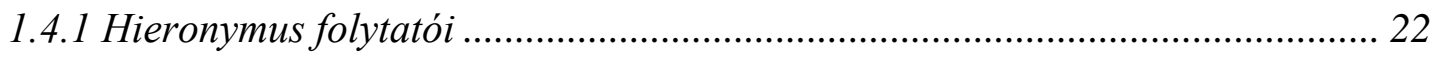

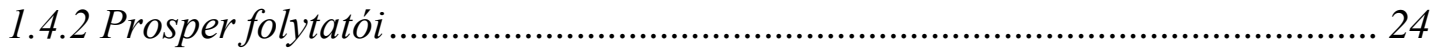

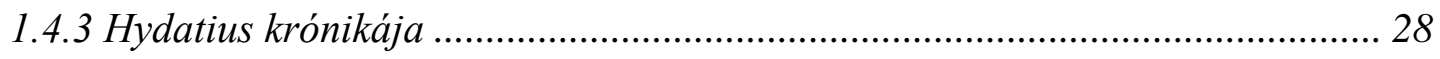

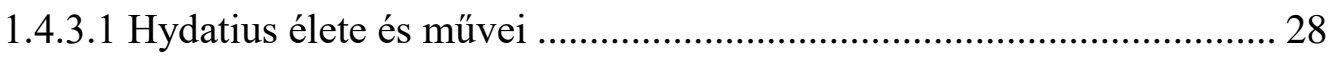

1.4.3.2 A Chronica forrásai ........................................................................... 31

1.4.3.3 Kronológia és kézirati hagyomány ............................................... 35

2. A SZVÉVEK KÜLPOLITIKÁJA ........................................................................... 39

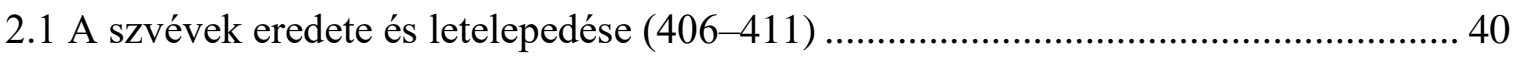

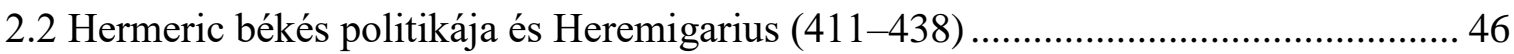

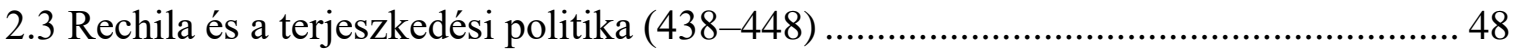

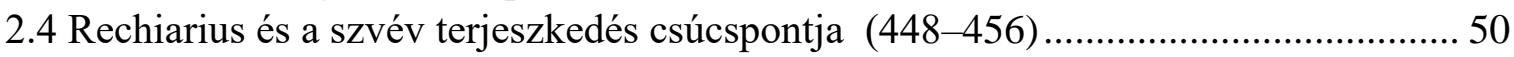

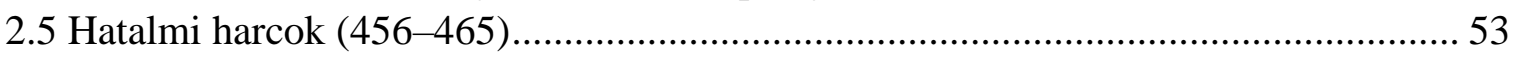

2.6 Remismund kapcsolata a gótokkal és a rómaiakkal (465-469) ..................................56

3. SZÉTFESZÍTŐ ERŐK AZ 5. SZÁZADBAN ............................................................ 58

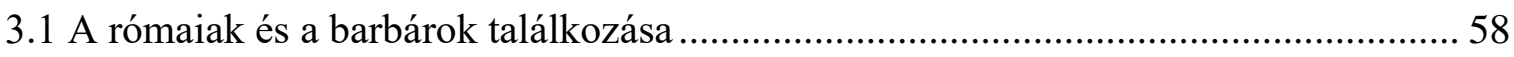

3.1.1 Barbár inváziók és katonai szempontok .................................................... 58

3.1.2 Együttmüködés és kulturális interakciók ......................................................6. 63

3.1.3 Vallási különbségek és az egyház szerepe ................................................... 69

3.2 A szétfeszítő erők szerepe Hydatius krónikájában .................................................... 77

3.2.1 Barbár fosztogatások és szövetségkötések .................................................... 82

3.2.1.1 A szvévek és a szvév-gallaeciai kapcsolatok ................................... 84

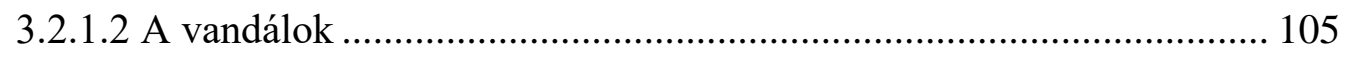

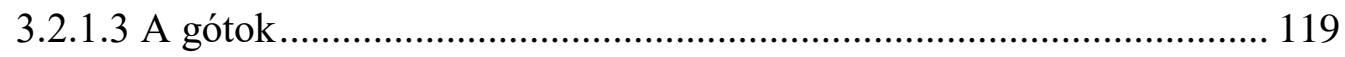




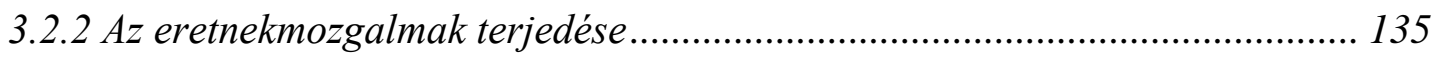

3.2.2.1 Az eretnekség és igazhitüség kérdése ............................................ 135

3.2.2.2 Az arianizmus és Róma egyházi primátusának kezdete ................... 138

3.2.2.3 Arianizmus a vandáloknál és a szvéveknél .................................... 149

3.2.2.4 A nesztorianizmus és a monofizitizmus........................................ 155

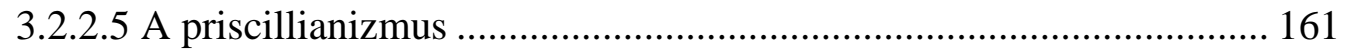

3.2.2.6 A manicheizmus ........................................................................... 166

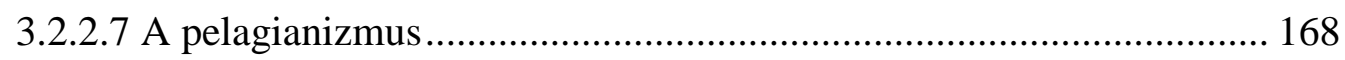

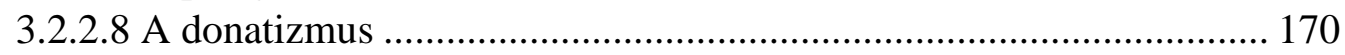

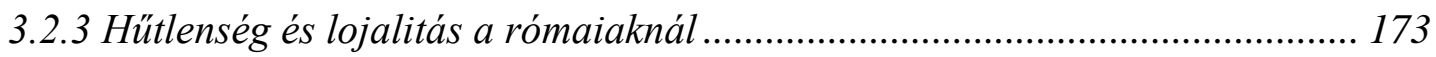

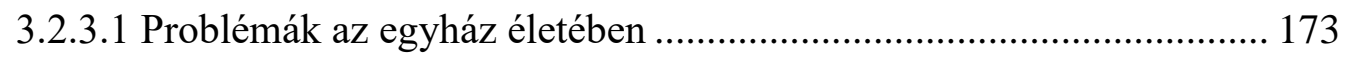

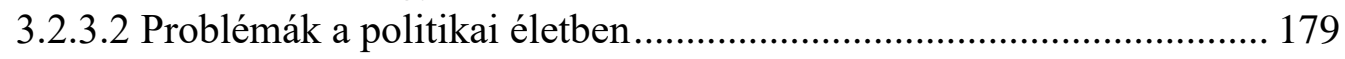

3.2.3.3 Hydatius példaképei ......................................................................... 188

\section{HYDATIUS TÖRTÉNELEMSZEMLÉLETE ÉS SZERZÖI MOTIVÁCIÓI ....... 202}

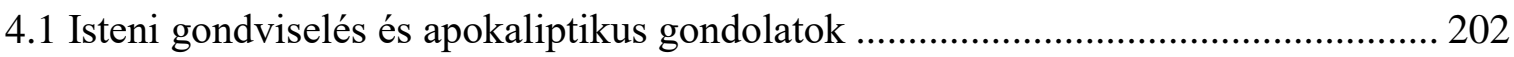

4.1.1 Büntetések, elöjelek, csodák .................................................................... 202

4.1.2 Jövökép és apokaliptikus hiedelmek ........................................................... 213

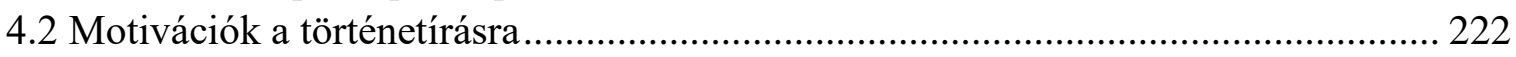

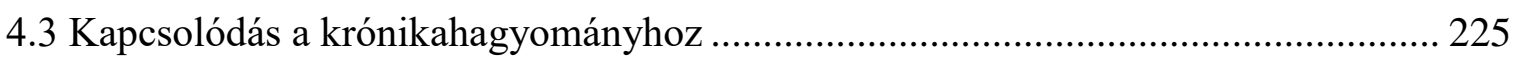

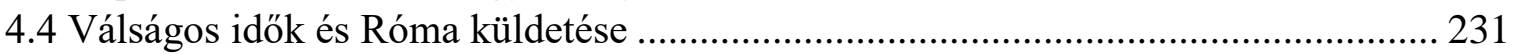

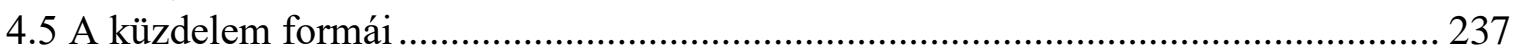

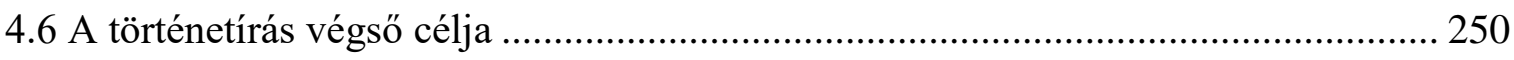

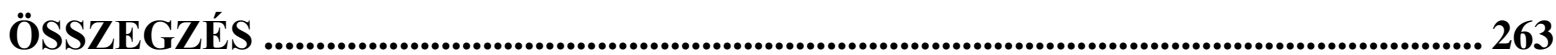

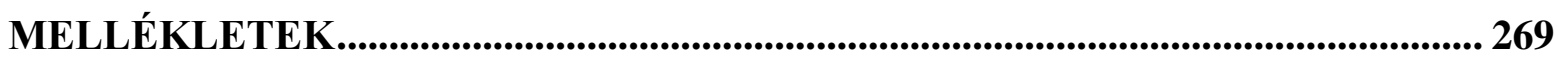

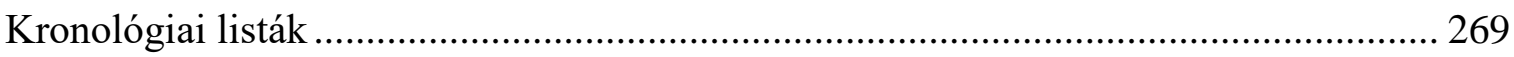

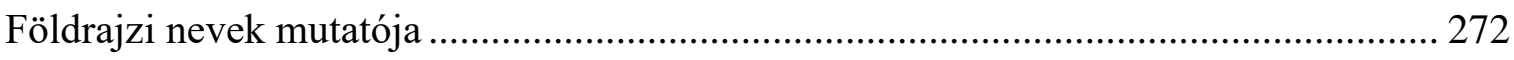

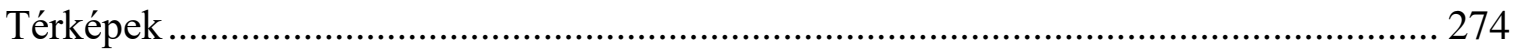

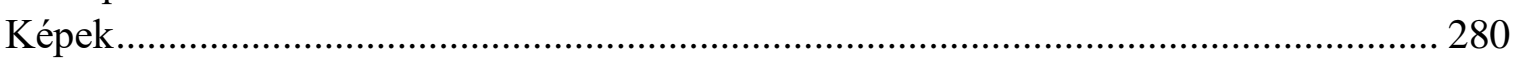

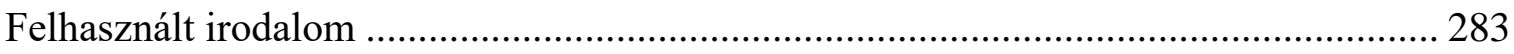

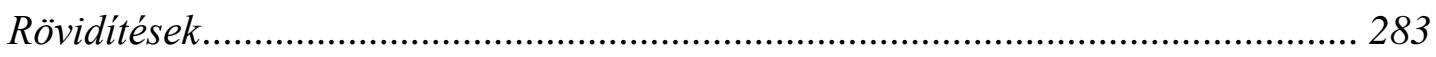

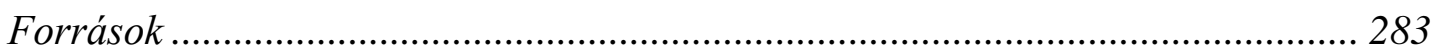

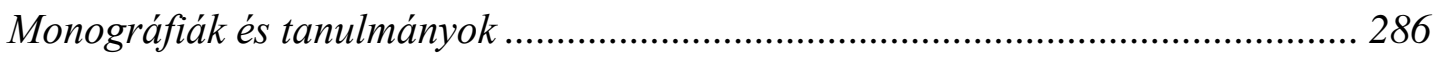




\section{BEVEZETÉS}

Hydatius Chronicája az 5. századi történelem egyik legértékesebb forrása, ugyanis egyedülállóan részletes beszámolót nyújt a korabeli Hispania történetéröl és a császári hatalom felbomlásáról. Hydatius munkája az egyik legkorábbról fennmaradt alkotás a latin nyelvü krónikák közül, ${ }^{1}$ ezt tartjuk a legfontosabb összefoglalásnak Hispania felbomlásáról az Orosius és a Iohannes Biclarensis közötti időszakból; ${ }^{2}$ Ammianus Marcellinus és Gregorius Turonensis között pedig nincs más olyan nyugati szerző, aki az 5. század politikai és katonai változásait is bemutatná történeti munkájában. ${ }^{3}$ Thompson „a stroke of extraordinary good luck"-nak minősíti, hogy a korabeli Gallaecia történetéről ilyen részletes forrás áll rendelkezésünkre, ${ }^{4}$ amely egyúttal azt is igazolja, hogy Hydatius „,un historiador preciso y minucioso." 5

Hydatius krónikája az egyetlen általunk ismert irodalmi kísérlet az 5. századi Hispaniából, 6 amely ,sole literary luminary”-ként emelkedik ki a korabeli provincia szellemi közegéből. ${ }^{7}$ Hydatius érdeklődése elsőként fordult kifejezetten az Ibériai-félsziget felé, ezért is tartják őt „az ibér történetírás atyjának." "Burgess szerint ő az első olyan európai krónikaszerző, aki a „post-Roman history” és a „Latin regional history” müfajában alkotott. ${ }^{9}$ Ahogyan Cassiodorust és Iordanest a gótok, Gregorius Turonensist a frankok, Paulus Diaconust a lombardok történetírójának tartjuk, úgy Hydatius a szvévek történetének bemutatása miatt emelkedett a legfontosabb krónikások közé. ${ }^{10}$

Hydatius feljegyzéseit ugyanakkor Muhlberger azért is tartja érdekesnek, mert elárulják, hogyan gondolkodott a kor egyik vezető tisztségviselöje a körülötte zajló eseményekről azon a területen, ahol a római hatalom rendkívül nagy törést szenvedett. ${ }^{11}$ Gelarda úgy látja, hogy Hydatius modern értelemben is „uno dei più attenti uomini politici”, aki más történetírókhoz képest rendkívül nagy figyelmet szentelt a diplomáciai

\footnotetext{
${ }^{1}$ Hydatiust csak Hieronymus, Prosper és a 452-es gall krónika szerzője előzte meg, vö. Burgess 1988a, 2.

2 Muhlberger 1990, 194.

${ }^{3}$ Burgess 1993, 10.

${ }^{4}$ Thompson 1982, 17.

${ }^{5}$ Candelas-Colodrón 2004, 357.

${ }^{6}$ Adamik 2014, 369.

${ }^{7}$ Collins 2004, 160.

${ }^{8}$ Székely 2008, 19.

${ }^{9}$ Burgess 1988a, 29.

10 Torres Rodríguez 1956, 795; Burgess 1988a, 239-240.

${ }^{11}$ Muhlberger 1990, 200.
} 
eseményeknek, ${ }^{12}$ hiszen a gallaeciai hatóságok külső és belső kapcsolatairól nem áll rendelkezésünkre más korabeli forrás, amelyből következtetni lehetne a barbárok és a rómaiak közötti kapcsolatok alakulására. ${ }^{13}$ Jó néhány keleti és nyugati területet érintő mozzanatról csak Hydatius krónikájából értesülünk, és mivel az 5. századi barbár megszállások alatt készítette feljegyzéseit, hitelesen tudja tájékoztatni az olvasókat a germán törzsek letelepedéséröl és tevékenységéről, ${ }^{14}$ ráadásul a korszak egyházi dokumentumaiból is nagyon kevés maradt ránk, és amit tudunk Gallaecia egyházi szervezetéről, azt Hydatius krónikájából tudjuk.

Burgess szerint az ókori és a modern ember egyaránt azt gondolja, hogy ha valaki egy távoli vidék kevésbé jelentős városának püspökeként kezd történetírásba, akkor az ő krónikája nem lehet annyira értékes és megbízható, mint híresebb kortársaié. ${ }^{15}$ Tovább erősítheti ezt a sztereotípiát az is, hogy Hydatius feltehetően nem végzett magas szintü tanulmányokat, a szvév megszállás miatt elszigetelt Gallaeciában pedig egyre kevésbé tudta tartani kapcsolatát a külvilággal, ezáltal alig juthatott hozzá megfelelő forrásanyaghoz. Hydatius egész életében a barbárok és az eretnekek ellen harcolt, Muhlberger szerint egyfajta „champion of the Roman community”-ként szállt szembe a hispán-római lakosság és az ortodoxia ellenségeivel. ${ }^{16}$ Politikai és vallási területen megmutatkozó személyes erőfeszítései és az a tény, hogy a zürzavaros 5. században mégis vállalkozni mert a krónikaírás feladatára, azt a nézetet erősíti, hogy sokat emlegetett borúlátásával szemben birtokában volt egyfajta optimizmusnak, jóllehet reálisan felmérve saját helyzetét azt is tudhatta, hogy a barbárok érkezésével nemcsak Gallaecia, hanem az egész birodalom helyzete végérvényesen megváltozik. ${ }^{17}$ Véleményünk szerint a császári hatalom iránti rendületlen bizalma, az ortodoxia melletti példamutató kiállása még akkor is kitartásra ösztönözte Hydatiust, amikor már egyértelmủen látszott, hogy Gallaecia többé nem számíthat a birodalom központi segítségére és a barbár megszállókkal való együttélés elkerülhetetlen a hispán-római lakosság számára, ráadásul az eretnek tanítások mérhetetlen népszerüséget szereztek nemcsak a hívek, hanem a püspökök körében is. Hydatius mindezek ellenére kitartott saját értékrendje mellett, a krónika megírásával pedig olvasóit is hasonló magatartásra próbálta ösztönözni. A korábbi kutatások hosszasan érvelnek amellett, hogy Hydatius saját korának nehézségeit észlelve apokaliptikus hiedelmeket táplált és a

\footnotetext{
${ }^{12}$ Gelarda 2008-2009, 305.

${ }^{13}$ Gillett 2003, 37; Humphries 2009, 105.

${ }^{14}$ Burgess 1988a, 2.

15 Burgess 1988a, 250.

${ }^{16}$ Muhlberger 1990, 199.

${ }^{17}$ Gelarda 2008-2009, 306.
} 
közelgő világvégére készült, ambiciózus személyisége és sajátos történelemszemlélete viszont azt mutatja számunkra, hogy erőfeszítéseinek kudarcai mégis arra inspirálták őt, hogy a krónika megírásával népszerüségre és elismertségre törekedjen a gallaeciaiak körében, miközben a körülötte lévő római világ mind katonai, mind vallási szempontból látszólag kilátástalan helyzetbe került.

A 4-5. században a Római Birodalom határainál élő barbár népek egyre gyakrabban indítottak támadást a birodalom ellen, amelynek következtében a római határvédelem fokozatosan felmorzsolódott, a barbárok a birodalomba betörve fosztogatni kezdték a római területeket, majd sikeres hódításaik után önálló államokat hoztak létre és bizonyos fokú együttmüködésre vagy ellenállásra kényszerítették a római lakosságot. A császári hatalom gyengesége és a katolikus hit politikai védelmének változó intenzitása azt eredményezte, hogy a rómaiak körében is nagy népszerüséget szereztek az eretnek tanítások, különösen az arianus és a priscillianus eszmék sodorták veszélybe a pápai hatalom tekintélyét és a püspökök egyházi fegyelmének megtartását. A római politikai és egyházi életben megjelenő hütlenség motívuma tovább fokozta a válságot a császári hatalom és a katolikus egyház müködésében. Hydatius krónikája pontosan ezt az átmeneti időszakot mutatja be az olvasóknak, akik előtt a barbárokra és az eretnekekre vonatkozó feljegyzések alapján kirajzolódhat egy olyan egyházi vezető portréja, aki egész életében a római világ megmentéséért küzdött egy periférikus területen. Hydatius munkája annak tanulmányozására is alkalmas, hogy a barbár betörések és letelepedések hogyan változtatták meg a gallaeciabeliek gondolkodását, és mindez milyen reakciókat váltott ki Hydatius kudarcokkal teli életében és történelemszemléletében.

Mivel Hydatius elsősorban a rómaiak szemszögéből mutatta be a szvévek tevékenységét, és nincs birtokunkban olyan forrás, amelyet maguk a szvévek írtak volna saját történetükről, különösen nagy jelentősége van azoknak a régészeti és numizmatikai kutatásoknak, amelyek segítségével objektíven tudjuk értékelni a szvévek gallaeciai jelenlétét, ahogyan az utóbbi években meg is fogalmazódott az a törekvés, hogy a korábban elhanyagolt gallaeciai régészeti adatokat a ,historical narrative” részeként kell tárgyalni. ${ }^{18}$ 2018 első felében In Tempore Sueborum. El Tiempo de los Suevos en la Gallaecia (411$585)$ címmel Ourensében rendezték meg azt az egyedülálló kiállítást, amely értékes európai mütárgyak és a legújabb feltárások eredményeinek bemutatásával próbált meg szakítani a hagyományos szvév-ábrázolással, és a nagy népvándorlás és a Római Birodalom hanyatlása közötti összefüggés helyett a barbárok és a római arisztokrácia közötti kapcsolatok

18 Sánchez Pardo 2013, 140-143. 
ábrázolására fókuszált. ${ }^{19}$ Vizsgálatunk éppen ezért röviden érinti a régészeti és a numizmatikai kutatások, a temetök, a villák, a települések és az egyházi építmények feltárásának eredményeit is, hogy minél pontosabb képet alkothassunk a szvévek hatalmi rendszerének kiépüléséről és vallási helyzetéről, valamint a kora középkori Gallaecia társadalmának dinamikájáról is.

A dolgozat első fejezetében áttekintjük azokat a müfaji előzményeket, formai és kronológiai követelményeket, amelyek nagy hatást gyakorolhattak a zsidó és görög gyökerekkel rendelkező keresztény világkrónikák kialakulására. Mivel az apologetikus történetírás már egységes kronológiai keretet használva próbálta összefoglalni a világ történetét, a késő császárkor világkrónikái többnyire keresztény szerzők nevéhez füződnek. Eusebius sajátos kronológiai táblázatok segítségével kapcsolta össze az egyháztörténetet a bibliai hagyománnyal, ezáltal egyetlen munkában összegezni tudta az emberiség teljes történetét, Hieronymus pedig elődje müvét lefordítva és kiegészítve elérhetővé tette ezt a beszámolót a csak latinul értő olvasók számára is, egy könnyen utánozható mintát teremtve ezzel az 5-6. századi krónikaszerzőknek. Eusebius és Hieronymus újításainak bemutatása és a római annalisztikus hagyomány hatásának elemzése után a korszak fontosabb latin nyelvű világkrónikáit tekintjük át röviden, különös figyelemmel arra, hogy a Hieronymust folytató Prosper és Marcellinus Comes, illetve Prosper folytatói közül Tunnunai Victor és Iohannes Biclarensis milyen kronológiai keretben rögzítette az eseményeket, a középkorra nagy hatást gyakorló Cassiodorus és Isidorus pedig hogyan járult hozzá a műfaj későbbi fejlődéséhez. Ezt követően Hydatius életének bemutatásával áttekintjük a származásával, a zarándoklatával és a püspökké választásával kapcsolatos vitákat, majd a krónikához használt forrástípusok elemzésekor a korábbi kutatásoknál nagyobb figyelmet szentelünk az egyházi vezetők közötti levelezésnek, a szóbeli beszámolóknak és a hivatalos jelentéseknek, végül megvizsgáljuk a kronológia és a kézirati hagyomány sajátosságait is.

A második fejezetben a szvév külpolitika változásaihoz kapcsolódó kutatási problémákkal foglalkozunk részletesebben. A téma bemutatását az indokolja, hogy Hydatius az egyetlen olyan szerző, aki személyes tapasztalatai alapján, nemcsak az események szemtanújaként, hanem gyakran aktív részeseként számolt be arról, hogy a szvévek hogyan telepedtek le 409-es betörésük után Gallaeciában, és milyen eszközökkel próbálták uralmukat egész Hispania területére kiterjeszteni. A szvév külpolitikai tendenciákra

\footnotetext{
${ }^{19}$ A 2017. december 15. és 2018. május 6. között megrendezett kiállítás honlapja és katalógusa számos értékes információval szolgál számunkra, vö. López Quiroga - Martínez Tejera 2017; www.intemporesueborum.es/ (2018.12.30.)
} 
támaszkodva igyekszünk tisztázni, hogy milyen körülmények között és mely barbár csoportok vettek részt a 406-os galliai és 409-es hispaniai invázióban, majd megvizsgáljuk, hogy Hermeric békés és Róma-barát uralkodását követően milyen katonai vagy diplomáciai események hatására alakult ki Rechila és Rechiarius expanzív külpolitikája. A 456-os nyugati gótoktól ${ }^{20}$ elszenvedett vereség új korszakot nyitott a szvévek történetében, mivel a különböző politikai pártok és uralkodójelöltek tevékenységének köszönhetően polgárháborús helyzet alakult ki Gallaeciában. A szvév vezetők saját pozíciójuk megerősítése érdekében hol a gótokkal, hol a rómaiakkal kerültek háborús konfliktusba, miközben a hatalomra kerülő Remismund egyre erősebb fosztogatásokkal nyugtalanította a hispán-római lakosságot és megszakította a szvévek diplomáciai kapcsolatait.

A harmadik fejezetben azokkal a szétfeszítő erökkel foglalkozunk, amelyek megbontották az 5. század politikai és vallási rendjét, ezáltal válságba sodorták a Hydatius által idealizált római világot. Először általánosságban vizsgáljuk, hogy a rómaiak és a barbárok találkozását milyen sajátos stratégiai és gazdasági körülmények befolyásolták, különös tekintettel arra, hogy Róma barbár-politikája és a hadsereg összetétele hogyan változott a germán betelepítések következtében. A barbárok szerepének növekedése a római társadalomban ugyan nagyfokú nyugtalanságot eredményezett, de a germánok római kultúra iránti csodálata és a társadalmi kiváltságokért tanúsított katonai hüsége mindkét oldalt bizonyos fokú együttműködésre és kulturális interakciókra ösztönözte. Ehhez kapcsolódóan vizsgáljuk az akkulturáció folyamatát a latin nyelv használatában, a római intézmények átvételében és a barbár királyok uralkodói attitüdjeiben is, de kitérünk a romanizáció és a multikulturalizmus fogalmának 5. századi létjogosultságára is. A római-barbár interakciók különös aspektusát jelentik a vallási különbségek megszüntetésére és az eretnekek megtérítésére irányuló egyházi törekvések, ezért kell elemeznünk a barbárok krisztianizálódásának feltételeit és a germánok által nemzeti vallássá emelt arianizmus népszerüségének okait is.

A harmadik fejezet legterjedelmesebb részében azokat a szétfeszítő erőket vizsgáljuk, amelyek Hydatius szerint hozzájárultak az 5. századi Gallaecia és a Római Birodalom válságos helyzetének kialakulásához. Mivel ma is vita tárgyát képezi, hogy melyik történelmi időszakot vagy folyamatot tekintjük a római császárkor végének, szükségesnek látszott összefoglalnunk az ezzel kapcsolatos véleményeket, ezt követően pedig rámutatunk arra, hogy a germán betörések és a központi irányítás gyengesége a birodalomban tapasztalható válságjelenségekkel milyen logikai kombinációkat alkotva

${ }^{20}$ A dolgozatban a nyugati gótokra egyszerüen gótként hivatkozunk a továbbiakban. 
vezethetett a nyugatrómai területek bukásához. A szétfeszítő erők első csoportját a barbár népek fosztogatással és szövetségeik megszegésével társuló sztereotipikus viselkedése alkotja, amelyet a szvévek, a vandálok és a gótok vonatkozásában vizsgálunk Hydatius feljegyzései alapján. Különösen nagy figyelmet fordítunk arra, hogy a barbárok 411-ben sorsolás útján vagy a rómaiakkal kötött szerződés alapján telepedhettek le Hispaniában, de kitérünk a szvév-gallaeciai kapcsolatok körülményektől függő változására, a vandálok africai expanziójára és Gaiseric 455-ös római betörésére is, a gótokra vonatkozóan pedig foglalkozunk a 382-ben megkötött foedus jelentőségével, a gót-római diplomáciai kapcsolatok alakulásával, valamint a catalaunumi csata és a 456-os összecsapás szövetségi viszonyokban betöltött szerepével.

A szétfeszítő erők másik csoportját azok az eretnekmozgalmak alkotják, amelyek a barbár népek közötti népszerüségük és a központi hatalom gyengesége miatt széles körben elterjedtek a római lakosság és a püspökök körében egyaránt. Az eretnekség és az igazhitűség fogalmának tisztázása után megvizsgáljuk, hogy az arianizmus terjedése mennyiben kapcsolható össze Róma egyházi primátusának kialakulásával és a birodalmi egyházat támogató császári politikával, ezen kívül foglalkozunk a patriarchatusok rivalizálásával és az egyházi hatalom függetlenedésének problémájával is. Külön vizsgálat tárgyát kell képeznie annak, hogy az arianizmus hogyan terjedt el a vandálok és a szvévek körében, és hogy milyen szerepet játszott Gaiseric, illetve Rechiarius valláspolitikája a barbárok fölötti hatalom stabilizálásában. Mivel Hydatius más eretnek tanítások veszélyességére is felhívta az olvasók figyelmét, szükségesnek látszott annak áttekintése, hogy milyen módon próbált az egyházi és a világi hatalom fellépni a dogmatikai vitákat generáló nesztorianizmus és monofizitizmus, a Gallaeciában rendkívül népszerü és politikai botrányt is kavaró priscillianizmus, a titkos mozgalomként müködő manicheizmus, valamint az egyházatyák megítélése szempontjából fontos pelagianizmus és donatizmus tanításával szemben, bár Hydatius a dogmatikai viták bemutatása helyett inkább az ortodoxia képviseletére és a központi hatalomra gyakorolt káros hatások megjelenítésére törekedett.

A szétfeszítő erők harmadik csoportját a politikai és egyházi vezetők körében megfigyelhető hütlenség és lojalitás dilemmája jelenti, amellyel Hydatius arra próbál utalni, hogy nemcsak a barbárok és az eretnekek tevékenysége sodorta válságba a nyugati területeket, hanem nagy szerepe volt ebben a rómaiak hütlen viselkedésének is, ahogyan ez nyomon követhető az egyházi fegyelem lazulásában, a botrányos püspökválasztásokban, valamint a katonai vezetők és az usurpatorok hatalmi törekvéseiben is. Hydatius mindezek ellensúlyozására olyan politikai és egyházi vezetőket állít példaképnek saját maga és az 
olvasói elé, akik lojálisak maradtak a római eszmékhez, és képesek lennének helyreállítani a meggyengült birodalom katonai és vallási rendjét.

A negyedik fejezetben kísérletet teszünk Hydatius történelemszemléletének és szerzői motivációinak részletes elemzésére. Mivel az 5. században bekövetkező katasztrófákat nem mindig tudták racionális okokkal magyarázni, Hydatius történelemszemléletének egyik legérdekesebb aspektusa az isteni gondviseléshez és az apokaliptikus gondolatokhoz kapcsolódik. A természetfölötti jelenségeket gyakran isteni figyelmeztetésként vagy konkrét események előjeleként szokás értelmezni, ezért meg kell vizsgálnunk, hogy tekinthetjük-e a barbárok fosztogató tevékenységét a bünös rómaiak megnevelésére irányuló isteni igazságszolgáltatásnak. Érdemes foglalkoznunk azzal is, hogy Hydatius miért mutatott különösen nagy érdeklödést a természetfölötti jelenségek és a próféciák iránt, és mi célból kaptak kiemelt szerepet az isteni büntetéssel, előjelekkel és csodákkal foglalkozó feljegyzések a krónikában. A végső kérdés természetesen az, hogy Hydatius a saját korában megtapasztalt szenvedéseket valóban értelmezhette-e a parúszia előjeleként, és a Tamás-apokalipszisre való utalás bizonyíték lehet-e arra, hogy Hydatius hitt a közeledő világvégében. Ennek eldöntéséhez ismernünk kell az apokrif iratok egyházi megítélését, a parúszia késlekedésére adott katolikus reakciókat és az eszkatologikus számításokra vonatkozó véleményeket egyaránt.

Ezt követően Hydatius és a krónikahagyomány kapcsolatát vizsgálva arra próbálunk választ keresni, hogy vajon mi késztethette Hydatiust a krónika megírására és mikor kezdte el a feljegyzések összeállítását. Hydatius sok szempontból követte a Hieronymus által kínált mintákat, ugyanakkor mégsem tudott teljes mértékben elődje nyomdokaiba lépni, ezért fontos eredményeket hozhat, ha megvizsgáljuk, hogy a krónika elején szereplő praefatio mennyiben igazolja Hydatius hagyománykövetését a műfaj, a témaválasztás és a forráskezelés tekintetében, és milyen újítások bevezetésével próbálta felülmúlni a kortárs történetírókat. Hydatius a barbárok 409-es betörését fordulópontnak tekinti Hispania történetében és a saját életében egyaránt, ezért ki kell térnünk Gallaecia válságos helyzetére és azokra a társadalmi következményekre, amelyeket a császári hatalommal szemben támasztott lakossági elvárások eredménytelensége okozott. Tanulságos lehet annak elemzése is, hogy az 5. századi pogány és keresztény szerzők, különösen Augustinus hogyan gondolkodott a római állam szerepéröl, és mennyiben hatott a történelmet korszakoló módszerekre Dániel 4 világbirodalomról szóló próféciája és a translatio imperii hagyományozódása. 
Hydatius Gallaecia egyre súlyosabb helyzetét érzékelve a barbárok és az eretnekek elleni harcban a küzdelem több formájára is vállalkozott. Első lépésként politikai fronton, a helyi lakosság érdekeit képviselve próbált Aëtiustól segítséget kérni a szvév fosztogatások megállításához, ez pedig jól mutatja a korabeli római közigazgatási rendszer felbomlását és a püspökök diplomáciában betöltött jelentőségét. A küzdelem második szakaszában vallási téren igyekezett fellépni Thoribius kérésének megfelelően az eretnekmozgalmak ellen, ez pedig jó alkalmat szolgáltat arra, hogy Hydatius püspöki tevékenységének és a 460-as fogságba esés körülményeinek vizsgálatával pontosabb képet alkothassunk a gallaeciai egyház helyzetéről, valamint a vallási és társadalmi rend felbomlásának tüneteiről. A lesüllyedt középrétegek elégedetlensége, a villákba menekült lakosság és a colonusok rossz helyzete, a patrocinium rendszerének kialakulása, valamint a bagaudák és a circumcelliók rablóhadjáratai egyaránt azt jelezték, hogy a rómaiak jelentős része elidegenedett a császári politikától, és korábbi helyzetét megőrizve inkább a barbárokkal való együttmüködést választotta. Hydatius ezzel szemben sohasem fogadja el, hogy a római lakosság idegen uralom alá kerüljön, ellenségként tekint mindazokra, akik barbár uralkodók szolgálatába álltak, és elutasít mindenféle együttmüködést a szvév megszállókkal.

Hydatius élete végén korábbi küzdelmeinek kudarca után irodalmi síkon folytatta a harcot, és szülőföldjén szerzett tapasztalataira alapozva krónikaformában próbálta rögzíteni a birodalom hanyatlásának fontosabb eseményeit. Gallaecia periférikus helyzetéből kiindulva lehetővé válik, hogy megvizsgáljuk a Hydatius rendelkezésére álló források mennyiségét, és ebből következtessünk fizikai elszigeteltségére és a külvilággal való kapcsolatainak fokozatos beszükülésére. Érdemes megvizsgálni azt is, hogy a szintén hispaniai Orosius és Prudentius történelemszemlélete mennyiben különbözik Hydatius nézeteitől, de más krónikaszerzők optimizmusát is szembeállíthatjuk Hydatius borúlátásával és Róma szerepéről vallott felfogásával. Hydatius ugyan átveszi a krónika müfajának formai és kronológiai kereteit, de szokatlanul részletes beszámolót igyekszik nyújtani a korabeli olvasóknak, ez pedig hozzájárulhatott irodalmi küzdelmének kudarcához és későbbi népszerütlenségéhez is. A dolgozat végén kronológiai listák, földrajzi névmutató, térképek és képek segítik a vizsgált problémákon belüli tájékozódást.

Köszönettel tartozom témavezetőmnek, Dr. Székely Melindának, aki felkeltette érdeklődésemet a késő antikvitás latin nyelvű krónikái iránt, és szakmai tanácsaival, értékes megjegyzéseivel folyamatosan segítette az értekezés megírását. Hálával tartozom édesanyámnak, feleségemnek és gyermekemnek, hogy állandó biztatásukkal és türelmükkel biztosították az alkotáshoz szükséges nyugodt hátteret. 


\section{AZ 5. SZÁZADI VILÁGKRÓNIKÁK KIALAKULÁSA}

\subsection{A világkrónika müfajának kezdetei}

Az 5. századi világkrónikák egyik legfontosabb sajátossága, hogy szerzőik nem kifejezetten törekedtek irodalmi igényességre, ${ }^{21}$ hanem korábbi müvek feldolgozóinak vagy folytatóinak vallották magukat, és általában hangoztatták is az elődeiktől való függést. Emiatt Hydatius krónikájának elemzéséhez elengedhetetlen, hogy áttekintsük azokat a mintákat, amelyekhez a szerző nemcsak visszanyúlt, hanem egyúttal talán versenyre is kelt velük. Hydatiusra nagy hatást gyakoroltak a zsidó és görög gyökerekkel rendelkező világkrónikák és a római consuli annalesek, ezért ki kell térnünk mindkét hagyomány fejlődésére és jellegzetességeire. Nem mellőzhetjük annak vizsgálatát sem, hogy a krónikaszerzők milyen kronológiai rendszereket használtak a bemutatott események datálásához, mivel jó néhányan a császári hatalom fokozatos gyengülése és a Római Birodalom hanyatlása miatt kezdtek a kronológia tanulmányozásába és egyetemes történeti munkák írásába. ${ }^{22}$ Eusebius és Hieronymus újításainak bemutatása után a korszak fontosabb latin nyelvű világkrónikáit tekintjük át, ezt követően térünk át Hydatius életének és a krónikában alkalmazott forráshasználatának részletes bemutatására.

\subsubsection{Formai és kronológiai követelmények}

A római történetírás jellemző témái alapján már Gellius is különbséget tett az események felsorolását $a b$ urbe condita alkalmazó annales és az író korának történetét bemutató historiae között, ugyanakkor megjegyezte, hogy az elnevezéseket már saját korában, a Kr. u. 2. században is gyakran megkülönböztetés nélkül használták. ${ }^{23} \mathrm{~A}$ naplószerü annalesekben a történeti eseményeket éves elrendezésben mutatták be az olvasóknak, a historiae kortörténete pedig az események hátterét és okait (consilium et ratio) igyekezett feltárni. Servius és Isidorus a historein kifejezés etimológiája alapján próbálta igazolni,

\footnotetext{
${ }^{21}$ Muhlberger 1990, 8.

22 Breisach 2004, 99.

23 Gell. 5,18,8. A fogalmak további értelmezéséhez lásd: Cichorius 1932; Hofmann 1997, 418; Havas Németh - Szabó 2001, 60-61; Mellor 2002, 2; Albrecht 2004, 271-272; Marincola 2007, 8; 31-35; 39-42.
} 
hogy a historiae valójában olyan annales, amely a szerző személyes élményein és tapasztalatain alapul, ${ }^{24}$ szerzőjük pedig annak ellenére megtartja az annalisztikus ábrázolásmódot, hogy eredetileg a historiae az elmúlt idők eseményeit jelölte. ${ }^{25}$

Amikor késő császárkorban a rövidebb terjedelmü összefoglalások jöttek divatba, a korábbi hosszabb munkák kivonatatát tartalmazó epitomék és a kezdetektől a szerzők koráig tartó breviariumok mellett népszerüvé váltak az eseményeket kronológiai sorrendben tárgyaló chronikák, amelynek fogalmát elsőként Isidorus határozta meg olyan módon, hogy a chrónos etimológiájából kiindulva temporum seriesként értelmezte azt, példaként pedig Eusebius és Hieronymus krónikáját említette. ${ }^{26}$ A késő római történetírásban a müfajok terminológiája már teljesen összemosódott, historiae alatt elbeszélő történeti munkát értettek, a chronica legfőbb célkitüzése pedig az volt, hogy a világtörténeti események idejét minél pontosabban meghatározzák. ${ }^{27}$ Ez a törekvés kezdetben a bemutatni kívánt eseményeket teljesen háttérbe szorította, mivel a szerzők figyelmük nagy részét a különböző kronológiai rendszerek összehangolására fordították, később viszont saját korukhoz közeledve a történeti elbeszélés egyre részletesebbé vált. ${ }^{28}$

Az első görög nyelvü kronológiai munkák pinax (lista) formájában íródtak, ${ }^{29}$ amelyeken az éveket ismert papokra, uralkodókra és hivatalnokokra, esetleg olimpiai győztesekre való utalással jelölték meg, később az uralkodók regnálási évének vagy a hivatalnoklisták éveinek feltüntetése a legnépszerübb időmeghatározási módszerré vált. ${ }^{30} \mathrm{~A}$ pinax a Kr. e. 5. században a szofisták müködésének köszönhetően irodalmi műfaj lett, a hellenizmus idején pedig írók és költők munkáinak katalógusává, földrajzi leírások vagy természeti csodák jegyzékévé bővült, hogy minél több történeti adatot tudjanak rendszerezve az olvasók elé tárni. ${ }^{31}$

\footnotetext{
${ }^{24}$ Serv., Aen. 1,373; Isid., Etym. 1,41,1.

25 Cic., Inv. 1,27. Ehhez hasonlóan a görögök számára a történelem általában a közelmúlt eseményeinek történetét jelentette, így szoros kapcsolat jött létre a történelem és a történetírás között, ugyanakkor a múlt és a jelen eseményeit legtöbbször csak akkor sikerült összehangolniuk, ha egy rövid időszak vagy kisebb terület eseményeivel foglalkoztak, vö. Breisach 2004, 47; Vanyó 2007b, 59.

${ }^{26}$ Isid., Etym. 5,28. A tendencia áttekintéséhez lásd: Marincola 2007, 305-311.

${ }^{27}$ Guenée 1973, 997-1016; Hofmann 1997, 418.

${ }^{28}$ Az egyiptomi és babilóni királykatalógusok még rendszerezés nélkül ismertették az összegyüjtött történelmi anyagot, elsőként a görögöknél merült fel igény az eltérő időszámítási rendszerek egyeztetésére és a kronológiai gondolkodásmód alkalmazására, vö. Vanyó 2007b, 57-58.

29 A pinax eredetileg olyan festett, fából vagy terrakottából készült táblácskát jelentett, amelyen hasonló információk vagy személyek vannak felsorolva, vö. Regenbogen 1966.

${ }^{30}$ Muhlberger 1990, 10.

${ }^{31}$ Pfeiffer 1968, 51-52; 255-257; Croke 1983, 119-120.
} 
Elsőként a tauromenioni Timaius (Kr. e. 346 k.-250) használt olimpiászokat a siciliai görögök történetének bemutatásához, ${ }^{32}$ később az alexandriai könyvtárban kutató Eratosthenés (Kr. e. 275-195) fejlesztette tovább a módszert az elveszett Chronographia címü munkájában úgy, hogy $\mathrm{Kr}$. e. 776-tól kezdve a négy évente megtartott olimpiai versenyeket folyamatos számozással látta el, és a két olimpia közötti négy éves ciklusokon, az olimpiászokon belül megjelölte, hogy annak hanyadik évében történt az adott esemény. ${ }^{33}$ $\mathrm{Az}$ alexandriai pinaxok közül Eratosthenés munkájánál is népszerübbé vált Apollodórus $\mathrm{Kr}$. e. 140 körül keletkezett Chronicája, amely áttekintést adott a Földközi-tenger térségében élő népek történetéről és szellemi eredményeiről. ${ }^{34}$ Későbbi történetírók szívesen kapcsolták össze munkájukat az Eratosthenés és Apollodórus által kidolgozott kronográfiával, ${ }^{35}$ bár mindkét szerzőnél a politikai, az irodalmi és a kulturális események kronológiai vázát elsősorban az olimpiászok felsorolása jelentette. ${ }^{36}$

\subsubsection{Az apologetikus történetírás kezdete}

A görög nyelv átvétele után a Kr. e. 3. században a diaszpórában élő zsidók is készítettek kronológiai összefoglalásokat az Ótestamentum történeteiből. Ezek a szerzők saját népük kronologikus történetével igyekeztek igazolni a görög hódítóknak, hogy a zsidó hagyomány az összes többinél, így a görögnél is régebbi. ${ }^{37} \mathrm{Az}$ apologetikus szándék népszerüségét jól mutatja, hogy ezt követően a görög nyelvü kronológiákban is sorra megjelent a zsidó történelem nagy alakjai szerinti datálás. ${ }^{38} \mathrm{Az}$ apologetikus történetírás második hulláma a Kr. u. 1. században a keresztényüldözések miatt alakult ki, ${ }^{39}$ a 2 . század végétől pedig a khiliazmus híveinek elvárásai határozták meg keresztény történetírás irányvonalát, mivel

\footnotetext{
32 Timaius az athéni és a spártai tisztségviselők és az olimpiai győztesek névsorának felhasználásával hangolta össze a korábbi helyi kronológiai rendszereket, egységes időkeretet nyújtva így a későbbi görög történetírók számára, vö. Polyb. 12,11; Breisach 2004, 45-46; Marincola 2007, 196-199.

33 Olajos 1999, 224.

${ }^{34}$ Breisach 2004, 67.

$35 \mathrm{Az}$ Apollodórust követő történetírók közül ki kell emelnünk a rhodusi Castort és Claudius Ptolemaiust, vö. Breisach 2004, 67; 81.

${ }^{36}$ Fraser 1972, 1,456-457.

${ }^{37}$ Még Iosephus Flavius is a Kr. u. 1. században azt hangsúlyozta a világ teremtésének bemutatásakor, hogy a zsidók múltja sokkal ősibb a görögökénél, így Mózes is korábban élt, mint Homerus, vö. Ios. Flav., Ant. Iud. praef. 4. A korabeli zsidó történetírás jellemzőiröl lásd: Marincola 2007, 234-238.

Később a keresztények hasonló érvekkel igyekezték megcáfolni a pogány gondolkodás vádjait, ezért kezdtek el foglalkozni maguk is kronológiai kérdésekkel, vö. Breisach 2004, $78 ; 87$.

38 Muhlberger 1990, 11. Berosus babilóni csillagász és Manetho egyiptomi fópap már saját kronológiai magyarázatokkal ellátott uralkodólistákat készített, vö. Breisach 2004, 44; Marincola 2007, 222-228.

${ }^{39}$ Tiberiasi Iustus elsőként igazította Mózes idejéhez az évek számítását, vö. Waxman 1960, 95-107.
} 
Krisztus második eljövetelét várva kronológiai számításokkal próbálták meghatározni a Teremtés és a világvége időpontját. ${ }^{40}$ Az Apokalipszis 20,4-6 fejezetén alapuló nézet szerint a parúszia után Krisztus ezeréves uralma szabadítja majd meg az emberiséget a földi szenvedésektől. ${ }^{41}$ Mivel a bibliai hivatkozások szerint ${ }^{42}$ egy évezred az Úr számára csak egyetlen nap, a világ története a 6 napig tartó Teremtés mintájára csak 6 ezer évre korlátozódik, ${ }^{43}$ ezért Krisztus második eljövetelére, vagyis az emberiség történetének végére a millenarizmus tanítása szerint a 6. napnak megfelelő 6000 . év végén kerül sor. ${ }^{44} \mathrm{Ha}$ a Krisztus mennybemenetelétől eltelt időt 50 évenként ioboleusokra osztjuk, Krisztus második eljövetelének ideje egybeesik a 9. ioboleus végével, azaz a 482. esztendővel. ${ }^{45}$ Ezek alapján nem meglepő, hogy a késő császárkor világkrónikái többnyire keresztény szerzőkhöz kapcsolódnak. ${ }^{46}$

A 3. századi keresztény szerzők a zsidó kronológiai összefoglalások mellett már pogány írók müveit is használták forrásként. Közülük az első, széles körben ismert alkotás Sextus Iulius Africanus (megh. 240 k.) 221-ben írt Chronographiája és az Alexander Severusnak ajánlott 24 kötetes Kestoi c. enciklopédiája, ${ }^{47}$ amelyek szoros rokonságot mutatnak az egyre népszerübbé vált pinax müfajával. A töredékesen ránk maradt Chronographia eredeti formájáról csak annyit tudunk, hogy 5 könyvböl állt, és a Teremtéstől 217-ig egységes zsidó-keresztény időkeretbe szerkesztve tartalmazta az ótestamentumi, egyiptomi, görög és római eseményeket, ami meghatározó újításnak számít az antik történetírásban, ${ }^{48}$ hiszen ez az első általunk ismert keresztény világtörténet, amely megpróbálta egyesíteni a zsidó, a görög-hellenisztikus kronográfiát a keresztény apologetikus történetírással. ${ }^{49}$ Africanus újraszámolta az eltérő uralkodólistákat és

\footnotetext{
${ }^{40}$ Ilyen jellegủ munkát írt az antiochiai Theophilus és az alexandriai Clemens Stromata, vö. PL 6,1023-1168; Pilhofer 1990; Ridings 1995; Hofmann 1997, 419.

${ }^{41}$ Sok kutató azt gondolja, hogy ez a felfogás a pogány szerzők szubsztancialista nézeteiből és ciklikus történelemszemléletéből alakult ki, ezt meggyőzően cáfolja: Burgess 1988a, 27-28.

${ }^{42}$ Zsolt 90,4; Jel 20,1-10; 2Pét 3,8.

${ }^{43}$ A zsidó aión-felfogás három 2 ezer éves ciklusra osztja a világ történetét, vö. Vanyó 2009, 243-245.

${ }^{44}$ A babiloni asztrológia hatását mutató millenarista eszmékre utalásokat találunk Dániel és Izaiás könyvében, Máté evangéliumában, a Jelenések könyvében, valamint Iustinus, Tertullianus és Irenaeus müveiben, vö. Iustin., Fr. 15; Tertull., De anima 55,2-4; Iren., Haer. 5,28,3. A millenarizmus eszméjéröl és további forrásokról bővebben: Landes 1988, 142-144; Palmer 2014, 12-14; Aguzzi 2017.

${ }^{45}$ Muhlberger 1990, 13.

${ }^{46}$ A keletrómai történetírás számon tart néhány görög nyelvű chronicát is, amelyek az események évenkénti felsorolásával hasonlóságot mutatnak a keresztény munkákkal, ide tartozik Dexippus, Porphyrius és Eustathius munkája, vö. Hofmann 1997, 418.

${ }^{47}$ PG 10; Gelzer 1964, 1,1-19; Wallraff - Mecella 2009.

${ }^{48}$ Albrecht 2004, 1102; Vanyó 2007b, 57.

${ }^{49}$ Roberto 2007, 15-28.
} 
olimpiászokat, a világ teremtését pedig Kr. e. 5500-ra datálta. ${ }^{50}$ Bár munkáit gyakran kritizálták a kutatók, népszerüségét feltehetően annak köszönhette, hogy megfelelő tudományos alapokkal rendelkezett, de mégis közérthető stílusban írt. ${ }^{51} \mathrm{Az}$ általa kidolgozott africanusi aerát a nyugati történetírás Hieronymusig használta, keleten pedig a constantinopolisi időszámítás alapja lett. ${ }^{52}$

A keresztény kronológia másik korai feldolgozója a római Hippolytus (170 k.-235) volt, aki két kronológiai munkát is írt. ${ }^{53} \mathrm{~A}$ húsvéti ünnepkörrel kapcsolatos írása egy régóta fennálló kronológiai problémára kereste a megoldást, mivel szükséges volt a két használatban lévő naptárrendszer összehangolására, ${ }^{54}$ így Hippolytus a húsvéti időszakot 16 éves ciklusokban, 222. április 13-ával kezdődően számolta ki. ${ }^{55}$ Hippolytus másik, töredékesen ránk maradt kronológiai munkája, a 234-ben írt és nagy sikerü Chronica $^{56}$ erősen támaszkodott Africanus Chronographiájára, célja azonban éppen ellenkező volt, mert igyekezett megcáfolni a fenyegető világvégére vonatkozó hiedelmeket, amelyek a korabeli keresztényüldözések miatt ismét terjedni kezdtek. Szerinte a Teremtés óta nem 6 ezer, hanem csak 5738 év telt el, ezért Krisztus második eljövetelére még sokat kell várni, ${ }^{57}$ ennek igazolására pedig felsorolja a Teremtés óta eltelt időszak egyházatyáit és uralkodóit regnálási idejük megjelölésével. ${ }^{58}$ Hippolytus Africanushoz képest tehát kevésbé volt apologetikus, csak néhány esetben egyeztette a bibliai és a világtörténeti kronológiát, nem foglalkoztatta az események pontos datálása sem, helyette inkább etnográfiai kitérökkel és földrajzi leírásokkal színesítette az uralkodólistákat. ${ }^{59}$ Hippolytus jelentőségét mutatja, hogy munkáit gyakran kivonatolták és átdolgozták, hatására számos későbbi szerző illesztett kronográfiájához néprajzi vagy földrajzi beszámolót. ${ }^{60}$ Africanus és Hippolytus azonban

\footnotetext{
${ }^{50}$ Gelzer 1964, 1,24-26; Landes 1988, 138; Hofmann 1997, 420; Breisach 2004, 90; Croke 2007, 578.

${ }^{51}$ Muhlberger 1990, 12.

52 Grumel 1958, 219-221; Mosshammer 1979, 146-157; Olajos 1999, 230.

${ }^{53}$ Hippolytus életéről és müveiről bővebben: Quasten 1951-1955, 2,163-166; Vanyó 2007a, 305-314.

${ }^{54}$ A kisázsiai egyházak a zsidó Nisan hónap 14. napján emlékeztek Krisztus halálára, a rómaiaknál 160 körül bevezetett gyakorlat szerint viszont a húsvétot Nisan 14. napja utáni vasárnap ünnepelték, amely gyakorlati okokból a tavaszi napéjegyenlőséget követő első telihold utáni vasárnappal esett egybe, vö. Eus., Hist. Ecc. 5,23-25; Chadwick 1999, 77.

55 Quasten 1951-1955, 2,163-178; Hofmann 1997, 420. A rendszer asztronómiai pontatlansága miatt ugyan nem került bevezetésre, de később Hippolytus ciklusait a laodiceai Anatolius az athéni csillagász, Metónus Kr. e. 432-es számításai alapján 19 éves ciklusokra egészítette ki, amelyet a keleti egyházak a 3. századtól kezdve alkalmaztak. A húsvéti vitáról bővebben: Vanyó 2007a, 314-318.

${ }^{56}$ GCS 46; Schmidt - Nicholas 2017.

57 Vanyó 2007a, 311.

${ }^{58}$ Muhlberger 1990, 14.

${ }^{59}$ Croke 1983, 123.

${ }^{60}$ Hatása kimutatható az 5-6. századi városok gyüjteményeiben, a Goleniscev-papirusz krónikájában és a 7. századi névtelen latin szerkesztő, Barbarus Scaligeri mára már elveszett görög nyelvü forrásában is. A
} 
népszerüségük ellenére csak a nyugati történetírás egy részére gyakorolhattak hatást, mivel a munkájukban előforduló uralkodók és háborúk adatai csak a kronológiai rögzítés eszközeként szolgáltak és a bibliai hagyomány anyagára támaszkodtak. ${ }^{61}$ Elsőként Eusebius és Hieronymus írt olyan jellegü világkrónikát, amely egy átfogóbb szemléletü és nagyobb kritikával összeállított kronológiát tartalmazott a müfaj újrafeltalálásával, ${ }^{62}$ innentől kezdve pedig azok a szerzők, akik a legjobb mintát akarták követni a krónikaírás során, kizárólag Hieronymus Eusebius-fordítását vették alapul.

\subsection{Eusebius és Hieronymus újításai}

\subsubsection{Eusebius}

Eusebius, (263 k.-339) Caesarea Maritima püspöke Chronici canones (Idörendi táblázatok) című munkája ${ }^{63}$ teljesen eltért a korábbi keresztény történetírók műveitől. ${ }^{64} \mathrm{~A}$ korábbi apologéták a bibliai hagyomány elsőbbségét igyekeztek bizonyítani a pogány hagyománnyal szemben, Africanus és Hippolytus pedig a khiliazmus híveként az Ótestamentum felhasználásával próbálta bemutatni a világ történetét, hogy a Teremtés óta eltelt idő kiszámításával megjósolhassa, mennyi idő van még hátra a világ végéig. Eusebius szakított ezzel a hagyománnyal, nem foglalkozott a világ kezdetével és eszkatologikus spekulációkkal, csak a Diocletianus-féle keresztényüldözések előzményeiről írt, amely hiába volt minden korábbi üldözésnél nagyobb mértékü, mégsem ösztönözte öt arra, hogy a világ végével fenyegesse olvasóit. Mivel a korábbi szerzők szerint Krisztus közbenjárása után nem történt semmilyen fontos esemény a világban, müveikben nem tárgyaltak a keresztény tanításokról és a hit terjesztéséről, Eusebius ezzel szemben elsőként próbált olyan művet írni, amely összekapcsolja az egyháztörténetet a bibliai hagyománnyal, ${ }^{65}$

Chronicát kétszer is lefordították latinra, rövidített változata mindkét esetben a Liber Generationis nevet kapta, az egyik változat Dionysius Philocalus 354-es Chronographiájában, a másik pedig a 7. századi Fredegarius-krónikában található, vö. Muhlberger 1990, 15. A 354-es Chronographiáról bővebben: Vanyó 2004, 138; Hunt 2007, 253; a Fredegarius-krónikáról bővebben: PL 71; Adamik 2014, 350-363; Hippolytus kronológiájának jelentőségéről lásd: Landes 1988, 144-149.

${ }^{61}$ Hofmann 1997, 421. A problémáról bővebben: Inglebert 2001, 464-493.

${ }^{62}$ Woods 2009, 360.

${ }^{63}$ Barnes szerint először 280 körül adták ki Eusebius munkáját, Wallace-Hadrill ezt 303-ra, Woods 311-re, Albrecht 323-ra, Mosshammer pedig 325-re datálja, vö. Barnes 1981, 111; Wallace-Hadrill 1961, 43; Woods 2009, 361; Albrecht 2004, 1102; Mosshammer 1979, 75.

${ }^{64}$ A Chronici canones jelentőségéről lásd: Burgess 1999, 21-27; 46-65.

${ }^{65}$ Muhlberger 1990, 15-16. 
vagyis az egyház történetét a „világtörténet összefüggésrendszerébe” helyezve ${ }^{66}$ megalkotta az egyetemes történet „,keresztény szintézisét”, 67 ezáltal „müve az idő és történelem keresztény bemutatásának mindenkori modellje lett."68

Eusebius a Krisztus utáni események közül különösen az egyház hatalmára és tanítására összpontosított, megnevezte és számozással látta el Róma, Alexandria, Antiochia és Hierosolyma egyházi vezetőit, és megemlítette a leghíresebb keresztény és eretnek írókat is, ${ }^{69}$ ezáltal sajátos kronológiai rendszerben tudta rögzíteni a pogányoktól, illetve a bibliai és egyháztörténetböl átvett eseményeket. Az így létrejött vázlatos világtörténet jóval többet tudott nyújtani az olvasóinak, mint a korábbi szerzők művei, ${ }^{70}$ mert megvalósulni látszott a keresztény történelemszemlélet azon univerzalizáló törekvése, hogy az emberiség történetét a kezdetektől fogva egyetlen történeti munkában kell rögzíteni.

Eusebius a rendelkezésére álló ismeretanyagot sajátos „tudományos módszerrel” kezelte, ${ }^{71}$ és mivel a Teremtés pontos idejét Mózes könyveinek ellentmondásos adatai alapján nem tudta megállapítani, az Ábrahám előtti időszakot a tudományos kronológián kívül helyezte, ${ }^{72}$ az eseményeket pedig Kr. e. 2016-tól, Ábrahám születésétől datálta, ami így Eusebius aerájának kezdőpontja lett. ${ }^{73} \mathrm{Ez}$ az új keresztény kronológia a görög olimpiászoktól és a rómaiak consuli jelöléseitől eltérően már képes volt átfogni az egész világtörténetet, és Krisztust állította nemcsak az időszámítás, hanem a történelem középpontjába is. ${ }^{74}$

A Canones első könyvében a kaldeusok, asszírok, zsidók, egyiptomiak, görögök és rómaiak történetéhez Eusebius nemcsak Africanust és az általa is használt hiányos kompilációkat vette alapul, hanem számos pogány kronográfiaszerző munkájára is

\footnotetext{
${ }^{66}$ Bultmann 1994, 70.

${ }^{67}$ Horváth 1993, 14.

${ }^{68}$ Wieser 2016, 104.

${ }^{69}$ Helm 1927, 18-19.

${ }^{70}$ Eusebius fó célja egyes kutatók szerint az volt, hogy bebizonyítsa, a zsidó-keresztény történet minden más hagyománynál korábbi, vö. Croke 1983, 124-126; Kelly 2003, 119.

${ }^{71}$ Bultmann 1994, 70.

${ }^{72}$ Eusebius kronológiai jelöléseiről lásd: Burgess 1999, 28-35.

${ }^{73}$ Brincken 1957, 59-63; Wallace-Hadrill 1961, 157. Eusebius Ábrahámot tekintette az első kereszténynek, vö. Eus., Hist. Ecc. 1,4; Barnes 1981, 126-127; Burgess 1988a, 24; szerinte Ádámtól Krisztusig 5198 év, az özönvízig 2242 év, Ábrahámig 942 év, Krisztus megtestesüléséig pedig 2014 év telt el, vö. Hofmann 1997, 421.

${ }^{74}$ Bultmann 1994, 70. A keresztény időmeghatározások közül három új módszer terjedt el a 4. század elején: az Ábrahám születésétől, Kr. e. 2016-tól számított évjelölést Eusebius is alkalmazta, a Krisztus születésétől számított anno Domini megjelölés inkább a nyugati területeken vált általánossá, a világ teremtésétől számított időt pedig az alexandriai aera alapján határozták meg, vö. Grumel 1958, 219-235; Landes 1988, 149-156; Olajos 1999, 229-230.
} 
hivatkozott, ${ }^{75}$ a második könyvben pedig a történetírásban valószínüleg elsőként szemléletes módon, kronológiai táblázatok segítségével mutatta be a történeti eseményeket. ${ }^{76}$ Eusebius különböző oszlopokban sorolja fel a királyok regnálási éveit, egyidejűségüket pedig az oszlopok párhuzamos elrendezésével, a filum regnorummal jelzi. Ha az olvasó a szemét végigfuttatja az oldalon, első pillantásra is észre tudja venni az események időbeli párhuzamosságát, ${ }^{77}$ vagyis a szinkronisztikus szerkesztésnek köszönhetően lehetővé vált az események kronológiai összehasonlítása. ${ }^{78}$ A táblázatok spatium historicumként 2 oszlopban (columna) mutatják be a kereszténység és a pogány népek történetének fontosabb eseményeit, ${ }^{79}$ ezzel a párhuzamos elrendezéssel pedig egy szemléletes apologetikus összefoglaló jön létre, elkülönítve és egyúttal szembe is állítva a keresztény történetet a pogányok történetével. ${ }^{80}$ Hieronymus fordításában a kétoldalas elrendezés a babiloni fogság leírásával Kr. e. 446-ban véget ér, ezután a táblázat egyoldalas formátumban folytatódik, vagyis innentől egybeesik a keresztény és a világtörténet. ${ }^{81}$

Az eseményeket alkalomszerüen más kronológiai jelölések is kiegészítik. Eusebius az Ábrahám születését követő időszakot 10 éves dekádokra osztotta fel, így jelezte a bal oldali margón aláhúzva az Ábrahám születése óta eltelt időt. A lap többi üres részén szerepelnek azok az olimpiászok, amelyek újabb szakaszokra osztják az időt, de kevésbé rendszerezett elhelyezésük miatt valószínüleg ezeket csak utólag csatolta hozzá a már befejezett kronológiához. ${ }^{82} \mathrm{Az}$ uralkodók trónra lépésének dátuma szintén megtöri a felsorolás folyamatosságát, néhány bejegyzés pedig közvetlenül az olimpiászok után szerepel. ${ }^{83}$ Mivel a Canones táblázataiban nagyon sok információ rendkívül kis helyen

\footnotetext{
75 Gelzer 1964, 2,23-24; Croke 1983, 123; Wieser 2016, 104.

76 Mosshammer 1979, 32-37. Eusebius ezek elkészítéséhez feltehetően hellenisztikus forrásokat használt, biztosan ismerte például a rhodusi Castor kronológiai táblázatait, vö. Breisach 2004, 90.

77 Muhlberger 1990, 17.

78 Vanyó 2007b, 61.

${ }^{79}$ Hofmann 1997, 421.

${ }^{80}$ Muhlberger 1990, 18. Eusebius pogányság elleni küzdelméröl lásd: Kofsky 2000.

${ }^{81}$ Nem tudjuk, hogy ez a terjedelembeli csökkenés Eusebiustól származik, vö. Mosshammer 1979, 63-65; 7173; vagy Hieronymus változtatta meg a formátumot kétoldalasról egyoldalasra, vö. Caspar 1926, 274-293; Kelly 2003, 119; a változtatás mindenesetre indokolt volt, mert a Canones első felében a kronológiai táblák 9 filumot tartalmaztak, a második felében már csak 3 filum szerepel, a $\mathrm{Kr}$. u. 70. évtől kezdve pedig a római császárok felsorolásához elegendő volt egyetlen filum alkalmazása.

${ }^{82}$ Mosshammer 1979, 68-71.

${ }^{83}$ Mosshammer szerint ezek az események olyan krónikákban voltak feljegyezve, ahol csak az olimpiászok jelölték a hozzávetőleges időt, ezért Eusebius minden igyekezete ellenére sem tudta őket évre pontosan datálni, vö. Mosshammer 1979, 49-67. Caspar ezzel ellentétben szándékosságot feltételez, és úgy látja, Eusebius csak megközelítőleg akarta meghatározni az események időpontját, vö. Caspar 1926, 217-225. A kérdést sem Eusebius esetében, sem későbbi krónikaszerzőknél nem lehet egyértelmüen eldönteni.
} 
zsúfolódik össze, Eusebius munkáját tekinthetjük az ókori pinax utolsó állomásának. ${ }^{84} \mathrm{Az}$ eredeti görög nyelvü Canonesből csak töredékek maradtak fenn, rendelkezésünkre áll viszont a bővített változat örmény fordítása és a Hieronymus által később latinra fordított és átdolgozott szöveg, amely valójában Eusebius nagy munkájának csak a második részét foglalja magában. ${ }^{85}$

Mivel a 4. század új problémáira adott válaszként két müfaj született a történetírásban, a krónika és az egyháztörténet, ${ }^{86}$ érdemes röviden megvizsgálnunk Eusebius Historia Ecclesiastica címü munkáját is, ${ }^{87}$ amely 10 könyvben mutatja be a kereszténység történetét Krisztus korától 324-ig, felsorolva a fontosabb apostolokat, keresztény írókat, eretnek vezetőket és mártírokat. ${ }^{88}$ Eusebius kortársai és Hydatius is ${ }^{89}$ ezt a múvét becsülte a legjobban annak ellenére, hogy Eusebius egyháztörténete több szempontból is különbözik a korábbi mintáktól. Eusebius a klasszikus történetírás szabályaitól eltérően számos dokumentumból idézett művében, nem törődve azzal, hogy azok megbonthatják az írói stílus egységességét, ráadásul saját korának egyháztörténeténél jóval többet foglalkozott a korábbi időszak eseményeivel, ezért elfogadhatjuk Vanyó feltételezését, mely szerint Eusebius ,tudatosan vétett a szabályok ellen”, hogy az egyháztörténethez kapcsolódó anyagok összefoglalásával egy jól használható munkát adjon az olvasók kezébe. ${ }^{90}$ Eusebius munkájának görög és szír fordítása maradt fenn, Rufinus pedig 403-ban latinra fordította és kiegészítette a művet, ${ }^{91}$ később Socrates, Sozomenus és Theodoretus egyháztörténetében már nagyobb szerep jutott a politikatörténetnek. ${ }^{92}$

\footnotetext{
${ }^{84}$ Muhlberger 1990, 18.

${ }^{85}$ Hieronymus nem fordította le azt a Chronographiát, amelyben Eusebius a Canones előtanulmányaként saját forrásait és a bemutatni kívánt történelmi anyagot vizsgálta, vö. Burgess 1988a, 23. A Canonest folytató világkrónikák közül érdemes megemlíteni Dionysius Philocalus 354-es római chronographiáját, vö. CM 1, 131-192; Gesztelyi - Havas 1999, 254-255; Hilarius khiliasztikus müvét, vö. PL 13,1097-1105; és Sulpicius Severus krónikáját, vö. CSEL 1,1866.

${ }^{86}$ Burgess 1988a, 31.

${ }^{87}$ PG $19-24$.

${ }^{88}$ Albrecht 2004, 1102.

${ }^{89}$ Hyd. praef. 2.

${ }^{90}$ Vanyó 2007b, 62-63; Croke 2007, 574-575; Eus., Hist. Ecc. 1,1,5.

91 Rufinus a szövegböl számos dokumentumot kihagyott, a 324-395 közötti eseményekkel viszont kiegészítette Eusebius munkáját, vö. Albrecht 2004, 1112.

92 Socrates a 305-439, Sozomenus a 324-425, Theodoretus a 323-428 közötti időszakkal foglalkozik, mindhármuk munkáját Epiphanius fordította latinra Historia tripartita címmel, vö. CSEL 71; Croke 2007, 573-577; Vanyó 2007b, 73-74; Woods 2009, 361-363.
} 


\subsubsection{Hieronymus}

A 4. század végén a chronica müfaja ismét az érdeklődés középpontjába került, mivel Hieronymus (347 k.-420) elsőként fordította latin nyelvre Eusebius 325-ig kiegészített Canonesét, majd folytatta a római események bemutatását Valens császár 378-as haláláig. ${ }^{93}$ Elfogadhatjuk Muhlberger feltételezését, mely szerint Hieronymus egyrészt ezzel irodalmi szenzációt akart kelteni, másrészt ilyen módon igyekezett kifejezni Eusebius teljesítménye iránti csodálatát; ${ }^{94}$ hasonló célokat figyelhetünk meg későbbi szerzők, többek között Hydatius esetében is. Nem túlzás azt állítani, hogy Hieronymusnak mindkét törekvését siker koronázta, mert a legtöbb kutató a nyugati történetírás legjelentősebb eseményének tartja, hogy elkészült Eusebius munkájának latin fordítása. ${ }^{95}$

Hieronymus a Chronica bevezetöjében kiemelte, ${ }^{96}$ hogy rendkívül fárasztó munkát végzett, mert opus tumultuariumnak nevezett munkája elkészítéséhez nagyon kevés idő állt rendelkezésére. ${ }^{97}$ Megoszlanak a vélemények azzal kapcsolatban, hogy Hieronymusnak valójában mennyi lehetősége volt a különféle források tanulmányozására. Mommsen megpróbálta igazolni, hogy Hieronymus az általa is hivatkozott Suetoniuson kívül legalább négy történeti forrást használt, ${ }^{98}$ Albrecht szerint Eutropiuson és Suetoniuson kívül római hivatalnoklisták is a rendelkezésére álltak. ${ }^{99}$ Ha figyelembe vesszük, hogy Hieronymus csak kevés időt tudott a források tanulmányozására fordítani, elfogadhatónak látszik az a népszerü feltevés, mely szerint a politikatörténeti feljegyzések alapját csupán egyetlen, mára már elveszett kompiláció képezte, ezért is felületesek a császárkorra vonatkozó kiegészítések. ${ }^{100}$

Hieronymus nemcsak arra hívta fel a másolók figyelmét, hogy az eusebiusi anyagot lefordította és sok helyen kiegészítette, majd hozzácsatolta folytatásként a római történelemmel kapcsolatos feljegyzéseket, hanem arra is kitért, hogy a filumoknál újításként vörös és fekete tintát alkalmazott, hogy látványos módon el tudja választani az oszlopokat

\footnotetext{
93 Hieronymus életéről és műveiről lásd: Rebenich 2002; Albrecht 2004, 1336-1349; Williams 2006; Vanyó 2007b, 294-306; Adamik 2009, 778-791; PL 22-30; CCL 72.

94 Muhlberger 1990, 19.

95 Burgess 1988a, 23.

${ }^{96}$ Hier., Chr. praef. 1-7.

${ }^{97}$ Hieronymus feltehetően 380-381 között dolgozott Constantinopolisban a Canones fordításán és folytatásán, a 382-es római zsinatra pedig már el is készült a munkájával, vö. Mosshammer 1979, 37-38; 67-73; Burgess 1988a, 23.

98 Mommsen hivatkozik Valens két titkárára, Eutropiusra és Festusra, Róma városi krónikájára és más elveszett történeti forrásokra, vö. Mommsen 1909, 606-632.

${ }^{99}$ Albrecht 2004, 1111.

${ }^{100}$ Muhlberger 1990, 21; Kelly 2003, 120-121.
} 
egymástól, míg tehát Eusebius különféle írástípusokkal és a feljegyzések sajátos elhelyezésével különítette el egymástól az eseményeket, Hieronymus egyszerüsített is a szöveg grafikai elrendezésén. ${ }^{101}$ A fordítás első szakasza nagyon hasonlít a Canonesre, a második részben viszont a római császárokkal kapcsolatos feljegyzések egyetlen oszlopban szerepelnek, így az összes kronológiai jelzés a bal margóra került. A második rész szövege szinte már folyamatos és a korábbinál jóval terjedelmesebb, ${ }^{102}$ ezért Caspar szerint Hieronymus az első olyan történetíró, akinél a hagyományos értelemben vett szöveg kiszorítja a kronológiai jelöléseket. ${ }^{103}$

Érdemes összehasonlítani Eusebius és Hieronymus íráshoz való hozzáállását is, mert Muhlberger szerint Hieronymus összes kiegészítését és változtatását ez a szempont indokolja. ${ }^{104}$ Eusebius Canonese alapvetően apologetikus célokat szolgált, Hieronymus hitvallásában viszont alig van nyoma ennek, ezért nem is egészítette ki a korai bibliai időkre vonatkozó feljegyzéseket, csak a trójai háború utáni szakaszhoz füzte hozzá egyre többször saját megjegyzéseit a római történelemmel, irodalommal és a kereszténységgel kapcsolatban. ${ }^{105}$ Általánosságban is elmondhatjuk, hogy a 4. század végére nemcsak a szerzők apologetikus érdeklődése csökkent, hanem egyre nyilvánvalóbbá vált a bibliai hagyományon alapuló kronológia pontatlansága is. Hieronymus éppen ezért a Chronica első felében Eusebiustól eltéröen nem különítette el a bibliai és a világtörténeti anyagot, míg tehát Eusebius a bal oldali lapokon a kereszténység történetéről számolt be, Hieronymusnál ezen a helyen a római események szerepelnek. ${ }^{106}$ Hieronymus Chronicájának eseményeit négy csoportra szokás osztani: a vallási témájú feljegyzések híres egyházi személyek tetteit és eretnekség elleni harcát mutatják be, a politikai események császárok és trónbitorlók tevékenységéhez kapcsolódnak, ezen kívül vannak természeti jelenségeket, valamint katonai eseményeket és háborúkat bemutató részek is a feljegyzések között. ${ }^{107}$ Hieronymusnál különösen nagy hangsúlyt kapnak az arianizmus gyors terjedésére, a dogmatikai vitákra és az eretnekké vált püspökökre vonatkozó beszámolók, ${ }^{108}$ néhány kivételtől eltekintve ${ }^{109}$

\footnotetext{
${ }^{101}$ Hier., Chr. praef. 5; Helm 1923, 28-32; Caspar 1926, 251-273.

102 Muhlberger 1990, 20.

${ }^{103}$ Caspar 1926, 290-291. Mosshammer valószínűleg téved, amikor ezt a formátumbeli változást Eusebiusnak tulajdonítja, mert figyelmen kívül hagyja, hogy Hieronymus a latin fordítást kiegészítette saját anyagával, vö. Mosshammer 1979, 72-73.

${ }^{104}$ Muhlberger 1990, 20.

${ }^{105}$ Hier., Ep. 18A, in: CSEL 54,75; Burgess 1988a, 23; Kelly 2003, 120.

106 Muhlberger 1990, 20.

${ }^{107}$ Burgess 1988a, 25.

${ }^{108}$ Hier., Chr. 2344; 2353; 2358; 2364; 2378; 2386

${ }^{109}$ Hier., Chr. 2370; 2372.
} 
ugyanis Eusebiustól eltérően kíméletlenül bírálja az eretnek mozgalmakat, ${ }^{110}$ feltehetően azért, hogy mindenképpen jó keresztény képében tűnhessen fel az olvasók előtt, ráadásul talán hiúsága miatt megpróbálta még olvasottabbnak feltüntetni magát. Ez a fajta önreklámozás és hevesség Grützmacher és Kelly nézetét elfogadva kifejezetten Hieronymusra jellemző, Eusebiusnál pedig egyáltalán nem található ilyen motívum, ${ }^{111}$ emiatt Hieronymus sokkal találóbb és színesebb kifejezéseket igyekezett használni az eusebiusi száraz és tömör stílushoz képest. ${ }^{112}$

Hieronymus az Eusebius-fordítást csupán egy rövid mondattal választotta el a folytatástól, ${ }^{113}$ vagyis igyekezett feltűnés nélkül hozzáfüzni saját feljegyzéseit a korábbi eseményekhez, hogy az olvasó ne vegye észre a változást, ugyanakkor életrajzi utalásaival mégis érzékeltette, hogy a szóban forgó rész már nem Eusebius munkája. Hieronymus a bevezetöben említi, hogy a korszak legjobb világtörténetét igyekszik összeállítani, ezért is csatolta hozzá Eusebius művéhez saját római anyagát, a fordítás legfőbb erényének pedig azt tartja, hogy olyan anyagot emelhet be a latin történetírásba, amely addig ismeretlen volt a csak latinul értő olvasók számára. ${ }^{114}$ Vitathatatlan, hogy Hieronymus a Canones fordításával valóban egyedülálló világtörténeti összefoglalót készített, mert a hatalmas mennyiségü beszámolót annalisztikus formában szerkesztette meg és tudományos igényü kronológiai jelöléseket alkalmazott, ${ }^{115}$ a folytatás megírásával pedig egy magas színvonalú, mégis könnyen utánozható mintát nyújtott a későbbi nyugati krónikások számára, akik saját koruk eseményeinek feldolgozását igyekeztek összekapcsolni Hieronymus munkájával. ${ }^{116}$ Bár a bevezetőben reális képet kapunk a munkafolyamat írói és fordítási nehézségeiről, ${ }^{117}$ Hieronymus tisztában volt munkája jelentőségével, és a Chronica végére illesztett megjegyzéssel valósággal ösztönözte az 5-6. század egyházi szerzőit arra, hogy tehetségüknek megfelelően folytassák a beszámolót saját koruk eseményeinek

\footnotetext{
${ }^{110}$ Ezzel szemben az Eusebius egyháztörténete nyomán írt De viris illustribusban Hieronymus a keresztények mellett pogány, eretnek és zsidó szerzőkröl is tárgyalt, vö. Albrecht 2004, 111.

${ }^{111}$ Grützmacher 1901, 1,194; Kelly 2003, 507.

${ }^{112}$ Mulhberger 1990, 22.

${ }^{113}$ Hier., Chr. 2342: huc usque historiam scribit Eusebius Pamphili martyris contubernalis, cui nos ista subiecimus.

${ }^{114}$ Hier., Chr. praef.; Caspar 1926, 296; Croke 2007, 578.

${ }^{115}$ Kelly 2003, 121.

${ }^{116}$ Hofmann 1997, 418.

${ }^{117}$ Hier., Chr. praef. A kutatók számos hibát találtak a fordításban és az adatok pontosságában, az események bemutatásánál sok lényegtelen, pletykaszerü epizód is szerepel, a keresztények értékelése pedig meglehetősen elfogult, Kelly ezért Hieronymus történetírói tevékenységét egyenesen komolytalannak ítéli, vö. Kelly 2003, $122-123$.
} 
feljegyzésével. ${ }^{118}$ Mindez hozzájárult egy új irodalmi műfaj, a latin nyelvű világkrónika létrejöttéhez, amely népszerüsége miatt összekötő kapcsot jelent az ókori és a középkori történetírás között.

\subsection{A római hagyomány}

A keresztény világkrónikák kialakulásában vitathatatlanul nagy szerepe volt Eusebius és Hieronymus munkájának, de röviden azt is meg kell vizsgálnunk, hogy az annalisztikus hagyomány milyen hatást gyakorolt a nyugati történetírásra.

Az annalisztikus római történetírás kezdete visszanyúlik a tabulae annales évenkénti feljegyzéseire. A pontifexek által vezetett naptár (fasti) kezdetben a dies fasti és a dies nefasti listáját tartalmazta, később fokozatosan kibővült a fontosabb magistratusok és pontifexek nevével, az adott esztendőben történt vallási ünnepek és természeti jelenségek dátumával, valamint az éhínségek, a tüzvészek, a csaták és a diadalmenetek felsorolásával. ${ }^{119} \mathrm{Az}$ évenkénti feljegyzéseket tartalmazó táblákból kialakuló Annales Maximi egyaránt szolgált mintaként és adatbázisként a későbbi szerzők számára. ${ }^{120}$

A consullistákon alapuló consuli annalesek a hivatali időt kronológiai keretként használva röviden és sablonosan rögzítették a tisztségviselők nevén kívül az uralkodással és a természeti katasztrófákkal kapcsolatos eseményeket. ${ }^{121}$ Mivel az annalesek nélkülözték a stílusbeli díszítéseket és a személyes megnyilatkozásokat, szerzőjük és keletkezési dátumok általában nehezen megállapítható, ${ }^{122}$ ennélfogva nem tekintették őket valódi történeti munkának, inkább csak puszta adatforrásnak, ${ }^{123}$ egyszerüségük és tárgyilagosságuk miatt viszont már a 4. század elejétől népszerüvé váltak és segítették a világkrónikák szerzőinek munkáját. $^{124}$

A fastikban általában katonai, a naptárakban pedig az államélettel kapcsolatos feljegyzések kaptak helyet, de egyre nagyobb arányban találunk bennük a császári családra vonatkozó információkat. Nincs bizonyítékunk arra, hogy az 1. század után naptárakat, a 3.

\footnotetext{
118 Muhlberger 1990, 22-23.

119 Burgess 1988a, 20; Albrecht 2004, 273-274; Marincola 2007, 261-262; Adamik 2009, 65-66.

${ }^{120}$ Cic., De orat. 2,51-52; Havas - Németh - Szabó 2001, 60; Breisach 2004, 51. Az Annales Maximiról bővebben: Mellor 2002, 13-14; Albrecht 2004, 278-280; Marincola 2007, 70; Adamik 2009, 67-68; Mehl 2011, 37-40.

${ }^{121}$ Muhlberger 1990, 24.

122 Muhlberger 1990, 30.

${ }^{123}$ Iord., Rom. 388; Greg. Tur. 2,9; Cassiodorus nem is említi ezt a műfajt, talán mert nem tartja méltónak arra, hogy szerepeljen a katalógusában, vö. Muhlberger 1990, 24.

${ }^{124}$ A consuli annalesekről bővebben: Muhlberger 1990, 23-46.
} 
század után fastikat használtak volna az események datálásához, ${ }^{125}$ de a fasti kronológiai formájának és a rövidebb történetírói stílusnak a kombinálásával a 360-as években megjelentek a constantinopolisi breviariumok. ${ }^{126}$ A kora császárkorban megújult fastik legkorábbi darabja a Consularia Constantinopolitana, amely eredetileg a Kr. e. 509 és $\mathrm{Kr}$. u. 388 közötti consullistákat tartalmazta a császári, katonai, városi és vallási események kronológiai áttkintésével, nem tudjuk azonban, hogy erre a munkára mennyiben hatott Eusebius és a görög kronográfiai hagyomány. ${ }^{127}$ Úgy tünik, hogy miután 389-ben a Hydatius által is említett Cynegius ${ }^{128}$ és özvegye, Acanthia jóvoltából a Consularia Constantinopolitana Constantinopolisból nyugatra került, ${ }^{129}$ Italiában is keletkeztek olyan fastik, amelyek a sajátos datálási jelöléseket megtartva nagy segítséget nyújtottak az 5. századi szerzőknek krónikáik összeállításában. ${ }^{130}$

\subsection{Latin nyelvü világkrónikák}

\subsubsection{Hieronymus folytatói}

Kétségtelen, hogy a legtöbb latin nyelvű világkrónika valamilyen formában kapcsolódik Eusebius és Hieronymus munkájához, mert szerzőik saját koruk eseményeinek bemutatásával mindig naprakészen próbálták kiegészíteni elődjük történelmi beszámolóját, mégsem tekinthetjük azokat pusztán a „regional or local history” első próbálkozásainak. ${ }^{131}$

A Hieronymus munkáját folytató szerzők közül Prosper Aquitanus (390 k.-455) volt a legnépszerübb, aki Epitomé Chronicón címü mủvében a Teremtéstől 455-ig, Róma vandál kifosztásáig számolt be a világ történetéről, különös tekintettel a 412 utáni germánok támadásaira. ${ }^{132}$ Prosper az elbeszélést Ádámmal kezdte, de az Ábrahám születése és a Kr. u.

\footnotetext{
125 A fasti jellemzőiről és fejlődéséről lásd: Schön 1933; Degrassi 1952; Havas - Németh - Szabó 2001, 221225.

126 A 4. századi fastik közül a legjelentősebb a Consularia Italica, a Consularia Constantinopolitana és az alexandriai krónika, de a 354-es római Chronographia consullistája eredetileg nem tartozott ide, vö. CM $1,274-339 ; 1,205-247$.

127 Többen feltételezték, hogy a 326-370 közötti eseményekhez Hieronymus és a Consularia Constantinoplitana szerzője egyaránt használt egy mára már elveszett fastit, vö. Croke 1983, 87-88; Burgess 1988a, 22.

${ }^{128}$ Hyd. 18 .

${ }^{129}$ Muhlberger 1990, 197.

${ }^{130}$ Burgess 1988a, 23.

${ }^{131}$ Woods 2009, 360.

132 Prosper 427-435 között szerzetesként fanatikusan védte Augustinus nézeteit a semipelagianusokkal szemben, később Hilariusszal Rómába utazott és 440-ben a pápai kancellária munkatársa lett, ahol Leo pápa
} 
378 közötti időszak bemutatására egyszerüen a Canones kivonatát használta, majd ehhez az epitoméhoz hozzáillesztette saját folytatását két alkalommal is, 445-ben és 455-ben. ${ }^{133}$ Prosper a keresztrefeszítés előtti eseményeket nem próbálta datálni, ezt követően pedig két kronológiai rendszert alkalmazott az időpontok megjelöléséhez. Ő az első ismert nyugati történetíró, aki a fastik mellett a nyugatra került consulariákat is használta a datáláshoz, másrészt pedig figyelembe vette és megjelölte a Krisztus szenvedésétől eltelt időtávolságot is. ${ }^{134}$ Prospert tartjuk az 5. század legnépszerübb krónikásának, mert munkájához számos folytatás készült, de többen kivonatolták és összegezték is a szövegét. ${ }^{135}$

Szintén Hieronymus munkáját folytatta a 379-469 közötti események ábrázolásával a dolgozatunk fő tárgyát képező Hydatius, Aquae Flaviae püspöke, aki egyedülállóan részletes beszámolót nyújt Chronicájában az 5. századi Hispania történetéről és a császári hatalom felbomlásáról.

Hieronymus munkájából indult ki Marcellinus Comes (megh. 534) is, aki Hydatiushoz hasonlóan 379-től számolt be Chronicájában a keleti területek eseményeiről először 518-ig, majd 534-ig, a vandál birodalom visszahódításáig. ${ }^{136}$ Bár munkáját szerényen csak egyszerü computatiónak tartja, a császár titkáraként első kézből szerezhetett információkat Constantinopolisban. Marcellinus Comes Hieronymus teljes szövegét átvette, de a régi kronológiai jelölések helyett elsőként használt indictiókat az események datálásához, amelynek sajátosságaira érdemes külön is kitérnünk, hogy teljesebb képet kapjunk a korszak kronológiai jelöléseiröl.

A 3. század végétől gyakorlattá vált, hogy az események idejét a lakosságra kivetett adók kihirdetéséhez (indictio) képest is meghatározzák. Ilyen adóösszeírásokra 297-től ötévenként, 312 után tizenöt évenként került sor, később pedig már visszamenőleg is számítottak indictiót Augustus uralkodásának 15. évétől. ${ }^{137}$ Iustinianus császár 537-ben már kötelezően előírta, hogy a császári iratokat a consuli és az uralkodási évek mellett ${ }^{138}$ az

hatására mérséklődött a ragaszkodása Augustinus tanítása iránt. Prosper életéről és mủveiről lásd: Muhlberger 1990, 48-77; Humphries 1996; Hwang 2009.

${ }^{133}$ Prosper Chronicájának kiadásairól lásd: Muhlberger 1990, 78-126.

${ }^{134}$ Burgess 1988a, 32.

135 457-ben Aquitaniai Victor például már alapként használta a húsvéti táblák elkészítéséhez a Prosper által összeállított consullistát, vö. Muhlberger 1990, 276.

${ }^{136}$ Marcellinus Comes munkáját egy ismeretlen szerző is folytatta, de ez a kézirat 548-nál megszakadt, vö. Burgess 1993, 8.

${ }^{137}$ A 15 éves időbeosztás valószínüleg Egyiptom provinciában fejlődött ki, de azt nem sikerült igazolni, hogy Constantinus vagy Diocletianus vezette be ezt az időszámítási rendszert, vö. Hofmann 1997, 419; Gesztelyi Havas 1999, 251.

138 A consulok szerinti évjelölés korábban is sok problémát okozott, mivel a consulok Kr. e. 222 előtt valószínüleg az év bármely szakaszában elfoglalhatták a hivatalukat, Kr. e. 222-153 között többnyire március 
indictiók szerinti jelöléssel is el kell látni. ${ }^{139}$ A tizenöt évenkénti indictiót elsőként Dionysius Exiguus (500-545) szerzetes alkalmazta, akit 532-ben Bonifatius pápa egyik hivatalnoka bízott meg a húsvéti ünnepkör újraszámolásával a keleti és a nyugati egyházakban kialakult eltérés miatt. ${ }^{140}$ Dionysius latinra fordított számos zsinati határozatot, a Libellus de cyclo magno Paschae megírásakor pedig egyéb újításokat is bevezetett: elhagyta a consulok szerinti megjelölést, és az éveket már nem Diocletianus 284-ben kezdődő aerája szerint számolta, hanem Krisztus születésétől kezdve anno Domini megjelöléssel, mert nem akarta egy keresztényüldöző császár nevét használni munkájában. ${ }^{141}$

\subsubsection{Prosper folytatói}

Prosper munkáját elsőként Tunnunai Victor (megh. 570) folytatta, aki constantinopolisi számüzetésének idején a 444-565 közötti események leírásával a korszak legfontosabb latin nyelvű egyháztörténetét állította össze, emellett rövid összefoglalást nyújtott az északafricai vandálok történetéröl és közölte az öt patriarchatus vezetőinek listáját. ${ }^{142}$ Victor Chronicája a világ teremtésétől 565-ig tárgyalja az eseményeket, de ránk csak a 444-565 közötti rész maradt, munkájával azonban nemcsak egyszerüen folytatta Prosper művét,

1-jén, később január 1-jén léptek szolgálatba, ezért a naptári évvel rendszerint nem esett egybe a hivatali idő. Augustus kísérletet tett arra, hogy a consulok szerinti időszámítást kiszorítva az uralkodási vagy tribunusi évek alapján történő datálás terjedjen el, 541 után pedig a consuli hivatal megszüntetésével az uralkodási évek szerinti datálás vált jellemzövé, vö. Hofmann 1997, 419; Gesztelyi - Havas 1999, 243; 249.

${ }^{139}$ Iustin., Nov. 47. Ez a módszer sem volt alkalmas az évek pontos jelölésére, mert egyrészt az indictiós év szeptember 1-jén kezdődött, másrészt pedig általában csak azt adták meg a szerzők, hogy az adott indictiós ciklus hányadik évéröl van szó, azt viszont nem közölték, hogy melyik indictiós ciklusban járnak, mivel eredetileg az indictiókat nem sorszámozták. Ezek alapján az indictiókat többnyire csak más datálási jelölésekkel együtt alkalmazták, vö. Gesztelyi - Havas 1999, 251; Olajos 1999, 227.

${ }^{140}$ Dionysius az 532-626 közötti évekre az anatoliusi 19 éves ciklusok alapján március 22. és április 25. közötti intervallumban rögzítette a húsvét idejét, attól függően, hogy mikorra esik a tavaszi napéjegyenlőséget követő első telihold utáni vasárnap, ezáltal nyugaton is elterjesztette a húsvéti dátum kiszámításának alexandriai módszerét, vö. Vanyó 2007b, 391.

${ }^{141}$ PL 67,487. Számításai nem voltak pontosak, hiszen Krisztus születésének időpontját 4 évnyi tévedéssel, egy 19 éves ciklus első évére, Caesar és Paulus consulságának idejére, Róma alapításának 754. évében határozta meg, vö. Hofmann 1997, 420. Beda később már Dionysius aeráját veszi alapul és kiszámítja, hogy a világ teremtésétôl Krisztus születéséig 3952 év telt el, így általa nyugaton 532 után széles körben elterjedt a Krisztus születéséhez viszonyított időmeghatározás, vö. Stevens 1993, 27-51; Landes 1988, 140; Angenendt 2008, 254. A Kr. e. évszámítás azonban csak a 15. századtól válik elfogadottá, vö. Breisach 2004, 100; keleten ráadásul egymástól eltérő aerákat használtak a történetírók, ezért datálásaik 3-9 évnyi eltérést mutatnak a nyugati számításhoz képest, vö. Olajos 1999, 229.

${ }^{142}$ Victor Tunnuna város püspökeként részt vett az africai egyházban szervezett ellenállási akcióban, amikor Iustinianus császár a monofizitákkal való egyezségre törekedve elítélte a Három fejezetet, ezért monofizitaellenessége miatt többször számüzték, valószínüleg ez alatt kezdte írni történeti munkáját. 
hanem át is dolgozta a 444-455 közötti időszak anyagát. Úgy tünik, hogy nem törekedett kronológiai pontosságra, gyakran helytelenül datálta az eseményeket vagy felcserélte a sorrendjüket, mert ennél sokkal fontosabbnak tartotta megmutatni azt, hogy érdemes kiállni az ortodox tanítás mellett. Külön vizsgálat tárgyát képezi, hogy milyen kronológiai jelöléseket találunk Victor munkájában. A 444-457 közötti és az 501 utáni éveknél valószínüleg a nyugati mintát követve használta a Prospernél is megtalálható consullistákat, a 458-500 közötti események datálásánál viszont már a keleti hagyományra épített és gyakran nemcsak a szokásos módon, a hivatalban lévő consulokkal jelölte az időt, hanem az előző év tisztségviselőinek nevével is. ${ }^{143}$ A császárok számozása látszólag Prosperre nyúlik vissza, valójában Victor ezt is módosította, mivel a nyugati császárok sorrendje helyett csak a keletiek pontosságára ügyelt, a 15 évenkénti indictiót pedig csak egyetlen alkalommal használta. ${ }^{144}$

Victor művének folytatását Iohannes Biclarensis (540 k.-621) készítette el, amikor összefoglalta a keletrómai császárok és a nyugati gót királyok uralkodási éveit használva az 567-590 közötti eseményeket. ${ }^{145}$ A szerző a lusitaniai Scallabisban született, 559 körül Constantinopolisba ment, hogy latin és görög nyelvü tanulmányokat folytathasson, feltehetően innen hozta magával Victor munkáját Hispaniába, hogy ott néhány interpolatióval kiegészítve megjelentesse azt. ${ }^{146}$

Egy ismeretlen dél-galliai szerzőtől származik a Chronica Gallica ad annum CCCCLII, amely a Teremtéstől 452-ig foglalja össze az eseményeket, külön figyelmet szentelve a világi és az egyházi hatalom szétesésének. A szerző Hieronymus munkáját úgy folytatta, hogy a fontosabb kronológiai jelzéseket, az uralkodási éveket, az Ábrahámtól számított éveket és az olimpiászokat megtartotta, de nem törekedett arra, hogy pontosan lemásolja elődje feljegyzéseit. ${ }^{147}$ Egy későbbi, szintén Dél-Galliában keletkezett Chronica 511-ig követi az eseményeket, elsősorban a 452-es chronicára, Orosiusra és Hydatiusra támaszkodva. A krónika 379-cel indul, és csak epitoméként maradt fenn egyetlen kéziratban, azt is sokáig tévesen Sulpicius Severusnak tulajdonították. ${ }^{148}$ A 452-es gall krónikát és Prosper munkáját folytatta Marius Aventicensis (532-596) is 455-től 581-ig, fontos adatokat közölve a frankokról, a gótokról, a longobárdokról és a burgundokról. Egy

\footnotetext{
143 A post consulatum alkalmazására több nyugati példát is látunk, vö. Vict. Aquit., Chr. Pasch. 3,535-536; Marc. Com. 541-548.

144 Tunnunai Victor életéről és a Chronicáról bővebben: Széll 2008b, 5-12.

145 Biclarensis gót történetének elemzéséhez lásd: Horváth 1993, 16-22; Wolf 1999, 1-10.

${ }^{146}$ Isid., Vir. ill. 31.

${ }^{147}$ Burgess 1988a, 32. A 452-es galliai chronicáról bővebben: Muhlberger 1990, 136-192.

${ }^{148}$ Burgess 1988a, 32; Woods 2009, 369.
} 
ismeretlen itáliai szerző Prosper „koppenhágai folytatójaként” 625 körül megtartotta Prosper rövidített történetének nagy részét, a hozzákapcsolt új anyag consuli évkönyvekből és más ismeretlen munkákból származik. ${ }^{149}$

Van még két olyan szerző, Cassiodorus és Isidorus, akik müveiket és az utókorra gyakorolt hatásukat tekintve lényegesen felülmúlják az eddig említett krónikásokat, és bár tevékenységük túlmutat az általunk vizsgált időszakon, a krónikahagyomány és Hydatius munkájának pontosabb megértéséhez mégis szükségesnek látszik, hogy röviden megemlítsük őket.

Flavius Magnus Aurelius Cassiodorius ${ }^{150}$ (485-583) a szerzetesek képzésére összeállított Institutiones divinarum et saecularium litterarum címü munkájában kritikával illette a korábbi történetírókat, szerinte ugyanis Eusebius, Hieronymus és Prosper az eseményeket ékesszólással, de kevésbé választékosan mutatta be, ${ }^{151}$ éppen ezért munkájuk csak puszta árnyékai és rövid emlékeztetői lehetnek az elmúlt időknek. ${ }^{152}$ A negatív kritika ellenére a krónikaszerzők közé sorolja saját magát is, a Theoderic vejének ajánlott világkrónikája pedig éppen Prosper kivonatán alapszik, amelyet Consularia formájában a 456-519 közötti események rögzítésével folytatott. Korábban láttuk, hogy Prosper folytatói lényegesen átdolgozták a Hieronymustól és a Prospertől átvett részeket, de Cassiodorus különösen sokat rövidített és bizonyos egyházhoz kapcsolódó részeket ki is hagyott elödje beszámolójából. ${ }^{153}$ A perzsa, görög, zsidó és keleti gót királyok és a római uralkodók felsorolása mellett művének legnagyobb érdeme az a római consullista, amely mára már elveszett listák adatait is tartalmazza. ${ }^{154}$ Cassiodorus Historia Gothorum című munkáját Eutharic consuli kinevezésének alkalmából írta, kiemelve benne a gótok római történelemben betöltött szerepét, ezért müve egészen a 11. századig feledésbe merült és csak Iordanes 551-es kivonatában maradt ránk. A tanítványaival összeállított Historia ecclesiastica tripartita című munkája rendkívül népszerü volt a középkor iskoláiban, ${ }^{155}$ a

\footnotetext{
${ }^{149}$ CM 1, 249-339; Muhlberger 1984, 50-95.

150 A calabriai senatori családból származó szerző Theoderic szolgálatában állt magántitkárként 507-511 között, majd magas rangú hivatalokat töltött be, 538-ban pedig visszavonult a közéleti szerepléstől a Scyllaceum melletti birtokán alapított Vivarium-kolostorba, ahol irodalmi és tudományos munkának szentelte az idejét, vö. Brown 1999, 136; Adamik 2014, 85-86. A Vivarium müködéséről bővebben: Riché 2016, 156162.

${ }^{151}$ Cass., Instit. 1,17,1: lacteo quidem sed cautissimo nitore.

152 Cass., Instit. 1,17,2: imagines historiarum brevissimaeque commemorationes temporum.

153 Muhlberger 1990, 276.

${ }^{154}$ PL 69,1217-1226.

155 PL 69,879-1214.
} 
Variarum libri duodecim gyüjteménye pedig nagy forrásértékü leveleket és hivatalos aktákat tartalmaz. ${ }^{156}$

Cassiodorus mellett a középkori Európa müveltségére szintén döntő hatást gyakorolt Isidorus Hispalensis (560 k.-636), akinek enciklopédikus munkáit rendkívül kedvelték és sokáig tankönyvként is használták. ${ }^{157}$ Legnagyobb hatású müve az Etymologiarum sive originum libri $X X$, amely a kor tudásanyagát foglalta össze tudományágak szerint, a De viris illustribus címü művében Hieronymus, Gennadius és Pontianus nyomán írt keresztény irodalomtörténetet, Contra Iudaeos de fide catholica címü írásában pedig elsőként mutatta be Reccared gót király zsidókat korlátozó tevékenységét, akit fivére, Leander térített a katolikus hitre 587-ben. Chronica maiora címü világkrónikája Hieronymushoz és Tunnunai Victorhoz kapcsolódva a Teremtéstől 615-ig, Sisebut uralkodásának 4. évéig mutatta be az eseményeket az augustinusi 6 aetas felosztásának megfelelően. Isidorus újszerűen közelítette meg a világkrónika müfaját, mert a Teremtéstől kezdve párhuzamos táblázatok nélkül, a bibliai és a világi események összekeverésével ábrázolta az eseményeket. ${ }^{158} \mathrm{~A}$ Chronica 627-ig tartó rövidebb változatát Isidorus tanítványa, Braulius az Etymologiae 5. könyvéhez csatolta. A nyugati gótok történetét 624-ig feldolgozó Historia Gothorum két változatban maradt fenn, az egyiket 619-ben, Sisebut halálakor, a másikat 624-ben fejezte be. ${ }^{159}$ Később a Historia Gothorum egyik példányát két rövidebb részlettel, a Historia Vandalorummal és a Historia Suevorummal egészítette ki, és ezt az új királynak, Sisenandnak ajánlotta. ${ }^{160}$ Isidorus forrásként elsősorban a legjobb világkrónikákat, Hieronymus, Prosper, Hydatius, Tunnunai Victor és Iohannes Biclarensis munkáját használta fel, és nála mutatható ki elsőként Orosius hatása.

\footnotetext{
156 Cassiodorus életéről és műveiről bővebben: PL 68-70; CCSL 96-97; Albrecht 2004, 1208-1212; Vanyó 2007b, 399-400; Adamik 2014, 85-105; a Variae elemzéséhez lásd: Gillett 2003, 172-219.

157 Isidorus Hispalisban született előkelő családban, apja Athanagild gót király magas beosztású tisztségviselője volt. Mivel korán árva lett, legidősebb testvérére, Leander (549-600) hispalisi érsekre bízták a nevelését, aki nemcsak óriási hatást gyakorolt rá, hanem 600 körül Isidorus őt követhette az érseki székben is. Sisebut 612-es hatalomra lépésétől Isidorus rendkívül nagy befolyásra tett szert, 633-ban ő elnökölt a negyedik toletumi zsinaton. Isidorus életéről és müveiről bővebben: Vanyó 2007b, 404-405; Székely 2008, 11-15; Adamik 2014, 389-418.

158 Johnson 1993, 14.

${ }^{159}$ Isidorus gót történetének elemzéséhez lásd: Horváth 1993, 16-22; Wolf 1999, 11-24.

${ }^{160}$ Székely 2008, 14; Adamik 2014, 407.
} 


\subsubsection{Hydatius krónikája}

\subsubsection{Hydatius élete és müvei}

Hydatius a gallaeciai Lemicában született 400 körül, ${ }^{161}$ szülei feltehetően keresztények voltak és Hispania társadalmának jómódú középosztályába tartoztak, apja valószínüleg állami vagy katonai hivatalt töltött be. ${ }^{162}$ Bár Hydatius nagyra tartja Theodosius tevékenységét, ${ }^{163}$ nem tünik megalapozottnak az a feltételezés, mely szerint Hydatius családja a Theodosius köré szerveződö hispaniai körhöz tartozott volna, amelynek tagjai vallásosságuk miatt elősegítették a császári udvar és a keresztény egyház közötti kapcsolat erősödését. ${ }^{164}$ Hydatius ugyan említi, hogy a kör egyik vezéralakja, Maternus Cynegius dicső tetteket hajtott végre és lerombolta a pogány templomokat Egyiptomban és Mezopotámiában, ${ }^{165}$ de ez minden bizonnyal csak a tájékozottságát mutatja, nem pedig azt, hogy ténylegesen kapcsolatban állt volna ezzel a csoporttal. ${ }^{166}$ Bizonyítékok híján Burgesszel egyetértve ${ }^{167}$ ugyancsak elutasíthatjuk Molé azon elképzelését, hogy Hydatius városi származása miatt lenézte volna a vidéki lakosságot, és inkább azzal a földbirtokos arisztokráciával szimpatizált, amely a császári hatalommal szembefordulva a barbár megszállókkal próbált szövetségre lépni. ${ }^{168}$

Többen feltételezték, hogy Hydatius családja rokonságban állt azzal a priscillianusellenességéről ismert Hydatiusszal, aki a lusitaniai Emerita püspöke volt a 4. század második felében, de erre a névazonosságon kívül semmi sem utal. ${ }^{169}$ Ha rokonok lennének, Hydatius minden bizonnyal említette volna híres elődjét a priscillianusokkal kapcsolatban. ${ }^{170}$ Nem lehet azonban véletlen, hogy az emeritai Hydatiusról a következő nemzedékben két püspököt is elneveztek: az egyiket Gallaeciában, a másikat pedig

\footnotetext{
${ }^{161}$ Hyd. praef. 1. Lemica civitas vagy civitas Limicorum, vö. CIL 2,2516-2517; Ptolemaius 2,6,44, ma Nocelo da Pena városa Hispania Tarraconensis területén, 12 kilométerre Xinzo de Limiától, vö. Burgess 1988a, 6; Candelas-Colodrón 2004, 17-35.

${ }^{162}$ Ha Hydatius családja a társadalom alsó rétegéhez tartozott volna, nem valószínű, hogy később püspökké szentelhették volna, vö. Torres Rodriguez 1956, 766; Jones 1964, 1,920-929; Tranoy 1974, 1,10; Burgess 1988a, 12; Candelas-Colodrón 2004, 40-55; Arias 2007, 4.

${ }_{163}$ Muhlberger 1990, 197; Gelarda 2008-2009, 296.

${ }^{164}$ Matthews 1975, 140-145.

165 Hyd. 18.

166 Burgess 1988a, 13. Torres Rodríguez szerint néhány évvel később egy Theodosius köréhez tartozó hivatalnok kísérte el Hydatiust a szenföldi zarándoklatra, vö. Torres Rodríguez 1956, 766-767.

${ }^{167}$ Burgess 1988a, 11-12.

168 Molé 1974, 290-294; 303-341; 347-351.

169 Burgess 1993, 3.

${ }^{170}$ Hyd. 13; 16.
} 
Galliában, éppen a priscillianus-mozgalom két nagy központjában. ${ }^{171}$ Ezek alapján valószínü, hogy a szülök csupán Hydatius iránti tiszteletük jeléül nevezték el így gyermeküket, és nem álltak vele semmilyen rokoni kapcsolatban. ${ }^{172}$

Hydatius 406-407 körül kisfiúként részt vett egy szentföldi peregrinatión Alexandriában, Caesareában, Hierosolymában és Betlehemben, ${ }^{173}$ ahol rendkívül nagy hatást gyakorolt rá, hogy látott jó néhány híres, a krónikában is említett püspököt, köztük Iohannest, Eulogiust, Theophilust és mindenekelőtt Hieronymust. ${ }^{174}$ Hydatius önmagát itt árva kisfiúnak (infantulus et pupillus) nevezte, így elképzelhető, hogy ekkorra már elveszítette apját vagy mindkét szülöjét, de Isidorus és Hieronymus értelmezése szerint az is lehet, ${ }^{175}$ hogy csak nagyon fiatal korára akart utalni ezzel a kifejezéssel. ${ }^{176}$ Mindenesetre elfogadhatjuk azt az álláspontot, hogy szülei igyekeztek alapos nevelést biztosítani számára, amelyhez hozzátartoztak a nagyobb utazások és talán az irodalmi tanulmányok is, ${ }^{177}$ azt viszont nem tudjuk, hogy az ortodox nevelésen kívül részesült-e valamilyen vallási képzésben. ${ }^{178}$ Hydatius feltehetően még 409 októbere elött visszatért Gallaeciába, amikor az alánok, a vandálok és a szvévek betörtek Hispaniába. ${ }^{179}$ Valószínüleg azért nem tudunk arról, hogy Hydatius a kortársaihoz hasonlóan ${ }^{180}$ tanulmányai folytatása érdekében elhagyta volna Gallaeciát, mert a barbárok betörése miatt a lakosság nagy része saját lakóhelyén

\footnotetext{
${ }^{171}$ Leo, Ep. 99; Hilar., Ep. 10; Burgess 1988a, 8; Muhlberger 1990, 198.

172 Burgess 1993, 4.

${ }^{173}$ Burgess 1988a, 14; Muhlberger 1990, 196; Candelas-Colodrón 2004, 77-85.

${ }^{174}$ Hyd. praef. 4; 33.

175 Isid., Etym. 11,1,37; 11,2,12; Hier., Tract. in Psalm. 1,280,13.

176 Burgess szerint Hydatius 400-ban született, így a zarándoklat idején körülbelül 6-7 éves volt, ezt Hydatius is alátámasztja a két önmegjelöléssel, ezért ez a feltételezés tünik a legvalószínübbnek, vö. Burgess 1988a, 910. Más kutatók viszont úgy látják, hogy Hydatius 12-13 évesen vett részt a zarándoklaton, ezért születését 394-395 körülre datálják, vö. Mommsen 1894, 4; Seeck 1921, col. 40; Tranoy 1974, 1,12-13; Thompson 1982, 139; Muhlberger 1990, 197. Brown szerint Hydatius 10 éves volt és anyjával utazott, Gelarda és Vilella 391-395 körüli születést és 406-408 körüli zarándoklatot valószínüsít, Johnson pedig felületesen 390-400 közötti születésről ír, vö. Brown 1999, 62; Gelarda 2008-2009, 296; Vilella 1999, 41; Johnson 1993, 6.

177 Muhlberger 1990, 199. Molé Hydatius előkelő származását azzal próbálja igazolni, hogy a zarándoklaton személyesen találkozhatott az említett püspökökkel, Brown szerint pedig Hieronymusnak egyenesen be is mutatták a tízéves kisfiút, Hydatius azonban csak annyit mond, hogy látta (vidisse me certus sum) öket az utazás során, vö. Hyd. praef. 4; Molé 1974, 291; Brown 1999, 62; Burgess 1988a, 12.

178 Candelas-Colodrón 2004, 56-76. Bár a későbbi püspökké szentelésnek nem volt feltétele a vallási területen szerzett képzettség, elképzelhető, hogy Bracarában vagy Aquae Flaviae városában a helyi püspök foglalkozott Hydatiusszal, vö. Burgess 1988a, 199.

${ }^{179}$ Hyd. 34.

${ }^{180}$ Orosius például Bracarából Hippóba utazott Augustinushoz, vö. Oros. 3,20,5-10; 5,2,1-2; Burgess 1988a, 199.
} 
maradt és a korábban jómódú szülei minden bizonnyal elszegényedtek, ez a gyerekkori élmény pedig szintén mély nyomot hagyhatott Hydatius emlékezetében. ${ }^{181}$

Több kutató szerint 416-ban megtért és elkezdett vallásos életet élni, ${ }^{182}$ később pedig a helyi közösség életében nagy tekintélyt kellett szereznie, ${ }^{183}$ mert 427 -ben, alig harminc évesen ${ }^{184}$ püspökké választották ${ }^{185}$ Aquae Flaviae városában. ${ }^{186}$ Amikor 431-ben a szvévek Gallaeciába szorultak vissza és fosztogatni kezdték a hispán-római lakosságot, Hydatius bekapcsolódott a politikai életbe és követséget vállalt a Galliában hadjáratot tartó Aëtiushoz, 432-ben Censoriusszal, a császári követtel tért vissza, egy évvel később pedig megerősítette a gallaeciabeliekkel kötött békét. ${ }^{187}$

445-ben Thoribius, Asturica új püspöke Leo pápa támogatásával Hydatius és Caeponius segítségét kérte levélben a manicheusok elleni küzdelemhez. ${ }^{188}$ A két püspök lelkesen kutatta fel a bujkáló manicheusokat, közülük jó néhányat fel is jelentettek Antoninusnál, Emerita püspökénél. ${ }^{189}$ Thoribius 447-ben Leo pápától ismét segítséget kért az eretnekek elleni küzdelemhez. Ebben az elveszett levélben ${ }^{190}$ minden bizonnyal megnevezte munkatársaként Hydatiust, mert Leo Thoribiusnak írt 447. július 21-ei

${ }^{181}$ Jones 1964, 1,997-998; Burgess 1988a, 13. Gelarda ugyanakkor feltételezi, hogy a korábbi zarándoklat egy menekülési kísérlet volt Hydatius szülei részéröl a barbárok várható betörése miatt, vö. Gelarda 2008-2009, 296.

${ }^{182}$ Seeck 1921, col. 40; Thompson 1982, 139; Campos 1984, 64; Muhlberger 1990, 198; Candelas-Colodrón 2002a, 288-290. Burgess interpolatiónak tartja, ezért elutasítja Flórez erre vonatkozó feljegyzését, amely a krónika 570-es években készített epitoméjában szerepel, vö. Hyd. 62b: Idatii ad deum conversio peccatoris; Burgess 1988a, 14. Johnson szerint a conversio kifejezés konkrétan pappá szentelést jelent, azt viszont ő sem valószínüsíti, hogy Hydatius szerzetes lett volna, vö. Johnson 1993, 7.

${ }_{183}$ Pawlak szerint Hydatiusnak származása miatt is természetes volt, hogy aktívan szerepet vállaljon a társadalmi életben, vö. Pawlak 2007, 29.

${ }^{184}$ Hyd. praef. 1; 6. Gelarda szerint 424-427 között, vö. Gelarda 2008-2009, 296; Díaz szerint 427-ben vagy 428-ban, vö. Díaz 2011, 41; Burgess szerint 428-ban, vö. Burgess 1988a, 219; Burgess 1993, 4. Molé hivatkozik Siricius pápa egyik 385-ös levelére, mely szerint egy klerikust leghamarabb 45 éves korában lehetett püspökké választani, ezért Hydatius biztosan jóval korábban, 390-391 körül született, vö. PL 56,560; Molé 1974, 286-289. Hydatius azonban ebben az esetben sem érte volna el a minimumkorhatárt, ráadásul azt sem tudjuk, hogy az 5. század eleji Hispaniában érvényben volt-e még ez a szabály, vö. Burgess 1988a, 11.

${ }^{185}$ Nem tudjuk azt sem, hogy Hydatius korábban milyen egyházi hivatalokat töltött be, de fiatal kora miatt valószínű, hogy néhányat ugrott az egyházi hierarchiában, vö. Burgess 1988a, 202.

${ }^{186}$ Hyd. praef. 1; praef. 6. Thompson kétségbe vonja Mommsen azon feltételezését, hogy Hydatius Aquae Flaviae püspöke lett volna, mivel szerinte a városnak sohasem volt püspöki rangja, és csak annyit ismer el, hogy Hydatius egy „eminent churchman” volt, vö. Thompson 1982, 140. Muhlberger azt feltételezi, hogy a város püspöki székét a 6. század eleji zürzavaros helyzetben szüntették meg, vö. Muhlberger 1990, 197. Több kutató vizsgálta azt a lehetőséget is, hogy Hydatius lehetett-e egy másik város püspöke, vö. Torres Rodríguez 1956, 775; Molé 1974, 289-290; Collins 1983, 14; Burgess 1988a, 15; Candelas-Colodrón 2002a, 287-294; Díaz 2011, 36. Aquae Flaviae korabeli helyzetéről lásd: Candelas-Colodrón 2004, 143-152.

${ }^{187}$ Hyd. 86; 88; 91.

${ }^{188}$ Thor., Ep. ad Hyd. et Cep., in: PL 54,693-695.

${ }^{189}$ Hyd. 122.

${ }^{190}$ Muhlberger 1990, 195. 
válaszában ${ }^{191}$ már név szerint kérte Hydatius és Caeponius segítségét a priscillianizmus visszaszorításában és a katolikus hit helyreállításában. ${ }^{192}$

460. július 26-án három besúgó (delatores) ösztönzésére Frumarius szvév csapatai elfogták Hydatiust és feldúlták Aquae Flaviae kolostorát a környező területekkel együtt. ${ }^{193}$ Novemberben, háromhónapnyi fogság után valószínüleg a gallaeciabeliek és a szvévek közötti látszólagos béke jegyében szabadon engedték Hydatiust, aki azt állítja, hogy nem Frumarius vagy a szvévek, hanem az említett besúgók akarták őt félreállítani, az viszont nem derül ki, hogy pontosan miért. ${ }^{194}$ Hydatius itt említi önmagát utoljára a krónikában. Az utolsó feljegyzett esemény 468-ra ${ }^{195}$ vagy 469-re ${ }^{196}$ datálható, így valószínüleg 469 elején, közel hetven évesen fejezte be az írást. Feltehetően röviddel ezután, vagy Pseudo-Isidorus szerint Leo uralkodása alatt, tehát 474 előtt halt meg. ${ }^{197}$

\subsubsection{A Chronica forrásai}

Hydatius többnyire nem nevezte meg az általa használt forrásokat, ezért csak néhány kutató foglalkozott ezzel a témával részletesebben, ${ }^{198}$ pedig a feltételezhető források száma és sokfélesége jól rávilágíthat Hydatius valódi jelentőségére. Maga Hydatius is jóval többet mond a krónika bevezetőjében saját forráshasználatáról, mint más szerzők a késő antikvitásban. ${ }^{199}$ Állítása szerint háromféle módon tudott információkhoz jutni: hozzáférhetett bizonyos írott forrásokhoz (ex studio et stilo scriptorum), rendelkezésére álltak tudósítók hiteles szóbeli jelentései (ex certo aliquantorum relatu et relationibus indicantum), de saját tudását és tapasztalatait (ex cognitione et studio) is beépítette a feljegyzések szövegébe. ${ }^{200}$ Igyekezett meggyőzni az olvasóit saját lelkiismeretességéről és megbízhatóságáról a források kezelésével kapcsolatban, ugyanakkor fordulópontnak tekinti püspöki kinevezését, ${ }^{201}$ mivel a közügyekben vállalt vezető szerepe miatt sokkal több és

\footnotetext{
${ }^{191}$ Leo, Ep. 15,17, in: PL 54,677-692.

192 Hyd. 127.

193 Hyd. 196.

194 Hyd. 199; 202.

195 Courtois 1951, 51; Burgess 1993, 5.

196 Thompson 1982, 138; Burgess 1988a, 19; Muhlberger 1990, 199.

197 PL 83,1088-1089.

198 Tranoy 1974, 1,50-55; Burgess 1988a, 33-72; Muhlberger 1990, 204-212; Cardelle de Hartmann 1994, 17-23; Candelas-Colodrón 2004, 327-344.

${ }^{199}$ Muhlberger 1990, 204.

${ }^{200}$ Hyd. praef. 5-6. Ezek az információforrás-típusok a legtöbb korabeli krónikára jellemzőek, vö. Johnson 1993, 20.

${ }^{201}$ Hyd. praef. 6.
} 
pontosabb forráshoz is hozzá tudott jutni, ${ }^{202}$ bár siralmas öregsége (lacrimabile propriae vitae tempus) megnehezítette a krónikaírás nehéz folyamatát. ${ }^{203}$

Sokáig Hydatius nevéhez kapcsolták és a Chronica legfontosabb forrásának tartották a korábban említett Consularia Constantinopolitana egyik változatát, amelynek több szerzője és szerkesztője volt. A feltételezések szerint Hydatius lehetett a Kr. e. 509 és Kr. u. 395 közötti események másolója és a 396-468 közötti lista első szerkesztője is, amelyet tovább erősített az a tény, hogy a Chronica és a Consularia egyaránt Phillips 1829-es $(B)$ kéziratára vezethető vissza. Bár Muhlberger igyekezett feltárni a két szöveg hasonlóságának bizonyítékait, ${ }^{204}$ egyetérthetünk a kutatók többségével, mely szerint csak fenntartásokkal fogadható el, hogy Hydatius forrásként használta és folytatta a Consulariát. ${ }^{205}$ Hydatius és Prosper szövegének belső bizonyítékai alapján valószínűleg létezett egy mára már elveszett galliai krónika, amelynek a 410-439 közötti beszámolóját mindketten forrásként használták, ugyanakkor a kutatások azt mutatják, hogy Hydatius nem ismerte sem Prosper munkáját, sem a 452-es krónikát. ${ }^{206}$

Hydatius Martinus Turonensis életrajzírójaként ${ }^{207}$ megemlíti Sulpicius Severust, akinek történeti feljegyzéseit forrásként használhatta a priscillianizmus eredetének meghatározásakor. ${ }^{208}$ Sulpicius két kötetes Chronicája Eusebiusig és Tacitusig visszanyúlva vázlatszerűen foglalta össze a bibliai eseményeket a Teremtéstől 400-ig azok számára, akik a Szentírást nem tudják olvasni. A szerző elsősorban kronológiai pontosságra törekedett és igyekezett egyesíteni az egyháztörténetet a világi eseményekkel. ${ }^{209}$

Hydatiusnak ismernie kellett Hieronymus jó néhány munkáját és fordítását, mert azt állítja, hogy számtalan művet (studia operis innumera) hagyott hátra, ráadásul nagyszerü munkái (probatissima monimenta) fennmaradtak. ${ }^{210}$ Bár személyét rendkívül nagyra tartja fordításai és a pelagianusokkal szemben vívott sikerei miatt, Eusebius-fordításán kívül nem

\footnotetext{
${ }^{202}$ Muhlberger 1990, 205.

${ }^{203}$ Hyd. praef. 5.

${ }^{204}$ Muhlberger 1990, 205.

205 Burgess 1988a, 35-50; Cardelle de Hartmann 1994, 24-38.

206 Burgess 1988a, 50-55; Cardelle de Hartmann 1994, 20. Burgess fasti miscelli néven azonosít három olyan annalisztikus forrást, amelyet Hydatius valószínüleg felhasznált a krónika összeállításakor, vö. Burgess 1988a, 57.

${ }^{207}$ CSEL 1,1-105.

208 Hyd. 30.

${ }^{209}$ Cardelle de Hartmann 1994, 19; Albrecht 2004, 1112. Sulpicius Severus történelemfelfogásáról lásd: Havas - Takács - Tegyey 2001, 261-262; Sulpicius Severus és Paulinus Nolanus müvének jelentőségéről bővebben: Wieser 2016, 89-91.

${ }^{210}$ Hyd. 51.
} 
utal Hydatius konkrét munka felhasználására. ${ }^{211} \mathrm{Az}$ általa lefordított húsvéti levelekben ${ }^{212}$ olvashatott többek között Theophilus alexandriai patriarcha 399-ben kiadott húsvéti időrendi számításairól is. ${ }^{213}$ Hydatius elismerően szól Paulinus nolai püspök fennmaradt műveiröl, de jól ismerhette Merobaudes irodalmi tevékenységét is, ${ }^{214}$ aki Ravennába kerülve Aëtius udvari költője lett és consulságát több alkalommal is megénekelte verseiben.

Különös, hogy Hydatius egyáltalán nem említette azokat a kortárs szerzőket, akik hozzá hasonlóan Hispaniából származnak és nagy népszerüséget szereztek. A magas állami hivatalt is betöltő Aurelius Prudentius Clemens (348-410 k.) nagy tehetségü lírai költőnek számított, különösen a hispaniai és az italiai mártírok életéről írt versei miatt. ${ }^{215}$ Ennél is meglepőbb, hogy egyáltalán nem hivatkozik a szintén gallaeciai Orosius (385 k.-420) történetírói munkásságára, pedig ő is szembeszállt az eretnek tanításokkal, ${ }^{216}$ az Augustinus ösztönzésére írt Historiae adversum paganos 7 könyvében pedig a Teremtéstől 417-ig foglalta össze a görög és a római világtörténet eseményeit, részletesen beszámolva a barbárok hispaniai betöréséről és tevékenységéről.

A priscillianizmussal kapcsolatban Hydatius két egyházi forrást említ. Priscillianus galliai és italiai utazásakor Sulpicius Severus Chronicájára nyúlik vissza, ${ }^{217}$ másolatokból pedig ismerhette a 400 körül megtartott toletumi zsinat határozatait is. ${ }^{218}$ Bár Hydatius nagy érdeklödést mutatott Priscillianus tevékenysége iránt, úgy tünik, nem használt más erre vonatkozó forrást, ${ }^{219}$ ismerhette viszont Augustinus munkái közül azokat, amelyekkel a donatisták ellen ért el sikereket. ${ }^{220}$

Hydatius több alkalommal is beszámolt a püspökök egymás közötti levelezéséröl, amelyekben nemcsak vallási kérdések szerepeltek, hanem csodajelek és égi jelenségek is helyet kaptak. ${ }^{221}$ Szent Stephanus ereklyéinek megtalálásáról Avitus és Lucianus presbyterek levelében olvashatott, ${ }^{222}$ de ismerte Iohannes püspök csodajelekről és

\footnotetext{
${ }^{211}$ Muhlberger 1990, 206.

${ }^{212}$ Hier., Ep. 96; 98; 100, in: CSEL 55,159-181; 185-211; 213-232.

${ }^{213}$ Hyd. 5; Tranoy 1974, 2,14.

214 Hyd. 72; 120.

215 Chadwick 1999, 202.

${ }^{216}$ Commonitorium de errore Priscillianistarum et Origenistarum címü munkáját a priscillianizmus ellen írta 414-ben, a Liber apologeticus contra Pelagianos pedig Pelagius tanítása ellen született 415 körül.

${ }^{217}$ Hyd. 13; 30; vö. Sulp. Sev., Chr. 2,48; Tranoy 1974, 1,52.

${ }^{218}$ Hyd. 25; vö. Mansi 3,997-1020; Tranoy 1974, 1,53; 2,27-30; Cardelle de Hartmann 1994, 20.

${ }^{219}$ Muhlberger 1990, 206.

${ }^{220}$ Hyd. 45. Augustinus eretnekségek elleni írásairól bővebben: Albrecht 2004, 1353-1356.

${ }^{221}$ Burgess 1988a, 59-64; Muhlberger 1990, 207-208.

${ }^{222}$ Hyd. 50; Cons. Const. 415; vö. PL 41,805-818.
} 
földrengésekről szóló írásait (scripta), ${ }^{223}$ és Paulinus közkézen forgó levelét (epistola ubique directa), amelyben a galliai Biterraeben tapasztalt rettenetes előjelekről tudósított. ${ }^{224}$ Hydatius birtokában lehetett egy levél másolatának, amelyet az alexandriai Cyrill küldött Nestoriusnak Constantinopolisba még 431-es leváltásuk előtt. ${ }^{225}$ A 440-es évek közepén a hispaniai püspökökhöz hasonlóan ő is megkaphatta Leo pápa manicheusokról szóló jelentéseit és Thoribiuson keresztül a pápai hatalom növekedését tárgyaló 444-es decretumot. ${ }^{226}$ Galliából elküldték neki a Leo és más püspökök közötti levélváltás darabjait is, amelyeket 450 körül az egész egyházban szétküldtek különböző jelentésekkel és írásokkal együtt, ${ }^{227}$ ezen kívül ismerhette az augustodunumi Eufronius püspök Agrippinusnak címzett levelét is, amelyben beszámolt a 451-es galliai égi jelenségekről. ${ }^{228}$ Ezek a levelek jól mutatják, hogy a távoli provinciákban müködő püspökök is rendelkeztek bizonyos mértékű információval a kiterjedt pápai levelezésnek köszönhetően, ${ }^{229}$ ugyanakkor 451 után már nem találunk püspökök közötti levelezésre vagy zsinati beszámolóra való utalásokat Hydatiusnál. ${ }^{230}$

Ahogyan korábban láttuk, Hydatius arról tájékoztatja az olvasóit, hogy 427 előtt leginkább hiteles szóbeli beszámolókra támaszkodott, ${ }^{231}$ püspökké szentelésétől azonban már saját ismeretei is voltak az eseményekről. Valóban logikus lenne, hogy Hydatiusnak ilyen magas egyházi pozícióban a korábbinál nagyobb rálátása legyen az eseményekre, de Muhlberger meggyőzően igazolta, hogy éppen a 427 utáni időszak beszámolójában mutatható ki gyakrabban a szóbeli hagyomány jelenléte. ${ }^{232}$ Hydatius többször utalt is arra, hogy szóbeli értesülésekből szerezte információi egy részét, Gaisericről például azt beszélték (dictus est), hogy a katolikus hitről tért át az arianus hitre, a rossz nyelvek szerint (ut malum fama dispergit) pedig Valentinianus özvegyének hívására érkezett Rómába. ${ }^{233}$ Hasonló módon, egyesek és mások (alii dicunt... alii) véleményére támaszkodva számol be

\footnotetext{
${ }^{223}$ Hyd. 58; Cons. Const. 419.

${ }^{224}$ Hyd. 65.

225 Hyd. 100.

${ }^{226}$ Hyd. 125; 127; vö. Leo, Ep. 15,19, in: PL 54,677-692.

227 Hyd. 137: De Gallis epistolae deferuntur Flaviani episcopi ad Leonem episcopum missae cum scriptis Cyrilli episcopi Alexandrini ad Nestorium Constantinopolitanum de Eutychete Hebionita heretico et Leonis episcopi ad eumdem responsa, quae cum aliorum episcoporum et gestis et scriptis per ecclesias diriguntur. Tranoy és Burgess megpróbálta azonosítani a szóban forgó leveleket, vö. Tranoy 1974, 2,90-91; Burgess 1988a, 224-225.

${ }^{228}$ Hyd. 143.

${ }^{229}$ Muhlberger 1990, 208.

230 Thompson 1982, 144-145.

${ }^{231}$ Hyd. praef. 5-6. Az időszak szóbeli forrásainak elemzését lásd: Burgess 1988a, 64-65.

${ }^{232}$ Muhlberger 1990, 210.

${ }^{233}$ Hyd. 79; 160.
} 
Aegidius halálának körülményeiről, a 431-es első ephesusi zsinatról szóló részletes feljegyzés azonban számos tévedést tartalmaz annak ellenére, hogy bizonyos görög források (aliorum Grecorum relatione) és tudósítók nyilatkozatai (referentum sermo), többek között Germanus, az arab területek presbyterének beszámolója is a rendelkezésére állt. ${ }^{234} \mathrm{Az}$ Aëtius 430-432-es galliai hadjáratáról szóló beszámoló biztosan a szerző saját tapasztalataiból származik, hiszen 431-432 telén feltehetően a galliai Arelatéban tartózkodott. ${ }^{235}$

Az uralkodók dinasztikus eseményeiről, a fontosabb katonai müveletekről és néhány csodajelről Hydatius valószínüleg követek útján hivatalos jelentéseket is kapott, de ezekkel kapcsolatban semmilyen konkrét információnk nincs. ${ }^{236}$ Bár a 455 utáni időszakban gyakran hallunk a rómaiak és a barbár uralkodók közötti követváltásról, ${ }^{237}$ Hydatiushoz valószínűleg csak szóbeli híradások juthattak el, ahogyan ő is csak a tudósítók szóbeli jelentéseit említette $^{238}$ és soha nem hivatkozott konkrét levélre, szerződésre vagy más írásban rögzített dokumentumra. ${ }^{239}$ Gillett ugyanakkor feltételezi, hogy a követjárásokról szerzett információk saját tapasztalatain és szóbeli értesülésein kívül akár levelezésekből is származhatnak, ${ }^{240}$ erre vonatkozóan a nehézkes információáramlás okait és következményeit a későbbiekben vizsgáljuk majd meg.

\subsubsection{Kronológia és kézirati hagyomány}

A világkrónikák egyik általános jellemzője, hogy a közelmúlt eseményeit vagy akár az egész történelmet csak röviden jegyezték fel, és ehhez elnagyolt kronológiai rendszert használtak, beszúrva a különböző datálási jelöléseket az összegyüjtött események mellé. ${ }^{241}$ Hydatius igyekezett pontosan megőrizni Hieronymus szövegének kronológiai kereteit, ${ }^{242}$ így az oldalak közepén lévő hasábban jegyezte fel a történeti eseményeket, a bal oldali margón futnak a császárok uralkodási évei, a jobb oldalon pedig további négy kronológiai

\footnotetext{
${ }^{234}$ Hyd. 224; 97. Burgess irónikusan megjegyzi, hogy Hydatius annyira büszke volt arra, hogy találkozott Germanusszal és a görög hírforrásaival, hogy az olvasóinak nemcsak azt mondja el, amit hallott tölük, hanem azt is, amit nem, vö. Burgess 1988a, 213.

${ }^{235}$ Hyd. 86.

${ }^{236}$ A követektől kapott hírek elemzését lásd: Burgess 1988a, 65-69.

${ }^{237}$ Hyd. 163; 169-170; 179; 192; 226-227; 238; 241.

${ }^{238}$ Hyd. praef. 6.

${ }^{239}$ Muhlberger 1990, 211.

${ }^{240}$ Gillett 2003, 51.

${ }^{241}$ Muhlberger 1990, 2

242 Burgess 1993, 59.
} 
jelölés segíti az események pontosabb időbeli elhelyezését. ${ }^{243}$ Hydatius követte az uralkodási és a consuli évek megjelölését, ez viszont ritkán esett egybe a naptári évvel, így csak akkor volt alkalmas pontos időmegjelölésre, ha ismert volt az uralkodói regnálás hosszúsága, vagy ha más kronológiai jelölések is segítettek a datálásban. ${ }^{244}$

Hydatius a Canones alapján tovább folytatta a négyévenkénti olimpiászok felsorolását, de ezek uralkodási évekhez viszonyított elhelyezése nem mutat szabályosságot, használatuk Burgess és Thompson szerint nem következetes, ${ }^{245}$ ráadásul ahogyan Eusebiusnál, úgy Hydatiusnál sem tudjuk, hogy az év elejétől vagy a közepétől számolta az olimpiászokat. ${ }^{246}$ Feltételezhető, hogy Eusebiushoz hasonlóan ő is csak utólag kapcsolta hozzá ezeket a krónika befejezett kronológiájához, és valójában nem volt tisztában az olimpiászok jelentésével és használatuk szabályaival, ${ }^{247}$ ahogyan ez látszik az Arcadius és Honorius trónra lépésekor közölt zavaros megjegyzésnél is. ${ }^{248}$ Eusebius és Hieronymus gyakorlatát követve folytatta az Ábrahám születésétől, Kr. e. 2016-tól számított dekádok számozását is, de mivel a Hieronymusnál megjelölt 2390. évet tévesen a Kr. u. 373. évvel azonosította, az Ábrahám születésétől számított 2400. év Theodosius uralkodásának ötödik évére, 383-ra esett. ${ }^{249}$

A Hieronymustól átvett kronológiai jelöléseken kívül Hydatius saját maga egészítette ki elődje munkáját a ioboleusokkal, amelyek a Krisztus mennybemenetelétől eltelt időt 50 éves szakaszokra tagolják. ${ }^{250}$ Hydatius a legkorábbról ismert olyan szerző, aki külön hispaniai aerát is csatolt a kronológiájához, ${ }^{251}$ amely elsősorban Gallaecia és Lusitania területén volt népszerü, de sohasem vált általánossá Hispania keleti részein, ennek ellenére Isidorus történeti müveiben tovább alkalmazta a Hydatiustól átvett módszert. ${ }^{252} \mathrm{~A}$ hispaniai aera a hagyomány szerint Kr. e. 38-tól, Hispania római meghódításától számítja az éveket, de a félsziget elfoglalása valójában már Kr. e. 19-ben, Augustus és Agrippa hadjáratával befejeződött, így 38-hoz semmilyen jelentős esemény nem kapcsolódik, vagyis

\footnotetext{
${ }^{243}$ A Chronica kronológiájáról bővebben: Burgess 1988a, 73-97; Burgess 1993, 27-46; Cardelle de Hartmann 1994, 40-46.

${ }^{244}$ Az uralkodási évek értelmezéséről és használatának nehézségeiről bővebben: Burgess 1988a, 75-91.

245 Burgess 1993, 38; Thompson 1982, 228.

${ }^{246}$ Az olimpiászok eredetileg júliusban, a nyári napforduló után kezdődtek, vö. Olajos 1999, 224.

${ }^{247}$ Burgess 1993, 39.

248 Hyd. 23. A problémát súlyosbítja, hogy mivel Theodosius 394-ben pogány kultusznak minősítette és betiltotta az olimpiai játékokat, hivatalosan az olimpiászok szerinti időszámítás sem folytatódott tovább, vö. Olajos 1999, 228.

249 Burgess 1993, 36.

${ }^{250}$ Gesztelyi - Havas 1999, 255.

${ }^{251}$ Burgess 1993, 33; Horváth 1993, 15.

${ }^{252}$ A hispaniai aera és az uralkodási évek összefüggéseiről bővebben: Burgess 1988a, 74-75; Cardelle de Hartmann 1994, 43-46.
} 
a hispaniai aera kezdete ma is nyitott kérdés. ${ }^{253}$ Ezek alapján a kronológiai jelölésekről elmondhatjuk, hogy bár Iordanes kivételével az összes 5-6. századi nyugati történetíró az Eusebius által kidolgozott kronológiai rendszert használta az események datálásához, a legtöbb krónikaszerzőre mégis hatást gyakoroltak más időszámítási módszerek is, és Hydatiushoz hasonlóan hol a régi birodalmi időszámítást, hol pedig az újabb, helyi kronológiát használták az események időbeli elhelyezéséhez. ${ }^{254}$

A Chronicának nem maradt fenn a teljes szövege, csak egy majdnem teljes kézirata, ennek egy sokkal későbbi másolata, illetve jó néhány kivonat és összefoglalás. ${ }^{255} \mathrm{~A}$ codex optimus Phillips 1829-es (B) kézirata, amelyet feltehetően a treveri Szent Maximinusmonostorban másoltak az eredetiről 830 körül. ${ }^{256} \mathrm{Ez}$ az egyetlen olyan kézirat, amely egyaránt megörizte az eredeti szöveg felépítését, az oldalak beosztását és a margón lévő kronológiai jelöléseket, míg a többi kézirat szövegét inkább csak rövid kivonatnak és összefoglalásnak tekinthetjük, amelyben számos interpolatio és szövegromlás található. ${ }^{257}$ El kell fogadnunk tehát azt a feltételezést, hogy Hydatius feljegyzéseinek sorrendje helyes, ugyanis nincs másik forrásunk, amelyből az időrendet pontosan rekonstruálni tudnánk. ${ }^{258}$ Mivel a krónikában jó néhány esemény a különféle kronológiai jelöléseknek köszönhetően többszörös dátumozással lett ellátva, a kézirati hagyományban előforduló bizonytalanságok és a római számok használatát kevésbé ismerő másolók tévedései gyakran kronológiai hibákhoz és azok későbbi átvételéhez vezettek. ${ }^{259}$ Hydatius esetében a felhasznált források különböző datálása, a szóbeli értesülések során hallott téves információk és saját számításbeli tévedései okozhatták a legtöbb kronológiai pontatlanságot, ${ }^{260}$ de a későbbi másolók valószínüleg még tovább rontottak az egyébként is hibás datálások pontosságán. ${ }^{261}$

A modern kiadások ${ }^{262}$ közül Mommsen ${ }^{263}$ próbálta meg először egyesíteni a három legfontosabb kézirat szövegét, de a párhuzamos jelölések egészen bonyolulttá tették

\footnotetext{
253 Székely 2008, 14; 20. Neugebauer szerint Hispaniában 19 éves holdciklusok segítségével határozták meg a húsvét idejét, ezért a 38-as dátum egyszerüen két ciklusnak felel meg Krisztus születése előtt, vö. Neugebauer $1981,380$.

${ }^{254}$ Breisach 2004, 100.

${ }^{255}$ A Chronica kéziratairól bővebben: Burgess 1993, 11-26; 65-66.

256 A berlini Deutsche Staatsbibliothek kézirata 192 darab 26 soros folióból áll (287 mm x $262 \mathrm{~mm})$, tartalmazza a Canones fordítását Hieronymus folytatásával $\left(1^{\mathrm{v}}-153^{\mathrm{v}}\right)$, Hydatius Chronicáját $\left(153^{\mathrm{r}}-172^{\mathrm{v}}\right)$, a Consularia Constantinopolitanát (173 $\left.-184^{\mathrm{r}}\right)$ és a Liber Generationist (184v-192 $)$, vö. Burgess $1993,11$.

${ }^{257}$ Burgess 1993, 12.

${ }^{258}$ A problémáról bővebben: Burgess 1993, 47-58.

${ }^{259}$ A másolók lehetséges hibáiról bővebben: Székely 2008, 20; Woods 2009, 370.

${ }^{260}$ Burgess 1988a, 93.

${ }^{261}$ Muhlberger 1990, 283-284; Johnson 1993, 33.

${ }^{262}$ A szövegkiadásokról bővebben: Burgess 1993, 23-25.

${ }^{263}$ Mommsen 1894.
} 
munkáját, ráadásul mintegy 150 helyen téves vagy hiányos a javítása. Tranoy ${ }^{264}$ kiadása majdnem teljesen Mommsenén alapul, de felhasználja a kéziratokat újraértelmező és csak Mommsenre támaszkodó Courtois ${ }^{265}$ vitatható tanulmányát is. Campos ${ }^{266}$ a kéziratok vizsgálata helyett egy 1619-es kiadás javított változatát közölte kritika nélkül, Tranoy kiadását pedig teljesen figyelmen kívül hagyta; ez utóbbi hiányosságait igyekezett pótolni Nautin. ${ }^{267}$ Burgess ${ }^{268}$ szövege az első, amely az elérhető kéziratokat és a korábbi kiadások teljes apparátusát is figyelembe vette, ugyanakkor a háttérbe szorította Mommsen, Tranoy és Campos szövegértelmezését. ${ }^{269}$ A korábbi szakirodalomban a Mommsen által közreadott szöveg szakaszaira nyúltak vissza, az újabb tanulmányok hivatkozásai viszont többnyire Burgess szövegbeosztásán alapulnak, ahogyan jelen dolgozatban is ez utóbbi gyakorlatot követjük.

\footnotetext{
264 Tranoy 1974.

${ }^{265}$ Courtois 1951

${ }^{266}$ Campos 1984.

${ }^{267}$ Nautin 1984-1985.

${ }^{268}$ Burgess 1993.

${ }^{269}$ Burgess 1988a, 2-3.
} 


\section{A SZVÉVEK KÜLPOLITIKÁJA}

A szvévek egy kevésbé ismert germán népcsoport, akik a 406-os galliai és a 409-es hispaniai betörésük után Gallaeciában telepedtek le és elsőként hoztak létre önálló barbár királyságot a Nyugatrómai Birodalom területén, amely saját irányításuk alatt állt egészen 584-ig. Első uralkodóik megteremtették a Szvév Királyság alapjait, és olyan politikai lépésekkel segítették a szvévek expanziós törekvéseit, hogy fél évszázaddal később majdnem sikerült az egész félszigetet az uralmuk alá hajtani.

A szvévek történetére vonatkozóan Hydatius krónikája a legfontosabb forrásunk. Ö az egyetlen olyan szerző, aki személyes tapasztalatai alapján, a gallaeciai események szemtanújaként és gyakran aktív résztvevőjeként számolt be a provinciális eseményekről. Hydatius krónikája ugyan egyetemes történeti munka, de saját korához közeledve egyre inkább Gallaecia eseményei kerülnek a figyelem középpontjába, így ábrázolva rendkívüli pesszimizmussal a szvévek letelepedését és terjeszkedési politikáját, a római hatalom hispaniai hanyatlását, illetve a szvév-római interakciók változásait. 270

Orosius szintén Gallaeciából származott, de már sokkal pozitívabb színben tüntette fel a szvéveket, mivel Hispaniából való elköltözése után Augustinus felkérésére olyan munkát írt, amellyel igazolni lehet, hogy a kereszténység megjelenése elött sokkal nagyobb katasztrófák sújtották a Római Birodalmat, ezáltal a barbár népekre vonatkozóan optimizmust kellett sugároznia az olvasók felé. Iohannes Biclarensis a szvévek 6. század végi történetéröl ad tömör beszámolót, Iordanes Geticájában a szvév uralkodók ugyan határozott vezetőként jelennek meg, de vereséget szenvednek a gótoktól, Isidorus Hispalensis pedig a korábbi szerzők munkáit felhasználva néhány olyan részlettel egészíti ki a szvévek történetét, amely kapcsolódik a gótok tevékenységéhez. A prímer források között meg kell még említenünk az 1-2. bracarai zsinat aktáit, a 3. toletumi gyülés iratait, Leo és Vigilius pápák levelezését, valamint Strabón, Caesar, Tacitus, Prosper, Hieronymus, Marcellinus Comes, Sidonius Apollinaris, Gregorius Turonensis és a bracarai Martinus néhány rájuk vonatkozó utalását.

\footnotetext{
270 A negatív képhez az is hozzájárul, hogy csak Hydatius külső perspektívája alapján tudjuk megítélni a szvévek tevékenységét, mert nincs olyan egyéb forrásunk, amelyet maguk a szvévek írtak volna saját történetükről, vö. Trambauer 2008, 13. Mivel Hydatius római szemszögből ábrázolja az eseményeket, nagy jelentősége van a régészeti és numizmatikai kutatásoknak, amelyek hozzájárulhatnak a szvévek gallaeciai jelenlétének objektív elemzéséhez, vö. López Quiroga - Martínez Tejera 2017, 439.
} 


\subsection{A szvévek eredete és letelepedése (406-411)}

Kevés beszámolót ismerünk a szvévek korai történetéről, de a legtöbb szerző úgy nyilatkozott, hogy a legerősebbek és a legnagyobb létszámúak a germán népek közül,271 őshazájuk Észak-Brandenburg és Mecklenburg vidékén volt. Miután Caesar gall hadjáratában vereséget szenvedtek, ${ }^{272}$ kelet felé indulva a Közép-Dunától északra, a mai Alsó-Ausztria és Nyugat-Szlovákia területén telepedtek le, ${ }^{273}$ majd több évszázadon át a dunai és a rajnai határvidéket fenyegették, végül a hunok és az alánok terjeszkedése miatt nagy részük a Rajna irányába húzódott. ${ }^{274}$ Már az is vita tárgyát képezi, hogy a korabeli források pontosan kiket neveznek szvéveknek, mivel eredetileg különféle germán népek szövetségét jelölték ezzel kifejezéssel. ${ }^{275}$ Nevüket Tacitus használja a legtágabb értelemben, mert az összes, Duna és a Balti-tenger között élő germán és nem germán törzset így nevezi, közéjük sorolva még a longobárdok, a naristusok, a kvádok, a lugiak, a gotonok, a suinok és az aestiusok népét is. ${ }^{276} \mathrm{Id}$. Plinius a germánok 5 törzse között hivatkozik a szvévekre, Gregorius Turonensis alemannoknak is nevezi őket, Orosius pedig a kvádok, a markomannok, a vandálok és a szarmaták mellett említi törzsüket. ${ }^{277}$ Torres Rodríguez római szerzőkre hivatkozva összesíteni próbálja, hogy a szvévek közé szokás sorolni a markomannok, a kvádok, a szarmaták, az alemannok és a hasding vandálok csoportjait is, ${ }^{278}$ több kutató pedig igazolja, hogy a szvév kifejezést a római szerzők gyakran használták a kvád és a markomann megjelölés helyett. ${ }^{279}$

Bár a 19-20. század fordulójának történészei többnyire a germán népek összetartozását és hasonlóságát hangsúlyozták a népvándorlás során, a modern kutatók inkább a népek közötti különbségeket és sajátosságokat emelik ki, rávilágítva arra, hogy a germán népek identitása hosszú kulturális és etnikai változások eredményeképpen alakult ki az 5. századra. Sok esetben az ,ethnic identity” megtartásának lehetősége ösztönözte a

\footnotetext{
${ }^{271}$ Strab., Geog. 4,3,4; Caes., Gal. 4,1,7; Tac., Ger. 2.

272 Caes., Gal. 1,31-51; King 1990, 43.

273 Thompson 1965, 92-93.

274 Goffart 2006, 75-78. A szvévek 3-4. századi vándorlásáról, forrásokban való megjelenéséről és régészeti leleteiről bővebben: Hummer 1998, 12-16; López Quiroga - Martínez Tejera 2017, 434-436; a germán népek vándorlásának nyelvi vonatkozásairól lásd: Todd 2004, 11-14; Wiik 2008, 162-163.

${ }^{275}$ A szvévek etnogeneziséröl és elnevezéséröl lásd: Trambauer 2008, 16-28.

276 Tac., Ger. 38. Tacitus csaknem 50 germán törzsnevet említ, közülük viszont csak nagyon kevéssel találkozunk újra a 4. század végén, vö. Todd 2004, 5-9; Halsall 2007, 118-123.

277 Plin., Nat. 4,14; Greg. Tur. 2,2; Oros. 7,15; 7,38; 7,40,3.

278 Torres Rodríguez 1977, 25.

${ }^{279}$ Pitts 1989, 48; Hummer 1998, 16; Pohl 2004, 36.
} 
barbárokat a Rómával való együttmüködésre, máskor viszont a barbárok között létrejött heterogén szövetségeket szükségszerüen éppen a rómaiak ellen vívott küzdelem hívta életre. ${ }^{280}$ Angenendt részletesen elemzi azokat a germán kistörzseket, akik patriarchális paraszti és harcos társadalomban élve csak lazán kapcsolódtak egymáshoz, szükség esetén viszont képesek voltak összefogni és nagyobb katonai akciókat végrehajtani. ${ }^{281}$ Katus szerint a különféle barbár törzsek nem vérségi alapon szerveződtek, hanem vándorlásuk során „mesterségesen integrált” laza közösségeket alkottak, a közöttük lévő politikai és katonai kötelékek éppen ezért folyamatosan változtak. ${ }^{282}$ Brown ehhez hasonlóan úgy véli, hogy nem beszélhetünk zárt, kompakt népcsoportokról, hiszen a barbár uralkodók a hadsereg megszervezésekor nem válogathattak az emberanyagban, és akár az identitásukat vesztett szökött rabszolgák vagy vidéki nemesek is harcolhattak a barbárok között, az azonban lehetséges, hogy egy-egy sereget arról a barbár csoportról neveztek el, amelyik létszámbeli fölényben volt a többihez képest. ${ }^{283}$ Ezek alapján feltételezhetjük, hogy a szvévek közé sorolt törzsek nem alkottak különálló, zárt etnikai csoportot, ezért sem tudták őket megfelelően beazonosítani és megkülönböztetni a római szerzők. ${ }^{284}$

Az általánosan elfogadott és számos forrás által alátámasztott nézet szerint 406. december 31-én a befagyott Rajna jegén átkelve a szvévek, az alánok, a siling és a hasding vandálok áttörték a rajnai limest, harc nélkül elfoglalták Moguntiacum és Treveri városát, majd elözönlötték Galliát egészen a Pireneusokig. ${ }^{285}$ Az átkelés pontos helyére, idejére és körülményeire vonatkozóan azonban máig számos nyitott kérdés maradt. A galliai betörést a kutatók többsége Zosimusra és Prosperre hivatkozva 406. december 31-ére datálja, ${ }^{286}$ Kulikowski és Halsall azonban valószínűbbnek tartja a 405. december 31-ei időpontot. ${ }^{287}$

\footnotetext{
${ }^{280}$ Pohl 2018, 3-5; Hummer 1998, 16; Collins 1999, 98; Trambauer 2008, 3-4.

${ }^{281}$ A 3. századi erőviszonyok megváltozásával például ezek a csoportok elhelyezkedésük szerint szervezett szövetségekbe tömörültek a birodalom nyugati határánál, és megpróbáltak együtt eredményesebben harcolni Róma ellen, vö. Angenendt 2008, 128.

${ }^{282}$ Katus 2014, 83.

${ }^{283}$ Brown 1999, 66. A germán népek etnikai identitásáról lásd: Todd 2007a, 440-441; Halsall 2007, 35-62; 457-462; Pohl 2018, 1-12; a rokonságtudatról és a törzsi tagolódásról bővebben: Angi 1999, 20-21; a gótok etnikai csoportjainak szövetségéröl lásd: Collins 2004, 22-24.

${ }^{284}$ Arias 2007, 34. A szvévek külső megjelenéséről lásd: López Quiroga - Martínez Tejera 2017, 434-435.

${ }^{285}$ Isid., Hist. Vand. 71; Zos. 6,3,1.

${ }^{286}$ Zosimus szerint Marcus britanniai trónbitorlása egyfajta reakció volt a barbárok 406-os galliai betörésére, vö. Zos. 6,3,1. Prosper Arcadius és Probus 6. consulságának évével jelöli a január Kalendaeje előtti napot, 406. december 31-ét, Radagaisus keleti gót király betörését pedig a III. Constantinus 407-es trónbitorlását megelöző év legfontosabb eseményének tartja, vö. Prosp. 379; 406.

287 Kulikowski 2010, 159; Halsall 2007, 211. Kulikowski szerint Prosper krónikaszerzőként igyekezett elkerülni az üres sorokat, és a három éves ciklusok minden egyes évéhez próbált egy-egy eseményt füzni, így a hátralévő feljegyzéseket egyszerủen kiadagolta egyesével az évekhez. A vitáról bővebben: Goffart 2006, 73 119.
} 
Orosius az alemannokat ${ }^{288}$ és a burgundokat is az átkelö csoportok között említi, ${ }^{289}$ Hieronymus pedig a 409-es betlehemi levelében még ide sorolja a kvádokat, a vandálokat, a szarmatákat, az alánokat, a gepidákat, a herulokat és a szászokat is, de a szvévekröl egyáltalán nem ejt szót. ${ }^{290}$ Gregorius Turonensis szerint a Rómával szövetséges frankok az átkelés közben megtámadták a hasding vandálokat és megölték Godigiselt királyt 20 ezer vandállal együtt, ezzel kis híján kiirtották az egész törzsüket. ${ }^{291}$ A vandálok segítségére Respendial alán király sietett, aki legyőzte a frankokat, így a vandálok és az alánok szóban forgó csoportjával együtt szabadon átkelhetett Galliába. A vandálok átkelését Godigisel fia, Gunderic vezette, ${ }^{292}$ aki hatalmas pusztítást végzett Galliában és fosztogató hadjáratokat indított Aquitania irányába. Az alánok másik csoportja Goar vezetésével kelt át a Rajnán, de a burgundok Moguntiacum környéki letelepedése miatt váratlanul csatlakoztak a rómaiakhoz és letelepedtek Galliában. Az is elképzelhető, hogy Goar valójában a frankokhoz csatlakozott a többi barbár törzs elleni harcban, mindenesetre az általa vezetett alánok néhány évvel később a többi barbár néptől eltérően nem vonultak tovább Hispania felé. 293

Nem tudjuk pontosan azt sem, hogy mennyien vettek részt az átkelésben. Heather szerint 30 ezer katona és 100 ember érkezett Galliába, ${ }^{294}$ Goldsworthy viszont úgy gondolja, hogy döntően csak ,groups of warriors” keltek át a Rajnán és nem egész törzsek vándoroltak az új területek felé. ${ }^{295}$ Mivel Hieronymus a kifosztott városok közül elsőként Moguntiacumot említi, amelyet a barbárok teljesen leromboltak és templomában ezreket lemészároltak, ${ }^{296}$ más bizonyítékok híján arra következtethetünk, hogy az átkelés a moguntiacumi Rajna-hídon vagy annak közelében történt. ${ }^{297}$ Mivel a további

\footnotetext{
${ }^{288}$ Oros. 7,40,3. Jelenlétüket néhány modern kutatás is igazolja Argontoratum és Novimagus elfoglalásánál, vö. Angenendt 2008, 131; 147. A szvévek és az alemannok hasonló identitásáról lásd: Hummer 1998, 19-27.

${ }^{289}$ A burgundok feltehetően 407-ben keltek át a Rajnán Gundahar király vezetésével, majd 413-ban Honorius engedélyével Moguntiacum és Spira környékén telepedtek le.

${ }^{290}$ Hier., Ep. 123,16. Mivel a többi forrás említi a szvéveket, a kvádok későbbi galliai jelenlétéről viszont egyáltalán nem tudunk, Hieronymus valószínúleg a szvéveket nevezte kvádoknak, vö. Thompson 1982, 152; a szarmaták pedig tévedésböl kerülhettek a listára, vö. Kulikowski 2000, 326; vagy a szvévek helyett szerepelnek, vö. Hummer 1998, 17. Pohl szerint a legújabb kutatási eredmények figyelembevételével sem lehet pontosan bezonosítani az „,aggregate comprising”-be tartozó barbár népeket, vö. Pohl 2018, 5-6.

${ }^{291}$ Greg. Tur. 2,9.

292 Proc. 1,3,23; Theoph. 5931; 6026.

${ }^{293}$ King 1990, 206-207; Randers-Pehrson 1993, 105; Frassetto 2003, 14-15. A frankok korabeli helyzetéröl bövebben: Várady 1961, 210. j.

${ }^{294}$ Heather 2006, 198.

${ }^{295}$ Goldsworthy 2009, 296.

${ }^{296}$ Hier., Ep. 123,15.

${ }^{297}$ Angenendt 2008, 139.
} 
városfoglalásokra egy jól körülhatárolható körzetben került sor, ${ }^{298}$ elfogadhatónak tünik Várady feltételezése, mely szerint a barbár törzsek egy konkrét haditerv alapján egyesíthették haderejüket. ${ }^{299}$ A 406-os barbár betörésnél nem találkozunk a rómaiak oldalán szervezett ellenállással, mivel Stilicho korábban felemésztette a helyőrséget a vandálokkal és gótokkal szemben vívott ütközetekben, ugyanakkor Várady szerint mégsem beszélhetünk a római katonai erők azonnali összeomlásáról, inkább a védelmi vonal fokozatos és gazdasági okokból bekövetkező „elhalásáról." ${ }^{300}$ A barbár betörésnek feltehetően nem volt egyetlen vezetője, a különböző törzsek közötti együttmüködésből azonban valószínűsíthető, hogy néhány tehetséges és karizmatikus vezér a hadmüveletek élére állt. ${ }^{301}$ Isidorus, Iordanes, Orosius és Hieronymus meglepő módon azt állítja, ${ }^{302}$ hogy Stilicho hívására érkeztek a barbár törzsek Galliába. ${ }^{303}$ Bár a fővezér valóban gyanúba keveredhetett vandál származása miatt és magister utriusque militiae pozíciója révén bizonyos felelősséggel is tartozott a barbárok elleni védelem megszervezéséért, ebben az időben egészen más területeken harcolt és nem hibáztatható a rajnai betörésért. A Stilicho ellen felhozott vádakat inkább azzal magyarázhatjuk, hogy a barbár katonaság növekvő szerepével egyre jobban szembefordult a közhangulat. ${ }^{304}$

Érdemes azt is megvizsgálnunk, milyen politikai körülmények között került sor a barbárok átkelésére. Miután a britanniai legiók 407-ben III. Constantinust Honorius ellencsászárává nyilvánították, szüksége volt olyan területre, ahol ténylegesen gyakorolni is tudja hatalmát, ezért a barbár invázió miatt seregével áttelepült Galliába és irányítása alá vonta az ottani frank, burgund és alemann csapatokat. ${ }^{305}$ Isidorus beszámol arról, hogy egy előkelő római testvérpár, Didymus, Verinianus, illetve Lagodius és Theodosiolus colonusaikkal és rabszolgáikkal három évig féken tartotta a barbár seregeket a Pireneusoknál, de miután alaptalanul kivégezték őket hatalomra törés gyanúja miatt, már

\footnotetext{
${ }^{298}$ A barbárok többek között elfoglalták Argontoratum, Remi, Ambianum, Nemetacum, Morinorum Castellum és Turnacum városát, vö. Zos. 6,5,2-3; Pohl 2004, 36; Blockey 2007a, 122; Díaz 2011, 47.

${ }^{299}$ Várady 1961, 160. A barbárok rajnai betöréséröl áttekintő térképet közöl: Heather 2006, 207.

300 Várady 1961, 116, 168. j.

${ }^{301}$ Goldsworthy 2009, 296.

302 Isid., Hist. Vand. 71; Iord., Get. 115; Oros. 7,38,1; Hier., Ep. 123,16,17.

${ }^{303}$ Nem véletlen, hogy a birodalom szolgálatában 3 auxiliaris egység is szerveződött a szvévekböl, vö. Not. Dig., Occ. 42,34-35; 42,42; López Quiroga - Martínez Tejera 2017, 435.

${ }^{304}$ Schmidt 1970a, 15-16; Alföldy 2000, 203; Kiss 2005, 132.

305 Oros. 7,40,4; Prosp. 407; Zos. 5,27,2-3; Iord., Get. 165; vö. Demandt 1989, 143; King 1990, 207; Cortázar - Vesga 2001, 97; Kiss 2008, 90. Constantinus uzurpációjáról és következményeiről bővebben: Arce 2007, $31-55$.
} 
nem tudták megakadályozni a barbárok betörését. ${ }^{306}$ III. Constantinus Hispaniába küldte fiát, Constanst, aki Gerontius magister militummal 408-ban vereséget mért Honorius csapataira. ${ }^{307}$ Amikor 409-ben Constantinust Galliában augustusszá nevezték ki, Honoriusnak a gót csapatok közeledése miatt el kellett ismernie Constantinus hatalmát, aki Gerontiust nevezte ki Hispania kormányzójának. Később Constans egy másik hadvezérrel, Iustusszal érkezett Hispaniába és megromlott a Gerontius és Constantinus közötti viszony, emiatt Gerontius nyíltan a császár ellen fordult és arra ösztönözte a Galliában fosztogató barbár törzseket, hogy keljenek át Hispaniába, ahol katonai szolgálatért cserébe földet kaphatnak és letelepedhetnek. ${ }^{308}$

Az alánok, a vandálok és a szvévek 409. szeptember 28-án vagy október 12-én keltek át Hispaniába, hogy itt tovább fosztogassanak. ${ }^{309}$ Mivel Hydatius szerint néhány feljegyzés az egyik dátumot, míg mások a másikat közlik (alii... alii memorant), a modern kutatók többféleképpen értelmezik a két időpont említését. Muhlberger abból kiindulva, hogy Hydatius mindig a lehető legnagyobb pontosságra törekedett, azt feltételezi, hogy több szóbeli vagy írásbeli forrás állt Hydatius rendelkezésére, de nem tudott dönteni a dátumok között. ${ }^{310}$ További nehézséget jelent, hogy Mommsen szövegében a IIII (quarto) Kalendas... III (tertio) Idus Octobris die megjelölés, vagyis október 13-a szerepel, de mivel Hydatius határozottan állítja, hogy egy keddi napról (die tertia feria) van szó, Burgess magabiztosan IIII (quarto) Idus-ra javítja a második dátumot, hogy a két időpont között pontosan két hét távolság legyen és Hydatius állítása érvényesülhessen. Burgess szerint a két dátum a Kalendae $(K l)$ és az Idus $(I d)$ hasonló rövidítésének köszönhető, Hydatius pedig nem tudta eldönteni, melyik a helyes jelölés, így mindkettőt feljegyezte. ${ }^{311}$ A leginkább logikus magyarázat Thompsontól származik, aki a két dátumot az átkelés kezdetének és végének

\footnotetext{
${ }^{306}$ Isid., Hist. Vand. 71; Oros. 7,40,5-8; Sozom. 9,11,4; Zos. 6,4-5; vö. Arce 1997, 27-28; Alföldy 2000, 201; Halsall 2007, 214; Díaz 2011, 48-49; López Quiroga - Martínez Tejera 2017, 437.

${ }^{307}$ Demandt 1989, 147; Randers-Pehrson 1993, 109. Orosiusnál Constans, Isidorusnál tévesen Constantius a seregek vezetője, vö. Oros. 7,40,5-7; Isid., Hist. Vand. 71; a probléma elemzését lásd: Székely 2008, 21-22.

${ }^{308}$ Várady 1961, 160-161; Collins 2004, 13-14; Bowes - Kulikowski 2005, 156-157; Heather 2006, 210-211; Merrills - Miles 2010, 37-39. Gerontius a hispán-rómaiakat is igyekezett megnyerni azzal, hogy az általuk javasolt Maximust nevezte ki augustusnak, de miután szétverte Constantinus seregét, Honorius hatalmát megerősítve meggyilkoltatta Maximust, Gerontiusszal pedig saját hívei végeztek, így Honorius kezén maradt Hispania Tarraconensis területe, vö. Oros. 7,42,5; Cortázar - Vesga 2001, 97. Maximus uzurpációjáról bővebben: Arce 2007, 56-71. Kevésbé fogadható el az a vélemény, mely szerint a fenti politikai körülmények miatt ,invasion” helyett inkább „civil war”-röl érdemes beszélni, ahogyan a 711-es arab betörést is így kellene értelmezni, vö. López Quiroga - Martínez Tejera 2017, 437.

${ }^{309}$ Hyd. 34; Prosp. 409; Oros. 7,38,3; 7,40,3; Cass. 409; Isid., Hist. Vand. 72; Hist. Suev. 85. Marcellinus Comes tévesen 408-ra datálja az eseményt, vö. Marc. Com. 408.

${ }^{310}$ Muhlberger 1990, 210.

311 Burgess 1993, 128. Merrills és Miles a második dátumot tartja valószínübbnek, de a Mommsen-féle október 13-ával számol, vö. Merrills - Miles 2010, 41.
} 
tekinti, mivel egy több ezer főből álló sereg ilyen természeti akadályon csak nehezen tudna 24 óra alatt átkelni. ${ }^{312}$

A 409-es betörés után a germán törzsek csaknem két évig fosztották Hispania urbanizált és vidéki területeit egyaránt. Hydatius 409 végén egy másik barbár támadásról is beszámol, de ez valószínúleg a korábbi megszállás újabb hulláma lehetett, ahogyan Isidorus sem különböztette meg a barbárok többszöri támadását. ${ }^{313}$ Talán 410-ben lehetett a fosztogatások csúcspontja, mert a következő évben Hydatius már csak Hispania tartományait említi a végigpusztított területek között. ${ }^{314} \mathrm{Az}$ éhínség részletes leírása mindenesetre jól mutatja, hogy mennyire súlyos élelemhiány következhetett be, ha a barbárok úgy döntöttek, hogy korábbi életformájukkal szakítva megpróbálnak letelepedni. 411-ben ennek megfelelően a barbár népek békét kötöttek a rómaiakkal és felosztották Hispania provinciáit egymás között. A siling vandálok Hispania Baeticában telepedtek le, az alánok megkapták Lusitaniát és Hispania Carthaginiensist, a hasding vandáloknak és a szvéveknek Gallaecián kellett osztozniuk, de Hispania Tarraconensis továbbra is római ellenőrzés alatt maradt. ${ }^{315}$ A szvévek Gallaecia nyugati részén, az Atlanti-óceán partjánál telepedtek le, valószínüleg a Portus Cale és Ponte Vetera közötti területen. Számos becslés áll a rendelkezésünkre, amely a letelepülő barbár törzsek létszámára vonatkozik. Általánosságban elmondható, hogy a germán népek kevésbé romanizált területeken, csoportosan és a római lakossághoz képest jóval kisebb arányban telepedtek le, az 5. századi törzsek létszáma így általában $25-90$ ezer között mozgott. ${ }^{316}$ Mivel Thompson a Hispaniába érkező alánok számát 30-40 ezer, a siling vandálokét 50 ezer, a hasding vandálokét Procopius túlzott adatára hivatkozva maximum 80 ezer körülire becsüli, ${ }^{317}$ nagy valószínüséggel a szvévek képezték a betörő népek közül a legkisebb csoportot, amelynek létszámát igen eltérő módon $20-35$ ezer közöttire becsülik, ${ }^{318}$ Hydatius viszont nem

\footnotetext{
312 Thompson 1982, 153; Dahn 1911, 546. Thompson példaként hozza az alemannokat, akik 357-ben csaknem 35 ezren keltek át a Rajnán 72 óra alatt, így a barbárok 406-407-es átkelése eltarthatott akár néhány hétig is, vö. Amm. Marc. 16,12,19; 26; Thompson 1982, 159. Más népek vonatkozásában ugyanakkor látunk rendkívül gyors átkeléseket is, a középkori gyakorlat szerint pedig a folyókat inkább összekötő, mintsem elválasztó szerepük miatt tartották fontosnak.

313 Hyd. 38; Isid., Hist. Vand. 72.

${ }^{314}$ Hyd. 40-41.

315 Hyd. 41; Isid., Hist. Vand. 73. López és Rodríguez szerint a szvévek Gallaecia délnyugati részén, a hasdingok pedig északon telepedtek le, vö. López - Rodríguez 1997, 530-537. A barbárok 411-es hispaniai letelepedéséhez és az általuk elfoglalt területek áttekintéséhez lásd: 3. sz. térkép.

316 Klaniczay 2005, 114; Koenigsberger 1987, 24.

${ }^{317}$ Proc. 1,5,18-21; Thompson 1982, 159.

318 A szvévek száma feltehetően Thompson, Arce, López Quiroga és Martínez Tejera becslésére alapozva 2025 ezer fő lehetett, de Wallace-Hadrill 30 ezer, Reinhart 30-35 ezer föben határozta meg létszámukat, vö.
} 
szolgáltat erre vonatkozó adatot. Id. Plinius szerint az 1. században a szvévek által később elfoglalt területen a rabszolgákon kívül legfeljebb 700 ezren éltek, így a demográfiai változásokat figyelembe véve az 5. század elején a szvévek az itt élők 5-9 \%-át tették ki Thompson számításai alapján. ${ }^{319}$ Székely Melinda összesítése szerint a 7-8 milliós hispaniai lakosságból csak 30-35 ezres szvév népességről beszélhetünk, ami még alacsonyabb, 4 \%os hányadot jelent, López Quiroga és Martínez Tejera pedig még kisebb, 3 \%-os szvév jelenléttel számol. ${ }^{320}$

\subsection{Hermeric békés politikája és Heremigarius (411-438)}

409-ben a szvév csapatokat Hermeric, a szvévek első királya vezette Hispaniába. Isidorus úgy tudja, hogy amikor Hermeric 438-ban visszavonult, már 32 éve, tehát 406-tól uralkodott, Hydatius viszont csak 419-ben említi őt elöször. ${ }^{321}$ Elfogadható Hummer feltételezése, mely szerint Hermeric az átkelésben csak vezető szerepet játszhatott, jó képességeinek és a letelepedés sikerességének köszönhetően viszont annyira meg tudta erősíteni a hatalmát, hogy a letelepedés után már királynak tekintették. ${ }^{322}$ A letelepedés utáni békés időszakot az zavarta meg, hogy 412-ben Athaulf király a gót birodalom megteremtése érdekében Honoriusszal való egyezsége alapján Galliába vezette a népét és 413-415 között a vandálok ellen harcolt. ${ }^{323}$ 416-ban Honorius biztatására az Athaulfot követő Vallia vezetésével a gótok Hispaniába érkeztek, hogy leszámoljanak az ott letelepedett alánokkal és siling vandálokkal. Vallia 416-417 között akkora mészárlást végzett a rómaiak nevében (Romani nominis causa), ${ }^{324}$ hogy a siling vandálokat 418-ra teljesen kiirtotta, ${ }^{325}$ a vandálok és a szvévek fölött uralkodó alánok pedig óriási emberveszteséget szenvedtek, amikor viszont királyuk, Addax ${ }^{326}$ is elesett a 418 -as ütközetben, a megmaradt alánok így kénytelenek voltak csatlakozni a Gunderic által

Thompson 1982, 158; Arce 2007, 130-131; López Quiroga - Martínez Tejera 2017, 438; Wallace-Hadrill 1967, 118; Reinhart 1952, 32; a további becslésekről lásd: Thompson 1982, 295, 98. j.

319 Plin., Nat. 3,28; Thompson 1982, 159.

${ }^{320}$ Székely 2008, 75, 85. j.; López Quiroga - Martínez Tejera 2017, 438.

${ }^{321}$ Isid., Hist. Suev. 85; Hyd. 63.

322 A barbár törzsek egyik fontos jellemzője, hogy egy karizmatikus vezető öntudatot és egységet tud kovácsolni a népének, amely egyúttal hozzásegíti őt a politikai hatalom gyakorlásához, vö. Hummer 1998, 1718. López Quiroga és Martínez Tejera emiatt 409-re teszi Hermeric uralkodásának kezdetét, vö. López Quiroga - Martínez Tejera 2017, 438.

${ }^{323}$ Oros. 7,43; Iord., Get. 163.

${ }^{324}$ Hyd. 52; 55.

${ }^{325}$ Hyd. 59; Isid., Hist. Goth. 22; Iord., Get. 162-163; 166.

${ }^{326}$ Hyd. 60. Más források Addac vagy Attac alakot használnak, vö. PLRE 2,8; Isid., Hist. Goth. 22. 
vezetett hasding vandálokhoz. ${ }^{327}$ A latin forrásokban ettől kezdve reges Vandalorum et Alanorumként szerepelnek a vandál uralkodók. 419-ben egy személyes konfliktus révén Hermeric háborúba keveredett Gunderic vandál királlyal, aki körbezárta a szvév csapatokat az erbasisi hegyekben. ${ }^{328}$ Hydatius szerint a szvév sereget csak Astirius comes Hispaniarum közbelépése mentette meg a katasztrofális vereségtől 420-ban, mert hadjáratával a vandálokat arra kényszerítette, hogy dél felé vonuljanak, így Gallaecia egész területe a szvévek kezébe került. ${ }^{329}$

A szvévekről legközelebb csak 429-ben hallunk, amikor a szvév Heremigarius Lusitaniába érkezve hátba támadta és kifosztotta a vandálokat, ${ }^{330}$ de vereséget szenvedett, mert Gaiseric vandál király Emerita mellett lemészárolta a szvév katonákat, Heremigarius pedig menekülés közben az Anas folyóba fulladt. ${ }^{331}$ Elképzelhető, hogy Heremigarius $427-$ 429 között együtt uralkodott Hermerickel, de Dahn nem tudta meggyőzően igazolni, hogy a germánok korai történetében jellemző kettős királyság a szvévek hatalmi rendszerében is müködött volna. ${ }^{332}$ Arias említi Vicettót, aki Isidorus tévedéseire hivatkozva alaptalanul feltételezte, hogy élt egy II. Hermeric is, aki Heremigarius uralkodása után lépett trónra, így Hermeric 32 éves regnálási idejét három királyra osztotta volna fel, és ebből Hermericre csak 14 éves uralkodás jutott volna. ${ }^{333}$ Mivel nem tudunk arról, hogy Heremigarius Hermerickel rokonságban állt vagy átvette tőle a hatalmat, valószínűnek tűnik Thompson elmélete, mely szerint Heremigarius egy befolyásos katonai vezető volt Hermeric mellett, akinek a hadjáratával a szvévek elsőként kezdeményeztek fegyveres harcot Gallaecia határain kívül. ${ }^{334}$

430-ban Hermeric a korábban megkötött békét megtörve több alkalommal indított kegyetlen támadást a gallaeciabeliek ellen, feltehetően azért, hogy megerősítse hatalmát és közelebb kerüljön azokhoz a területekhez, amelyek az alánok eltünése és a vandálok 429-es africai kivonulása miatt megüresedtek. Hermeric először Gallaecia középső részét fosztogatta, de a gallaeciabeliek egy része sikeresen ellenállt, így a megszegett békeszerződést (pacem quam ruperant) ismét helyre kellett állítani. Amikor 431-ben a

\footnotetext{
${ }^{327}$ Hyd. 60; Isid., Hist. Goth. 22.

${ }^{328}$ Hyd. 63; Isid., Hist. Vand. 73. A konkrét összecsapást valószínűleg a szvévek kezdeményezték, mivel a terület a 409-es felosztás alapján a hasding vandálokhoz tartozott. ${ }^{329}$ Hyd. 66.

${ }^{330} \mathrm{Az}$ itt futó nagy jelentőségü kereskedelmi utakat eddig az alánok és a vandálok használták, vö. López Sánchez 2005, 511.

${ }^{331}$ Hyd. 80.

${ }^{332}$ Dahn 1911, 547; 561.

${ }^{333}$ Isid., Hist. Suev. 85; Arias 2007, 7.

${ }^{334}$ Thompson 1982, 166.
} 
szvévek Hermeric vezetésével újra támadásba lendültek Gallaeciában, Hydatius követséget vállalt Aëtiushoz, hogy segítséget kérjen tőle a fosztogatások megállításához. ${ }^{335}$ Néhány követváltás után bizonyos mértékben sikerült helyreállítani a szvévek és a gallaeciabeliek közötti békét, ${ }^{336}$ de később újabb egyezkedésekre volt szükség a két fél közöttt. ${ }^{337}$

\subsection{Rechila és a terjeszkedési politika (438-448)}

Hermeric hosszú betegeskedés után 438-ban visszavonulásra kényszerült, és átadta a hatalmat (substituit in regnm) fiának, Rechilának. Hydatius szerint Hermeric négy évig tartó betegeskedést követően 441-ben halt meg, ezért Isidorus feltehetően téved, amikor hét évi betegeskedés után, 440-ben tudósít Hermeric haláláról. ${ }^{338}$ Mivel Hermeric saját maga adta át a hatalmat fiának, és nincs olyan forrás, amely egy királyválasztásra utalna, a legtöbb kutató szerint a szvévek egy örökletes királyságot hoztak létre Rechila trónra lépésével. ${ }^{339}$ Hummer ezt azzal magyarázza, hogy a jó vezetői képességekkel rendelkező Hermeric annyira megszilárdította hatalmát, hogy megengedték neki, hogy a királyi hatalmat utódjára hagyja, vagyis a korábbi szokásoktól eltérően dinasztiát alapítson, ${ }^{340}$ és ha a későbbi kutatók óvatosabban is fogalmaznak a trónörökléssel kapcsolatban, ${ }^{341}$ nincs okunk megkérdőjelezni Hermeric tekintélyét és az örökletes királyi hatalom kialakulását.

Rechila többnyire a szvévek által ekkor még kevésbé ismert déli területek felé vezette hadjáratait, így szinte folyamatosan harcban állt a rómaiakkal. 438-ban a Singillium folyó mellett legyőzte Andevotus Romanae militiae dux seregét, akitől rengeteg aranyat és ezüstöt zsákmányolt. Andevotus feltehetően a Baeticában maradt vandálokat irányította, miután Gaiseric egy részükkel átkelt Africába. Isidorus szerint Hermeric küldte Rechilát Andevotus ellen, de Hydatius és Isidorus is azt állította, hogy ekkorra a hatalomátadás már megtörtént, ${ }^{342}$ arra pedig nincsenek bizonyítékaink, hogy Hermeric megtartott volna valamennyi hatalmat 438-as visszavonulása és Rechila trónra lépése után. Mindenesetre ez

\footnotetext{
${ }^{335}$ Hyd. 81; 86.

336 Hyd. 88; 91.

${ }^{337}$ Hyd. 92; 103; 105.

${ }^{338}$ Hyd. 106; 114; Isid., Hist. Suev. 85-86.

339 Torres Rodríguez 1977, 268; Van Schoor 1995, 335; Arias 2007, 35.

${ }^{340}$ Hummer 1998, 18.

341 Angenendt 2008, 128; Barbero - Loring 2005, 164-165.

${ }^{342}$ Hyd. 106; Isid., Hist. Suev. 85; Cass. 5,29.
} 
volt az első olyan ütközet, ahol a rómaiak komolyabb haderőt vetettek be annak érdekében, hogy szembeszálljanak a szvévekkel. ${ }^{343}$

439-ben a szvévek megszállták Lusitaniát és elfoglalták Emeritát, amely hamarosan a Szvév Királyság új fővárosa lett, 440-ben pedig sikerrel ostromolták a stratégiai fontosságú Martylist, ahol Censorius comes feltétel nélkül megadta magát. Hydatius szerint 441-ben, néhány hónappal Hermeric halála után Rechila meghódította Baetica központi városát, Hispalist, majd uralma alá hajtotta Baetica és Carthaginiensis egész területét is, ${ }^{344}$ Carthaginiensis elfoglalása azonban erős túlzás lehet, amely azt mutatja, hogy Hydatiusnak pontatlan ismeretei voltak a keleti és a partmenti eseményekröl. A szvévek ugyan meghódították Hispania középső területeit, mégsem valószínü, hogy eljutottak a Földközitenger partvidékéig, mivel nem tudunk arról, hogy később a rómaiaknak vissza kellett volna foglalniuk ezt a területet, ugyanakkor a római haderő gyengülését mutatja, hogy 441-446 között három magister utriusque militiaet is küldtek a félszigetre a szvév expanzió megállítása érdekében. Nem kételkedhetünk abban, hogy Emerita és Hispalis a szvévek kezére került, de úgy tünik, hogy az új hódítások kimerültek kisebb fosztogatásokban, és még nem volt meghatározó tényező a szvévek katonai jelenléte az érintett területeken. ${ }^{345}$

441 végére a szvév hódítások sikere miatt már csak Tarraconensis tartozott római uralom alá, amely éppen ezért stratégiai szempontból nagy jelentőséggel bírt. A bagaudák azonban a válságos politikai és gazdasági helyzetet kihasználva helyi lázadók segítségével önszerveződésre buzdították az elszegényedett lakosságot és fosztogatni kezdték a római területeket. ${ }^{346}$ A helyzet rendezésére Asturius magister utriusque militiae érkezett seregével, hogy hatalmas mészárlást végezzen a bagaudák között, 443-ban pedig veje és utóda, Merobaudes költő Aracelliben verte le a lázadásukat, mielött III. Valentinianus visszahívta volna őt Rómába. ${ }^{347}$ A felkelést végül csak hosszú idő után, 445 körül tudták elfojtani az alánok közremüködésével. ${ }^{348}$

446-ban a rómaiak Carthaginiensis és Baetica területére küldték Vitus magister utriusque militiaet egy jelentős gót sereg kíséretében, hogy megpróbálják legyőzni a

\footnotetext{
343 Thompson 1982, 178.

${ }^{344}$ Hyd. 111; 113; 115.

345 Bowes - Kulikowski 2005, 180-181. A szvév ellenőrzés alá tartozó területek áttekintéséhez lásd: 4. $s z$. térkép.

${ }^{346}$ Collins 2004, 27. A bagaudák mozgalmát a későbbiekben elemezzük részletesen.

${ }^{347}$ Hyd. 117; 120.

348 Thompson sajátos módon úgy látja, hogy a szóban forgó 441-es és 443-as lázadó csoport valójában nem is a bagaudák közül szerveződött, hanem olyan római parasztokból és rabszolgákból, akik a barbár népek fosztogatását utánozva próbáltak megélhetést biztosítani maguknak, vö. Thompson 1982, 183. Várady szerint a rómaiak több esetben azért engedtek a barbárok nyomásának, mert azok a bagaudákkal való szövetséggel fenyegetőztek, vö. Várady 1961, 180, 313.j.
} 
szvéveket és visszaszerezzék tőlük a római irányítás alól kicsúszott területeket. Rechila többször is támadást indított a római csapatok ellen, és amikor a gótokat is sikerült legyőznie, Vitus elmenekült a katonáival, hogy elkerülje a megsemmisítő vereséget. Hydatius szerint a szvévek ezután végigfosztogatták az elfoglalt tartományokat, és bár Heather szerint a félsziget legnagyobb részét ekkor már a szvévek uralták, ${ }^{349}$ valójában csak a déli, a nyugati és a középső területek fölött gyakoroltak ellenőrzést, így Carthaginiensis és Tarraconensis továbbra is római uralom alatt állt. Rechila 446-os győzelme és az a tény, hogy a 441-446 közötti időszakban a Hispaniába küldött három magister utriusque militiae tevékenysége nem járt jelentős sikerrel, arra enged következtetni, hogy a római hadsereg befolyása jelentősen csökkent Hispaniában, és minden császári erőfeszítés ellenére a birodalmi hatóságok is elveszítették valódi jelentőségüket. Nem véletlen, hogy a rómaiak 446 után hosszú ideig nem is indítottak hadjáratot a félsziget visszaszerzéséért. ${ }^{350}$

\subsection{Rechiarius és a szvév terjeszkedés csúcspontja (448-456)}

Hydatius és Isidorus szerint Rechila pogányként halt meg 448 augusztusában Emeritában. ${ }^{351}$ Thompson szerint nincsenek bizonyítékok arra, hogy Rechila eleve úgy nevelte volna a fiát, Rechiariust, hogy elősegítse az egyházzal való jó kapcsolat kiépítését és a szvévek megtérését, ${ }^{352}$ pedig logikus szempont lenne ez Rechiarius tevékenységének megítélésékor. Rechiarius 415 után született, 448-ban követte apját a trónon, és Isidorus ugyan kilenc éves regnálásról tudósít, ${ }^{353}$ valójában a források többsége szerint csak hét évig uralkodott.

Rechiarius volt az első germán uralkodó, aki saját nevével pénzt veretett Bracarában. A három ránk maradt, siliqua típusú érmén látható iussu Rechiari reges felirat a pénzverés jogának monopolizálására utal. ${ }^{354}$ Mivel a késő császárkorban az önálló pénzverést a függetlenség egyik szimbólumaként szokás értelmezni, a megtalált leletek a római hatalommal szemben nagyfokú szvév autonómiára utalnak. ${ }^{355}$ Metcalf numizmatikai

\footnotetext{
${ }^{349}$ Hyd. 126; Heather 2006, 345.

${ }^{350}$ Bowes - Kulikowski 2005, 183-184.

${ }^{351}$ Hyd. 129; Isid., Hist. Suev. 86.

352 Thompson 1980, 79.

${ }^{353}$ Isid., Hist. Suev. 87.

354 1. sz. kép; Edmondson 1989, 100; Díaz 2011, 11; Sánchez Pardo 2013, 155; López Quiroga - Martínez Tejera 2017, 430; 441; 456-457. Ez az 1-3 g tömegü érmetípus Kr. u. 310-650 között volt forgalomban, vö. Grüll 2017, 313; a leletekről bővebben: López Quiroga - Martínez Tejera 2017, 74-76.

${ }^{355}$ Reinhart 1952, 135-136; Thompson 1982, 212.
} 
kutatásai igazolják, hogy a 440-es évektől a szvév hatalom megerösödött, a pénzminták latinizációja pedig még arra is enged következtetni, hogy a Rómával való kulturális kapcsolatok erösödésével versengés indulhatott a gótokkal a félsziget fölötti hatalom megszerzéséért, ${ }^{356}$ amely során Rechiarius megpróbálta azt a látszatot kelteni, hogy a császári hatalom legitim képviselőjeként uralkodik Gallaecia fölött, ahogyan korábban Hermeric is veretett római mintára Honorius nevével arany solidust, majd Honorius és III. Valentinianus nevével arany tremissist. ${ }^{357}$ Rechiarius volt az első a germán királyok között abban is, hogy áttért a katolikus hitre, de ennek idejéről és körülményeiről szinte semmit sem tudunk, feltehetően politikai okok motiválták a katolikusokhoz való csatlakozást. ${ }^{358}$ Szintén meghatározó lépés volt Rechiarius részéről, hogy 449 körül egy házassági szerződés alapján feleségül vette I. Theoderic gót király lányát, ${ }^{359}$ meghatározva így külpolitikájának kezdeti irányait.

Rechiarius sok szempontból folytatta Hermeric és Rechila expanzív törekvéseit, számos területen azonban úttörőnek számított a germán királyok között, így bátor újításai és harcias kedve a Szvév Királyság első szakaszának tetőpontját jelentik. A kutatók többsége kiemeli, hogy feltűnően sokszor igyekezett támadásokat indítani Tarraconensis felé, de ő volt egyike azon kevés uralkodóknak, akik együtt tudtak müködni a bagaudákkal. Thompson ugyanakkor nem tud napirendre térni afölött, hogy ez a határozott külpolitikai agresszió, az önálló pénzverés és a katolikus vallás felvétele minek köszönhető, ezért megpróbálja ezeket egyszerűen Rechiarius eredetiségével és különleges személyiségével magyarázni, az viszont nem vitatható, hogy Rechiarius uralkodása alatt vált a szvév állam territoriális monarchiává. ${ }^{360}$

Rechiarius hatalomra lépése után 448-ban egy Agiulf nevü szvév előkelő meggyilkolta Hispalisban a nyolc éve fogságban lévő Censoriust, aki több alkalommal is követséget vállalt a szvévekhez. ${ }^{361}$ 448-tól Rechiarius Gallaecia legtávolabbi területeire is betört, 449 februárjában pedig kifosztotta Vasconiában az Iberus folyó völgyét, hogy innen kiindulva Tarraconensis irányába is támadást indíthasson. ${ }^{362} \mathrm{~A}$ hadjárat valószínúleg csak puszta fosztogatásokból állt, de elképzelhető, hogy előkészítette volna az egész tartomány

\footnotetext{
356 Metcalf 1993, 355; Arias 2007, 47-48.

357 2. sz. kép; López Sánchez 2005, 512-513; López Quiroga - Martínez Tejera 2017, 70-72; 440; 454-455.

358 A szvévek vallási helyzetének tárgyalásakor részletesebben foglalkozunk majd a problémával.

${ }^{359}$ Hyd. 132.

360 Thompson 1982, 212; Barbero - Loring 2005, 164.

${ }^{361}$ Hyd. 131; PLRE 2,34.

${ }^{362}$ Hyd. 129; 132; 163; 165.
} 
meghódítását. ${ }^{363} 449$ júliusában Rechiarius meglátogatta apósát, visszafelé pedig kifosztotta Caesaraugusta környékét, majd erőszakkal és csellel bevette Ilerda városát. A hadjárat közben meglepő módon szövetséget köthetett Basiliusszal, a gótok egyik főemberével, aki a bagaudák segítségével rajtaütésszerü támadásokat indított a császári csapatok ellen; a 449-es caesaraugustai fosztogatás előtt például Tyriasso templomában végzett kegyetlen mészárlást, kísérői pedig halálos sebet ejtettek Leo pápán. ${ }^{364}$ Rechiarius ugyan sok foglyot szerzett, akiket földmüvesként hurcoltak a szvév földekre Gallaeciában és Lusitaniában, mégsem tudta megszerezni a teljes tartományt, mert még a fővárosáig, Tarracóig sem jutott el seregével, ${ }^{365}$ ennélfogva a 450 -es évek első felében két alkalommal helyre is állították a rómaiak és a szvévek közötti békét a korábbi feltételek alapján. ${ }^{366}$

Rechiarius 455-ben a római hadsereg gyengeségét és a hatalmi válságot kihasználva stratégiát változtatott és Carthaginiensis kifosztására indult. 456 elején a rómaiak Fronto comest küldték a szvévekhez, a gótok pedig római kérésre szintén követeket indítottak Rechiariushoz, de ő visszautasította őket és betört a római Tarraconensis területére. ${ }^{367}$ II. Theoderic 456-ban követek útján Rechiariust visszavonulásra szólította fel, de ő ezzel nem törődve háborúval fenyegetőzött, ${ }^{368}$ és egy nagyobb erejű támadással másodszor is kifosztotta Tarraconensist, ahonnan nagy számú fogollyal tért vissza Gallaeciába. Theoderic 456-ban válaszként saját akaratából és Avitus császár utasítására (cum voluntate suo et ordinatione Aviti imperatoris) hatalmas csapattal vonult Gallaecia ellen. ${ }^{369}$ A két sereg 456. október 5-én találkozott Asturica városától 12 mérföldnyire, az Urbicus folyó partján lévő Campus Paramuson, ahol Theoderic rövid idő alatt legyőzte és megfutamította a szvévek csapatait. ${ }^{370}$ A források egyetértenek abban, hogy Rechiarius is megsebesült egy dárdától, ${ }^{371}$ ezért menekülnie kellett Gallaecia legtávolabb eső területeire. Hydatius azt állítja, hogy Rechiarius a tengerpart felé indult, és egészen Portus Caléig jutott, de ott elfogták és visszavitték Theoderichez. ${ }^{372}$ A nagy távolság miatt kevésbé hihető Iordanes állítása, mely szerint Rechiarius egészen a Tirrén-tengerig el tudott hajózni, de egy vihar miatt vissza

\footnotetext{
363 A vasconiai hadjárat előzményeiről lásd: Brestian 2011, 283-284.

${ }^{364}$ Hyd. 133-134.

365 Thompson 1982, 162.

${ }^{366}$ Hyd. 147; 153.

${ }^{367}$ Hyd. 161; 163.

${ }^{368}$ Iord., Get. 231.

${ }^{369}$ Hyd. 165-166.

${ }^{370}$ Sid. Ap., Ep. 8,12; Thompson 1982, 163.

${ }^{371}$ Isid., Hist. Goth. 31.

372 Hyd. 168. Portus Cale régészeti feltárása során megtalálták azt a helyet, ahol feltételezhetően sor került Rechiarius elfogására, vö. López Quiroga - Martínez Tejera 2017, 518-519.
} 
kellett fordulnia és ekkor esett fogságba. ${ }^{373}$ Theoderic seregei mindenesetre október 28-án rendkívül durva módon fosztották ki Bracara városát, kegyetlenül bántak a polgári lakossággal és az egyházi személyekkel egyaránt, decemberben pedig kivégezték Rechiariust is. ${ }^{374}$ A gótok ezután három hónap alatt felszabadították Hispania déli részét a szvév uralom alól, majd a következő években a hátramaradt seregek visszavonulás közben fosztották ki Asturica és Palentia városát.

A 456-os események döntő jelentőségüek voltak a szvévek történetében: Hispania 409-ben érkezett megszállói közül már csak ők maradtak a félszigeten, és nagyon közel álltak ahhoz, hogy Rechiarius tervének megfelelően az egész területet uralmuk alá vonják. Rechila és Rechiarius fosztogatásai szinte minden esetben új területek meghódítását, és nem a gallaeciabeliek kirablását célozták meg, ugyanakkor Rechiarius külpolitikai koncepcióját a szvévek kis létszáma és fegyelmezetlensége sem tette megvalósíthatóvá. A 456-os Urbicusmenti vereség és Rechiarius halála után úgy tünt, a szvévek politikai és területi egysége végérvényesen felbomlik, ${ }^{375}$ ahogyan Hydatius szerint is romba dőlt és elpusztult a szvévek királysága (regnum destructum et finitum est Suevorum). ${ }^{376}$

\subsection{Hatalmi harcok (456-465)}

Rechiarius halálával valószínúleg kihalt a Hermeric által alapított szvév királyi ág, ezért kérdésessé vált, hogy kinek a kezébe kerülhet a hatalom. Polgárháborús helyzet alakult ki különböző csoportok között, ez pedig új korszakot nyitott a szvévek történetében, hiszen 456 elött talán az egységes Róma-ellenességnek köszönhetően nem hallunk arról, hogy szvév politikai pártok harcoltak volna egymás ellen, vagy hogy a királyi hatalommal szemben lázadások törtek volna ki. ${ }^{377}$ Rechiarius halála után Theoderic elhagyta Gallaeciát és Lusitaniába vonult, de helyőrséget hagyott maga után, hogy a meghódított szvév területek védelme biztosítva legyen. ${ }^{378}$ 456-ban Theoderic egyik parancsnoka, Aioulf azonban elárulta a gótokat és Gallaeciába ment, hogy a szvévek királya lehessen, de Theoderic 457ben Portus Caléban elfogta és lefejeztette őt. ${ }^{379}$

\footnotetext{
${ }^{373}$ Iord., Get. 232.

${ }^{374}$ Hyd. 171.

${ }^{375}$ Wolfram 1990, 184

${ }^{376}$ Hyd. 168.

${ }^{377}$ López Quiroga - Martínez Tejera 2017, 438. Thompson ellenpéldaként említi a gótokat, akiknél a Rómabarátság vagy Róma-ellenesség kérdése a gót társadalom megosztásához vezetett, vö. Thompson 1982, 165.

${ }^{378}$ Hyd. 171; Reinhart 1952, 48.

${ }^{379}$ Hyd. 173; 180.
} 
Hydatius úgy tudja, hogy a szvévek Gallaecia legtávolabbi részein (in extrema parte) élő csoportja nem támogatta Aioulfot, ezért 457-ben egy szvév előkelő, Massilia ${ }^{380}$ fiát, Maldrast választották királlyá. Mivel nem tudunk arról, hogy Maldras rokonságban állt volna Hermerickel, sokan az ö uralmát sem ismerték el törvényesnek, ezért a szvévek két csoportra szakadtak: egy részük Maldrast támogatta, másik részük viszont 457-ben Framtanét választotta királynak. Mindketten egymástól függetlenül tevékenykedtek, ${ }^{381}$ többnyire békés viszonyt alakítottak ki a gallaeciabeliekkel, ugyanakkor tovább folytatták fosztogató hadjárataikat. Elfogadhatónak tűnik Thompson ötlete, mely szerint Maldras és Framtane megválasztásából következik, hogy a Hermerictől származó dinasztia kihalása után a szvéveknek maradt bizonyos joguk arra, hogy saját maguk válasszanak új uralkodót. ${ }^{382}$ Maldras mindenesetre 457 végén betört Ulixippona városába, kifosztotta és lemészárolta a római lakosságot, majd 458-ban végigpusztította a Durius folyó partvidékét. ${ }^{383}$

Framtane néhány hónapnyi uralkodás után 458-ban, húsvét és pünkösd között meghalt, ezért a gótok és a vandálok követeket küldtek Maldrashoz, de a tárgyalások feltehetően nem hoztak eredményt, mert a követek hamarosan visszatértek. ${ }^{384}$ Néhány kutató feltételezi, hogy Framtane halála után a szvévek két csoportja újra egyesült Maldras vezetése alatt, ${ }^{385}$ de ha ez így is történt, csak rövid ideig tarthatott, mert 459-ben Framtane hívei új vezért választottak Rechimund személyében, ${ }^{386}$ aki békét kötött Maldrasszal, így együtt indíthattak fosztogató hadjáratokat Lusitania és Gallaecia vidékére. ${ }^{387}$ Maldras 459 ben megölte saját fivérét, majd betört Portus Caléba és vérfürdőt rendezett a római előkelők között, kegyetlensége miatt azonban egyre kevesebb támogatóra számíthatott, végül saját emberei gyilkolták meg 460. február végén. ${ }^{388}$ Úgy tünik, hogy ezután Maldras hívei meglepő módon nem csatlakoztak Rechimundhoz, hanem egy addig kevésbé jelentős vezérük, Frumarius irányítása alá kerültek, aki talán Maldras fivére volt. ${ }^{389}$ Bár Rechimund 459-460 között együtt fosztogatott Maldrasszal és Frumariusszal, ez valószínűleg nem jelentett politikai együttmüködést a két táborra szakadt szvévek vezetői között, mivel

\footnotetext{
${ }^{380}$ Hyd. 174. Isidorus a Massila alakot használja, vö. Isid., Hist. Goth. 32; Hist. Suev. 88.

381 Maldras idején feltehetően Portus Cale volt a főváros, Framtane Lucust használhatta központként, vö. López Quiroga - Martínez Tejera 2017, 438.

382 Thompson 1982, 167.

${ }^{383}$ Hyd. 181; 183.

${ }^{384}$ Hyd. 182; 186.

385 Schmidt 1970b, 1,210. Thompson ezt az álláspontot elutasítja, vö. Thompson 1982, 297, 29. j.

${ }^{386}$ Rechimund feltételezhetően rokonságban állt a korábban uralkodó dinasztiával, vö. Collins 2007, 121.

${ }^{387}$ Hyd. 188; Isid., Hist. Suev. 88.

${ }^{388}$ Hyd. 190-191; 193; Isid., Hist. Suev. 88.

${ }^{389}$ Arias 2007, 22.
} 
Maldras halála után hívei megtartották függetlenségüket, 460-ban pedig hatalmi viszály (de regni potestate dissensio) támadt Frumarius és Rechimund között, ${ }^{390}$ végül egyiküknek sem sikerült megszereznie a hatalmat és a szvévek 464-ig király nélkül maradtak.

A szvévek 460-ban húsvét körül egy váratlan rajtaütés alkalmával megölték Lucus római helytartóját és több előkelőjét, ennek következtében a római Nepotianus megosztotta vezérségét a gót Sunierickel, hogy együtt kényszerítsék visszavonulásra a szvéveket. ${ }^{391}$ A hadmüvelet részeként a gót sereg kifosztotta a Lucus környékén élő szvéveket, de három gallaeciabeli informátor, Dictynius, Spinio és Ascanius ${ }^{392}$ pánikot keltett a hadseregben és figyelmeztette a szvéveket a gót támadásra, így az elárult gótok kénytelenek voltak visszavonulni. Frumarius július 26-án elfoglalta Aquae Flaviae városát, foglyul ejtette Hydatiust és feldúlta a város kolostorát a környezö területekkel együtt. Frumarius támadásával egy időben Rechimund Auregens és Lucus környékét fosztogatta, Sunieric pedig elfoglalta Scallabis városát, majd 461-ben visszatért Galliába. ${ }^{393} 460$ második felében a szvévek látszólagos békét (pacis quedam umbre) kötöttek a rómaiakkal, ugyanakkor nem sikerült megegyezniük a gótokkal két követváltás után sem, novemberben viszont Hydatius visszatérhetett Aquae Flaviae városába. ${ }^{394}$ Legközelebb csak 463-ban hallunk a szvévekről, amikor a római és a gót követek többször találkoztak a szvévek küldötteivel. A szvévek ennek ellenére ismét Gallaecia fosztogatására indultak, ezért Theoderic hozzájuk küldte néhány követtel együtt azt a Remismundot, aki Isidorus szerint Maldras fia volt, és egy gót nőt vett feleségül, korábban pedig Theoderic udvarában élt. ${ }^{395}$

\footnotetext{
${ }^{390}$ Hyd. 198; Isid., Hist. Suev. 89. Frumarius feltehetően két központi városból, Portus Caléból és Bracarából irányította a területeit, vö. López Quiroga - Martínez Tejera 2017, 438.

${ }^{391}$ Hyd. 194; 196; Isid., Hist. Goth. 33.

392 Burgess és Campos szövegében három informátorról olvashatunk, kevésbé valószínüsíthető viszont Mommsen feltételezése, mely szerint csak két besúgó volt, Spinio és Ascanius, Dictynius pedig nem egy személy neve, hanem egy ismeretlen hely, Dictynium megjelölése, amelyet szintén kifosztottak a gótok, vö. Muhlberger 190, 241.

${ }^{393}$ Hyd. 196-197; 201; Isid., Hist. Suev. 89.

${ }^{394}$ Hyd. 199-200; 202-203.

${ }^{395}$ Hyd. 215-216; Isid., Hist. Goth. 33.
} 


\subsection{Remismund kapcsolata a gótokkal és a rómaiakkal (465-469)}

465-ben, Frumarius halála után a szvévek Theoderic ösztönzésére Remismundot választották meg uralkodónak. Bár a legtöbben visszautasítják, ${ }^{396}$ hogy Rechimund és Remismund ugyanaz a személy lenne, ${ }^{397}$ Burgess szerint a két eltérő pályafutás ellenére és Hydatius elbeszélői stílusa alapján a két személynek azonosnak kell lennie, ${ }^{398}$ így viszont a gótok 463-as követe nem azonosítható a korábbi Remismunddal, ${ }^{399}$ mert Iordanes is királyként nevezte meg őt. ${ }^{400}$ Bár nem tudjuk pontosan, mi lett Rechimund sorsa, nem támogatható Tranoy feltételezése, mely szerint elveszett a krónika utolsó, 3 évet felölelő része, amelyben még szó lehetett az idős Rechimundról. ${ }^{401}$ A források nem segítik annak az eldöntését sem, hogy Remismund trónra lépésében mennyire játszott döntő szerepet Frumarius halála, hiszen ha Frumarius csak a szvévek egy részét irányította, Remismund kezdetben a másik rész felett gyakorolhatta a hatalmat. ${ }^{402}$ Mindenesetre Remismund Frumarius halála után már királyi felségjogon (regali iure) vonta uralma alá az összes szvévet (omnibus Suevis) és megújította az időközben érvénytelenné vált békét, ${ }^{403}$ vagyis a polgárháborús állapotok felszámolásával újra egyesíteni tudta a csaknem egy évtizede táborokra szakadt szvév népet. ${ }^{404}$

Theoderic fegyverekkel, ajándékokkal és felesége visszaadásával fejezte ki, hogy elismeri Remismund szvévek fölötti hatalmát. A szvévek ezt követően Conimbricára támadtak és kifosztották az előkelő származású Contaber családját, Remismund pedig kétszer is követeket küldött a gótokhoz, akik visszatérésükkor hírt hoztak Severus császár haláláról. ${ }^{405}$ Hydatius arra is kitér, hogy valószínűleg Remismund jóváhagyásával és Theoderic utasítására érkezett a szvévek közé Aiax, a galliai arianusok vezetője, hogy elterjessze eretnek tanítását Gallaeciában is. Remismund politikája azonban gyorsan megváltozott, mert rövidesen több támadást is Theoderic akarata ellenére indított el, a gótok követeit pedig nem fogadta sem 465-ben, Aunona fosztogatása után, sem pedig 466-ban,

\footnotetext{
396 Tranoy 1974, 2,119-120; Claude 1978, 667-668; Thompson 1982, 297.

397 Torres López 1940, 33-36; Schmidt 1970b, 1,210; López Quiroga - Martínez Tejera 2017, 438.

${ }^{398}$ Burgess 1993, 130.

${ }^{399}$ Campos 1984, 199.

${ }^{400}$ Iord., Get. 234.

401 Tranoy 1974, 2,119-120; Muhlberger 1990, 255.

402 Thompson 1982, 167.

${ }^{403}$ Hyd. 219; Isid., Hist. Suev. 90.

${ }^{404}$ Wolfram 1990, 186.

${ }^{405}$ Hyd. 222; 225-227.
} 
Theoderic halálát megelőzően. ${ }^{406}$ 467-ben, Aunona újabb kifosztása után a gótok egyik vezére, Opilio népes küldöttség élén Eurichez ment, hogy segítséget kérjen a szvévek elleni harchoz. A szvév követek visszatérése után Remismund Lusitaniába vonult és a békeszerződés ellenére újabb pusztítást végzett Conimbricában. A gótok egy része 468-ban csatlakozott a szvévekhez, akik Lusidius elöljáró árulásának köszönhetően elfoglalták Ulixipponát, az odaérkező gótok pedig fosztogatni kezdtek a szvévek és a rómaiak között.. ${ }^{407}$ Aunona lakói végül békét kötöttek a szvévekkel, de ők ismét zsákmányszerzésre indultak Lusitania és Asturica környékén, a gótok pedig erre hasonló rablóhadjárattal válaszoltak. Úgy tűnik, hogy a szvévek ugyan nem csaptak össze közvetlenül a gótokkal, de megszakítottak velük minden diplomáciai kapcsolatot, ugyanakkor Lusidius közvetítésével Leo császárral igyekeztek tárgyalásokba kezdeni. ${ }^{408} \mathrm{Ez}$ az utolsó szvévekre vonatkozó feljegyzés a krónikában.

A 456-os szvév vereség után tehát egyre többször találkozunk rómaiak elleni támadásokkal, a szvév vezetők pedig csak akkor tartottak kisebb szünetet a fosztogatásokban, ha közvetlenül egymással csaptak össze a hatalom megszerzéséért, vagy ha egy részük békét kötött a rómaiakkal, ${ }^{409}$ ennek megfelelően a szvév királyok saját pozíciójuk erősítése érdekében hol a gótokkal, hol a rómaiakkal léptek békés vagy háborús kapcsolatba. Mivel a szvévek történetének 550-ig tartó szakaszáról rendkívül kevés forrás áll a rendelkezésünkre, pontosan még a szvév királyok nevét sem ismerjük, ${ }^{410}$ Thompson jogosan nevezi ezt az időszakot ,the dark age of Galicia”-nak. ${ }^{411}$

\footnotetext{
${ }^{406}$ Hyd. 228-229; 233.

${ }^{407}$ Hyd. 235-237; 239-240.

${ }^{408}$ Hyd. 243-245.

${ }^{409}$ Arias 2007, 64.

${ }^{410}$ Isid., Hist. Suev. 91-92; Székely 2008, 77-78, 90-92. j.; López Quiroga - Martínez Tejera 2017, 440.

411 Thompson 1982, 199.
} 


\section{SZÉTFESZÍTŐ ERŐK AZ 5. SZÁZADBAN}

\subsection{A rómaiak és a barbárok találkozása}

\subsubsection{Barbár inváziók és katonai szempontok}

Thompson alapvető munkáját, a Romans and Barbarians bevezetőjét azzal kezdi, hogy különbséget tesz a barbárok két csoportja között. ${ }^{412}$ A Közép-Európából származó, letelepült és földműves életmódot folytató, germán nyelveket ismerő népek közé sorolja többek között a keleti és a nyugati gótokat, a vandálokat, a szvéveket, a frankokat és a szászokat, míg a Délkelet-Európa sztyeppéiről érkező és állataikat terelgető nomád népek, az alánok és a hunok nem ismerik a germán nyelveket és a földművelést. ${ }^{413}$ Közös vonás viszont bennük, hogy félelemmel és irigységgel tekintettek a Római Birodalomban tapasztalható jólétre és biztonságra, minden bizonnyal még csodálták is a sajátjuknál jóval magasabb szintű római civilizáció széles körü elterjedését, ${ }^{414}$ így talán ennek is köszönhető, hogy a Kr. u. 1-2. századtól már több népcsoport is szeretett volna felvételt nyerni a birodalomba, ${ }^{415}$ a 3 . század közepén pedig az örizetlenül hagyott germán határon át fosztogató barbár elemek szivárogtak be Gallia és Hispania területére. ${ }^{416}$ Thompson a 4-5. századi birodalmat érő barbár betöréseket vizsgálva három inváziós hullámot különböztet meg, Kulikowski ezek alapján joggal nevezi az 5. századot a „great invasions” korának. ${ }^{417}$

Mivel a római külpolitika állandó része volt az idegenek (peregrini) befogadása, ${ }^{418}$ ennek gyakorlati lépéseit és az idegenek betelepítését különböző jogi eszközök segítségével

\footnotetext{
412 Thompson 1982, 3.

413 Klaniczay Thompson elméletét kibővítve úgy látja, hogy a népvándorlásban részt vevő népek nagyobb csoportját a római földmüvesekhez hasonló germánok alkotják, a másikba pedig a valóban nomád harcosként pusztító hunok, avarok és magyarok tartoznak, vö. Klaniczay 2005, 88-89. A hunok és az alánok laza törzsszövetségeiről bővebben: Várady 1961, 165-167; Heather 2007a, 499-500.

414 Angi 1999, 3.

415 Ebben az időszakban gyakran több 10 ezer fös barbár törzseket is betelepítettek a munkaerőhiánnyal küszködő tartományokba, ahol földmüveléssel és adófizetéssel tartoztak, vö. Grüll 2016, 79.

${ }^{416}$ A 270-es években Hispania belső és keleti területein került sor nagyobb rablóhadjáratokra, innentől kezdve a római lakosság körében nagyfokú félelem tapasztalható a barbárokkal szemben, vö. Cortázar - Vesga 2001, 90.

417 Thompson 1982, 15-19; Kulikowski 2013, 684. Az 5. századi európai népvándorlás és a barbár népek mozgásának áttekintéséhez lásd: 5. sz. térkép.

418 Plin., Ep. 10,40,3; Alföldy 2000, 113. A rómaiak külföld-fogalmának jogi értelmezéséhez lásd: Várady 1961, 121-123.
} 
végezték. A rómaiak a meghódított népcsoportokat a cliens-királyságok kivételével ${ }^{419}$ általában városonként vagy törzsenként vonták uralmuk alá, így meghagytak számukra bizonyos fokú autonómiát. ${ }^{420}$ A dediticii vagy laeti formájában letelepített csoportok többnyire hadifogolyként kerültek a birodalom területére, esküvel kötelezték magukat a Róma iránti hüségre, ${ }^{421}$ többnyire elvesztették saját polgárjogukat és a rómait sem kapták meg automatikusan, ezért katonáskodásért és adózásért cserébe colonusként telepedhettek le a földeken. ${ }^{422}$ Ezek alapján jól látszik, hogy a 3. századtól kezdve a barbárok földmüvesként vagy katonaként való egyéni és csoportos betelepítése megszokott gyakorlattá vált, és a kezdeti időszakban békés folyamatnak tekinthető. ${ }^{423}$

Constantinus korától kezdve már általánossá vált az a vélemény, mely szerint a római hadsereg legjobb katonái a Rajna-Duna vonaltól északra lévő germán törzsekből származnak, ezért a 4. század végére a barbárok kerültek túlsúlyba a nyugati területeken állomásozó hadseregben. ${ }^{424}$ Valentinianus a senatorok helyett germán tiszteket állított a legmagasabb parancsnoki pozíciókba, ${ }^{425}$ később a gótok közül annyira sokan kaptak magas rangú állami vagy katonai tisztségeket, hogy gyakorlatilag nélkülözhetetlenné váltak a római hadseregben. ${ }^{426}$ Iulianus császár és a római arisztokrácia ugyan helytelenítette, hogy a germánok ilyen fontos pozíciókat töltsenek be, ennek ellenére ö is több alkalommal kényszerült arra, hogy barbár férfiaknak adományozzon magas rangú hivatalokat, ${ }^{427}$ a keletrómai Synesius Arcadiushoz intézett levelében pedig már arról panaszkodik, hogy

\footnotetext{
${ }^{419}$ A cliens-királyságok a birodalom szomszédságában helyezkedtek el, csak látszólag voltak függetlenek, külügy, pénzügy és hadügy tekintetében nem hozhattak önálló döntéseket, a római érdekek képviselete mellett pedig újoncozásra és adófizetésre voltak kötelezve, vö. Grüll 2017, 117. A kvád és markomann clienskirályságról és a rómaiakkal való társadalmi-gazdasági kapcsolatukról lásd: Pitts 1989, 45-58.

${ }^{420}$ Ennek köszönhetően a római társadalom mellett minitársadalmak jöttek létre, a későbbi fejlődés azonban megkövetelte ezeknek a csoportoknak az integrálódását a rómaiak közé, vö. Havas - Hegyi - Szabó 2007, 772. ${ }^{421}$ Kiss részletesen beszámol a deditio (meghódolás) és az adoratio (imádás) szertartásáról, amelyek során az idegeneknek le kell borulniuk a császár elött, majd fegyverek és túszok átadásával le kell mondaniuk az önálló államiságukról, vö. Kiss 2008, 1-2; Demandt 1989, 306-307; Alföldy 2000, 141-142.

422 Valentinianus például 370 körül a Raetiában legyőzött alemann foglyok sokaságát laeti státuszban telepítette le a Pó-síkságon, vö. Várady 1961, 129-130; Todd 2007b, 470-471. A dediticii és laeti fogalmának tisztázásához lásd: Schönfeld 1958; Schulten 1960; Havas - Németh - Szabó 2001, 184; Várady 1961, 34-39; Halsall 2007, 152-161.

${ }^{423}$ Goldsworthy 2004, 208; Klaniczay 2005, 99. Már a principatus idején a kb. 300-350 ezer fös hadseregböl 125-150 ezer auxiliaris és 40 ezres flottalegénység a meghódított idegen jogállású lakosság köréből került ki, vö. Havas - Hegyi - Szabó 2007, 739.

${ }^{424}$ A barbarizálódás folyamatáról bővebben: Halsall 2007, 101-110.

${ }^{425}$ Valentinianus és a senatus konfliktusáról lásd: Alföldi 2006, 52-114.

${ }^{426}$ Chadwick 1999, 231; Vanyó 2007b, 375; Kiss 2008, 2; 11-12. A gótok a 3. század elején még független gensként harcoltak a római seregben, vö. Iord., Get. 89; 106; 110-112; Várady 1961, 40; Wolfram 1990, 71.

${ }^{427}$ Amm. Marc. 21,10,8; 21,12,25.
} 
olyan emberek védelmezik a birodalmat és vállalnak római hivatalt, akik korábban a rabszolgák csoportjához tartoztak. ${ }^{428}$

Amikor 375 után a barbárok szabályozott és mértékletes bevándorlását a Thompson által említett invázió első hullámaként a hunok elöl menekülő gótok hatalmas tömege váltotta fel, később pedig más germán népek is a birodalom határai felé vették az irányt, már kevésbé hittek a rómaiak abban, hogy a barbár betörések nem fogják veszélybe sodorni a birodalom erejét, ${ }^{429}$ ugyanakkor az idegen népcsoportok befogadását katonai és gazdasági szempontok egyaránt indokolták. A betelepítésekkel egyértelmúen csökkent a birodalom határainál kialakult feszültség, nőttek az állami bevételek és olcsó munkaerő jelent meg a mezőgazdaságban, ráadásul a katonállítási kötelezettségük miatt vagy újoncokat állítottak, vagy megváltották ezt a szolgálatot a meghatározott összegü aurum tironicorummal, mivel a rómaiak kisebb hajlandóságot mutattak a katonai szolgálat vállalására, a soraikból szervezett utánpótlás pedig egyre rosszabb minőségű és alig képzett haderőnek bizonyult. ${ }^{430}$ Amikor a gótok a 378-as hadrianopolisi győzelem után elsőként települhettek be foederatiként a birodalom területére a 382-es szerződés alapján, ${ }^{431}$ a rómaiak igazolni látták azon félelmüket, hogy a barbárok fölött aratott több évszázados sikerek után a birodalom válságba került és valójában képtelen a barbárokkal szemben hatékony védekezésre, ${ }^{432}$ többen pedig talán felismerték azt a betelepítésekkel járó kockázatot is, hogy a germán seregek egyre nagyobb önállósággal rendelkező vezetői idővel akár teljes függetlenséget és politikai hatalmat is követelhetnek majd maguknak. ${ }^{433}$ Minden nehézség ellenére azonban elsődlegessé vált az a stratégiai szempont, hogy a kényszerhelyzetben és átmeneti

\footnotetext{
${ }^{428}$ Synes., Peri Basil. 14-15; Várady 1961, 162-163. A hivatalvállalás újszerü gyakorlata jól mutatja, hogy a hivatali rang és a társadalmi státusz összekapcsolódása is megváltozott, mivel a császárkor elején származás alapján lehetett állami tisztségeket betölteni, a késő császárkorban viszont magas rangú hivatalok vállalásával volt esély kedvezőbb társadalmi státuszba kerülni és kiváltságokat szerezni, vö. Kelemen 2007, 1-2; 181.

${ }^{429}$ Török 1999, 81.

${ }^{430}$ Demandt 1989, 268-270; Kiss 2008, 2-3; Pohl 2018, 1-2. A római haderő létszámkiegészítését alapvetően örökletes szolgálati kötelezettség, sorozás vagy önkéntes jelentkezés alapján próbálták megoldani, ennek késő császárkori gyakorlatáról bővebben: Várady 1961, 21-34; a hadsereg keretállományának részletes elemzését és a Notitia Dignitatumban szereplő csapatnemek és létszámviszonyaik bemutatását lásd: Várady 1961, 48-75; Whitby 2007, 288-295; 300-308.

${ }^{431}$ Ennek bővebb tárgyalására később visszatérünk. Egyes kutatók vitatják, hogy ez a szerződés valóban fordulatot jelent a római külpolitikában, vö. Schulz 1993, 146-147; Kiss 2008, 45; Halsall szerint ez a foedus csak ,a historian's construct”, amely a sajátos jogállás biztosítása miatt megváltoztatta a gótok természetét, vö. Halsall 2007, 184-185. Ha egyet is értünk ezekkel a feltételezésekkel, vitán felül áll, hogy a gótokkal kötött foedus később követendő mintát jelentett a többi barbár nép számára a Rómával kötött szerződések megkötéséhez.

432 Amm. Marc. 31,4,5; Ladner 1976, 2; Angenendt 2008, 129.

${ }^{433}$ Angenendt 2008, 127. A római hadsereget a barbárok gyakran tekintették eszköznek a saját identitásuk megörzéséhez, vö. Pohl 2018, 4-5.
} 
megoldásként betelepített gótok komoly katonai segítséget jelenthetnek más barbár népek elleni harcban. ${ }^{434}$

Thompson szerint a második inváziós hullám 406 utolsó napjaiban a barbárok rajnai átkelésével kezdődött, ${ }^{435}$ később a vandálok és a szvévek 409-es hispaniai betörése, majd az újabb városok és tartományok kifosztása a központi hatalom fokozatos összeomlását eredményezte a barbárok által megszállt területeken, a helyzetet pedig tovább súlyosbította az a folyamat, amelynek során a Gallaeciában maradt szvévek, a Gallia nyugati részébe telepített gótok és Africába való átkelésük után a vandálok is saját államot hoztak létre a birodalom területén. ${ }^{436} \mathrm{Az} 5$. század elején a nyugati hadseregállományban és a vezető katonai pozíciókban is riasztóan nagyra nőtt a barbárok aránya, ${ }^{437}$ Stilicho hadseregreformja után pedig a teljes nyugati haderő egyetlen, általában barbár származású magister utriusque militiae kezébe került, ennek következtében az uralkodó környezetében lévő germán katonai körök az 5. század végén szinte észrevétlenül meg tudják majd dönteni a nyugatrómai császár hatalmát. ${ }^{438}$ Ezzel szemben keleten az egyre inkább fokozódó germánellenes hangulat miatt nagy mértékü tisztogatást hajtottak végre, ${ }^{439}$ így a hadsereg parancsnoki pozíciói nem germanizálódtak, ráadásul a katonai hatalom decentralizálódásának köszönhetően a constantinopolisi császár sem volt annyira kiszolgáltatva egyetlen katonai parancsnoknak sem. Mindenesetre a 410-es évek közepén Italiában, Africában és DélGalliában még voltak római parancsnokság alatt álló katonai egységek, de Britannia, Hispania és Észak-Gallia területe védelem nélkül maradt és katonai vákuumot képezve teret engedett a barbár terjeszkedésnek. ${ }^{440}$

A Római Birodalom állapota az 5. század elején még többnyire hasonlított a korábban megszokott viszonyokhoz, a század végén azonban már teljesen más kép tárul elénk az időközben kialakult polgárháborús helyzet, a nyugatrómai területek válsága, Constantinopolis növekvő jelentősége, a barbárok fosztogatásai és államszervező tevékenysége, illetve az eretnekmozgalmak gyors terjedése miatt. ${ }^{441}$ Ezek a válságtünetek a

\footnotetext{
${ }^{434}$ Thompson 1982, 16; Halsall 2007, 149-150; Kiss 2008, 11; 45-46.

${ }^{435}$ A harmadik inváziós hullámot a 455 körül feltünt keleti gótok és a gepidák inváziós tevékenysége jelenti, vö. Thompson 1982, 19.

${ }^{436}$ A hispaniai és galliai barbár királyságokról bővebben: Thompson 1963, 3-33.

${ }^{437}$ Koenigsberger 1987, 17-19.

${ }^{438}$ Zsinka 2012, 2.

${ }^{439}$ A középrétegek leginkább azt sérelmezték, hogy a germánok elleni háborúk és a barbár katonáknak fizetett zsold súlyos anyagi terhet jelentett számukra, a felső rétegek pedig nem nézték jó szemmel, hogy Theodosius leginkább csak saját embereiböl nevezte ki a hadsereg, a hivatalok és a provinciák vezetöit, vö. Zos. 4,27; Havas - Hegyi - Szabó 2007, 672.

${ }^{440}$ Collins 2004, 26.

${ }^{441}$ Muhlberger 1990, 1.
} 
római társadalomban egyre nagyobb nyugtalanságot eredményeztek, különösen a mindennapokra és a gazdasági életre gyakorolt hatásuk miatt, hiszen a senatorok elsősorban a hatalmukat és a vagyonukat féltették, a polgárok pedig a városok ostromától és saját helyzetük romlásától tartottak. ${ }^{442}$ Általánosságban elmondható, hogy a késő császárkorban a városok szerepe megváltozott, ${ }^{443}$ a polgárok életminősége jelentősen romlott az infrastruktúra csökkenésével, ${ }^{444}$ vidéken a szállítás nehézsége és a pénzforgalom leállása miatt az önellátás vált jellemzővé, ezért a korábbiakhoz képest nőtt a vidéki nagybirtokok jelentősége, ${ }^{445}$ a gabonára és a marhaállományra irányuló barbár fosztogatások viszont alapvető nehézségeket okoztak a lakosság élelmiszerellátásában. ${ }^{446}$ A kockázatos szállítási útvonalakra, a városok hanyatlására és Diocletianus 301-es ármaximáló rendeletére hivatkozva $^{447}$ szokás az 5 . századi kereskedelem nehézségeiről vagy egyenesen a megbénulásáról beszélni, a kereskedelem müködési feltételei azonban alapvetően nem változtak, ${ }^{448}$ a Földközi-tenger Pirenne szerint a népvándorlás korában is megtartotta hagyományosan központi és civilizációközvetítő szerepét, továbbra is itt húzódtak a keletrómai területekkel folytatott kereskedelem fontosabb útvonalai, a keleti részeken pedig a városi élet, az ipari termelés és a tengeri hajózás csaknem a korábbi feltételekkel müködhetett tovább. ${ }^{449}$

\footnotetext{
${ }^{442}$ Halsall 2005, 36-37. A nyugati senatorok körében, különösen Galliában, Hispaniában és Észak-Africában kialakultak olyan regionális csoportok, akik saját érdekeiket védve egyre többször megtagadták az együttműködést a császári hatalommal és a katolikus egyházzal, vö. Alföldy 2000, 185-186.

443 A túlméretezetté vált római városok teljes területét már nem tudták hasznosítani, ráadásul néhány megerösített központi részen kívül nem is jelentettek biztonságot a barbár betörésekkel szemben, vö. Benevolo 1994, 18-19; 26.

${ }^{444}$ A vízvezetékek megrongálása, a fürdők más célra való használása, a városfalak rossz állapota, a bányák müködésének felfüggesztése, a fütőberendezések és a luxuscikkek hiánya számtalan nehézséget okozott a mindennapokban, vö. Angenendt 2008, 127. Hasonló folyamat játszódott le a 4. századi Pannoniában is, ahol különösen a nagyvárosokban voltak tapasztalhatóak a lassú hanyatlás és elszegényedés jelei, vö. Mócsy 1974, $144-147$.

${ }^{445}$ Alföldy 2000, 176; Cortázar - Vesga 2001, 93. A latifundiumok korábbi működéséről lásd: Hoffmann 2014, 61-64.

${ }^{446}$ Angenendt 2008, 127.

${ }^{447}$ A diocletianusi rendeletröl és következményeiröl lásd: Grüll 2007, 200-202.

448 A mindennapi élethez kapcsolódó kereskedelmi cikkek és a katonai felszerelések esetében egyfajta kiegyenlítődést figyelhetünk meg, vagyis a barbárok és a római lakosság ilyen téren is hatott egymásra, vö. Kiss 2008, 3. A germán lábbeli és nadrág, valamint a hosszú haj viselését például az 5. század elején még tiltották, később már engedélyezték a rómaiak számára, vö. Katus 2014, 97.

${ }^{449}$ Pirenne 1983, 39-40; 330-331.
} 


\subsubsection{Együttmüködés és kulturális interakciók}

Thompson szerint a gótok voltak az első olyan barbár hódítók, akiknek vezetői a Római Birodalom megbuktatása helyett arra törekedtek, hogy a római élet részesévé váljanak, ezért a római villák és fürdők kifosztása és felégetése helyett inkább igyekeztek azokat elfoglalni és a rómaiak módjára irányítani. ${ }^{450}$ Bubnó még az 5-6. századi vandál uralkodókról is azt állítja, hogy rombolás helyett hasznosítani próbálták a meghódított területek „,természeti és kulturális javait" a római szokások és ceremoniális külsőségek átvételével, ${ }^{451}$ ugyanakkor azt is tudjuk, hogy a rómaiak kulturális fölényét elsősorban a magas rangú barbár vezetők ismerték el, és a germánok alsóbb társadalmi csoportjai sokkal nehezebben asszimilálódtak. ${ }^{452}$ Koenigsberger éppen ezért tartja paradox jelenségnek, hogy a barbárok katonai szempontból ugyan legyőzték a rómaiakat, de mégis alkalmazkodtak az új környezethez és saját identitásukat feladva beolvadtak a római társadalomba. ${ }^{453}$

Segítette ezt a homogenizálódást az a császári törekvés, hogy a római sereg nagy részét a 4. századtól kezdve azokról a határmenti területekről toborozták, ahol a rómaiak és a barbárok között már nem sok különbség volt, mert uralkodói szempontból a Róma iránti hüség volt a legfontosabb szempont, cserébe viszont vagyont és társadalmi rangot szerezhettek a birodalom kötelékében harcoló katonák. Ebböl a szempontból tehát igazat kell adnunk Pohlnak, aki szerint valójában sohasem volt „Rome against the barbarians”, mert az számított, hogy melyik fél tudja gyorsabban és hatékonyabban mozgósítani a barbár elemeket. ${ }^{454}$ A polgárjog fokozatos kiterjesztése miatt már a köztársaság korában sem volt igazán releváns a tényleges etnikai hovatartozás, ${ }^{455}$ amikor pedig Caracalla 212-ben kiadott edictumának köszönhetően a birodalom minden szabad lakosa megkapta a római polgárjogot, ${ }^{456}$ az idegenek (peregrini) számára hüséges közigazgatási vagy katonai szolgálattal biztosítottá vált a társadalmi ranglétrán való felemelkedés lehetősége. ${ }^{457} \mathrm{~A}$

\footnotetext{
450 Thompson 1982, 17; Riché 2016, 68. A gót katonák gyakran váltották kiváltságaikat hagyományos római javakra, földekre és rabszolgákra, hogy a villák berendezésétől kezdve a vadászatokon viselt ruhákig sok szempontból valóban a rómaiak módjára élhessenek, vö. Brown 1999, 65.

451 Bubnó 2013, 19.

452 Riché 2016, 61.

${ }^{453}$ Koenigsberger 1987, 42.

${ }^{454}$ Pohl 2018, 2-3; 7; Brown 1999, 64.

455 Grüll 2007, 71-72.

${ }^{456}$ A rendelet fó célja a szélesebb csoportok adózásra és katonai szolgálatra való kényszerítése volt, vö. Grüll 2016, 78-79.

457 Alföldy 2000, 180. Aristeidés egyenesen azt írja, hogy semmi sem akadályozhatja meg, hogy valaki római polgár lehessen, mert ez a lehetőség mindenki számára elérhető, vö. Aristid., Or. 26,59-60; Grüll $2007,79$. Várady ugyanakkor kitér a katonák zsoldfizetéséhez és rendfokozatához kapcsolódó korrupciós és spekulációs
} 
barbárok integrációját látszólag nehezítette, hogy a 4. század végétől a legtöbb germán nép a birodalmon belül autonómiát kapott, saját államalakulatot hozhatott létre, megtarthatta társadalmi szerkezetét és politikai intézményeit, ráadásul többnyire nem is keveredhetett a helyi római népességgel. ${ }^{458} \mathrm{Ez}$ a tiltás azonban csak jogi természetű volt, hiszen a latin jog (ius Latii) birtokában szabadon lehetett rómaiakkal is törvényes házasságot kötni, ${ }^{459}$ így az auxiliarisként harcoló peregrinusok a szolgálat végén gyermekeikkel együtt római polgárjogot nyertek, ha pedig germánokat kellett a legiókba sorozni, akkor nekik gyakran elöre megadták a polgárjogot. ${ }^{460} \mathrm{Ez}$ alapján sem jogi, sem politikai akadályba nem ütközött a barbárok integrálódása, a meghódított területek birodalomba való beilleszkedését pedig úgy próbálták még tovább gyorsítani, hogy egyrészt ott telepítették le coloniákban a győztes hadsereg veterán katonáinak egy részét, biztosítva ezzel a katonai hivatás öröklödését és a hadsereg utánpótlását is, másrészt pedig a meghódított települések lakossága megkapta az autonómiát jelentő municipiumi rangot. ${ }^{461}$

Ennek megfelelően a 4. század végére a hadsereg olyan mértékben barbarizálódott a nyugati területeken, hogy a segédcsapatokon kívül a római egységekben is nagy számban harcoltak barbárok, ráadásul a magister militumok jelentős része is germán származású volt, ${ }^{462}$ keleten viszont a gazdasági stabilitásnak köszönhetően továbbra is sokkal kisebb szerepet játszottak a barbár elemek a hadsereg összetételében. ${ }^{463}$ Goldsworthy azonban kételkedik abban, hogy a nyugati területek válságában valóban nagy szerepe lett volna a hadsereg barbarizálódásának. Nem túl meggyőzően cáfolja, hogy a hadsereg barbár elemei ténylegesen lojálisak lettek volna Rómához politikai vagy katonai szempontból, másutt viszont azt állítja, hogy a barbár parancsnokok kulturálisan már asszimilálódtak a rómaiakhoz, és legtöbbjük még akkor is jó katonának számított, ha saját népük ellen kellett

lehetőségekre, vö. Várady 1961, 76. A hivatali előmenetelt szabályozó jogi háttérről lásd: Kelemen 2007, 140150 .

458 A felső rétegek kivételével a rómaiak és a barbárok közötti törvényes házasságot Valentinianus és Theodosius is tiltotta rendeleteiben, vö. CTh 3,14,1.

459 A latin jogot eredetileg a kulturálisan fejlettebb és municipiumi rangot elért törzsi közösségek kapták, átmenetet képezve a peregrinus és a római polgár státusza között, ennek birtokában lehetőség volt gazdasági ügyekkel is foglalkozni.

${ }^{460}$ Havas - Hegyi - Szabó 2007, 742; 744. Az 5. századi barbár törvényhozásban már éppen fordítottan, a rómaiakkal szemben tiltották a vegyes házasságokat, vö. Várady 1961, 194.

${ }^{461}$ Alföldy 2000, 164; Grüll 2007, 80. A coloniák jellemzőiröl lásd: Hoffmann 2014, 65-69.

462 Klaniczay 2005, 99-100. A késő császárkori római sereg egységeiről bővebben: Goldsworthy 2004, 202205.

${ }^{463}$ Havas idézi Gluschanin vizsgálatát, amely szerint Theodosius halálakor a 20 keleti dux és comes közül csak 3 volt germán származású, másik 3 már romanizálódott, 14 vezető pedig teljes mértékben római származású volt, vö. Havas - Hegyi - Szabó 2007, 673; Gluschanin 1989, 233-234. 
harcolnia. ${ }^{464}$ Ezek alapján mégis úgy tünik, hogy a római sereg fokozatos barbarizálódása döntő szerepet játszhatott a nyugatrómai területek válságában.

Bár a császári politika kényszerüségből alkalmazott jelentős számú germán katonát a hadseregben, letelepedésüket pedig különbözö jogállásban engedélyezte a birodalom területén, a folyamatos külső fenyegetettség különböző mértékben mégis a Rómával való együttmüködésre késztette a barbár törzseket és speciális, „long and bi-directional symbiotic relationships"-t alakított ki a császári hatalom és a barbár elemek között. ${ }^{465}$ A birodalom iránti elkötelezettség és az egység megörzésére való törekvés a vandálok kivételével minden betelepített germán népnél megfigyelhető, ${ }^{466}$ mivel a Róma és a barbár fejedelmek közötti kölcsönös segítségnyújtásra vonatkozó szerződések alapján gyakran Róma szövetségeseként harcoltak más barbár népekkel szemben, hogy önfeláldozóan és megkéröjelezhetetlen lojalitással védjék a birodalom határait. ${ }^{467}$ Várady ezt találóan „barbárt barbárral semlegesítö politikai-katonai manőverezésnek" nevezi, ${ }^{468}$ Angenendt szerint pedig éppen az vezetett a germánok későbbi szétforgácsolódásához, hogy a birodalom határait germán zsoldosok és szövetségeseik védték a germán támadókkal szemben. ${ }^{469}$ Mócsy kiemeli, hogy a „ritkán fegyverrel, gyakrabban pénzzel” elven alapuló szövetségi politika ellenére Róma sohasem avatkozott bele az egymással rivalizáló barbár fejedelmek közötti háborúba, amely ha nem is igazolja a defenzív imperializmus népszerü elméletét, ${ }^{470}$ sajátos megvilágításba helyezi Róma barbárpolitikáját.

A rómaiak és a barbárok közötti kapcsolat egyik legérdekesebb aspektusa, hogy a barbárok többnyire tiszteletben tartották a római kultúrát, így az a folyamatos harcok ellenére fennmaradt az általuk megszállt területeken is, és csak hosszú évszázadok alatt, békés úton ment végbe az átalakulása. ${ }^{471}$ Ezzel magyarázható, hogy a birodalom területére betörő barbárok ugyan veszélyeztették a római kultúra fennmaradását, de végül meghódoltak előtte azzal, hogy ha nem is változtatások nélkül, de átvették és megőrizték a

\footnotetext{
464 Goldsworthy 2004, 208-209.

465 Sánchez Pardo 2013, 155.

${ }^{466}$ A vandálokkal Africába való telepedésük után már semmilyen együttmüködésre nem volt képes a birodalmi vezetés.

${ }^{467}$ Cass. Dio 79,27,1.

${ }^{468}$ Várady 1961, 154. Klasszikus példát jelent erre Stilicho és Aëtius gótokkal, alánokkal és hunokkal való jó kapcsolata.

469 Angenendt 2008, 129

${ }^{470}$ Mócsy 1974, 10. Ez alapján Róma mindig igazságos háborúkat vívott vagy akaratán kívül keveredett bele konfliktusokba, legfeljebb az őt ért támadásokat megelőzve preventív hadmüveleteket indított az ellenséges népekkel szemben, vö. Grüll 2007, 15.

${ }^{471}$ Heussi 2000, 122.
} 
legfőbb vívmányait. ${ }^{472} \mathrm{~A}$ betelepült germánok nyelvi asszimilációját elősegítette a római és a romanizált lakosság jelentős létszámbeli fölénye, hiszen az 5. század elején a birodalom területén élő germánok együttes létszáma 1 millió alattira tehető, a nyugati területeken viszont összesen 15-20 millió ember élhetett. ${ }^{473}$ Ennek köszönhetően a legtöbb barbár nép a saját nyelvét elhagyva átvette a latin nyelvet, a barbár uralkodók is megtanultak latinul, ${ }^{474} \mathrm{a}$ kereszténység felvételével pedig olyannyira tovább erösödött a latin nyelv monopol helyzete, hogy még a liturgiában a saját népi nyelvüket használó arianus törzsek is latinul kezdték írásba foglalni törvényeiket. ${ }^{475} \mathrm{Ez}$ viszont nem jelenti azt, hogy a barbárok a rómaiaktól elkülönülve ne használták volna a saját nyelvüket is, különösen Gallia és Hispania elzártabb, hegyvidéki területein, ahol a romanizáció kevésbé tudott érvényesülni, illetve a Rajna, a Szajna és a Duna melléki térségekben, ahol sürü volt a germán települések hálózata és az itt élő barbárok még közvetlenül érintkezni tudtak a határon túli saját területeikkel. ${ }^{476}$

A barbárok többnyire tiszteletben tartották és átvették a római intézményeket, tovább müködött az általuk megszállt területeken a közigazgatási szervezet és a római adminisztráció is, amelynek irányítását a vandálok kivételével gyakran római tisztségviselőkre bízták. ${ }^{477}$ A barbár királyok római vagy constantinopolisi mintára berendezett uralkodói udvarában olyan római rhétorok, jogászok és költők tevékenykedtek, mint Sidonius Apollinaris, Isidorus, Boethius, Cassiodorus és Ennodius, akik „hol hiúságból, hol észszerüségböl, de vállalták a feladatot”, és dicsérték megbízójukat müveikben. ${ }^{478}$ A barbár királyok tehát a római „regional elites” alkalmazkodóképességét kihasználva felajánlották számukra, hogy az egyre kisebb hatalommal rendelkező római császár helyett a germán királyi udvarban a barbárokat szolgálva müködjenek tovább, és így próbálják megőrizni korábbi életformájukat és rómaiságukat. ${ }^{479}$ Bubnó az akkulturáció és a kultúramegőrzés tekintetében azt vizsgálta, hogy az 5-6. századi barbár uralkodók hogyan törekedtek a római kultúra megőrzésére a romanizált arisztokrata réteggel és a germán elittel

\footnotetext{
472 Adamik 2014, 26.

${ }^{473}$ Katus 2014, 93-94.

474 Riché 2016, 69.

475 Angenendt 2008, 167.

476 Koenigsberger 1987, 12; Kiss 2008, 3. Mócsy vizsgálatából kiderül, hogy a falusi római lakosság Pannoniában a 4. századtól annyira elkeveredett a barbár lakossággal, hogy anyanyelvét már nem tudta megőrizni, a társadalom felső rétege azonban kohéziós eröként is igyekezett a latin nyelv használatát megörizni, vö. Mócsy 1974, 200.

477 Nem tudunk olyan egyházi vagy senatori rangú személyről, aki Gaiseric vagy más vandál király szolgálatában állt volna.

478 Bubnó 2013, 18.

${ }^{479}$ Brown 2012, 393; Hendrik 2015, 109.
} 
együttmüködve. Nézete szerint a romanizált lakosság létszámbeli fölényének és a barbár királyok Róma iránti csodálatának köszönhetően a római kultúra folytonosságáról beszélhetünk, amely egyre inkább kiszorította a hagyományos barbár elemeket. ${ }^{480}$

A germán származású tisztek és uralkodók a római eszméket átvéve gyakran hangoztatták, hogy ők Róma régi nagyságának örökösei, a 2. századi Aristeidés szerint ezek után nem is nagyon számított, hogy valójában melyik néptől származnak. ${ }^{481}$ Alaric például kifejezetten büszke volt arra, hogy más barbár vezetőktől eltérően nem végzett rombolást Róma épületeiben a 410-es fosztogatás során, ${ }^{482}$ Athaulf pedig a gót birodalom létrehozásának kudarca után a római világ helyreállitójának (restitutor orbis Romani) tartotta magát és gyakran hangoztatta, hogy római módon kötött házasságot Galla Placidiával. ${ }^{483}$ Nagy Theoderic és Cassiodorus viszonya jól mutatja, hogy a barbár királyok nem kívántak a római császár helyébe lépni, de büszkén használták a római titulusokat és intézményeket, számos római épületet fel is újítottak, ennek következtében a germán hagyomány szerepe egyre inkább csökkent még a haj- és ruhaviseletek tekintetében is. ${ }^{484}$

Több kutató azon az állásponton van, hogy a germán uralkodók a római kultúra iránti csodálatuk miatt vették át a római hagyományokat és emiatt érezték magukat a „római államidea képviselőinek", ${ }^{485}$ a valódi magyarázat azonban ennél sokkal praktikusabb lehet. A rómaiak és a barbárok közötti erőviszonyok megváltozása ellenére a barbár királyoknak hatalmuk legitimizálásához még az 5. század végén is szükségük volt a constantinopolisi császár jóváhagyására, ezért viselték büszkén a tölük kapott hatalmi jelvényeket, jóllehet a császár felsőbbsége csak névleges és szimbolikus volt. ${ }^{486}$ Másrészről a római intézményrendszer és kultúra átvételét azzal is magyarázhatjuk, hogy a barbár uralkodók felismerték azt a lehetőséget, hogy a kulturális egység fenntartásával saját hatalmukat is

\footnotetext{
480 Bubnó 2013, 16.

${ }^{481}$ Aristid., Or. 26,75; Alföldy 2000, 160; Grüll 2007, 76-77.

482 Oros. 7,39,15; Iord., Get. 30,17-18; August., De Civ. 1,1; Riché 2016, 29; López Quiroga - Martínez Tejera 2017, 433. Kiss Alarickal kapcsolatban megjegyzi, hogy a hozzá hasonló barbár vezetők nem voltak könnyü helyzetben, mivel a Rómával kötött szerződés és a birodalmi seregben betöltött katonai pozíciójuk következtében bizonyos fokú kompromisszumot kellett kötniük, másrészről viszont uralkodóként elsősorban a gótok érdekeit kellett képviselniük, vö. Kiss 2008, 81.

483 Oros. 7,43; Bubnó 2013, 19.

${ }^{484}$ Bubnó 2013, 16-17. A 6. századi barbár uralkodók művészetpártolásáról és a klasszikus római kultúrához füződő viszonyáról bővebben: Klaniczay 2005, 115-116.

485 Grüll 2007, 222.

${ }^{486}$ Katus 2014, 94-95. A constantinopolisi császár képmásával és nevével, illetve a másik oldalon a barbár uralkodó monogramjával vert érmék általában a császártól való függést és a császári hatalom legalább formális elismerését jelentették, ugyanakkor azt is igazolták, hogy Constantinopolis elismeri a barbár uralkodók hatalmát, ahogyan látjuk ezt Nagy Theoderic esetében is.
} 
könnyebben tudják biztosítani a meghódított területen élő római lakosság fölött, ${ }^{487}$ ahogyan ezt majd megfigyelhetjük a szvév uralkodók valláspolitikájában is. A „római jogfelfogás és adminisztrációs apparátus" átvétele azonban nem automatikusan történt, hanem gyakran kétféle jogrendszer egyidejü alkalmazását jelentette, különösen azokon a területeken, ahol a római lakosság többségben volt a barbár betelepülőkhöz képest. ${ }^{488}$

Havas szerint a késő császárkorban a római társadalom már ,kimeritette belső fejlődési lehetőségeit”, az államgépezet azért volt képes több évszázadra mégis konzerválni az „önmagát már túlélt társadalmat”, mert „,magasfokú szellemi és anyagi civilizációt is védett a kultúra alacsonyabb szintjén álló” barbár népekkel szemben. ${ }^{489}$ Várady úgy véli, hogy éppen a fejlettebb állami, politikai és gazdasági szint miatt adódott az a helyzet, hogy a birodalmat megdöntő erők belülröl, a barbárok betelepedésével és hadseregben való alkalmazásával születtek meg, Dawson azonban úgy látja, hogy a barbárok és a rómaiak találkozásakor hiába került kapcsolatba egy ,primitív nép egy régóta fennálló civilizációval”, ez az interakció „elporlasztotta úgy a meghódított állam, mint a hóditó néptörzs intézményeit."490 Themistius 4. századi constantinopolisi filozófus szerint mindenesetre a római császárok feladata az, hogy a barbárokat megnyerjék a római kultúra számára, és ezt a kultúrmissziót teljesítve, akár a barbárok katonai erejére támaszkodva beillesszék őket a római imperium működésébe. ${ }^{491}$ Orosius egyenesen azt állítja, hogy a barbárok érkezése kifejezetten jó hatást gyakorolt a római civilizációra és a keresztény vallásra, mert hódításaik miatt sokkal több néphez eljutottak a római kultúra vívmányai, mint ahányan megismerkedtek volna velük a hanyatló római hatalomnak köszönhetően. ${ }^{492} \mathrm{~A}$ rómaiak szerint tehát a görögök megközelítésétől eltérően a civilizáltságot tanulni is lehet, Róma pedig a korszak világbirodalmi központjaként kifejezetten azzal a civilizatórikus küldetéssel rendelkezik, hogy a humanitas nélküli barbár népeket kulturális szempontból is meghódítsa. ${ }^{493}$ A kulturális különbségek elemzésekor nem hagyhatjuk figyelmen kívül Mócsy álláspontját sem, mely szerint nem szabad a romanizációs politikát túlértékelni és

\footnotetext{
487 Cameron 1993, 138; Bubnó 2013, 27. Edwards 2007, 260-287; Halsall 2007, 462-468; Heather 2007c, 450-455.

${ }^{489}$ Havas 1998, 44.

${ }^{490}$ Várady 1961, 17; Dawson 1938, 111.

491 Themist., Or. 5,66; 10,131; Katus 2014, 94.

492 Oros. 2,6,14; 7,41,8; Löwith 1996, 225-227.

493 Grüll 2007, 33-34.
}

488 Klaniczay 2005, 112-113. Euric törvényei még külön szabályozták a római és a gót lakosság életét, elsőként a 7. század közepéről maradt fenn olyan gyüjtemény, amely jogi szempontból is igyekezett egyesíteni a római és a barbár lakosságot. Az Euric által megteremtett gót jogrend igazgatási és társadalmi vonatkozásairól bővebben: Várady 1961, 191-200; a római jog gót kodifikációjáról lásd: Albrecht 2004, 1226-1228; Riché 2016, 78-79; a római jogrend és az etnikai identitás problémájáról bővebben: Charles- 
egyfajta kultúrmisszióként értelmezni, mert például a latin nyelv terjesztését leginkább igazgatási, gazdasági és katonai szempontok indokolták. ${ }^{494}$ Grüll ehhez hasonlóan úgy látja, hogy túlságosan is népszerü az az „előfeltevés”, mely szerint Róma kulturális értékeinek átadásával szükségképpen gazdagította a barbár népeket, ezért a romanizáció fogalmát újraértelmezve inkább „egymás mellett létezö kulturális sokszínüségről”, egyfajta multikulturalizmusról beszél a birodalmon belül, ahogyan López Quiroga és Martínez Tejera is úgy látja a 4-6. századi temetési rítusok és epigráfiai leletek elemzésekor, hogy a „great cultural heterogeneity” csak nagyon hosszú idő alatt alakult át egyfajta „hybrid cultural syncretism" formájává. ${ }^{495}$

\subsubsection{Vallási különbségek és az egyház szerepe}

A Római Birodalom két germánok lakta provinciájában, Germania Superiorban és Germania Inferiorban Irenaeus térítése nyomán már 185 körül keresztény közösségek jöttek létre, leginkább a Rajna mentén fekvő római városokban. ${ }^{496}$ Tertullianus beszámolójából kiderül, hogy a hívek főként a városi kereskedők, iparosok és rabszolgák közül kerültek ki, a falvakban élő germánok megtérése általában az őslakossággal való összeolvadásnak köszönhetö. Ezek alapján nehezen állapítható meg, hogy a germán provinciák lakossága pontosan mikor tért a keresztény hitre. ${ }^{497}$ Galliából a 2. századtól vannak adataink a kereszténység terjedéséről, Britanniában csak a 3. század közepétől tudunk nagyobb csoportok létezéséröl, az észak-africai kereszténység viszont 200 körül Carthago köré szerveződve már jelentős közösséggel rendelkezett. ${ }^{498}$

Hispaniában feltehetően a 250-es években jöttek létre az első keresztény csoportok, Asturica, Legio és Emerita híveit Diocletianus üldözései után említik először, akik feltehetően az észak-africai keresztény közösségekkel álltak kapcsolatban. ${ }^{499}$ A 306 körül Elvirában összehívott hispaniai zsinat résztvevőinek listájából ${ }^{500}$ és a feltárt régészeti leletekből jól látszik, hogy a legnagyobb központok a fejlettebb gazdasággal rendelkező és urbanizálódott középső és déli területeken, tehát Baeticában, Carthaginensisben,

\footnotetext{
${ }^{494}$ Mócsy 1987, 10-11.

495 Grüll 2016, 75-78; López Quiroga - Martínez Tejera 2017, 442.

496 Iren., Haer. 1,13,7; Heussi 2000, 63.

497 Tertull., De idol. 11; Szántó 1983, 235.

498 A kereszténység korabeli földrajzi kiterjedéséről bővebben: Vanyó 2007a, 139-145.

${ }^{499}$ Cypr., Ep. 67; Cortázar - Vesga 2001, 87; Chadwick 1999, 61. Az első gallaeciai keresztény emléket lásd: López Quiroga - Martínez Tejera 2017, 118.

500 Vives 1963, 1-16; Edwards 2007, 368; Löhr 2007, 37.
} 
Lusitaniában, Gallaeciában és Tarraconensisben müködtek, míg északon a pogány szokások és a bálványimádás lehetett túlsúlyban ebben az időszakban. ${ }^{501} \mathrm{~A} 3$. század végétôl a germánok birodalom ellen vezetett hadjáratai során feltehetően jó néhány keresztényt is fogságba ejtettek, ${ }^{502}$ később a kereskedelmi kapcsolatok révén találkozhattak a katolikus tanítással, ${ }^{503}$ a 4 . századtól pedig a Római Birodalomba érkező germán csoportok közül egyre többen keresztelkedtek meg. A nyugati tartományok benépesítése és a hadsereg felduzzasztása miatti áttelepítéseknek köszönhetően ez a folyamat még inkább felgyorsult, bár a 4. század végétől a foedus alapján betelepült törzsek nemcsak saját vezetőiket és társadalmi szervezetüket tarthatták meg, hanem vallásukat is. ${ }^{504}$

A birodalomba érkező germán népek megtérését számos tényező gátolta, más szempontok viszont segítették kereszténnyé válásukat. A barbárok térítésében nehézséget jelentett, hogy többnyire még törzsi szervezetben éltek, nem ismerték az államiság fogalmát ${ }^{505}$ és a rómaiakhoz képest teljesen más, pogány szokásokkal rendelkeztek, ${ }^{506}$ ezért a vallási különbségek még inkább erősíthették a rómaiakban a barbárok iránti ellenszenvet. Valószínüleg politeista elveket vallottak, ezért eleve nyitottak voltak a keresztény vallás elfogadására, ugyanakkor a nyugati barbárokra jellemző gentilizmus akadályozhatta is őket a keresztényekkel való egyszerü kapcsolattartásban. ${ }^{507}$ Gátolhatta megtérítésüket a babonára

${ }^{501}$ Horváth 2004, 68-69; López Quiroga - Martínez Tejera 2017, 478-482. A keresztény közösségek 3-4. századi jelenlétét igazolja többek között egy Lucusban talált ezüstgyưrü és bronzcsillár, egy Asturicában előkerült bronzgyürü, valamint számos istentiszteleti épület és szarkofág maradványa, vö. 3. sz. kép; López Quiroga - Martínez Tejera 2017, 123; 156-163; 169-170; 191-192. Az első püspöki székhelyek müködéséröl 4-5. századi edény-, pohár- és szarkofágtöredékek tanúskodnak, vö. López Quiroga - Martínez Tejera 2017, 164-167; Lucus, Asturica és Bracara vezetésével pedig más területekhez hasonlóan római mintára épült ki a gallaeciai egyházszervezet, ennek áttekintéséhez lásd: 6. sz. térkép. A kereszténység vidéki terjedését az arisztokrácia körében épületmaradványok igazolják, vö. López Quiroga - Martínez Tejera 2017, 155; 159; 168.

${ }^{502}$ Székely 2008, 68, 7. j.

${ }^{503}$ A hispaniai egyház kialakulására nemcsak az észak-africai közösségekkel való érintkezés és a kereskedelmi kapcsolatok voltak nagy hatással, hanem a 4. századtól azok a Szentföldre irányuló peregrinatiók is, amelyeket Hydatiusszal kapcsolatban is említettünk; az erre vonatkozó forrásokat lásd: López Quiroga Martínez Tejera 2017, 478.

504 Török 1999, 89; Marton 2004, 223. A germán törzsek néppé alakulási folyamatáról és társadalmuk felépítéséről lásd: Angi 1999, 22-23; Todd 2007a, 440-460; a gótok társadalmi szerveződéséről bővebben: Heather 2007a, 493-496.

${ }^{505}$ A pogány germánok matrilineáris felfogása, archaikus és formalista jogrendjük jellegzetességei teljesen szemben álltak mind a fejlett római joggal, mind pedig a keresztény felfogással, vö. Klaniczay 2005, 69; 113; Todd 2007b, 486.

506 A germánok népvándorlás előtti szokásairól Caesar és Tacitus alapján rövid összefoglalót közöl: Katus 2014, 78-80. A barbár nevelés is nagy mértékben különbözött a római felfogástól, vö. Tac., Germ. 2,3; 7,3; 13,1; 20,1-2; Salv. 5,2-8; Riché 2016, 24-25. A gótok pogány szokásairól bővebben: Wolfram 1988, 106111; Székely 2008, 68, 6. j.; a hunok és az alánok szokásairól lásd: Amm Marc. 31,2,1-12; 31,2,17-25.

${ }^{507}$ A barbárok vallási öntudatának egyik jellemzöje, hogy csak saját népükre összpontosítják figyelmüket és saját törzsükön belüli emberekkel érintkeznek, így nem foglalkoznak az univerzális világ vagy az emberiség 
és a bosszúállásra való hajlandóság, ${ }^{508}$ az ösi istenekbe vetett hit és a tőlük való félelem, de attól is tartottak, hogy ha elhagyják a régi isteneiket, akkor nem segítik öket tovább és katonai vereségeket kell elszenvedniük. ${ }^{509}$ Márészről viszont a germánok között végzett hittérítést mindenképpen könnyítette a keresztények igazságot kereső erkölcsrendszere és a látványos szertartások, de fontos szerepe volt a hittérítők munkáját kísérő csodajeleknek is, amelyek Daniel-Rops szerint meggyőzték a barbár népeket arról, hogy a keresztények istene a legerősebb, ráadásul minden egyén számára így biztosított az üdvözülés. ${ }^{510}$

Amikor a népvándorlás során az első germán csoportok a birodalomba érkeztek és találkoztak olyan törzsekkel, akik már korábban betelepedtek és keresztényekké váltak, ők is hamarosan megtértek. Mivel különösen jellemző volt rájuk a törvényeikhez és vezetőikhez való hűség, általában nem személyes meggyőződés alapján, hanem csoportosan, vezetőik parancsára csatlakoztak a kereszténységhez, ilyen csoportos megtérést látunk 407 körül a burgundoknál és 450 körül a szvéveknél. Ezek a törzsek először katolikusok lettek, majd később vezetőik döntése miatt tértek át az arianus kereszténységre. ${ }^{511}$ A 4 . században betelepített népek körében végzett missziós tevékenység sikerét jól mutatja, hogy a 381-es constantinopolisi zsinaton határozatot hoztak arról, hogy az egyházat a korábbi szokásoknak megfelelően kell kormányozni a barbár népek között is, vagyis ebben az időszakban jelentős keresztény csoportok jöhettek létre a germánok körében. ${ }^{512}$ A gótoknál kialakult szórványos keresztény közösségeket a cappadociai keresztényektől származó Wulfila (310-383k.) erősítette meg, és neki köszönhetően az egész nép felvette a keresztény vallást. ${ }^{513}$ Wulfila egy gót betörés alkalmával esett a rómaiak fogságába, később 341-ben lectorként küldték követségbe II. Constantius constantinopolisi udvarába, ${ }^{514}$ így került kapcsolatba a római egyház képviselőivel. Miután Arius egyik tanítványa, a nicomediai Eusebius 341-ben az antiochiai zsinaton püspökké

\footnotetext{
létezésével, ennélfogva zárkózottságuk miatt rendkívül nehéz őket megtéríteni; vö. Angenendt 2008, 170; Kulikowski 2013, 692.

${ }^{508}$ Az emberölés jóvátételként való elfogadásáról, a családi szolidaritásról és az istenítéletek alkalmazásáról lásd: Klaniczay 2005, 113.

509 Szántó 1983, 236. A germánok istenvilágáról és kozmogóniájáról lásd: Angi 1999, 25-26; Eliade 2006, 391-400; Katus 2014, 80-82. Grüll szerint a rómaiak a barbárok hitét babonaságnak (superstitio) tartották, de nem azt gondolták, hogy a barbárok rossz isteneket tisztelnek, hanem csak azt, hogy rossz módon fejezik ki hitüket; vö. Grüll 2007, 132.

510 Daniel-Rops 1957, 2,238; Zsinka 2012, 7. A germánok vallásfelfogása sok hasonlóságot mutat a keresztények álláspontjával, ilyen közös elem a lineáris történelemszemlélet, a szentkultusz és a zarándoklatok gyakorlata, illetve a világvége motívumának megléte, vö. Angi 1999, 26.

${ }^{511}$ Jedin 1962, 1,234; Marton 2004, 223; Angenendt 2008, 41.

512 Theodor. 5,30-31; Sozom. 7,26; Chadwick 1999, 232; Vanyó 2007b, 376.

${ }^{513}$ Iord., Get. 132; Isid., Hist. Goth. 8.

${ }^{514}$ Chadwick 1999, 232.
} 
szentelte őt, visszatért és áttérítette a gótokat ${ }^{515}$ a józan vallásosságot és természetes erkölcsöt hirdető primitív arianizmusra. ${ }^{516}$

A gótok hatására a velük érintkező germán népek a birodalomba való betelepedésük után általában rövid időn belül kereszténnyé váltak, és ebben nagy szerepe volt annak, hogy az arianusok a Wulfila által gótra fordított Bibliát használták eszközként a többi germán nép megtérítésekor. ${ }^{517}$ A betelepedés szükségszerü feltételének látszott a kereszténység elfogadása, hiszen Valens már a gótok betelepítését is azzal a feltétellel engedélyezte, hogy ha felhagynak régi vallásgyakorlatukkal és átveszik a rómaiak hitét. ${ }^{518} \mathrm{~A}$ barbár népek azonban a rómaiakkal azonosították a katolikus vallást, ezért velük szembefordulva általában az arianus hitet vallották, ${ }^{519}$ mivel az ortodoxia elfogadása gyengítette volna a germánok nemzeti sajátosságait. Az arianizmust saját népi identitásuk összetevőjének tekintették, ebben látták biztosítva a birodalmon belüli függetlenségüket, ${ }^{520}$ ezért az arianus hit a rómaiak és a barbárok közötti elkülönülés szimbólumává váltt. ${ }^{521} \mathrm{~A}$ barbárok azért is vonzódtak az arianus eszmékhez, mert az ortodoxiához képest egyszerübb vallásgyakorlatot hirdetett és a köznyelvet használta, ráadásul a helyi közösségekre épülve nem alakult ki centralizált egyháza, ez alapján joggal állítja Horváth, hogy az arianizmus „nem az ortodoxiával összemért tudatos választás, hanem az elérhetöség" miatt lett a barbárok vallása, ${ }^{522}$ éppen ezért fogadhatjuk el Angenendt véleményét, aki a barbár vallásosság minőségét elemezve elutasítja, hogy a germánok megtérése egyfajta ballépésként saját gyengeségükkel és önmegalázásukkal lenne indokolható. ${ }^{523}$

\footnotetext{
${ }^{515}$ Thompson 1966, 93; Horváth 1999, 46. Socrates szerint a gótok egyik vezetöje, Fritigern Valens császárhoz való hűsége jeléül vette fel az arianus vallást, vö. Socr. 4,33; Iordanes viszont arra utal, hogy 382 elött a gótok többsége még pogány volt, vö. Iord., Get. 267.

516 Wulfila ezzel követte a 360-as constantinopolisi zsinaton jóváhagyott tanítást, de figyelmen kívül hagyta a 359-es ariminiumi deklarációt, vö. Török 1999, 90-91. Wulfila tevékenységéröl és a gót arianizmusról bővebben: Wolfram 1988, 75-84; Heather - Matthews 1991, 124-144; Székely 2008, 68, 8. j.; Falluomini 2015, 4-24.

${ }^{517}$ Russell 1996, 135-139; Marton 2004, 225.

${ }^{518}$ Russell 1996, 134-135; Klaniczay 2005, 131.

${ }^{519}$ A vandálok azonnal az arianizmus hívei lettek, a szvévek és a burgundok csak a katolikus vallás felvétele után, feltehetően gót hatásra tértek át az arianus hitre. A burgundok vallási helyzetéről lásd: Török 1999, 106108; Wood 2005, 712-713. A frankok ettől eltérően úgy ítélték meg, hogy leginkább a rómaiak támogatására van szükségük, ezért Chlodvig vezetésével rögtön a katolikus hitet vették fel 498 körül, vö. Socr. 2,41; Sozom. 1,24; 6,37; Iord., Get. 51; Greg. Tur. 2,21-22. A frankok megtéréséről bővebben: Horváth 1999, 48-49; Wood 2005, 713-714; Zsinka 2012, 16-17.

${ }^{520}$ Koenigsberger 1987, 30; Chadwick 1999, 233; Barbero - Loring 2005, 192; Angenendt 2008, 143.

${ }^{521}$ Horváth 1999, 45. Az arianizmus felvételének lehetséges okairól bővebben: Thompson 1966, 107-110.

${ }^{522}$ Horváth 1999, 51; Klaniczay 2005, 131.

523 Angenendt kissé ellentmondásosan úgy látja, hogy a barbárok megtartották a primitív vallásosságuk alapvető vonásait, ugyanakkor saját szükségleteikhez igazítva germanizálták a keresztény vallást, vö. Angenendt 2008, 40-41.
} 
Az arianussá vált germán népek valójában nem törődtek azzal, hogy Krisztusról vallott elképzeléseik mennyiben térnek el a katolikusokétól, nem voltak különösebben tisztában a dogmatikai kérdésekkel sem, ${ }^{524}$ ennek ellenére hittek abban, hogy egy helyes tanításról szóló vita során a saját hitük megállná a helyét a katolikussal szemben. ${ }^{525} \mathrm{~A}$ rómaiak éppen ezt a különbséget hangsúlyozva müveletlenségnek és a hódítók vallásának tartották a barbár hitvallást, ezért a rómaiakban tovább erősödött a kulturális fölény gondolata, a gótok pedig népük összetartásának növelésére nemzeti vallássá emelték az arianizmust. ${ }^{526}$ Horváth találó módon kifejti, hogy ez a jelenség nem a gótoknak, hanem maguknak a rómaiaknak köszönhető, mivel a birodalomba érkezésükkel már nem volt lehetőség a barbároktól való fizikai elhatárolódásra, ezért az elkülönülést máshová, a „spirituális szférába” helyezték át. ${ }^{527} \mathrm{~A}$ római császárok egy része ugyan szimpatizált az arianizmussal, az mégis hatásos eszközzé válhatott az általunk vizsgált barbár uralkodók kezében is arra, hogy egységben tudják tartani a saját népüket, és ezáltal elkerüljék a meghódított lakossággal történő keveredést, más szempontból viszont éppen a közös vallás segítette később a rómaiak és a barbárok közötti együttmüködést, mivel a kereszténység felvétele nemcsak a germán népek között játszott közvetítő szerepet, hanem a rómaiakhoz is közelítette a barbár lakosságot. ${ }^{528}$ A legtöbb germán uralkodó a vandálok kivételével eleinte toleranciát mutatott a más vallásúakkal szemben, nem akarták a rómaiakat áttérésre kényszeríteni, az 5. század közepén azonban változott a helyzet, és többnyire politikai céllal fordultak szembe a helyi katolikus lakossággal a gótok Galliában, a szvévek Hispaniában, a vandálok pedig Észak-Afrikában. ${ }^{529}$

A gótok által létrehozott szervezeti és hitbeli formákat a többi barbár nép is átvette. A germán államokban működő egyházak kiterjedése az uralkodó felségterületével esett egybe, így a barbár területeken nem alakultak ki olyan szövetségi rendszerek, mint a katolikus egyházon belül. ${ }^{530} \mathrm{~A}$ kutatók nagy része egyetért abban, hogy a barbár uralkodók

\footnotetext{
524 Török 1999, 92; Horváth 1999, 48.

525 Brown 1999, 67. Chadwick idézi Philostorgiust, aki 425 körül írt apologiájában azt írja, hogy az arianusok eleinte igyekeztek átformálni a keresztény tanítást, hogy a müveltek körében is népszerü legyen, de végül „elavult jelmondatok babonás ismételgetésévé” változott a tanításuk, vö. Chadwick 1999, 140.

${ }^{526}$ Daniel-Rops 1957, 2,222; Török 1999, 111.

${ }^{527}$ Horváth 1999, 48.

${ }^{528}$ Duby 1978, 114; Török 1999, 92; Horváth 1999, 51.

${ }^{529}$ Horváth 1999, 48; Chadwick 1999, 233; Török 1999, 92.

${ }^{530}$ Heussi 2000, 124. A gót egyház földrajzi szerveződése ugyanakkor eltért a klasszikus mintától, mivel a hívek létszámának megfelelően a patriarcha tevékenysége és intézkedései szabták meg az egyházmegye tényleges határait, vö. Török 1999, 104-105.
} 
és az egyház között szoros viszony alakult ki, ${ }^{531}$ ezért a primitív vallásosság jegyében az arianus egyház felépítése a katonai szervezetnek megfelelően alakult ki. ${ }^{532}$ A rex és a sacerdos titulussal felruházott uralkodók kompetenciája ezáltal nemcsak az állam irányításában, hanem az egyházi élet vezetésében is érvényesült, így viszont a vallást többnyire saját hatalmi törekvéseinek legitimizálására használták, ${ }^{533}$ ahogyan jól látszik majd ez a vandálok és a szvévek esetében is. Míg a 4. század elött a gensek törzsi vezetői korlátozott hatalommal rendelkeztek, leginkább kultikus feladatokat láttak el és hatalmukat szakrális szempontok erősítették, addig a népvándorlás korától kezdve a hadvezérek a katonák sikereire támaszkodva erősítették meg hatalmukat. ${ }^{534} \mathrm{Az}$ így létrejött hadikirályságokban sikeres hódítások esetén az uralkodó örökletessé tudta tenni a hatalmát, vagyis a katonai eredmények legitimálták az uralkodását, ${ }^{535}$ a római császár viszont hiába volt az egyház védelmezője és a keresztény hit hirdetője, nem mindig rendelkezett szakrális hatalommal és feladatkörrel.

Marton szerint a barbár uralkodó hívta össze a zsinatokat és az ő feladata volt a törzsi csoportok papjaiból kiemelt püspökök kinevezése és leváltása is, akik Katus véleménye alapján a király tanácsadói és fontos állami feladatok végrehajtói is voltak egyben, a tartományi egyház zsinatain viszont a világi előkelők is részt vettek és a vallási témák mellett világi ügyekkel is foglalkoztak. ${ }^{536}$ Jedin a papok hadseregben teljesített szolgálata mellett azt hangsúlyozza, hogy a püspökök nagy mértékben függtek a törzsi vezetőktől, nincsenek viszont bizonyítékaink Török azon állítására, hogy a barbár területeken csak azért nem tartottak zsinatokat, mert itt nem alakult ki semmilyen egyházi hierarchia. ${ }^{537}$ Heussi és Angenendt a germán egyház felépítését a katolikus egyház hierarchiájához hasonlítja, mivel a püspökök, a presbyterek és a diaconusok a germán nép tagjaiból, illetve arianussá lett katolikusok közül származtak, de nem ismerték a metropolita intézményét. A gót és a szvév egyház felépítése valószínüleg abban különbözött a többi germán egyházétól, hogy a magánszentélyek mintájára magántemplomokat hoztak létre,

\footnotetext{
531 Angenendt szerint ezt a közvetlen kapcsolatot azzal indokolhatjuk, hogy az arianus germán államoknak különösen nagy szükségük volt a magasabb szintü szakrális védelemre, vö. Angenendt 2008, 43-44.

532 Várady 1961, 142. Segesváry szerint a barbárok „katonapapjai” által fejlődött ki a későbbi „Eigenkirche” gyakorlata, ami alapján az egyház összes épülete és javadalma a vezető tulajdonát képezi, vö. Segesváry 1994 , 65.

533 Angenendt 2008, 171.

534 Trambauer 2008, 5-8. A barbár vezetők gensek fölötti hatalmát általában a rómaiaknak is el kellett ismernie ahhoz, hogy elnyerjék az együttmüködésüket, vö. Pohl 2018, 3-4.

535 Angi 1999, 21. A barbár királyok katonai hatalmáról bővebben: Klaniczay 2005, 112.

${ }_{536}$ Marton 2004, 225; Katus 2014, 99.

537 Jedin 1962, 2,369; Török 1999, 92.
} 
amelyek előképei talán a római nagybirtokok villáin épült magánkápolnák és temetkezési épületek lehettek. ${ }^{538}$

Általánosan elfogadott nézet, hogy az arianizmus a 325-ös nicaeai és a 381-es constantinopolisi zsinatok következtében sokat veszített népszerüségéböl, és miután a kereszténységet Theodosius államvallássá nyilvánította, a 4. század végén már nem jelentett különösebb veszélyt a császári irányítás alatt álló katolikus területeken, a germán államok egy részénél viszont még sokáig megőrizte népszerüségét. ${ }^{539} \mathrm{Az}$ arianizmus 6. századi eltűnését elsősorban a germán uralkodók Constantinopolistól és a frankoktól elszenvedett vereségével szokás magyarázni, ${ }^{540}$ de egyházi hierarchiájuk kezdetleges formája is hozzájárulhatott ahhoz, hogy végül teljesen alulmaradjon az ortodoxiával szemben.

A rómaiak számára a katolikus vallás tünt saját civilizációjuk utolsó összetartójának, és a barbár népek betöréseit elsősorban azért utasították el, mert féltek a vallási és a birodalmi egység megsemmisülésétől. Hispania esetében különösen érdekes, hogy a kereszténység egyházi szervezete éppen ebben a válságos időszakban épült ki, túlzás viszont Anderle azon következtetése, mely szerint a püspökségek ,egyetlen stabil eröként” a barbár népeket is integrálni tudták a római társadalomba, hacsak nem azonosítjuk ezt a megállapítást a kereszténység hadseregre gyakorolt hatásával. ${ }^{541}$ A politikai válság növekedésével a katolikus egyháznak is új feladatai lettek: nemcsak a lakosságot kellett megvédeniük a barbár fosztogatásoktól, hanem az elpusztult városokban újjá kellett szervezni a mindennapi életet és enyhíteni kellett a barbárok okozta pusztítás tüneteit. ${ }^{542} \mathrm{~A}$ barbár támadásoknak köszönhetően a nyugati területeken megerösödött a püspökök hatalma, mivel a legtöbb városban ez a hivatal maradt az egyetlen müködőképes római intézmény, így a városok az 5. század első felében is megtartották központi szerepüket éppen a társadalom rendezésére vonatkozó feladataik miatt. ${ }^{543}$ A lakosság patronusként

\footnotetext{
${ }^{538}$ Heussi 2000, 124; Angenendt 2008, 178.

${ }^{539}$ Angenendt 2008, 68. Bár a birodalom keleti részein az arianizmus valóban nem terjedt el széles körben, Wulfila környezetében az értelmiség nagy tekintélye miatt az arianus hit annyira megerősödött, hogy egyre több arianus püspök is latin nyelvü munkák írásába kezdett, a cappadociai Auxentiust pedig 374-ben egyenesen Mediolanum püspökévé választották, vö. Török 1999, 91.

${ }^{540}$ A katolikussá vált frankok domináns helyzete nagyban hozzájárult az arianizmus visszaszorulásához, vö. Gárdonyi 2006, 108. A gótok 586-ban, a longobárdok 671-ben tértek meg, Africában az 534-es constantinopolisi hódítás számolta fel ezt az eretnekséget.

${ }^{541}$ Anderle 1999, 16. A keresztény hit birodalmi vallássá emelése nem hozott jelentős változást a hadsereg életében, mivel az 5. századi római sereg minden egységénél tábori papok szolgáltak, ez pedig elösegítette a barbárok megtérését is, vö. Goldsworthy 2004, 212.

542 Török 1999, 87; Horváth 1999, 48. Az egyház intellektuális szinten is próbált reagálni a barbár támadásokra, és többek között az arianus eszmék terjedésének megállítása érdekében indultak el a keresztény iskolák, vö. Riché 2016, 84.

${ }^{543}$ Hendrik 2015, 14.
} 
tekintett a helyi katolikus közösség vezetőjére, aki a közigazgatási tisztségviselőktől eltérően nemcsak a hivatali idő alatt, hanem egész életében a híveket szolgálta, ráadásul nemcsak a lelki vezetést, hanem gyakran az anyagi és szociális biztonságot is igyekezett megteremteni a városlakók számára. ${ }^{544}$

A rómaiak a kezdeti időszakban a barbárok támadását csak átmeneti nehézségnek, egyfajta isteni figyelmeztetésnek tekintették és reménykedtek a gyors elmúlásában, ezért az egyház csak nagyon lassan kezdte el szervezetten téríteni a barbár törzseket. Ahogyan azonban gyengült a központi hatalom hatékonysága és növekedett az eretnek tanítások népszerüsége, egyre fontosabbá vált az egyház számára, hogy ezt a feladatot is felvállalja, és a meglévő közösségek megmentésén túl párbeszédet kezdeményezzen a barbár hódítókkal. Bár úgy tűnt, hogy a germán királyságok társadalma és kultúrája csak „,bizonytalan körvonalakkal" határozható meg, a barbár népek térítése folyamatos kihívást jelentett az egyház számára, vagyis a germán betörések nemcsak a helyi lakosság életére voltak negatív hatással, hanem az egyház életében is rendkívül súlyos károkat okoztak. ${ }^{545}$ A barbárokkal szembeni helyi ellenállás megszervezése Hispaniában és Galliában is egyre inkább a püspökök feladatává vált, vagy ahogyan Brown találóan fogalmaz, „a városfalak és a püspökök egymáshoz tartoztak", ${ }^{546}$ ez pedig jól mutatja, hogy a megnövekedett feladatok a kétségbeesés helyett többnyire inkább egyfajta dinamizmust adtak az egyház vezetőinek. ${ }^{547}$

\footnotetext{
${ }^{544}$ Klaniczay 2005, 125; Hunt 2007, 263-272. Az egyház karitatív tevékenységének növelésével próbálta enyhíteni az éhínség és az ostromok következményeit, az arelatéi Caesarius például még a bazilika ezüstdíszeit is beolvasztotta, hogy több ezer fogságba esett földmüvest kiválthasson. A barbárok által megszállt területeken a templomok váltak az egyetlen közösségi térré, ezért Galliában például jó néhány bazilikát emeltek a városközpontokban, míg a világi építkezések többnyire leálltak ebben az időszakban, vö. Benevolo 1994, 24 26; Brown 1999, 68-69; Liebeschuetz 2007, 209-210.

${ }^{545}$ Zsinka 2012, 9. A birodalom határvidékén élő keresztények sokszor kiszorultak saját területeikről, a Rajna bal partján pedig a lakosság jelentős része a barbárok hatására visszapogányosodott. Angenendt hosszú listát közöl azokról a városokról, ahol a helyi püspökök a barbárok nyomására visszaléptek hivataluktól, vagy székhelyüket más városba helyezték át, de olyan példákat is látunk Észak-Galliából, a Rajna és a Duna vidékéröl, ahol akár egy évszázadra vonatkozóan is hiányosak a püspöklisták, ez pedig a folytonosság megszakadására utal, vö. Angenendt 2008, 132-133. A vidékre menekült lakosság hitének megtartása és visszatérítése sem volt könnyü feladat, mivel a régi templomok fenntartása, az újak felépítése és felszerelése, a hívek oktatása sokszor lehetetlen feladatnak bizonyult, vö. Angenendt 2008, 164.

${ }^{546}$ Brown 1999, 68. Thraciában például egy püspök hajítógéppel hatástalanította a várost ostromló hunok vezérét, vö. Chadwick 1999, 232; Tolosa püspöke parancsnokként igyekezett hősiesen helytállni a város ostromakor, vö. Vanyó 2007b, 376; Aureliani lakói Annianus püspök tanácsára Istenhez fohászkodva védték meg városukat a hunok támadásától, vö. Brown 1999, 68; Tricassis püspöke, Lupus pedig úgy mentette meg a város lakosságát, hogy tájékozódásban segítette Attila seregét, vö. Klaniczay 2005, 93. Sidonius Apollinarisnál olvashatjuk, hogy Augustonemetum püspökeként azért egy Simplicius nevü arisztokratát nevezett ki Avaricum püspökének, mert csak ő tudta biztosítani a lakosság élelmiszerellátását és gótokkal szembeni védelmét, az pedig kevésbé számított, hogy a klérusból származik-e és van-e teológiai műveltsége, vö. Sid. Ap., Ep. 7,6,9; Brown 1999, 71-72. Más püspökök helytállásáról bővebben: Synes., Ep. 112; Hier., Ep. 123,16; Theodor. 5,39 .
}

${ }^{547}$ Breisach 2004, 102. 
Bár a barbárok és a rómaiak közötti együttmüködés egyik elősegítője éppen a keresztény hit lehetett, mert ennek közös etikája nem alakított ki olyan választóvonalat, mint korábban a mos maiorumot követő rómaiak és az idegenek között, ${ }^{548}$ mégis számtalan nehézséget okozott a két eltérő életformájú, kultúrájú és vallású népesség együttélése. ${ }^{549}$ Ezzel magyarázható, hogy igyekeztek a rómaiakat és a barbárokat eleve szétválasztani egymástól: gyakran külön településeken éltek, nem házasodhattak egymással, a germánok saját vezetőik és törvényeik szerint éltek, katonai szolgálatuk miatt nem kellett adót fizetniük, a rómaiaknál viszont érvényben maradt a római jog, a római intézmények és tisztségviselők továbbra is működtek, a rómaiak nem vállalhattak katonai szolgálatot, ugyanakkor továbbra is adót kellett fizetniük. ${ }^{550}$ A két népesség elkülönülése leginkább a keleti gótoknál és a vandáloknál szembetűnő, a 6. század végén azonban mindenhol megindult a két csoport összeolvadása, amelyet elősegített, hogy a barbárok is áttértek a katolikus hitre, feloldották a házassági tilalmat és egységes törvénykönyveket adtak ki az egész népre vonatkozóan.

\subsection{A szétfeszítő erők szerepe Hydatius krónikájában}

Ma is komoly vita tárgyát képezi, hogy melyik történelmi eseményt vagy szükebb időszakot tekinthetjük a római császárkor végének, egyben a kora középkor kezdetének. Néhány kutató korabeli forrásokra hivatkozva a 378-as hadrianopolisi csatát tartja fordulópontnak, mert ez volt a barbárok első jelentős győzelme a rómaiak fölött és emiatt kerülhetett sor a római történelem legsúlyosabb következményekkel járó szerződésének megkötésére 382ben. ${ }^{551}$ Fordulópontnak tekinthető a Római Birodalom területének kettéosztását jelző 395. esztendő is, de ez a sajátos közigazgatási és adminisztratív megosztottság jogi értelemben már Theodosius halála elött is fennállt, ráadásul alkotmányos értelemben aligha beszélhetünk két önálló birodalom kialakulásáról, mert később számos esetben megnyilvánul még az összetartozás és a közös kormányzás gyakorlata. ${ }^{552}$ A nyugati történeti hagyományban a legtöbb 19-20. századi kutató Marcellinus Comes, Iordanes és

\footnotetext{
${ }^{548}$ Oros. 5,2,6; 7,32,9; Alföldy 2000, 204.

549 Alföldy szerint még így is kevesebb konfliktus alakult ki, mint amennyi a nyelvi és a kulturális különbségekből adódhatott volna, vö. Alföldy 2000, 203.

${ }^{550}$ Katus 2014, 96-97.

${ }^{551}$ Sz. Jónás 1994, 10; Angenendt 2008, 25; 129; Wieser 2016, 87-88; Amm Marc. 31,4; Oros. 7,33,9-19.

552 A két birodalomrész ugyan külön hadsereggel és császári székhellyel rendelkezett, de gyakran együtt léptek fel a barbár betörésekkel szemben, közös volt többek között a fizetőeszközük, az adórendszerük, a vallásuk és az egyházi szervezetük is, vö. Hier., Ep. 60,15; Oros. 7,36,1; Havas - Hegyi - Szabó 2007, 650; 654; 733; a birodalom kettéválása azonban egyértelmüen jelezte az államszervezet meggyengülését, vö. Alföldy 2000, 179.
} 
Paulus Diaconus feljegyzéseire hivatkozva Niebuhr javaslatának megfelelően a Nyugatrómai Birodalom bukásának évét, 476-ot tartotta korszakhatárnak, ${ }^{553}$ ugyanakkor Romulus Augustulus trónfosztásának valójában nem volt ekkora jelentősége, az utolsó törvényesen regnáló nyugati császár, Iulius Nepos pedig csak 480-ban fejezte be uralkodását, ${ }^{554}$ ráadásul 476-ban valójában csak Italia került a barbárok kezére, ${ }^{555}$ a többi nyugati terület már korábban kicsúszott a római uralom alól, 480-tól viszont a nyugati területek is a gazdaságilag és katonailag jóval erősebb Keletrómai Birodalom császárának fennhatósága alá tartoztak, ezt pedig rendszerint a barbár uralkodók is elismertek. ${ }^{556}$ Mindez azonban nem indokolja, hogy a Nyugatrómai Birodalom bukását ne tartsuk jelentős eseménynek, és erre hivatkozva kisebb figyelmet szenteljünk azoknak a betelepülő barbároknak, akik sok szempontból a római világ folytatóinak számítanak. ${ }^{557}$

Katus középkortörténetének előszavában röviden összefoglalta, hogy Diocletianus 284-es trónralépése, Constantinus 313-as türelmi rendelete vagy Constantinopolis 330-as alapítása, a kereszténység 380-as államvallássá nyilvánítása, a gótok 375-ös betelepedése vagy 410-es római ostroma, illetve a barbárok 406-os rajnai betörése egyaránt jelezhetné egy új időszak kezdetét. ${ }^{558}$ Mások a középkor nyitányának tartják Chlodvig 498 körüli megkeresztelkedését, az athéni Akadémia 529-es bezárását és a bencés rend megalapítását, Gregorius Magnus pápa 604-es halálát, a krisztológiai fejlődés végét jelző 680-681-es 3. constantinopolisi zsinatot vagy az arabok 711-es hispaniai betörését. ${ }^{559} \mathrm{Az}$ angol szakirodalom szerint rendkívül jelentős ilyen szempontból Mohamed 622-es fellépése, Pirenne kifejezetten az iszlám gyors előretörésével magyarázza az ókori hagyománnyal való radikális szakítást. ${ }^{560}$ Egyre több német kutató vallja azonban azt, hogy a birodalom keleti és nyugati részei között megmaradó földrajzi egység, a városok civilizációmegőrző szerepe és az uralkodó szolgálatában álló nagybirtokos réteg hatalma egészen Iustinianus koráig

\footnotetext{
553 Marc. Com. 2,90-91; Iord., Rom. 344; Get. 242; Paul. Diac. 15,10. Marcellinus Comes nézőpontjáról bővebben: Goltz 2007, 39-59; a probléma részletes elemzését lásd: Demandt 2013, 467-488.

554 Angenendt 2008, 155. Mivel a császári éremverés ekkor fejeződött be nyugaton, numizmatikai szempontból akár 480 is lehetne a korszakhatár, vö. Havas - Hegyi - Szabó 2007, 685.

${ }^{555}$ Mivel Theoderic nem változtatta meg a római közigazgatási és a társadalmi struktúrát, sokak szerint Italia elvesztése nem is járt jelentős változásokkal, vö. Havas - Vilmos - Szabó 1999, 123.

556 Alföldy 2000, 179.

557 James 2014, 4. Halsall külön fejezetet szentel annak tárgyalására, hogy a barbár migráció valójában a nyugatrómai területek bukását ( fall) okozta, vagy inkább átalakította (transformation) a római örökséget, vö. Halsall 2007, 19-22.

558 Katus 2014, 13.

${ }^{559}$ Angenendt 2008, 25; Gárdonyi 2006, 98-99.

${ }^{560}$ Pirenne 1983, 43; a Pirenne-tézis vitájának friss szakirodalmát lásd: Zsinka 2012, 14, 18. j.
} 
kimutatható, ezért a császár 565-ös halála és a kb. 600 közötti időszakot tekintik korszakhatárnak. ${ }^{561}$

Egyetértünk azzal, hogy valójában „különbözö okok sokaságáról és bonyolult hálójáról" beszélhetünk, ${ }^{562}$ és egy konkrét évszám kutatása helyett inkább azt kell hangsúlyozni, hogy a birodalom egyes részein különböző tempóban és időben, de folyamatosan jelentős változások következtek be, és az ókori világra jellemző struktúrák az átmenet „széles sávján” keresztül alakultak át a kora középkor jellemzőivé. ${ }^{563}$ Konszenzus alakult ki abban is, hogy a folytonosság és az összetartozás legfőbb hordozója az egyház volt, amely megőrizte többek között a püspöki tisztségeket és a fontosabb egyházi székhelyeket is. ${ }^{564}$ További fontos tényezőnek számít, hogy a birodalom területére betörő germán népek az 5-6. században visszafordíthatatlan változásokat indítottak el a nyugati területeken, ezért támogatjuk a legtöbb kutató által képviselt álláspontot, mely szerint ez az „átmeneti periódus” szorosan összekapcsolódik a barbár népek vándorlásával, ${ }^{565}$ vagy ahogyan Dawson fogalmaz, „a barbár betörések és az új nyugati germán királyságok kialakulásának korát mindig fordulópontnak tekintették az emberiség történetében, amely elválasztja az antik világot a modern világtól." ${ }^{566}$ Bár a hatalmi intézmények és az egyházi szervezet átalakulása, illetve a lakosság helyzetének megváltozása valójában csak jóval később mutatható ki látványosan, ${ }^{567}$ a nyugati területek számára a barbárok beözönlése akkora törést okozott, amely valószínüleg a rómainál erősebb társadalmat és államot is összeroppantott volna. ${ }^{568}$

Általánosan elfogadott nézet, hogy a nyugatrómai területek bukásához elsősorban a császári hatalom gyengesége és az erős központi hatalom hiánya vezetett, de ezt a folyamatot számtalan külső és belső tényező még inkább felgyorsította. A szétfeszítő erők közül hagyományosan a barbárok egyre erösebb külső támadásait tartják a legfontosabb tényezőnek, ${ }^{569}$ ugyanakkor a germán fosztogatások és betelepítések nem feltétlenül okozták volna a római állam müködésének megbénulását és a birodalom felbomlását, ha a nyugati területek nem kerülnek már a 4. században politikai, társadalmi, gazdasági és ideológiai

\footnotetext{
${ }^{561}$ Bleicken 1978, 11-12; Foss - Magdalino 1990, 39.

562 Németh - Hegyi 2011, 565.

${ }^{563}$ Alföldy 2000, 176, 205. j.; Gerberding 2005, 25-26; Angenendt 2008, 25; 175.

564 Angenendt 2008, 37.

565 Sz. Jónás 1994, 5.

566 Dawson 1938, 91.

${ }^{567}$ Havas - Vilmos - Szabó 1999, 123.

${ }^{568}$ Németh - Hegyi 2011, 565.

${ }^{569}$ Halsall 2007, 10.
} 
válságba, ${ }^{570}$ a helyzet súlyosságát pedig tovább fokozhatta, hogy a rómaiak egy része együttmüködött a barbár hódítókkal vagy esetleg át is állt az ő oldalukra. ${ }^{571}$ A nyugati területek válságával kapcsolatban számtalan magyarázat született, Havas például a népvándorlás miatt bekövetkező barbár támadásokat és az erre hibásan reagáló római politikát tartja a legfontosabb tényezőnek, Eliade szerint viszont éppen ezeknek köszönhetően tudott a keresztény egyház ilyen nagy befolyást szerezni. ${ }^{572}$ Heather úgy látja, hogy a 4. századi birodalmi apparátus még hatékony müködésre lett volna képes, de a barbár fenyegetésekkel szemben már nem tudta megfelelően ellátni a feladatát. ${ }^{573}$ Goldsworthy szerint a központi hatalom gyengesége, a társadalmi, a gazdasági és a politikai problémák következtében ,felörlödött az a politikai képesség”, amely egy hatékony hadsereg fenntartásával képes lett volna visszaverni a barbár támadásokat. ${ }^{574}$

Foss és Magdalino a válságos helyzetet leginkább gazdasági okokra vezeti vissza, és a talaj kimerülésére, a földek elnéptelenedésére, éghajlatváltozásra, ólommérgezésre és a nemesfémek hiányára hivatkozik, Angi pedig a lecsökkent rabszolga-utánpótlást és a felduzzasztott hadsereg ellátási nehézségeit, a barbár fosztogatásokat, a társadalom alsó rétegeit sújtó gazdasági korlátozásokat, a gyorsan terjedő járványokat és a megváltozott időjárási körülményeket okolja a hanyatlásért. ${ }^{575}$ Koenigsberger szerint a rendelkezésre álló erőforrások csökkenése, valamint a hadsereg, a hivatali apparátus, a privilegizált rétegek és a városi lakosság ellátásának nehézségei jól mutatják, hogy a birodalom elérte gazdasági teljesítőképességének határait, az alsó rétegek egyre rosszabb helyzete és ebből fakadó felkelései pedig tovább gyengítették a császári hatalom erejét, mindez azonban még nem okozta volna önmagában a nyugati birodalom összeomlását. Koenigsberger a nyugati és a keleti területek fejlődésének különbségeit vizsgálva meghatározónak tartja a katonai védelem helyzetének romlását, a barbárok harcias morálját és erkölcsi tisztaságát, ezzel szemben a római virtus kereszténységgel való lecserélését és az eretnekmozgalmak terjedését puszta spekulációnak véli. ${ }^{576}$ Ezzel ellentétben Marton a dogmatikai és krisztológiai viták nyomán kibontakozó eretnekmozgalmakat és a birodalmi egyháztól

\footnotetext{
570 Angenendt 2008, 127. Alföldy szerint már a korábbi barbár betörések is olyan időpontban érték a birodalmat, amikor belső gyengeségei felerősödtek és minimálisra csökkent az állam ellenállóképessége, vö. Alföldy 2000, 156.

571 Török 1999, 82. Anderle szerint éppen ezek a „barbárokkal való paktumok” vezettek a római Hispania bukásához, vö. Anderle 1999, 16.

572 Havas - Hegyi - Szabó 2007, 679; Eliade 2006, 624.

${ }^{573}$ Heather 2006, 18-19.

574 Goldsworthy 2004, 214.

${ }^{575}$ Foss - Magdalino 1990, 27; Angi 1999, 4-5.

${ }^{576}$ Koenigsberger 1987, 21-22.
} 
leszakadó többmilliós tömegek nemzeti egyházait tartja a legveszélyesebb tényezőnek, Alföldy pedig a birodalomrészek sajátosságait összehasonlítva azt emelte ki, hogy keleten a kedvezőbb politikai feltételek miatt a társadalom nem idegenedett el a birodalmi vezetéstől, ennélfogva nem voltak olyan nagy mértékü társadalmi feszültségek, a keleti egyház összefonódott az állammal, a városok és azok vezetői nem fordultak a hatalommal szembe, ezáltal sokkal jobban tudtak védekezni a barbár betörések ellen, mint nyugaton, vagyis azok az intézkedések, amelyeket Róma saját megmentéséért hozott, éppen önmagát tették életképtelenné. ${ }^{577} \mathrm{Sz}$. Jónás a rómaiak és a barbárok kapcsolatát vizsgálva két fontos szempontra hívja fel a figyelmünket. Egyrészt a 3. századtól hanyatlásnak indult nyugati területekkel szemben a keleti birodalomrész helyzete sokrétü fejlettségének köszönhetően a barbárok érkezése után is stabil maradt, másrészt pedig a germán hódítók már a 4. század előtt is kapcsolatba kerültek a rómaiakkal hadifoglyokként vagy a hadsereg katonáiként. ${ }^{578}$

Mindezek alapján arra következtethetünk, hogy a szétfeszítő erők elemzésekor nem elegendő csupán azt vizsgálnunk, hogy a nyugati területek miért kerültek válságba, és a birodalomba érkező barbárok fosztogatásaikkal hogyan sodorták még rosszabb helyzetbe a római lakosságot, mivel a barbárok és a rómaiak kapcsolata „, an enormously complex and uncertain one", amely régiónként, népenként és időszakonként más-más jellegzetességeket mutat. ${ }^{579}$ Halsall a korszakkal foglalkozó kutatókat találó módon két csoportra osztotta: „Movers"-nek tartja azokat, akik szerint a birodalomban azért következtek be ilyen jellegü változások, mert barbár népek törtek be a területére, a „Shakers” csoportjába pedig azok tartoznak, akik úgy gondolják, hogy a római világ már korábban válságba került, ezért a barbárok megjelenésére inkább tünetként, mintsem okként tekinthetünk ebben a folyamatban. Bár a források többsége „Movers”-ként a barbár inváziókat hibáztatja a birodalom válságos helyzetéért, Halsall másutt egyértelmüen kijelenti, hogy azok „the product of the end of the Roman Empire, and not vice versa." $" 580$

Maga Hydatius a hanyatlás legfőbb okaként Hieronymushoz hasonlóan a barbárok tevékenységét jelölte meg, ${ }^{581}$ a krónika bevezetőjében azonban több jelenségre is felhívja az olvasók figyelmét. A féktelen barbárok betörése következtében zürzavar és pusztulás keletkezett, a birodalom szűk határok közé szorult, az ellenséges barbár törzsek szétszakadása és az eretnekségek terjedése pedig a katolikus vallás csaknem teljes romlását

\footnotetext{
577 Marton 2004, 130-131; Alföldy 2000, 204.

578 Sz. Jónás 1994, 5.

579 James 2014, 4.

${ }^{580}$ Halsall 1999, 145; Halsall 2007, 34.

${ }^{581}$ Hier., Chr. 7; Hier., Ep. ad Heliod. 60,16; Pawlak 2007, 31.
} 
okozta. ${ }^{582}$ Az így kialakult válságos helyzet annyira összezavarta a rómaiakat, hogy nemcsak az egyházi rend állapotát mocskolták be meggondolatlan kinevezésekkel, hanem a dicső szabadság is elbukott. ${ }^{583}$ Hydatius tehát részletesen tárgyalja azokat a szétfeszítő erőket, amelyek hozzájárultak az 5. századi Gallaecia és a Római Birodalom válságos helyzetének kialakulásához, sajátos módon még egy bizonyos logikai sorrend is felállítható az általa bemutatott tényezők között. Ezt követve fogjuk alaposabban megvizsgálni a barbár népek fosztogatással és szövetségkötéssel párosuló sztereotipikus viselkedését a szvévek, a vandálok és a gótok vonatkozásában, különös tekintettel a szvév-gallaeciai kapcsolatok alakulására, majd részletesen foglalkozunk az eretnekség kérdésével és a különféle eretnekmozgalmak rómaiakra gyakorolt hatásával, ezután bemutatjuk a hủtlenség és a lojalitás megnyilvánulásait az egyházi és a politikai vezetök viselkedésében, végül rávilágítunk arra, hogy kiket tekintett Hydatius példaképnek saját maga és az olvasói számára.

\subsubsection{Barbár fosztogatások és szövetségkötések}

A barbár népeket a legtöbb római szerző fosztogató és müveletlen embereknek tartotta, akik kulturálatlan és civilizálatlan tömegként felborították a Római Birodalom rendjét, ${ }^{584}$ az írásbeliség hiánya miatt még nem voltak írott törvényeik ${ }^{585}$ és megfelelő szaktudással sem rendelkeztek a nagybirtokok megmüveléséhez. ${ }^{586}$ Általánosan elfogadott viszont az a nézet, hogy a nomadizáló társadalmaknak folyamatosan szüksége volt katonai sikerekre és

\footnotetext{
${ }^{582}$ Hyd. praef. 4: debacchantibus iam in Romano solo barbaris omnia haberi permixta atque confusa; praef. 6 : conclusi in angustias imperii Romani metas... universae propemodum in divina disciplina religionis occasum ex furentium dominatione permixta iniquarum perturbatione nationum.

${ }^{583}$ Hyd. praef. 6: deformem ecclesiastici ordinis statum creationibus indiscretis, honestae libertatis interitum.

${ }^{584}$ López Quiroga - Martínez Tejera 2017, 432. Hieronymus arról panaszkodott a Galliát megszálló barbár népekkel kapcsolatban, hogy Rómának saját földjén kell idegenekkel harcolnia a megmaradásáért, ráadásul háború helyett gyakran csak arannyal és ezüsttel tudják megmenteni a lakosság életét, vö. Hier., Chr. 7; Dawson 1938, 101; Isidorus Hispalensis gót történetében pedig azt látjuk, hogy a barbár népekkel való együttélés „területszerzö háborúkkal, békés hétköznapokat biztositó szerzödésekkel és azok felbomlásával”, illetve az önállóság vagy függőség folyamatos dilemmájával jár együtt, vö. Isid., Hist. Goth. 11-12; 15; Székely 2008, 17.

${ }^{585}$ A rómaiak a görög barbár-fogalom sztereotípiáit átvéve azt vallották, hogy a barbár népek ,furcsa idegen nyelveken" beszélnek, különös módon viselkednek és erkölcsi szempontból alacsonyabbrendủek, vagyis összességében műveletlen kívülállóknak tartották öket, vö. Koenigsberger 1987, 23. A barbárság és a Romanitas fogalom további értelmezéséhez lásd: Halsall 2005, 38-41; Grüll 2007, 234; James 2014, 5-9.

${ }^{586}$ A latifundiumokon alkalmazott rabszolgák Augustus korától kezdve egyre kisebb számban származtak mediterrán kultúrvidékről, így kevésbé értettek a szőlö- és olívatermesztéshez, ami komoly munkaerőgondokat okozott a mezőgazdaságban, vö. Havas - Hegyi - Szabó 2007, 757. Iordanes a Campaniában fosztogató gótokról gúnyosan megjegyezi, hogy korábban bor helyett csak tejet ittak, és Italiában láttak elöször szólőskerteket, vö. Iord., Get. 267; Sz. Jónás 1994, 12.
} 
zsákmányszerzésre, ellenkező esetben belső hatalmi problémák adódhattak és a hadsereg bizalma megrendülhetett a katonai vezetőben. ${ }^{587}$ Mivel a barbárok a földek elfoglalása mellett városok bevételére és kifosztására is törekedtek, de még nem rendelkeztek olyan hatékony eszközökkel, mint a rómaiak, az ostromok sikerét gyakran megtévesztéssel, árulással vagy erőszakkal próbálták biztosítani. ${ }^{588}$

Hydatius éppen ezért mindig erőszakkal, fosztogatással és halállal kapcsolatban említi a barbárokat, ${ }^{589}$ élesen bírálva az expanziós politikájukból következő mértéktelen fosztogatásokat és a békeszerződések esetében tanúsított megbízhatatlanságot. Hydatius számára a barbárok mindig „treacherous law-breakers”, akik ugyan idegenek és más kultúrát képviselnek, de legnagyobb hibájuk mégis az, hogy nem követik a hagyományos római rendet, hanem annak elpusztítására törekednek. ${ }^{590}$ Ehhez hasonlóan Thompson is úgy látja, hogy Hydatius sohasem azért ítéli el a barbárokat, mert ők nem rómaiak, hanem inkább azért, mert megszegték a korábbi békeszerződéseket vagy nem siettek a szövetségeseik segítségére. ${ }^{591}$ A római szerzők többsége a barbár népek ábrázolásához ugyanilyen negatív sztereotípiákat használt, ${ }^{592}$ de Burgess szerint ezeket inkább „Germanic ideals of behaviour"-nak kell tekinteni, mert a germán történetírás kialakulásával rögtön dicsérendő tulajdonságokká váltak. ${ }^{593}$ A barbárok római földre érkezése a 20. század elejéig tartó szemlélet alapján „a civilizáció és a barbarizmus összecsapásának” tekintendő, és ebben a barbárokkal szembeni, egyértelműen negatív látásmódban a római elit hagyományos hozzáállása tükröződik. 594

Az irodalmi források alapján a legtöbb kutató a barbár invázió mértékét és az azt követő pusztításokat hatalmas mértékünek ábrázolta, ${ }^{595}$ amely egyfajta ,topos of the destructive enemy"-ként felborította a római világ rendjét, ${ }^{596}$ a népvándorlás kora azonban mégsem volt olyan „,brutális” jellegü, mint ahogyan korábban feltételezték, ${ }^{597}$ és mivel a régészeti leletek sem támasztják alá ezt a hipotézist, Kulikowski szerint szakítanunk kell a

\footnotetext{
${ }^{587}$ Havas - Hegyi - Szabó 2007, 665.

588 Thompson 1982, 171-172; Burgess 1988a, 148.

589 Burgess 1988a, 146; Sánchez Pardo 2013, 154.

590 Johnson 1993, 44.

591 Thompson 1982, 141.

${ }^{592}$ Ammianus úgy véli, hogy a gótok saepe fallaces et perfidi, Sidonius szerint foedifraga gens, míg a hunok pacis fallentes nomen inane, ahogyan Orosiusnál a vandálok perfida et dolosa gens, vö. Amm. Marc. 22,7,8; Sid. Ap., Ep. 6,6,1; Carm. 7,244-250; Oros. 7,38,1.

${ }^{593}$ Burgess 1988a, 145.

${ }^{594}$ Klaniczay 2005, 88; Arias 2007, 4.

${ }^{595}$ Courtois 1955, 38-54.

${ }^{596}$ Díaz - Menéndez-Bueyes 2005, 265.

${ }^{597}$ Sz. Jónás 1994, 5.
} 
hagyományos állásponttal. ${ }^{598}$ Jól látszik ennek az elméletnek a helyessége Hydatius esetében is, aki a jól ismert sztereotípiákat használva módszeresen elhallgatja, hogy a legtöbb esetben a barbárok szerződésszegéseinek konkrét oka volt, és gyakran éppen a rómaiak provokálták ki a korábban megkötött szövetségek felbontását. ${ }^{599}$ Hydatius még a római támadások esetében is a barbárok kegyetlenségére hivatkozik, mivel amikor római veszteségekről beszél, igyekszik konkrét személyek kiemelésével hatni az olvasók érzelmeire, amikor viszont a barbárok kerülnek szóba, ott többnyire csak személytelen népneveket használ és nem részletezi a rómaiak kegyetlenségét. ${ }^{600}$

Hydatius a legtöbb esetben külső szemlélőként, az okok és a reakciók elemzése nélkül mutatja be a barbárok viselkedését, ennek ellenére érdemes alaposabban megvizsgálnunk, hogyan ábrázolja a barbárok fosztogatásait és szövetségkötéseit, mert ezek jól megvilágíthatják Hydatius történelemszemléletének sajátosságait, ráadásul ahogyan említettük, az olvasók érdeklődésének felkeltésére is alkalmasak.

\subsubsection{A szvévek és a szvév-gallaeciai kapcsolatok}

Hydatius a barbárok 409-es hispaniai támadását először csak egyszerü betörésnek (ingressi) ábrázolja, elvetemült mészárlásuk (caede hostili) következményeiről viszont részletes beszámolót nyújt. ${ }^{601}$ Hydatius és Isidorus olyan hatalmas éhínségről (fames) és járványokról (pestilentiae) tudósít, hogy szerintük egy időre még a kannibalizmus is elterjedt az éhezők között, hiszen az emberek éhségüket emberhússal csillapították, az anyák pedig saját gyermekeiket fogyasztották el. ${ }^{602} \mathrm{Ez}$ a kép erős túlzásnak tünik és valószínűleg az olvasók figyelmének megragadására szolgál, a családra és a gyermekekre való utalás pedig az érzelmek felkorbácsolására alkalmas. ${ }^{603}$ A pestilentiae gyakori említése és a négy csapás között külön kategóriát képező éhínség és dögvész egyúttal utalhat a fosztogatás közbeni mészárlások nagyságára és területi kiterjedésére is, ezért érezheti úgy Hydatius, hogy az emberi faj a pusztulása felé halad. ${ }^{604}$ Mindenesetre a rómaiak ellenállása sikertelen volt és sok pénzt emésztett fel, a megszálló barbár csapatok pedig rengeteg kincset és élelmet

\footnotetext{
${ }^{598}$ Kulikowski 2013, 687.

${ }^{599}$ Pawlak 2007, 36.

${ }^{600}$ Burgess 1988a, 150.

${ }^{601}$ Hyd. 34; 38.

${ }^{602}$ Hyd. 40: humanae carnes ab humano genere vi famis fuerint devoratae, matres quoque necatis vel coctis per se natorum suorum sint paste corporibus; Isid., Hist. Vand. 72.

${ }^{603}$ Burgess 1988a, 150; Kulikowski 2010, 161-162.

${ }^{604}$ Hyd. 40: passim in humani generis efferantur interitum, et ita quatuor plagis ferri famis pestilentie bestiarum ubique in toto orbe sevientibus.
} 
raboltak a helyi lakosságtól, feltehetően sikerült megszerezniük a római hatóságok által beszedett adók egy részét is, amely egy ideig fedezhette saját ellátásukat. ${ }^{605}$

Hydatius szerint 411-ben a barbárok a tartományokat kisorsolták egymás között, ${ }^{606}$ vagyis sorsolás útján (sorte), a római hatóságok közremüködése nélkül osztották el a megszállt területeket. Ezt az álláspontot támasztja alá Orosius is a sorte possessione, illetve Isidorus a sorte in possessionem és a sortiti sunt kifejezések használatával. ${ }^{607}$ Hasonló elvek szerint müködött a sortes Vandalorum eljárása is 439-ben, amikor a vandálok a Carthago környéki földeket „katonai rendszer szerint, a fegyveres nép zsákmányelosztási rendje” alapján sorsolással osztották szét egymás között. ${ }^{608}$ Számos kutató azonban úgy véli, hogy a sorte inkább a sortes (telek) szóra utal, tehát sorsolás helyett osztozkodásról volt szó, amely alapján a barbár népek létszámuknak megfelelö nagyságú földet kaphattak egy megállapodás keretében a római kormányzattól. Merrills és Miles szerint a területek elosztása semmiképpen sem lehetett „a random distribution”, inkább a barbár törzsek létszámához és erőviszonyaihoz igazodott. ${ }^{609}$ Brown kiemeli, hogy a barbárok nem a klasszikus hódítással szerezték a földjeiket, letelepítésük során pedig fontos szempont lehetett a korábbi időszakból ismert divide et impera elve is, melynek során a barbár katonák családjai a római veteránokhoz hasonlóan földet kaptak és azokból jelentős jövedelemre tettek szert. ${ }^{610}$ Wood a gótok, a burgundok és az alánok letelepedési szokásait vizsgálva a probléma komplexitására hívja fel a figyelmet, hiszen a kezdeti felosztáshoz képest eltéréseket mutathatnak a tényleges, letelepedéshez használt területfoglalások. ${ }^{611}$

Hydatius és Isidorus szerint a barbárok hajlandóak voltak békét kötni (ad pacem ineundam conversi), ${ }^{612}$ amelyet értelemszerüen írásban is kellett rögzíteniük. A szvévek és a rómaiak közötti lehetséges szerződésről egyik oldalukon Hermericet, a másikon Honoriust ábrázoló solidusok és tremissisek tanúskodnak, ${ }^{613}$ Orosius pedig azt állítja, hogy a vandál, az alán és a szvév királyok aktívan törekedtek egy olyan szerződés megkötésére, amely hasonló volt a gótok későbbi egyezményéhez, ezért Collins azt gondolja, hogy a barbárok egy „treaty of federation” alapján megállapodtak a római kormányzattal, hogy katonai

\footnotetext{
${ }^{605}$ Heather 2006, 209. A római államháztartás korabeli helyzetéről lásd: Várady 1961, 114.

${ }^{606}$ Hyd. 41: sorte ad inhabitandum sibi provinciarum dividunt regiones.

${ }^{607}$ Oros. 7,40,10; Isid., Hist. Vand. 73; Hist. Suev. 85.

${ }^{608}$ Várady 1961, 183-184; Proc. 3,5,11-15; Vict. Vit. 1,12-14. A germán népek földtulajdoni viszonyairól bővebben: Angi 1999, 24.

${ }^{609}$ Merrills - Miles 2010, 44.

${ }^{610}$ Brown 1999, 64-65.

${ }^{611}$ Wood 2007a, 523-524.

612 Hyd. 41; Isid., Hist. Vand. 73.

${ }^{613}$ Schmidt 1938, 217; López Quiroga - Martínez Tejera 2017, 440.
} 
szolgálatért cserébe zsoldot és a letelepedéshez területeket kapnak. ${ }^{614}$ Mommsen, Reinhart és Blockey szerint akár az is elképzelhető, hogy valódi foedus típusú szerződés jött létre a szvévek és a rómaiak között, ${ }^{615}$ ahogyan Honorius 418-ban a hasding vandáloknak is ilyen módon engedélyezte a letelepedést, Koenigsberger pedig egyenesen azt állítja, hogy a barbár vezetők azért ismerték el a római császár hatalmát, hogy foederatiként élhessenek a birodalom területén. ${ }^{616}$ Pohl úgy gondolja, hogy a barbárok az usurpatorok partnereiként telepedtek le, Stein szerint Maximus kötött egyezséget a barbárokkal, Székely Melinda egy Gerontiusszal kötött szerződést valószínüsít, Bury szerint a szvévek és a hasdingok Honorius hozzájárulásával foglalták el földjeiket, Schmidt pedig konkrétan Honorius és Hermeric közötti egyezségről beszél. ${ }^{617}$ Díaz számtalan lehetőséget megvizsgálva arra a következtetésre jut, hogy a barbárok csakis egy nagyon különleges „pacto de federación” alapján telepedhettek le Hispaniában, de a legújabb kutatási eredmények is valószínüsítik a foedus alapján történő osztozkodást és a rómaiakkal való szerződés megkötését. ${ }^{618}$

Nem vitathatjuk azonban, hogy Theodosius a gótoknak tett engedményeket csak kényszerhelyzetben és időnyerés céljából, a gótok tömeges megjelenése miatt biztosította, és a velük kötött szerződéssel semmiképpen sem kívánt precedenst teremteni, ezért ha a birodalom területére később újabb barbár csoportok érkeztek, azokat elsősorban megpróbálta legyőzni, ha pedig ez nem sikerült, akkor csökkentett jogkörrel (laeti) telepítette le öket, és igyekezett jogi különállásukat fokozatosan megszüntetni. ${ }^{619}$ Thompson és Díaz éppen ezért úgy véli, hogy az ad inhabitandum megjelölés inkább egy jogi formulára, mintsem konkrét szerződésre utal, és a szvévek a rómaiak jóváhagyása nélkül foglalták el Gallaeciát. Mivel szerintük a szvév vezetők egyáltalán nem úgy viselkedtek, ahogyan egy foedus alapján elvárható lett volna, hanem inkább a teljes függetlenségre törekedtek, sohasem jött létre semmilyen szerződés a rómaiak és a szvévek között. ${ }^{620}$

Bár konkrét bizonyítékunk valóban nincs semmilyen szerződéskötésre, mégis elfogadhatónak tünik Torres Rodríguez feltételezése, mely szerint a szvévek ius hospitii típusú szerződést kötöttek a rómaiakkal a letelepedés során, vagyis az állami földekből kaptak területeket, de nem vethetjük el Arias álláspontját sem, mely szerint kisebb,

\footnotetext{
${ }^{614}$ Oros. 7,43,14; Collins 2004, 13-14.

${ }^{615}$ Mommsen 1894, 3; Reinhart 1952, 35; 65; Blockey 2007a, 132.

616 Proc. 3,3,2; Koenigsberger 1987, 29.

${ }^{617}$ Pohl 2004, 37; Stein 1949, 1,263; Székely 2008, 75, 85. j.; Bury 1923, 1,204; Schmidt 1970a, $22-24$.

${ }^{618}$ Díaz 2011, 58-61; López Quiroga - Martínez Tejera 2017, 430; 437.

${ }^{619}$ Demandt 1989, 127; Schulz 1993, 71; 74; Gerberding 2005, 24; Kiss 2008, 45-46. Ilyen letelepítést látunk például 386-ban a keleti gótok egy részénél Phrygiában és 392-ben egy gót csoportnál Thraciában.

620 Thompson 1982, 154-155; Díaz 1993, 213.
} 
alkuszerü megegyezésekről van szó, vagy csak néhány csoportjuk telepedett le a szerződés alapján, Kulikowski pedig a sibi dividunt kifejezés miatt kizártnak tartja, hogy a területek felosztása a „scheme of late Roman receptio" alapján történt volna. ${ }^{621}$ Arce és Bubnó a barbárok „egyenlőtlen területelosztását” a betörés gyorsaságával és elökészítetlenségével indokolja, ugyanakkor szerintük elképzelhető, hogy a sors alapú földosztás foedus alapján valósult meg. ${ }^{622}$ Figyelemre méltó még Pawlak azon következtetése is, hogy mivel a letelepedés rendje és a szerződés betartása általában csak a római hatóságok ellenőrzésével volt lehetséges, valószínűleg állami beavatkozás nélkül került sor a területek egyenlőtlen felosztására, mert Hydatius betolakodóknak tartja a betelepült törzseket. ${ }^{623}$

Nem mellőzhetjük továbbá azt a szempontot sem, hogy 398-tól az ius hospitalitatis (vendégjog) alapján a római birtokosok a barbárok által megszállt területeken kötelesek voltak a házukat és a földjüket a rajta lévő munkaerővel együtt megosztani a germánokkal, jellemző módon Italiában az egyharmad rész, Galliában és Hispaniában pedig a kétharmad rész átadásával. ${ }^{624} \mathrm{Ez}$ a közösség által kiosztott sors nevü terület csak 50 év után vált a germánok tényleges tulajdonává, addig viszont jogi és adózási szempontból is a római birtokos vállalt felelősséget a földdel kapcsolatban. ${ }^{625}$ Bár a legtöbb esetben, így a szvévek által megszállt Gallaeciában is a nagybirtokos arisztokrácia tagjai megtarthatták a földjeiket, az észak-africai vandálok és a dél-galliai gótok már nem osztozkodtak ilyen békés módon, hanem a római birtokosokat elüzték a földjeikről és sok esetben kegyetlen fosztogatásokat is végrehajtottak. $^{626}$

A történészek mindenesetre egyetértenek abban, hogy a szvév letelepedés központi helye a nyugati partvidék volt, a Szvév Királyság fővárosa pedig az egykori római provincia központja, Bracara Augusta lett. ${ }^{627}$ A szvévek letelepedési helyét az ibériai germán helynevek elhelyezkedésének vizsgálatával Sachs és Piel is igazolta, Sánchez Pardo pedig valószínüsíti, hogy a Közép- és Dél-Gallaecia városaiban letelepült szvévek rendkívül

\footnotetext{
${ }^{621}$ Torres Rodríguez 1977, 71; 270; Arias 2007, 15; 40; Kulikowski 2010, 166.

${ }^{622}$ Arce 2002, 79-80; Bubnó 2013, 22. Muhlberger teljesen nyitva hagyja a kérdést, vö. Muhlberger 1990, 248; Tranoy és Thompson viszont bővebben elemzi a problémát, vö. Tranoy 1974, 1,35-38; Thompson 1982, 153-156.

${ }^{623}$ Pawlak 2007, 30. Ez az érv azonban nem állja meg a helyét, ha számításba vesszük azt a lehetőséget, hogy Hydatius szándékosan hallgatja el a barbárok római törvényekhez való alkalmazkodását és a császári hatalom segítségnyújtását a barbár letelepedésekkel kapcsolatban.

${ }^{624}$ A hospitalitas kérdésének részletes vizsgálatát lásd: Halsall 2007, 422-446.

${ }^{625}$ Horváth 1999, 47; Alföldy 2000, 203.

${ }^{626}$ Már az 5. században megkezdödött viszont a római possessio és a barbár földtulajdon összeolvadása, így korlátozás nélkül lehetett földet kapni a korábbi közföldekböl, vö. Angi 1999, 37.

${ }^{627}$ Bracara központi jelentőségéről lásd: Díaz 2000a, 403-423.
} 
gyorsan asszimilálódtak a helyi arisztokráciához. ${ }^{628}$ Thompson szerint a szvévek sohasem támadták meg Bracara, Asturica és Lucus környékét, ${ }^{629}$ ezért ezek a területek lehettek a letelepedés fontosabb központjai, de mivel arról sem tudunk, hogy lettek volna olyan vidéki területek, amelyeket ne érintett volna a szvévek fosztogatása, feltehetően nagy részük Bracara környékén telepedett le. ${ }^{630}$ A szvévek minden bizonnyal csak ott tudtak később önálló közigazgatási rendszert létrehozni, ahol eredetileg is letelepedtek, így a további terjeszkedés keletre és Lusitania felé mindig erőszakos eszközöket igényelt és fosztogatásokkal párosult. Egyes feltételezések szerint éppen ezért jöhetett létre Bracarától és Lucustól keletre egy olyan római irányítás alatt álló független terület, amely többször is szembe tudott szállni a barbár hódítókkal. ${ }^{631}$

Annak ellenére, hogy feltételezésünk szerint Hermeric szövetséget kötött a rómaiakkal, egyre fontosabbnak tartotta, hogy a Szvév Királyság területét megnövelje, így összetüzésbe keveredett a szomszédos vandálokkal, akik szintén Hispania meghódítására törekedtek. ${ }^{632}$ Amikor 419-ben az erbasisi hegyekben Gunderic körbezárta a szvévek csapatait, csak a római Asturius comes és Maurocellus vicarius segítségével lehetett elkerülni a vereséget, mert a két római sereg harapófogóként közrefogta a vandálokat, akik így kénytelenek voltak Baeticába vonulni. ${ }^{633}$ Gregorius Turonensis szerint a szvévek felajánlották a vandáloknak, hogy a vita eldöntésére egy-egy emberük küzdjön meg egymással, de amikor a szvévek megnyerték a párbajt, a vandálok elhagyták Gallaeciát. ${ }^{634}$ Az a két tény, hogy 418-ban a gótok Constantius kérésére félbeszakították a hadjáratot (intermisso certamine) Hispaniában, ${ }^{635}$ 419-ben pedig a comes Hispaniarum kiállt a szvévek mellett, megerősíti azt a feltételezésünket, hogy Hermeric valóban szerződést kötött a rómaiakkal a letelepedés során, ahogyan Gillett is úgy véli, hogy Asturius beavatkozása mindenképpen a szvév-római szövetségnek volt köszönhető. ${ }^{636}$ Asturius és Maurocellus tevékenysége jelenti egyébként az utolsó olyan akciót, amikor a Hispaniában állomásozó

\footnotetext{
${ }^{628}$ Sachs 1932; Piel 1936; Reinhart 1952, 100-101; Moreira 1993, 400-401; Arias 2007, 41; Sánchez Pardo 2013, 155. A szvév letelepedés központjainak meghatározásához lásd: 7. sz. térkép.

${ }^{629}$ Hyd. 66; 81; 179; 194; 196; 243.

630 Thompson 1982, 158.

${ }^{631}$ López - Rodríguez 1997, 552; Arias 2007, 49.

${ }^{632}$ Arce 2005, 111.

${ }^{633}$ Hyd. 63; 66. Az erbasisi eseményekröl bővebben: Thompson 1982, 157.

${ }^{634}$ Greg. Tur. 2,2.

635 Hyd. 61.

${ }^{636}$ Gillett 2003, 64. Kulikowski ugyanakkor azt állítja, hogy Asturius fö feladata Maximus ellensúlyozása lett volna, vö. Bowes - Kulikowski 2005, 14.
} 
római helyőrség 10-11 ezer katonája még sikeresen és nagyobb veszteségek nélkül tudott fellépni a barbárokkal szemben. ${ }^{637}$

Hermeric politikája a vandálok kivonulásáig békésnek mutatkozott, mivel 411-430 között Hydatius nem említ háborút vagy konfliktust a szvévek és a rómaiak között. A békés időszakot felváltó és egyre nagyobb erejü fosztogatások egyfajta ellentmondást is jelentenek, hiszen a döntően földmüves életformával nehezen egyeztethetőek össze a germán népek körében nagyon gyakori zsákmányoló és területszerző hadjáratok. Arias szerint az egyre erősödő fosztogatásokat a szvév előkelők gazdagságért folytatott küzdelme idézte elő, amely fokozatosan átalakult egy előre átgondolt expanziós külpolitikává, ${ }^{638}$ Thompson viszont bizonyítékok híján próbálja a szerződés alapján történő letelepedést cáfolni azzal, hogy a szvévek a gótok 416-418 közötti hadjáratától eltérően sohasem siettek Róma segítségére. ${ }^{639}$ Hydatius beszámolójából jól látszik, hogy Hermeric talán a megállapodás kötöttsége miatt csaknem két évtizedig nem indított háborút újabb területekért, de az is szembetűnő, hogy többször találunk utalást a korábbi békeszerződés megszegésére. Hermeric feltehetően a letelepedés és az államszervezés nyugalmas körülményeit akarta biztosítani azzal, hogy békeszerződést kötött a rómaiakkal, ugyanakkor elképzelhető, hogy a szvévek tudatosan készültek az állam megerősítése és a népesség gyarapítása céljából a későbbi Gallaecián kívüli hódításokra. ${ }^{640}$

Egy évtizeddel később a szvév katonák már súlyos emberveszteséget szenvedtek a vandálokkal és a rómaiakkal való összecsapások következtében. Amikor 429-ben a szvév Heremigarius fosztogatni kezdte a Lusitaniában maradt vandálokat, ez annyira ijesztőnek tünhetett Gaiseric számára, ${ }^{641}$ hogy megszakította az africai átkelést és visszafordult, hogy személyesen számoljon le a szvév katonákkal. 430-ban Hermeric már Gallaecia középső részeit fosztogatta, ezért a biztonságosabb erődítményeket (castella tutiora) birtokló gallaeciabeliek a szvév katonák között akkora mészárlást végeztek, hogy sikerült egy új békét kikényszeríteniük, amelynek értelmében a korábban fogságba esett rómaiakat szabadon kellett engedni és a zsákmányt vissza kellett adni számukra. Hydatius szerint így

637 Thompson 1982, 173. Mindketten valószínüleg a 422-ben a vandálok ellen harcoló Castinus magister utriusque militiae-vel együtt a palatini és a comitatenses pamplonai alakulatához tartoztak, vö. Hyd. 69; Not. Dig., Occ. 7,118-134; Díaz - Menéndez-Bueyes 2005, 286.

638 Arias 2007, 38.

${ }^{639}$ Thompson 1982, 154.

${ }^{640}$ Arias 2007, 44; Torres Rodríguez 1977, 66; 69; 84-87.

${ }^{641} \mathrm{Az}$ emeritai pusztítás mértékéről, a feltárt régészeti leletekről és a datálás nehézségeiről lásd: Kulikowski 2013, 694-698. 
helyreállt a mgszegett békeszerződés (pacem quam ruperant, restaurant), ${ }^{642}$ ami szintén megerősíti azt a feltételezésünket, hogy a szvévek egy rómaiakkal kötött szerződés alapján telepedtek le Gallaeciában.

Érdemes azonban alaposabban is megvizsgálnunk, hogy milyen hatást gyakorolt a szvévek betelepedése a gallaeciai lakosságra, és hogyan alakultak a kezdeti interakciók a két fél között. Carr szerint a gallaeciabeliek az első fosztogatások hatására egy idő után felhagytak korábbi földmüves tevékenységeikkel, és az alacsonyan fekvő területekről a biztonságosabb magaslatokra és az erődített területekre költöztek, ezáltal a várak és az erődítmények környékén megnőtt a lakosság száma. ${ }^{643}$ Kulikowski régészeti és numizmatikai bizonyítékokkal is alátámasztotta, hogy az 5. század második felében a szvév megszállás elől a rómaiak egy része Gallaecia mezőgazdasági területeiről és közigazgatási központjaiból korábban kevésbé lakott hegyvidéki területekre és erődök közelébe menekült. ${ }^{644}$ Hasonló folyamat játszódott le a birodalom más részein is, mivel az arisztokrácia és a városi decuriók a belső területekre, Dél-Galliába vagy Italiába húzódtak vissza, a barbár fosztogatásoktól szenvedő lakosság pedig a magasabb erődítményekben és a városokban keresett menedéket, ezáltal egész vidékek néptelenedtek el, ahová a barbár törzsek később beszivárogtak vagy szervezetten betelepedtek. ${ }^{645}$ Egy 420-ban elfogadott törvény már kifejezetten megengedte a birtokosok számára, hogy a barbárok elleni védekezés hatékonyságának érdekében erődítményeket építhessenek a birtokokon, ${ }^{646}$ ezáltal nagyvállalkozók közmunkákkal fogtak bele az erődök és városfalak építésébe, és „valóságos magánhadseregek” bevetésével próbálták biztosítani az oda menekült lakosság nyugalmát, az 5. század végén pedig már döntő részben a nagybirtokosok feladata volt, hogy a barbárok elleni védekezést saját személyzetükkel és erődítéseikkel megoldják. ${ }^{647}$ Mivel ezek az erődített területek nemcsak a lakosság számára nyújtottak menedéket, hanem helyi szinten a római arisztokrácia hatalmát is jelképezték „real centres of power and spatial

\footnotetext{
642 Hyd. 80-81.

${ }^{643}$ Carr 2002, 199-203. A gallaeciai castellumok helyzetéről bővebben: Castellanos 2015, 500, 106. j.

${ }^{644}$ Kulikowski 2013, 688-689.

${ }^{645}$ Alföldy 2000, 162; Angenendt 2008, 127. A késő császárkorban épült pannoniai castellumokra jellemző volt, hogy magaslatokra, vagy lehetőség szerint olyan fennsíkra épültek, amelyet meredek lejtő vett körül, hogy a római lakosság ténylegesen biztonságban legyen, vö. Mócsy 1974, 111-113; 199.

${ }^{646}$ CI 8,10,10; Mócsy 1974, 140.

647 Alföldy 2000, 201; Cortázar - Vesga 2001, 92-93. Jóval később, a Karoling-korban is ezek az erődített területek szolgáltak a helyi lakosság menedékeként a szaracén, a normann és a magyar támadásokkal szemben, vö. Pirenne 1983, 90.
} 
hierarchization" formájában, hasonló szerveződést figyelhetünk meg a völgyekben és a gazdagabb mezőgazdasági területeken is. ${ }^{648}$

Hydatius szerint a csapásokat túlélö hispaniaiak városonként és erődítményenként hódoltak be a szvéveknek, ${ }^{649}$ később viszont már azt írja, ahogyan láttuk, hogy Gallaecia középső részén a biztonságosabb erődítmények (castella tutiora) sikeresen szembeszálltak a szvévekkel. ${ }^{650}$ Arias és Carr szerint itt elsősorban a gallaeciai földművesekből szerveződhettek római csapatok a szvévek ellen, mivel leginkább az ö érdekükben állt megszüntetni azt az állapotot, amelyben a szvév katonák elvették a rómaiak által megtermelt gabonát, ${ }^{651}$ ugyanakkor ezek az erőfeszítések feltehetően csak alkalomszerü ellenállások lehettek és nem folyamatosan szerveződtek. Muhlberger ezzel egyetértve úgy gondolja, hogy a vidéki erődítmények egy része nem szervezett keretek között, hanem magánakcióként szállt szembe a szvév hódítókkal, Burgess viszont ezt a feljegyzést éppen annak igazolására próbálja felhasználni, hogy valójában már semmilyen ellenállás nem volt tapasztalható a római lakosság részéről, mert teljesen megadták magukat a barbár hódítóknak, ${ }^{652}$ vannak azonban olyan leleteink, amelyek a megszállás folytonosságára, a lakosság növekvő félelmére és fokozott fegyveres ellenállására utalnak. ${ }^{653}$ Egyes kutatók szerint a castellumok saját igazgatással rendelkező, várostól függő benépesített területeket jelentenek, de ezt a fogalmat gyakran a castrumok helyett használják, ${ }^{654}$ így a biztonságot kereső lakosság az általa elfoglalt magaslatokon nemcsak ideiglenes vagy állandó településeket hozott létre, hanem katonai védelmi pontok kialakítására is törekedett, különösen Gallaecia középső területein, ${ }^{655}$ ahogyan Isidorus is egyaránt használja a fogalmat a lakó- és menedékhely megjelölésére, Iohannes Biclarensis pedig a civitasszal kapcsolatban említi a castellumokat. ${ }^{656}$ A 4 . századi partmenti területekről előkerült pénzleletek sem segítenek annak eldöntésében, hogy a történeti kutatásban castrónak

\footnotetext{
${ }^{648}$ Sánchez Pardo 2013, 152-154.

${ }^{649}$ Hyd. 41: Spani per civitates et castella residui a plagis barbarorum per provincias dominantium se subiciunt servituti. Isidorus ehhez hasonlóan arról számolt be, hogy a hispaniaiak városonként és váranként (per civitates et castella) adták meg magukat, vö. Isid., Hist Vand. 73.

${ }^{650}$ Hyd. 81. Hydatiusnak azért lehettek megbízható információi arról, hogy mi történt a castellumokban, mert püspöki feladatai közé tartozott, hogy megszervezze ezeknek a területeknek az egyházi életét, vö. Várady 1961, 182; Burgess 1988a, 202.

${ }^{651}$ Arias 2007, 62; Carr 2002, 128.

${ }_{652}$ Muhlberger 1990, 249; Burgess 1988a, 129.

${ }^{653}$ López Quiroga - Martínez Tejera 2017, 517-520. A római értékek elrejtésére, a katonai viseletekre és a tipikus foglalkozási formákra vonatkozó leletekről bővebben: 4. sz. kép; López Quiroga - Martínez Tejera 2017, 216-217; 256-258.

${ }^{654}$ A castellum és a castrum fogalmának értelmezéséhez lásd: Havas - Németh - Szabó 2001, 88-91.

${ }^{655}$ Díaz - Menéndez-Bueyes 2005, 291. Az erődített települések elhelyezkedéséhez lásd: 7. sz. térkép; a kutatás jelenlegi állásáról bővebben: Sánchez Pardo 2013, 143-146.

${ }^{656}$ Isid., Etym. 15,2; Ioh. Bicl. 20,46; 20,48; López Quiroga - Martínez Tejera 2017, 517.
} 
nevezett, jellegzetesen gallaeciai települések már a szvévek megérkezése előtt is lakottak voltak-e, mindenesetre a régészeti dokumentáció szerint a római lakosság az 5. század második felében sem hagyta el tömegesen ezeket a védett területeket, ${ }^{657}$ és még arra is látunk példákat, hogy a szvévek és a gallaeciaiak gyakran ugyanazokban a hegyvidéken elhelyezkedő városokban éltek és nem tudunk arról, hogy különösebb konfliktusok alakultak volna ki közöttük. ${ }^{658}$ Bár a szvévek gallaeciai jelenlétéről nagyon kevés régészeti emlék maradt fenn, a nyugati részek temetői kultúráinak elemzése során bizonyítékok kerültek elő arra vonatkozóan, hogy különösen az előkelők esetében egyértelmű a folytonosság a római hagyományok és a barbár népesség között, ebből viszont arra következtethetünk, hogy a romanizált szvévek a mértéktelen pusztítás helyett inkább felhasználták a meglévő római struktúrákat és adottságokat. ${ }^{659}$

Gallaeciát azért szokás a legkevésbé romanizált provinciának tartani Hispaniában, mert még az 5. század elején is léteztek azok a római kor előtti identitások, amelyek kevésbé urbanizált rétegként szembeszálltak az idegenekkel. ${ }^{660}$ Kivételt jelent ez alól a kulcsfontosságú Lucus és környéke, amely erődítményeinek köszönhetően egészen az 5. század közepéig megőrizte római jellegét, a nagybirtokrendszer itteni elterjedése miatt pedig a központi hatalom gyengesége ellenére felerősödött a terület romanizálódása. ${ }^{661} \mathrm{~A}$ modern kutatások azonban azt igazolják, hogy eredetileg a szvévek is a római parasztokhoz hasonló földművesek voltak, a letelepedés után pedig Gallaeciában visszatértek ehhez a foglalkozáshoz, és csak szükség esetén ragadtak fegyvert, ${ }^{662}$ leginkább gyalogos hadrendet, mintsem lovasságot alkotva. ${ }^{663}$ Orosius ezt megerősítve beszámolt arról, hogy a szvév letelepülök a fegyvereiket ekére cserélve (exsecrati gladios suos ad aratra conversi) földet

${ }^{657}$ López Quiroga - Martínez Tejera 2017, 515-516. A főleg Arcadius és Honorius idejéből származó érmék lelőhelyeit lásd: 8. sz. térkép; az előkerült numizmatikai anyagról bővebben: López Quiroga - Martínez Tejera 2017, 210-212.

${ }^{658}$ Kulikowski 2013, 690.

${ }^{659}$ Chavarría Arnau 2005, 545-546; Halsall 2007, 342-343; López Quiroga - Martínez Tejera 2017, 440-441. Tipikus germán temetkezési szokások alig mutathatók ki az 5. századi Gallaeciában; a „double stole tombstones" továbbhasználatáról és a temetők és erődök melletti plébániák létrehozásáról lásd: Sánchez Pardo 2013, 147-149; 155.

660 Arias 2007, 40. Hispania északi része már a római köztársaság idején sem vonzotta a telepeseket, egyedül katonai vagy bányászati szempontok miatt jöttek létre itt nagyobb városok, Gallaeciában például jelentős arany-, ezüst- és ónlelöhelyek voltak, vö. Cortázar - Vesga 2001, 78; 81; López Quiroga - Martínez Tejera 2017, 520-521. A hispaniai urbanizáció folyamatáról lásd: Alföldy 2007, 450-452; a gazdasági és katonai szempontok miatt létrehozott út- és településhálózatról bővebben: López Quiroga - Martínez Tejera 2017, 221-223.

${ }^{661}$ Cortázar - Vesga 2001, 91-92.

662 Livermore 1971, 59; Torres Rogríguez 1977, 269; Arias 2007, 37; Riché 2016, 74. A Gallaeciában feltárt „,agricultural terraces” elhelyezkedéséhez lásd: 7. sz. térkép; az itt folyó mezőgazdasági termelésről bővebben: Sánchez Pardo 2013, 146-147.

${ }^{663}$ Iord., Get. 261; Thompson 1982, 171. 
müveltek, mások pedig testőrként vagy zsoldosként szolgáltak, vagyis békésen éltek együtt a hispán-római lakossággal. ${ }^{664}$

431-ben a szvévek ismét megszegték a gallaeciabeliekkel kötött békét és újra fosztogatni kezdtek, ${ }^{665}$ mivel a szvév külpolitika a vandálok távozása után agresszívabbá vált és az ambíciózus Hermeric a félsziget többi részének elfoglalására törekedett. ${ }^{666}$ Támadásaik annyira állandósulhattak és veszélyesnek tünhettek, hogy maga Hydatius is bekapcsolódott a politikai életbe és követséget vállalt, hogy a szvév fosztogatások megállításához Aëtiustól kérjen segítséget, aki ekkor éppen Galliában tartott hadjáratot. Hydatius ugyan utal arra, hogy önként vállalta ezt a feladatot (suscipit legationem), hogy püspökként a helyiek érdekeit képviselhesse, valószínübb azonban, hogy a későbbi Symphosius püspökhöz hasonlóan öt is Hermeric kérte fel és küldte követként (legatus missus) Aëtiushoz ${ }^{667}$ mert abban bízott, hogy egy katolikus püspök többet érhet el a tárgyalásokon, mint egy pogány követ. Hydatius követvállalásából ugyanakkor arra következtethetünk, hogy a térségben ekkor már nem állomásoztak római csapatok, mert ebben az esetben az itteni cohors vezetője lett volna illetékes ennek a feladatnak a végrehajtására, ${ }^{668}$ és más források is megerősítik azt a feltételezést, hogy a 430-as évektől valójában már sem közigazgatási, sem jogi hatóság nem müködött a megosztott Gallaeciában, ${ }^{669}$ éppen ezért a birodalmi és a barbár „exclusive centrepoints” hiányában a politikai tevékenységekben és a diplomáciai ügyekben való részvétel nyitva állt a polgári és katonai tisztviselök, a tartományi testületek tagjai és az egyházat vezető papok előtt egyaránt. ${ }^{670}$

Aëtius végül csak 432-ben, a frankok legyőzése után küldte vissza a szvévekhez Hydatiust Censorius comes kíséretében. ${ }^{671}$ Egyes kutatók szerint az a tény, hogy Aëtius „diplomatic pressure” formájában csak egy követet küldött válaszként és nem tett konkrét katonai lépéseket a gallaeciaiak védelmében, egyértelmüen igazolja, hogy Aëtius nem volt elkötelezett a Gallián kívüli római területek megmentésében, ${ }^{672}$ ugyanakkor meglepő módon

\footnotetext{
${ }^{664}$ Oros. 7,41,7. Burgess szerint azonban Orosius ,gives the lie”, mivel Gallaecia elhagyása után sohasem tért vissza szülöföldjére, így nem is rendelkezhetett pontos információkkal az ott kialakult helyzetről, vö. Burgess 1988a, 190.

${ }^{665}$ Hyd. 86: rursum initam cum Callicis pacem libata sibi occasione conturbant.

666 Tranoy 1974, 1,28-33.

${ }^{667}$ Hyd. 86; 91-92.

668 Burgess 1988a, 127.

${ }^{669}$ Not. Dig., Occ. 1,67; 21,10; Thompson 1982, 169; Gillett 2003, 58.

${ }^{670}$ Gillett 2003, 76.

${ }^{671}$ Hyd. 88; Iord., Get. 176; Prosp. 429-430; Ioh. Ant. 201; Chr. Gall. 452, 106; Sid. Ap., Carm. 7,233.

${ }^{672}$ Heather 2006, 288; Burgess 1988a, 129. Aëtius stratégiájáról és a hispaniai küldöttség lehetséges céljairól bővebben: Gillett 2003, 55-58.
} 
azt látjuk, hogy Hydatius nem volt elégedetlen a kialakult helyzettel. Feltételezhetően a követség küldetése sikerrel végződött, mert Censorius 433-ban visszatért Ravennába, a szvévek és a gallaeciabeliek közötti békét pedig a püspök közbenjárásának köszönhetően (sub interventu episcopali) ismét megerősítették. ${ }^{673}$ Hermeric hatalma ennek következtében biztosan növekedett, mert még túszokat is sikerült ejtenie a béke helyreállítására hivatkozva, ez viszont arra utal, hogy nem látta biztosítottnak, hogy maguk a gallaeciaiak betartják majd a szerződést. ${ }^{674}$ Úgy tünik, a helyzetet végül mégsem sikerült megnyugtató módon rendezni, mert Hermeric újabb követséget indított a rómaiakhoz Symphosius püspök személyében, kezdeményezése viszont feltehetően a császári udvar elutasítása miatt meghiúsult (rebus incassum frustratur arreptis). 437-ben ismét Censorius indult követségbe Fretimund kíséretében a szvévekhez, ennek eredményeképpen 438-ban a szvévek békét kötöttek a gallaeciaiak egy részével, akik korábban harcban álltak velük (cum parte plebis Calleciae cui adversabatur). ${ }^{675} \mathrm{Nem}$ tudjuk pontosan azonosítani, hogy itt a hispán-római lakosság melyik csoportjáról van szó, a kutatók nagy része a plebs kifejezés miatt azt feltételezi, hogy a korábbiakhoz hasonlóan a vidéki területek lakossága köthetett békét a szvévekkel, az erősebben romanizált területek és a püspökök által patronált városok pedig továbbra is római ellenőrzés alatt maradtak. ${ }^{676}$ Thompson szerint a 431-438 közötti gyakori követváltások azt igazolják, hogy a szvévek és a rómaiak között elkezdődött egyfajta együttműködés a kialakítandó béke feltételeiről, még akkor is, ha ezek a tárgyalások nem mindig voltak sikeresek és hosszú távúak, ${ }^{677}$ talán mert a megállapodásokat nem mindenki tartotta tiszteletben egyik oldalon sem. Díaz és Menéndez-Bueyes az alkalomszerüségét hangsúlyozza ezeknek az alkuszerü békeszerződéseknek, amelyeket ugyan helyi közösségek és városok kötöttek meg egymással, de mindenképpen hatást gyakorolhattak a hivatalos tárgyalási folyamatokra, ${ }^{678}$ erről viszont Hydatius nem tájékoztatja az olvasóit.

Néhány hónappal később azonban megváltozott a helyzet, mert amikor Rechila Emerita elfoglalása után 440-ben ostromolni kezdte Martylist, a korábbi követjárásairól ismert Censorius feltétel nélkül megadta magát (in pace se tradidit), 441-ben pedig Hispalis

\footnotetext{
${ }^{673}$ Hyd. 91. Thompson nem biztos abban, hogy a béke 433-as helyreállításánál is Hydatiusról van szó, és elképzelhetőnek tartja, hogy Hermerickel egy másik püspök került kapcsolatba, vö. Thompson 1982, 179.

${ }^{674}$ Gelarda 2008-2009, 302.

675 Hyd. 92; 103; 105.

676 Tranoy 1974, 1,41; Gelarda 2008-2009, 303. A hydatiusi plebs értelmezéséhez bővebben: Gillett 2003, 5860.

677 Thompson 1982, 176.

${ }^{678}$ Díaz - Menéndez-Bueyes 2005, 294.
} 
is a szvévek kezére került. ${ }^{679}$ Szvév fosztogatásokról legközelebb csak 446-ban hallunk, amikor Rechila több támadást is indított a Carthaginiensis és Baetica védelmére érkező római csapatok ellen. Amikor a rómaiakat segítő gót csapatok vereséget szenvedtek a szvévektől, a rómaiak megfutamodtak, a szvévek pedig felforgatták az elfoglalt tartományokat. ${ }^{680}$ Rechila hódításközpontú politikája minden bizonnyal nagyobb hadsereget és több erőforrást igényelt, ezért feltételezhetjük, hogy a gallaeciabeliek egy része együttmüködött a szvévekkel a hódítások során. ${ }^{681}$ Mivel a szvévek által sürün lakott területeken sem tudunk ellenállásról vagy lázadásokról, elképzelhető, hogy a gallaeciabeliek egy része szívesebben élt a szvévek uralma alatt, ahogyan ezt látjuk a vandálok és a gótok esetében is. A szvév uralkodók hatalma nem volt konstans, hanem leginkább alkalmi és büntető fosztogatásokban nyilvánult meg, ezért a gallaeciaiak egy része megértette, hogy a szvév uralom elfogadásával már nem kell tartania a fosztogatásoktól, ${ }^{682}$ mentesülhet a római adóterhektől, és mivel nem veszélyezteti a további elszegényedés lehetősége, akár még javulhatnak is társadalmi és gazdasági pozíciói. ${ }^{683}$

Rechiarius 448-as hatalomra kerülése után a szvévek Róma-ellenes politikája miatt ${ }^{684}$ megerősödött a szvév fosztogatások intenzitása, ennek megfelelően 448-ban Hispalisban meggyilkolták a korábban több követséget vállaló Censoriust, kifosztották Gallaecia legtávolabbi területeit (ulteriores regiones) és a vasconiai Iberus folyó völgyét, hogy innen kiindulva előkészíthessék Tarraconensis meghódítását. 449-ben Rechiarius Basilius segítségével már Caesaraugusta környékét fosztogatta, erőszakkal és csellel (inrupta per dolum) pedig Ilerda városát is megszerezte jelentős számú foglyot ejtve. ${ }^{685} \mathrm{~A}$ szvév-gót viszony jelentős javulását és a rómaiak elleni közös fellépést lehetőségét eredményezte, hogy 449-ben Rechiarius egy házassági szerződés alapján feleségül vette Theoderic lányát. ${ }^{686}$ Thompson szerint az a tény, hogy a szvévek nem tiltották az idegenekkel való házasságot, azt igazolja, hogy nem voltak saját törvényeik, emiatt nem is köthettek a rómaiakkal foedus típusú szerződést, következtetése azonban nem megalapozott, hiszen például a burgundokról tudjuk, hogy mivel igyekeztek jó viszony ápolni a római senatorok felső rétegével, nem tiltották a vegyes házasságokat, a grófságok élén pedig egy-

\footnotetext{
${ }^{679}$ Hyd. 111; 113; 115.

${ }^{680}$ Hyd. 126.

681 Torres Rodríguez 1977, 87; Arias 2007, 46.

682 Díaz - Menéndez-Bueyes 2005, 297; Carr 2002, 128.

${ }^{683}$ Oros. 7,41,5-7; Salv. 4,4; Halsall 2007, 227.

${ }^{684}$ Thompson 1980, 80.

${ }^{685}$ Hyd. 129; 131-132; 134.

${ }^{686}$ Hyd. 132; Collins 2004, 31. Egyes kutatók szerint ezt a szövetséget más királyi házasságok is erősítették a korábbi időszakból, vö. López Sánchez 2005, 511, 83. j.
} 
egy római és burgund comes közösen bíráskodott a lakosság fölött, ennek ellenére jogi értelemben mégis megtarthatták elkülönültségüket és saját törvényeiket is. ${ }^{687}$ Rechiarius házassága ugyanakkor jól tükrözi azt a sajátos germán gyakorlatot, mely szerint a házasság egyfajta ,politikai aktusnak” minősült és házasságokat gyakran a készülődő háborúk megakadályozására kötöttek. ${ }^{688}$

A szvévek a későbbi időszakban kétszer is elfogadták a rómaiak kezdeményezését a békés viszony fenntartására: 452-ben vagy 453-ban két hispaniai comes, Mansuetus és Fronto révén sikerült megerősíteni a korábbi békefeltételeket, 454-ben pedig Iustinianus segítségével újult meg a szerződés. ${ }^{689}$ Ezek a követségek valószínűleg III. Valentinianus és a szvévek közötti kapcsolatok élénkülését igazolják, és feltételeznek egyfajta hatalommegosztást is a birodalom és a szvév uralkodó között. ${ }^{690}$ Rechila és Rechiarius győzelmeit ugyanakkor a városok kifosztása és a gótokkal való kapcsolat erősödése miatt Hydatius rossz szemmel nézte, ezért annak ellenére, hogy a 438-456 közötti időszak a rómaiak és a barbárok között viszonylag nyugalmasnak tekinthető, Hydatius semmit sem mond a két fél közötti kapcsolatról vagy együttélésről, hanem inkább igyekszik az eseményeket a római és a barbár hadvezérek folyamatos küzdelmének ábrázolni. ${ }^{691}$

A szvévek kihasználták, hogy 455-ben a rómaiak hadereje Aëtius és III. Valentinianus meggyilkolása miatt csökkent, ezért korábbi taktikájukon változtatva annak ellenére fosztogatták Carthaginiensis területét, hogy a 453-as szerződés értelmében a terület visszakerült római uralom alá. 456-ban a rómaiak és a gótok is követeket küldtek Rechiariushoz, hogy fenntartsák a békeszerződést, de a szvévek a követeket visszautasítva megszegték az esküjüket, majd Tarraconensis kifosztására indultak, ${ }^{692}$ amikor pedig 456ban Theoderic ismét követeket küldött Rechiariushoz, ő egy újabb tarraconensisi támadással válaszolt. ${ }^{693}$ A két hadjárattal a szvévek meg akarták hódítani az egyetlen olyan provinciát, amely még mindig római fennhatóság alá tartozott, ugyanakkor a Gallaeciába vezetett foglyok nagy száma arra utalhat, hogy a római lakosság egy része igyekezett hasznot húzni a szvévek fosztogatásaiból. ${ }^{694}$ Iordanes szerint Rechiarius azt gondolta, hogy mivel a gótok

\footnotetext{
${ }^{687}$ Thompson 1982, 170; Angenendt 2008, 147.

${ }^{688}$ Klaniczay 2005, 69.

${ }^{689}$ Hyd. 147; 153.

${ }^{690}$ Díaz - Menéndez-Bueyes 2005, 268, 8. j.

${ }^{691}$ Burgess 1988a, 149; Muhlberger 1990, 222.

${ }^{692}$ Hyd. 161; 163: quia uno essent pacis foedere copulati, iurati foederis promissa servarent. Remissis legatis utriusque partis atque omni iurationi violata.

${ }^{693}$ Hyd. 165. Isidorus nem tud erről a második akcióról, vö. Isid., Hist. Suev. 87.

${ }^{694}$ Muhlberger 1990, 251.
} 
a rómaiakkal foederati viszonyban voltak, II. Theoderickel való sógorságát kihasználva akár egész Hispania a szvévek fennhatósága alá kerülhet. ${ }^{695}$

Sajátos problémát jelent a gótok és a szvévek közötti kapcsolat vizsgálatában Aoiulf szerepe és azonosítása. Hydatius szerint 456-ban Theoderic egyik parancsnoka, Aioulf elhagyta a Lusitaniába tartó gót sereget és Gallaeciában várakozott, hogy a szvévek királya lehessen. ${ }^{696}$ Iordanes ezzel szemben azt állítja, hogy Aioulf a varnusok törzséből származott, és Theoderic clienseként 455-ben konkrét megbízást kapott arra, hogy kormányzóként irányítsa a szvéveket, ők azonban kezdeményezték, hogy inkább önállósodjon és legyen a szvévek királya. ${ }^{697}$ Aioulf pontos azonosítását tovább nehezíti, hogy vélhetően azonos a Hydatius által 449-ben említett Agiulffal, Censorius gyilkosával. ${ }^{698}$ Thompson szerint Iordanes kevésbé hiteles forrás, mint Hydatius, mivel időben és térben is távolabb élt a gallaeciai eseményektől és általánosságban is pontatlanabbak a feljegyzései. Iordanes gótok iránti elfogultsága miatt Aioulfot egy hütlen varnusnak állította be és magukat a szvéveket is belekeverte Theoderic elárulásába, mivel szerinte Aioulf a szvévek rábeszélésének hatására vált kétszínűvé. Amikor Aioulf megpróbálta megszerezni a hatalmat Gallaecia fölött, Theoderic 457 júniusában, Portus Caléban elfogta és lefejeztette őt. ${ }^{69}$ Iordanes szerint a szvévek ezután papokból álló követséget indítottak Theoderichez, aki nemcsak hogy elengedte a szvévek büntetését, de ahhoz is hozzájárult, hogy saját vezetőt válasszanak maguk közül, valójában azonban Remismund csak 465-ben lett a szvévek királya. Thompson jogosan kételkedik Iordanes hitelességében a szvév föpapok és Theoderic találkozásáról szóló tudósítással kapcsolatban, hiszen a püspököket a gót király nem üdvözölhette a nekik kijáró tisztelettel, mivel 457-ben a szvévek még pogányok voltak.

Rechiarius halála után a 456-460 közötti belső hatalmi harcok a szvév lakosság megosztottságához vezettek és minden korábbinál erőszakosabb terjeszkedési politikát generáltak. 457-ben a szvévek egy része Maldras vezetésével a szokásos kétszínűséget alkalmazva (solito more perfidiae) kifosztotta Lusitaniát és lemészárolta a rómaiakat, majd

\footnotetext{
${ }^{695}$ Iord., Get. 229-230.

${ }^{696}$ Hyd. 173; 180; Thompson 1965, 96; Trambauer 2008, 61.

${ }^{697}$ Iord., Get. 233. Várady szerint Theoderic és Aioulf viszonya azt bizonyítja, hogy a romanizált barbároknál is meghonosodott a római protektorátusi gyakorlat, vö. Várady 1961, 200.

${ }^{698}$ Hyd. 131. A Burgess által $(B)$-nek nevezett kézirat alapján nem azonos a két személy, az $(F)$-ből viszont egyértelmüen kiolvasható a megfelelésük. Iordanes a szvévek betörésekor Aioulfra Agrivulfként utal, így ő is azonos személyként kezeli őket, felmerül tehát a gyanú, hogy a $(B)$ kézirata kevésbé pontos ebben az esetben. Mivel Iordanes a 6. században alkotott, az $(F)$-et összeállító Fredegarius pedig a 7. századból származik, Iordanes nem használhatta Fredegariust forrásként, de arra sincs bizonyítékunk, hogy Fredegarius ismerte volna Iordanes szövegét; vö. Iord., Get. 233; Burgess 1993, 129. Az azonosításról bővebben: Claude 1978, 654; Thompson 1982, 298, 40. j.

${ }^{699}$ Hyd. 180; Iord., Get. 233-234; PLRE 2,39-40; Thompson 1982, 168-169.
} 
zsákmányszerzés után békét színlelve (sub specie pacis) Ulixippona városára támadt, 458ban pedig a szokásos álnokságukkal (in solitam perfidiam versi) Gallaecia Durius-menti területeit pusztították végig. ${ }^{700}$ A gótok és a vandálok követei valószínüleg Framtane halála miatt kezdtek sikertelen tárgyalásokba a szvévekkel, 459-ben pedig már mindkét szvév király, Maldras és Rechimund is egyszerre fosztogatta Lusitania és Gallaecia egyes részeit. ${ }^{701}$ Miután Maldras saját fivérével is végzett, a rómaiak között rendezett vérfürdőt Portus Caléban, ez pedig felerősítette a szvévek és a gallaeciabeliek közötti ellenségeskedést (malum hostile). ${ }^{702}$ Hydatius itt utal először a szvévekkel kapcsolatban kétszínűségre, álnokságra és a békék színlelésére, talán mert ekkor vált számára nyilvánvalóvá a szvévek által gyakran alkalmazott taktika, mely szerint megüzenik az ellenségnek a békekötés szándékát, ezért azok jóhiszeműen beengedik őket a városba és így lehetővé válik a terület gyors, ostrom nélküli elfoglalása. Úgy tűnik, hogy a gótok 456-os betörése és a szvév hatalom összeomlása után a gallaeciaiak talán alkalmazkodni próbáltak az új hatalmi viszonyokhoz, és először a győzedelmeskedő gótokat hitték a császári hatalom képviselőjének, ${ }^{703}$ amikor azonban az ő kegyetlenségükkel is szembesültek, ismét a szvévek felé fordultak, őket pedig az ekkor kibontakozó belső hatalmi harcok kényszeríthették arra, hogy a korábbinál sokkal óvatosabb politikát folytatva békét kérjenek a gallaeciaiaktól (pacem ambiunt Galleciorum). ${ }^{704}$

Egyedülálló diplomáciai eseménynek számít, amikor a római Nepotianus magister utriusque militiae és a gót Sunieric comes 459 végén követeket küldött Gallaeciába, hogy hírt vigyenek a gótok és a rómaiak közötti békéről Arelate ostroma után. Ez volt tudomásunk szerint az egyetlen olyan eset, amikor a római császár követsége kifejezetten a gallaeciaiakhoz ment, talán hogy megkérje őket, hogy támogassák, vagy legalábbis maradjanak semlegesek a császár hódító törekvéseivel kapcsolatban. ${ }^{705}$ A szvévek valószínűleg éppen ezt a rómaiak és a gallaeciaiak között alakuló együttműködést próbálták meghiúsítani azzal, hogy 460 húsvétján az új szvév király, Frumarius vezetésével megöltek néhány Lucusban élő római előkelőt helytartójukkal együtt (cum rectore suo), annak ellenére, hogy a rómaiak ünnepet ültek és egyáltalán nem számítottak a rajtaütésre. ${ }^{706}$

\footnotetext{
${ }^{700}$ Hyd. 181; 183.

${ }^{701}$ Hyd. 186; 188.

${ }^{702}$ Hyd. 190-191.

${ }^{703}$ Muhlberger 1990, 252.

${ }^{704}$ Hyd. 179; 181.

${ }^{705}$ Hyd. 192; Muhlberger 1990, 253.

706 Hyd. 194. Hasonló eset történt 368-ban is, amikor az alemannok szintén ünnep idején fosztották ki Moguntiacum városát, vö. Havas - Hegyi - Szabó 2007, 631.
} 
A 460-as lucusi esettel kapcsolatban érdemes részletesebben kitérni arra, hogy a rómaiaktól megmaradt hatalmi struktúra milyen hatást gyakorolhatott a szvév hatalom fejlődésére. Díaz szerint az 5. századi betörések egy olyan folyamatot indítottak el a hispánrómai lakosság szemében, amely társadalmi és gazdasági okokból a központi hatalom visszafordíthatatlan felbomlását eredményezte. ${ }^{707}$ A császári hatalom ugyan a szvév szuverenitás erősödésével egyre kevésbé tudott érvényesülni, a szvév igazgatási rendszer viszont még nem volt elég fejlett ahhoz, hogy egy önálló struktúrát hozzon létre, ezért a szvévek egyszerüen a megörökölt római rendszert használták tovább saját igényeikhez igazítva, ahogyan ez például az adószedéssel kapcsolatos eljárásokban is megfigyelhető. ${ }^{708}$ Mivel Hydatius 460-ban Lucus római helytartójának meggyilkolásáról tudósít, Thompson szerint ez azt igazolja, hogy ebben az időszakban Rómának még sikerült saját kormányzót kineveznie Gallaecia élére, aki a római törvényeket alkalmazta a közigazgatásban és összegyüjtötte a Rómának fizetendő adót a helyi lakosságtól, Díaz ugyanakkor valószínütlennek tartja, hogy ezt a helyi tisztségviselőt a korábbi gyakorlat alapján még mindig Róma állította volna hivatalba. ${ }^{709}$ Bár a források nem utalnak szvév törvényekre, valószínüleg a szvév jogrendszer is a római jog és a germán szokásjog keveredéséből alakult ki, de mivel a római lakosság még kizárólag a római jog rendelkezéseit alkalmazta, a szvévek nem is tudtak volna olyan gyorsan integrálódni a helyi lakosságba. ${ }^{710}$ Bizonyítékaink vannak arra is, hogy Gallaeciában megmaradtak a római időkből származó igazgatási, bírósági és adózási körzetek, a conventusok Bracarában, Lucusban, Asturicában és Aquae Flaviae városában. ${ }^{711}$ Bár Hydatius 460-as beszámolójából nem látszik egyértelmüen, hogy a szvévek elfoglalták-e Lucus egy részét vagy a városon kívül telepedtek le, feltételezhetjük, hogy a szvévek és a rómaiak különálló közösségekben éltek egy-egy városon belül, és a Hydatius által említett helytartó egyfajta rector civitatis volt, akit a helyi lakosság választott a rómaiak és a szvévek közötti ügyek lebonyolítására. ${ }^{712}$ Lucus helyzetéről további információkkal is rendelkezünk, hiszen néhány évvel korábban a herul kalózok Cantabria és Vardullia feldúlása után kegyetlen pusztítást végeztek

\footnotetext{
${ }^{707}$ Díaz 2000b, 19.

${ }^{708}$ Arias 2007, 50; Reinhart 1952, 64; Thompson 1982, 164.

709 Thompson 1982, 169. Thompson szerint a tribunus cohortis lucensis tisztségről lehet szó, vö. Not. Dig., Occ. 42,29; Díaz 2000b, 17.

${ }^{710}$ Arias 2007, 51; Díaz 1993, 219.

711 Thompson 1982, 170; Díaz 2011, 53-54. Augustus korától 14 conventus müködött Hispaniában: 7 Tarraconensisben, 3 Lusitaniában, 4 pedig Baeticában, vö. Cortázar - Vesga 2001, 80; Kulikowski $2005,33$. Hispania Diocletianus-kori közigazgatási rendszerének áttekintéséhez lásd: 9. sz. térkép.

${ }^{712}$ Díaz - Menéndez-Bueyes 2005, 292; Burgess 1988a, 124.
} 
(crudelissime depredati sunt) Lucus környékén is, ${ }^{713}$ ez pedig jól mutatja, hogy a római lakosság nagy része fegyvertelen polgárként már képtelen volt bármilyen fosztogatásnak ellenállni. ${ }^{714}$

460 júliusában a gótok Lucus melletti támadására reagálva Frumarius csapata fogságba ejtette Hydatiust, feldúlta Aquae Flaviae kolostorát és hatalmas pusztításba kezdett a város környékén, Rechimund pedig hasonlóképpen végigfosztogatta Auregens és Lucus környékét. Ezt követően a rómaiak és a szvévek több alkalommal folytattak rövid és kevésbé eredményes tárgyalásokat: a látszólagos béke (pacis quedam umbra) megkötése után a Theoderic által küldött követek gyorsan visszatértek, de a kétszínü pogányoknak (gentis perfide) tartott szvévek követei sem időztek sokáig a gótoknál. ${ }^{715}$ 463-ban a rómaiak és a gótok követei többször is találkoztak a szvév küldöttekkel; először Theoderic indította hozzájuk a gót Cyrilát egy gallaeciabeli előkelővel, Palogoriusszal, aki korábban Theoderichez menet találkozott Rechimund küldöttségével. ${ }^{716}$ A követek Lucusban várták, hogy Cyrila visszatérjen Rechimundtól, de a szvévek meghazudtolva saját ígéreteiket a rájuk jellemző módon ismét fosztogatni kezdték Gallaecia különböző területeit. ${ }^{717}$ Theoderic ezután a szvévekhez küldte Cyrilát és néhány korábban érkezett gót követet Remismunddal, de Cyrila Gallaeciában maradt, Remismund pedig még pár alkalommal követként utazott Gallaecia és Gallia térségében, amikor viszont visszatért a gót királyhoz, féktelen lázadás (indisciplinata perturbatio) tört ki a gallaeciabeliek és a szvévek között. ${ }^{718}$

Amikor 465-ben Remismund királyságát egyhangúlag elismerték a szvévek, első lépésként megújította az elévült békét (pacem reformat elabsam). Theoderic annak jeleként, hogy támogatja Remismund hatalomra kerülését, fegyvereket és ajándékokat adott neki, és még a gót udvarban élő feleségét is elküldte hozzá, ${ }^{719}$ ebből pedig arra következtethetünk, hogy Theoderic a gót hercegnővel igyekezett a Szvév Királyságot saját befolyása alá

\footnotetext{
${ }^{713}$ Hyd. 164; 189; Proc. 6,15,27-28. A herulok nyugati csoportja korábban rablóhadjáratokat indított Gallia és Hispania irányába, keleti csapataik pedig a gótokkal együtt fenyegették a Római Birodalmat és önálló államot hoztak létre a Dunánál. A Lucus partjait 456-ban elérő katonák megfutamodásuk során Hispania északi részét pusztították, 459-ben pedig Baeticába tartó csoportjuk háborgatta a lucusi kolostor melletti partvidéket.

714 Thompson 1982, 181; Wood 2007b, 506. A herul kalózok fosztogatásairól bővebben: Arce 2007, 173-176.

${ }^{715}$ Hyd. 196-197; 199-200; 203.

716 Elképzelhetö, hogy Palogorius nem a szvévek követeként ment Theoderichez, hanem egy magánakció keretében vállalta a küldöttséget, vö. Thompson 1982, 305, 1. j.

${ }^{717}$ Hyd. 215: Suevi promissionum suarum ut semper fallaces et perfidi diversa loca infelicis Galleciae solito depredantur.

${ }^{718}$ Hyd. 216; Thompson 1982, 167.

${ }^{719}$ Hyd. 219; 222; Isid., Hist. Goth. 33; Hist. Suev. 90.
} 
vonni. ${ }^{720}$ Iordanes biztosan túloz, amikor azt állítja, hogy Theoderic megengedte a szvéveknek, hogy saját vezetöt válasszanak maguknak, és így került volna hatalomra Remismund, ${ }^{721}$ ugyanakkor felidézhetjük a korábban tárgyalt Aioulf esetét, aki szintén Theoderic clienseként lett a szvévek vezetője.

Remismund uralkodása alatt a szvévek egyre intenzívebb támadásokat indítottak, részben azért, hogy újabb területeket szerezzenek, részben pedig azért, hogy a gótok befolyását ellensúlyozva önállósodni tudjanak. 465-ben például csalárd módon (dolose) Conimbricára támadtak, kifosztották az előkelő származású Contaber családját, és elhurcolták a foglyul ejtett anyát fiaival együtt. Hydatius pontos leírásából feltételezzük, hogy ez a támadás konkrétan Contaber és családja ellen irányult, talán mert Contaber fellázadt a szvévek uralma ellen, ${ }^{722}$ ugyanakkor a család és a gyermekek említése a korábbiakhoz hasonló módon alkalmas az olvasók érzelmeinek mozgósítására, Thompson pedig valószínüsíti, hogy Cantaber családja mindezek ellenére túlélte a fosztogatásokat. ${ }^{723}$

Remismund 465-ben még két alkalommal váltott követeket Theoderickel, 465 végére azonban váratlanul megváltozott a szvévek és a gótok közötti kapcsolat, mert Remismund sorozatosan Theoderic tiltakozása ellenére indított fosztogató hadjáratokat. Amikor például a szvévek Aunona népén töltötték ki haragjukat (adversus seviunt plebem), Theoderic magyarázatot követelve követeket küldött Remismundhoz, de a próbálkozás eredménytelenül (in cassum) végződött, mivel elutasították őket, 466-ban pedig Sallát küldte egyezkedni a szvévekhez, ${ }^{724}$ de mire a követ visszatért, Theodericet már megölte a fivére, Euric. A gótok új királya azonnal követeket indított a császárhoz és a szvévekhez, Remismund azonban visszaküldte őket és saját emberei révén kezdett tárgyalásokba a rómaiakkal, a vandálokkal és a gótokkal, Aunona újabb kifosztása után pedig az összes gót követ visszatért Galliába Opilio vezetésével, hogy segítséget kérjenek a szvévek elleni küzdelemhez. ${ }^{725}$ Remismund külpolitikai lépései arra utalnak, hogy mivel Theoderic nem tudta ellenőrzése alá vonni a Szvév Királyság területét, Remismund önállóan igyekezett újabb földeket szerezni, Theoderic halála után pedig még inkább próbált nagyobb

\footnotetext{
${ }^{720}$ Reinhart 1952, 51; Torres Rodríguez 1977, 175; Muhlberger 1990, 254; Diego - Béjar 1992, 604; Arias 2007, 23.

${ }^{721}$ Iord., Get. 234.

${ }^{722}$ Hyd. 225; Arias 2007, 65; Kulikowski 2010, 200-201.

723 Bizonyíték lehet erre, hogy a 666-os emeritai zsinaton részt vett Conimbrica püspöke is, akit szintén Cantabernek hívtak, vö. Thompson 1982, 201.

${ }^{724}$ Hyd. 226-227; 229; 233. Isidorus a Sallanes alakot használja, vö. Isid., Hist. Goth. 33.

${ }^{725}$ Hyd. 234-235. A követjárás részleteiről lásd: Barbero - Loring 2005, 167-168.
} 
önállóságot kivívni magának, ez viszont a szvévek és a gótok közötti viszony megromlását eredményezte. $^{726}$

467-ben a szvévek követeik visszaérkezése után a békéröl megfeledkezve (in pace decepta), a rájuk jellemző módon különböző területeken szétszóródva átkeltek Lusitaniába, ${ }^{727}$ és hatalmas pusztítást végeztek Conimbricában: a házakat kifosztották és a falakat lerombolták, a lakosság egy részét megölték, a többieket pedig fogságba ejtették és az egész környéket otthagyták néptelenül (regio desolatur). Ha elfogadjuk Arias azon feltételezését, hogy ez a hadjárat a 465 -ös események folytatása lehet, ${ }^{728}$ akkor valószínűleg az azóta eltelt két évben megerősödhetett a szvévek ellen lázadó gallaeciabeliek tábora, mivel az ilyen mértékü fellépést csak a rend megteremtése indokolhatja, ráadásul Muhlberger is támogatja azt a nézetet, hogy Remismund sikeres külpolitikája ellenére azért kényszerült erődemonstrációra, mert képtelen volt megnyerni magának a gallaeciaiak támogatását. ${ }^{729}$

468-ban Lusidius árulása következtében (tradente Lusidio) a szvévek elfoglalták Ulixipponát. Isidorus szerint a város a korábbi békekötés miatt felkészületlen volt egy esetleges támadásra, így az elöljáró ellenállás nélkül átadta neki a várost, ${ }^{730}$ de 468 -ban más példát is látunk arra, hogy a gallaeciabeliek egy része átállt a szvévek oldalára. Hydatius szerint Aunona lakói békét kötöttek (pacem faciunt) a szvévekkel, amely egyúttal egy hosszú folyamat lezárásának is tekinthető. Aunonát ugyanis már 465 óta fosztogatta Remismund, a város lakói azonban folyamatosan ellenálltak és váltakozó sikerrel hárították el a szvévek hódító törekvéseit. ${ }^{731}$ Mindez arra utal, hogy Aunona lakói egyfajta politikai önállósággal rendelkeztek, és saját döntéseik alapján indíthattak követeket a szvévekhez és a gótokhoz. ${ }^{732}$ Bár 468-ban a szvévekhez hasonlóan a gótok is Lusitania és Asturica fosztogatásába kezdtek, nem tudunk arról, hogy a két sereg egymással is összecsapott volna, ugyanakkor a szvévek vélhetően a korábbi tendenciát folytatva teljesen megszakították a

\footnotetext{
${ }^{726}$ Arias 2007, 23.

727 Hyd. 236: pariter et Suevi qui post legatos more solito per diversa loca in praedam dispersi fuerant revocantur.

${ }^{728}$ Hyd. 237; Arias 2007, 65.

${ }^{729}$ Muhlberger 1990, 256.

${ }^{730}$ Hyd. 240; Isid., Hist. Suev. 90.

${ }^{731}$ Hyd. 243; Arias 2007, 65.

732 Díaz - Menéndez-Bueyes 2005, 295. Aunona pontos helyét máig nem sikerült meghatározni, Reinhart szerint Lusitania és Asturica között található, Schmidt viszont úgy gondolja, hogy Lusitaniában fekszik; vö. Reinhart 1952, 52; Schmidt 1970b, 1,212; a probléma bővebb elemzéséhez lásd: Thompson 1982, 294, 74. j.
} 
diplomáciai kapcsolatot a gótokkal, és inkább a rómaiakkal kezdtek tárgyalásokat Lusidius közvetítésével. ${ }^{733}$

Mivel Hydatius feljegyzései itt megszakadnak, nem tudjuk pontosan, hogy mi lett Remismund sorsa és hogyan alakult a szvévek története az 5. század végén. Remismund külpolitikájának egyik fő célja az lehetett, hogy újra szvév ellenőrzés alá vonja a Theoderic támadása miatt elveszített területeket, a hadjáratok másik része pedig a lázadó gallaeciabeliek ellen irányult, akik Remismund növekvő hatalmával próbáltak szembeszállni. ${ }^{734}$ Több kutató viszont arra a következtetésre jutott, hogy a gallaeciabeliek vezető rétege egyre inkább elfogadta a szvévek uralmát, leginkább annak köszönhetően, hogy Remismund sikeres külpolitikájával és dinamikus diplomáciai eszközeivel stabilizálni tudta a Szvév Királyság helyzetét. ${ }^{735}$ Nem valószínű, hogy a 468 utáni sötét időszakban jelentős események történtek, hiszen egyetlen forrás sem számol be ilyen jellegü fejleményekről. Ha elfogadjuk, hogy Remismund uralkodásának végére a szvévek és a gallaeciabeliek közötti kapcsolatok az esetleges kisebb lázadások ellenére rendeződtek, a későbbi, hosszú és eseménytelen időszakban a viszonyuk még inkább javulhatott. Bár Remismund az arianus kereszténységet támogatta, ettől eltekintve a szvévek integrációja egyre inkább kiteljesedhetett a későbbiekben. ${ }^{736}$

A szvév-gallaeciai kapcsolatok áttekintése után érdemes kitérnünk még néhány érdekes szempontra a gallaeciaiak gondolkodására és aktivitására vonatkozóan. Thompson értelmezésében Hydatius Gallaeciája egy olyan provincia, amely teljesen kicsúszott a római irányítás alól, területét a szvévek folyamatosan fosztogatták, a római lakosság pedig egyöntetüen boldogtalan volt és alávetve szenvedett a rengeteg erőszaktól. ${ }^{737}$ Muhlberger azonban több példa segítségével igyekszik megcáfolni, hogy a provincia lakosságának sorsa teljes mértékben a szvévek önkényétől függött, és elutasítja azt a hagyományos álláspontot, mely szerint a gallaeciaiak politikailag közömbös tömeget alkottak és nem vállaltak semmiféle szerepet saját maguk védelmében. Feltételezése szerint Hydatius azért ábrázolja egysíkúan, leginkább a lakosság problémáit és szenvedéseit kiemelve Gallaecia helyzetét, hogy megpróbálja eltitkolni az olvasói előtt, milyen együttműködések és alkuszerü megegyezések jöttek létre a gallaeciaiak és a szvévek között. ${ }^{738}$ A birodalom más részein azt látjuk, hogy a barbárok jelenléte kezdetben közéleti aktivitásra ösztönözte a helyi

\footnotetext{
${ }^{733}$ Hyd. 244-245.

${ }^{734}$ Arias 2007, 66.

735 Diego - Béjar 1992, 606-607; Díaz 2000b, 21.

${ }^{736}$ Arias 2007, 66; Torres Rodríguez 1977, 193.

737 Thompson 1982, 160.

${ }^{738}$ Muhlberger 1990, 245; 252.
} 
lakosságot, később azonban a felső réteg egyre kevesebb szerepet vállalt a provinciák irányításában. Sidonius Apollinaris leveleiben a galliai római arisztokrácia közömbösségéről tudósít, akiknek egy része visszavonult birtokára és nem törődött vallási kérdésekkel, más részük viszont éppen hogy püspöki hivatalt vállalt, hogy számára elönyös politikai kapcsolatokat építhessen ki a barbárokkal. ${ }^{739}$ Mócsy a Severus-kori feliratanyag vizsgálatával igazolta, hogy a pannoniai határvidéken bekövetkezett gazdasági virágzásnak köszönhetően a helyi lakosság eleinte élénken foglalkozott a közügyekkel, később azonban a nagybirtokos arisztokrácia létszámának csökkenése és a romanizált lakosság folyamatos kivándorlása miatt a vezető szerep a barbárok kezébe került. ${ }^{740}$

Elfogadhatjuk Muhlberger azon véleményét, hogy a szvévek sohasem foglalták el teljesen Gallaecia területét és nem gyakoroltak fölötte abszolút hatalmat. ${ }^{741}$ Bár ebben az időszakban a római hatalom már csak formálisan létezett Gallaeciában és inkább a helyi arisztokrácia hatalmi ambícióinak kiélésére szolgált, a szvévek 438-ig biztosan meghagyták a rómaiaktól átvett igazgatási formákat, és nem avatkoztak bele a gallaeciaiak menedékeként szolgáló erődítmények és városok életébe sem. ${ }^{742}$ Ezek alapján feltételezhetjük azt is, hogy a gallaeciai lakosok bizonyos fokú katonai és politikai önállósággal rendelkeztek, több esetben pedig együtt is müködtek a szvévek vezetőivel, amelyet Arias is megerősít Gallaecia keleti területeivel kapcsolatban. ${ }^{743}$ Hydatius azt sugallja, hogy a gallaeciaiak közömbösek és tehetetlenek voltak saját sorsukkal kapcsolatban, ennek ellenére mégis igyekszik minden gallaeciaiak és szvévek közötti követségről beszámolni. ${ }^{744}$ Burgess különösen a krónika második felében hangsúlyozza a hispán-római lakosság barbárokkal szembeni tehetetlenségét, mégis számtalan példát láttunk olyan erőfeszítésekre, amikor a rómaiak ellenállással, együttmüködéssel vagy szövetségkötéssel igyekeztek megőrizni függetlenségüket olyan mértékben, amennyire a barbár vezetés lehetővé tette számukra. Nem ellentétes ezzel Muhlberger álláspontja sem, mely szerint a gallaeciaiakat a körülmények ösztönözték arra, hogy a gyenge központi hatalomtól függetlenül önállóan kezdjenek alkuszerü tárgyalásokba a szvévekkel. ${ }^{745}$

Arias, López Quiroga és Martínez Tejera kiemeli a gallaeciaiak és a szvévek közötti kapcsolat összetettségét, amelyet éppen ezért nem jellemezhetünk általánosságban sem

\footnotetext{
${ }^{739}$ Sid. Ap., Ep. 4,9; 4,21; 7,15; Chadwick 1999, 233; Vanyó 2007b, 377.

${ }^{740}$ Mócsy 1974, 62; 198.

${ }^{741}$ Muhlberger 1990, 247.

742 Cortázar - Vesga 2001, 98.

${ }^{743}$ Arias 2007, 44.

${ }^{744}$ Gillett 2003, 45. A követségek áttekintését táblázatos formában lásd: Gillett 2003, 78-83.

745 Burgess 1988a, 185; Muhlberger 1990, 249.
} 
egyszerü ellenségeskedésnek, sem békés együttélésnek. Elfogadhatjuk, hogy a két csoport közötti kapcsolat nagyon sokat fejlődött, a kezdeti fosztogatások fokozatosan enyhültek és az interakciók egyre kevésbé voltak ellenségesek, ennek okát pedig a szvév politika és a körülmények változásában kereshetjük, mert ezek hatására folyamatosan változott a provinciabeli lakosság viselkedése, és ezáltal a szvévek és a gallaeciaiak közötti kapcsolat is. ${ }^{746}$ Több példát láttunk arra vonatkozóan is, hogy ezt az enyhülő folyamatot sok esetben ugyan megakasztották újabb konfliktusok, fosztogatások és szerződésszegések, a gallaeciaiak egy csoportja mégis egyre szorosabbá tudta alakítani a szvévekkel való viszonyát. Thompson kissé leegyszerüsítve próbál érvelni amellett, hogy Hydatius krónikája nem a barbárokról, hanem a rómaiakról szól, mivel nem sokat tudunk meg arról, hogy a barbárok hogyan viselkedtek azokkal szemben, akik közé betelepedtek. Burgess ezt azzal cáfolja, hogy Hydatius a rómaiakról sem közölt több szociológiai vagy antropológiai részletet, mint a szvévekről és a gótokról, egyszerüen azért, mert ő nem társadalomtudós, hanem egy eseményeket rögzítő krónikás. ${ }^{747}$ Ebből viszont arra következtethetünk, hogy a barbárok jelenléte és tevékenysége valójában csak olyan mértékben fontos a krónikában, amennyire azok hatással vannak a rómaiak és különösen a szerző életére, vagyis a krónika nem a barbárokról, nem a rómaiakról, hanem magáról Hydatiusról és a barbár megszállás miatt megváltozott életéröl szól.

\subsubsection{A vandálok}

A római hadsereg jó néhány katonája a vandálok közül származott, közülük a legnagyobb befolyásra Stilicho tett szert, aki hosszú ideig sikeresen védte a birodalom határait a barbár betörésekkel szemben, így 401-402 telén sikerült megállítania a hasding vandálok és az alánok előrenyomulását Noricum és Raetia területén. ${ }^{748}$ Stilicho a hunok nyugati szárnyát vezető Uldin és a gót Sarus összevont csapataival 406-ban Faesulaenál mért vereséget többek között a vandálokra, ${ }^{749}$ akik 405-ben még Radagaisus keleti gót király vezetésével próbáltak betörni Italiába és három részre szakadva fosztogatták a gazdag római birtokokat. ${ }^{750}$ Korábban láttuk, hogy 406-ban a vandálok Godigisel vezetésével még

\footnotetext{
746 Arias 2007, 1-2; 61; 68; López Quiroga - Martínez Tejera 2017, 432.

747 Thompson 1982, 210; Burgess 1988a, 134-135.

${ }^{748}$ A vandálok 3-4. századi történetéröl lásd: Merrills - Miles 2010, 27-34.

749 Sarus tevékenységéről lásd: Olymp. 20; Pohl 2018, 6; a faesulaei csata körülményeiről és Stilicho szerepéről bővebben: Várady 1961, 155-157.

${ }^{750}$ August., De Civ. 5,23; Oros. 7,37,4; Zos. 5,26,3-5; Wolfram 1988, 168-169; Randers-Pehrson 1993, 107109; Heather 2007a, 504-505; Merrills - Miles 2010, 34-35; Wieser 2016, 95. A győzelem után Radagaisus
} 
nyugatabbra húzódtak egészen a Rajnáig, ahol a rómaiakkal szövetséges frankok feltartóztatták őket, de Respendial alán csapatai segítségével sikerült visszaverni a támadásukat és az új király, Gunderic vezetésével szabadon átkelhettek Galliába, hogy fosztogatva Aquitania felé vonuljanak. 409-ben a gótoktól való félelmükben ${ }^{751}$ ők is átkeltek a Pireneusokon Hispaniába, ${ }^{752}$ később a siling vandálok Baeticában, a hasdingok pedig Gallaecia egy részén telepedtek le. Iordanes szerint a vandálok királya, Gaiseric 408 táján Gallia és Hispania jelentős részét pusztává tette, ${ }^{753}$ ez azonban anakronizmus, hiszen Gaiseric csak 428-ban lett vandál király, és akkor sem okozott olyan mértékü pusztítást, mint amiről Iordanes tudósít.

Miután 413-415 között Athaulf gót király a vandálok ellen harcolt csapataival, 416418 között Vallia teljesen leszámolt a baeticai siling vandálokkal, az alánok pedig nagy veszteségeket szenvedve a hasdingekhez csatlakoztak $^{754}$ és Gunderic lett a közös uralkodójuk, ${ }^{755}$ aki 420-ban a szvévektől elszenvedett erbasisi vereség után kénytelen volt Gallaeciából Baetica területére vonulni. ${ }^{756}$ Nem sokat tudunk a vandálok baeticai jelenlétéről, elképzelhető, hogy itt csak vandál fegyveresek állomásoztak jelentősebb államszervezői tevékenység nélkül. ${ }^{757}$ Isidorus a vandálokat sokkal kegyetlenebbnek ábrázolja, mint a szvéveket és a gótokat, ez pedig valószínűleg azzal magyarázható, hogy az általa forrásként használt Orosius is hatalmas gyülölettel írt a hazáját pusztító vandálokról. ${ }^{758}$ Hydatiusnál ezzel szemben a vandálok kegyetlensége a 410-es években egyáltalán nem tünik nagyobb mértékűnek, mint a többi barbár nép esetében, Vallia mészárlásai következtében Gundericet egyenesen a megmaradt alánok védelmezőjeként mutatja be ${ }^{759}$ talán mert nem használta forrásként Orosiust, és sokkal nagyobbnak akarja mutatni a szvévek kegyetlenségét a vandálokénál.

A következő időszakban a vandálok nagymértékü pusztítást végeztek a nyugati területeken. 422-ben a római Castinus magister utriusque militiae súlyos vereséget

200-400 ezer közöttire becsült seregéből Stilicho révén csaknem 100 ezer barbár került hadifogolyként a rómaiak kezére, vö. Halsall 2007, 206-210; Székely 2008, 91. Ez tipikus esete annak a késő császárkori gyakorlatnak, hogy a barbár hadifoglyokat időnként rabszolgasorba vetették, vö. Alföldy 2000, 190.

${ }^{751}$ Iord., Get. 161. Isidorus szerint már jövetelük hírére megfutamodtak a vandálok, vö. Isid., Hist. Goth. 68.

${ }^{752}$ Hyd. 34; Iord., Get. 162; Greg. Tur. 2,2.

${ }^{753}$ Hyd. 41; Iord., Get. 153.

${ }^{754}$ Hyd. 52; 55; 59-60.

${ }^{755}$ Isidorus a 411. év eseményei kapcsán azt mondja, hogy Gunderic 18 évig uralkodott, vö. Isid., Hist. Vand. 73; valójában 22 évig volt a vandálok királya, vö. Székely 2008, 22.

${ }^{756}$ Hyd. 63; 66.

757 Török 1999, 103.

${ }^{758}$ Oros. 7,40,3-7; 7,43,14; Székely 2008, 18-19; Adamik 2014, 408.

${ }^{759}$ Hyd. 60. 
szenvedett Gunderictől meggondolatlansága és a gót szövetségesek árulása miatt, így 425ben a vandálok kifosztották a Baleares szigeteket, feldúlták Carthago Spartariát és Hispalist, ahonnan tengeri hadjáratok indítására is volt már lehetőség, majd betörtek Mauritaniába. ${ }^{760}$ Isidorus már ekkor hatalmas pusztításról és vérfürdőről beszél, Hydatius viszont csak Hispalis 428-as megszállásakor szembesíti az olvasóit Gunderic különös kegyetlenségével (impie elatus), amikor hatalmával visszaélve megszerezte a város templomát, ezért elfogták és az isteni büntetés következményeként meghalt. ${ }^{761}$

Gunderic halála után Gaiseric, Godigisel törvénytelen fia és Gunderic féltestvére ${ }^{762}$ lett a vandálok és az alánok királya, ${ }^{763}$ uralkodásának hosszúságát azonban rendkívül eltérően becsülték meg a történetírók. ${ }^{764}$ Gaisericet sok történész a népvándorlás korának legbarbárabb vezéreként tartja számon, Frassetto szerint neki egyedül nagyobb szerepe volt Róma pusztulásában, mint bármelyik kortársának. ${ }^{765}$ Talán ennek is köszönhető, hogy Gaiseric már rögtön trónralépésekor igyekezett a hatalmát megerősíteni és a vezetők vagyonát megnövelni, de nekifogott egy tengeri flotta építéséhez is.

A vandálok történetének egyik fordulópontja, hogy Gaiseric 429 májusában az összes vandállal Baetica partvidékéről átkelt Africába, és a marokkói partvidéken lévő Gaditanus-szorosnál partraszállt csapataival. ${ }^{766}$ Ahogyan láttuk, az átkelés a szvév Heremigarius fosztogatása miatt egy időre megszakadt, de miután Gaiseric leszámolt vele, a vandál csapat folytathatta útját. ${ }^{767}$ Nincsenek pontos adataink a résztvevők számára vonatkozóan: Vitai Victor szerint 80 ezer vandál és alán kelt át Africába, Procopius viszont úgy tudja, hogy ez a szám csak a vandál harcosok létszámát jelölte, a kutatók viszont

\footnotetext{
${ }^{760}$ Hyd. 69; 77.

${ }^{761}$ Isid., Hist. Vand. 73; Hyd. 79. Az események mögött valójában Gaiseric állhatott, aki később megölette Gunderic feleségét és fiait is, vö. Proc. 1,3,32-33; Theoph. 5931; Vict. Vit. 2,14.

762 Proc. 1,3,23; Theoph. 5931; 6026. Gaiseric anyja feltételezhetően egy rabszolga volt, vö. Sid. Ap., Carm. 2,358-360; 5,97.

${ }^{763}$ Hyd. 79; Proc. 1,3,32-33. Gregorius Turonensis tévesen azt állítja, hogy Thrasamund követte Gundericet az uralkodásban, vö. Greg. Tur. 2,2.

764 Tunnunai Victor számításai szerint 464-ben, uralkodásának 40. évében halt meg Gaiseric, vagyis 424-től volt a vandálok királya, vö. Vict. Tunn. 464. Mivel Hydatius nem említi Gaiseric halálát, hiszen még uralkodott, amikor Hydatius abbahagyta a krónika írását és meghalt, Isidorus valószínüleg Victortól vette át a téves adatot, vö. Isid., Hist. Vand. 74; 77. Vitai Victor szerint 37 év és 3 hónap volt Gaiseric uralkodásának hosszúsága, vö. Vict. Vit. 1,51; valójában 428-477 között, csaknem 50 éven át állt a Vandál Királyság élén, vö. Székely 2008, 22.

${ }^{765}$ Frassetto 2003, 173.

${ }^{766}$ Hyd. 80: Gaisericus rex de Beticae provinciae litore cum Vandalis omnibus eorumque familiis mense Maio ad Mauritaniam et Africam relictis transit Hispaniis; Isid., Hist. Vand. 74; Iord., Get. 167.

${ }^{767}$ Hyd. 80.
} 
mindkét becslést erős túlzásnak tartják. ${ }^{768} \mathrm{Az}$ Africába való átkelést tekintjük az északafricai vandál birodalom kezdetének, amely 534-ig állt fenn. ${ }^{769}$ A források többsége azt állítja, hogy a vandálok a 427-ben lázadónak nyilvánított és bosszúra készülő africai comes, Bonifatius hívására érkeztek Africába, aki Aëtiusszal is ellenséges viszonyban állt. ${ }^{770}$ Miután Africa frissen kinevezett gót előljárója, Sigisvult elfoglalta Hippo Regius és Carthago városát, Bonifatius feltehetően Gaisericet kérte szövetségesnek a Sigisvult elleni harcban, cserébe neki ígérhette Africa egy részét, arra viszont biztosan nem számított, hogy a vandálok ilyen nagy létszámban érkeznek majd Africába. ${ }^{771}$

A vandálok végigpusztították a teljes partvidéket, 430. május-június körül pedig Numidia keleti partjainál vereséget mértek Bonifatiusra, aki elbarikádozta magát Hippo Regiusban. ${ }^{772}$ A városban Augustinus a papjaival imádkozott a megmenekülésért, de 430. augusztus 28-án, három hónappal az ostrom kezdete után 75 éves korában meghalt, talán a stressztől vagy az éhségtől, hiszen a város környéki búzamezők tönkrementek vagy nem tudták learatni őket. Augustinus halála megdöbbentette a nyugati területek regensét, Galla Placidiát, aki attól félve, hogy elveszíti a birodalom fő gabonaforrását, felállított egy új hadsereget Italiában, és unokaöccse, II. Theodosius javaslatára Aspar magister utriusque militiae vezetésével küldte azt Észak-Africába, ehhez csatlakozott Bonifatius is csapataival. Gaiseric csaknem egy évig tartó ostrom után 431 júliusára elfoglalta Hippo Regiust, amely az africai vandál birodalom első székhelye lett. A vandálok 435. február 11-én itt kötöttek egy formális békeszerződést III. Valentinianusszal, amely szerint a vandál állam továbbra is önálló marad, Mauritania Sitifensis, Numidia tengerparti területei és Africa Proconsularis

\footnotetext{
768 Vict. Vit. 1,1,2; Proc. 1,5,18-21. Heather 15-20 ezerre becsüli a sereg létszámát, vö. Heather 2006, $197-$ 198; Várady szerint a 80 ezres vandál népességből 50 ezer fö viselhetett ténylegesen fegyvert, a maradék 30 ezres tömeg valószínúleg más népekből vagy felszabadított barbár rabszolgákból állt, vö. Várady 1961, 195; Angenendt megoldásában pedig a 80 ezer vandál közül csak legfeljebb 20 ezren rendeződhettek csapatokba, vö. Angenendt 2008, 177. Bár a források alapján nem tudjuk megállapítani az Africába átkelő vandálok létszámát, nem vethetjük el azokat a feltételezéseket sem, melyek szerint a vandálokon és az alánokon kívül egy nagyobb gót csoport, illetve kisebb arányban rómaiak és szvévek is részt vettek az átkelésben, vö. Courtois 1955, 220; Rummel 2008, 151. A vandálok létszámára vonatkozó további becsléseket lásd: Goffart 1980, 231-235; Cameron 2007b, 553.

${ }^{769}$ A vandálok észak-africai letelepedéséröl bővebben: Schwarz 2004, 49-58.

${ }^{770}$ Iord., Get. 167; 169; Proc. 1,3,33; Prosp. 427; Theoph. 5931. A korabeli gyakorlat szerint a legtöbben a barbárok közül szereztek jól felszerelt katonákat egy hadjárathoz, ennek ellenére elképzelhető, hogy a Bonifatiust valamelyik riválisa, Aëtius vagy Felix vádolta meg azzal, hogy segítséget kért a vandáloktól.

771 Várady 1961, 183; Frassetto 2003, 173. A vandálok átkelése során mind a vandálok, mind a rómaiak jelentős stratégiai tapasztalatot szereztek, amelyet később Iustinianus is kiválóan felhasznál majd hadjáratai során, vö. Várady 1961, 249, 257. j.

${ }^{772}$ Merrils - Miles 2010, 53-55; Reynolds 2011, 130-131; Randers-Pehrson 1993, 153-154; Collins 2007, 124.
} 
egy része pedig a vandálok ellenőrzése alá kerül. ${ }^{773}$ Miután 438-ban a baeticai vandálokat vezető Andevotus vereséget szenvedett a szvévektől, Gaiseric a korábbi szerződést figyelmen kívül hagyva kihasználta, hogy Aëtius a galliai hadjárattal van elfoglalva, és Africa Proconsularis területére betörve 439. október 19-én ravasz csellel (fraude decepta) harc nélkül megszerezte Carthagót az itt állomásozó római flottával együtt. ${ }^{774}$

Hydatius szerint Gaiseric ezzel egész Africa (omnem Africam) ellen indított támadást, mert amikor már feltétel nélkül bíztak benne, megszegte esküjét és békét színlelve betört a városba. ${ }^{775}$ Bár Oost úgy látja, hogy a vandálok elsősorban a város elfoglalására törekedtek, ${ }^{776}$ Hydatius számára ez kiváló alkalomnak bizonyult, hogy bemutassa az olvasóinak, milyen különös kegyetlenséggel (elatus inpie) bántak a helyi lakossággal, hogy lerombolják a rómaiak összes méltóságát és tekintélyét. ${ }^{777}$ Isidorus szerint Gaiseric válogatott kínzásoknak vetette alá a polgárokat (excrutiatis diverso tormentorum genere civibus), a város vagyonát a kikötőben állomásozó hajókkal együtt lefoglalta, Hydatius viszont csak azt említi, hogy Carthago püspökét, Quodvultdeust más papokkal együtt számüztek, a szentek nyughelyeit feldúlták, az arianusok pedig megkapták a keresztény templomokat, amelyek ezután nem istentiszteleti helyszínként, hanem a vandálok lakóhelyeként szolgáltak. ${ }^{778}$ Procopius szerint Gaiseric a város környéki római földbirtokosok egy részét elüzte, az így megszerzett jó minőségű földeket a sortes Vandalorum alapján kiosztotta a vandálok között és adómentességet biztosított számukra, a rómaiak kezén hagyott rossz minőségü területek adóját pedig hatalmas nagyságúra emelte és kötelezővé tette számukra a föld megmüvelését. ${ }^{779}$ Cameron úgy véli, hogy a vandálok uralmát emiatt nem fogadta szívesen Észak-Africa lakossága, ráadásul a római kormányzat helyi védelemre irányuló törekvései is sorra kudarcot vallottak, ${ }^{780}$ Thompson ezek alapján a

\footnotetext{
${ }^{773}$ Isid., Hist. Vand. 74; Prosp. 435; Randers-Pehrson 1993, 155; Angenendt 2008, 177.

${ }^{774}$ Hyd. 107; Cass. 439; Chr. Gall. 452, 129; Marc. Com. 439,3; Prosp. 439; Várady 1961, 250.

${ }^{775}$ Hyd. 107; Isid., Hist. Vand. 75: de cuius amicitia iam nihil ambigebatur violata sacramenti religionem dolo pacis.

776 Oost 1968, 259.

${ }^{777}$ Hyd. 110; Vict. Vit. 1,2,6-7; 1,4,12-14.

778 Hyd. 110; Isid., Hist. Vand. 75. Quodvultdeus Augustinus tanítványa volt, 437-ben szentelték Carthago püspökévé, 439-es száműzetése után 453-ban halt meg.

${ }^{779}$ Proc. 1,5,12-17. Várady a Tablettes Albertini szerződéseit vizsgálva ugyanakkor igazolta, hogy a 490-es évektől már a rómaiak számára is lehetőség volt a birtokok fejlesztésére és koncentrációjára, vö. Várady 1961, 184, 331. j.

${ }^{780}$ Cameron 2007b, 553-554. Mivel Theodosius és Aëtius felmentő seregei még nem érkeztek meg, a római lakosság felfegyverzésével és a belső védelembe való bekapcsolásával igyekeztek a vandálokkal szembeni ellenállást megszervezni, ugyanakkor talán ennek is köszönhetö, hogy a következö években felgyorsultak Róma, Constantinopolis és Neapolis erődítési munkálatai, vö. Várady 1961, 250.
} 
vandálok africai expanzióját méltán nevezte az 5. század legpusztítóbb katonai akciójának. $^{781}$

Hydatius és a többi krónikás azonban hallgat arról, hogy ha Gaiseric a vezetőktől meg is követelte az arianus hitet, a katolikusok kezdetben szabadon gyakorolhatták vallásukat, így a vandál uralkodók más barbár királyokhoz hasonlóan együttmüködésre tudták ösztönözni a római arisztokrácia egy részét. ${ }^{782}$ Ennek mellőzését azzal magyarázhatjuk, hogy Gaiseric toleráns lépéseinek ismeretében kevésbé tünne kegyetlennek a vandálok viselkedése, ugyanakkor a papság elleni erőszakos fellépés érthető módon felháborította Hydatiust. Gaiseric uralkodása idején folytatta munkásságát Carthagóban többek között Martianus Capella, Cassius Felix és Vitai Victor is, a város tudományoskulturális életben betöltött vezető szerepe egy időre mégis megtört és a carthagói iskolák a vandál uralom következtében hanyatlásnak indultak, leginkább azért, mert a senatorok számüzésével az iskoláknak nem maradt elegendő közönsége. ${ }^{783}$ Bubnó ugyanakkor felhívja a figyelmünket arra, hogy a birodalom hanyatlásának és a kereszténység elöretörésének időszakában „élénk irodalmi-bölcseleti és kulturális életről” beszélhetünk a vandálok által megszállt területeken is, a vandál királyok és az arisztokrácia római grammatikusokkal és rhétorokkal vette körbe magát, és a többi barbár uralkodóhoz hasonlóan egy ideig megpróbálták a „,birodalmi értékeket” saját „királyságuk fényének emelésére” használni. ${ }^{784}$ Az 5. század végétől a birodalom többi részén megtiltották a barbároknak, hogy római iskolákban tanuljanak, ezzel szemben Carthago iskolái különleges kulturális központokat alkotva újra müködni kezdtek, pár évtized múlva pedig a vandálok által megszállt területeken egyenesen a latin költészet virágzásáról beszélhetünk. ${ }^{785}$ A legtöbb ókori forrás szerint Carthago és Észak-Africa vandál uralom alá kerülésével széles körü leépülés következett be, a források és a modern régészeti leletek azonban nem igazolják egyértelműen a vandálok destruktív tevékenységét. ${ }^{786}$

Gaiseric Carthago elfoglalásához hasonló módon fosztotta ki 440. június 24-én a siciliai Panormus városát, a terület arianus közösségének vezetője, Maximinus pedig

\footnotetext{
781 Thompson 1982, 17.

782 Hendrik 2015, 109.

${ }^{783}$ Salv. 7,16,68; Riché 2016, 48.

${ }^{784}$ Bubnó 2013, 21; 24; Merrills 2004, 133.

785 Proc. 2,6,7; Courtois 1955, 227-228; Riché 2016, 70-71; Bubnó 2013, 25-26. A vandál uralom alatti Romanitasról bővebben: Nsiri 2018.

${ }^{786}$ Gaiseric uralma alatt a vandálok nemcsakhogy használták a római fürdőket, vö. Proc. 1,17,8; 2,6,9; Arce 1997, 29-30; hanem új gazdasági központok és középületek is létrejöttek, az ehhez kapcsolódó leletek ezért megkérdőjelezik a vandálok által okozott pusztításra és a gazdasági bizonytalanságra vonatkozó elméleteket, vö. 5. sz. kép; Courtois 1955, 313-314; Merrills 2004, 10-11; Rummel 2008, 153-157.
} 
üldözést indított (precipitatur instinctu) a katolikusokkal szemben, de a legtöbben kitartottak hitük mellett és inkább vértanúságot szenvedtek (consummavere martyrium). ${ }^{787}$ A következő években a vandálok kalózok módjára fosztogatták a Mediterráneum partvidékét, a nyugati seregek azonban túlságosan el voltak foglalva a galliai háborúval, a keletrómai II. Theodosius viszont hatalmas hajóhadat indított 441-ben a vandálok ellen, de azok csak Siciliáig jutottak, ${ }^{788}$ mert tényleges hadművelet nélkül vissza kellett fordulniuk, hogy megvédjék Thraciát és Illyricumot a hunok fosztogatásaitól. ${ }^{789}$ Hydatius nem beszél arról, hogy a rómaiak ekkor már nem rendelkeztek olyan számottevő parti őrséggel, amely visszaverhette volna Gaiseric támadásait, de jól mutatja a vandál sereg erejét, hogy III. Valentinianus 442-ben első alkalommal volt kénytelen egy foedus típusú szerződésben elismerni a vandálok hódításait, amelynek következtében Kelet-Numidia, Africa Proconsularis, Byzacena és Tripolitana egy része szuverén vandál területként müködhetett tovább, Collins szerint ezzel egyenesen meg is szünt a rómaiak katonai jelenléte Africában. ${ }^{790} \mathrm{Ez}$ a megegyezés nemcsak a vandál külpolitikában, hanem a Róma és a barbárok közötti viszonyban is fordulatot jelentett, hiszen már nemcsak a birodalmon belüli letelepedést engedélyezték a vandálok számára, hanem átengedték nekik saját területként a legjobb africai provinciákat is, cserébe viszont a rómaiak visszakapták Numidia nyugati részét és két mauritaniai provinciát, Gaiseric fia, Huneric Ravennába került kezesnek, a vandálok pedig biztosították Róma gabonaellátását, mivel Észak-Africa elfoglalásával a nyugati és a keleti területek is élelmezési problémákkal küzdöttek. ${ }^{791}$ Már a 420-as évektől nyilvánvalóvá vált, hogy a nyugati csapatok keletrómai segítség nélkül képtelenek eredményesen harcolni a barbárok ellen, ezért Gaiseric mind diplomáciai, mind katonai eszközökkel arra törekedett, hogy a két terület hadereje ne tudjon egyesülni a vandálok ellen. ${ }^{792}$ Hydatius valószínúleg azért nem számolt be a III. Valentinianusszal kötött szerződésről, mert az éppen a keleti és a nyugati területek különállására jelentett garanciát, ráadásul helytelennek is tartotta, hogy a rómaiak gabonaellátása egy barbár néppel kötött egyezménytől függjön.

\footnotetext{
${ }^{787}$ Hyd. 112; Cass. 440; Prosp. 440.

788 Prosp. 441; Theoph. 5941.

789 Isid., Hist. Vand. 76; Prosp. 442. 440-ben Attilának sikerült elfoglalnia Moesia Primát és Pannonia Secundát, 442-ben pedig a rómaiak legyőzése után sok várost feldúlva előrenyomult egészen Helléspontosig. ${ }^{790}$ Cass. 442; Prosp. 440-442; Várady 1961, 251; Collins 2004, 30.

${ }^{791}$ Proc. 1,4,12-14; Claude 1970, 29; Wolfram 1990, 182. A Kr. e. 3. századtól Sicilia és Sardinia, a Kr. e. 2. századtól Észak-Africa, a Kr. e. 1. századtól Egyiptom vidéke biztosította Róma gabonaellátását, vö. Grüll 2017, 178. A legjobb, kb. 10-szeres hozamot nyújtó észak-africai és siciliai gabonatermő vidékek a római lakosság, Alsó-Egyiptom pedig Constantinopolis élelmezését fedezte, vö. Havas - Hegyi - Szabó 2007, 761. 792 Proc. 1,3,7; Várady 1961, 254.
} 
Gaiseric kegyetlen módszereire és újabb szövetségek keresésére több példát is látunk a 440-es években, Prosper például feljegyezte, hogy a vandál előkelők összeesküvést szőttek Gaiseric ellen. ${ }^{793}$ Huneric még 429-ben, a Nyugatrómai Birodalom ellen létrehozott vandálgót szövetség jegyében vette feleségül I. Theoderic egyik lányát, aki most a gyanú szerint szintén belekeveredett ebbe az összeesküvésbe, ezért Gaiseric a leányt levágott orral és fülekkel küldte vissza apjához Galliába, ezzel kapcsolatban pedig még Iordanes is elismeri, hogy az eljárás kegyetlensége más népeket is megdöbbentett. ${ }^{794}$ A lázadás leverése után Huneric házasságát felbontották és 445-ben eljegyezték III. Valentinianus 5 éves lányával, Eudociával, hogy megerősítsék a szövetséget a nyugati udvar és a vandál király között. ${ }^{795}$ $\mathrm{Az}$ észak-africai lakosság ebben az időben már nem mutatott különösebb ellenállást a vandál hódítókkal szemben, mivel az itteni gabonaellátási bázisok vandál kézre kerülése és a rendkívül magas adók miatt a római lakosság ekkor már „teljesen kimerült állapotban” volt. ${ }^{796}$ Jól mutatja ezt Turoni esete is, amelyet a vandálok 445-ben egy gyors partraszállás után kifosztottak és a lakosságból sok foglyot is ejtettek. ${ }^{797}$ 450-ben Gaiseric ajándékokat küldött Attilának, hogy rávegye a gótok elleni támadás elindítására, mert feltehetően félt, hogy Theoderic megbosszulja a lányát ért jogtalanságot. ${ }^{798}$ Attila 453-as halála után a rómaiak ismét a vandálokra fordíthatták figyelmüket, akik ekkor már az egykori birodalom leggazdagabb földjeit tartották irányításuk alatt.

Miután 455-ben a trónbitorló Petronius Maximus meggyilkolta Valentinianust, trónra lépett és házasságra kényszerítette az özvegy Eudoxia császárnét, idősebb lányát, Eudociát pedig hozzáadta korábbi házasságából született fiához, Palladiushoz, ${ }^{799}$ hogy szorosabbra füzze a viszonyt a Theodosius-dinasztiával. Ezzel azonban érvénytelenné vált Eudocia és Huneric 445-ös jegyessége, amely azért nem vezetett korábban házassághoz, mert Eudocia még mindig túl fiatal volt. ${ }^{800}$ Amikor a sértődött Gaiseric a szóbeszéd szerint Eudoxia hívására ${ }^{801}$ és a 442-es szerződésre hivatkozva 455 májusában Italiába érkezett, sokan pánikszerüen menekülni kezdtek, Maximus pedig a vandálok gyors partraszállásától tartva igyekezett megszervezni a saját menekülését, de a tömeg lázadása és egy katonai zendülés alkalmával (tumultu populi et seditione militari) meggyilkolták. Gaiseric 455.

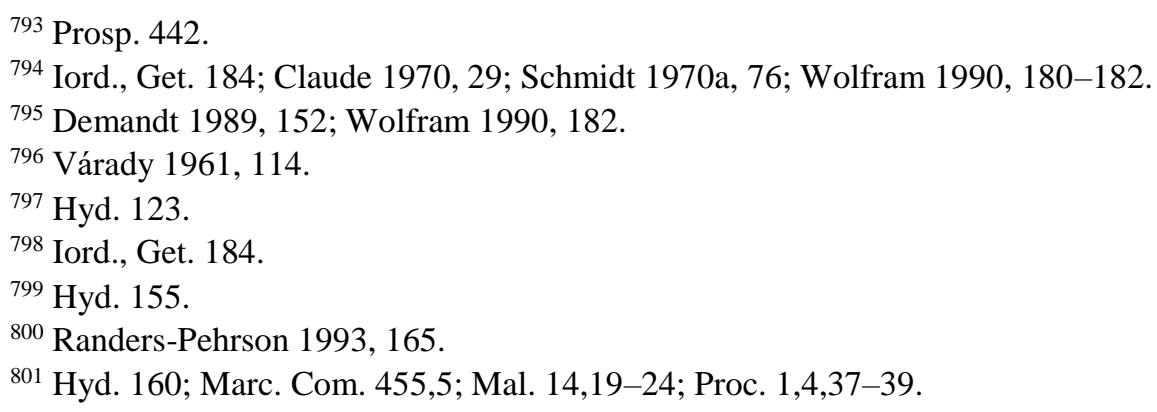


június 2-án tört be Rómába, amelynek körülményeiröl Hydatius részletes beszámolót nyújt. A vandálok két héten át tartó fosztogatás után, június 16-án sok ezer fogoly és rengeteg arany és ezüst kíséretében hagyták el a várost, Tunnunai Victor ugyanakkor azt állítja, hogy Gaiseric minden kincsétől (cunctis opibus) megfosztotta Rómát. ${ }^{802}$ A foglyok között volt Eudoxia és két lánya, Eudocia és Placidia, valamint Aëtius fia, Gaudentius is. Huneric Carthagóba érve feleségül vette Eudociát, Gaudentius és Placidia 454-es jegyessége viszont mindkét apa, Aëtius és III. Valentinianus halála miatt érvényét vesztette. ${ }^{803}$ Prosper tudni véli, hogy amikor Leo pápa találkozott Gaiserickel, könyörgött hozzá, hogy kímélje meg Róma lakosságát a mészárlástól és a város felgyújtásától, és elégedjen meg csak Róma kifosztásával, de Tunnunai Victor is Leo közbenjárásának tulajdonítja, hogy a lakosság megmenekülhetett a tüzvésztől, a kínzásoktól és a kivégzésektől. ${ }^{804}$ Valójában nem tudjuk, hogy a pápa befolyásának volt-e köszönhető, hogy a rómaiak életét megkímélték, arról viszont vannak forrásaink, hogy a vandálok érkezésükkor szétütötték a város összes vízvezetékét, felégettek egy templomot és rombolni kezdték a városfalakat. ${ }^{805}$

Összességében vita tárgyát képezi, hogy a vandálok mennyire végeztek komoly pusztítást 455-ben, ezért érdemes megvizsgálnunk, hogy miért alakult ki a francia forradalom idején a hazáját féltő Orosius és Procopius nyomán a vandalizmus fogalma, amelyet ma „az esztelen, önmagáért való barbár pusztítás” szinonimájaként használunk. ${ }^{806}$ A vandálok 455-ös fosztogatását általában nagyobbnak ábrázolják, mint a gótok 410-es tevékenységét, valószínűleg azért, mert a vandálok 14 napig voltak a városban, ${ }^{807}$ a gótok viszont már 3 nap után elhagyták Rómát. A vandálok betörése azonban nem tekinthető mértéktelen fosztogatásnak, mert ugyan kíméletlenül, de csak a legértékesebb kincseket rabolták el, a sok ezer fogoly nagy része pedig mesterember lehetett, akikből hiány volt a vandáloknál. ${ }^{808}$ A róluk kialakult rendkívül negatív képet részben magyarázhatja az a tény, hogy Gaiseric Carthago kivételével igyekezett lerombolni azokat a régi római erődöket,

\footnotetext{
${ }^{802}$ Hyd. 155; 160; Vict. Tunn. 455. Gaiseric római fosztogatásáról bővebben: Czúth 1979, 25 -32.

${ }^{803}$ Hyd. 160; Proc. 1,5,6; Theoph. 5947; 5949; Oost 1968, 287. Mivel Aëtiust sokan vádolták azzal, hogy a catalaunumi csata után nem tudta megfékezni Attila italiai hadjáratát, úgy próbálta bebiztosítani a helyzetét, hogy 454-ben fiával eljegyezte Valentinianus kisebbik lányát, ezáltal Gaudentius számára akár a császári trón is nyitva állhatott volna.

${ }^{804}$ Prosp. 455; Chr. Gall. 511, 623; PL 51,603-605; Vict. Tunn. 455.

${ }^{805}$ Vict. Tunn. 455; Isid., Hist. Vand. 77; Proc. 1,15,31; 1,5,4-9; Theoph. 5947; Marc. Com. 455,5; Mal. $14,19-24$.

${ }^{806}$ Székely 2008, 19; Oros. 7,38,1. A kérdés elemzését részletes szakirodalommal lásd: Merrills - Miles 2010, 9-11; a barbár kifejezés hasonló értelmezéséről bővebben: James 2014, 9.

${ }^{807}$ Isid., Hist. Vand. 77; Vict. Tunn. 455.

${ }^{808}$ Németh - Hegyi 2011, 562. Kétségtelen viszont, hogy Gaiseric a kincstár teljes nemesfémállományán kívül a korábban érintetlen kincseket is elszállíttatta, súlyos pénzügyi katasztrófát okozva ezzel a Nyugatrómai Birodalomban, vö. Proc. 1,5,3; Várady 1961, 114.
} 
amelyek segíthették volna a belső lázadásokat vagy a rómaiak későbbi invázióját, a 461-es hadmüveletek során pedig a császári seregek azzal szembesültek, hogy a vandálok az összes vízforrást is megmérgezték, nehogy az ellenség felhasználhassa őket. ${ }^{809} \mathrm{Ha}$ a 455 -ös eseményektől elvonatkoztatva általános értelemben vizsgáljuk a vandálok tevékenységét, akkor egyedül politikai szempontból lehet indokolt a vandalizmus fogalmának ilyen értelmezése, mivel Gaiseric nagyszabású fosztogatásaival valóban akadályozta Italia gabonaellátását és a keleti kereskedelem folytonosságát, ellehetetlenítve így a két birodalomrész közötti kapcsolattartást. ${ }^{810}$ A vandál ellenségkép továbbélése egy Procopius által közvetített constantinopolisi propaganda eredményének is köszönhető, mivel a Iustinianus-féle restauráció jegyében ideológiailag is fontos volt a római egység gondolatának megteremtése a civilizálatlan barbár ellenségekkel szemben, ${ }^{811}$ másrészről viszont a vandálok által megszállt africai területeken a római kultúra továbbélése, a római városi struktúra megmaradása, a tengerparti központok érintetlensége és egyes vandál városok virágzása Carthago helyzetének fenti vizsgálatához hasonlóan azt mutatja, hogy a vandálokkal kapcsolatos sztereotípiákat fenntartásokkal kell kezelnünk. ${ }^{812}$

A következő években Gaiseric tengeri flottájával a birodalom partjait nyugtalanította és Italia felé nyomult, 456-ban már egy 60 hajóból álló vandál sereg fenyegette Galliát és Itáliát, de a nyugatrómai comes rei militaris, Ricimer tavasszal és nyár elején egy római hajókból, segédcsapatokból és germán szövetségesekből álló csapatot vezetett a vandálok ellen Siciliába. Kezdetben a vandálok védekezésre kényszerítették a rómaiakat egy félig erdős területen, de nem tudták megtörni Ricimer csapatait, ezért Agrigentum mellett vereséget szenvedtek és meghiúsult partra szállásuk. ${ }^{813} \mathrm{~A}$ megmaradt vandálok hajóra szálltak és Corsica felé indultak, Ricimer pedig követte őket és hajóival a partoknál tőrbe csalta a vandálokat. Hydatius szerint Avitus gyilkolta le a vandálok egy részét, valójában Ricimernek köszönhető a győzelem, aki Italiába visszaérve megfosztotta Avitust a hatalmától, egyes források szerint még Marcianus is végzett mészárlást a vandálok között. ${ }^{814}$ Mindenesetre az a tény, hogy 457-ben Hesychius tribunus hírt vitt Theodericnek a corsicai mészárlásról, a keletiek pedig Hispalisba hajózva hoztak információkat, igazolja a rómaiak

\footnotetext{
${ }^{809}$ Proc. 1,5,8-9. Később Belisarius hadjárata idején a vandálok éppen ezért nem tudnak majd megfelelően védekezni a császári támadással szemben, vö. Várady 1961, 251; 253.

810 Bubnó 2013, 23.

811 Proc. 2,6,33; 2,7,10; Cameron 1993, 117; Bubnó 2013, 27.

812 Bubnó 2013, 24.

${ }^{813}$ Hyd. 169; Sid. Ap., Ep. 2,367.

${ }^{814}$ Hyd. 169-170. Mommsen szövegében a caesam helyett caes[os Laz]as áll, erről bővebben: Burgess 1988b, 357-363.
} 
és a gótok közötti „kölcsönös katonai tájékoztatás” még müködő gyakorlatát. ${ }^{815}$ Amikor Gaiseric 460 májusában partraszállt a Liris torkolatánál és Campaniát pusztította, Maiorianus germán, hun és szkíta csapatokból szervezett 300 hajós flottája meglepetésszerüen a hispaniai Carthago Nova ellen vonult. ${ }^{816}$ A császárnak sikerült a zsákmánytól megfosztania és visszakergetnie a vandálokat a hajóikra, Gaisericet azonban árulók figyelmeztették a veszélyre, így a tél folyamán sikerült megszereznie és felégetnie az örizetlenül hagyott római hajók kétharmad részét a Lucentumi-öbölben. Amikor a vandálok felderítőik segítségével tudomást szereztek a rómaiak érkezéséről, jó néhány kapitányt megvesztegettek, hogy álljanak át az ő oldalukra, így a 439-es carthagói rajtaütést megismételve szinte gyalogos távozásra kényszerítették a császári csapatokat. ${ }^{817}$ Hydatius nem közölt részleteket a vandál pusztítás mértékéről, talán mert nem rendelkezett elegendő információval ezzel kapcsolatban, ráadásul a római veszteségek felsorolásával Maiorianus jelentőségét is csökkentette volna. Később Hydatius szerint Gaiseric követek útján békét kért (per legatos postulat pacem) a császártól, valójában Maiorianusnak egy kedvezőtlen megállapodást kellett kötnie a vandálokkal, amelyben elismerte a fennhatóságukat Mauritania és Tripolitania fölött, ${ }^{818}$ így remény sem maradt arra, hogy a rómaiak visszaszerezzék Észak-Africát.

A 460-as években Gaiseric több hadjáratot indított Italia felé, hogy újabb területeket tudjon megszerezni csapataival. Maiorianus 461-es halálakor Olybrius patriciust jelölte a nyugati trónra, hogy minél nagyobb befolyást szerezzen a nyugati területek fölött, ezért 6 vagy 7 évi fogság után, 461-ben vagy 462-ben ${ }^{819}$ Leo keletrómai császár hatalmas váltságdíjáért cserébe elengedte Eudoxiát, akinek Hydatius szerint egyik lánya Gentóval, Gaiseric fiával, a másik Olybriusszal házasodott össze, ${ }^{820}$ érdemes viszont ennek a körülményeit alaposabban is megvizsgálnunk, mert nem ismerjük Olybrius és Placidia házasságának pontos időpontját. Priscus úgy tudja, hogy mindez a vandálok római fosztogatása, tehát 455. június 2. előtt történt, Hydatius szerint Placidia 455-ben még hajadon volt, Muhlberger viszont azt gondolja, hogy Hydatius adatközlése csupán szóbeszéden alapszik, ezért itt nem tekinthető hitelesnek. ${ }^{821}$ Azt is tudjuk, hogy Aëtius

\footnotetext{
${ }^{815}$ Várady 1961, 252.

816 Prisc. 27. Ez nagyjából a teljes nyugatrómai hajóállomány bevetését jelentette, vö. Várady 1961, 253.

${ }^{817}$ Hyd. 195; Isid., Hist. Vand. 76; Várady 1961, 253.

${ }^{818}$ Hyd. 204; Chr. Gall. 511, 633-634.

${ }^{819}$ PLRE 2,796-797; Demandt 1989, 174.

${ }^{820}$ Hyd. 211: filiae ipsius una Gentoni Gaiserici filio, alia Olybrio senatori urbis Romae iure matrimonii copulantur; Proc. 1,5,6; Theoph. 5949.

${ }^{821}$ Prisc. 30; Muhlberger 1990, 211.
} 
kényszerítette Valentinianust, hogy Placidiát jegyezze el fiával, Gaudentiusszal, így Olybrius nem tudta öt feleségül venni Aëtius halála, vagyis 454. szeptember 21. előtt. Néhány kutató úgy gondolja, hogy Olybrius Maximus fia volt, így Olybrius és Placidia házasságára Maximus császárrá választása és halála, tehát 455. április 17. és május 31 . közötti időszakban került sor, hogy ezzel is biztosítva legyen Maximus törvényes uralma. ${ }^{822}$ Oost szerint akár az is előfordulhat, hogy Olybrius és Placidia 455-ben csak eljegyezték egymást, és valójában Gaiserictől való szabadulása után házasodtak össze, de a meglévő források ezt nem támasztják alá, mások szerint Placidia és Olybrius házassága 455-ben volt, mivel ebben az évben három házasság is kötődött a Theodosius-dinasztiával, Olybrius pedig Maximus harmadik fia volt. ${ }^{823}$ Hydatius ugyanakkor tévesen állítja, hogy az egyik lányt, Eudociát Gaiseric fia, Gento vette feleségül, Isidorus pedig csak annyit mond, hogy az egyik lány feleségül ment Hunerichez, ez viszont már 455-ben, közvetlenül Róma kifosztása után megtörtént. ${ }^{824}$

465 májusában a galliai magister utriusque militiae, Aegidius próbált Gaiserickel szövetségre lépni, de szeptemberben tőrbe csalták vagy megmérgezték őt, ezért a követek csalódottan tértek vissza, eközben Marcellinus comes hun segédcsapatokkal próbálta visszaverni a vandálok siciliai betörését, ${ }^{825} \mathrm{de}$ ez veszélyeztette volna Ricimer hatalmát, ezért megvesztegette a katonákat, így Marcellinusnak sereg nélkül kellett visszatérnie Dalmatiába. Amikor később Leo keletrómai császárnak már egyre nagyobb gondot okoztak Gaiseric fosztogató hadjáratai Siciliában, Italiában és Illyricumban, Ricimer kérésére 467. március 25-én Anthemiust jelölte a nyugati trónra és Italiába küldte őt egy hatalmas méretü, jól felszerelt népes sereggel (cum ingenti multitudine exercitus copiosi) Marcellinus magister militum vezetésével. Április 12-én Anthemiust császárrá kiáltották, amivel Leo elérte, hogy ne Gaiseric jelöltje, Olybrius legyen a nyugati császár, ráadásul Anthemius katonai tapasztalatai és sikerei reményt is adtak arra, hogy ezúttal eredményes lesz a vandálok elleni harc. ${ }^{826} \mathrm{~A}$ hadjáratot azonban meg kellett szakítani a körülmények megváltozása és a hajózásra való alkalmatlanság (metabularum commutatione et

\footnotetext{
${ }^{822}$ Mommaerts - Kelley 1992, 119-120.

${ }^{823}$ Oost 1968, 306; Drinkwater 1992, 117-120.

${ }^{824}$ Isid., Hist. Vand. 77-78.

${ }^{825}$ Hyd. 220; 223-224; Greg. Tur. 2,18.

826 Hyd. 230-231. Anthemius törekedett arra, hogy Ricimer hatalmát visszaszorítsa, ezért befolyásának növelésére saját lányát adta feleségül hozzá, Marcellinust pedig kinevezte magister militumnak.
} 
navigationis inoportunitate), vagyis a rossz időjárás miatt, ${ }^{827}$ a római flotta pedig kénytelen volt visszafordulni még a hadmüveletek befejezése előtt. ${ }^{828}$

Miután Gaiseric végigdúlta a Peloponnésost és a barbár népek közötti tárgyalások kudarcba fulladtak, 468-ban Leo és Anthemius javaslatára elindították az utolsó olyan támadást a vandálok ellen, amelyben a keleti és a nyugati területek vezetői még együttmüködtek. ${ }^{829}$ A rendkívül nagy sereg (magnum valde exercitum) Basiliscus és Marcellinus irányításával vonult Gaiseric ellen, amelyben csaknem a teljes keletrómai flotta, 1163 hajó és 100 ezer ember vett részt, ezért ezt az összehangolt támadást tartják a történelem egyik legnagyobb feljegyzett katonai akciójának. ${ }^{830}$ A tervek szerint három sereg gyülekezett volna Siciliában: Basiliscusnak innen egyenesen Carthagóba kellett volna hajóznia, Marcellinus ezalatt elfoglalta volna Siciliát és Sardiniát, a harmadik sereg pedig az edessai Heraclius vezetésével Carthagótól keletre, a libyai partoknál kötött volna ki, hogy gyorsítsa az előrehaladást. ${ }^{831}$ Miután azonban Basiliscus elérte seregével Carthagót, Marcellinus pedig kikötött Sardinia és Tripolitania partjainál, Marcellinus fővezérsége távol tartotta a sértődött Ricimert a harcoktól, aki eleve ellenezte a vandálok elleni hadjárat elindítását, így a rómaiak veresége elkerülhetetlen volt. Gaiseric ugyan annyira meglepődött, amikor Basiliscus hatalmas seregével horgonyt vetett a Siciliával szemközti Promunturium Mercuriin, hogy ha Basiliscus azonnal lerohanta volna Carthagót, még legyőzhette volna a vandálokat, ${ }^{832}$ Gaiseric azonban időhúzásként 5 napot kért a békefeltételek kidolgozására, ezalatt összevonta csapatait és néhány hajót megtöltött gyúlékony anyaggal, hogy azok éjszaka váratlanul az örizetlenül hagyott és gyanútlan római

\footnotetext{
${ }^{827}$ A Hydatius által használt első kifejezés értelmezése nehézségekbe ütközik, Burgess szerint talán Hydatius nem is tudta, mit jelent pontosan a görög szófordulat. Isidorus definíciója alapján a metabulum jelentése prospera navigatio, ebböl Hydatius szókapcsolata improspera navigatiónak értelmezhetö, bár Isidorus ismerte és ezáltal fel is használta Hydatius mủvét, vö. Burgess 1993, 132-133; PL 83,1360; 1044. Leo vandálok elleni expedíciója során ellátási nehézségekkel is számolniuk kellett a római seregeknek, mivel ekkor már csak rövid távú hadtápot tudtak a katonáknak biztosítani, vö. Várady 1961, 112; akár ez is utalhat a körülmények megváltozására.

${ }^{828}$ Hyd. 232. Leo seregéhez hasonlóan járt Theodosius vandálok ellen szervezett csapata is 442 -ben, amikor összecsapás nélkül kellett távozniuk a római haderőknek Siciliából, vö. Várady 1961, 251.

${ }^{829}$ Hyd. 234; 236; 241; Iord., Get. 244.

${ }^{830}$ Demandt 1989, 187. Priscus szerint 100 ezer hajó gyült össze, de modern kutatók ezt reálisan 1100-ra javították, ami közelebb áll Cedrenus 1163-as számához, vö. Prisc. 42. Várady a források figyelembevételével megcáfolta a kutatók 130 ezer librás költségvetését, 1000 hajóegységgel és 100 ezer fős hadsereggel számolt, amelynek ellátását a 300 hajóból álló nyugatrómai flotta és Anthemius magánvagyona is próbálta biztosítani, vö. Várady 1961, 112; 117-118; Marc. Com. 468; Proc. 1,6,1-2; Prisc. 27,338.

${ }^{831}$ Proc. 1,6,8-9. Procopius szerint Leo azért a sógorát, Basiliscust nevezte ki császári parancsnokká, hogy ellensúlyozza Aspar növekvő hatalmát, aki a keleti területeket irányította magister utriusque militiae rangban, vö. Proc. 3,6,4

${ }^{832}$ Marc. Com. 468; Proc. 1,6,10-11; Várady 1961, 254.
} 
flotta ellen vonuljanak és megbomlasszák a hadirendjüket. ${ }^{833}$ Procopius szerint a vandálok 500 hajójából az első összecsapás során 340-et veszítettek el, de a másodikban 600 római hajót sikerült elpusztítaniuk. ${ }^{834}$ A római flotta egyik fele elégett, elsüllyedt vagy fogságba esett, a másik fele pedig elmenekült Basiliscusszal. Marcellinus visszavonult Siciliába, de Ricimer ösztönzésére megölték, Heraclius pedig megpróbált a sivatagon át Tripolitaniába vonulni, később visszament Constantinopolisba. ${ }^{835}$ Amikor Basiliscus is visszaért a városba, a Hagia Sophiában keresett menedéket, hogy megmeneküljön a nép haragjától és a császár bosszújától, végül kegyelmet kapott és csak a thraciai Heraclea Sinticába való számüzetéssel büntették. ${ }^{836}$ Az utolsó, vandálokra vonatkozó feljegyzés a krónikában a 468as hadjárat elindításáról szól, ${ }^{837}$ az események kimenetelét és a rómaiak vereségét Hydatius viszont már nem jegyezte fel.

A 460-as években meglepő módon Hydatius egyáltalán nem beszél a vandálok kegyetlenségéröl és erőszakosságáról, hanem minden ezzel kapcsolatos információt elhallgat az olvasói előtt. 460-ban például nem rögzíti a vandálok területi hódításait, 462ben kifejezetten pozitív személyként ábrázolja a házasságokat megszervező Gaisericet, 465ben elhallgatja a visszavonuló Marcellinus vereségét, és inkább valótlanul a vandálok lemészárlásáról tudósít, a 468-as vandálok elleni hadjárat bemutatásakor pedig nem számol be arról, hogy Gaiseric mennyi veszteséget okozott a rómaiaknak. ${ }^{838}$ Hydatius valószínűleg azért hallgat következetesen a vandálok erőszakosságáról, hogy a szvévek kegyetlensége és agresszív terjeszkedési politikája még nagyobbnak tünjön az olvasók számára. Különösen érthető ez annak ismeretében, hogy Hydatius személyesen a szvévektől szenvedett el sérelmeket, nem pedig a vandáloktól, ráadásul a róluk szóló információk elhallgatása is a fogságba esése után jellemző. ${ }^{839}$

\footnotetext{
${ }^{833}$ Collins 2007, 125. A bravúros vandál támadás részleteiről lásd: Proc. 1,6,13-24; Várady 1961, 255.

834 Proc. 1,6,1. Basiliscus kapitánya, Iohannes ennek ellenére sok katonát legyilkolt a vandálok közül, de amikor látta, hogy a hajóját elfoglalják, nem adta meg magát Gentónak, hanem nehéz páncélzatban kiugrott a hajóból és a vízbe fojtotta magát, vö. Proc. 1,6,24.

${ }^{835}$ Demandt 1989, 175.

${ }^{836}$ A támadás után a vandálok megpróbáltak betörni a Peloponnésosra, de Cenipolisnál súlyos veszteségeket szenvedtek, ezért bosszúból 500 túszt ejtettek Zakynthosnál, széttépett testük darabjait pedig kidobálták a hajóból a Carthagóba vezető útra.

${ }^{837}$ Hyd. 241.

${ }^{838}$ Hyd. 204; 211; 223; 241.

${ }^{839}$ Hyd. 196.
} 


\subsubsection{A gótok}

Hydatius a rómaiak és a gótok közötti csaták (multa certamina) említése után Athanaric gót király 381-ben bekövetkezett haláláról tájékoztatja az olvasóit, akit Theodosius korábban befogadott (susceptus fuerat), ${ }^{840}$ elhallgatja viszont azt a tényt, hogy a császár nem tudta legyőzni a gótokat, ezért barátsági szerződést (ius amicitamque) kötött velük, Athanaricot pedig 20 ezer fős kíséretével együtt nagy tisztelettel fogadta és később állami temetésben részesítette. ${ }^{841}$ Hydatius a gótok és a rómaiak közötti 382-es szerződés említésekor rendkívül szükszavúan és elfogultan nyilatkozik, ráadásul azt állítja, hogy a gótok látszólagos békéért cserébe megadták magukat a rómaiaknak (Gothi in infida Romanis pace se tradunt), ahogyan később Isidorus is azt mondja, hogy a gótok Theodosius jóindulatát látva szövetséget kötöttek vele és alávetették magukat a római uralomnak (inito foedere Romano se imperio tradiderunt) ${ }^{842}$ Bár a részletekről semmit sem közöl Hydatius, érdemes alaposabban megvizsgálni a gótokkal kötött szerződést és annak előzményeit.

Constantinus császár és a gótok között már 322 körül létrejött egy olyan egyezség, mely szerint a gótok évente ajándékokat kapnak Rómától, cserébe katonákat kell küldeniük az északi határ védelmére. ${ }^{843}$ Amikor erre hivatkozva 364-ben Procopius fellépett Valens uralmával szemben és a hatalom megszerzéséhez a gótok katonai segítségét kérte, a császár felszámolta ezt a sereget és 367-től háborút indított ellenük, hogy megpróbálja rendezni a gótokkal való viszonyát. ${ }^{844}$ Mivel Valens nem tudott döntő győzelmet aratni fölöttük és keleten a perzsákkal is harcolnia kellett, a gót Athanaric pedig 375-ben a Közép-Ázsiából érkező hunoktól folyamatosan vereséget szenvedve a Dunához vonult és bebocsátást kért a birodalom területére, ${ }^{845}$ egy kompromisszumos béke született a két fél között. A legtöbb kutató a gótok betelepedésével kapcsolatban a békés szándékot hangsúlyozza, vagyis a barbárok a hunok nyomására kényszerüségből, az állandó fenyegetettség miatt kértek

\footnotetext{
${ }^{840}$ Hyd. 3; 6.

${ }^{841}$ Isid., Hist Goth. 11; Iord., Get. 142-145; Randers-Pehrson 1993, 51. Ammianus Marcellinus Athanaric müveltségével és politikai érettségével indokolja ezt az udvariassági gesztust, vö. Amm. Marc. 27,5,9-10; Várady pedig azt emeli ki, hogy Athanaric arianizmus-ellenessége vallási szempontból is egyezett Theodosius nézeteivel, amely hozzájárulhatott a gótok rokonszenvének megnyeréséhez, vö. Várady 1961, 141-142. Valójában Theodosius bőkezüségével és figyelmességével próbálta visszaszerezni a gótok bizalmát, vö. Iord., Get. 28; Oros. 7,34,7; Zos. 4,34,4; 4,56; Székely 2003, 27. Athanaric és Fritigern Rómához kapcsolódó politikájáról és vallási helyzetéröl bővebben: Wolfram 1988, 64-74; Horváth 1999, 45-46.

${ }^{842}$ Hyd. 7; Isid., Hist. Goth. 11.

${ }^{843}$ A szerződés előzményeiről és részleteiről lásd: Iord., Get. 89-90; Wolfram 1988, 131-138; Wolfram 1990, 68-71; Székely 2003, 25; Székely 2008, 68, 5. j.; Kiss 2008, 42.

${ }^{844}$ Amm. Marc. 26,6,11; Heather 2007a, 497-499.

${ }^{845}$ A hunok támadásáról bővebben: Halsall 2007, 170-175.
} 
menedéket a Római Birodalom területén, hogy aztán földmüveléssel vagy katonai szolgálat vállalásával próbálják saját ellátásukat megoldani vagy ennek anyagi feltételeit megteremteni, ezeket nevezi Collins összefoglaló néven gazdasági, éghajlati és katonai nyomásnak. ${ }^{846}$ Mivel a nyugati területek válsága miatt Valens már nem tudott fizetni és fenntartani egy hivatásos hadsereget, a gótok Thraciába való betelepítésével nemcsak a népesség gyarapodását és a katonai utánpótlás biztosítását remélhette, hanem ilyen módon egy ütközőzóna is kialakíthatóvá vált a római és a barbár területek között, ráadásul a katonai szolgálat megváltásáért fizetett pénzösszegek jelentősen megnövelhették az állami bevételeket. $^{847}$

A római hatóságok azonban már a kezdeti időszakban, 376 öszén sem tudták ellenőrizni a Fritigern és Alaviv vezetésével érkező csoportokat, $^{848}$ ráadásul a megállapodástól eltérően a hatalmas mennyiségü góttal együtt ${ }^{849}$ más germán csoportok és rabszolgák is tömegesen telepedtek be a birodalom területére. ${ }^{850}$ Ennek köszönhetően rövid időn belül ellátási nehézségek adódtak és a fellázadt gótok a római birtokok fosztogatásába kezdtek, a kialakult helyzetet pedig tovább súlyosbította, hogy a római hivatalnokok gyakran visszaéltek a hatalmukkal. ${ }^{851}$ Miután a gótok végigfosztogatták a balkáni területeket és legyőzték az ellenük küldött csapatokat, ${ }^{852}$ 378-ban Hadrianopolisnál katasztrofális

${ }^{846}$ Ladner 1976, 3-4; Heather 1994, 135-142; Székely 2008, 69, 9. j.; Collins 2004, 21.

847 Amm. Marc. 31,4,4. Az aurum tironicorum fizetésével a hadköteles, de nem harcoló férfiak katonai szolgálatát lehetett megváltani, amiből Róma a birodalmon kívülről germán katonákat tudott toborozni a hadseregbe.

848 Ammianus Marcellinus megbotránkozva tudósít arról, hogy a római hivatalnokok nem is próbálták megszámolni az érkezőket, így a gótok tömegei ellenőrzés nélkül keltek át a Dunán, vö. Amm. Marc. 31,4,89.

${ }^{849} \mathrm{Ma}$ is vita tárgyát képezi, hogy pontosan hány gót vett részt az átkelésben. Eunapius túlzóan 200 ezer föről beszél, Wolfram és Jones 100 ezerre, Curran 90 ezerre, Frassetto 80 ezerre, Koenigsberger 70 ezerre, Gutman 50 ezerre becsüli a létszámukat, vö. Székely 2008, 69, 9. j.; Jones 1964, 1,195-196; Curran 2007, 98; Frassetto 2003, 16; Koenigsberger 1987, 24. Collins 30 ezer gótot valószínüsítve a 100 ezres adatot erős túlzásnak tartja, mivel ennyi ember élelmezését nem lehetett volna megoldani, ráadásul tudjuk, hogy a gótok betelepedése után valóban adódtak ellátási nehézségek, vö. Collins 2004, 24-25. Hydatius a korabeli forrásokhoz hasonlóan hallgat a gótok létszámáról és érkezésük módjáról, hiszen ez a császári vezetés gyengeségét és tehetetlenségét mutatná az olvasók számára.

${ }^{850}$ A keleti gótok is bebocsátást kértek a birodalomba Alatheus és Saphrax vezetésével, de visszautasították őket, így csak később tudtak önkényesen területeket szerezni, vö. Amm. Marc. 31,4,12-13; Várady 1961, 144; Todd 2007b, 483-484; Halsall 2007, 175-176.

${ }^{851}$ Heather 2007a, 508-509; Halsall 2007, 177-178. A thraciai comes például nem engedte, hogy a gótok a római városokban élelmiszereket vásároljanak, élelemért cserébe viszont arra akarta rávenni őket, hogy gyermekeiket adják el rabszolgának, ezért a gótok már a felkelés elején végeztek vele, vö. Amm. Marc. $31,4,11$.

${ }^{852}$ A fosztogatás részleteiről és a gótokhoz csatlakozó alsó társadalmi csoportokról bővebben: Várady 1961, 145-146; Wolfram 1988, 117-130. 
vereséget mértek a keletről érkező Valens seregeire, ${ }^{853}$ majd tovább zsákmányoltak Illyricum és Pannonia területén. ${ }^{854}$ Theodosius hiába próbálta meg szigorú intézkedésekkel újjászervezni a hadsereget, ${ }^{855}$ a gótok hatalmas létszáma és hadseregben betöltött szerepe miatt kénytelen volt új szempontok alapján rendezni a gótokkal való együttélés feltételeit. ${ }^{856}$

A gótok vagy egy részük ${ }^{857}$ a 382 . október 3-án megkötött letelepedési szerződés alapján kerültek szövetséges viszonyba a rómaiakkal. Foederatinak nevezték a rómaiak azokat a népeket, ${ }^{858}$ akikkel a nemzetközi jog alapján kötöttek béke- és barátsági szerződést, szemben a korábban alkalmazott laeti vagy dediticii kategóriával, amelyek az önként behódolt és a birodalomba felvételüket kérő népeknek csak csökkentett vagy semmilyen jogokat sem biztosítottak. A szerződést általában a császár vagy megbízottja kötötte meg, amelynek értelmében Róma különböző kedvezmények mellett biztosítja, hogy az idegenek a birodalmon belül egy nagyobb zárt, politikailag és jogilag autonóm területen élhessenek, nem kell adót fizetniük, cserébe viszont a császár hatalmát elismerik és határvédelmi feladatokat látnak el, háború esetén pedig saját vezérük alatt a római hadseregbe tagozódva katonai segédcsapatokat állítanak ki, amelyek zsoldját Róma biztosítja. ${ }^{859}$ A 382-es megállapodás alapján ${ }^{860}$ a gótok zárt településterületet kaptak Thracia északi részén, Moesia Inferiorban és Dacia Ripensisben, saját vezéreik alatt és saját törvényeik szerint élhettek, cserébe katonai szolgálatot kellett vállalniuk. Hydatius ezt a békét csak látszólagosnak (infida) nevezi, amivel arra utalhat, hogy néhány hónappal később a gótok megszegték a feltételeket és felmondták a rómaiakkal kötött szerződést (Romani foederis recusantes), mivel az ellátási nehézségek tovább folytatódtak és a római hivatalnokok a helyzetet

${ }^{853}$ Amm. Marc. 31,13. A hadrianopolisi csata hadműveleteiről és erőviszonyairól lásd: Várady 1961, 227-231; Heather 1994, 142-147; Wolfram 1990, 125-127; Halsall 2007, 178-180; a római külpolitika változásairól bővebben: Blockey 2007b, 426-429.

${ }^{854}$ Curran 2007, 98-102.

${ }^{855}$ Mivel a keleti lakosság nem szívesen katonáskodott, sokan pedig inkább megváltották a katonai szolgálatot vagy foglalkozásuk miatt eleve nem is foghattak fegyvert, Theodosius a veteránokat és a katonák fiait is fegyverviselésre kötelezte, és még öncsonkítás esetén sem adott mentességet a szolgálat alól, vö. Várady 1961, 23; CTh 7,1,8; 7,22,1.

856 Theodosius 379-382 közötti gót politikájáról bővebben: Székely 2017, 82-84.

${ }^{857}$ A legtöbb kutató véleménye alapján ez a szerződés valószínüleg csak a thervingi gótokra vonatkozott, a greuthungokkal még 380-ban sikerült megegyeznie Gratianusnak, amikor a keleti gótok egy részét Valeria és Pannonia Secunda területén telepítette le, vö. Burns 1994, 85-86; Székely 2003, 28; Heather ennek ellenére azt állítja, hogy mindkét gót csoportra vonatkozott a 382-es megállapodás, vö. Heather 1994, 157. A gót törzsek korábbi helyzetéről lásd: Halsall 2007, 134-136.

${ }^{858}$ A foedus és a foederati fogalmának értelmezéséhez lásd: Neumann 1917; Ziegler 1972; Ladner 1976, 9-10; Havas - Német - Szabó 2001, 234.

859 Demandt 1989, 270. A 4. században a rómaiak más birodalmon kívüli népekkel is kötöttek foederati szerződéseket, vö. Amm Marc. 28,2,1-10; 29,6,1-5; Kiss 2008, 42-43.

860 A foedus tartalmáról és a betelepített gótok jogállásáról bővebben: Iord., Get. 145; Marc. Com. 382; Wolfram 1990, 138-141; Kiss 2008, 35-52; Halsall 2007, 180-185. 
kihasználva gyakran megvesztegethetőnek bizonyultak. ${ }^{861}$ Theodosius a gótok területfoglalásait követően helyőrséggel biztosította a városokat, a római népességre pedig a korábbinál jóval súlyosabb adóterheket szabott ki, így az elkeseredett lakosság gyakran a gótokhoz fordult segítségért, jóllehet a rómaiak gyakran éppen őket okolták az alsó rétegek kilátástalan helyzetéért. ${ }^{862}$

A gótok a 394-es Frigidus-menti csatában Theodosius oldalán harcoltak, de kevésnek találták a kifizetett zsoldot, ${ }^{863}$ ezért Alaric vezetésével a Balkán fosztogatására indultak. ${ }^{864}$ Stilicho a nyugati területek vezetőjeként Thessaliában próbálta legyőzni a gótokat, de a vele rivalizáló Rufinus praefectus praetorio Stilicho hatalmának visszaszorítása érdekében Constantinopolisba rendelte őt vissza seregével. ${ }^{865}$ Alaric hiába végzett rendkívül kegyetlen pusztítást Peloponnésos azon területein, ahol a lakosság ellenállásával találkozott, Stilichót keleten mégis ellenséggé nyilvánították és elkobozták a vagyonát, Alaricot pedig Illyricum magister militumává nevezték ki. Amikor 401-ben a gótok váratlanul Italiára támadtak és Mediolanumot ostromolták, ${ }^{866}$ Stilicho az alánok és a vandálok Raetiából és Noricumból való kiszorításával volt elfoglalva, ezért csak súlyos veszteségek árán sikerült megállítania Alaric előrenyomulását 402-ben Pollentiánál, 403ban pedig Hastánál és Veronánál. Honorius ezután a gótokat Pannonia déli és nyugati részén telepítette le, Stilicho pedig szövetségesként használta őket 405-ben Radagaisus csapatainak legyőzésekor. Amikor a rómaiakkal kötött egyezség értelmében Alaric seregével előrenyomult a Balkánon, de Stilicho a 406-os rajnai invázió miatt mégsem tudta megerősíteni a nyugati határszakaszt, ismét megromlott a gótokkal való viszony, mert Alaric a korábbi szerződés értelmében hatalmas fizetséget követelt a feladat teljesítéséért cserébe és Honoriusszal alkudozásba kezdett. ${ }^{867}$

\footnotetext{
${ }^{861}$ Hyd. 7; Isid., Hist. Goth. 12; Amm. Marc. 31,4,11; Demandt 1989, 123. Ennek ellenére 391-ben érkezett egy újabb gót csoport letelepedés céljából Thraciába és Pannoniába, amelynek következtében 392-ben megújították a korábbi 382-es szerződést, vö. Demandt 1989, 126-127; Wolfram 1990, 144; Schulz 1993, 67; Curran 2007, 101-102; Kiss 2008, 46; 81.

${ }^{862}$ Zos. 4,32; Hier., Ep. 60,16-17; Várady 1961, 149. Theodosius 382-394 közötti gót politikájáról bővebben: Székely 2017, 85-88.

${ }^{863}$ A zsoldok rendszertelen és akadozó kifizetése gyakori jelenség volt a korszakban, ilyenkor a katonák többnyire rablóhadjáratokkal egészítették ki megélhetési forrásaikat, vö. Amm. Marc. 18,9,3-6; Várady 1961, 76.

${ }^{864}$ Halsall vizsgálja azt a kérdést, hogy Alaric valóban a gótok királya volt-e, vö. Halsall 2007, 202-206.

${ }^{865}$ Rufinus tevékenységéről bővebben: Blockey 2007a, 113-115.

${ }^{866}$ Alaric italiai hadjáratáról bővebben: Wolfram 1988, 150-160; Blockey 2007, 125-128; Halsall 2007, 200202.

${ }^{867}$ Alaric és Stilicho stratégiájáról és hatalmi harcairól bővebben: Várady 1961, 238-242; Blockey 2007a, 120-121; Kiss 2008, 85-92.
} 
A gótok a zavaros politikai helyzetet kihasználva három alkalommal is Róma ellen vonultak. 408 őszén egy hatalmas összeg átadásával Honoriusnak még sikerült elhárítania a veszélyt, ${ }^{868}$ Stilicho halála után, 409 végén Alaric már elfoglalta a Portus Augustit és kényszerítette a senatust, hogy jelöltjét, Priscus Attalus praefectus urbit ültessék a trónra, ${ }^{869}$ 410. augusztus 24-én viszont árulás folytán az egész város a gótok kezére került. ${ }^{870}$ Hydatius Isidorushoz hasonlóan csak a 410-es fosztogatásokról tudósít, ${ }^{871}$ beszámol a városon kívüli és belüli mészárlásokról, de kiemeli, hogy a szentélyekbe menekült embereknek megkegyelmeztek. ${ }^{872}$ Alaric ugyan szabad rablást engedélyezett katonáinak a városban, amelyben nagy segítséget nyújtottak a rabszolgaként fogvatartott barbárok, de megkímélték az épületeket és a templomokban felhalmozott mükincsek egy részét is. Hydatius azonban nem részletezi azokat a körülményeket, amelyek miatt a gótok kedvezőbb színben tünnének fel az olvasók előtt. Isidorus szerint ugyanis a gótok korábban tett fogadalmuk miatt (ut votum antea darent) mutatkoztak kíméletesnek, és a város elfoglalása után is tartózkodtak a kegyetlenségtől (feriendi inmanitas refrenata est), néhány épület felgyújtása és kevés zsákmány megszerzése után pedig 3 nap múlva ${ }^{873}$ az elfogott Galla Placidiával együtt elhagyták a várost. ${ }^{874}$ Alaric a campaniai hadjárat során sem rombolt és gyújtogatott az elfoglalt területeken, ebből pedig arra következtethetünk, hogy a gótokkal itt kívánt letelepedni, de újabb gabonaföldeket keresve valószínüleg Africába kelt volna át, ha a messinai szorosnál egy vihar nem akadályozta volna meg ebben, később váratlanul meg is halt Cosentiánál. ${ }^{875}$

Isidorus szerint Róma hiába hódított meg korábban szinte minden népet, most a gótok igázták le és tették szolgálóvá a rómaiakat. ${ }^{876}$ Hieronymus, Augustinus és a legtöbb kortárs szerző beszámolójában szörnyü katasztrófaként tünik fel a gótok fosztogatása, ${ }^{877}$ ez

\footnotetext{
${ }^{868}$ Alaric 4 ezer libra arany fejében állt el Róma ostromától, ezt a rendkívül nagy összeget azonban Stilicho alig tudta megszavaztatni a római senatusszal, vö. Zos. 5,29,9; Várady 1961, 114; Halsall 2007, 214.

${ }^{869}$ Attalus ellencsászárságáról lásd: Olymp. 18; Blockey 2007, 129-131; Pohl 2018, 6.

${ }^{870}$ Sozom. 9,9.

${ }^{871}$ Isid., Hist. Goth. 15-18. Hydatius 382-410 között nem is említi a gótokat, ezért valószínü, hogy nem álltak a rendelkezésére ezzel kapcsolatos források, vö. Burgess 1988a, 233.

${ }^{872}$ Hyd. 35: cum intra et extra urbem caedes agerentur, omnibus indultum est qui ad sanctorum limina confugerunt.

${ }^{873}$ Isid., Hist. Goth. 15-18. Mások 6 napos fosztogatásról írnak, vö. Sz. Jónás 1994, 12; Klaniczay 2005, 101.

${ }^{874}$ Hyd. 36. A gótok fosztogatásáról bővebben: Iord., Get. 156-158; a Róma elleni hadjárat előzményeiről és stratégiai jelentőségéről lásd: Várady 1961, 243-246; Kiss 2008, 93-97; a 410-es ostrom forrásainak áttekintését közli: Piganiol 1964.

${ }^{875}$ Hyd. 37; Iord., Get. 156; Sz. Jónás 1994, 12. A hagyomány szerint a gótok a Burentinus folyó medrében temették el királyukat, vö. Iord., Get. 158.

${ }^{876}$ Isid., Hist. Goth. 15: urbs cunctarum gentium victrix Gothicis triumphis victa subcubuit eisque capta subiugataque servivit.

${ }^{877}$ Hier., Ep. 127,12; August., De Civ. 1,7; August., Serm. 93,7; Marc. Com. 410; Prosp. 410.
} 
pedig azzal magyarázható, hogy még mindig Róma számított a birodalom központjának, és korábban csaknem 800 éven keresztül sohasem fosztogattak a városban barbár csapatok. ${ }^{878}$ Orosius viszont kevésbé tartja tragikus eseménynek Róma megszállását, mivel a gótok is keresztények, így hódításaikkal valójában a katolikus vallás és a római kultúra terjedését segítették elő, ugyanakkor azt is állítja, hogy a barbár fosztogatásokról szóló híradások csupán kitalációk és nem hiteles beszámolók. ${ }^{879}$ Nem kételkedhetünk azonban abban, hogy Róma 410-es kifosztása a birodalom teljes lakosságát sokkolta, így szimbolikus eseménynek tekinthető a birodalom összeomlásához vezető úton, ${ }^{880}$ ugyanakkor ennél sokkal nagyobb problémát jelentett olyan fontos tartományok elvesztése, mint Pannonia vagy Britannia, amelyet viszont alig említenek a források. Hydatius számára a világ központját jelentő Róma a kegyetlen barbár fosztogatások miatt megsemmisült, elveszítette régi büszkeségét és civilizációban betöltött vezető szerepét, és a 410-es, illetve 455-ös fosztogatás után már csak egy átlagos hispaniai kisvároshoz hasonló civitasnak volt tekinthető. ${ }^{881}$

Hydatius következetesen hallgat arról, hogy 412-ben Alaric sógora, Athaulf egyezséget kötött Honoriusszal, mely szerint évi gabonaszállítmány fejében katonai segítséget nyújt a birodalom védelmében, de azt sem közli az olvasóival, hogy amikor a gótok 413-ban Dél-Galliába vonulva Tolosa és Burdigala mellett Narbót is megtámadták, akkor azért szegték meg a megállapodást, mert Africa zavaros politikai helyzete miatt nem kapták meg a beígért gabonaszállítmányt. A gót vezetés válságára utal, hogy Athaulfot egyik katonája, Dubius gyilkolta meg talán személyes bosszúból bizalmas beszélgetés közben (inter familiares fabulas) 415 nyarán, de halálát csak szeptember 24-én jelentették be Constantinopolisban. ${ }^{882}$ Athaulf utódjául Sigericet választották, de kevésbé meggyőző Isidorus magyarázata, mely szerint röviddel később Sigericet is azért ölték meg, mert nagyon hajlott a rómaiakkal való békére, hiszen amikor fivére, Vallia trónra került, azonnal békét kötött Constantiusszal. ${ }^{883}$ Hydatius igyekszik a lehető legkevesebbet elárulni a rómaiak és a gótok közötti szövetségről, így azt sem említi, hogy Vallia 416 nyarán megígérte Constantiusnak, hogy hatalmas mennyiségü, 600 ezer modius gabonáért és

\footnotetext{
${ }^{878}$ Hier., Ep. 123,16.

${ }^{879}$ Oros. 7,41,8; Löwith 1996, 225; Alföldy 2000, 204.

${ }^{880}$ Collins 1999, 55-57. Az egyetemes történetírásban Róma 410-es gót kifosztásához csak Hierosolyma lerombolását és Constantinopolis 1453-as elestét szokták hasonlítani, vö. Löwith 1996, 218.

${ }^{881}$ Burgess 1988a, 109-110.

${ }^{882}$ Hyd. 47; 52; Oros. 7,43; Iord., Get. 163. Athaulf Róma-politikáját megalkuvásnak tartotta a gótok egy radikális csoportja, feltehetően ezért buktatták meg, vö. Várady 1961, 179. Athaulf politikájáról bővebben: Arce 2007, 72-89.

${ }^{883}$ Hyd. 52; Isid., Hist. Goth. 20.
} 
élelemszállítmányért cserébe ${ }^{884}$ a birodalomért kész bárki ellen harcolni (propter rem publicam omne certamen inplendum), és visszaengedi a rómaiakhoz Galla Placidiát, aki 414 januárjában feltehetően a gótok Rómából való kivonulásának fejében lett Athaulf felesége. ${ }^{885}$ Hydatius a feltételekről semmit sem mond, csak tárgyilagosan megjegyzi, hogy Constantius 417. január 1-jén feleségül vette Placidiát. ${ }^{886}$ Hydatius az események drámiaságának fokozásával számol be arról, hogy Vallia 416-417-ben hogyan fordult szembe (adversatur) a rómaiak nevében (Romani nominis causa) az alánokkal és a siling vandálokkal, hogy hatalmas mészárlással teljesen kiirtsa (omnes extincti) a siling vandálok törzsét Baeticában, ${ }^{887}$ de a gótok kegyetlenségét hangsúlyozza akkor is, amikor azt állítja, hogy Addax alán király halála után a túlélők még országuk nevét is kénytelenek voltak elfelejteni, hogy a hasding vandálok védelme alá tartozhassanak. ${ }^{888}$

Hydatius nem árulja el, hogy a gótok szándékosan, vagy csak az idő hiányában nem támadták meg a hasding vandálok és a szvévek által lakott területeket, mindenesetre 418ban félbeszakították a hadjáratot (intermisso certamine) és letelepedtek Aquitaniában. ${ }^{889}$ Elképzelhető, hogy Vallia annyira sikeresen harcolt a barbárok ellen, hogy a római vezetés félelmében állította le a hadjáratot, ahogyan Honorius is a gótok letelepítésével próbálta megmenti Hispaniát a kizsákmányolástól, szükség esetén pedig be tudta vetni őket a lázadó bagaudákkal szemben is. ${ }^{890}$ Talán Hydatius is erre céloz, amikor elárulja, hogy Constantius rendelte vissza a gót csapatokat Galliába, bár Várady ezzel szemben úgy látja, hogy a római megbízásra való utalás pusztán „illuzórikus és tartalmát vesztett formaság."891 Isidorus szerint Vallia Africába akart átkelni egy hajóhaddal, de a Gadesi-szorosnál támadt vihar megakadályozta őt ebben, korábbi katonai sikerei miatt azonban a győzelem jutalmaként ( ob meritum victoriae) engedélyt kapott arra, hogy a gótok visszatérhessenek Galliába és letelepedjenek Aquitania Secundában és a szomszédos tartományok néhány városában. ${ }^{892}$ Az így létrejött római-gót szerződés egyben elrendezte a gabonaellátás kérdését is, hiszen a

884 Iord., Get. 164-165; Oros. 7,43,12-13; Várady 1961, 114; Heather 2006, 241; Wood 2007a, 530; Kulikowski 2010, 168.

${ }^{885}$ Isid., Hist. Goth. 21; Hyd. 49.

${ }^{886}$ Hyd. 54; Prosp. 416.

${ }^{887}$ Hyd. 52; 55; 59. A gót politika céljairól bővebben: López Sánchez 2005, 509; Vallia hadjáratáról lásd: Wolfram 1988, 170-171; Arce 2007, 108-110.

${ }^{888}$ Hyd. 60: pauci qui superfuerant oblito regni nomine Gunderici regis Vandalorum, qui in Gallicia resederat, se patrocinio subiugarent.

${ }^{889}$ Hyd. 61. Schulz szerint a szerződést később, 419-ben kötötték, vö. Schulz 1993, 88; 181; más források viszont arra utalnak, hogy Vallia a szerződés megkötésekor már nem élt, vö. PLRE 2,1147-1148; bár Hydatius szerint Vallia a gótok letelepedése után halt meg, vö. Hyd. 62.

${ }^{890}$ Demandt 1989, 149; Wolfram 1990, 177; Cortázar - Vesga 2001, 98; Collins 2004, $27-28$.

${ }^{891}$ Hyd. 61; Várady 1961, 186.

${ }^{892}$ Isid., Hist. Goth. 22. 
gótok vándorlásának fó oka a táplálékigényük kielégítése volt. ${ }^{893}$ Mivel Aquitania az egyik leggazdagabb galliai tartomány volt, a gótok egy gazdaságilag is előnyös megállapodást köthettek a rómaiakkal, ${ }^{894}$ ugyanakkor a rómaiak is profitáltak a területen élő népesség adóiból és katonai kötelezettségeiből, emiatt Gallia szerepe kulcsfontosságúnak mutatkozik a nyugati területek megtartásában. ${ }^{895}$

Hydatius a gótok megbízhatatlanságát jó néhány történettel igyekszik igazolni. 422ben a római Castinus gót segédcsapatokkal indított háborút a vandálok ellen, de azok elárulták őt, ezért súlyos vereséget szenvedett Gunderic csapataitól és csaknem 20 ezer római katona elesett a harcban. ${ }^{896}$ Valójában Theodericnek Róma szövetségeseként kötelessége volt segédcsapatokat küldeni a háborúhoz, bármennyire is próbált semleges maradni vagy jóindulatúan viszonyulni a többi barbár néphez. ${ }^{897}$ Hydatius nem árulja el, hogy Aëtiusnak miért kellett lemészárolnia a gót Anaolsus csapatát Arelate közelében 430ban. A gót fősereg kíséretének vezetője valószínüleg a szvév Heremigariushoz hasonlóan függetlenedni próbált Theoderic királytól, ezért volt szükség az elfogására, Isidorus pedig tévesen magyarázza az eseményeket Theoderic expanzív törekvéseivel. ${ }^{898}$ Nem sokat tudunk annak az esetnek a körülményeiről sem, amikor a gótok 431-ben feltehetően a rómaiak ellen harcoltak, és a gótoktól Vetto csalárd módon (dolose), talán békekötés céljából Gallaeciába ment, de küldetése eredménytelen maradt, a következő években pedig ismét felerősödtek a gótok és a rómaiak közötti fegyveres összecsapások: 436-ban a gótok Narbót ostromolták, de 437-ben a rómaiak felszabadították a várost, 438-ban Aëtius nyolcezer gótot mészárolt le a mons Colubrarius mellett, a római Litorius 439-es veresége és halála után pedig végül megvalósult a rómaiak és a gótok közötti béke. ${ }^{899}$ Amikor 446ban a római Vitus magister utriusque militiae védeni próbálta a szvév fosztogatásoktól Carthaginiensis és Baetica területét, jelentős katonai csapatok támogatásában bízott (non exigue manus fultus auxilio), de a gótok kudarcot vallottak a hadjárat során..$^{900}$

\footnotetext{
893 Hispania gabonaellátását a félsziget déli területeiröl, a Rajna-vidék élelmezését pedig leginkább az Aquitaniából érkező szállítmányokkal biztosították.

${ }^{894}$ Thompson 1982, 50-52; Wolfram 1990, 178-181; Székely 2008, 71, 22. j., Kiss 2008, 113. A gótok aquitaniai jelenlétéről és letelepedéséről bővebben: Thompson 1982, 251-255; Wolfram 1988, 173-174; Burns 1992, 53-63; Wood 2007a, 531-533; Halsall 2007, 232-233; Schwarz 2011, 265-270.

${ }^{895}$ A galliai lakosság öntudatáról és katonai jelentőségéről bővebben: Várady 1961, 138-141.

${ }^{896}$ Hyd. 69; Chr. Gall. 452, 107. A vandálok csak az utolsó pillanatban tudták áttörni Castinus ostromgyürüjét, de a nyílt csata elindulásakor a gótok átálltak az oldalukra, vö. Várady 1961, 248.

${ }^{897}$ Thompson 1982, 188.

${ }^{898}$ Hyd. 82; Isid., Hist. Goth. 23; Thompson 1982, 166.

${ }^{899}$ Hyd. 87; 98; 101; 104; 108-109. Theoderic megpróbálkozott Gallia római részeinek meghódításával is, de Aëtius hun seregével megakadályozta öt ebben, vö. Sid. Ap., Carm. 7,301; Várady 1961, 188.

${ }^{900}$ Hyd. 126.
} 
Hydatius rendkívüli merészségnek (ob testimonium egregii ausus) tartja, hogy 449ben a szvévek és a gótok közötti megállapodás értelmében Basilius, a gótok egyik főembere a szövetséges bagaudákkal kegyetlen vérengzést tartott Tyriasso templomában, és még a város püspökét, Leót is halálosan megsebesítette. Itt olvashatunk először Hydatiusnál arról, hogy a barbárok erőszakot alkalmaznak az egyház egyik vezető tisztségviselőjével szemben, de ez a feljegyzés abból a szempontból is különleges, hogy bizonyítékot szolgáltat arra, hogy egy germán uralkodó és a helyi lázadó parasztok vezetője együttmüködésre is hajlandó. ${ }^{901}$ Egyes kutatók szerint Basilius a bagaudák vezetője volt és a szövetség közvetlenül a szvévek és a bagaudák között jött létre, kevésbé igazolt viszont Van Schoor feltételezése, mely szerint erre azért kerülhetett sor, mert a bagaudák lázadása akkora zürzavart okozott a területen, hogy sem a római, sem a gót csapatoknak nem volt esélye az eredményes beavatkozásra, így a szvévek szabad kezet kaptak a további hódításokra. Maga Isidorus is annyira valószínütlennek tartja a szvévek és a bagaudák közötti szövetséget, hogy inkább a gótokat említi partnerként. ${ }^{902}$ Valójában Hydatiusnak és Isidorusnak is igaza van, mert Basilius feltehetően nem a bagaudák vezetője volt, hanem egy vállalkozó szelleméről ismert gót főember, aki alkalmilag szövetkezett a bagaudákkal és rajtaütésszerü támadásokkal állította meg a császári csapatokat. ${ }^{903}$

451-ben a balkáni tartományokat fosztogató Attila a korábbi politikáján változtatva a nyugati területek ellen is támadást indított. A hunok korábban 430-tól Ruga, majd 434-től Bleda uralma alatt néhány évenként rendszeresen betörtek Thraciába, hogy biztosítsák csapataiknak a folyamatos zsákmányszerzést, a békéért cserébe viszont a szökevények visszaadásán vagy megváltásán túl egyre magasabb összegü subsidiumot követeltek.904 Mivel Aëtius Pannonia egy részét átengedte a hunoknak, azok hosszú ideig nem háborgatták a nyugati területeket, Iordanes szerint azonban III. Valentinianus nővére, Honoria gyürüt küldött Attilának, aki ezt házassági ajánlatként értékelve Gallia területét kérte hozományként, Priscus viszont azt állítja, hogy a frankok trónöröklési vitájában az egyik örökös Attilától, a másik Aëtiustól kért segítséget a hatalom megszerzéséhez. ${ }^{905}$ Miután Attila 447-es balkáni győzelemsorozata után csapataival előrenyomult a Thermopylai-

\footnotetext{
${ }^{901}$ Hyd. 133. A bagaudák 449-es müködéséröl bővebben: Thompson 1982, 184-185.

902 Cortázar - Vesga 2001, 98; Van Schoor 1995, 335; Isid., Hist. Suev. 87.

${ }^{903}$ Szádeczky-Kardoss 1961, 148-152; Várady 1961, 181, 316. j.

904 Ez az összeg 422-ben 300, 430-ban 350, 434-ben pedig már 700 libra arany volt évente, a foglyok megváltásáért 8 solidust kellett fizetni, vö. Prisc. 1; Várady 1961, 168; Sz. Jónás 1994, 17; Katus $2014,87$.

905 Iord., Get. 224; Rom. 328; Prisc. 16. Ez volt az első olyan eset, amikor egy barbár uralkodó a császári családba beházasodva a nőági örökösödés révén nyíltan igényt tartott a birodalom egy részére, vö. Várady $1961,169$.
} 
szorosig és Constantinopolisig, ${ }^{906}$ Theodosius hosszú tárgyalások után kénytelen volt a hunok által diktált feltételek szerint békét kötni és a háborús jóvátételen kívül a korábbi subsidium összegének a háromszorosát megfizetni, az új keleti császár, Marcianus azonban 450-ben megtagadta a megemelt subsidium további fizetését. ${ }^{907}$ Attila ezért meggyőzte Theodericet, hogy adja fel a rómaiakkal 439-ben kötött szövetséget, és egyesítsék a gótok és a hunok erejét a rómaiakkal szemben, nem sokkal később viszont maga Attila szegte meg a megállapodást és fosztogató hadjáratot indított Dél-Gallia irányába, melynek során rengeteg várost kizsákmányolt, többek között a püspöki és katonai székhelyként müködő Mettist. ${ }^{908}$ Theoderic erre ismét a rómaiakhoz pártolt és Aëtiusszal békeszövetséget kötve (in pace societas) a hunok seregével szemben vonult a catalaunumi csatába. ${ }^{909}$

Az ütközetben részt vevő, többnyire gyalogos csapatok összetétele rendkívül heterogén képet mutat, mivel Attila seregében a hunok mellett keleti és nyugati gótok, gepidák, rugiak, szkirek, alemannok, herulok, szvévek, türingek, ripuári frankok és rajnai burgundok, a rómaiakkal pedig nyugati gótok, Rhodanus-menti burgundok, száli frankok, szarmaták, armoricumiak, szászok és olibrionok is harcoltak. ${ }^{910}$ Attila valószínüleg megpróbálta alaposan előkészíteni a galliai támadást, mert a hátbatámadástól tartva csökkentett a fizetendő subsidium összegén, befogadta a korábban levert Róma-ellenes burgundok vezetöit, és tárgyalásokat folytatott Gaiserickel a vandálok esetleges italiai támadásáról is. ${ }^{911}$ Aëtius és Theoderic csapatai lemészárolták a hunokat, de ezt Hydatius nemcsak hogy magától értetődőnek tartja, hanem egyenesen Isten segítségével (divino auxilio) megvívott győzelemnek ábrázolja. ${ }^{912}$ Egyszerü tényként közli az olvasókkal az áldozatok számát is: Theoderic holtan esett össze (prostratus occubuit), az Isidorus által is megerősített 300 ezernyi halott azonban túlzás lehet, mert Iordanes jóval kevesebb, 165 ezer áldozatot említ. ${ }^{913}$

\footnotetext{
906 Attila hatalmának jellegéről és embereinek hűségéről lásd: Sz. Jónás 1994, 20-25; Man 2009; Snaedal 2015.

907 Az új összeg 2100 libra volt, a szökevényeket pedig ezentúl 12 solidusért váltották meg, vö. Klaniczay 2005, 92.

${ }^{908}$ Iord., Get. 186. A hunok vonulásáról és fosztogatásáról szóló legendákat lásd: Klaniczay 2005, 93.

${ }^{909}$ Hyd. 142; Prosp. 451. Catalaunum pontos azonosítása máig nem sikerült, a kutatók általában Châlons-surMarne környékére lokalizálják, Tircassestöl 5 km-re, vö. Iord., Get. 197; Várady 1961, 258.

${ }^{910}$ Iord., Get. 191; Heather 2007b, 17-18; Angenendt 2008, 147. A Iordanes által megjelölt fél-fél milliós sereg létszáma azonban erős túlzás lehet, vö. Iord., Get. 194-195.

${ }^{911}$ Prisc. 15; Iord., Get. 184; Várady 1961, 258.

${ }^{912}$ Hyd. 142. A csata hadmüveleteiröl bővebben: Iord., Get. 197-217; Várady 1961, 258-260.

${ }^{913}$ Isid., Hist. Goth. 25; Iord., Get. 217. Várady szerint az ütközet jelentőségét az utókor túlságosan nagyra értékelte, jóllehet ez volt „az utolsó ókori méretü tömegcsata”, amely azonban nem tette lehetővé a különbözö manőverek kibontakozását, vö. Várady 1961, 259-260. Iordanes catalaunumi ábrázolásáról bővebben: Whately 2012, 61-64.
} 
Attila visszavonulása után 452-ben váratlanul Italiára támadt, csapatai tovább fosztogattak és Aquileiát lerombolták, Ticinumot, Veronát, Brixiát és Mediolanumot pedig elfoglalták. ${ }^{914}$ Attila a galliai kudarc után valószínüleg Italiában próbált zsákmányt szerezni, és helyesen feltételezte, hogy itt Aëtius már nem tud megfelelő segédcsapatokat állítani ellene. ${ }^{915}$ Iordanes azt állítja, hogy amikor a hun sereg Ticinumnál elakadt, Leo pápa találkozott Attilával, hogy a hadifoglyok kiváltásáról tárgyaljon és meggyőzze őt arról, hogy Róma kifosztása helyett inkább forduljon vissza csapataival. ${ }^{916}$ Attila végül az égi csapások (caelestibus plagis) és Marcianus seregének hatására azonnal békét kötött (subacti pace facta) a rómaiakkal és visszatért seregével a szállásterületükre. ${ }^{917}$ Bury szerint Hydatius azért nem mond semmit Attila és Leo tárgyalásáról, mert erre nem is került sor, hiszen eleve észszerütlen lenne, hogy egy pogány vezér engedelmeskedjen a pápai intelemnek, Castellanos viszont alaptalanul feltételezi, hogy Hydatius azért nem tartja lényegesnek ezt a találkozót, mert meg van győződve arról, hogy a világ a végéhez közeledik. ${ }^{918}$ Klaniczay szerint III. Valentinianus Leo pápán kívül Avienus consult és Trigetius praefectust küldte Attilához, aki évi adó kivetéséért cserébe hajlandó volt békét kötni a rómaiakkal. ${ }^{919}$ Leo szerepe azonban kevésbé igazolható ebben az esetben, ${ }^{920}$ minden bizonnyal egy

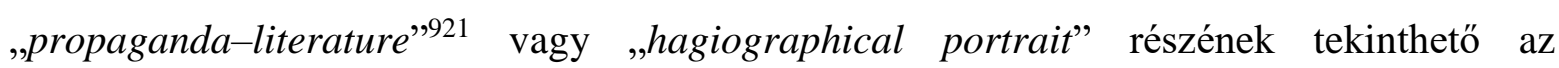
ábrázolása. ${ }^{922}$ A legmeggyőzőbb Thompson és Várady magyarázata, mely szerint Attila nem akarta, hogy a hun sereget is sújtsák az egyre nagyobb méretủ éhínségek és járványok, ráadásul a két birodalomrész még együtt tudott müködni és az italiai erődök is képesek voltak bizonyos fokú védekezésre, ezért a hunok Róma bizonytalan kimenetelü ostroma helyett inkább gazdag zsákmányt szerezve elhagyták Italiát. ${ }^{923}$

A következő években a gótok hatalmi viszonyairól és más népekkel való kapcsolatáról kapunk bővebb információkat. Thorismund gót király és öt testvére között

\footnotetext{
${ }^{914}$ Hyd. 145-146; Iord., Get. 223; Prosp. 452.

915 Várady 1961, 260. Az italiai hadjárat taktikai lépéseiről és a hun fegyverkezés fejlődéséről bővebben: Iord., Get. 220-223; Várady 1961, 261-266.

916 Iord., Get. 223.

917 Hyd. 146.

918 Bury 1923, 1,295; Castellanos 2015, 14.

919 Klaniczay 2005, 93.

${ }^{920}$ Koenigsberger 1987, 56.

921 Wallace-Hadrill 1967, 28.

922 Gillett 2003, 114-115.

923 Thompson 1982, 151; Várady 1961, 261. Amikor Attila 453-as halála után két fia, Ellac és Dengizik között trónviszály tört ki, a zavaros belpolitikai helyzetet kihasználva a hun uralom alatt álló népek fellázadtak és függetlenítették magukat. A hunok ezt követően több csoportra szakadva bebocsátást kértek a birodalom területére, és Thraciában, Moesiában, illetve az Alföldön telepedtek le. A hunok Attila utáni történetéről bővebben: Várady 1961, 174-176.
} 
már Theoderic halála előtt is feszült volt a viszony, de amikor 453 tavaszán Thorismund ellenségesen fenyegetőzött (spirans hostilia) és az alánok ellen vonult, hogy elfoglalhassa a Rhodanus völgyét, veszélybe sodorta a rómaiakkal kötött békét, ezért testvérei meggyilkolták, 453 körül pedig Theoderic testvére, Frederic lemészárolta a Tarraconensisben lázadó bagaudákat. ${ }^{924}$ Hydatius ugyan nem utal ennek a jelentőségére, de a korábbi évtizedek bagauda felkelései után Hispaniában ez volt az utolsó megmozdulásuk, amelyről konkrét adataink vannak. ${ }^{925}$ Miután a szvévek 455-ben megszegték a rómaiakkal kötött békét, Avitus kérésére a gótok kétszer is indítottak követséget a szvévekhez, hogy kifejezzék a birodalomhoz való hüségüket (fidus Romano esset imperio), és rávegyék Rechiariust a korábbi szerződés betartására. ${ }^{926}$ Theoderic végül 456 őszén tört be Gallaeciába egy hatalmas, szövetségesekből álló csapat élén, amelyben Iordanes szerint nemcsak gót és frank, hanem burgund katonák is harcoltak Gundioc és I. Chilperic irányításával. ${ }^{927}$

Hydatius szerint Theoderic részben saját akaratából, részben Avitus császár utasítására (et cum voluntate suo et ordinatione Aviti imperatoris) indította el a 456-os támadást, mások viszont úgy látják, hogy inkább a gótok akarata érvényesült, mert Tarraconensis szvév ellenőrzése veszélyeztette Theoderic királyságát. ${ }^{928}$ Ehhez hasonlóan Várady is túlzásnak tartja ezt a „diplomáciai nyelvben” gyakori szóhasználatot, mivel a gótok „saját érdekeik szerint” vettek részt a római hadműveletekben, és a birodalmi vezetésnek ekkor már csak kevés beleszólása volt a tényleges döntésekbe. ${ }^{929}$ Annyi biztos, hogy Avitus ebben az időben Pannoniában harcolt, vagyis nem tudott volna részt venni a szvévek elleni hadjáratban, de feltehetően tisztában volt azzal, hogy Theodericnek is érdekében áll Rechiarius terjeszkedését és fosztogatását megállítani. A 456-os Asturica melletti ütközet előzményein túl Hydatius a csata részleteiről és következményeiről is

\footnotetext{
${ }_{924}$ Hyd. 144; 148; 150; Prosp. 453.

925 Cortázar - Vesga 2001, 98. A 457 körül Bracara környékén garázdálkodó rablókat (latrocinantum) többnyire a bagaudákkal szokták azonosítani, de ök más eredetüek, mint akikröl korábban hallottunk, vö. Hyd. 172.

${ }^{926}$ Hyd. $163 ; 165$.

927 Iord. Get. 231; Collins 2007, 115; Kulikowski 2010, 188. A burgundok 435 körül érkeztek Belgica területére Gundahar király vezetésével élelemhiány miatt, de miután Aëtius 436-ban hun seregével a középrajnai határt védve legyőzte őket, 20 ezer burgundot is lemészárolt, vö. Hyd. 99; 102; Frassetto 2003, 5. A megmaradt burgund népességet Gallia Sapaudiában, a mai Savoya környékén telepítették le 443-ban, hogy később más barbár népek elleni harchoz is felhasználhassák őket, vö. Várady 1961, 180; Collins 1999, 76. Bár a burgundok korábban békés viszonyban éltek a rómaiakkal és a gótokkal, miután 450 körül Gundioc király feleségül vette Ricimer nővérét, kénytelenek voltak aktívan részt venni a rómaiak által indított hadjáratokban, vö. Sz. Jónás 1994, 46.

${ }^{928}$ Hyd. 166; Thompson 1982, 296, 12. j.

${ }^{929}$ Várady 1961, 186.
} 
igyekszik pontos tájékoztatást adni, ami valóban arra utal, hogy Hydatius ezt az eseményt tekintette a krónika csúcspontjának. ${ }^{930}$ Miután a gótok legyőzték a szvéveket és seregüket lemészárolták, néhányukat foglyul ejtették, legtöbbjük azonban megfutamodott, Rechiarius pedig sebesülést szenvedett. ${ }^{931}$ Iordanes ellentmondásosan tudósít a csatáról, hiszen nem kis túlzással szinte az egész nép megsemmisüléséről beszél, később viszont azt állítja, hogy Theoderic megkímélte a szvéveket, és a gót katonáknak sem engedte, hogy durván bánjanak velük. ${ }^{932}$ Ennek ellentmond, hogy október végén Theoderic seregei már rendkívül kegyetlen módon fosztogatták Bracara városát, amely ugyan nem járt vérontással (etsi incruenta), de Hydatius rendkívül tragikusnak és borzalmasnak (satis maesta et lacrimabilis) találta a lakossággal és a papsággal szemben alkalmazott bánásmódot. Úgy tünik, hogy a menedékhelyre menekült szvéveken kívül azok sem kaptak feltétlenül kegyelmet, akik Rechiarius elfogása után megadták magukat, mert Isidorus szerint ők csak a szvév király halála után lettek volna hajlandóak elfogadni a gótok uralmát. ${ }^{933}$ Torres Rodríguez feltételezése szerint a gótok túlságosan kegyetlen fellépése azzal is magyarázható, hogy Rechiarius Róma mellé állt, amikor felvette a katolikus vallást, ${ }^{934}$ a megtorlás-elméletet viszont cáfolja az a tény, hogy 456-ban a gótok Rómával voltak szövetségben. A drasztikus ábrázolás és a gyermekek említése ugyanakkor itt is magyarázható az olvasók érzelmeinek mozgósításával, de elfogadhatjuk Díaz feltételezését is, mely szerint Bracara Emeritával együtt a szvévek hosszú jelenléte és pusztításai miatt puszta „città simbolo”-vá vált az 5. században. ${ }^{935}$

Hydatius gótokkal szembeni megítélése a 456-os események ábrázolásakor úgy tünik, hogy rendkívül nagy fordulatot vett, hiszen a krónika első felében a gótok viselkedését még nem tartotta olyan veszélyesnek, mint a szvévek vagy a vandálok esetében, 456 után azonban már ők is legalább annyira megbízhatatlanok és kegyetlenek Hydatius szemében, mint a többi barbár nép. Mindezt azzal is magyarázhatjuk, hogy Hydatius nem hajlandó elfogadni, de még elismerni sem a gótok katonai segítségét, ${ }^{936}$ ezért inkább negatív színben tünteti fel őket a többi barbár néphez hasonlóan. A megváltozott értékelésnek megfelelően Avitus bukásakor Hydatius a gótokat vádolta azzal, hogy

\footnotetext{
${ }^{930}$ Burgess 1988a, 237; Drinkwater 1992, 6; López Sánchez 2005, 516, 94. j.

931 Hyd. 166.

932 Iord., Get. 232-233.

${ }^{933}$ Hyd. 167-168; 171; Isid., Hist. Goth. 32.

934 Torres Rodríguez 1977, 141.

935 Díaz 2000a, 404. López Quiroga és Martínez Tejera szerint Rechiarius idején két főváros volt a Szvév Királyságban, Barcara és Emerita, vö. López Quiroga - Martínez Tejera 2017, 438; 525.

936 Castellanos 2015, 154.
} 
megszegték ígéretüket és megvonták tőle a támogatásukat (promisso destitutus auxilio), holott valójában Ricimer üldözte a Galliában menedéket kereső császárt, akinek a gótok valóban nem nyújtottak segítséget. Amikor Theoderic Emerita kifosztására indult, a város vértanúja, Eulalia közbenjárásának köszönhetően még félbeszakította a hadmüveletet, ${ }^{937}$ 457-ben viszont a korábbiakhoz hasonlóan burgund és frank szövetségesekkel vonult Gallaeciába, hogy Asturicában példátlan fosztogatást végezzen nemcsak a lakosság, hanem a papság soraiban is. Hydatius itt már rendkívül negatív színben ábrázolja a gótokat, hiszen csellel és hamis esküvel állították, hogy a szvévek ellen vezetnek hadjáratot, ehelyett a lakosság soraiban mészárlást végeztek, a várost felgyújtották, a templomok felszereléseit pedig sok emberrel együtt elrabolták. ${ }^{938}$ A kegyetlen fosztogatás azonban más városokban is folytatódott: Palentiát hasonló pusztítással döntötték romba (simili perit exitio), Coviacum erődítményét pedig sokáig tartó csatában a végsőkig ostromolták (diutino certamine fatigatum) és rengeteget megöltek az ellenfél csapatai közül. Muhlberger szerint a gótok is a gonoszt testesítik meg a krónikában, de Hydatius elsősorban nem vadságuk és eretnekségük, hanem megbízhatatlanságuk és az esküvel megerősített szerződések megszegése miatt bírálja őket, ${ }^{939}$ ennek a feltételezésnek viszont ellentmond, hogy Hydatius mindkét gót fosztogatás részleteiről meglepő alapossággal tudósít. Elfogadhatjuk viszont Burgess álláspontját, mely szerint Hydatius azért számolt be ilyen részletesen a papságot és a gyülekezetet ért támadásokról, hogy felhívja az olvasók figyelmét arra, hogy az egyházat is egyre gyakrabban érik erőszakos atrocitások, ez azonban nem igazolja Tranoy azon állítását, hogy a támadásoknak mindenképpen vallási indítéka volt és az ortodoxia eretnekséggel való összecsapását jelenítette meg. ${ }^{940}$ Mindenesetre Hydatius a 456-457-es évektől a gótok tevékenységét is keményebb kritikával illeti, és megbízhatatlanságuk miatt egyre veszélyesebbnek tartja tevékenységüket.

A következő évek eseményeinek segítségével a gót-római kapcsolatok átalakulását figyelhetjük meg. 458 júliusában Theoderic Cyrila katonai parancsnokot $(d u x)$ küldte egy gót sereg élén Baeticába, de valószínűleg nem ért el tartós sikereket, mert 459 elején visszahívta és helyette Suniericet küldte el a hadsereg egy részével. Hydatius Maiorianus

\footnotetext{
${ }^{937}$ Hyd. 175-176.

${ }^{938}$ Hyd. 179: dolis et periuriis instructi, sicut eis fuerat imperatum, Asturicam, quam iam praedones ipsius sub specie Romanae ordinationis intraverant, mentientes ad Suevos qui remanserant iussam sibi expeditionem, ingrediuntur pace fucata solita arte perfidiae. Nec mora promiscui generis reperta illic caeditur multitudo; sanctae effringuntur aecclesiae; altaribus direptis et demolitis sacer omnis ornatus et usus aufertur; duo illic episcopi inventi cum omni clero abducuntur in captivitatem; invalidiorum promiscui sexus agitur miseranda captivitas; residuis et vacuis civitatis domibus datis incendio camporum loca vastantur.

${ }^{939}$ Muhlberger 1990, 228.

${ }^{940}$ Burgess 1988a, 211; Tranoy 1974, 1, 42-45.
} 
császár érdemeit szem előtt tartva büszke vállalja, hogy a gótok és a rómaiak megerősítették egymás között a tartós békét (firmissima inter se pacis iura sanxisse), ${ }^{941}$ mivel Maiorianus igyekezett minden olyan akadályt elhárítani, amely veszélyeztette volna a római sereg jobb szárnyának átvonulását a Pireneusoktól egészen Carthago Nováig. Ennek a békeszerződésnek a hírét üzente meg a gót Sunieric és a római Nepotianus a gallaeciabelieknek 459-ben, hogy aztán a szvévek 460-as lucusi rajtaütését megbosszulva a rómaiak nevében gót sereggel fosztogassák a Lucus közelében élő szvéveket, mivel feltehetően ekkor már egyáltalán nem állomásozott római haderő Hispaniában. ${ }^{942}$ A gót befolyás erösödését és a római hatalom további gyengülését mutatja az a tény is, hogy Scallabis megszerzése és Sunieric visszatérése után 462-ben Theoderic utasította (ordinante) Nepotianust, hogy fogadja el Arboriust utódjának, tehát a legmagasabb római katonai tisztségre a gótok jelöltjét választották meg, amelyre egyre gyakrabban kerül majd sor a 460-as évek második felében. ${ }^{943}$ Néhány évvel később a leváltott Nepotianus haláláról már csak rendkívül szükszavúan nyilatkozik Hydatius, ugyanakkor azt is látjuk, hogy Arborius még 465-ben is a hivatalában volt. ${ }^{944}$ Nepotianus és Arborius esetét látva Thompson arra a következtetésre jut, hogy a 460-as évek elején nemcsak katonai, hanem politikai értelemben is véget ért a rómaiak Hispania fölötti uralma, a gótokkal való kapcsolatkeresés azonban nemcsak a rómaiakat, hanem magát Hydatiust is aggodalommal töltötte el. ${ }^{945}$

465-től a gótok szvévekkel szembeni politikája és diplomáciai kapcsolata került a figyelem középpontjába. Remismund egy követváltás után Theoderic támogatását élvezte a szvév királyi trónon és egy ideig még igyekezett követek útján jó kapcsolatot fenntartani a gótokkal, ők viszont közben meghódították Narbót és római területekre törtek be. ${ }^{946}$ Amikor Remismund 465 végén önálló terjeszkedési politikába kezdett és Aunona városára támadt, Theoderic követek útján többször is megpróbálta leállítani a szvévek expanzív törekvéseit, különösen hogy meggátolja Remismund gótoktól való függetlenedését. Amikor Hydatius arról tudósít, hogy Euric megölte saját testvérét, Theodericet, akkor hangsúlyozza, hogy annak idején ő is hasonló gaztett révén lett király (pari scelere succedit in regnum) és a

\footnotetext{
${ }^{941}$ Hyd. 185; 188; 192.

942 Hyd. 194; 196; Thompson 1982, 181. A legio VII Gemina korábban Legio és Lucus központtal állomásozott a területen, vö. Not. Dig., Occ. 42,25-29. A római haderő hispaniai felszámolásáról bővebben: Arce 2007, 197-210.

${ }^{943}$ Hyd. 201; 207-208; Heather 2007b, 28.

${ }^{944}$ Hyd. 218; 226.

945 Thompson 1982, 216; Kulikowski 2005, 66.

946 Hyd. 212; 222; 224; 226-227.
} 
tisztséget bünös úton szerezte meg (quo honore provectus et crimine), amikor Frederic segítségével megölte Thorismundot. ${ }^{947}$ Hydatius ezzel azt sugallja, hogy a barbárok azért végeznek uralkodóikkal és állítanak helyükre szinte automatikusan egy másikat, mert semmilyen külső „legitimate authority” nem védi a hatalmukat, és uralmuk gyakorlatilag tyrannisnak tekinthető. ${ }^{948}$ A gótok és a szvévek közötti kapcsolat megromlását jól mutatja, hogy a gótok követeit a szvévek folyamatosan visszautasították, a vandál katonai sikerek miatt pedig a gótok gyorsan visszavonultak, 467-ben a rómaiak küldöttségét fogadták, egy évvel később azonban jó néhány gót csapat csatlakozott az Emeritába tartó szvév követekhez. ${ }^{949}$ Mindezekből látható, hogy Euric igyekezett széleskörü diplomáciai kapcsolatot fenntartani a gót érdekek biztosítása miatt, Hydatius ugyanakkor csak a Gallaeciát érintő ügyekre és tárgyalásokra próbált fókuszálni beszámolójában. ${ }^{950}$

Miután 468-ban a szvévek elfoglalták Ulixipponát, a gótok az alávetett (servientes) szvévekre és rómaiakra támadtak Lusitaniában, de még Hydatiusnak is feltünik, hogy a gótok mintha utánozni próbálták volna a Lusitania és Asturica környékét fosztogató szvéveket, amikor talán a szvév hadjáratok ellensúlyozására ugyanezeket a területeket hasonló ellenségeskedéssel (pari hostilitate) kezdték fosztogatni. ${ }^{951}$ Burgess szerint ebben Hydatius egyfajta szerkesztési elve érvényesül, mivel a 409-410-ben Hispaniára és Rómára szinte egyszerre támadó szvévek és gótok pár évtizeddel később, 456-ban, a krónika feltételezett csúcspontján már külön harcoltak, Hydatius élete végén pedig újra szövetséget kötöttek a rómaiak ellen. ${ }^{952}$ Burgesszel egyetértve megcáfolhatjuk azt az általánosan elfogadott nézetet, mely szerint a gótok 456 után fokozatosan megszállták Baetica és Lusitania tartományait, mivel Hydatius nem tudósít egyértelműen gót expanzióról, 468-ban viszont utal a gótok és a szvévek közötti békekötésre. ${ }^{953}$ Ahogyan korábban már többször is láttuk, Hydatius 456 után a gótokat sokkal kritikusabb szemmel figyelte, saját korában viszont még nem feltétlenül látta világosan, hogy milyen irányba tart a gót külpolitika, ráadásul az sem biztos, hogy megfelelő mennyiségü információ jutott el hozzá Gallaeciába a déli tartományok helyzetéről.

\footnotetext{
${ }^{947}$ Hyd. 229; 233-234; vö. 148.

948 Johnson 1993, 54.

949 Hyd. 229; 233-236; 238-239.

${ }^{950}$ Gillett 2003, 72-73.

${ }^{951}$ Hyd. 240; 243-244.

952 Burgess 1988a, 234.

${ }^{953}$ Hyd. 239; Burgess 1988a, 140-141.
} 


\subsubsection{Az eretnekmozgalmak terjedése}

Hydatius életének minden szakaszában, a gyerekkori zarándoklattól a püspökké szentelésen át egészen az eretnekségek elleni harcig folyamatosan egy igazhitủ keresztény ember ideáját testesíti meg, ugyanakkor a krónikában bemutatott események ábrázolása, a kereszténység vezetőihez és szerzőihez kapcsolódó feljegyzések ezzel teljes összhangot alkotva igazolják, hogy történetíróként is elkötelezett volt a vallási témák iránt. ${ }^{954}$ Az Úr szolgájaként a katolikus egyház által hirdetett szigorú ortodoxiát támogatja, és nemcsak önmagától, hanem másoktól is elvárja az egyházi fegyelmet és az egyetlen helyes tanítás védelmezését az eretnek tanításokkal szemben, ezért is ajánlja mủvét a hozzá hasonló igazhitüeknek. ${ }^{955}$

Hydatius felismerte azt az összefüggést, hogy a birodalom vezetésében mutatkozó politikai instabilitás megnehezíti a katolikus egyház számára az ortodoxia érvényesítését, és mivel a központi irányítást gyengítő barbárok többnyire az arianizmus hívei voltak, a 4. századtól kezdve rendkívül nehéz volt féken tartani az eretnek irányzatokat. ${ }^{956} \mathrm{~A}$ folyamat azonban fordítva is igaz, hiszen a keresztény meggyőződés szerint amíg az ortodoxia a barbár betörések ellenére érvényesülni tud, addig a birodalom legföbb értékei, a római kultúra és a császári hatalom sem pusztulhat el, tehát ha a barbárok egyszer majd keresztények lesznek, akkor egyben rómaiakká is válnak, vagyis a barbár betöréseken és az általuk terjesztett eretnek tanításokon az ortodoxia végül győzedelmeskedni tud. ${ }^{957}$

\subsubsection{Az eretnekség és igazhitüség kérdése}

Az egyház a hivatalos tanítással szembeforduló és a hitüket megtagadó eretnekekkel szemben igyekezett már a korai időszakban is határozottan fellépni. A heretikusok a szó eredeti jelentése alapján válogatnak a különbözö hittételek között, kiemelik azt eredeti összefüggésükből vagy a kinyilatkoztatott igazságok tudatos tagadásával tévtanításokat hirdetnek. ${ }^{958}$ A birodalmi egyház az eretnekségek terjedése miatt arra kényszerült, hogy a keresztény hitelvek részletes kidolgozásával és a szentírási kánon pontosításával megjelölje

\footnotetext{
${ }^{954}$ Burgess 1988a, 194.

${ }^{955}$ Hyd. praef. 1: Ydatius servus domini nostri Iesu Christi universis fidelibus in domino nostro Iesu Christo et servientibus et in veritate, salutem.

956 Johnson 1993, 67.

${ }^{957}$ Dawson 1938, 105.

958 Szántó 1983, 96; Chadwick 2007, 561-562.
} 
azokat az írásokat, amelyek hitelesen közvetítik az igaz tanítást, másrészt pedig a keresztény hit lényegének összefoglalásával közérthető módon cáfolja meg az eretnek tanításokat. ${ }^{959}$

Szántó világosan kifejti, hogy az eretnek tanítások nemcsak a krisztusi hit tisztaságát, hanem az egyházi szervezet egységét és tekintélyét is veszélyeztették, ezért többféle módon fel kellett venni velük a küzdelmet. Az eretnekek elleni fellépés kezdetben kizárólag azoknak a püspököknek volt a feladata, akiknek az illetékességi területén a téves tanítások megjelentek, de ők gyakran egymással összefogva tanácskozásokon és zsinatokon próbáltak szembeszállni velük. ${ }^{960}$ Ennek az egységes fellépésnek és a Rómával való egyre gyakoribb kapcsolattartásnak köszönhetően az egyházközösségek nagyobb egységekbe szerveződésével ténylegesen is kialakulhatott az igaz hitet hirdető birodalmi egyház, ezáltal minden olyan vallási mozgalom eretneknek számított, amelyik a hivatalos egyházi tanítással ellenkezett, vagyis az ortodoxia feltételeit a zsinatokon elfogadott dogmatikai megfogalmazások szabták meg. ${ }^{961}$ Nem véletlen, hogy a Codex Iustinianus meghatározása alapján eretneknek minősül az, aki nem tartozik a katolikus és ortodox egyházhoz (non est addictus catholicae ecclesiae et ortodoxae), vagy aki más vallást követ, mint amit a katolikus és apostoli egyház és az ortodox hit elöír (aliter venerantur atque catholica et apostolica ecclesia et ortodoxa fides). ${ }^{962}$

Az eretnekekkel szembeni fellépés a 4. század elejéig kizárólag egyházi jellegü volt, ${ }^{963}$ Constantinus korától kezdve viszont már világi szankciókat is alkalmaztak velük szemben és az eretneknek nyilvánított személyeket száműzetésben is részesítették. Földjük és vagyonuk rendszerint a császári birtokállományt gyarapította, politikai jogaiktól megfosztva pedig a legtöbb esetben hivatalt sem vállalhattak. ${ }^{964}$ Ennek megfelelően már a 4. század közepén látjuk az első nyomait annak a középkori felfogásnak, mely szerint „az egyház azonos a szervezett társadalom egészével”, és azok, akik eretneknek minősültek, nem rendelkezhetnek teljes polgárjoggal, rosszabb esetben pedig „még arra sem volt joguk,

\footnotetext{
${ }^{959}$ Lyman 2007, 296-298. Ennek is köszönhető, hogy az ortodoxia összefüggő gondolatrendszerével szemben az eretnek tanítások töredékes és gyakran összefüggéstelen módon jelennek meg, ugyanakkor a kereszténység első, tradicionálisabb formái és a Rómán kívüli egyházi központok kezdetben eretnek tanításokat hirdettek a későbbi ortodoxia fogalmához képest, vö. Benoit - Simon 1998, 303-306.

$960 \mathrm{Az}$ eretnekmozgalmak megfékezése érdekében már a 2. században sor került provinciális zsinatok összehívására egy-egy tartomány püspökeinek részvételével, vö. Jedin 1998, 11-13.

${ }^{961}$ Szántó 1983, 104-105. Az ortodoxia fogalmáról és értelmezéséről bővebben: Lafont 1998, 101-104; Eliade 2006, 549-551; Allen 2007, 811-818.

962 CI 1,5,12,4; CI 1,5,18,4; Kelemen 2007, 82.

${ }^{963}$ Ennek során az eretnek személyeket kiközösítették az egyházi közösségböl és ezzel megfosztották őket az üdvösség lehetőségétől.

${ }^{964}$ Gárdonyi 2006, 77. Ezeket a szankciókat a gyakorlatban azonban csak az eretnekségek vezetőivel szemben tudták érvényesíteni, mivel a követők és a szimpatizánsok magas száma miatt rájuk nézve inkább csak elvi jelentősége lehetett a büntetéseknek. Az eretnekek jogi helyzetéről bővebben: Kelemen 2007, 82-86.
} 
hogy létezzenek."965 A hatalommal szembenálló irányzatok eltérő hitértelmezései szinte versengtek egymással, támogatóik különböző társadalmi rétegek soraiból szerveződtek, így mozgalmuk gyakran vallási formában fejezte ki egy tartomány vagy társadalmi réteg partikuláris érdekeit, megtestesítve ezzel „a birodalomban meglévö széthúzó erők” egy újabb formáját. ${ }^{966}$

Hydatius az igaz hit képviselőjeként a szigorú ortodoxiát támogatta, és amikor csak alkalom adódott rá, ennek fontosságát igyekezett hangsúlyozni. ${ }^{967}$ Számos olyan eretnekséget említett a krónikában, amelyik Hispaniában nagy népszerüséget szerzett és veszélyeztette a katolikus hit egységét, nem véletlen, hogy a legtöbb vallásra vonatkozó feljegyzés az eretnekmozgalmak elleni harchoz kapcsolódik, és ő maga is jó néhány alkalommal használta az eretnek kifejezést. Az eretnekségek terjedésével (ex furentium dominatione) magyarázza, hogy a katolikus vallás nehéz helyzetbe került, Hieronymus munkái közül pedig azokat emeli ki, amelyek eretnekségek ellen (adversum alios hereticos) íródtak. ${ }^{968}$ Részletesen beszámol arról, hogy a gnosztikus eretnekség felé forduló (declinans in heresem gnosticorum) Priscillianust hiába nyilvánították eretnekké (hereticus iudicatus), eretneksége (heresis) mégis átterjedt Gallaeciába, ezért Hydatius többször is istenkáromló eretnekségnek (heresem blasphemissimam) és veszedelmes szektának (sectam perniciosissimam) nevezi mozgalmukat. ${ }^{96} \mathrm{Az}$ arianizmusra különös módon egyetlen alkalommal sem utalt ezzel a szóval, helyette hitetlenségnek (Arrianam perfidiam), kegyetlenségnek (impietatem Arrianam) és veszedelmes méregnek (pestiferum virus) tartja tanításukat, a nestorianusok nézeteit viszont téves elnevezéssel ugyan, de többször is az elpusztítandó eretnekségek (ad destruendam Hebionitarum heresem) közé sorolja. ${ }^{970}$

Muhlberger szerint Hydatius az arianusok, a priscillianusok és a manicheusok mozgalmával foglalkozik a legtöbbet, mert ezek Gallaeciában is sok támogatót szereztek, ugyanakkor egyáltalán nem említi a gallaeciai pogányságot, holott a vidéki területeken még nagyon erősen kimutatható a jelenléte. ${ }^{971}$ Ennek magyarázata az lehet, hogy Hydatius úgy látta püspökként, hogy az ortodox lakosság inkább hajlamos áttérni az arianus vagy priscillianus tanításra, mint csatlakozni a pogány eszmékhez. ${ }^{972}$ Hydatius az

\footnotetext{
965 Southern $1987,15$.

966 Wieser 2016, 89; Gecse 1977, 53-54.

${ }^{967}$ Hyd. praef.; $1 ; 29 ; 79 ; 110 ; 112 ; 127 ; 129 ; 228$.

968 Hyd. praef. 6; 51.

${ }^{969}$ Hyd. 13; 16; 25; 127; 30.

${ }^{970}$ Hyd. 79; 112; 228; 97; 100; 137.

${ }^{971}$ Muhlberger 1990, 235; Burgess 1988a, 198. A gallaeciai pogányság működéséről lásd: Molé 1975, 94-96.

${ }^{972}$ A keresztény hit elhagyásával kapcsolatos jogi szankciókat lásd: Sáry 2009, 50-53.
} 
eretnekmozgalmak említésekor meg sem próbálta elemezni a tanításukat, az arianizmus terjedésére vonatkozó egyetlen utaláson kívül nem is akarta pontosan megmagyarázni az olvasóinak, hogy milyen módon állnak szemben az ortodoxiával, ezért semmi sem igazolja, hogy valójában megértette volna az általa elítélt eszméket. ${ }^{973}$ Hydatius nem érdeklődött az eretnekségek fejlődése iránt sem, több alkalommal össze is keverte vagy félremagyarázta a mozgalmakat, emiatt feltételezhető, hogy nem azért harcolt ellenük, mert nem értett egyet a tanításukkal, hanem azért, mert azok gyengítették az ortodoxia helyzetét és válságba sodorták a birodalmi irányítást, emiatt pedig nem fontos, hogy ismerte-e pontosan az eretnek tanításokat, vagy hogy rendelkezett-e egyáltalán ilyen irányú képzettséggel. ${ }^{974}$

\subsubsection{Az arianizmus és Róma egyházi primátusának kezdete}

Hydatius élete végén már nem volt jelentős tényező Gallaeciában az arianizmus, mégis sokat foglalkozik a tanításukkal, ráadásul olyan látszatot kelt, mintha az arianusok szövetkeztek volna a barbár népekkel, hogy letelepedésük után hasznot húzzanak ebből a kapcsolatból és még szélesebb körben terjesszék el téves tanításukat. ${ }^{975}$ Ennek egyik oka az lehet, hogy az arianizmus hosszú időn keresztül rendkívül népszerü volt a barbár népek körében, ezért Hydatius általános értelemben ezt a mozgalmat tartotta a legveszélyesebbnek a birodalmi egyház tanításával szemben. Az arianizmus kialakulásának és terjedésének alaposabb vizsgálata azonban nemcsak azért érdekes számunkra, mert az ezzel kapcsolatos dogmatikai kérdések nagy mértékben megosztották a katolikus püspököket és befolyásolták a birodalmi egyházat vezető pápa tekintélyét, hanem mert a jelenség politikai ellentéteket is gerjesztett és segítette a barbár népek elkülönülését a Rómához füződő kapcsolataikban. ${ }^{976}$ A legtöbb kutató szerint az arianizmus azért válhatott a korszak legveszélyesebb eretnekmozgalmává, mert tanítása ,a felületesen gondolkodó emberek számára logikusnak tünt, igy az egész kereszténységet képes lett volna romba dönteni”, ${ }^{977}$ ráadásul „benne

\footnotetext{
973 Hyd. 228; Burgess 1988a, 205; 214.

${ }^{974}$ Burgess azt is vizsgálta, hogy Hydatius tisztában volt-e az ortodox nézetekkel. A Hispaniában forgalomban levő három hitvallás közül kettőt Hydatius bizonyíthatóan jóváhagyott és alkalmazott is püspöki müködése során, vö. Burgess 1988a, 262-263.

${ }^{975}$ Muhlberger 1990, 235; 267.

976 Horváth 1999, 45.

977 Sáry 2009, 120.
} 
összegzödnek a keresztény teológia ingadozásai", ${ }^{978}$ ennélfogva a népszerüsége miatt kibontakozó dogmatikai viták „komoly sérüléseket okoztak az egyház egységében."979

Ahogyan fentebb megállapítottuk, Hydatius még rövid összefoglalót sem nyújtott olvasóinak az arianizmus korai történetéröl, a 4-5. század hatalmi és vallási viszonyainak megismeréséhez azonban elengedhetetlennek látszik a fenti szempontok bővebb elemzése. Már a 4. század első felében folyamatosan nőtt a feszültség a keleti és a nyugati egyházak között, nemcsak Róma primátusi igényének erősödése miatt, hanem a szentháromságtani viták során és az arianusokkal szemben kialakult eltérő álláspontok következtében, ${ }^{980}$ mindez pedig arra ösztönözte az egyházat, hogy pontosítsa a Krisztus személyéhez, illetve isteni és emberi természetéhez kapcsolódó fogalmakat. Arius, az alexandriai Baucalistemplom presbytere (260 k.-336) vitába keveredett Alexanderrel, a város püspökével, amikor azt hirdette, hogy Krisztus nem egylényegü az Atyával, hanem csak annak teremtménye, ezért nem is lehet örökkévaló. ${ }^{981}$ Arius rövid idő alatt híveket gyüjtött maga köré Alexandriában, így az eredetileg helyi jelentőségü vita a birodalom keleti felében egyre nagyobb visszhangra talált, népszerüségét pedig még az sem csökkentette, hogy a 318-as alexandriai zsinaton az africai püspökök kiközösítették őt az egyházból, tanítását pedig eretneknek nyilvánították. ${ }^{982}$ Constantinus kérésére tanácsadója, a cordubai Osius püspök eleinte megpróbált közvetíteni Arius és a császár között, de ez nem járt sikerrel, ezért a 322ben összehívott alexandriai zsinat száz püspöke és a 324-ben rendezett anctiochiai tanácskozás ismét elítélte Arius tanítását.

A 325-ben összehívott nicaeai zsinaton Ariusnak már saját maga kellett megvédenie az álláspontját, ${ }^{983}$ a résztvevő püspökök közül ${ }^{984}$ tizenheten a nicomediai Eusebius vezetésével Ariust támogatták, a többség viszont elfogadta a Krisztus istenségét pontosító nicaeai hitvallást. ${ }^{985}$ A császár által birodalmi törvényként is kihirdetett dogmát végül csak

\footnotetext{
978 Lafont 1998, 72. Az arianizmus teológiai vonatkozásairól bővebben: Lafont 1998, 71-78.

979 Timkó 1971, 137-138.

980 A keresztény gondolkodók egy része már a 2-3. század fordulóján elutasította az Atya és a Fiú közötti alárendelést (subordinatio), és a monarchianizmus jegyében Krisztus egységét hangsúlyozta. Theodotus, Samosatai Paulus, Órigenés és Sabellius nézeteiről bővebben: Frenyó 2002, 87-91; Chadwick 1999, 78-82; Vanyó 2007a, 318-323.

981 Arius teológiai nézeteiről és az arianizmus tanításáról bővebben: Socr. 1,5-6; Hanson 1988; Barnes Williams 1993; Ayres 2004; Vanyó 2009, 380-390; Berndt - Steinacher 2014.

982 PG 18,585-604. Arius ezt követően Palaestinába, később Nicomediába ment, ahol ifjúkori barátja, a nicomediai Eusebius támogatásával terjesztette nézeteit.

${ }^{983}$ Eus., Vita Const. 3,6-23; Socr. 1,8; Theodor. 1,6-13.

984 A zsinaton 220 püspök jelent meg, közülük csak heten voltak a nyugati egyház képviseletében, vö. Vanyó 2007b, 17; de tudunk egy vagy két gót püspökről is, vö. Török 1999, 90; Gárdonyi 2006, 106.

985 Az alexandriai Alexander, Athanasius diaconus, az ancyrai Marcellus és az antiochiai Eustathius által kidolgozott hitvallás szövegét lásd: Vanyó 2009, 390-395. Az új megfogalmazás szerint Krisztus öröktől
} 
két püspök nem írta alá, őket Ariusszal együtt eretneknek nyilvánították és számüzték az egyházból. ${ }^{986} \mathrm{Ma}$ is vita tárgyát képezi, hogy Constantinus „politikai számításból” vagy személyes meggyőződés miatt támogatta a kereszténységet. Úgy tünik, hogy valójában nem ismerte fel az arianusokkal folytatott vita teológiai jelentőségét és nem is törekedett arra, hogy valamelyik fél mellett állást foglaljon, mivel a legtöbb érv a személyes megtérése ellen szól, ${ }^{987}$ ugyanakkor kétségtelen, hogy saját védőistenének tekintette a keresztények Istenét, az elfogadott formulával pedig megpróbált békét teremteni a viszálykodó felek között, vagyis politikai célokra használta fel a kereszténységben rejlő erőket. ${ }^{988}$

Constantinus igyekezett egyre szorosabbra füzni a keresztény egyházhoz való viszonyát, ennek köszönhető, hogy uralkodásától a császári hatalom szövetségeseként és a birodalom szerves részeként kezelték az egyházat. Már a 313-as mediolanumi edictum alapján „official religion"-nak tekintették a keresztény vallást, ${ }^{989}$ mivel jó néhány kedvezményt rögzítettek az egyház vezetői számára, később még több kiváltságban részesültek és szélesebb körben terjeszthették az ortodox tanítást, ${ }^{990}$ cserébe viszont a császár is elvárta, hogy az egyház támogassa a politikáját és járuljon hozzá a birodalom helyzetének megerősítéséhez. ${ }^{991}$ Mivel a császár a birodalmi egyház védelmezőjeként garantálni tudta a kereszténység rendkívül gyors terjedését, személye az állam urából az állam gondnoka és Isten szolgája lett, ${ }^{992}$ aki a külsö ügyek püspökeként (episkopos tón ektos)

fogva létezett, az Atyától elválaszthatatlan és vele egylényegủ (homousios), tehát nincs közöttük subordinatio, vö. Jedin 1998, 19. A trinitológiai vita újkori vonatkozásairól lásd: Frenyó 2002, 24-27.

986 Eus., Vita Const. 3,18-19; Athan., De syn. 5; Apol. c. arian. 71.

${ }^{987}$ Gárdonyi 2006, 62-63. Constantinus „lelki kétarcúságát” jól tükrözi, hogy megtartotta a pontifex maximusi címet, pénzérméin feltünik a pogányságot idéző Sol invictus jelző, Constantinopolis föterén pedig felállíttatta a saját arcvonásait viselő napisten szobrát, vö. Segesváry 1994, 61; Grüll 1998, 75; ennek ellenére egyes kutatók szerint mégis „öszinte és személyes inditékok vezettek” a kereszténység felvételéhez, vö. Foss - Magdalino 1990, 24.

988 Eus., Vita Const. 3,12. Constantinus megtérésének körülményeiröl bővebben: Alföldi 2005, 11-33; a pogánysággal kapcsolatos politikáját lásd: Socr. 18; CTh 907; Alföldi 2005, 65-92; Brandt 2007, 113-122; Sáry 2009, 14-17.

${ }^{989}$ López Quiroga - Martínez Tejera 2017, 477; Lact., De mort. pers. 48,1-30; Eus., Hist. Ecc. 10,5.

${ }^{990}$ Constantinus többek között szélesebb bírói jogkört és adómentességet adott a keresztény püspököknek, akiknek a korábbi gyakorlat alapján jogukban állt rabszolgákat felszabadítani és polgárjogot adományozni, ezenkívül magas állami címeket viseltek és igénybe vehették az állami postaszolgálatot. Az egyházi személyeket kivonta a katonáskodási kötelezettség és a világi bíróságok joghatósága alól, végrendeletben bárki az egyházra hagyhatta a vagyonát, a katolikus templomok pedig menedékjogot adhattak a polgároknak. Az egyház jelentős császári birtokokkal, arany és ezüst kegytárgyakkal gazdagodott, számos bazilika épült, a lateráni palota Róma püspökéhez került, a vasárnap pedig ünnepnappá vált az egész birodalomban, vö. Havas - Takács - Tegyey 2001, 153-154; Gárdonyi 2006, 60-61. Constantinus keresztényeket támogató rendeleteiről és az egyház jogi helyzetének rendezéséről bővebben: Alföldy 2005, 34-44; Sáry 2009, 77-106.

${ }^{991}$ A 314-es arelatéi zsinaton például az egyház kiátkozással fenyegette meg azokat, akik a katonai szolgálatot megtagadták, vö. August., De Civ. 5,25.

${ }^{992}$ Socr. 1,9; Sáry 2009, 59; Halsall 2007, 100; Kelemen 2007, 14. 
egyfajta charisma birtokában ${ }^{993}$ gyakran bele is avatkozott az egyházon belüli teológiai vitákba, hogy ezzel is biztosítsa a katolikus vallás egységét és a császári hatalom ideológiai alapját. ${ }^{994}$ Eusebius Constantinus uralkodásának 30. évfordulóján mondott beszédében kifejtette, hogy a császár a hatalmát és erényeit Istentől kapta, ő az az uralkodó, akit Dávid próféciájában megjövendölt egy „,messianic kingdom” élén, ${ }^{995}$ ezért a pietas birtokában Isten földi helytartója és az egyház legföbb védelmezőjeként episcopus episcoporum lett, ${ }^{996}$ vagyis a püspökök fölött állva joga van beleszólni az egyház külső és belső ügyeibe egyaránt. ${ }^{997}$ Constantinus a birodalmi egység fenntartása érdekében megtartotta a dominus et deus cím mellett a pontifex maximus és a restitutor urbis titulusokat, ezenkívül „megörizte az uralkodó szakralitását” is, hiszen Isten kiválasztottjaként, egyfajta karizmatikus hatalom birtokában avatkozott bele a vallási ügyekbe, ez pedig elősegítette rövid távon a katolikus vallás megszilárdulását és a birodalmi egység biztosítását. ${ }^{998}$

Ennek ellenére az arianizmus népszerüsége a nicaeai zsinat után sem csökkent, mivel az arianus hit alkalmasabbnak tünt a „monarchia eszmevilágának szimbolikus megjelenitésére", 999 így a constantinopolisi arianusok egyre nagyobb hatást gyakoroltak még a császár környezetében lévő személyekre is, uralkodása végén pedig maga Constantinus is a befolyásuk alá került. ${ }^{1000} \mathrm{Az}$ ő nyomásukra 328-ban a nicomediai Eusebius és Arius is visszatérhetett a számüzetésből, de csak később került sor végleges rehabilitációjukra. Constantinus halála után Constans és II. Constantius apjukhoz hasonlóan igyekeztek beleszólni az egyház ügyeibe, de egyre többször megkérdőjelezték a császárok ilyen irányú felhatalmazását, ezért a keleti és a nyugati területek püspökei Arius 337 körüli halála után is eltérő véleményt képviseltek az arianizmussal kapcsolatban. ${ }^{1001}$ A béke

\footnotetext{
${ }^{993}$ Meyendorff 2001, 52. Már Augustus korától kezdve rendelkezett a princeps egyfajta vallási charismával, amely kultikus tiszteletet biztosított számára, a késő császárkorban pedig egyenesen a summa divinitas kiválasztottjaként az összes földi dolog fölötti kormányzás jogát megkapta, vö. Alföldy 2000, 102; 177.

${ }^{994}$ Szántó 1983, 141-142; 148; Havas 1998, 49.

${ }_{995}$ Wallace-Hadrill 1967, 13; Marincola 2007, 299-300. Eusebius és Constantinus viszonyához lásd: Barnes 1981.

${ }^{996}$ Drake 2007, 408-409; Szántó 1983, 145.

${ }^{997}$ Eus., Hist. Ecc. 10,8,18; Cameron 2007a, 107-108. Eusebius ezzel megteremtette a „keresztény császáreszme ideológiáját", vö. Timkó 1971, 91. Az uralkodók egyházzal való együttmüködése innentől kezdve saját hatalmuk megóvását is elősegítette az egész középkorban, vö. Southern 1987, 19.

${ }_{998}$ Vanyó 2007a, 208; Klaniczay 2005, 19; Sághy 2007, 9; Sáry 2009, 120.

${ }^{999}$ Sáry 2009, 59. Az arianizmus 325-381 közötti terjedéséről lásd: Vanyó 2009, 405-414.

${ }^{1000}$ Különösen mostohahúga, Constantia, a császárt megkeresztelő nicomediai Eusebius és a tanácsadók közé tartozó caesareai Eusebius került kapcsolatba az arianusokkal, vö. Szántó 1983, 152.

1001 Horváth 2004, 77; PG 25,685-687. Keleten az arianusokkal rokonszenvezö II. Constantius ugyan külsőségekben és szertartásokban megtartotta a keresztény szokásokat, ezért felruházták öt az imperator Christianissimus jelzővel, de a nicaeai dogmát hirdető Athanasiust 335-ben Treveribe számüzte, helyére pedig a cappadociai Gregoriust állította Alexandriában, míg 339-ben Constantinopolis patriarchája a nicomediai
} 
helyreállítása érdekében 343-ban zsinatot hívtak össze a két birodalom határán fekvő Serdicában, de a keleti és a nyugati püspökök egymás iránti bizalmatlansága miatt itt sem sikerült közelíteni az álláspontokat. A keleti püspökök ezután átmentek a saját területükön lévő Philippopolisba, a nyugatiak pedig Serdicában határoztak arról, hogy a tartományi zsinatok döntései ellen csak a pápához lehet fellebbezni, mert kizárólag neki van joga a regionális döntések felülvizsgálatára, ${ }^{1002}$ ezzel a nyugati területeken jogilag is rögzítették Róma primátusát, keleten viszont nem sikerült hasonló megállapodást elérni.

Constans meggyilkolása után II. Constantius már az egész birodalom fejeként lépett fel a katolikusok ellen, ${ }^{1003}$ tanácsadója, a mursai Valens javaslatára pedig a 357-es sirmiumi zsinaton egy olyan hitvallási szöveg elfogadását javasolta, amely kevésbé egyértelmü megfogalmazásával kompromisszum lehetett volna a keleti és a nyugati püspökök számára. ${ }^{1004}$ A 359-es ariminiumi zsinaton az arianusok feltartóztattak csaknem 400 nyugati püspököt, hogy fogadják el az új szöveget, Constantius pedig hiába fenyegette őket száműzetéssel, ők mégis kiálltak a nicaeai hitvallás mellett. ${ }^{1005}$ A 360-ban Constantinopolisban jóváhagyott kompromisszumos formula végül mégsem hozta meg a várt eredményt, mert a császár egységesítő törekvései kudarcba fulladtak és az arianus irányzat még több pártra szakadt, 362-ben pedig az alexandriai zsinat döntése alapján a nicaeai hitvallást elfogadó püspökök visszakaphatták a hivatalaikat, ha korábban kényszerítés miatt tértek át az arianus hitre. ${ }^{1006}$ Iulianus a pogányság javára igyekezett felszámolni a keresztény egyház kiváltságait, ${ }^{1007}$ de 363-ban Iovianus visszavonta ezeket a

Eusebius lett. A nyugati püspökök egy ideig meg tudták őrizni a császártól való függetlenségüket, de amikor 339-ben I. Iulius pápa Rómába hívta a II. Constantius által leváltott Athanasiust és Marcellust, ök is belekeveredtek a vitába. A 340-es római zsinaton Iulius jogtalannak ítélte az alexandriai hivatalváltást, a 341es antiochiai tanácskozáson viszont a keleti püspökök kitartottak álláspontjuk mellett, vö. Sozom. 3,8; Chadwick 2007, 567.

1002 Athan., Apol. c. arian. 45; Theodor. 2,8,37-38; Socr. 2,20; Sulp. Sev., Chr. 2,38; Jedin 1998, 21; Hunt 2007, 241. Különösen azokban az esetekben vált ez gyakorlattá, amikor a tartományi zsinatokon megfosztottak egy püspököt a hivatalától, hiszen Rómának jogában állt az ítéletet megerősíteni, vagy felfüggeszteni és az ügyet egy másik zsinat elé rendelni, vö. Denzinger - Umberg 1942, 57.

${ }^{1003}$ A 353-as arelatéi zsinaton rákényszerítette a püspököket az időközben visszatért Athanasius leváltására, a 355-ös mediolanumi tanácskozáson pedig vele együtt számüzte azokat, akik nem értettek egyet a püspök kiközösítésével, vö. Athan., Hist. arian. 35-41; Sulp. Sev., Chr. 2,3. 356-ban három legiót is vezényelt Alexandriába Athanasius ellen, de a hatóságokkal és a császárral szemben kirobbant felkelést kihasználva Athanasiusnak sikerült Egyiptomba szöknie.

${ }^{1004}$ Vanyó 2007b, 29-30; Edwards 2007, 372. A politikailag észszerü, de teológiailag kevésbé elfogadható megoldás szerint az új szöveg az Atya és a Fiú hasonlóságát (homoios) hangsúlyozta, nem szerepelt viszont benne a sok vitát okozó lényeg (ousia) kifejezés; vö. Socr. 2,41; Sozom. 4,24; Theodor. 2,28.

${ }^{1005}$ Socr. 2,37,40; Jedin 1998, 22.

${ }^{1006}$ Socr. 3,7; Chadwick 2007, 571-572.

${ }^{1007}$ Iulianus eltörölte a püspökök bíráskodási jogát és az egyházi személyek adómentességét, a II. Constantius által 356-ban átadott pogány templomok pedig ismét kikerültek a keresztények kezéből, vö. Grüll 2007, 97; Sáry 2009, 22; Németh - Hegyi 2011, 558. 
rendeleteket, Valentinianus pedig nem avatkozott bele korának vallási kérdéseibe és meg sem próbálkozott azok megoldásával, így nagyfokú toleranciát gyakorolva minden vallási csoport müködését engedélyezte a manicheusok kivételével. ${ }^{1008}$ A nyugati tartományok közül elsőként Gallia püspökei léptek fel az arianusok ellen 361-ben a pictaviumi Hilarius vezetésével, ${ }^{1009}$ a mozgalom visszaszorításában pedig különösen Ambrosiusnak vannak jelentős érdemei, akit az arianus Auxentius után 374-ben választottak Mediolanum püspökévé. ${ }^{1010}$ A keleti tartományokban a 360-as évektől újabb kérdések merültek fel Krisztus személyével és a Szentháromsággal kapcsolatban, ${ }^{1011}$ ezekre Basileius, Caesarea püspöke és Cappadocia metropolitája találta meg a választ. ${ }^{1012}$

Gratianus császár és Damasus pápa politikája a nyugati és a keleti területeken egyaránt a nicaeai dogma megerősödését eredményezte, hiszen Valentinianus toleranciájától eltávolodva gyakorlatilag felszámolták a vallásszabadságot. Gratianus Ambrosius javaslatára 376-ban lemondott a pontifex maximusi címről, így véget vetett annak a gyakorlatnak, hogy az állam kötelező jelleggel gyámkodik a nem keresztény irányzatok és a pogányság fölött is. ${ }^{1013} 380$. február 27-28-án Gratianus és Theodosius a közösen kiadott thessalonikéi rendeletben ${ }^{1014}$ a keleti területek lakosságának is kötelezővé tette a nicaeai dogma elfogadását, és a birodalom összes lakosának megparancsolta, hogy abban a vallásban éljenek, amelyet a római pápa, Damasus és az alexandriai patriarcha, Péter helyesnek tart. ${ }^{1015}$ Theodosius azzal, hogy elsőként határozta meg az ortodoxia kritériumait, a kereszténységet államvallásává emelte, így a hatalommal szembeni engedelmesség ezentúl

\footnotetext{
1008 Amm. Marc. 30,9,6; CTh 9,16,9. Az egyezség ellenére Athanasiusnak további számüzetéseket kellett elviselnie: 362-ben Iulianus, 365-ben pedig Valens császár távolította el őt hivatalából. Athanasius híveinek nyomására 366-ban mégis visszatérhetett Alexandriába, ahol 373-ban bekövetkező haláláig vezette a püspökséget. Athanasius életéröl és müveiröl bővebben: Vanyó 2007b, 100-112; PG 25-28.

${ }^{1009}$ Hilarius a cappadociai számüzetése idején 356-359 között ismerte meg az arianusok mozgalmát. Hilarius életéről és műveiről bővebben: Albrecht 2004, 1320-1323; Vanyó 2007b, 275-280; PL 9-10; CSEL 22; 65.

1010 Ambrosius arianusok elleni sikereiről lásd: Williams 2017, 167-175; Ambrosius életéröl és műveiről bővebben: McLynn 1994; Albrecht 2004, 1324-1336; Vanyó 2007b, 280-290; Adamik 2009, 769-777; PL $14-17$.

1011 A constantinopolisi Macedonius elfogadta a nicaeai hitvallás Krisztusra vonatkozó részét, de tagadta a Szentlélek istenségét, vö. CTh 16,5,11-13; 16,5,59-60.

1012 Basileius szerint az ousia (lényeg) az Atya és a Fiú egységét fejezi ki, a hypostatis (személy) pedig a közöttük lévő különbségre utal, Istennek tehát egy természete (mia ousia) van, de benne megkülönböztetünk három személyt (treis hypostateis), amelyek ugyanazzal a lényeggel rendelkeznek, vö. Althaner 1947, 166; Gárdonyi 2006, 81; Chadwick 2007, 565-566. Basileius életéröl és müveiről bővebben: Vanyó 2007b, 119129; Vanyó 2009, 420-426; PG 29-32.

${ }^{1013}$ Ezt a pogány eredetű titulust Augustus óta a római császárok a birodalmon belüli vallások felügyeleti jogának kifejezésére használták, a lemondással viszont megszünt a császár és a nem keresztény vallások közötti intézményes kapcsolat, vö. Randers-Pehrson 1993, 65.

${ }^{1014}$ CTh 16,1,2. A rendelet datálásáról bővebben: Sáry 2009, 60, 212. j.

1015 Zimmermann 2002, 10; Curran 2007, 103. Ambrosius hálából Gratianust felruházta a Christianissimus és a fidelissimus jelzőkkel, bár a császár nem is volt megkeresztelve.
} 
a birodalmi egyháznak való engedelmességet is jelentette, ráadásul hivatalosan is lehetővé vált, hogy a keresztény vallási parancsok megszegőin kívül üldözzék a pogány, a zsidó és az eretnek tanítások követőit is. ${ }^{1016}$ Mivel keleten a rendelet hatására sem mutattak engedelmességet az arianus püspökök, a 381-es aquileiai zsinaton arról is határoztak, hogy a keresztények nem térhetnek át más vallásra, betiltották az összes szekta és eretnekmozgalom müködését, átadták az arianusok templomait a katolikusoknak, az arianizmus híveit kitiltották a városokból, ráadásul elsőként bocsátották el a pogányokat a magas rangú állami és katonai hivatalokból, helyettük pedig szinte kizárólag keresztényeket neveztek ki. ${ }^{1017}$

Theodosius az egyházon belüli egység megteremtése érdekében egy újabb zsinatot hívott össze Constantinopolisban, a nyugati területek és Alexandria ugyanis határozottan elutasították az újításokat, Antiochiában pedig egy kisebb szkizma is kialakulóban volt. A 381 májusában kezdődő tanácskozásra csak a keleti egyház püspökei kaptak meghívást, közülük is csak 150-en jelentek meg a tárgyalások kezdetén, Damasus pápa pedig még csak nem is képviseltette magát, a nyugati püspökök viszont nem sokkal később Aquileiában kezdtek tanácskozni. ${ }^{1018}$ A zsinaton elítélték az arianizmust az összes irányzatával együtt, megtiltották az egész birodalomban az arianus szertartásokat, a templomokat át kellett adni a katolikusok számára, a nicaeai hitvallás szövegét pedig kiegészítették a Basileius által megfogalmazott formulával. ${ }^{1019}$ A jelentősebb patriarchatusok egymáshoz való viszonyát

1016 CTh $9,16,2 ; 16,2,5 ; 16,2,25 ; 16,5,1 ; 16,10,10$; Sáry 2009, 61. A 4. századi Rómában ugyan jelentős keresztény közösségek múködtek, de mivel a római arisztokrácia nagy része még ragaszkodott a pogány kultuszokhoz és a városi praefectust is általában a pogányok közül jelölték ki, Róma megörizte pogány arculatát. A felső rétegekben csak a 4. század második felétől voltak gyakoribbak a megtérések, míg a vidéki lakosság jelentős része sokáig megőrizte a pogány szokásokat, vö. Angenendt 2008, 91; Segesváry például Róma 410-es gót ostromakor még jelentős pogány csoport létezéséröl tud, vö. Segesváry 1994, 63. Ambrosius arra is rávette Gratianust, hogy 383-ban távolítsa el a senatusból a Victoria-oltárt és szüntesse meg a Vestapapnők, az állami ünnepek és áldozatok, valamint a papi testületek támogatását, vö. Adamik 2009, 773-775. 384-ben egy küldöttség ugyan megpróbálta elérni, hogy II. Valentinianus ismét támogassa a pogányságot, de Ambrosius az államvallásra hivatkozva sikeresen megvédte álláspontját, vö. Symm., Rel. 3; Ambr., Ep. 18,1516; Grüll 2007, 98-99.

${ }^{1017}$ Adriányi 2001, 152. Később II. Theodosius és III. Valentinianus is hozott olyan rendeletet, mely szerint a nagy anyagi terhekkel járó curialisi hivatal kivételével csak katolikusok tölthettek be állami tisztségeket, vö. Alföldy 2000, 200; Kelemen 2007, 84-85.

1018 A zsinaton kezdetben a Theodosius által támogatott Meletius antiochiai patriarcha elnökölt, halála után pedig a constantinopolisi patriarchát, Gregorius Nazianzenust választották elnöknek, de jó néhány zsinati atya tiltakozása miatt lemondott és átadta a helyét Nectariusnak, vö. Fliche - Martin 1947, 3,287-289; PG 37,1157-1159. Gregorius Nazianzenus életéről és műveiről bővebben: Vanyó 2007b, 129-151; PG 35-38.

1019 CTh 16,1,3; Sáry 2009, 63. A hitvallás szövegét és elemzését lásd: Vanyó 2009, 429-442. Jelentős szerepet vállalt a hitvallás megszerkesztésében Basileius öccse, a nyssai Gregorius, akit arianusellenessége miatt 375-ben elüztek, és csak Valens császár 378-as halála után térhetett vissza hivatalába. Nyssai Gregorius életéről és müveiröl bővebben: Croke 2007, 575-576; Vanyó 2007b, 151-173; Vanyó 2009, 484-497; PG 4446. 
úgy szabályozták, hogy Alexandria és Antiochia továbbra is megtarthatta a nicaeai zsinat 6 . kánonjában rögzített előjogokat, de a constantinopolisi zsinat 3. kánonja szerint Róma püspöke után tekintélyben közvetlenül Nova Roma, vagyis Constantinopolis patriarchája következik. ${ }^{1020}$ Constantinopolis hatalma így jogilag is erősödött a többi keleti püspökséghez, különösen Alexandriához képest, ezért a nyugati püspökök azonnal heves tiltakozásba kezdtek, mert a döntéssel megkérdőjeleződni látták Róma elsőbbségét. Bár a 381-es zsinaton csak a keleti egyház püspökei vettek részt, határozatait később a pápa általános jelentőségük miatt az egész egyház döntéseinek ismerte el és nyugaton is kötelezővé tette a püspökségek számára. ${ }^{1021}$

Theodosius intézkedéseinek és az eretnekmozgalmakat sújtó szankcióknak köszönhetően az egész birodalom hivatalos vallása a katolikus lett, ${ }^{1022}$ amelynek egyedüli és hivatalos képviselője a birodalmi egyház. A katolikusok még mindig számos állami kiváltságban részesültek, az egyházi vezetőket pedig a hatalmi rendszer támaszaként rendkívül nagy tisztelet övezte a császári udvarban, különösen szembetünő ez Ambrosius esetében, aki egy „új típusú püspök” ideáját megtestesítve az egyház tekintélyét és függetlenségét védelmezte a világi hatalommal szemben, nagy hatást gyakorolva így nemcsak Theodosius valláspolitikájára, hanem személyes lépéseire is. ${ }^{1023}$ Ambrosius elképzelhetetlennek tartotta, hogy a keresztény egyházat (sacerdotium) és a birodalmat (imperium) szét lehessen választani egymástól, mivel a világtörténelem és az egyház története szorosan összekapcsolódik, ${ }^{1024}$ ugyanakkor a császár egyház fölötti hatalmát megkérdőjelezve elutasította, hogy a püspökök feletti ügyekben a császár ítélkezzen zsinati tanácskozás helyett, mivel az uralkodó „az egyházban van, nem pedig felette”, éppen ezért „,nem ura, hanem támasza” az egyháznak. ${ }^{1025}$ Ezt követően vált általános gyakorlattá, hogy

1020 A patriarchatusok viszonyáról bővebben: CTh 16,2,45; Gárdonyi 2006, 79-80; Hunt 2007, $246-249$. Constantinopolis alapításának egyházjogi jelentőségéről lásd: Timkó 1971, 83-84; Alföldi 2005, 107-116; Cameron 2007a, 103-105.

1021 Vanyó 2007b, 38-39. Jól látszik ebben az a gyakorlat, hogy a zsinatok egyetemessége nem azt jelenti, hogy az egész lakott föld összes püspöke teljes létszámban részt vesz a tanácskozáson; az elnevezés inkább csak arra utal, hogy a keresztény világ püspökeinek jelentős része képviselteti magát, és a pápa által jóváhagyott döntéseket az egész egyháznak el kell fogadnia, vö. Jedin 1998, 15; Hall 2007, 738-739.

${ }^{1022}$ CTh 16,5,9; Sáry 2009, 71.

1023 Klaniczay 2005, 122; Alföldy 2000, 187. Ambrosius a 7 ezer áldozatot követelő 390-es thessalonikéi vérfürdő miatt nyilvános bünbánatra kényszerítette Theodosiust, vö. Ambr., Ep. 51; Albrecht 2004, 1325; Curran 2007, 108; de az ő befolyása tükröződik a 391-392-ben hozott pogányellenes császári rendeletekben is, amelyek megtiltották a régi vallás gyakorlásának összes formáját és nagy zavargások közepette lerombolták a pogány templomokat is, vö. CTh 16,10,10; Randers-Pehrson 1993, 70-71; Curran 2007, 107-108; Sáry 2009, $22-23$.

1024 Albrecht 2004, 1331. Ugyanerre hivatkozik majd Iustinianus is, amikor beavatkozik az egyház ügyeibe, vö. Baán 1997, 19-22.

${ }^{1025}$ Ambr., Ep. 21,51; Adamik 2009, 768. 
a keresztény császárnak ugyan kötelessége volt az egyházat támogatni, amely cserébe legitimizálja az uralkodó hatalmát, de nem szólhat bele teológiai és egyházfegyelmi kérdésekbe, ${ }^{1026}$ ugyanakkor egyetlen olyan alkalmat sem tudunk a 4-5. századból, amikor az egyház tiltakozott volna az ellen, ha a császár hív össze egy zsinati tanácskozást. ${ }^{1027}$

II. Valentinianus anyja hatására 386-ban nyíltan kiállt a császári udvarban lévő arianusok mellett, elismerte a gyülekezési jogukat és az ellenük való fellépést halállal büntette, ezért az Ambrosiusszal elmérgesedett vitából kihátrálva székhelyét inkább áttette a nicaeai dogmát védő Mediolanumból Aquileiába, ${ }^{1028}$ 388-ban viszont a Theodosiusszal kötött egyezség alapján visszavonta rendeletét és az arianusokat sújtotta halálbüntetéssel. ${ }^{1029}$ Ambrosius egy esetben még arra is ösztönözni tudta a lakosságot, hogy szálljon szembe Iustina császárnő azon rendeletével, mely szerint egy katolikus templomot át kell adni az arianusoknak. ${ }^{1030}$ Theodosius ezt követően a katolikusok védelmében megtiltotta az arianusok vallásgyakorlását és büntetéssel fenyegette meg azokat, akik nyilvánosan vallási kérdéseket fejtegetnek. ${ }^{1031}$

Róma tekintélye az arianusokkal folytatott vita során kétségtelenül megnövekedett a nyugati egyházon belül, ennek köszönhetően egyre gyakrabban fordult elö, hogy galliai és hispaniai egyházi vezetők már nem saját elöljárójukhoz, hanem egyenesen Rómához fordultak tanácsért, különösen ha a helyi zsinatok döntései ellen próbáltak fellebbezni, a pápa képviseletében pedig vicariusokat küldtek a Rómától távoli egyházmegyékbe is. ${ }^{1032}$ Damasus a pápai hatalom bírói jellegét kiemelve elsőként használta a sedes apostolica kifejezést a leveleiben, ${ }^{1033}$ Siricius pápa pedig az egész egyház fölötti rendelkezési és felügyeleti jogra igényt tartott és erről az összes püspököt értesítette. ${ }^{1034}$ Míg azonban a római császár hatalmának gyengesége miatt a pápa fokozatosan kiterjesztette hatalmát a

\footnotetext{
${ }^{1026}$ Angenendt 2008, 77. Gelasius pápa 494-ben Anastasius császárhoz írt levelében a keresztény birodalom irányítását két egymást kiegészítő és segítő hatalmi tényezőre, a pápai auctoritasra és a császári potestasra bízta, de az oszthatatlan pápai hatalom nagyobb és elsődlegesebb a világi uralkodók tekintélyénél, vö. Gel., Ep. 8, in: PL 59,41-47; Timkó 1971, 92; Drake 2007, 412-416.

${ }^{1027}$ Angenendt 2008, 73.

1028 CTh 16,1,4; Sáry 2009, 64. Mediolanum a 4. századtól császári székhely és metropolita rangja miatt az észak-italiai térités központja volt, Aquileia viszont Italia és a keletről érkező barbárok érintkezési pontjaként alkalmas helynek tünt az arianizmus terjesztésére, vö. Angenendt 2008, 93-94.

${ }^{1029}$ CTh $16,5,15$.

1030 Sozom. 7,13. Amikor a császárnő fegyvereket is be akart vetni a rendelet végrehajtásához, akkor Ambrosius a hívekkel együtt zsoltárénekléssel húzta az időt, míg végül Iustina elállt a szándékától, vö. Adamik 2009, 768.

${ }^{1031}$ CTh 16,4,2; 16,5,16; Sáry 2009, 64.

1032 Brown 1999, 75; Zimmermann 2002, 10; Cortázar - Vesga 2001, 87, 24. j.

1033 Damasus levelei a zsinati határozatok és a császári leiratok mintájára íródtak, így akár pápai decretumoknak is tekinthetők, vö. CIL 1,2,221; Chadwick 1999, 224; Hunt 2007, 249-250.

${ }^{1034}$ Zimmermann 2002, 9; Angenendt 2008, 72.
} 
nyugati egyházak fölé, addig keleten versengés kezdődött az elsőbbségért: az 5. század első felében az alexandriai patriarchák kerültek vezető pozícióba, akik megpróbálták kiterjeszteni uralmukat egészen Egyiptomig. Ebben a hatalmi helyzetben Alexandria szövetségesének leginkább a római pápa számított, aki döntéseivel többnyire kedvezett Alexandriának, hogy gyengítse az egyre nagyobb hatalommal rendelkező constantinopolisi patriarchát. ${ }^{1035}$

Alexandria és Constantinopolis első nagy vitája Órigenésszel kapcsolatban tört ki, ${ }^{1036}$ amikor 392-ben Epiphanius salamisi metropolita Órigenést eretneknek nyilvánította. ${ }^{1037}$ Hieronymus nagy meglepetésre Epiphanius oldalára állt, barátja, az alexandriai Rufinus viszont védelmébe vette Órigenés tanítását, ${ }^{1038}$ így Theophilus alexandriai patriarcha csak egy rövid időre tudta kibékíteni az ellenfeleket egymással. ${ }^{1039} \mathrm{~A}$ vita színtere akkor tevődött át Constantinopolisba, amikor a város 398-ban kinevezett patriarchája, Iohannes Chrysostomus befogadott csaknem 50 Alexandriából menekülő órigenista szerzetest. Iohannes 401-ben ugyan megkeresztelte Eudoxia császárnét és fiát, II. Theodosiust, de amikor 403-ban Theophilus is Constantinopolisba érkezett és a chalcedoni császári birtokon megrendezték a tölgyfazsinatot (synodus ad quercum), nőellenes prédikációira hivatkozva száműzetésre ítélték Asia Minor tartományba. ${ }^{1040}$ Iohannes ugyan segítséget kért Innocentius pápától és más nyugati püspököktől, de továbbra is fenntartotta a kapcsolatot híveivel, ezért 404-ben még távolabbi helyre számúzték és itt élt 407-ben bekövetkezett haláláig. ${ }^{1041}$ Hydatius azt állítja, hogy az arianus hitű (Arrianam) Eudoxia a katolikus hite miatt ( ob fidem catholicam) fordult Iohannes ellen, valójában a püspök szenvedélyesen kritizálta az egyházon belüli visszaéléseket és szembefordult a fényüző életet élő Eudoxiával, ${ }^{1042}$ ezért elsősorban személyes és politikai sérelmek állhatnak az

\footnotetext{
1035 Heussi 2000, 133.

1036 Órigenést a háromszemélyü egy Istenről írt tanítása miatt sokan az arianizmus atyjának tartották és elítélték műveinek az olvasását. Tanításának kimerítő vizsgálatát lásd: Frenyó 2002, 53-86; Vanyó 2007a, 368-388; Vanyó 2009, 256-266; Heine 2010.

${ }^{1037}$ Epiphanius életéről és müveiről bővebben: Vanyó 2007b, 190-193; PG 41-42.

1038 Rufinus életéről és müveiről bővebben: Albrecht 2004, 1112; Vanyó 2007b, 292-293.

1039 Amikor Rufinus lefordította Órigenés egyik munkáját és Hieronymust Órigenés korábbi csodálójaként említette, ismét felerősödött a vita, Theophilus korábbi álláspontját feladva az alexandriai Órigenés-ellenesek pártjára állt, és 399-ben fegyveres szerzetesek segítségével elérte, hogy Órigenést elítéljék, követőit pedig üldözzék, a római Anastasius ezt a példát követve szintén elítélte Órigenést, Rufinust pedig Rómába hívatta, vö. Jedin 1962, 2,1,130.

1040 Socr. 6,15; Fliche - Martin 1947, 4,137-138.

${ }^{1041}$ Iohannes életéről és müveiről bővebben: Allen - Mayer 2000; Vanyó 2007b, 196-210; PG 47-64.

1042 Hyd. 29. Iohannes több ezer szegény élelmezésének anyagi fedezetét is előteremtette, kiváló példát mutatva abban, hogy a korszak püspökeinek minden téren segíteni kell a lakosság mindennapjait, vö. Segesváry 1994, 77; Hunt 2007, 262-263.
} 
üldöztetés hátterében, ugyanakkor sok ellenséget szerzett azzal is az egyházon belül, hogy patriarchiai jogait igyekezett az egyházmegye határain túlra is kiterjeszteni. ${ }^{1043}$ Iohannes és a nem arianus hitü Eudoxia bonyolult kapcsolatát Hydatius valószínüleg nem tudta értelmezni, ezért vallási okokkal próbálta magyarázni ellenséges viszonyukat. ${ }^{1044}$

Honorius Theodosius politikáját folytatva 405-ben a katolikus hit követésére szólította fel a lakosságot, 407-ben pedig az eretnekséget büncselekménynek nyilvánítva megtiltotta a gyülekezésüket. ${ }^{1045}$ Innocentius a pápai befolyás növelése érdekében új hivatalokat létesített, ${ }^{1046}$ a serdicai zsinat 3. kánonjára hivatkozva pedig felvette a rector ecclesiae Dei címet, ezért mondja Augustinus a pelagianizmus elítélésével kapcsolatban, hogy „Roma locuta, causa finita est." ${ }^{1047}$ Innentől kezdve a viták végső fórumának Rómát tekintették, minden fontosabb ügyről (causae maiores) tájékoztatni kellett a pápát, hogy ő hozzon benne döntést. ${ }^{1048}$ Zosimus és Bonifatius a pápa legfelsőbb bírói pozícióját azzal indokolta, hogy Péter örököseként Róma püspöke a princeps apostolorum vagy culmen apostolicum, akinek a hatalma a keleti és a nyugati egyházra egyaránt kiterjed. ${ }^{1049}$

Jelentős állomást jelent Róma egyházon belüli elsőbbségének megteremtésében Leo pápa regnálása, aki a Bibliára hivatkozva ${ }^{1050}$ próbálta igazolni, hogy Péter Krisztustól teljhatalmat (plenitudo potestatis) kapott az egyház és az apostolok irányításához, így a római pápa feladata, ${ }^{1051}$ hogy Krisztus földi helytartójaként (vicarius Christi) az összes püspök munkáját felügyelje. ${ }^{1052}$ Leo volt az első pápa, aki ténylegesen irányítása alá tudta vonni a nyugati egyházat, de átmenetileg a keleti egyházakra is kiterjesztette hatalmát, befolyása alá tartoztak Hispania és Észak-Africa püspökségei, Dél-Galliában pedig

\footnotetext{
1043 Jones 1964, 1,213; Vanyó 2007b, 201.

1044 Johnson 1993, 71. Elfogadható Burgess találó ötlete, mely szerint Hydatius összekeverte Iohannes és Eudoxia esetét Ambrosius és Iustina konfliktusával, vö. Burgess 1988a, 212; Duschesne 1912, 436-438; Drake 2007, 410-411.

1045 CTh 16,5,38; 16,5,40; 16,5,51; 16,11,2; Sáry 2009, 64-65.

1046 412-ben Thessaloniké püspökét vicariusszá nevezte ki, hogy hivatalossá tegye Róma és Illyricum Orientale kapcsolatát, és továbbra is megmaradjon pápai befolyása a 379-ben a keleti birodalomrészhez csatolt területek fölött. Bár Constantinopolis az 5. században többször is megpróbált változtatni a kialakult helyzeten, Róma egészen a 8. századig müködtetni tudta az új hivatalt, vö. Chadwick 1999, 226.

1047 August., Ep. 43,13. Augustinus életéről és müveiről bővebben: Deane 1963; Albrecht 2004, 1350-1387; Matthews 2005; Vanyó 2007b, 307-346; Adamik 2009, 792-806; PL 32-47.

${ }^{1048}$ Innoc., Ep. 29,1; 37,1.

1049 Angenendt 2008, 72; 157.

${ }^{1050}$ Mt 16,18; Jn 21,15-17; Lk 22,32.

1051 Hall 2007, 732. A pappas címet korábban magas rangú egyházi tisztségviselők, különösen a püspökök használhatták, Leótól kezdve viszont már kizárólag a római püspök titulusa lett, vö. Heussi 2000, 127.

1052 Török 1999, 78. Leo érveit használták fel később Róma elsőbbségének igazolására, és ennek érdekében még az Ecclesia Romana semper habuit primatum kezdetü 6. nicaeai kánont is meghamisították, amely 445-től már a De primatu ecclesiae Romanae címet viselte. A középkori egyházi okiratok hamisításának jelentőségéröl bővebben: Southern 1987, 107-109.
} 
sikeresen szembeszállt Hilarius püspökkel, aki az arelatéi metropolita függetlenségéért harcolt és a pápa megkérdezése nélkül hozott önkényesen döntéseket. ${ }^{1053}$ Leo még azt is elérte, hogy III. Valentinianus 445-ben egy edictumban erősítse meg Róma elsőbbségét a nyugati püspökségek fölött. ${ }^{1054}$ Ahogyan láttuk, Leo pápai hatalmát és világi ügyekben megmutatkozó befolyását a későbbiekben azzal próbálták még tovább növelni a történetírók, hogy az egykori fővárosban a császár szerepét átvéve 452-ben Attilát, 455-ben pedig Gaisericet rábeszélte a római lakosság megkímélésére. Constantinopolisban Leótól kezdve pápai apocrisiariusok állomásoztak, hogy biztosítsák Róma és a császár közötti kapcsolattartást és képviseljék Róma érdekeit a keleti udvarban, ${ }^{1055}$ később pedig Iustinianus is Theodosius rendeletét megerösítve a katolikus hitet tette kötelezővé a birodalom összes lakója számára, egyedül a gótoknak engedélyezte bizalmuk megtartása érdekében az arianus hit gyakorlását. ${ }^{1056}$

\subsubsection{Arianizmus a vandáloknál és a szvéveknél}

Nem tudjuk pontosan, hogy a vandálok mikor vették fel az arianus hitet. Török szerint már a 409-es betörés idején eretnekek voltak, Angenendt pedig úgy látja, hogy a vandálok már a dunai területükön csatlakoztak az arianus valláshoz. Horváth szerint 409-417 között érkeztek hozzájuk Hispaniába gót hittérítők, Burgess viszont meg van róla győződve, hogy 411-es letelepedésük idején már arianusok voltak, ezért amikor 420 körül Baetica felé vándoroltak tovább, Gallaeciában már sok követője volt az arianus hitnek. ${ }^{1057} \mathrm{~A}$ kérdés tisztázásában az is nehézséget jelent, hogy a vandálok a Kr. u. 2. század végén két csoportra szakadtak és egymástól elkülönülve éltek, ${ }^{1058}$ közülük a hasdingokról úgy tudjuk, hogy már Pannoniában kereszténnyé váltak, de Valens uralkodása alatt már az arianus hitet

\footnotetext{
${ }^{1053}$ Arelate 417-ben Zosimustól vicariusi tisztséget kapott, mivel ez a város lett a katonai és közigazgatási székhely Treveri helyett. Gallia püspökeinek felháborodása miatt a késöbbi pápák ugyan megfosztották a várost a szélesebb jogkörtől, Arelate viszont folyamatosan megpróbálta érvényesíteni korábbi előjogait a többi püspökséggel szemben. Arelate megnövekedett jogköréről és ennek hatásairól bővebben: Brown 1999, 74; Angenendt 2008, 97; 150-151; 200.

${ }^{1054}$ Valentinianus világi büntetéssel fenyegette meg azokat a nyugati püspököket, akik nem engedelmeskednek Róma parancsainak, vö. Zos., Ep. 1; PL 20,642-645; Chadwick 1999, 226.

1055 Zimmermann 2002, 13; Szántó 1983, 204.

${ }^{1056}$ A pápai primátus az általunk vizsgált időszakon túl, Gregorius Magnus pápa idején válik majd teljessé, aki consul Dei-ként az egész egyház fölötti vezetést felvállalta, és önmagát elöször nevezte servus servorum Deinek, vö. Gárdonyi 2006, 94-95.

1057 Török 1999, 104; Angenendt 2008, 178; Horváth 1999, 51; Burgess 1988a, 198; Greg. Tur. 10,2,2.

${ }^{1058}$ A siling vandálok eredetileg a mai Szilézia területén telepedtek le, a hasding vandálok a Visztula és a Dnyeper felső folyásánál éltek, később a hasdingok 248-tól pannoniai területre húzódtak, a silingek pedig 277től a Majna felső szakaszához vándoroltak, vö. Kiss 2008, 9-10.
} 
gyakorolták, vagyis a gótok térítő hatása a vandálok esetében is valószínü, de nem bizonyítható egyértelműen. ${ }^{1059}$

Hydatius ábrázolása szerint Gaiseric volt saját korának legnagyobb hatalommal rendelkező eretnek uralkodója, aki nemcsak hogy a katolikus hitről tért át az arianizmusra, hanem a katolikus vallást elárulva más barbár népekkel is szövetkezett. ${ }^{1060}$ Mivel Hydatius 428-hoz kapcsolt állítása az egyetlen forrás arra vonatkozóan, hogy Gaiseric hitehagyottá vált (effectus apostata), a legtöbb kutatóhoz hasonlóan el kell fogadnunk ezt a feltételezést. ${ }^{1061}$ Carthago 439-es elfoglalásakor Hydatius elkeserítőnek tartja, hogy Gaiseric különösen kegyetlenül (elatus inpie) bánt a katolikus lakossággal, hiszen a város püspökét és papságát elüzte, a szentek nyughelyeit feldúlta (demutatis ministeriis sanctorum), a katolikus templomokat pedig az arianusoknak adta (tradidit Arrianis), akik Isidorus szerint lakóhelyként használták ezeket az épületeket. ${ }^{1062}$ Ezek alapján azt látjuk, hogy a vandálok körében az arianizmus még rendkívül népszerü volt az 5 . század közepén, és annak ellenére, hogy az arianus vandálok a katolikus római lakosság mellett éltek saját patriarchájuk irányítása alatt, biztosan nem jöhetett létre közöttük semmiféle vallási együttműködés, mert Gaiseric kifejezetten az észak-africai keresztény közösség meggyengítésére törekedett. ${ }^{1063}$ Miután 439-ben az arianizmus a vandálok egységes államvallása volt, Gaiseric a többi barbár királytól eltérően saját politikai szolgálatába állította az arianus hitet. A források tanúsága szerint rendkívül agresszív intézkedéseket hozott a katolikusokkal szemben, az egyházi vezetőket és a földbirtokosokat száműzte, ráadásul a radikális lépések miatt más területek arianus közösségeivel sem alakítottak ki semmiféle kapcsolatot. ${ }^{1064}$

Ennek a folyamatnak sajátos példája Panormus 440-es ostroma, ahol a siciliai katolikus püspökök kiközösítették (damnati a catholicis episcopis) Maximinust, az arianusok vezetöjét. Maximinus ezt követően erőszakkal próbálta a katolikusokat az arianusok hitetlenségére (in impietatem Arrianam) kényszeríteni, és néhányan ugyan megadták magukat, de a legtöbben kitartottak és vértanúságot szenvedtek, ${ }^{1065}$ vagyis a nagyszabású üldözés ellenére Siciliában még kevésbé tudott teret hódítani az arianizmus. ${ }^{1066}$

\footnotetext{
${ }^{1059}$ Courtois 1955, 36; Thompson 1982, 157; Wood 2007a, 712.

${ }^{1060}$ Hyd. 79: de fide catholica in Arrianam transisse perfidiam; Muhlberger 1990, 235.

1061 Schmidt 1970a, 29.

1062 Hyd. 110; Isid., Hist. Vand. 75.

1063 Angenendt 2008, 82.

${ }^{1064}$ Horváth 1999, 50; Angenendt 2008, 178.

1065 Hyd. 112: nonnullis declinantibus aliquanti durantes in catholica fide consummavere martyrium.

1066 Maximinus személyét még nem sikerült pontosan azonosítani, mivel ismerünk egy arianus püspököt, aki a Balkánról érkező gótokat Africába kísérte, egy másikuk pedig 427-428 körül Hippóban vitázott Augustinusszal, vö. Vanyó 2007b, 271.
} 
Gaiseric 440-es fellépése a siciliai katolikusok ellen az egyik legvéresebb vallási üldözés volt ebben az időszakban, később pedig még törvényt is hoztak arról, hogy a vandálok által lakott településeken a katolikusok nem gyakorolhatják a vallásukat és nem szentelhetnek fel püspököket. ${ }^{1067}$

Nem vitathatjuk, hogy Gaiseric valláspolitikáját nem teológiai kérdések, hanem politikai és gazdasági érdekek, illetve a rómaiakkal szemben a vandálok összetartására irányuló törekvések határozták meg. Courtois úgy látja, hogy Gaiseric azért fordult ilyen határozottan az ortodoxia ellen, mert a nagy szolidaritást mutató és vagyonelkobzásokkal sújtott római nemességgel való ellentéte vallási színezetet kapott, Horváth pedig ezen túl a vandálok africai elszigetelődésével, kis létszámukkal, valamint a térség erős krisztianizáltságával magyarázza Gaiseric szokásosnál erőszakosabb valláspolitikáját. ${ }^{1068} \mathrm{Ne}$ feledkezzünk meg itt Gaiseric hatalmi struktúrájának jellegzetességeiről sem, hiszen autokratizmusát mutatja, hogy a barbár szokásoktól eltérően a vandál király hatalmát nem osztotta meg az örökösök között, a kalózkodásból meggazdagodó arisztokrácia pedig nem fejlődött olyan katonai nemesi réteggé, amely veszélyeztethette volna uralmát, ennélfogva Gaiseric hatalma lényegesen nagyobbnak tűnik, mint más barbár királyoké. ${ }^{1069}$

Hydatius a szvévek vallási helyzetéről sem közöl sokkal több információt, ezért nem tudjuk pontosan, hogy a szvévek milyen körülmények között lettek katolikusok, és nem ismerjük a megtérés okait és részletes lefolyását sem. A legtöbb kutatóval egyetérthetünk abban, hogy a szvévek még pogányok voltak a 409-es betörés idején, Rechiariust viszont már katolikus királyként említik. ${ }^{1070}$ Rechiarius megtérése valószínűleg még 448-as trónra lépése előtt megtörtént, mert Hydatius Rechilát még pogánynak nevezi, utódját, Rechiariust viszont eleve katolikusként mutatja be, ezáltal megtérésben csaknem fél évszázaddal megelőzte a frank Chlodvigot. ${ }^{1071}$ A 19 . század végén még vita tárgyát képezte, hogy a hispaniai egyház valóban elsőbbséget élvez-e a frank egyházzal szemben, ma már azonban kevesen vitatják, hogy a barbár népek közül a szvévek tértek át elsőként a katolikus

\footnotetext{
1067 Angenendt példaként hozza Deogratias carthagói püspök esetét, akinek 457-es halála után nem választhattak utódot a megüresedett püspöki székben, vö. Angenendt 2008, 179.

${ }^{1068}$ Courtois 1955, 220; Horváth 1999, 50-51.

${ }^{1069}$ Sz. Jónás 1994, 41. A Gaiseric után uralkodó Huneric, Gunthamund és Thrasamund kíméletlenül üldözték a katolikusokat, 484-ben például az összes ortodox templomot át kellett adni az arianusoknak, Hilderic viszont már egy katolikus zsinat összehívását is engedélyezte 525-ben, később az arianusok Gelimert ültették a trónra, vö. Isid., Hist. Vand. 81-83.

1070 Török 1999, 109. Burgess cáfolja Reinhart érveit, mely szerint a szvévek mégsem voltak pogányok a letelepedés idején, vö. Burgess 1988a, 198; Reinhart 1952, 44; 72-73.

${ }^{1071}$ Hyd. 129: mox filius suus catholicus Rechiarius succedit in regnum; Thompson 1980, 79.
} 
hitre. ${ }^{1072}$ Rechiarius megtérésének pontos idejéről és körülményeiről azonban semmit sem tudunk. A szvévek korábbi vándorlásuk során valószínüleg a hozzájuk hasonló germán népek vallási gyakorlatát követték és pogányok voltak, ráadásul a birodalmon belül sem telepedett le korábban egy csoportjuk sem, így nem érintkeztek olyan szorosan a római vallási gyakorlattal. Díaz szerint a szvévek nem alakítottak ki önálló vallási testületeket és nem akadályozták az újraszerveződő római egyház müködését, hanem hagyták, hogy az egyház igazgatásában és szervezetében függetlenül működjön, ${ }^{1073}$ ahogyan erről a régészeti feltárások eredményei is tanúskodnak. ${ }^{1074}$ Hydatius ezt megerősítve egyáltalán nem említ olyan eseteket, amikor a szvévek rómaiakat vagy vallási csoportokat üldöznének, később pedig látni fogjuk, hogy legfeljebb két esetben merül fel a gyanúja annak, hogy a szvévek beleavatkoztak volna a katolikus egyházon belüli püspökválasztásba. Arról sincs tudomásunk, hogy a szvévek engedélyére lett volna szükség ahhoz, hogy 445-ben Hydatius Caeponiusszal közremüködjön a manicheusok elleni küzdelemben, vagy hogy 447-ben Leo pápa javaslatára segítséget nyújtson a priscillianusok visszaszorításában és szabadon utazhasson a nyomozás érdekében Emeritába. ${ }^{1075}$

Elfogadhatónak látszik Reinhart és Arias álláspontja, mely szerint római térítők játszhattak szerepet abban, hogy a szvévek nem a szomszédos gótok vagy vandálok által terjesztett arianus hitre tértek át, hanem egy részük már korábban kapcsolatba kerülhetett keresztényekkel, vagy esetleg meg is tért, ${ }^{1076}$ bár úgy tünik, hogy Rechiarius nem alkalmazott római hivatalnokokat, nem ismerte el a római jogot és ebben az időben még formálisan sem volt kapcsolatban Rómával. ${ }^{1077}$ Kevésbé érthető az a tény, hogy a források szerint a szvévek közül egyedül Rechiarius tért meg, a szvévek pedig továbbra is pogányok maradtak, hiszen azt hihetnénk, hogy a krónikában biztosan lenne nyoma a szvévek megtérésének. Hydatius hitelessége ezen a ponton erősen megkérdőjelezhető, mert a krónika írásakor úgy ítélhette meg, hogy a szvévek expanzív politikája rossz hatással van a gallaeciai egyházra, ${ }^{1078}$ éppen ezért nem lenne érdemes hangoztatni azt a pozitív tényt, hogy a szvévek egy ideig az ortodox hitet gyakorolták. Egyetérthetünk Thompsonnal, aki

\footnotetext{
1072 López Quiroga - Martínez Tejera 2017, 430.

1073 Torres Rodríguez 1977, 112; Díaz 1986, 363-364; Reinhart 1952, 79.

${ }^{1074}$ López Quiroga - Martínez Tejera 2017, 481-482. Az 5-6. századi gallaeciai kereszténység müködését igazolják a Lucus és Bracara környékén talált ikonográfiai emlékek és temetkezési feliratok, vö. López Quiroga - Martínez Tejera 2017, 129; 160-161; 164-165; 171-172; 204.

1075 Hyd. 122; 127; Thompson 1982, 211; Burgess 1988a, 219. Különös viszont, hogy 448-tól kezdve semmit sem tudunk arról, hogy a szvévek hogyan viszonyultak a római lakossághoz, vö. Burgess 1988a, 223.

1076 Reinhart 1952, 21; 32; Arias 2007, 55.

1077 Thompson 1982, 209.

${ }^{1078}$ Muhlberger 1990, 251.
} 
egyenesen elutasítja, hogy Rechiarius mellett a többi szvévnek is át kellett térnie az új hitre, ${ }^{1079}$ hiszen Hydatius sohasem nevezi pogányoknak a szvéveket, ami azért meglepő, mert a gallaeciabeli arisztokrácia álláspontját képviselve olyan nagy ellenszenvvel fordult a barbárok felé, hogy biztosan említette volna, ha a szvévek pogányok vagy eretnekek. ${ }^{1080}$ Rechiarius nem tett különösebb erőfeszítéseket, hogy a népét a saját hitére térítse, talán mert trónra lépése előtt vetélytársai akadtak, de ennek okáról és a résztvevőkről semmit sem tudunk, ${ }^{1081}$ Thompson szerint ugyanakkor kizárt, hogy a megmozdulásnak vallási indítéka lett volna. ${ }^{1082}$

Rechiarius megtérését elsősorban politikai okokra vezethetjük vissza, Gelarda egyenesen „calcoli politici”-nak nevezi ezt a lépést, hiszen így közelebbi kapcsolatba kerülhetett a gallaeciai lakossághoz, ${ }^{1083}$ ugyanakkor nincsenek konkrét bizonyítékaink arra vonatkozóan, hogy a szvévek és a rómaiak közötti együttmüködés emiatt javult volna. Logikus érv lehet a gótok vallási toleranciájához hasonlóan, ${ }^{1084}$ hogy a szvév hódítások sikeréhez egyre inkább szükség volt a helyi lakosok együttműködésére és az általuk nyújtott erőforrásokra, ugyanakkor a katolikus hittel kevésbé lehet összeegyeztetni Rechiarius expanzív törekvéseit. Arias szerint a vallás ugyan fontos szerepet játszott a szvévek és a rómaiak közötti viszonyban, de az 550-es évek elött a szvévek többnyire közömbösnek mutatkoztak vallási kérdésekben, tévesen jut viszont arra a következtetésre, hogy ebben kivételt képez Rechiarius megtérése, ${ }^{1085}$ mivel éppen ez a tény magyarázná meg, hogy miért nem térítette meg az egész népet a katolikus hitre. Thompson a vallási közömbösséget megerősítve írja, hogy a többi germán néptől eltérően a szvévek esetében nem látunk vallási üldözéseket és egyházi ügyekbe való beavatkozást, az uralkodók sem váltogatták a vallásukat, és a szvév fosztogatásoknál sem találunk vallási indítékokat, mert a szvéveket soha nem vádolták a rómaiak keresztényüldözéssel. ${ }^{1086} \mathrm{~A}$ vallási megoszlás tekintetében egyetérthetünk Arias állításával, mely szerint a szvévek sem 448 elött, sem azt követően

\footnotetext{
1079 Thompson 1980, 78.

1080 Reinhart 1952, 72.

1081 Thompson 1980, 91. Hyd. 129: nonnullis quidem sibi de gente sua emulis, sed latenter, obtento tamen regno sine mora.

1082 Thompson 1982, 165.

${ }^{1083}$ Gelarda 2008-2009, 303; Collins 2007, 121.

${ }^{1084}$ Horváth 1999, 48

1085 Arias 2007, 54.

1086 Thompson 1982, 196; Thompson 1980, 77.
} 
nem gyakoroltak egységes vallást, vagyis néhányan felvették az új hitet, de többségük pogány maradt, ahogyan hasonló tolerancia müködött a burgundoknál is. ${ }^{1087}$

Sajátos helyzet, Thompson szavaival egy „historical surprise” állhatott elö, amikor 449-ben Rechiarius feleségül vette Theoderic lányát, vagyis egy katolikus uralkodó és egy arianus király lánya kötött házasságot. ${ }^{1088}$ Úgy tünik, hogy az újdonsült feleség befolyása sem volt elegendő ahhoz, hogy a szvévek inkább az arianus vallásra térjenek át, ${ }^{1089}$ ugyanakkor a két nép közötti jó viszony megőrzése érdekében nem lett volna előnyös az összes szvévet a katolikus vallásra téríteni.

Hydatius a 465-ös események között említi, hogy feltünt a szvévek közt egy gall származású arianus vezető, Aiax, aki a király segítségével az arianus hitet igyekezett elterjeszteni a szvévek között. ${ }^{1090}$ Aiax sokak szerint Remismund jóváhagyásával végezte misszionárius munkáját, ${ }^{1091}$ a regis sui auxilio kifejezés azonban nem a szvév, hanem a gót király segítségére utalhat, mindenesetre a szvév elökelők között nagy sikert arathatott a térítése, mert Isidorus még azt is hozzáteszi Hydatius szövegéhez, hogy az egész szvév népet (totam gentem Suevorum) megfertőzte tanításával. ${ }^{1092}$ Vita tárgyát képezi azonban, hogy Aiax galliai, görög vagy gallaeciai származású volt. Hydatius galatának nevezi, a gallaeciabelire nincs konkrét bizonyítékunk, Burgess viszont görögnek fordítja, mivel a görög szerzők ezt a szót használták azokra a keltákra, akik Anatóliában telepedtek le. ${ }^{1093}$ Megfontolandó Arias és Torres Rodríguez feltételezése is, mely szerint amikor Hydatius kisgyerekként keleten járt, találkozhatott ezzel a hivatkozási móddal, Aiax tehát egy Galliából származó kelta lehet, akit Theoderic küldött a szvévek közé, hogy ezzel is erősítse a gótok gallaeciai befolyását. ${ }^{1094}$

Mivel Hydatius is azt állítja, hogy Aiax galliai területről hozta be az arianus hitet, a legtöbb kutató elfogadja ezt az álláspontot, de néhányan tévesen azt gondolják, hogy a szvévek az arianizmus felvétele előtt pogányok voltak, ${ }^{1095}$ míg mások úgy látják, a katolikus

\footnotetext{
${ }^{1087}$ Arias 2007, 55. A burgundok a gótokkal való érintkezés hatására az arianizmus hívei lettek, de nem tudunk az általuk elfoglalt területeken vallásüldözésről, ugyanakkor azt is tolerálták a királyi udvarban, ha valaki az ortodox hitet gyakorolta, vö. Sz. Jónás 1994, 47.

1088 Thompson 1982, 212; Hyd. 132.

1089 Thompson 1980, 80.

${ }^{1090}$ Hyd. 228: Aiax natione Galata effectus apostata et senior Arrianus inter Suevos regis sui auxilio hostis catholicae fidei et divinae trinitatis emergit. De Gallicana Gothorum habitatione hoc pestiferum inimici hominis virus advectum.

1091 PLRE 2,938; Barbero - Loring 2005, 166-167.

1092 Isid., Hist. Suev. 90.

${ }^{1093}$ Hyd. 228; Burgess 1988a, 221, 94. j.; Amm. Marc. 15,9,3.

${ }^{1094}$ Hyd. praef. 4; Torres Rodríguez 1977, 175; Arias 2007, 23; Wood 2005, 712-714.

1095 Hyd. 228; Tranoy 1974, 2,122; Chadwick 1976, 223; Claude 1978, 655, 5. j.; Thompson 1982, 240.
} 
hitről tértek át az arianusra. ${ }^{1096}$ Burgess szerint Isidorus azért illesztette hozzá Hydatius szvévekre vonatkozó feljegyzéseihez a fent említett kiegészítést, mert nem rendelkezett megfelelö információval arra vonatkozóan, hogy hogyan alakult a szvévek vallási élete a krónika befejezése utáni évszázadban. Mivel Theudimir 561 körül visszatérítette a szvéveket a katolikus hitre, ${ }^{1097}$ azt megelőzően valamikor fel kellett venniük az arianus vallást, és mivel Isidorus úgy gondolta, hogy a szvévek sohasem voltak pogányok, Hydatius idején pedig az ortodoxiát képviselték, logikusnak tűnt az a kiegészítés, hogy Aiax az egész népet arianussá tette. ${ }^{1098}$

\subsubsection{A nesztorianizmus és a monofizitizmus}

Hydatius nagy érdeklődést mutat a Nestoriusszal és Eutychesszel kapcsolatos viták iránt, de nem ismeri pontosan a tanításukat, ${ }^{1099}$ ahogyan azt sem tudta felmérni, hogy az általuk hirdetett eszmék a későbbiekben a rendkívül népszerü monofizitizmus kialakulásához vezetnek majd. Hydatius szerint a két férfi azonos nézeteket vallott, ráadásul mindkettőt az ebionita eretnekség képviselőjének tartotta, ${ }^{1100}$ de az sem térben, sem időben nem kapcsolódhat Hydatius korához. ${ }^{1101}$ Ezek a tárgybeli tévedések és felületes magyarázatok jól mutatják, hogy Hydatius valójában nem is igyekezett pontosan bemutatni az eretnek tanításokat, Burgess mégis megpróbálta azzal indokolni Hydatius tájékozatlanságát, hogy vallási téren nem kapott megfelelő szintü képzést, ráadásul Gallaeciában az arianus és priscillianus tanítások népszerüsége miatt nem is könnyen juthatott pontos teológiai ismeretekhez. ${ }^{1102}$

Nem véletlen azonban, hogy Hydatius részletesen beszámol az 5. század elejétől kialakult dogmatikai küzdelmekröl, amelyek az egyház egységét egyre inkább veszélyeztették, ezért a helyzet megnyugtató rendezéséhez a központi hatalom tekintélyére lett volna szükség. Alexandria és Antiochia teológiai iskolái más-más álláspontot

\footnotetext{
1096 Thompson 1982, 196-197; 203-206; Wood 2005, 714.

${ }^{1097}$ Isid., Hist. Suev. 91: Arrianae impietatis errore destructo Suevos catholicae fidei reddidit.

1098 Burgess 1988a, 222.

${ }^{1099}$ Hyd. 97; 100; 119; 137; Johnson 1993, 70.

${ }^{1100}$ Hyd. 97, 100, 137. A zsidókeresztények alsóbb rétegeiből szerveződő ebioniták a szegénységet vállalva szigorúan aszketikus életet éltek, Krisztust pedig nem tartották Istennek, csak egy erényes embernek, aki megkeresztelkedve Isten prófétája és a világ megváltója lett, vö. Szántó 1983, 96-97; Burgess 1988a, $215,71$. j.

1101 Burgess megpróbált Eusebius segítségével magyarázatot keresni arra, hogy Hydatius miért tulajdonította Nestoriusnak az ebioniták tanítását, vö. Burgess 1988a, 215-216; Eus., Hist. Ecc. 3,27,1; 6,17,1.

1102 Burgess 1988a, 13; 200-201.
} 
képviseltek ebben a kérdésben, ez pedig hosszú ideig jelentős konfliktust okozott a két város patriarchája között. ${ }^{1103}$ A folyamat első szakaszában a nestorianus- és az eutycheanusvitával kapcsolatos dogmatikai kérdések kaptak nagyobb hangsúlyt, míg később a chalcedoni hitvallással és a monofizitákkal kibontakozó egyházpolitikai problémák kerültek előtérbe, bár az utóbbiakról Hydatius nem tudott feljegyzéseket készíteni, mert feltehetően már nem jutottak el ezzel kapcsolatos információk Gallaeciába. ${ }^{1104}$

Az 5. század dogmatikai vitáinak legfontosabb kérdése Krisztus isteni és emberi természetének viszonyára vonatkozott. ${ }^{1105}$ Amikor Apollinaris, a syriai Laodicea püspöke elsőként foglalkozott azzal, hogy Krisztusnak nem volt teljes emberi természete, tehát személyében egy természet (mia physis) van, ${ }^{106}$ jó néhány zsinaton bírálták a tanítását, ${ }^{1107}$ Antiochia és Alexandria teológiai iskolái viszont különböző módon foglaltak állást a kérdésben. A racionálisabb irányzatot képviselő antiochiai iskola a két természet elkülönítésével Máriát csak Krisztus-szülőnek (christotokos) tartotta, ${ }^{1108}$ az alexandriaiak viszont Krisztus személyének teljes egysége mellett érvelve Máriát Isten-szülőnek (theotokos) nevezték, ${ }^{1109}$ míg nyugaton Tertullianus és Novatianus a két természet keveredés nélküli összekapcsolódását hirdette. ${ }^{1110}$

Amikor 428-ban az antiochiai tanítást hirdető Nestoriust választották meg Constantinopolis patriarchájává, három prédikációban is szembefordult az alexandriai

${ }^{1103}$ A krisztológiai viták egyértelmüen jelezték Róma és Alexandria, illetve Constantinopolis és Antiochia versengését az egyházi hegemónia megszerzéséért, Constantinopolis tekintélyének emelkedése ugyanakkor Alexandria és Antiochia háttérbe szorulását eredményezte, és különösen Alexandria érezte megalázónak, hogy korábbi vezető hatalma a keleti területek fölött eröteljesen csökkent, vö. Szántó 1983, 173-174; Meyendorff 2001, 154-157.

${ }^{1104}$ Burgess 1988a, 225.

${ }^{1105}$ A nicaeai hitvallás Krisztus isteni természetét a legföbb isteni természettel azonosította, ugyanakkor Krisztus emberi természetéről csak az arianusok nyilakoztak szélsőséges formában. A viták áttekintését lásd: Frenyó 2002, 93-98; az arianizmus által felvetett problémákról bővebben: Vanyó 2009, 455-457.

${ }^{1106}$ CTh 16,5,12-14. Apollinaris életéről és műveiről bővebben: Vanyó 2007b, 185-190; Vanyó 2009, 459470.

${ }^{1107}$ Damasus pápa az antiochiai Paulinushoz írt három levelében már elítélte őt, majd 362-ben Alexandriában és 377-ben a római zsinaton ezt a döntést megerösítették, a 379-es antiochiai és a 381-es constantinopolisi tanácskozás pedig csatlakozott a római határozathoz.

${ }^{1108}$ Szerintük Krisztus két természete ugyan együtt létezik, de közöttük nem keveredés (krasis), hanem csak szoros kapcsolat (synapheia) áll fenn, és a kettő közül az emberi természet a hangsúlyosabb. Az antiochiai iskola történetéröl, valamint Lucianus, a tarsusi Diodorus, Iohannes Chrysostomus, a mopsuestiai Theodorus és a cyrusi Theodoretus tanításáról bövebben: Szántó 1983, 171-172; Jedin 1998, 25-26; Vanyó 2007a, 353354; Vanyó 2009, 470-480.

1109 Tanításuk alapján az emberi természet a sajátosságait elhagyva belemerült az isteni természetbe, és Krisztusban ugyan jelen van az emberi természet is, de ez kevésbé jelentős az isteni természethez képest. Az alexandriai iskola történetéről, valamint Demetrius, Órigenés, Heraclas, Dionysius, Pierius és Didymus tanításáról bővebben: Frenyó 2002, 103-104; Vanyó 2007a, 341-345; Chadwick 2007, 596-597.

1110 Tertullianus életéröl és müveiröl bővebben: Albrecht 2004, 1235-1257; Vanyó 2007a, 397-409; Adamik 2009, 663-669; Novatianus életéről és müveiröl lásd: Albrecht 2004, 1280-1283; Vanyó 2007a, 413-416. 
hagyománnyal, ${ }^{1111}$ ez viszont akkora felháborodást keltett Alexandriában, hogy Cyrillus patriarcha $^{1112}$ először egy magánlevelet írt Nestoriusnak a hit alapelveivel kapcsolatban, ${ }^{1113}$ majd ennek elutasítása után húsvéti körlevélben bírálta a tanítását, ${ }^{1114}$ szenvedélyes levélváltást indítva ezzel kettőjük között, amelyre Hydatius is próbált röviden utalni. ${ }^{115} \mathrm{Az}$ antiochiai egyházat vezető Iohannes a barátja, Nestorius pártjára állt és óvatosságra intette öt, Nestorius azonban a hosszas levelezgetés hatására sem engedett álláspontjából, ezért mindketten Coelestinus pápához fordultak segítségért. ${ }^{1116}$ Cyrillus 12 anathemában foglalta össze Nestorius tévedéseit, ${ }^{1117}$ aki válaszként 12 ellentételt állított össze és II. Theodosius császár támogatásában bízva zsinat összehívását kezdeményezte. ${ }^{118}$ Hydatius különböző forrásokból tévesen úgy értesült, hogy keleti és palaestinai püspökök részvételével 435-ben tartották meg ezt a tanácskozást Constantinopolisban, ${ }^{119}$ valójában erre 431-ben került sor Ephesusban, ${ }^{1120}$ ráadásul Hydatius a zsinattal kapcsolatban Nestorius helyett egy Atticus nevű constantinopolisi püspököt említ, aki az ebioniták nézeteit támogatta, ${ }^{1121}$ de ez szintén tévedés lehet, mert Atticus 406-425 között volt a város püspöke, és közismerten az ortodoxiát képviselte. $^{1122}$

Cyrillus az első ephesusi zsinatot a városban tartózkodó 198 püspök részvételével ${ }^{1123}$ 431. június 22-én nyitotta meg, amikor még sem a pápa követei, sem az antiochiaiak nem érkeztek meg a tanácskozásokra. ${ }^{1124}$ Amikor Nestorius nézeteit eretneknek ítélték és

\footnotetext{
${ }^{1111}$ Nestorius életéről és műveiről bővebben: Kosiński 2007, 155-170; Vanyó 2007b, 243-247; Vanyó 2009, 499-513.

${ }^{1112}$ Cyrillus életéröl és müveiröl bővebben: Vanyó 2007b, 236-242; Vanyó 2009, 513-524; PG 68-77.

${ }^{1113}$ Hyd. 100: ipsius ad eundem epistola et heresem destruentis et regulam fidei exponentis ostendit.

${ }^{1114}$ Cyrill., Ep. 10; ACO 1,1,1,25-28; PG 77,68A.

${ }^{1115}$ Hyd. 137. A levélváltás részleteiről bővebben: Vanyó 2007b, 214-217.

1116 ACO 1,1,5,10-12. A 430-as római zsinat Cyrillusnak adott igazat, aki egy Alexandriában összehívott zsinaton istenkáromlással vádolta meg Nestoriust.

${ }^{1117}$ Denzinger - Umberg 1942, 113-124; Gárdonyi 2006, 81-82; Vanyó 2009, 532-534.

1118 Jedin 1998, 27.

1119 Hyd. 97: Germani presbiteri Arabicae regionis exinde ad Calleciam venientis et aliorum Grecorum relatione comperimus, adicientibus Constantinopolim eum cum aliis et Palestinae provintiae et Orientis episcopis evocatum sub presentia Theodosii Augusti contracto episcoporum interfuisse concilio.

${ }_{120}$ Burgess azonban azt is feltételezi, hogy mivel Hydatius egy keleti tanácskozásról beszél, egyes információk a 381-es constantinopolisi zsinatra is vonatkozhatnak, vö. Burgess 1988a, 213-214; Fliche Martin 1947, 211-226.

${ }^{1121}$ Hyd. 97: ad destruendam Hebionitarum heresem, quam Atticus eiusdem urbis episcopus pravo stultissime secte resuscitabat ingenio.

${ }^{1122}$ Burgess 1988a, 214, 68. j.

${ }^{1123}$ Más források 150-160 püspökröl tudnak, vö. Szántó 1983, 175; Marton 2004, 167.

${ }^{1124}$ A zsinatra személyre szóló meghívót küldtek Augustinusnak is, de még a levél megérkezése előtt 430. szeptember 28-án meghalt, Nestorius pedig a háromszori felszólítás ellenére sem jelent meg, mert a közhangulat ellene fordult.
} 
megfosztották öt püspöki hivatalától, ${ }^{1125}$ a döntések ellen tiltakozva a császárhoz fordult segítségért, ezért Theodosius a határozatokat érvénytelenítette, a június 26-án vagy 27-én megérkező antiochiaiak pedig egy ellenzsinaton Cyrillust közösítették ki az egyházból. ${ }^{1126}$ Július elején a pápai küldöttek az alexandriaiaknak kedvező döntést hoztak, Cyrillust visszahelyezték hivatalába, Nestoriust és követőit pedig elítélték, augusztusban viszont egy császári határozat alapján Cyrillust is bebörtönözték a zsinaton résztvevő püspökök megtévesztése és a nép felbujtása miatt. ${ }^{1127}$ A későbbi egyeztetések is kudarcot vallottak, ezért Theodosius feloszlatta a zsinatot és Alexandria oldalára állva Cyrillust ismét visszahelyezte hivatalába, Nestoriust pedig Antiochiába száműzte, így Flavianus került Constantinopolis élére. ${ }^{128}$ Alexandria és Antiochia között tovább folytatódott az irodalmi vita, ezért 433-ban az antiochiai Iohannes nyomására a császár erőteljesebben beavatkozva a kérdésbe mindkét iskolával elfogadtatott egy antiochiai állásponthoz közelebb álló kompromisszumos formulát, az eretnekké nyilvánított Nestoriust pedig 435-ben Egyiptomba száműzte, ${ }^{1129}$ így a nestorianus eretnekség eltűnt a birodalom területéről, jó néhányan viszont Nestorius híveként számüzetésbe vonultak a Szászánida Birodalomba. ${ }^{1130}$

Az alexandriai iskola győzelme ellenére a 440-es évek elején az antiochiaiaknak sikerült megszerezni több fontos püspöki székhelyet is, Cyrillus 444-es halála után viszont Dioscorus lépett a helyére, aki a kezdődő eutychianus-vita bonyodalmait kihasználva ismét Alexandria hatalmának megerősítését tüzte ki célul. Eutyches, Constantinopolis idős archimandritája rendkívül népszerü volt az alexandriaiak körében, ${ }^{1131}$ mivel nemcsak egyszerüen folytatta, hanem a 433-ban elfogadott hitvallást félremagyarázva tovább is fejlesztette Cyrillus tanítását. ${ }^{1132}$ Leo pápa már 443-ban helytelenítette Eutyches nézeteit, 448-ban hivatalosan is elutasította a tanítását, az antiochiai Flavianus, Nestorius utódja pedig 448. november 22-én egy zsinati tanácskozást hívott össze Constantinopolisban az ügy tisztázására. ${ }^{1133}$ Amikor Eutychest eretnekké nyilvánították és megfosztották

\footnotetext{
1125 ACO 1,1,1,25-31; Meyendorff 2003, 41-43.

${ }_{1126}$ ACO 1,1,5,15; 1,1,5,119-127; Mansi 4,1377-1380.

${ }_{1127}$ ACO 1,1,3,53-57; 1,4,53. A zsinat határozatairól bővebben: Jedin 1998, 27-29; Vanyó 2009, 524-532.

1128 Hyd. 119. Hydatius mindkét eseményt 442-re datálja, valójában Nestoriust 431-ben távolították el a püspöki székből, Flavianus pedig csak 447-ben nyerte el a hivatalt, vö. Burgess 1988a, 213.

${ }^{1129}$ Cyrill., Ep. 39; PG 77,173; Edwards 2007, 377; Jedin 1962, 2,1,112.

1130 Nestorius követői 484-ben hivatalosan is elszakadtak a birodalmi egyháztól, 498-ban pedig saját patriarchatus alapításával megteremtették az önálló perzsa nemzeti egyházat, vö. Jedin 1998, 30. A nestorianusok későbbi missziójáról lásd: Timkó 1971, 141-164.

${ }^{1131}$ Eutyches életéröl és nézeteiről bővebben: Vanyó 2009, 536-540; Bevan - Gray 2009.

1132 Eutyches szerint Krisztus két természete ugyan egyesült, de az isteni sokkal hangsúlyosabbá vált, ezért valójában csak egyetlen, isteni természettel (mia physis) rendelkezik, vö. Fliche - Martin 1947, 4,213.

${ }^{1133}$ Leo, Ep. 20; Prosp. 448; Vict. Tunn. 447.
} 
hivatalától, ${ }^{1134}$ az ítélet ellen fellebbező Eutychest a politikai sikerekre vágyó és túlságosan erőszakos Dioscorus vette védelmébe, aki II. Theodosius császár bizalmát is megszerezte. ${ }^{1135}$ A tanácskozás előtt Flavianus és Dioscorus egyaránt Leo pápához fordult támogatásért, ezért ő korábbi taktikájával szakítva egyértelmüen Constantinopolis oldalára állt és elítélte Eutychest. ${ }^{1136}$ A 449. augusztus 8-ára összehívott második ephesusi zsinaton Dioscorus erőszakot alkalmazva és a császári katonaságot felvonultatva minden monofizitaellenes véleményt elhallgattatott és nem engedte felolvasni még Leo pápa Eutyches-ellenes Tomusát sem, ${ }^{1137}$ ezért felmentették Eutychest és jóváhagyták a monofiziták tanítását. ${ }^{1138}$

A zsinaton kikényszerített döntés Alexandria teljes győzelmét jelentette, hiszen az antiochiai tanítást elítélték és a rivalizáló Constantinopolis patriarcháját is leváltották. A kialakuló hatalmi helyzet azonban Róma tekintélyét is csorbította, ezért a pápa a 449 szeptemberében összehívott római zsinaton elutasította az ephesusi zsinat határozatait és azt rablózsinatnak (latrocinium Ephesinum) minősítette, egyúttal kérte egy újabb tanácskozás összehívását. ${ }^{1139}$ Marcianus a keletrómai trónra kerülve az egyházon belüli béke megteremtése érdekében 451. május 17-ére hívta össze a negyedik egyetemes zsinatot Chalcedonban, ${ }^{1140}$ amelyen a résztvevők száma minden korábbi egyházi tanácskozásét felülmúlta, ${ }^{1141}$ a nyugati egyházakat viszont csak 3 püspök és 2 pap képviselte, de ők elnöki pozíciót tölthettek be. A zsinaton a 449-es második ephesusi döntések kivételével megerősítették a korábbi tanácskozások határozatait, elítélték Eutychest pártfogójával, Dioscorusszal és Nestoriusszal együtt, a Tomus alapján megfogalmazott chalcedoni

\footnotetext{
${ }^{1134}$ ACO 2,1,1,3-4; Mansi 6,744; Vict. Tunn. 447.

1135 Vict. Tunn. 448; ACO 2,1,2,30; PL 54,714-720. Eutyches keresztfia, az udvari eunuchok közül kiemelkedő Chrysaphius 443-tól szinte kizárólagos hatalommal irányította II. Theodosius kegyenceként a constantinopolisi udvar életét, a 449-es tanácskozás után viszont Eutychesszel való barátsága miatt Pulcheria halálra vesszőztette; vö. Vict. Tunn. 450,2; Marc. Com. 450,3; Mal. 14,5-8; Theod. Lec. 353,6-8.

${ }^{1136}$ Hyd. 137; Tomus ad Flavian.; Ep. 95,2; ACO 2,1,1,32-32.

1137 Leo azért nem ment el a tanácskozásra, mert elutasította, hogy Theodosius császár a saját érdekeinek megfelelően beleszóljon az egyházi döntésekbe, ráadásul így utólag módjában állt elfogadni vagy elutasítani a zsinat határozatait is, vö. Vanyó 2007b, 223.

1138 Vict. Tunn. 448. Az elítélt atyák között volt a pápa álláspontját képviselő Flavianus, akit tiltakozása miatt úgy megvertek, hogy száműzetésbe vonulása közben meghalt, de elítélték a kemény bírálatairól ismert dorylaeumi Eusebiust, a Cyrillus tanítását kritizáló cyrusi Theodoretust és az edessai Ibast is, vö. CSEL 35,12 .

${ }^{1139}$ ACO 2,4,51; Leo, Ep. 95,2. A zsinati döntésekröl bővebben: Jedin 1962, 2,1,120-121; Randers-Pehrson 1993, 202; Jedin 1998, 30-31; Gárdonyi 2006, 83; Edwards 2007, 378; Williams - Friell 2014, 137-150.

${ }^{1140}$ Vict. Tunn. 450,3; ACO 2,1,1,29.

1141 A zsinaton a legtöbb forrás szerint 520 püspök vett részt, vö. Vict. Tunn. 451; Theod. Lec. 534,17-18; ACO 2,1,3,34-35; Leo 600 püspököt említ, vö. Leo, Ep. 102,2; PL 54,988; Marcellinus Comes már 630 résztvevőről ír, vö. Marc. Com. 451; a legújabb kutatások viszont csak 350 püspököt igazolnak, vö. Szántó 1983, 179. Hydatius egyáltalán nem említette a chalcedoni zsinatot, feltehetően azért, mert az erre vonatkozó információk már nem jutottak el Gallaeciába.
} 
hitvallással pedig megpróbáltak közvetíteni a két felfogás között. ${ }^{1142}$ A püspökök egy része elöször nem akarta elfogadni ezt a kompromisszumos megoldást, de végül az összes jelenlévő egyházi vezető aláírta az új formulát, elejét véve ezzel a szélsőséges krisztológiai megközelítéseknek. ${ }^{1143}$

A chalcedoni döntések azonban nemcsak a monofiziták elleni határozott fellépés miatt voltak jelentősek, hanem azért is, mert Alexandria megbuktatásával Constantinopolis vezető szerepe még tovább erősödött. Leo pápa a dogmatikai győzelem ellenére most sem tudott sikerrel fellépni a követek által kifogásolt 28. kánon ellen, ezért megmaradt ugyan a római pápa tiszteletbeli elsőbbsége, de Constantinopolis jogkörét tekintve Rómával mindenben egyenrangúvá vált, a keleti patriarchatusok viszont az ő irányítása alá tartoztak. ${ }^{144}$ Valentinianus és Marcianus császár 452-ben kötelezővé tette a chalcedoni dogma határozatait minden patriarchatusban, az intézkedések azonban nem hozták meg a kívánt békét. A megerősödött constantinopolisi egyház és a nemrég még Nestorius tanítását valló keleti tartományok között egyre feszültebbé vált a viszony, elsőként Hierosolyma szerzetesei, majd Alexandria lakossága lázadt fel, később viszont egyre nagyobb elismertségre tett szert a chalcedoni dogma. ${ }^{1145}$ Az arianizmus eltünésével sajátos helyzet alakult ki a birodalom két felében, hiszen nyugaton szinte mindenhol a pápaság vezetésével az ortodox hitet gyakorolták, keleten viszont a Constantinopolis által biztosított politikai egység ellenére a krisztológiai viták szétforgácsolták a vallási egységet, ennek következményeként pedig később az összes monofizita terület kicsúszott a császári irányítás alól. ${ }^{1146}$

\footnotetext{
1142 A zsinat üléseiről és határozatairól bővebben: Vanyó 2009, 544-553; a hitvallás szövegét és értelmezését lásd: Vanyó 2009, 553-559. Az új formula szerint Krisztus egy személy két természetben, valóságos Isten és valóságos ember, de ezek Eutyches tanításával szemben nem keverednek egymással és változhatatlanok, ugyanakkor Nestorius nézeteivel ellentétben oszthatatlan és szétválaszthatatlan módon egyesülnek egymással, vö. Segesváry 1992, 74-75.

1143 Jedin 1998, 31-32. Frenyó és Hahn különösnek tartja, hogy a császári kormányzat a két felfogás között egy „homályos és körmönfont harmadik megfogalmazást” fogadott el, mindez arra utal, hogy a zsinat hátterében a püspöki helyekért folyó hatalmi vetélkedések és a rendkívüli módon megadóztatott keleti lakosság elszakadási törekvései állnak, vö. Frenyó 2002, 27-28. A dogma fogadtatásáról lásd: Vanyó 2009, 559-565.

1144 Leo, Ep. 65; Mansi 7,445. A 28. kánonnal kapcsolatos vitáról bővebben: Grillmeier 1987, 120-149; Meyendorff 2001, 86-95; Hall 2007, 733-734.

1145 Vict. Tunn. 460; 468; Ep. 162; ACO 2,5,9-98; Coleman-Norton 1966, 2,804-810.

1146 Angenendt 2008, 169-170. A monofizitizmus későbbi terjedéséről és keleti vonatkozásairól bővebben: Timkó 1971, 168-220.
} 


\subsubsection{A priscillianizmus}

Hydatius a priscillianusok fenyegetését találhatta saját korában a legveszélyesebbnek, mert róluk írt a legrészletesebben az eretnekmozgalmak közül, ugyanakkor ezúttal sem adott számunkra rendszerezett áttekintést a priscillianizmussal szemben vívott harc folyamatáról. ${ }^{1147}$ Burgess szerint Hydatius kiállása az ortodoxia mellett azért is egyedülálló, mert az 5. században Gallaecia lakosságának nagy része priscillianus lehetett, ${ }^{1148}$ így még inkább meglepö, hogy a szerző mennyire higgadtan tárgyalja a priscillianizmussal kapcsolatos eseményeket. Amikor 370 körül Hispaniában feltűnt egy Priscillianus nevü laikus szerzetes, szigorú erkölcsei és szélsőséges aszkézise miatt ${ }^{1149}$ gyorsan szerzett tanítványokat a nemesség, a nők és a püspökök között, ${ }^{1150}$ mozgalma pedig a 370 -es évek végére már Hispanián kívülre is eljutott.

Amikor a cordubai Hyginus feljelentése miatt Hydatius emeritai püspök rendkívül hevesen lépett fel Priscillianus követőivel szemben, azok hitvallásukkal igyekeztek megcáfolni a manicheizmus és a gnoszticizmus vádját. 378-ban Damasus pápához is eljuthatott a mozgalom híre, mert 380. október 4-ére összehívta a caesaraugustai zsinatot, ahol a tanácskozáson részt vevő 12 püspök a priscillianusok ellen hozott döntéseket, többen viszont szimpatizáltak a mozgalommal. ${ }^{1151}$ Priscillianus néhány követője igyekezett megbékíteni az emeritai Hydatiust, de amikor a püspök az ossonubai Ithacius javaslatára nem fogadta őket, 381-ben a jóváhagyása nélkül emelték társai Priscillianust Avila püspökévé, figyelmen kívül hagyva ezzel mindenféle püspökszentelést szabályozó rendeletet. ${ }^{152}$ Miután az emeritai Hydatius jelentést küldött erről Gratianusnak és a nagy befolyással rendelkező mediolanumi Ambrosiusnak, Aquitaniába száműzték a priscillianus püspököket, ezért Priscillianus Rómába sietett, hogy a pápától kérjen segítséget. Damasus, a

\footnotetext{
1147 Thompson 1982, 194.

1148 Burgess 1988a, 194; 206; erre vonatkozóan további tanulmányokat közöl: Burgess 1988a, 195, 1.j.

1149 Priscillianus szembeszállt a dogmákat felállító egyházi tanítással és a dogma nélküli kereszténység eszméjét hirdette, elvetett mindenféle törvényt és egyházi hierarchiát, népszerüsítette az apokrif iratokat, vö. Löhr 2007, 38. Priscillianus müködéséröl és tanításáról részletes összefoglalót nyújt: Burrus 1995, 103-126; Spät 1998, 137-152; Horváth 2004, 67-81.

${ }^{1150}$ Hyd. 13: Priscillianus declinans in heresem gnosticorum per episcopos quos sibi in eadem pravitate collegerat. Instantius és Salvianus lusitaniai püspökök például esküvel kötelezték el magukat Priscillianus mellett, vö. Burgess 1988a, 195.

1151 Randers-Pehrson 1993, 122. A konkrét döntések hátteréről bővebben: Chadwick 1976, 12-15; Horváth 2004, 70-72; PL 84,315-318.

1152 Hyd. 13. Avila püspöki székéről nem sokat tudunk, Priscillianus megválasztása előttről nincs is róla információnk, legközelebb pedig csak 610-ben említik a várost, vö. Burgess 1988a, 16.
} 
burdigalai Delphinus püspök és Ambrosius azonban nem volt hajlandó fogadni öt, ${ }^{1153}$ az egyik mediolanumi magister officiorum megvesztegetésével viszont vissza tudta szerezni hivatalát, ${ }^{1154}$ emiatt adódhatott az a különös helyzet, hogy Priscillianus ellenfeleit, többek között az emeritai Hydatiust és Ithaciust ítélték el a hispaniai egyház felforgatása miatt.

Gratianus halála után 384-ben Magnus Maximus usurpator és társcsászár zsinatot hívott össze Burdigalában a priscillianusok elítélésére, ${ }^{1155}$ ahol eretnekké nyilvánították Priscillianust, de ő nem jelent meg a tanácskozáson, inkább felmentésért fellebbezett Maximushoz. ${ }^{156}$ A világi bíróság Treveriben mágiával (maleficium) vádolta meg Priscillianust és kínvallatással beismerő vallomásra késztette az eljárás során. Bár Martinus Turonensis és Ambrosius más püspökökkel együtt azt javasolta Maximusnak, hogy mivel a vallási kérdések elbírálása kizárólag a püspöki törvényszékek hatáskörébe tartozik, világi ítélet alapján semmiképpen se végezzék ki Priscillianust, ${ }^{1157}$ 385-ben ${ }^{1158}$ a császár mégis lefejeztette őt hat társával együtt, ${ }^{1159}$ köztük említ Hydatius egy Latronianus nevü papot, másokat pedig számüztek. ${ }^{1160}$

Priscillianus és követői voltak valószínüleg az első olyan eretnekek, akikkel szemben a világi hatalom halálos ítéletet hozott, ${ }^{1161}$ ezért kivégzésük politikai körülményei és a bírói hatalommal való visszaélés nagy megosztottságot eredményezett az egyházon belül. Martinus Turonensis azt javasolta, hogy az egyház és az állam is foglalkozzon a saját ügyeivel, Ambrosius és az időközben trónra lépő Siricius pápa pedig a Priscillianus elítéléséért küzdő püspököket okolta a történtekért, és megtagadták a közösséget az ügyet elindító hispaniai püspökökkel. ${ }^{1162}$ Heves tiltakozásuk olyan sok támogatóra talált, hogy végül megfosztották hivataluktól azokat a püspököket, akik hozzájárultak a halálos ítélet

\footnotetext{
1153 Hyd. 13: aliquot episcoporum conciliis auditus Italiam petit et Romam, ubi ne ad conspectum quidem sanctorum episcoporum Damasi et Ambrosii receptus.

1154 Burgess 1988a, 195.

1155 Gratianus halálának körülményeiről és Maximus esetleges szerepéről lásd: Socr. 5,11; Sozom. 7,13,8; Ambr., Ep. 24,10; Pac., Paneg. 24; Székely 2018, 104, 22. j. Maximustól a Galliába menekült Ithacius kért segítséget az igaz hit védelmében, vö. Burgess 1988a, 195.

${ }^{1156}$ Hyd. 13: inibi similiter a sancto Martino episcopo et ab aliis episcopis hereticus iudicatus appellat ad Caesarem, quia in Gallis hisdem diebus potestatem tyrannus Maximus obtinebat imperii.

1157 Ambr., Ep. 26,20; Lyman 2007, 308; Sáry 2009, 122.

${ }^{1158}$ Chadwick szerint 386-ban, vö. Chadwick 1976, 132-138. Az események pontos datálásához lásd: Burgess 1988a, 196, 2. j.

${ }^{1159}$ Sulp. Sev., Chr. 2,51; Randers-Pehrson 1993, 33.

${ }^{1160}$ Hyd. 16. Valójában először csak Priscillianust és 4 követőjét végezték ki, később Hispaniában még 2 kivégzésre került sor, vö. Pac., Paneg. 28-29; Ambr., Ep. 24,11; Hier., De vir. ill. 122; Sulp. Sev., Chr. 2,51; Löhr 2007, 39; Székely 2018, 106.

1161 Szántó 1983, 166; Segesváry 1994, 80.

${ }^{1162}$ Hyd. 15; Ambr., Ep. 30,12; Sulp. Sev., Chr. 2,50; Chadwick 1976, 145-148; 151-152; Vanyó 1999, 152.
} 
kimondásához. ${ }^{1163}$ Maximus túlkapását sokáig azzal magyarázták, hogy a halálra ítéltek vagyonelkobzása miatt jelentős vagyonra tett szert az eljárás végén, a források viszont Hydatiushoz hasonlóan azt igazolják, hogy a kortársak Priscillianus követőit a manicheusokkal vagy a gnosztikusokkal azonosították. ${ }^{1164}$ Maximus velük szembeni határozott fellépése tehát megfelelt a katolikus püspökök elvárásainak, így a hit elkötelezett védelmezőjeként a politikai pozíciója megerősödését is remélhette. ${ }^{1165}$

Feltűnő módon viszont sem Damasus és Siricius pápa, sem Ambrosius nem mondott nyíltan véleményt Priscillianus ügyében. Damasus idején Róma tekintélye még tovább növekedett a többi egyházi központhoz képest, ezért elvárható lett volna, hogy a pápa kifejezze véleményét egy ilyen kritikus és megosztó kérdésben, a gyors döntéseiről híres Ambrosiusnak pedig az arianusok és a manicheusok elleni harcban talán még kapóra is jött volna, hogy ha segít felszámolni egy újabb eretnekmozgalmat. ${ }^{1166}$ García Villada azzal magyarázza a viselkedésüket, hogy mindketten vigyáztak arra, nehogy bármilyen módon is eretnekséggel hozzák őket kapcsolatba, Horváth ezzel egyetértve még két további érvet igazol: mivel Priscillianus követőit manicheusoknak tartották, felesleges lett volna a pápának nyilatkoznia, hiszen a velük szemben alkalmazott szankciók már érvényben voltak, másrészről pedig ha helytelenül is, de világi bíróság döntött a vádlottak ügyében, ezért az egyház vezetői ebbe az ügybe már nem szólhattak bele. ${ }^{1167}$ Priscillianus elítélése tehát nemcsak teológiai, hanem erősen politikai üggyé is vált, és az eset szereplői saját pozíciójuk védelmében közremüködtek a koncepciós per lebonyolításában. ${ }^{168}$ A Priscillianus ellen felhozott vádakat és elítélésének körülményeit vizsgálva ugyanakkor azt is mondhatjuk, hogy a korábbi arianus vitából eredően a püspökök közötti konfliktusokat még jobban elmélyítette a Priscillianusszal szemben folytatott eljárás, a világi bíróság beavatkozása pedig birodalmi jelentőségüvé növelte a priscillianizmus politikától egyébként sem mentes ügyét. ${ }^{1169}$

A Priscillianus kivégzése körüli botrány nagy felháborodást váltott ki a hívek körében, ezért tanításai még nagyobb népszerüséget szereztek, különösen a kevésbé romanizált és lecsúszott rétegek körében Gallia és Hispania déli részén, Baetica és Lusitania

\footnotetext{
${ }^{1163}$ Ambr., Ep. 24,12. Az emeritai Hydatius önként mondott le püspöki hivataláról 388 körül, Ithacius pedig 7 évvel később halt meg száműzetésben, vö. Burgess 1988a, 196.

${ }^{1164}$ Hyd. 13; 122; Sulp. Sev., Chr. 2,46-49; Chadwick 1976, 94-99; 194-208; Burgess 1988a, 205.

1165 Horváth 2004, 79-80.

${ }^{1166}$ Horváth 2004, 76-77.

1167 García Villada 1932, 1,2,124-126; Horváth 2004, 80.

${ }^{1168}$ Horváth 2004, 68.

${ }^{1169}$ Escribano 2005, 121-149.
} 
területén, ${ }^{1170}$ illetve Hydatius beszámolója alapján Gallaeciában is, ${ }^{1171}$ arra vonatkozóan viszont nincsenek forrásaink, hogy 385 elött már voltak-e priscillianusok a területen. Elősegítette a mozgalom terjedését az is, hogy Priscillianus tanítása apokrif és eretnek forrásokra, valamint pogány népszokásokra támaszkodott, ezért a „teológiailag megmüveletlen talajon" különösen nagy népszerüséget tudott elérni. ${ }^{1172}$ A 400 körül megtartott toletumi zsinatról ${ }^{1173}$ Hydatius hosszabb beszámolót közöl: a tanácskozáson elítélték a priscillianusokat, és jó néhány gallaeciai püspök, akik korábban Priscillianus követői lettek, visszatértek a katolikus hitre, köztük az asturicai Symphosius és Dictinius nevű fia, aki még külön művet is írt Priscillianus védelmében. ${ }^{1174}$ A zsinat résztvevői között említi Hydatius Aquae Celenae püspökét, Ortygiust is, akit korábban katolikus hite miatt a priscillianusok száműzetésbe kényszerítettek. ${ }^{1175}$

Ezt követően egyre nagyobb erőkkel üldözték a priscillianusokat, akik ugyan nem alakítottak ki önálló egyházi hierarchiát, de a tanításukkal rokonszenvező püspökök megválasztása és egyházba való visszatérése állandó feszültséget teremtett, 402-403 körül pedig egyfajta szkizmát is eredményezett a hispaniai egyházon belül. ${ }^{1176}$ A szvévek 409-es betörésük és letelepedésük után talán még sajátos védelmet is biztosítottak számukra Gallaeciában, Tranoy ugyanis valószínüsíti, hogy a priscillianusok és a szvévek szövetséget kötöttek egymással, Muhlberger szerint pedig Hydatius szándékosan hallgat erről az egyezségről. ${ }^{1177}$ Tranoy feltételezésének viszont ellent mond, hogy a Hermeric által 433-ban a rómaiakhoz küldött Symphosius püspök kronológiai okok miatt nem azonosítható azzal a hasonló nevü püspökkel, aki még a 400 körül megtartott toletumi zsinat elött priscillianus volt. ${ }^{1178}$ Azt is tudjuk azonban, hogy a priscillianus eszmék annyira népszerüek voltak Gallaeciában, hogy ez erősen megkülönböztette a területet Hispania többi tartományától,

\footnotetext{
${ }^{1170}$ Sulp. Sev., Chr. 2,51,4; Augusto 2016, 637; Cortázar - Vesga 2001, 95.

${ }^{1171}$ Hyd. 16: exim in Galleciam Priscillianistarum ingreditur heresis; López Quiroga - Martínez Tejera 2017, 479.

1172 Vanyó 1999, 152.

${ }^{1173}$ A zsinatot valamikor 397-400 között hívták össze, vö. López Quiroga - Martínez Tejera 2017, 478.

${ }_{1174}$ Hyd. 25: in provincia Cartaginiensi in civitate Toleto synodus episcoporum contrahitur, in quo, quod gestis continetur, Symphosius et Dictinius et alii cum his Galleciae provintiae episcopi Priscilliani sectatores heresem eius blasphemissimam cum adsertore eodem professionis suae susscriptione condemnant.

1175 A zsinat eseményeiröl bővebben: Vives 1963, 19-33; Chadwick 1976, 170-188; 234-239; Díaz 2011, 40; D’Emilio 2015, 229-230.

1176 Chadwick 1976, 209; Burgess 1988a, 196. Erről tanúskodik Innocentius pápa levele is, Innoc., Ep. 3, in: PL 20,485-494. A legnagyobb felháborodást valószínủleg az keltette, hogy a priscillianus és az ortodox papok egyaránt áldoztathattak a templomokban, vö. Chadwick 1976, 153; 181; Burgess 1988a, 198; ugyanakkor azt is tudjuk, hogy a kolostorok jelentős része a priscillianusok kezére került, vö. Riché 2016, 110.

1177 Tranoy 1974, 1,42-45; Muhlberger 1990, 240.

${ }^{1178}$ Hyd. 92; 25; Chadwick 1976, 238; Burgess 1988a, 219.
} 
ezért rendkívül kockázatos lett volna nyíltan fellépni ellenük, és mivel ez Hydatiusnak sem sikerülhetett saját müködési területén, inkább hallgatott a közöttük lévő szövetségről. ${ }^{1179} \mathrm{~A}$ szvévekkel való kiegyezés mindenesetre azt mutathatja, hogy a priscillianusok nem ragaszkodtak minden áron az eszméikhez, megmaradásuk érdekében inkább kompromisszumokat kötöttek és kiegyeztek a politikai hatalommal, ${ }^{1180}$ ráadásul jó néhány forrásunk is van arra vonatkozóan, hogy a barbárok jelenléte kifejezetten kedvezett az eretnek eszmék terjedésének. ${ }^{1181}$

Augusto az irodalmi források és a régészeti bizonyítékok feltérképezésével próbálta kideríteni, hogy mi lehetett az oka annak, hogy a priscillianizmus ekkora népszerüséget szerzett Gallaeciában. Ideológiai magyarázatként elfogadja, hogy a gallaeciaiak patriotizmusát erősíthette a priscillianizmus elfogadása, Cardelle de Hartmann nyomán pedig hangsúlyozza, hogy Priscillianus sajátos jellemvonásai is hozzájárulhattak a mozgalom népszerüségéhez. ${ }^{1182}$ A vallási magyarázatok között felmerül Priscillianus ereklyéinek ismertsége és a tanítás fejlődésének „undercurrent”-je is, Chadwick pedig az ortodoxiát képviselő császári hatalom erőtlenségével indokolja az eretnekmozgalom terjedését. A korábbi kutatásokkal szemben Augusto szerint Priscillianus életében és közvetlenül a kivégzése utáni időszakban a felsőbb társadalmi rétegek körében is nagy népszerüséget szerzett a priscillianizmus egy „aristocratic movement” formájában, amely akkor veszített újra sok támogatót, amikor a toletumi zsinat nyomán jó néhány megtévedt püspök visszatért az egyházba. ${ }^{1183}$ Augusto összességében „socio-economic” jellegü okokra vezeti vissza a jelenséget, mivel az aszketikus eszméknek hódoló arisztokrata csoportok ellenőrzésük alatt tudták tartani Gallaecia lakosságát, miközben hatalmi harcot vívtak egymással korábbi életformájuk megtartásáért. ${ }^{1184}$

Sulpicius Severus valószínűleg azért is írta meg Martinus Turonensis életrajzát, mert a 4. század végén rendkívül sok gondot okozott a priscillianizmus Hispaniában, Augustinus és Orosius a 410-es évek közepétől támadta jó néhány munkában a priscillianusok nézeteit, ${ }^{185}$ a 440-es években pedig már Thoribiusnak is keményen fel kellett lépnie a

\footnotetext{
1179 Maldonado 2005, 155; Burgess 1988a, 203.

${ }^{1180}$ A priscillianizmus és a szvévek viszonyáról bővebben: Cardelle de Hartmann, 1998, 81-104.

${ }^{1181}$ August., Ep. 166, in: CSEL 44; Oros., Comm. 1,3; Leo, Ep. 15,16; López Quiroga - Martínez Tejera 2017, 479.

1182 Augusto 2016, 635-636; Cardelle de Hartmann 1998, 269-290.

1183 Chadwick 1976, 220-221; Augusto 2016, 640-643.

1184 Augusto 2016, 651.

1185 Augustinus a Liber ad Orosium contra Priscillianistas et Origenistas, Orosius pedig a Commonitorium de errore Priscillianistarum et Origenistarum címü munkájában fejtette ki nézeteit, vö. López Quiroga Martínez Tejera 2017, 479.
} 
gallaeciai priscillianusokkal szemben. Amikor 448-ban a szvévek felvették a kereszténységet, a priscillianizmus gyorsan hanyatlásnak indult, ezt pedig elősegítette az is, hogy az arianus gótok manicheusként üldözték a priscillianusokat. ${ }^{1186}$

A Priscillianusról kialakított kép folyamatosan változott. Sulpicius Severus kiváló adottságait, nagy tudását, vitakészségét és sikerorientáltságát emelte ki, ${ }^{1187}$ mások vértanúként tisztelték aszketizmusa miatt, ${ }^{1188}$ később viszont a manicheizmus hispaniai terjesztőjének tartva leginkább eretnekként tekintettek rá. Priscillianus reális megítélése azért nehéz feladat, mert ellenfelei erős érzelmi indulatokkal bírálták őt, a kutatók egy része viszont felmentette az eretnekség alól. ${ }^{189}$ Priscillianus esete jól mutatja a provinciabeli társadalom sajátos helyzetét a 4. század végén, hiszen az eretnekek sajátos nézeteikkel és vallásgyakorlatukkal egyfajta ellentársadalmat alkottak és elkülönültek a társadalom keresztény tagjaitól, ezért nemcsak az egyházi, hanem a császári hatalom is üldözte őket, gyakran még a létezésüket is igyekeztek meggátolni.

\subsubsection{A manicheizmus}

A korai kereszténység idején fellépő gnoszticizmus hatalmas veszélyt jelentett az egyházra, mert a keresztény tanításba szivárogva vált népszerűvé a 3. századi pogányság körében. ${ }^{1190}$ Legfejlettebb formáját a perzsa Mani (216-276) hirdette, aki aszketikus etikája mellett dualista jellegü tanítását a jó és a rossz, illetve a világosság és a sötétség állandó küzdelmére alapozta. $^{1191}$ Miután Mani I. Bahram király fogságába esett és 276 körül belehalt a kínzásokba, mozgalma önmagát az addigi vallások közül a legtökéletesebbnek hirdetve egyre népszerübbé vált a Földközi-tenger vidékétől egészen Kínáig. ${ }^{1192}$

\footnotetext{
1186 Vanyó 1999, 154. Az 561-es és az 572-es bracarai zsinatok még határozottabban léptek fel a priscillianusokkal szemben, Leovigild gót király pedig 585-ben a terület meghódításával felszámolta a priscillianusok mozgalmát, vö. Denzinger - Umberg 1942, 231-245.

${ }^{1187}$ Sulp. Sev., Chr. 2,3-5. Priscillianus Würzburgi Traktátusok néven ismert írásait a 19. század végén fedezték fel. Tanításait Orosius foglalta össze a 414-ben írt Commonitorium de errore Priscillianistarum címü munkájában, ennek elemzését lásd: Spät 1997, 21-27.

${ }^{1188}$ Ereklyéi feltehetően Santiago de Compostellában vannak, vö. Chadwick 1976, 233.

${ }^{1189}$ Horváth 2004, 67.

1190 Vanyó 2007a, 325-327. A gnosztikusok perzsa, görög, egyiptomi és keresztény elemeket keverve elválasztották a megváltást Krisztus személyétől, és azt gondolták, hogy tudásuk felülmúlja az egyház tagjainak ismereteit, vö. Grüll 1998, 91.

1191 Segesváry 1994, 49; Chadwick 2007, 582; Vanyó 2007b, 53. Mani életéről és a manicheus gnózisról bővebben: Burrus 1995, 48-79; Eliade 2006, 539-545; Lieu 2007.

1192 Szántó 1983, 100; Brown 1999, 50. A manicheizmus birodalmon belüli terjedéséről lásd: Brown 1972, 94 118.
} 
A manicheizmus veszélyességét jelzi, hogy mind a pogány, mind a keresztény császárok igyekeztek megfékezni a terjedését, ezért követői már a kezdeti időszakban is titkos összejövetelekre kényszerültek és föld alatti szektaként müködtek. Diocletianus 297es rendeletében a régi római vallás védelmében megpróbált szigorúan fellépni a mágia gyanújába keveredett manicheusokkal szemben, az eretnek vezetőknek máglyahalált ígért, követőiket pedig vagyonelkobzással sújtotta. Valentinianus is vagyonelkobzással élt a manicheizmus követőivel szemben, minden más vallási csoportnak viszont engedélyezte a müködését. ${ }^{1193}$

A fiatal Augustinus 9 éven át Carthagóban került kapcsolatba a manicheusokkal, a szekta auditor tagjaként fellépett a katolikus egyházzal szemben, ezért amikor 374 körül vissza akart térni szülővárosába, Thagastéba, keresztény anyja kitagadta őt manicheus hite miatt. A Carthagóban töltött időszak végén, 383 körül találkozott Faustus manicheus püspökkel, akivel való beszélgetése miatt kiábrándult a mozgalomból. ${ }^{1194}$ Amikor Rómába költözése után a manicheusok szereztek neki rhétori állást, saját szemével láthatta, hogy a manicheusok valóban a föld alatt tartják gyüléseiket. ${ }^{1195}$ Mivel az előkelő római körök ellenségesen tekintettek a manicheusok tevékenységére, Augustinus végleg szakított velük, és Africába való 388-as visszatérése után jó néhány munkát írt tanításuk ellen.

Theodosius uralkodása alatt a 381-es aquileiai zsinaton kifejezetten megtiltották a keresztények számára, hogy áttérjenek a manicheus vallásra, ezenkívül lehetővé tették, hogy időbeli korlát nélkül meg lehessen büntetni azokat a manicheusokat, akik megszegték a gyülekezési tilalmat, visszamenőleg pedig megfosztották őket a végrendelkezési és öröklési jogaiktól is. ${ }^{1196}$ Honorius 399 -es rendeletében már halállal büntette a manicheizmus követőit, II. Theodosius pedig különösen nagy szigorúsággal, a városokból való elűzéssel és szintén halálbüntetéssel lépett fel ellenük. ${ }^{1197}$

Az 5. század közepén még biztosan létezett egy titkos manicheus mozgalom, amely a katolikus lakosság és a papság körében is nagyon népszerü volt. ${ }^{1198}$ Hydatius 445-ben büszkén számolt be olvasóinak arról, hogy Asturicában Thoribius püspökkel együtt jelentéseket készítettek bujkáló manicheusokról, azokat pedig továbbították Antoninus

\footnotetext{
1193 Gárdonyi 2006, 51; Lyman 2007, 307; Chadwick 1999, 158.

${ }^{1194}$ August., De Civ. 15,9. Augustinus elsősorban a sekélyes képzés és a manicheusok túlságosan fantasztikus mitológiája miatt volt csalódott, Faustust pedig hízelgő fecsegőnek tartotta, vö. August., Conf. 5,6,10; Randers-Pehrson 1993, 64; Lieu 2007, 290-291; Adamik 2009, 793.

1195 August., Conf. 5,10,19; Vanyó 2007b, 308-309.

${ }^{1196}$ CTh 16,5,7; Sáry 2009, 51; 75.

${ }^{1197}$ CTh 16,5,35; 16,5,65,2; Kelemen 2007, 83; Sáry 2009, 71.

${ }^{1198}$ Chadwick 1999, 227; Vanyó 2007b, 371.
} 
emeritai püspökhöz, de Hydatius itt valószínüleg a priscillianusokra gondol, akiket a korszakban megvádoltak és gyakran össze is kevertek a manicheusokkal. ${ }^{1199}$ Leo pápa mindenesetre arra kényszerült, hogy az összes tartományba szétküldje a róluk szóló jelentéseket, hogy ezzel is megpróbálja felszámolni az eretnek tanításukat. ${ }^{1200} \mathrm{~A}$ manicheusok elleni fellépés hatékonyságát és Hydatiusék eredményes munkáját jól mutatja, hogy amikor 448-ban egy Rómából Asturicába utazó manicheus, Pascentius Emeritába menekült, Antoninusnak nemcsak hogy sikerült elfognia és kihallgatnia, hanem még azt is elérte, hogy távozzon Lusitania tartományból. ${ }^{1201}$

\subsubsection{A pelagianizmus}

Hydatius rendkívül szükszavúan nyilatkozik Pelagius szektájáról (Pelagiani sectam), amellyel szemben Hieronymus nagy erőkkel lépett fel és páratlan sikereket aratott. ${ }^{1202} \mathrm{Az} 5$. század elején a szentháromságtani problémák mellett antropológiai és szoteriológiai kérdések is megfogalmazódtak, különösen az ember szabad akaratával, illetve a bün és a kegyelem viszonyával kapcsolatban. ${ }^{1203}$ Amikor Pelagius (megh. 418) 384 körül Rómába érkezett és aszketikus életmódjával azt hirdette, hogy a kegyelem nem szükséges az üdvösséghez, mert az ember szabad akaratával megszerezheti azt, ${ }^{1204}$ nézetei rendkívül gyorsan terjedtek, különösen Dél-Italiában, Észak-Africában, Hispaniában, Galliában és az ír területeken. ${ }^{1205}$

\footnotetext{
${ }^{1199}$ Hyd. 122: in Asturicensi urbe Galleciae quidam ante aliquot annos latentes Manichei gestis episcopalibus deteguntur quae ab Ydatio et Thoribio episcopis, qui eos audierant, ad Antoninum Emeretensem episcopum directa; Burgess 1988a, 205.

1200 Hyd. 125: gesta de Manicheis per provintias diriguntur; Lieu 2007, 293. Mivel a manicheusok elutasították a kehelyböl való áldozást, Leo kötelezővé tette a két szín alatti áldozást, hogy ezzel is meggátolja a manicheizmus további terjedését, vö. Leo, Serm. 27,9-16; 82,3-4.

${ }^{1201}$ Hyd. 130. Iustinianusnak még a korábbiakhoz hasonlóan halálbüntetéssel kellett sújtania a manicheizmus követőit, vö. CI 1,5,12,3. Az európai, észak-africai és kis-ázsiai terjedés után az 5. században már visszaesés következett be, a 6. században pedig eltűntek Európából a manicheus eszmék, de africai, szászánida, örmény, bolgár és távol-keleti területeken még hosszú századokig nagy népszerüségnek örvendett, vö. Eliade 2006, 545.

${ }^{1202}$ Hyd. 51. Hydatius nemcsak hogy nem ismeri a tanításukat, hanem még alapítójukat, Pelagiust is hibásan nevezi meg.

${ }^{1203}$ Az ókeresztény antropológia fontosabb problémáiról lásd: Frenyó 2002, 111-146; Vanyó 2009, 637-646.

${ }^{1204}$ Pelagius tanításáról bővebben: Rees 1998; Vanyó 2009, 649-652; Bonner 2018. Az újabb kutatások cáfolják, hogy Pelagius az alexandriai Kelemen, Iohannes Chrysostomus és a mopsuestiai Theodorus munkáinak alapos tanulmányozása alapján alakította volna ki saját felfogását, nagy hatással volt rá viszont a Hieronymus betlehemi kolostorából Rómába érkező szír szerzetes, Rufinus, akivel 399-ben ismerkedett meg, vö. Vanyó 2007b, 272.

1205 Prete 1961, 20-27. Pelagius követőiről és a római arisztokrácia körében szerzett népszerüségéről bővebben: Brown 1972, 183-226.
} 
Pelagius a barbárok 409-es betörése után Észak-Africába menekült és találkozni akart Augustinusszal, de ö nem tartózkodott Carthagóban, ezért tovább hajózott a Szentföldre. Egy Caelestius nevü ügyvéd viszont Pelagiusszal való megismerkedése után provokatív formában kezdte hirdetni tanítását, de a 412-es carthagói zsinaton elítélték nézeteit, ezért ő Ephesusba vonult és pappá szenteltette magát. ${ }^{1206}$ Bár a pelagianus-vita Augustinus kegyelemtanával kapcsolatban robbant ki, 413-ban Augustinus még egy udvarias levelet is küldött Pelagiusnak, később viszont már ellenezte, hogy az igaz hívők az ő munkáit olvasgassák. ${ }^{1207}$ Hieronymus is fellépett az őt kritizáló és Palaestinába érkező Pelagius ellen, amikor a szentföldi helyeket felkereső nyugati zarándokokat, köztük Pelagius személyét is bírálta, Orosiustól pedig azt kérte, hogy a 415-ös hierosolymai zsinaton hívja fel a pelagianus püspökök figyelmét arra, hogy Pelagiust és Caelestiust már jó néhány zsinaton elítélték. ${ }^{1208}$ Hydatius biztosan túloz, amikor azt állítja, hogy Hieronymus teljesen szétzúzta a pelagianusok mozgalmát, mivel a 415-ös diospolisi tanácskozáson elítélés helyett még igazhitűnek is nyilvánították Pelagiust, aki elhatárolta magát Caelestius tanításától. ${ }^{1209}$ Pelagius rehabilitációjának hírére a 416-os carthagói és milevei zsinat Pelagius ellen foglalt állást, majd 417-ben Innocentius pápa javaslatára Pelagiust és Caelestiust kiközösítették az egyházból, Augustinus pedig több müvében, 417től pedig személyesen is fellépett a téves tanítások ellen. ${ }^{1210}$

Amikor Pelagius és Caelestius a pápai tekintély elismerésével elérte, hogy a trónra lépő Zosimus ismét ortodoxnak nyilvánítsa őket, az africai püspökök tiltakozni kezdtek és Augustinusszal együtt követeket indítottak Ravennába az uralkodó meggyőzése érdekében. Végül 418. április 30-án egy császár rendelet eretneknek nyilvánította és számüzte őket, Zosimus pedig Epistula tractoria címü körlevelében ítélte el őt. ${ }^{1211}$ Bár Caelestius Alexandriához és Constantinopolishoz is fellebbezett a döntés ellen, a 419-es carthagói zsinaton elítélték Pelagius nézeteit és 18 italiai püspököt is száműztek. ${ }^{1212}$ A 420 -as években fokozatosan gyengült a pelagianusok mozgalma, mert a száműzött püspökök nagy része visszatérhetett az egyházba, de Augustinusnak még jó néhány esetben segítséget kellett

\footnotetext{
1206 Jedin 1962, 2,1,173; Chadwick 2007, 589-590.

1207 August., Conf. 10,29,40; Ep. 146; 180; 188.

1208 PL 24,682A-785B; Vanyó 2007b, 333. A pelagianus eszméket hirdető latin nyelvű szerzőkről bővebben: Vanyó 2007b, 272-274.

1209 Hyd. 51: Pelagiani sectam cum eodem auctore adamantino veritatis malleo contrivit; Fliche - Martin 1947, 4,99-104.

1210 August., Ep. 175-176; Jedin 1962, 2,1,176; Chadwick 2007, 591. Augustinus kegyelemtanáról és Pelagiusszal folytatott vitájáról bővebben: Vanyó 2007b, 330-340; Vanyó 2009, 653-669.

1211 August., Ep. 201; Randers-Pehrson 1993, 126; Chadwick 1999, 216; Edwards 2007, 375; Löhr $2007,41$.

1212 Vanyó szerint a pelagianusoknak valamilyen, máig nem tisztázott szerepük lehetett a 419-es pápaválasztásban, vö. Vanyó 2007b, 334.
} 
nyújtania a galliai szerzeteseknek a pelagianus tanok megcáfolásában. A 431-es ephesusi zsinaton tárgyalás és meghallgatás nélkül nyilvánították eretneknek a pelagianizmus követöit, a brit keresztény közösségek azonban továbbra is szimpatizáltak a mozgalommal, ezért Coelestinus pápa egy Palladius nevü püspököt küldött a helyzet rendezésére. ${ }^{1213}$

\subsubsection{A donatizmus}

Hydatius csupán egyetlen alkalommal utal a donatistákra, amikor Augustinus fölöttük aratott győzelméről beszél. ${ }^{1214}$ Mivel a 4 . században a birodalom számos területén megjelentek olyan szakadár mozgalmak, amelyek nagy népszerüségük miatt veszélyeztették a birodalmi egyház megerősödését, a császári beavatkozásnak köszönhetően sok esetben sikerült ezeket az egyre szélesebb körben terjedő tanításokat féken tartani, de a donatizmus jó néhány évtizedre megnehezítette az uralkodók egységesítő törekvéseit ÉszakAfricában. ${ }^{1215}$

A főként Numidia és Mauritania lakossága körében népszerü mozgalom kialakulása a carthagói püspökválasztás során felmerült vitákhoz kapcsolódik, amelyben a traditorrá vált $^{1216}$ Felix támogatásával Caecilianust választották püspökké, ${ }^{1217}$ vele szemben pedig Donatus Maiorinust jelölte a carthagói egyház élére. ${ }^{1218}$ Amikor Caecilianus Constantinustól kért segítséget, először fordult elő, hogy vallási kérdésben magához a császárhoz nyújtottak be fellebbezést. Constantinus pénzbeli támogatást küldött Caecilianusnak és az africai helytartót bízta meg az ügy kivizsgálásával. ${ }^{1219}$ A 313-as római zsinaton Felixet

1213 Chadwick 2007, 593-594; Denzinger - Umberg 1942, 174-181; Randers-Pehrson 1993, 282; Vanyó 2007b, 380. Egy évszázaddal később az 529-es 2. arausiói zsinaton Caesarius arelatéi érsek vezetésével ismét eretneknek nyilvánították a pelagianizmust, II. Bonifatius pápa pedig 530-ban teljesen felszámolta a mozgalmat, vö. Szántó 1983, 197.

1214 Hyd. 45.

1215 A donatizmus kialakulásáról és terjedéséről bővebben: Frend 2004, 259-264; a donatisták tanításához és jelentőségéhez lásd: Tengsröm 1964; Hoover 2018.

1216 A Diocletianus-féle üldözések alatt jó néhány püspök az elöírt rendeletnek megfelelően keresztény könyveket szolgáltatott ki a pogány hatóságoknak, ezzel traditorrá vált, az ilyen magatartást tanúsítókat viszont a hívek egy része Cyprianus szentségtanára hivatkozva árulónak és a hívek megfertőzőjének tartotta, vö. Cypr., Ep. 67; Havas - Németh - Szabó 2001, 438.

1217 311-ben Mensurius püspök halála után a papság többsége Caecilianus archidiaconust választotta a város püspökévé, de amikor egyik támogatójáról, Felixről kiderült, hogy korábban traditorrá vált, felmerült Caecilianus felszentelésének érvénytelensége, vö. Lortz 1962, 1,140; Randers-Pehrson 1993, 136-138; Vanyó 2007a, 338-340.

1218 Amikor a Felix ügyében összehívott carthagói zsinaton 70 numidiai püspök úgy döntött, hogy Caecilianus beiktatása érvénytelen volt, a helyére Casae Nigrae püspöke, Donatus egy Maiorinus nevü lectort nevezett ki, Róma és a többi Észak-Africán kívüli egyház viszont kitartott Caecilianus hivatala mellett, vö. Heussi 2000, 103. Az esethez kapcsolódó forrásokat közli: Löhr 2007, 42-43.

${ }^{1219}$ Constantinus és Caecilianus viszonyáról bővebben: Brandt 2007, 94-101. 
felmentették a traditorság vádja alól, így Caecilianus felszentelése törvényesnek minősült, de Maiorinus hívei újra fellebbeztek az ítélet ellen. A 314-es arelatéi tanácskozásra már az összes nyugati provincia vezetője meghívást kapott, de a jelenlévő 33 püspök ugyanezt a döntést hozta, ${ }^{1220}$ amikor pedig 316-ban Maiorinus halála után Donatus foglalta el a püspöki széket, maga a császár állt ki Caecilianus mellett. Mivel az africaiak többsége nem fogadta el a zsinati döntést, a carthagói egyház két részre szakadt, és a donatisták a katolikusoktól elkülönülve más városokban is önálló gyülekezeteket hoztak létre, elutasítva ezzel a Rómával való együttmüködést.

A mozgalom társadalmi alapját elsősorban a lesüllyedt szabadok és a rabszolgák képezték, ezért a donatisták vallási törekvései kiegészültek a szegények helyzetének javítását és az emberek közötti egyenlőség megteremtését célzó követelésekkel. A nyugati tartományok és az africai nagyvárosok romanizált polgárai kitartottak a katolikus álláspont mellett, az elszegényedett falusi bennszülött réteg azonban tömegesen csatlakozott Donatus mozgalmához, ugyanakkor sok esetben egy-egy város püspökének saját véleménye határozta meg, hogy a közösség melyik oldalra állt a vitában. ${ }^{1221}$ Constantinus számos lépést tett az africai egység megteremtése érdekében: elvette a donatista közösségek templomait, számüzte a vezetőit, gyakran még a hadsereget és a helyi hatóságokat is bevetette, hogy üldözésükkel megfékezze az irányzat terjedését. Törekvései annyira eredménytelenek maradtak, hogy 321-ben még azt is meg kellett engednie a donatista vezetőknek, hogy hazatérjenek a száműzetésből. Amikor 336-ban a mozgalom megerősítése céljából maga Donatus hívott össze egy zsinatot Carthagóban, 270 püspök jelent meg a tanácskozáson, vagyis Donatus népszerüsége miatt jóval több egyházi vezetőt tudott mozgósítani saját védelmében, mint amennyit Constantinus részvételre bírt egy évtizeddel korábban a nicaeai zsinaton. $^{1222}$

Constans idején folytatódott a donatisták üldözése, különösen azért, mert egy aszkézist hirdető fanatikus csoportjuk, a circumcelliók csoportokba verődve vándoroltak és szélsőséges eszközökkel igyekeztek megfélemlíteni a katolikusokat. Donatus 347-es száműzetését követően a római katonaságnak rendkívül keményen kellett fellépnie a circumcelliókkal szemben, ${ }^{1223}$ 355-ben bekövetkezett halála után viszont csökkenni kezdett a donatisták befolyása. Iulianus 361-es restitúciós edictuma alapján egy időre szünetelt az

\footnotetext{
1220 Jedin 1998, 12, Edwards 2007, 369.

1221 Jedin 1962, 2,1,147-148; Gárdonyi 2006, 69.

1222 Cameron 2007a, 94-95; Chadwick 2007, 583.

${ }^{1223}$ August., Ep. 185,7,30. Tevékenységüket később vizsgáljuk meg részletesen.
} 
üldözésük és szabadon gyakorolhatták vallásukat, ${ }^{1224}$ Valentinianus uralkodása alatt viszont az ő támogatásukkal robbant ki az a felkelés, amelynek következtében Mauretania cliensének fiát, Firmust 370-ben császárrá kiáltották ki. ${ }^{1225}$ A donatisták egyik numidiai vezetője, Optatus püspök az africai helytartóval, Gildóval összefogva 398-ban leállította a Róma számára nélkülözhetetlen gabonaszállítmányokat és egy önálló africai állam létrehozására törekedett, Stilicho azonban kegyetlenül leverte a lázadásukat. ${ }^{1226}$

Augustinus a püspöksége alatt jó néhány zsinat összehívását kezdeményezte, hogy a katolikus püspökök egységes álláspontot alakíthassanak ki a donatizmussal kapcsolatban, és hogy megszünjön az africai egyházon belül kialakult szakadás. Először dialógusok formájában, majd az évenkénti africai tanácskozásokon történő felszólalásával próbálta a donatistákat visszatéríteni a katolikus egyházba, a római hatóságok pedig gyakran pénzbüntetések kiszabásával és erőszak alkalmazásával sújtották őket, hogy ezzel is segítsék Augustinus céljainak megvalósulását. ${ }^{1227}$ A határozott politikai nyomás és a 397-404 közötti püspöki tanácskozások eredményeképpen 405-ben törvényen kívül helyezték a donatistákat és felerősödött az üldözésük, Honorius pedig feltehetően a donatisták erőszakos fellépései miatt hozott rendeletet arról 409-ben, hogy a katolikus papok bántalmazása büncselekménynek számít. ${ }^{1228} 411$ májusában Marcellinus comes a katolikusok kezdeményezésére zsinatot hívott össze Carthagóba, ahol Augustinus a legnagyobb sikerét érte el, hiszen 286 katolikus és 284 donatista püspök jelenlétében ${ }^{1229}$ cáfolta meg a donatisták téves tanítását, amelynek következményét Hydatius frappánsan úgy fogalmazta meg, hogy Augustinus legyözte a donatistákat (Donatistas superatos). ${ }^{1230}$ 412-ben Honorius császár parancsot adott a donatisták kiátkozására, amely alapján a papjaikat száműzték, a híveket pedig pénzbírsággal és teljes vagyonelkobzással sújtották. ${ }^{1231}$ Miután a 413-ban

\footnotetext{
1224 August., Ep. 105,2,9.

1225 A helyi lakosság a nomád berber törzsek fosztogatásai miatt volt elégedetlen, ráadásul Romanus africai comestől sem kaptak segítséget a védekezésben, vö. Havas - Hegyi - Szabó 2007, 631-632.

1226 Jedin 1962, 2,1,151-152; Randers-Pehrson 1993, 143. Gildo az africai seregek föparancsnokaként hatalmas birtokokat szerzett, ezért amikor Honoriusszal szembefordult, a saját földjeiket féltő római senatorok támogatták Stilichót a rendteremtésben, bár a keleti katonai egységek nagy része még a hunok elleni harccal volt elfoglalva, vö. Havas - Hegyi - Szabó 2007, 656. A Gildo ellen vonuló római expedíciós sereg összetételéről és a hadjárat stratégiai jelentőségéről bővebben: Várady 1961, 60; 247-248.

${ }^{1227}$ August., Ep. 88; 93; 100; 104; 113; 115; 186; 229.

${ }^{1228}$ CTh 16,2,31; Löhr 2007, 40; Sáry 2009, 105-106.

${ }^{1229}$ Segesváry szerint csak 279 donatista püspök vett részt a tanácsozáson, vö. Segesváry 1994, 79.

${ }^{1230}$ Hyd. 45; PL 43,613-650. Augustinus donatisták elleni tevékenységéről bővebben: Corcoran 1997.

${ }^{1231}$ CTh 16,5,22; 16,5,52; 16,6,6; Löhr 2007, 44; Chadwick 2007, 586-587; Sáry 2009, 73.
} 
tartott gyülésen sem közeledtek az álláspontok, a donatisták ereje végleg megtört, és jelentős részük visszatért a katolikus egyházba. ${ }^{1232}$

\subsubsection{Hütlenség és lojalitás a rómaiaknál}

Hydatius szerint a barbárok viselkedése és az eretnekmozgalmak terjedése annyira összezavarta a rómaiakat, ${ }^{1233}$ hogy az egyházi és a politikai életben jó néhány római polgár tevékenysége is szétfeszítő erőként járult hozzá a birodalom zürzavaros helyzetének kialakulásához, ahogyan a moralizáló Ammianus Marcellinus is a birodalom életében felmerülő problémákért egyes személyek kudarcait és a császári hatalommal szembeforduló magatartásukat tartotta felelősnek. ${ }^{1234}$ Burgess szerint a rómaiak viselkedésének két legjelentősebb „deviation”-ja, a trónbitorlás és az eretnekség a császári család tagjai és a nagy vallási személyiségek ,,counterpoint”-jaként jelenik meg a krónikában, ${ }^{1235}$ éppen ezért érdemes részletesen kitérnünk a hütlenség és a lojalitás megnyilvánulásaira az egyházi és a politikai vezetők esetében.

\subsubsection{Problémák az egyház életében}

A 2. századi pogány filozófus, Celsus elismeréssel szólt arról, hogy a keresztények fő ereje az összetartozás tudatában van, és ezt elsősorban az ellenségtől való közös félelem alakította ki a keresztényüldözések során. ${ }^{1236}$ Hydatius három évszázaddal később már úgy látja, hogy az eretnekségek terjedése, mint külső veszély nem volt elegendő ahhoz, hogy a püspökök és a hívek egymással összefogva kiálljanak az ortodoxia mellett, és közösen lépjenek fel azok ellen, akik veszélybe sodorják a birodalmi vallást. Az egyházi fegyelem hívek közötti lazulását már a 4. században is többféle módon igyekeztek megakadályozni, Constantinopolisban például a nyilvános fegyelmezési eljárások mellett egy rövid ideig titkos szankciókat is alkalmaztak, Augustinus pedig a bün nagyságához mérten javasolta a

\footnotetext{
1232 Egyes kutatók valószínűsítik, hogy a donatisták és a katolikusok békésen éltek egymás mellett, és a püspökválasztások során akár egy időre egyesülhettek is, a vandálok érkezése után pedig csatlakozhattak az arianus hódítókhoz, vö. Löhr 2007, 45-47; Angenendt 2008, 82.

${ }^{1233}$ Hyd. praef. 6.

1234 Amm. Marc. 20,4,8; Breisach 2004, 82; Albrecht 2004, 1151.

1235 Burgess 1988a, 232.

1236 Orig., C. Cels. 3,14; Vanyó 2007a, 131-132.
} 
büntetések kiszabását, ${ }^{1237}$ Hydatius korára viszont ennél sokkal súlyosabb problémát jelentett a püspökök közötti fegyelem fokozatos romlása és az eretnekségek elleni egységes fellépés hiánya. Azt is meg kell jegyeznünk azonban, hogy az 5. századi Hispaniában a katolikus egyház még a „standardisation and expansion” állapotában volt, különösen az egyházigazgatási rendszer kiépítését és a népesség korábbi istentiszteleti szokásainak átalakítását tekintve, ${ }^{1238}$ ez pedig nagyban kedvezett a pogány és a keresztény vallásgyakorlat egymás mellett élésének és az eretnek irányzatok terjedésének.

Thoribius, Asturica püspöke arról tájékoztatta a fent említett levelében Hydatiust és Caeponiust, ${ }^{1239}$ hogy utazgatásai során úgy látta a legtöbb provinciában, hogy az egyházi vezetőknek sikerült megfékezniük az eretnekségek terjedését, és a mozgalmakkal szimpatizálók vagy visszatértek a katolikus hitre, vagy számüzetésbe kellett vonulniuk, Gallaeciában viszont a téves tanítások egyre jobban megfertőzték a lakosságot és veszélybe sodorták az ortodoxiát. ${ }^{1240}$ Úgy tünik, hogy a gallaeciai püspökök nem vették túl komolyan a katolikus hit védelmét, vagy túlságosan türelmesek voltak az eretnekmozgalmakkal szemben, Thoribius mindenesetre a kialakult helyzetért azokat a püspököket hibáztatja, akik nem tartják be következetesen a pápai utasításokat és fegyelmezetlenségükkel szabad utat engednek az eretnekmozgalmak terjedésének. ${ }^{1241}$ Vilella szerint a római császárság és a katolikus hit támogatói még mindig nagyon széles tábort alkottak ebben az időszakban, ezért Thoribius kritikája legfeljebb csak Hispania egészére vonatkozóan lehet helytálló, ${ }^{1242}$ ennél azonban sokkal valószínűbbnek tünik Burgess álláspontja, mely szerint a 440-es évek Gallaeciájában Thoribiuson és Hydatiuson kívül nem sok olyan püspököt találunk, aki teljes mértékben elutasítaná a priscillianus tanításokat, egy kívülálló szemével pedig akár az összes gallaeciabeli priscillianusnak tünhetett, ezért sem véletlen, hogy jó néhányan vallási okok miatt hagyták el a provinciát. ${ }^{1243}$

\footnotetext{
1237 August., De mend. 17,35; Segesváry 1994, 78.

${ }^{1238}$ López Quiroga - Martínez Tejera 2017, 477.

1239 Thor., Ep. ad Hyd. et Cep., in: PL 54,693-695.

1240 Hieronymus hasonlóan negatív képest fest a priscillianizmus hispaniai népszerüségéről, de szerinte Baeticában volt a legsúlyosabb a helyzet, vö. Hier., Ep. 75,3; Augusto 2016, 637.

${ }^{1241}$ Muhlberger 1990, 237; 241. Gregorius Turonensis néhány évtizeddel később egyenesen arról ír, hogy a papság körében hatalmas méreteket öltött a kapzsiság, az iszákosság, a hatalomért való törtetés és a féltékenykedés, vö. Breisach 2004, 103.

1242 Vilella 1999, 40.

${ }^{1243}$ Burgess 1988a, 197-200. Többek között a priscillianizmus megerősödése is közrejátszhatott abban, hogy Orosius elhagyta Gallaeciát, vö. Chadwick 1976, 191; Arce szerint viszont sem ez, sem a szvévek jelenléte nem indokolja az utazást, mert Orosius inkább csak találkozni akart a nagy tanítómesterrel, vö. Arce 2005, 356; Oros. 3,20,6-7; 5,2. Bachiarius pusztán gallaeciai származása miatt kényszerült arra, hogy igazhitüségét a pápa előtt igazolja, vö. Bach., De fide 1-2, in: PL 20,1019; López Pereira 1998, 30-31; de maga Thoribius is
} 
Thoribius már annyira veszélyesnek ítélte meg a helyzetet, hogy a pápától egy hispaniai vagy gallaeciai zsinat összehívására is engedélyt kapott, ${ }^{1244}$ de nem tudjuk biztosan, hogy megvalósult-e ez a tanácskozás, mivel Hydatius erről semmit sem nyilatkozik. ${ }^{1245}$ Gallaecia püspökei feltehetően nem segítették Thoribius és Hydatius manicheusok elleni küzdelmét sem, mert Leo pápának Hispania-szerte szét kellett küldenie a manicheusokról szóló jelentéseket, ${ }^{1246}$ 449-ben pedig Flavianus püspökkel folytatott levelezését Cyrill írásával és más jelentésekkel együtt terjesztette az egyházban. ${ }^{1247}$ Leo valószínűleg így próbálta egyértelmủen a katolikus egyház melletti kiállásra ösztönözni a hitükben megingott gallaeciai püspököket, akiknek egy része még mindig az eretnekek oldalán állt. Leo Thoribiusnak írt válaszában megerősíti feltételezésünket, amikor még borúsabb képet fest a gallaeciai püspökök hüségéről, mert jó néhányan nemcsak hogy nem léptek fel az eretnekekkel szemben, hanem még segítették is a hitük terjesztését. ${ }^{1248}$ Burgess azt állítja, hogy Hydatius nem értékelte az eretnekségekkel szembeni küzdelem apróbb sikereit, mert hamis prófétáknak tartotta őket és ezek az események inkább csak fokozták pesszimizmusát, ${ }^{1249}$ ha azonban ez így lenne, akkor nem látnánk a krónikában Hydatius kiállását az ortodoxia mellett, és nem buzdítaná ennek követésére a többi püspököt és az olvasókat sem.

A kutatók többsége felfigyelt arra, hogy a Hydatius és Caeponius által feljelentett manicheusok ügyét nem a gyakorlatnak megfelelően Bracarában, Gallaecia fővárosában tárgyalták, hanem Emeritában. Mivel Hydatius csak keveset nyilatkozik a bracarai egyházról, Balconius bracarai püspök szerepe pedig még ma is vita tárgyát képezi, ${ }^{1250}$ az esetet valószínűleg azzal magyarázhatjuk, hogy a legtöbb egyházi vezetővel ellentétben Emerita püspöke, Antoninus határozottan támogatta az eretnekekkel szembeni fellépést, míg

hosszú ideig volt távol püspökké szentelése elött, vö. Thor., Ep. ad Hyd. et Cep. 1, in: PL 54,693; Chadwick 1976, 209.

${ }^{1244}$ Leo, Ep. 15,17, in: PL 54,677-692; Muhlberger 1990, 239.

1245 Az 561-es első bracarai zsinat említ egy hispaniai gyülést, de ezek aktái nem maradtak fenn. A modern kutatók nincsenek egységes állásponton ebben a kérdésben, hiszen Torres Rodríguez szerint Gallaeciában és Hispaniában is tartottak egy-egy zsinatot, vö. Torres Rodríguez 1977, 102; Thompson csak a gallaeciairól tud, vö. Thompson 1982, 196; Tranoy és Chadwick viszont jogosan kételkedik abban, hogy bárhol is tárgyaltak volna az eretnekek ügyéröl, vö. Tranoy 1974, 2,85; Chadwick 1999, 216-217.

${ }^{1246}$ Hyd. 125: per episcopum Romae tunc presidentem gesta de Manicheis per provintias diriguntur.

1247 Hyd. 137: de Gallis epistolae deferuntur Flaviani episcopi ad Leonem episcopum missae cum scriptis Cyrilli episcopi Alexandrini ad Nestorium Constantinopolitanum de Eutychete Hebionita heretico et Leonis episcopi ad eumdem responsa, quae cum aliorum episcoporum et gestis et scriptis per ecclesias diriguntur. ${ }^{1248}$ Leo, Ep. 15,17, in: PL 54,677-692; Muhlberger 1990, 241.

1249 Burgess 1988a, 186.

${ }^{1250}$ Hyd. 122. Balconius tevékenységéről bővebben: Avit., Ep. ad Balc., in: PL 41,805-818; Torres Rodríguez 1977, 92-97; López Pereira 1998, 29-30; López Quiroga - Martínez Tejera 2017, 478. 
Bracara püspöke szimpatizálhatott a manicheusokkal vagy a priscillianusokkal, mivel a város a szvévek igazgatási központjaként funkcionált. ${ }^{1251}$ Bár Emerita katonai táborként és igazgatási központként is müködhetett ebben az időben, ${ }^{1252}$ a szvévek a jelek szerint nem akadályozták a nyomozásban részt vevő püspökök utazgatását és az eretnekmozgalmak ellen végzett tevékenységüket, ebből következően a 440-es években kevésbé tartották szoros ellenőrzés alatt a római lakosságot, mégha Burgess hipotézise szerint bele is avatkoztak néhány alkalommal Gallaecia egyházi ügyeibe. Ennek ellenére nem gondoljuk, hogy Hydatiusnak nagy bátorságra lett volna szüksége ahhoz, hogy elhagyja a püspöki székét az asturicai manicheusok felkutatása érdekében, mert mindezt a város püspöke, Thoribius kérésére tette, az intézkedés pedig összhangban volt Hydatius elveivel. ${ }^{1253}$ Ezek alapján jól látszik, hogy a gallaeciai püspökök többsége nem nyíltan fordult szembe a pápa akaratával, hanem inkább közömbösséget tanúsítva egyszerüen nem tett lépéseket az ortodoxia védelmében, meghiúsítva ezzel Thoribius és Hydatius kitartó munkáját, az emeritai Antoninus viszont valószínüleg továbbra is lelkesen folytatta az eretnekség elleni küzdelmet, mert 448-ra Lusitania egész területéről sikerült kiűznie a manicheus elveket valló Pascentiust. ${ }^{1254}$

Ahogyan láttuk, Hydatius feltünően sokat foglalkozik a priscillianusok mozgalmával, ezt viszont azzal is magyarázhatjuk, hogy meg szeretné győzni a többi püspököt arról, hogy ha a legnagyobb egyházi vezetők el tudták utasítani Priscillianus téves tanítását, akkor Gallaecia püspökeinek és híveinek is ezt a példát kell követnie. ${ }^{1255}$ Priscillianus püspökké választásakor Hydatius nem titkolja, hogy az egyházi vezetők egy része támogatta őt a gonoszságban (pravitate), de büszkeséggel tölti el, hogy Rómában sem Damasus, sem Ambrosius nem hallgatta meg őt, Priscillianus még a színük elé sem kerülhetett (ne ad conspectum receptus), Maximus pedig elöször hiába adott helyet a fellebbezésnek, később éppen az ő parancsára végezték ki Priscillianust és követőit. ${ }^{1256}$ Hydatius viszont érdekes módon nagyon keveset mond Priscillianus kivégzésének körülményeiröl, talán az eljárás körüli botrány és a politikai hatalom beavatkozása miatt nem mert állást foglalni az ügyben. Többször is utalt ugyan Ambrosius és Martinus

\footnotetext{
${ }^{1251}$ Muhlberger 1990, 238; Thompson 1982, 196; Kulikowski 2010, 188.

${ }^{1252}$ Az újabb kutatások szerint Bracara és Emerita katonai-politikai szempontból egyaránt a Szvév Királyság fővárosának tekinthető, ezeken kívül közigazgatási és gazdasági központot jelentett még többek között Lucus, Astiruca és Conimbrica városa is, vö. López Quiroga - Martínez Tejera 2017, 438.

1253 Burgess 1988a, 219; 203.

1254 Burgess 1988a, 202; Muhlberger 1990, 239; Hyd. 130.

1255 Muhlberger 1990, 236.

1256 Hyd. 13; 16.
} 
Turonensis jótéteményeire, de valószínüleg nem a priscillianusokkal kapcsolatos tevékenységükre gondolt, mivel érthető okokból sehol sem említi, hogy éppen ők tiltakoztak volna a kivégzések ellen, és hogy nekik köszönhetően váltották le az ítélet meghozatalában közremüködő ortodox püspököket. Már a 306 körül megtartott elvirai zsinat aktái is arról tanúskodnak, hogy a hispaniai keresztények egy része „erkölcsi lazaságáról” volt híres, ezért sem meglepő, hogy a 400 körüli toletumi zsinaton már szükség volt egyházfegyelmi rendelkezésekre (quaedam etiam observanda de ecclesiae disciplina) is, amelynek hatására jó néhány püspök visszatért a katolikus egyházba. ${ }^{1257}$ Bár a priscillianusok üldözése egyre nagyobb méreteket öltött, még több évtizeddel később is jó néhányan rokonszenvezhettek a mozgalommal, mert 447-ben Leo pápa kénytelen volt az ellenük szóló írásokat és más rendelkezéseket elküldeni a hispaniai püspökökhöz, ezenfelül még Sulpicius Severus is a priscillianusokig tárgyalja az eseményeket krónikájában. ${ }^{1258}$

Az egyházi vezetők számára azonban nemcsak az ortodoxia egységes védelmezése és az eretnekmozgalmakkal szembeni határozott fellépés jelentett nehézséget, hanem a püspökök közötti meggondolatlan kinevezések (creationibus indiscretis) is problémát okoztak az egyház belső életében. ${ }^{1259}$ Hydatius több olyan botrányos püspökválasztásról tudósít, amelyik azt igazolja, hogy a gallaeciai egyház nem volt egységes, és gyakran az igazhitü püspökök is egymás ellen vívtak hatalmi harcokat, ahogyan Sulpicius Severus is arról tájékoztatja olvasóit, hogy a püspökök irigysége és hataloméhsége folyamatosan nyugtalanította és alaposan összezavarta a keresztény híveket. ${ }^{1260}$ Elöször 433-ban találkozunk püspökválasztással kapcsolatos botránnyal, amikor Lucus püspöki székéből leváltották Agrestiust, helyére pedig a püspök akaratával szemben (contra voluntatem) Pastort és Syagriust választották. Hydatius semmit nem mond a leváltás okairól és a szóban forgó személyek vallási nézeteiről, de Tranoy névazonosságok alapján feltételezi, hogy Agrestius szimpatizált a priscillianusokkal, Pastor és Syagrius pedig a katolikus hitet próbálta képviselni priscillianusellenes írásaival. ${ }^{1261}$ Valószínübb magyarázatnak tünik azonban Burgess feltevése, mely szerint az alapján, hogy a város püspökének akaratával

\footnotetext{
${ }^{1257}$ Hyd. 8; 30; 25; Vanyó 2007a, 142-143.

1258 Hyd. 127: episcopus Leo, huius scripta per episcopi Thoribi diaconem Pervincum contra Priscillianistas ad Hispanienses episcopos deferuntur; inter que ad episcopum Thoribium de observatione catholicae fidei et de heresum blasphemiis disputatio plena dirigitur, quae ab aliquibus Gallecis subdolo probatur arbitrio; Hyd. 30; Sulp. Sev., Chr. 2,51.

${ }^{1259}$ Hyd. praef. 6.

${ }^{1260}$ Sulp. Sev., Chr. 2,46,1; 2,51,5; Wieser 2016, 93-94. Angenendt szerint Észak-Africa hívő közösségei már elöre rettegtek a püspökválasztásoktól, mert az ilyen alkalmakat sok becsvágyó ember megpróbálta kihasználni és saját magát akarta egyházi pozícióhoz juttatni, vö. Angenendt 2008, 83.

${ }^{1261}$ Hyd. 93; Tranoy 1974, 2,69; Chadwick 1976, 217; Thompson 1982, 195; Muhlberger 1990, 240.
} 
szemben iktatták be az új vezetőket, és hogy Agrestius priscillianusként aligha vehetett volna részt a 441-es arausiói zsinaton, Agrestiust tartja ortodoxnak, a másik két, feltehetően priscillianus püspökről viszont nem közöl információkat. ${ }^{1262}$

Miután 441-ben a szvévek elfoglalták Hispalist, Agrestiushoz hasonló módon váltották le Sabinust, hogy Epiphanius ülhessen a püspöki székbe. Mivel Hydatius azt állítja, hogy a régi püspököt fondorlat útján (factione) távolították el helyéről, Epiphanius megválasztására pedig csellel (fraude, non iure) került sor, Tranoy és Thompson joggal feltételezi, hogy Epiphanius a priscillianizmus híve volt, Sabinus pedig az ortodoxiát képviselte. ${ }^{1263}$ Muhlberger ezen felül azt sem tartja kizártnak, hogy egy elégedetlenkedő csoport Hispalisban a város bukását kihasználva aktivizálta magát, hogy saját jelöltjét ültethesse a püspöki székbe, vagyis a rómaiak belső konfliktusaik rendezésére kihasználták a szvévek jelenlétét, de emellett elfogadhatónak tünik Burgess azon javaslata is, hogy a szvévek avatkoztak bele a püspökválasztásba, mert amikor 458-ban a gótok előrenyomultak Baeticában, Sabinus visszatérhetett számüzetéséből és újra Hispalis püspöke lett. ${ }^{1264}$ Burgess a két eset kapcsán ugyanakkor arra a következtetésre jut, hogy ha az említett püspökök, Agrestius és Epiphanius valóban priscillianusok lettek volna, Hydatius mindenképpen tájékoztatta volna olvasóit erről az egyáltalán nem mellékes információról, ezért a püspökválasztással kapcsolatos vita eldöntése céljából nem szükséges őket feltétlenül kapcsolatba hozni a priscillianizmussal, ${ }^{1265}$ bár a későbbiekben látni fogjuk, hogy Hydatiusnak akár érdekében is állhatott, hogy elhallgassa a püspökválasztásokkal kapcsolatos részleteket.

Bár Hydatius nem említi, Thompson a püspökök egyházi fegyelmével és a botrányos választásokkal kapcsolatban hoz egy újabb példát is. ${ }^{1266}$ Ascanius, Tarraco metropolitája 463-464 körül egy zsinatot hívott össze Silvanus calagurrisi püspök ügyében, aki nemcsak hogy törvénytelenül szerezte meg egyházi hivatalát, hanem a tiltakozások ellenére egy olyan papot is püspöki székhez juttatott, aki nem is az ő joghatósága alá tartozik. ${ }^{1267} \mathrm{Az}$ a tény, hogy a zsinaton részt vevő püspökök Hilarus pápához fordultak tanácsért, azt mutatja, hogy a pápai hatalom tekintélye a legtöbb egyházi vezető számára még mindig megkérdőjelezhetetlen volt. Hasonló következtetésre juthatunk Nundinarius esetében is, akit

1262 CCL 148,87,9; Chadwick 1976, 221-222; Burgess 1988a, 220; López Quiroga - Martínez Tejera 2017, 478.

${ }^{1263}$ Hyd. 115-116; Tranoy 1974, 2,78-79; Thompson 1982, 195; 303, 42. j.

${ }^{1264}$ Muhlberger 1990, 242; Pawlak 2007, 31; Burgess 1988a, 218; vö. Hyd. 185; 187.

${ }^{1265}$ Burgess 1988a, 220.

1266 Thompson 1982, 197.

${ }^{1267}$ Hilar., Ep. 13,3. 
Barcilona püspöke, Irenaeus már korábban egy város püspökévé kinevezett, de Irenaeus a halálos ágyán inkább a barcilonai egyház vezetésére kérte őt. Mivel a város lakossága és papsága is egyetértett ezzel a hivatalváltással, utólag kérték meg Hilariust, hogy erösítse meg pápai tekintélyével a módosítást. Hilarius a 465-ös római zsinaton úgy próbálta rendre utasítani a szabályokat figyelmen kívül hagyó püspököket, hogy a nicaeai zsinat útmutatásait követve elöírta, hogy a hívek egyetértésével sem szabad egyik püspöki széket a másikra cserélni. ${ }^{1268}$

\subsubsection{Problémák a politikai életben}

Az 5. századi Vegetius szerint a rómaiak a fegyverforgatás és a fegyelem miatt tudtak olyan sok területet meghódítani, ugyanakkor a nyugati területeken kialakult polgárháborús helyzet és a császári udvarban rivalizáló hadvezérek kétségtelenül gyengítették a hadsereg ütőképességét, ezzel pedig megnőtt az esélye annak, hogy a rómaiak vereséget szenvedjenek a barbároktól. ${ }^{1269}$ Mivel az 5. századi Nyugatrómai Birodalomban sok szempontból a katonai védelem megszervezése jelentette a legnagyobb kihívást, azt sem hagyhatjuk figyelmen kívül, hogy ennek sikere nemcsak a rendelkezésre álló erőforrások nagyságától, hanem azok felhasználási módjától és a katonai vezetők ambíciójától is függött. ${ }^{1270}$

Hydatius rendületlenül hitt a Római Birodalom eszméjében, és kortársaihoz hasonlóan ${ }^{1271}$ durva kritikával illette azokat, akik a római császárhoz való hüség és a birodalmi rend visszaállítása helyett az árulást vagy a lázadást választották. Johnson meglátásával szemben Hydatius a hitszegő barbárok ellenpólusaként nemcsak „lawobeying" rómaiakat szerepeltet a krónikában, ${ }^{1272}$ hanem bemutatja azoknak a katonai vezetőknek és trónbitorlóknak a tevékenységét is, akik gyakran a törvénnyel szembeszállva és a katonáik segítségével megszerzett hatalom birtokában próbálták meg saját érdekeiket érvényesíteni. Burgess ezt a tényt Hydatius személyes érintettségével és fenyegetettségével indokolta, ${ }^{1273}$ de a magyarázat ennél jóval egyszerübb, hiszen a lázadók és az usurpatorok tevékenysége gyengíti azt a császári hatalmat, amely Hydatius szerint elviekben még mindig

\footnotetext{
1268 Thompson 1982, 198-199. A nicaeai zsinat 4. kánonja szerint a püspökök felszentelését lehetőleg az összes püspök, de legalább három részvételével kell elvégezni, a metropolitának viszont vétójoga van a püspökök kinevezésekor, vö. Schütz 1937, 604; Hilar., Ep. 16.

1269 Veget., Epit. rei milit. 1,1; Goldsworthy 2004, 214.

${ }^{1270}$ Koenigsberger 1987, 12.

${ }^{1271}$ Pohl 2018, 2.

1272 Johnson 1993, 44.

1273 Burgess 1988a, 102.
} 
a legfontosabb tényezőjét jelenthetné a birodalmi irányításnak, ezért bemutatásukkal megfelelően árnyalni tudja a saját korában kialakult erőviszonyokat.

Septimius Severus óta a hadsereg szerepe annyira felértékelődött, hogy a katonák házasodásának engedélyezése, a katonai fegyelem lazulása és a veteránoknak nyújtott kedvezmények miatt ${ }^{1274}$ „,ényegében kiszakadt a társadalomból”, 1275 a katonák „szinte kontroll felett álló" csoportot alkottak a társadalmi hierarchia élén, a nekik juttatott pénzbeli és egyéb kiváltságokért cserébe pedig politikai, vagy szükség esetén katonai támogatást nyújtottak az uralkodóvá kiáltott parancsnokuknak. ${ }^{1276} \mathrm{~A}$ hadvezérek hatalmának csökkentése érdekében Diocletianus szétválasztotta egymástól a katonai és a polgári közigazgatást, hogy a határmenti csapatokat vezető duxok és a belső seregek élén álló magister militumok csökkentett jogkörük miatt kénytelenek legyenek együttmüködni a praefectus praetoriókkal. ${ }^{1277}$ Különösen ez utóbbiaknak volt lehetősége a császári testőrség vezetőjeként befolyásukat és kapcsolataikat kihasználva hatalmi játszmákba kezdeni, a 4. század végétől pedig a nyugati területek magister militumai, Merobaudes, Arbogastes, Stilicho, Constantius, Aëtius és Ricimer jutottak döntő szerephez a politikai életben, és a császárok trónra ültetésével, az uralkodó dinasztiába való beházasodással vagy a kiskorú császár patronálásával ténylegesen ők irányították a birodalmat. ${ }^{1278}$ A késő császárkorban a hadsereg fóparancsnokaiból, a legtekintélyesebb egyházi vezetőkből és az uralkodó személyes szolgálóiból álló consistorium tagjai számítottak a legbefolyásosabb személyeknek, a központi hatalom centralizációja miatt azonban a császárok törekedtek arra, hogy a saját konkurenciájukat jelentő hatalmi tényezők hatáskörét fokozatosan

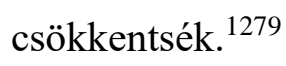

Hydatius többször is utal arra a logikai kapcsolatra, hogy a barbárok mérgezték meg a rómaiakat nemcsak az eretnekség, hanem az árulás és a lázadás gondolatával is. A krónikában bemutatott római császárokról és hadvezérekről Hydatius sok esetben csak olyan információkat közöl az olvasóival, amelyek nem rombolják le az általa kialakított pozitív uralkodói portrékat, ha pedig néhány esemény mégis rossz fényt vetne a császárok tevékenységének megítélésére, akkor azokat egyszerüen nem jegyezte fel az események

\footnotetext{
${ }^{1274}$ Dig. 49,18. A veteránoknak járó előjogokról bővebben: Kelemen 2007, 158-163.

1275 Angi 1999, 4.

1276 Grüll 2007, 105-107. Amikor a hadsereg valamelyik egysége acclamatióval imperatorrá kiáltotta vezetöjét, még nem rendelkezett közjogi felhatalmazással, ezért az uralkodás megkezdéséhez mindenképpen szükség volt a senatus jóváhagyására is, vö. Kelemen 2007, 6.

1277 Angi 1999, 7. A szétválasztás alóli kivételekről bővebben: Kelemen 2007, 38, 72. j.

${ }^{1278}$ Havas - Hegyi - Szabó 2007, 740; 752.

1279 Alföldy 2000, 179; Kelemen 2007, 180.
} 
között, vagy más szereplöre hárította az ezzel kapcsolatos felelősséget. Néhány esetben annyira megalázónak érezte a katonai vezetők és a trónbitorlók tevékenységét is, hogy inkább hallgatott a részletekről az olvasói előtt. Amikor például Priscillianus Maximustól kért segítséget az ellene felhozott vádak miatt, Hydatius rosszallóan hozzáteszi, hogy Galliát ekkor ő tartotta kezében tyrannusként. ${ }^{1280}$ Rendkívül pontosan igyekszik tudósítani később Maximus meggyilkolásáról, ugyanakkor elhallgatja, hogy a római katonák Gratianus tapasztalatlansága, Italia lakossága pedig II. Valentinianus arianusokkal való szimpatizálása miatt törvényesnek ismerték el uzurpációját 386-388 között, így sikerrel tudott védekezni a barbárokkal szemben. ${ }^{1281}$

Hydatius kiemeli, hogy II. Valentinianus meggyilkolása 392. május 15-én az egyre nagyobb befolyással rendelkező comes és magister equitum, Arbogast árulása (scelere) miatt következett be, hogy három hónappal később saját jelöltjét, a magister scrinii rangot betöltő Eugeniust ültethesse trónra. ${ }^{1282}$ Ezek alapján meglepő, hogy Hydatius csak szükszavúan emlékezik meg arról, hogy Theodosius 394. szeptember 6-án a Frigidus folyó menti csatában legyőzte Eugeniust, ${ }^{1283}$ pedig ezt tekintjük a kereszténység és a régi római vallás utolsó jelentős összecsapásának. Valószínűleg itt is arról lehet szó, hogy Theodosius 100 ezer fös seregében 20 ezer gót szövetséges harcolt, ${ }^{1284}$ együttmüködésüket viszont nem érdemes az olvasók tudomására hozni akkor, ha a rómaiak barbárokkal szembeni fölényét szeretnénk hangsúlyozni. ${ }^{1285}$

A császári hatalom gyengesége mutatkozik meg a 412-414 közötti galliai események ábrázolásában is. Miután Flavius Constantius, Honorius duxa megölte lázadó hadseregparancsnokát, Gerontiust, saját hatalmi érdekeinek érvényesítéséhez pedig leszámolt III. Constantinusszal három éves tyrannisa után, Iovinust, Sebastianust és az africai Heraclianust megszállta az egyeduralom iránti vágy (tyrannidis insania). Hydatius a

\footnotetext{
1280 Hyd. 13. Amikor Magnus Maximus ellencsászárként lépett fel Gratianusszal szemben Britanniában, Gratianus ellene vonult, de Maximus áttette a székhelyét Galliába és átcsábította Gratianus katonáit is a saját seregébe, vö. Collins 1999, 56; Székely 2018, 103, 13. j.; CTh 1,3,1; Zos. 4,35.

${ }^{1281}$ Hyd. 17. Maximus 387-es alpesi átkeléséről és italiai hadjáratáról bővebben: Várady 1961, 233-235; a nyugati területek fölötti uralmához lásd: Baldus 1984, 175-192; Theodosius Maximus felett aratott győzelméről és Pacatus ebből az alkalomból mondott panegyricusáról lásd: Székely 2018, 101-107.

1282 Hyd. 20; Oros. 7,35,10. II. Valentinianus frank tanácsadója, Bauto magister militum halála után fia, Arbogast önkényesen apja pozíciójába léptette magát, így kapcsolatukat leginkább konfliktusok jellemezték. Arbogast és Eugenius szerepéről bővebben: Várady 1961, 134-136; Gerberding 2005, 24; Curran 2007, 108 110 .

${ }^{1283}$ Hyd. 21; Zos. 2,2.

${ }^{1284}$ Ezt a gót sereget valószínüleg Alaric vezette a 392-ben a rómaiakkal kötött szerződés alapján, vö. Zos. 4,59,1; 5,5,4; Demandt 1989, 135; Kiss 2008, 81; Székely 2017, 79; 88-89; Pohl 2018, 1-2. Más vélemények szerint a gótok nem is vettek részt a csatában, vö. Kiss 2008, 98, 6. j.

${ }^{1285}$ A Frigidus-menti csata körülményeiröl és a barbár csapatok szerepéröl bővebben: Várady 1961, 137-138.
} 
rómaiak sikerének tulajdonítja, hogy 413-ban végezni tudott Iovinusszal és Sebastianusszal, ${ }^{1286}$ Iovinus elfogása azonban inkább Athaulf gót csapatainak köszönhető, mivel Honoriusszal korábban egyezséget kötött az együttmúködésről, ${ }^{1287}$ Heraclianust pedig 414-ben Carthagóban ölték meg, miután elveszítette Utriculumban a Honoriusszal vívott csatát. $^{1288}$

Miután 422-ben a római magister militum, Castinus meggondolatlanul (inconsulte) összecsapott a vandálokkal, de a gótok árulása miatt vereséget szenvedett és kénytelen volt visszavonulni Tarracóba, sok római és gót katona átállt a győztes Gunderic csapataihoz. ${ }^{1289}$ Valószínűleg ez is ösztönözhette arra Bonifatiust, aki Castinus kísérőjeként vett részt a vandálok elleni hadjáratban, hogy 423-ban elhagyja (deserens) a római sereget és Africába siessen, hogy az itteni sereg parancsnokaként törvénytelen módon megszerezze az egész provinciát. ${ }^{1290}$ Castinus később a Ravennából száműzött Galla Placidia ellen fordult és 423 szeptemberében Iohannest tette meg a nyugati rész augustusává, hogy megakadályozza a császárné visszatérését és fia, III. Valentinianus kinevezését. II. Theodosius betegsége miatt végül csak Helion magister officiorum segítségével tudta Constantinopolisban caesarrá koronázni unokaöccsét, Valentinianust, akit azonnal a tyrannusként uralkodó Iohannes ellen küldött Ravennába. ${ }^{1291}$ Iohannest végül Theodosius katonai parancsnoka, Aspar fogta el 425 májusában, majd Aquileiába vitte, ahol Placidia halálra ítélte. ${ }^{1292}$

A korábban patriciussá és Italia magister militumává kinevezett Felix ${ }^{1293}$ 427-ben sikertelen hadjáratot indított Bonifatius megfékezésére, aki Africa helytartójaként először Galla Placidia támogatását élvezte, de viszonyuk egy idő után megromlott. 429-ben Galla Placidia Bonifatiust Italiába hívatta, hogy elsimíthassák az ellentétüket, mert azt remélte, hogy Bonifatius fellépése véget vethet Aëtius hatalmának, ${ }^{1294}$ akit időközben a Iohannes usurpator ellen elért sikerei miatt comesnek és Gallia magister militumának neveztek ki. Bár Hydatius nem említi, de Felix összeesküvést szőtt Aëtius ellen feleségével, Padusiával és

\footnotetext{
${ }^{1286}$ Hyd. 42-43; 46.

${ }^{1287}$ Marc. Com. 411-412. Iovinus galliai senatort 411-től a burgundok és az alánok támogatták usurpatorként Honoriusszal szemben, 412-ben pedig Athaulf állt mellette, vö. Horváth 1999, 47.

1288 Hyd. 48. Heraclianus africai comes 408-ban Stilicho meggyilkolása és vagyonának megszerzése után valószínüleg a hadsereg föparancsnoka szeretett volna lenni. Stilicho megbuktatásának körülményeiröl és Heraclianus indítékairól bővebben: Várady 1961, 116; 248; Kulikowski 2010, 158-159.

${ }^{1289}$ Hyd. 69; Merrils - Miles 2010, 50.

${ }^{1290}$ Hyd. 70; Prosp. 422; Blockey 2007, 135-136.

${ }^{1291}$ Hyd. 74-75; Prosp. 423.

${ }^{1292}$ Chr. Gall. 452, 99; Randers-Pehrson 1993, 130-133.

${ }^{1293}$ Hyd. 75. A patriciusi cím eredetileg rendkívüli állami szolgálatért járó jutalom volt, de semmilyen meghatározott hivatalhoz nem kapcsolódott, és elsőbbséget élvezett minden más méltósággal szemben, vö. Kelemen 2007, 38; 63.

${ }^{1294}$ Hyd. 89; Blockey 2007a, 136-137.
} 
egy Grunitus nevü diaconussal együtt, ezért egy katonai zendülés alkalmával (tumultu militari) valószínűleg Aëtius parancsára megölték 430-ban Ravennában. ${ }^{1295}$ Galla Placidia 432-ben elbocsátotta Aëtiust, hogy az Italia fölötti magister militum praesentalis rangot Bonifatiusra ruházza át, de Aëtius Ariminium közelében legyőzte őt és halálos sebet ejtett rajta. ${ }^{1296}$ Bonifatius után veje, Sebastianus szerezte meg a föparancsnokságot, de 432-ben Aëtius elüzte őt, ezért 434-ben a keleti udvarhoz hajózott és egy ideig Helléspontoson tevékenykedett. Amikor 444-ben figyelmeztették, hogy az élete veszélyben van, I. Theoderic gót királyhoz menekült, de ő ellenséggé nyilvánította (hostis factus), ezért Barcilonába ment, majd 445-ben onnan is elüldözték és a vandálokhoz menekült. 449-ben Gaiseric védelmezte őt, Marcellinus Comes szerint a tanácsadója is lett, a vandál király azonban nem bízott benne és megölette. ${ }^{1297}$

A következő időszakban három olyan eseményről is olvashatunk, amely a római vezetők megbízhatatlanságáról vagy irigységéről tanúskodik. Amikor Theoderic 436-ban Narbo ellen vonult, Litorius római $d u x$ egy évvel később még el tudta hárítani a hunok segítségével a gótok támadását, 439-ben azonban meggondolatlanul (inconsultius) csatába bocsátkozott, de sebesülése után elfogták és néhány nappal később meghalt. ${ }^{1298} \mathrm{Az}$ elismert költő és hadvezér, Merobaudes rövid ideig tartó uralma alatt hiába győzte le 443-ban az Aracelliben lázadó bagaudákat, katonai karrierjét az irigyei megtörték, amikor rávették a császárt, hogy rendelje vissza őt Rómába. Amikor 446-ban a Baeticát és Carthaginiensist védelmező Vitus magister utriusque militiae többször is szembetalálta magát a szvévek katonáival, a rómaiakkal szövetséges gótok pedig vereséget szenvedtek, Vitus ijedtségében megfutamodott, hogy elkerülje a megsemmisítő vereséget. ${ }^{1299}$

Petronius Maximus praefectus praetorio 454-455-ös hatalomra törése, valamint Aëtius és Valentinianus halálának körülményei különösen jól mutatják a császári irányítás gyengeségét és a birodalmi vezetés labilis helyzetét. ${ }^{1300}$ A császári trón megszerzésére törekvő Maximus szövetséget kötött az udvar egyik eunuchjával, Heracliusszal, aki hosszú ideje ellenséges viszonyban volt Aëtiusszal, és ketten meggyőzték arról Valentinianust,

\footnotetext{
1295 Hyd. 84; Prosp. 430.

${ }^{1296}$ Hyd. 89; Chr. Gall. 452, 111. Bonifatius azt tanácsolta halálos ágyán feleségének, hogy a saját biztonsága érdekében menjen feleségül Aëtiushoz, vö. Pohl 2018, 3. Felix, Bonifatius és Aëtius hatalmi versengése jól mutatja, hogy Galla Placidia jól döntött, amikor a nyugati területek irányítását három önálló parancsnok alá rendelte, hogy egyikük se rendelkezzen akkorra befolyással, amellyel ki tudná sajátítani maga számára a hatalmat, vö. Collins 1999, 77-78; Heather 2007b, 5-8. Galla Placidia tevékenységéről bővebben: Sivan 2011; Honoré 1998, 248-257.

${ }^{1297}$ Hyd. 89; 95; 121; 124; 136; Marc. Com. 435.

${ }^{1298}$ Hyd. 98; 101; 108.

${ }^{1299}$ Hyd. 120; 126.

1300 Petronius Maximus tevékenységéről bővebben: Heather 2007b, 18-21.
} 
hogy Aëtius a hatalom megszerzéséért a császár életére akar törni, ezért inkább saját kezüleg végezzen vele. ${ }^{1301}$ Valentinianus 454. szeptember 21-én cseles módon (fraudulenter) egyedül hivatta magához Aëtiust, akivel a megbeszéltek alapján saját kezével végzett, a császár spathariusa pedig néhány előkelőt is meggyilkolt. ${ }^{1302}$ Hydatius nem véletlenül tartja teljesen jogtalannak Aëtius meggyilkolását, hiszen ő két évtizedig nemcsak a nyugatrómai birodalom legsikeresebb hadvezére volt, hanem Valentinianus uralkodását is mindvégig támogatta. ${ }^{1303}$

A császár Heraclius tanácsa ellenére mégsem Maximust nevezte ki Aëtius helyére magister militumnak, ezért ő felfogadott két gót vagy hun származású testőrt, Optilát és Thraustilát, hogy álljanak bosszút parancsnokuk, Aëtius haláláért. 455. március 16-án megölette velük Heracliust és Valentinianust: a császár éppen a lováról szállt le a Campus Martiuson, hogy íjászatot gyakoroljon, amikor arcára és halántékára halálos sebet kapott. ${ }^{1304}$ A történetírók többsége elárulja, hogy Maximus és Heraclius gyilkoltatta meg a császárt, ${ }^{1305}$ Hydatius azonban az események bemutatásakor nem utal arra, hogy kik adtak megbízást Valentinianus megölésére, ${ }^{1306}$ valószínüleg mert szégyellte a központi vezetés gyengeségét és a hatalomért folyó méltánytalan küzdelmet. A helyzetet még inkább súlyosbította, hogy amikor nyilvánvalóvá vált Eudoxia császárné számára, hogy férjét Maximus parancsára gyilkolták meg, akkor a vandál Gaiserictől kért segítséget, bár Hydatius szerint ezt a hírt csak a rossz nyelvek terjesztették (ut malum fama dispergit), vagyis a vandálok betörése nem Eudoxia kétségbeesésének, hanem Gaiseric terjeszkedő politikájának köszönhető, ${ }^{1307}$ mindenesetre azzal, hogy Gaiseric Rómába érkezett, kétségtelenül tovább gyengült a császári vezetés birodalom fölötti hatalma. ${ }^{1308}$

Hydatius látszólagos rövidlátásának egyik legkülönösebb példája, hogy kezdetben megpróbálta legitimizálni Maximus uralmát, és több alkalommal is Maximus császárrá választásáról tudósít. Egy sorral lejjebb már teljesen más színben tűnik fel Maximus, aki

\footnotetext{
${ }^{1301}$ Az eunuchok a császári magánlakosztály vezetőjeként, praepositus sacri cubiculi rangban folyamatosan kapcsolatban álltak a császárral, így nagy befolyással lehettek annak döntéseire, vö. Havas - Hegyi - Szabó 2007, 735; 781.

${ }^{1302}$ Hyd. 152; Vict. Tunn. 454.

${ }^{1303}$ Procopius találóan jegyezte meg Valentinianusról, hogy bal kezével a saját jobb kezét vágta le, vö. Proc. 4,28 .

${ }^{1304}$ Hyd. 154; Demandt 1989, 155-156.

${ }^{1305}$ Prosp. 454-455; Iord., Get. 235; Vict. Tunn. 455.

${ }^{1306}$ Hyd. 154.

${ }^{1307}$ Hyd. 160. Az Eudoxiával szemben felhozott vád ugyanúgy nem bizonyítható, mint az, hogy 410-ben Stilicho özvegye, Serena hívta be Alaric gótjait Rómába, vö. Sz. Jónás 1994, 40.

${ }^{1308}$ Várady 1961, 185.
} 
álnok módon a hatalomra tört és eltervezte Valentinianus halálát, ${ }^{1309}$ ráadásul mindez a Theodosius-dinasztia kihalását eredményezte, ${ }^{1310}$ amely jól mutatja, hogy Hydatius szerint a római császárság hatalma Maximus tevékenységével fordulóponthoz érkezett. ${ }^{1311}$ Elképzelhetetlen, hogy Hydatius ne vette volna észre a logikai ellentmondást egy feljegyzésen belül, és hogy csak véletlenül nem szerkesztette át a Maximus császárellenes terveiről szóló információt a Valentinianus meggyilkolásáról szóló események leírásához. ${ }^{1312}$ A sajátos szerkesztési módot könnyen magyarázhatjuk Hydatius azon törekvésével, hogy igyekezett meghökkenteni az olvasókat váratlan fordulatokkal: a trónt megszerző Maximusról hirtelen kiderül, hogy ő gyilkolta meg a császárt, ez pedig egyértelmüen jelzi az olvasónak, hogy rendkívül nagy válságba került a központi hatalom. Ha elfogadjuk Hydatius többszöri állítását, mely szerint Maximust úgy választotta meg császárnak a római arisztokrácia, akár azért, mert kényszerítették rá, akár azért, mert jóhiszeműen menteni akarták a császári hatalom egységét és nem tudtak Maximus bűnösségéről, úgy tűnik, hogy Hydatius szemében mindenképpen a társadalmi elit csalódottsága és félrevezetése lesz Maximus trónbitorlásának legfontosabb következménye.

Maximus 455. március 17-ei trónra lépésekor az özvegy Eudoxiát házasságra kényszerítette. ${ }^{1313}$ Tunnunai Victor szerint erre a házasságra már néhány nappal Valentinianus halála után sor került, így a római szokásoktól eltérően még ideje sem volt gyászolnia a férjét, különösen hogy ezt Maximus kifejezetten meg is tiltotta neki. Maximus Valentinianus és Eudoxia idősebb lányát, Eudociát hozzáadta korábbi házasságából született fiához, Palladiushoz, hogy még szorosabbra füzze a viszonyt a Theodosius-dinasztiával, mert hatalmát kiterjesztve így jogi alapja is lehet a császári trón megszerzésére. Maximus a védelem megszervezése helyett el akart menekülni Rómából, mivel tudta, hogy Avitus serege nélkül nem tudná felvenni a harcot a hamarosan Italiába érkező vandálokkal. Maximus igyekezett rábeszélni a senatorokat, hogy szökjenek meg együtt, ${ }^{1314}$ így talán kevésbé lett volna feltűnő az ő menekülése. A testőrök nélkül maradt Maximus viselkedése

\footnotetext{
${ }^{1309}$ Hyd. 155: post quem mox Maximus ex consulibus XLIII Romae Augustus appellatur; qui cum imperator factus relictam Valentiniani sibi duxisset uxorem et filio suo ex priore coniuge Paladio, quem Caesarem fecerat, Valentiniani filiam in coniugium tradidisset, magnorum motuum, quos verebatur, perturbatione distortus et quia et in occisorum per Valentinianum et in ipsius interitum Valentiniani ambitu regni consilia sceleste patrata contulerat.

${ }^{1310}$ Hyd. 157: usque ad Valentinianum Theodosi generatio tenuit principatum.

${ }^{1311}$ Ezt a megállapítást egyesek nem megalapozottan Hydatius apokaliptikus hiedelmeivel magyarázzák, vö. Castellanos 2015, 288-289.

${ }^{1312}$ Hyd. 154.

${ }^{1313}$ Hyd. 155; Chr. Gall. 511, 623; Proc. 1,4,38-39; Theoph. 5947.

${ }^{1314}$ Vict. Tunn. 455.
} 
miatt viszont a római sereg egy része fellázadt és meggyilkolta öt. ${ }^{1315}$ Tunnunai Victor szerint a merénylet sajátos módon történt, mert amikor Maximus kilovagolt a városból, kőzáporral támadtak rá, és miután belehalt sérüléseibe, a testét megcsonkították és a Tiberisbe dobták, valószínüleg ekkor ölték meg fiát, Palladiust is. Maximus sikertelen trónbitorlása és meggyilkolásának körülményei jól mutatják, hogy a gyengülő központi hatalom ellenére a korabeli katonaság sem tolerálta egy politikai vezető gyávaságát és mérhetetlen hatalomvágyát. ${ }^{1316}$

Hydatius 460-ra vonatkozó feljegyzéseiben több alkalommal is nagy szerepet tulajdonít azoknak az árulóknak (proditores) és besúgóknak (delatores), akik miatt a római sereg nem tudott hosszú távú győzelmet kivívni a barbár népekkel szemben. 460 májusában Maiorianus hatalmas flottát szervezett Gaiseric ellen, de Carthaginiensis partjainál árulók figyelmeztették a vandálokat, így a császár terve meghiúsult. Amikor a Lucus közelében élő szvéveket a gótok fosztogatni kezdték, három besúgó kétszínűen elárulta őket, ${ }^{1317}$ ennek köszönhetően került sor Aquae Flaviae környékének feldúlására és a római érdekeket képviselö Hydatius elfogására is. A három informátor müködése jó példa arra, hogy a rómaiak és a szvévek közötti, egyre súlyosbodó konfliktusban még mindig akadtak olyan gallaeciabeliek, akik a szvévek pártjára álltak. ${ }^{1318}$ A gót befolyás növekedésével ugyanakkor votlak olyanok is, akik a gótok támogatásában bíztak, 462-ben például egy gall comes, Agrippinus Theoderic kezére adta (tradidit) azt a Narbót, amelyet a rómaiak korábban hevesen védelmeztek, majd a gótok segédcsapataival Aegidius ellen vonult, ő azonban vereséget mért rájuk. Narbo önkéntes átadása a segédcsapatokért cserébe azt igazolja, hogy Ricimer mögött a saját kíséretén kívül ott álltak galliai hívei és rokonai, akik passzív magatartásukkal ekkor már szabad kezet adtak a gótok terjeszkedéséhez. ${ }^{1319}$

Ricimer tevékenységét Hydatius mindvégig gyanús szemmel figyelte, a személyével kapcsolatos óvatosság azonban nem volt teljesen alaptalan. ${ }^{1320}$ Mivel Ricimer egy szvév herceg és egy gót hercegnő fiaként mindkét ágról barbár származású volt, ráadásul az arianus hitet gyakorolta, Hydatius számára már ez a két tényező is elfogadhatatlannak

\footnotetext{
1315 Hyd. 155: cum imperium deserere vellet et Romam, vix quattuor regni sui mensibus expletis in ipsa urbe tumultu populi et seditione occiditur militari.

${ }^{1316}$ A források eltérnek abban, hogy Maximus mennyi ideig uralkodott. Hydatius szerint alig négy hónapig, vö. Hyd. 155; Prosper és Tunnunai Victor 77 napról beszél, vö. Prosp. 455; Vict. Tunn. 455; az 511-es gall krónika 70 napot említ, vö. Chr. Gall. 511, 623; néhány szerző pedig nem pontosítja az adatot, vö. Cass. 455; Marc. Com. 455,2.

${ }^{1317}$ Hyd. 195-196: delatoribus spargentibusque ad terrorem propriae venena perfidiae indigata.

1318 Thompson 1982, 171.

${ }^{1319}$ Hyd. 212; 214; Várady 1961, 187.

${ }^{1320}$ Ricimer pályafutásáról és politikai szerepéről bővebben: Halsall 2007, 266-278; Reynolds 2011, $175-195$.
} 
tünhetett, nem beszélve arról, hogy Ricimer csak Italia megtartására törekedett, és a vandálokkal szemben vagy más területekért indított háborút felesleges erőpazarlásnak tartotta. ${ }^{1321}$ Hydatius igyekszik bemutatni mindazokat az eseményeket, amelyek Ricimer megbízhatatlanságára és saját hatalmi érdekeinek érvényesítésére vonatkoznak, különösen abban az esetben, ha ezek ellentétben állnak a Hydatius által kedvelt uralkodók tevékenységével. Ugyanakkor Hydatius a legtöbb eseményt elhallgatja Ricimerrel kapcsolatban, és nem is mond róla elhamarkodottan végső ítéletet, mivel karrierjének csúcspontja és személyének átfogó értékelése jelentősen túlmutat Hydatius életén.

Ricimer a krónikában először 457-ben tünik fel, amikor comesként a birodalom partjait sokáig nyugtalanító vandálok ellen új flottát és szárazföldi sereget állított fel, amelyet felhasználva csellel (circumventione) legyilkolta az Agrigentum melletti csapataikat. Hydatius nem közli, hogy Avitus ezért magister militum praesentalisszá nevezte ki őt, Ricimer azonban hamarosan szembefordult Avitusszal és üldözni kezdte a császárt, de arról is hallgat, hogy az ő javaslatára nevezték ki Maiorianust nyugatrómai császárrá, ${ }^{1322}$ feltehetően azért, mert mindkét általa kedvelt uralkodó portréjára rossz fényt vetne Ricimer tevékenységének említése. 457-472 között magister utriusque militiae rangjának köszönhetően a nyugati területeken regnáló császárokat az ő javaslatára nevezték ki, amikor viszont egykori parancsnoktársa, a császárrá emelt Maiorianus önállósította magát és sikeresen harcolt a barbárok ellen, Ricimer tőrbe csalta és megölte őt. ${ }^{1323}$

Hydatius nem említi, hogy Aegidius javaslatára 465-ben Gaiseric serege megtámadta volna Ricimert Italiában, ahogyan azt is tévesen állítja, hogy a 461-ben comesszé kinevezett Marcellinus lemészárolta a siciliai vandálokat. Valójában Marcellinus hun segédcsapatokkal igyekezett visszaverni a vandálok betörését, de Ricimer megvesztegette őket, ezért a sereg nélkül maradt comes visszavonulásra kényszerült. ${ }^{1324}$ Arról sem olvashatunk a krónikában, hogy a szintén császárrá emelt Libius Severust valószínűleg Ricimer mérgezte meg 465. november 14-én, Aegidius meggyilkolása után, ${ }^{1325}$ de arról sincs információnk, hogy amikor 468-ban Anthemius és Leo egy összehangolt keleti-nyugati támadással vonult a vandálok

${ }^{1321}$ Ricimer tisztában volt azzal, hogy származása és hite miatt sohasem lehetne belőle római császár, éppen ezek a tényezők segítették hozzá, hogy minden eddiginél nagyobb területen elismerjék befolyását, mert a nyugati tartományok nagy része ekkor már barbár uralom alatt állt.

${ }^{1322}$ Hyd. 169; 176; 178.

${ }^{1323}$ Hyd. 205: ordinantem livore percitus et invidorum consilio fultus fraude interfecit circumventum.

${ }^{1324}$ Hyd. 220; 223; Demandt 1989, 173.

${ }^{1325}$ Hyd. 227. Severus uralkodásának hydatiusi datálásáról bővebben: Thompson 1982, 228. 
ellen, akkor Ricimer sértődöttsége miatt nem vett részt a hadjáratban, ez pedig nagyban hozzájárulhatott a rómaiak vereségéhez. ${ }^{1326}$

Hydatius ugyanakkor igyekszik pontos információkat adni arról, hogy mi történt a 468-as hadjáratot ellenző nyugati és keleti parancsnokkal, Ricimerrel és Asparral. Hydatius szerint Anthemius úgy próbálta Ricimer hatalmát megfékezni, hogy saját lányát adta feleségül hozzá, Aspart pedig elbocsátották és fiát megölték Róma-ellenes összeesküvés gyanúja miatt. ${ }^{1327}$ Valójában Aspart és idősebb fiát, a keleti csapatokat vezető Ardaburiust néhány évvel később, 471-ben ölték meg, másik fia, Patriocolus vagy Patricius, akit Aspar egy megállapodás értelmében Leo utódjának szánt, a vandáloktól elszenvedett császári vereség után 469-ben megkapta a caesari kinevezését és Leo kisebbik lányának, Leontiának a kezét, később sebesülést szenvedett és elmenekült Constantinopolisból. ${ }^{1328}$ Hydatius már nem érhette meg, hogy a vandáloktól elszenvedett vereség és Gallia nagy részének elvesztése után Ricimer és Anthemius viszonya megromoljon, 472-ben a császár Rómába meneküljön, Ricimer pedig hosszú ostrom után ismét kifossza a várost és Gaiseric jelöltjét, Olybriust ültesse a trónra. ${ }^{1329}$

\subsubsection{Hydatius példaképei}

A birodalom és az egyház életét szétfeszítő erőket Hydatius úgy próbálja ellensúlyozni, hogy már a krónika bevezetőjében elismeréssel szól azokról az erényes férfiakról, akiket nagyrabecsülés és tisztelet vesz körül. ${ }^{1330}$ Első látásra itt olyan keresztény szerzőkre gondolhatunk, akiket Hydatius jól ismert az ortodoxia melletti kiállásukról, ha viszont figyelembe vesszük azt a szempontot is, hogy az említett személyek feddhetetlen életvitelük miatt szereztek tekintélyt, akkor általánosabb értelemben is tekinthetünk Hydatius utalására, és a keresztény szerzők mellett politikai és egyházi személyiségek tevékenységére is gondolhatunk, akik egész életük során Hydatiushoz hasonlóan a barbárok és az eretnekek ellen harcoltak.

\footnotetext{
${ }^{1326}$ Hyd. 241; Marc. Com. 468.

1327 Hyd. 241: Asperem degradatum ad privatam vitam, filium eius occisum, adversum Romanum imperium, sicut indicati detectique sunt, Vandalis consulentes.

1328 Marc. Com. 471; Mal. 14,9-13. 471-ben Leo lakomára hívta és kegyetlenül megölte Aspart, majd a testőrei kiszabadították Aspar özvegyét a palotából és Thraciába menekítették az unokaöccséhez. Aspar sikertelen puccskísérletéről és bukásáról bővebben: Thompson 1982, 223-226.

${ }^{1329}$ Gallia 470-es évekbeli sorsáról bővebben: Várady 1961, 187-188.

1330 Hyd. praef. 1: probatissimorum in omnibus virorum studia, quos praecipue in fide catholica et conversatione perfecta testes veritatis divini cultus docet adsertio, ut ornantur decore dictorum, ita et commendantur honore meritorum, ut meram in omni opere suo obtineat veritas firmitatem.
} 
Hydatius krónikájában kiemelt szerepet kapnak azok az állami és egyházi vezetők, akiket követendő példaként az olvasói és saját maga elé tud állítani, így kifejezve ragaszkodását ahhoz a birodalmi eszméhez, amelynek hatékony müködése optimális esetben véget tudna vetni a barbár fosztogatásoknak, a császári udvarhoz való lojalitását pedig az mutatja jól, hogy gyakran még az uralkodócsalád nőtagjairól is megemlékezik. ${ }^{1331} \mathrm{Ha}$ Hydatius nem is tudott őszintén hinni abban, hogy meg lehet állítani a birodalom összeomlását, kétségtelenül nagyra értékelte azokat az egyéni teljesítményeket, amelyeket korának tehetséges politikai és egyházi vezetői nyújtottak a birodalmi rend megteremtése érdekében. Burgess téved, amikor arra a következtetésre jut, hogy Hydatius az általa bemutatott 13 császárról semmiféle értékítéletet nem mond, ${ }^{1332}$ az viszont kétségtelen, hogy csak azokat az uralkodókat és hadvezéreket ábrázolja pozitívan, akik eredményesen harcoltak a barbárokkal szemben, vagy legalábbis igyekeztek megvédeni a római lakosságot a fosztogatásoktól. Ahogyan fentebb láttuk, Hydatius rendkívül óvatosan rajzolja meg az uralkodói portrékat, az általa kedvelt császárokhoz kapcsolódó eseményeket saját értékítéletének és céljainak megfelelően, „so selectively and distortingly” ábrázolja, elhallgatva például a császári szolgálatban álló barbár vezérek tevékenységét. ${ }^{133}$

A római uralkodók közül rendkívül nagy csodálattal említi I. Theodosius politikai törekvéseit és a barbár népekkel szemben tanúsított magatartását, amivel erős és hatékony szuverén államot tudott kialakítani. ${ }^{1334}$ Burgess nem túl meggyőzően vonultatja fel azokat a kutatókat, akik ezt az álláspontot képviselik, mert nem látja bizonyítottnak, hogy Hydatius különösebben nagyra tartaná Theodosius tevékenységét azzal, hogy lemásolta más források rá vonatkozó feljegyzéseit. ${ }^{1335}$ Ugyanakkor bizonyítékok hiányában elvethetjük Molé arra vonatkozó ötletét is, hogy Hydatius az „uomini del suo governo” tagjaként politikai kapcsolatban volt Theodosius családjával, és ezért nyilatkozik kötelességszerüen pozitívan róluk. ${ }^{1336}$ Hydatius többször hivatkozik arra, hogy Theodosius uralkodásának első évétől jegyezte fel a krónika eseményeit, és még Gallaecia jelentőségét is megpróbálja növelni úgy az olvasói előtt, hogy Thedosius szülővárosát, Caucát saját tartományába helyezi Carthaginiensis helyett, így ez a tévedése akár szándékos is lehet. ${ }^{1337}$ Hydatius mindvégig úgy mutatja be Theodosiust, mint aki a 375-ben elnyert magister militumi rangban és a 389-

\footnotetext{
1331 Pawlak 2007, 32; Burgess 1988a, 102.

1332 Burgess 1988a, 122.

${ }^{1333}$ Bowes - Kulikowski 2005, 17-18.

${ }^{1334}$ Pawlak 2007, 31.

${ }^{1335}$ Burgess 1988a, 118-119.

1336 Molé 1974, 309-310.

${ }^{1337}$ Hyd. praef. 6; 1-2; Díaz - Menéndez-Bueyes 2005, 268.
} 
es augustusi kinevezése után is rendkívül jól tudott együttmüködni társuralkodóival és katonáival, elönyös diplomáciai kapcsolatot ápolt más népekkel, ugyanakkor a birodalomra veszélyt jelentő barbárokkal és trónbitorlókkal szemben sikeresen vette fel a harcot. ${ }^{1338}$

Nem vitathatjuk a II. Sabur perzsa király halála után kialakított béke jelentőségét és a keleti területek helyzetének rendezését, de Hydatius ezúttal is elhallgatja azokat az információkat, amelyek árnyalni tudnának az általa megrajzolt Theodosius-portrén. Nem véletlen, hogy csak homályos feljegyzést találunk a gótokkal 382-ben kötött szerződésről és thraciai betelepítésükről, arról pedig egyáltalán nem esik szó, hogy az usurpator Magnus Maximus katonai tehetségét 384-es italiai látogatása során még ő is nagyra tartotta. Nem olvashatjuk a krónikában, hogy Theodosius 388-ban a korábbi szerződésnek megfelelően gót és hun csapatok segítségével tudta legyőzni Maximust Sirmiumnál és Poetoviumnál, de arról sem kapunk információt, hogy jelentős gót csapatok harcoltak 394-ben a Frigidusmenti csatában Eugenius legyőzésekor. ${ }^{1339}$ Mivel Hydatius Theodosius regnálási idejére eső feljegyzései között 5 lacuna is szerepel, elképzelhető, hogy itt említette volna meg a császár érdemeként a pogányság és az arianizmus ellen hozott intézkedéseket. ${ }^{1340}$ Hydatius feltünően sokat foglalkozik fiai, Arcadius és Honorius hatalomátvételével, amelyet a krónika feljegyzései szerint Theodosius körültekintően előkészített, ${ }^{1341}$ Hydatius mégis úgy érzi, mintha magyarázkodnia kellene az olvasói elött, hogy a hagyományoktól eltérően miért uralkodik egyszerre két császár a keleti és a nyugati területek fölött. ${ }^{1342}$

Fentebb említettük, hogy Theodosius után a nyugati területeken a hadsereg ellenőrzése kikerült a császárok kezéből és a tényleges hatalmat a seregek élén álló föparancsnokok gyakorolták. Elősegítette ezt a folyamatot az is, hogy a magas katonai rangra emelkedett germán hadvezérek olyan ismereteket és készségeket szerezhettek a római sereg kötelékében, amelyek később akár önálló katonai akciókra is ösztönözhették őket, különösen ha személyes ambícióik is voltak a hatalom megszerzésére. ${ }^{1343}$ Általánosan elfogadott nézet viszont, hogy ha voltak is a rómaiak között tehetséges hadvezérek és követek, egyikük sem volt olyan erős és rendkívüli személyiség, hogy a hatalmi struktúrák megreformálásával meg tudta volna védeni a birodalmat a barbár támadásoktól. Ennek

\footnotetext{
${ }^{1338}$ Hyd. 1-4; 6; 11-12; 17-18; 21.

${ }^{1339}$ Hyd. $7 ; 17 ; 21$.

${ }^{1340}$ I. Theodosius uralkodásáról bővebben: Honoré 1998, 33-76.

${ }^{1341}$ Hyd. 9-10; 14; 19; 22-24.

1342 Hyd. 23. A rajnai határoknál kialakult súlyos helyzet és a trónbitorlások veszélye egyaránt indokolta, hogy mindkét területnek saját uralkodója legyen, ugyanakkor azt is láttuk, hogy ez a megosztás inkább csak az adminisztratív teendők elkülönülésében mutatkozott meg. Arcadius és Honorius uralkodásáról lásd: Honoré 1998, 77-96; 212-247.

1343 Collins 1999, 81-82; Angenendt 2008, 129; Reynolds 2011, 11; Pohl 2018, 2.
} 
ellenére Hydatius egyáltalán nem említi Stilichót, aki rendkívüli katonai és diplomáciai képességeinek köszönhetően 393-408 között magister peditumként a teljes nyugati haderőt irányította, ${ }^{1344}$ elnyerte a consuli és a patriciusi rangot, Theodosius pedig őt jelölte ki parens principumnak a fiai számára, és még unokahúgát, Serenát is hozzá adta feleségül. Bár a Stilicho titkos kabinetjéhez tartozó Claudianus Scipióhoz és Augustushoz hasonlítja Stuilicho jelentőségét, ${ }^{1345}$ a legtöbb kortárs szerző Stilicho személyét talán barbár származása miatt vádolja azzal, hogy a hatalmat magának vagy fiának akarta megszerezni és elárulta Honoriust, ráadásul egyesek szerint még a barbárokat is ő buzdította a Rajnán való átkelésre. ${ }^{1346}$

II. Theodosiusról Hydatius nem közöl túl sok információt, de igyekszik pozitív képet festeni az uralkodásáról. 402. január 10-től apja, Arcadius uralkodótársa volt, majd annak halála után, 408. május 1-től a Keletrómai Birodalom egyedüli császára lett. ${ }^{1347}$ Néhány megjegyzésen kívül alig olvashatunk arról, hogy Theodosiust nem igazán érdekelte a politikai élet, ezért helyette mások intézték a birodalom ügyeit, ${ }^{1348}$ de meglepő módon arról sem tájékoztatja olvasóit, hogy az uralkodása alatt épült falak hosszú időre garantálták az erődítménnyé emelt Constantinopolis biztonságát. ${ }^{1349}$ Hydatius megemlíti, hogy Theodosius nemcsak támogatta unokaöccse, Valentinianus trónralépését, hanem még segített is neki Iohannes usurpator legyőzésében, ezzel pedig még akkor is a keleti és a nyugati területek közötti jó viszony kialakulására próbál utalni, amikor az együttműködés más formáiról valószínűleg az információk elakadása miatt már nem olvashatunk a krónikában. ${ }^{1350}$ Hydatius nagyra értékelte viszont, hogy Theodosius védelmébe vette a katolikus hitet az első ephesusi zsinaton, de szigorúan fellépett az összes eretnek irányzattal szemben is,

\footnotetext{
1344 Török 1999, 84-85; Kelemen 2007, 18, 38. j.

1345 Albrecht 2004, 1071; 1079; Claud., Paneg. Stil. 1,16-19.

1346 Pohl 2018, 2. Stilicho egy vandál tiszt és egy római nő fiaként hivatali pályáját a katonai szolgálaton belül járta be, így tevékenysége egyáltalán nem illeszkedett a senatori rend kulturális elvárásaihoz, vö. Alföldy 2000, 186; ráadásul a barbárokkal való együttmúködése miatt a rómaiak egy része árulónak is tekintette őt, vö. López Quiroga - Martínez Tejera 2017, 433. Stilicho pályafutásáról és a constantinopolisi udvarral vívott hatalmi küzdelmeiről bővebben: Havas - Hegyi - Szabó 2007, 655-658; Reynolds 2011, 13-85; McEvoy 2013, 153-186.

1347 Hyd. 28; 34; 73.

1348 414-ig Anthemius praefectus praetorio per Orientem, utána a császár nagy tekintéllyel rendelkező nővére, Pulcheria, később felesége, Aelia Eudocia és kegyence, Cyrus praefectus urbi gyakorolt rá nagy befolyást, 443-tól pedig Chrysaphius udvari eunuch döntött a fontosabb kérdésekben.

1349 Theodosius falairól bővebben: Foss - Magdalino 1990, 102; Benevolo 1994, 22-24.

1350 Hyd. 75. III. Valentinianus 437-ben feleségül vette Theodosius egyetlen lányát, Licinia Eudoxiát, Constantinopolis fegyveres segítséget küldött 410-ben Ravennába a gótok ellen, majd 431-ben és 441-ben a vandálok elleni harchoz, ráadásul a Codex Theodosianus rendeleteit a nyugati területeken is bevezették, vö. Havas - Hegyi - Szabó 2007, 675. II. Theodosius uralkodásáról és törvényalkotásáról bővebben: Honoré 1998, 97-178.
} 
elbocsátotta a nem katolikus állami tisztségviselőket, és még a perzsák által elindított keresztényüldözés ellen is szót emelt. 450. július 28-án bekövetkezett haláláról Hydatius csak rövid tájékoztatást ad. ${ }^{1351}$

Aëtius, akit Procopius a Nyugatrómai Birodalom utolsó nagy védelmezőjének tartott, meglehetősen célirányos lépéseket tett a nyugati területek fölötti főparancsnokság 434-435ös megszerzésére. ${ }^{1352}$ Hydatius szinte az egész katonai pályafutását bemutatja a krónikában a comesi pozíciótól a dux utriusque militiae és a magister militum rangon keresztül a háromszoros consuli és patriciusi kitüntetésig, ${ }^{1353}$ de érthető módon nem említi, hogy Aëtius karrierje kezdetén milyen jó kapcsolatot ápolt a gótokkal és a hunokkal, és első katonai sikereit is nekik köszönheti. ${ }^{1354}$ Arról sem értesülünk kellő pontossággal, hogy Felixet 430ban az ö utasítására ölték meg, majd Bonifatius 433-ban a vele vívott csatában szerezte halálos sebesülését, ${ }^{1355}$ Galla Placidia pedig annyira tartott tőle, hogy csak akkor volt hajlandó elismerni főparancsnoki kinevezését, amikor az már Ravennát fenyegette hunokból szervezett hadseregével. Egyes kutatók szerint Aëtius teljes mértékben „a hunok kreatúrája” volt, ezért Galla Placidia a veszélyt látva jogosan fordult ellene, a hunok pedig az Aëtius által vezetett hadjáratok során felmérhették a birodalom valós katonai helyzetét a későbbi hódításaikhoz. ${ }^{1356}$

Hydatius büszkén sorolja fel, hogy Aëtius számtalan győzelmet aratott olyan ellenséges vagy lázadó népcsoportok fölött, mint a gótok, a juthungok, a norok, a frankok, a burgundok és a hunok, ${ }^{1357}$ mindezt pedig azzal indokolhatjuk, hogy Aëtius katonai sikerei Hydatiust személyesen is arra ösztönözték, hogy 431-ben követséget vállaljon hozzá, amikor Galliában tartott hadjáratot. Mivel Aëtius konkrét katonai segítség helyett csak egy követet küldött, Thompson feltételezi, hogy Hydatius valójában nem tartotta nagyra Aëtius tevékenységét, ${ }^{1358}$ ennek viszont ellentmond az a tény, hogy Hydatius elégedett volt a követség eredményével és a szvévekkel megerősített békével, így összességében Aëtiusról egy „positive view”-t alkot a krónikában, még akkor is, ha az egyházi személyekkel

\footnotetext{
${ }^{1351}$ Hyd. 97; 138.

1352 Proc. 1,3,14. Aëtius pályafutásáról és politikai szerepéről bővebben: Moss 1973, 711-731; Heather 2007 , 5-17; Reynolds 2011, 117-174; Hughes 2012; McEvoy 2013, 251-272.

${ }^{1353}$ Hyd. 82; 85-86; 89; 94; 102; 104; 142; 152.

1354 Aëtiust a gótok foglyaként Alaric katonai kiképzésben részesítette, 410-412 között pedig a hun uralkodó udvarában birodalmi túszként töltött be fontos diplomáciai szerepet, vö. Klaniczay 2005, 91.

1355 Hyd. 84; 89.

1356 Aëtius és a hunok kapcsolatáról bővebben: Klaniczay 2005, 90-93.

${ }^{1357}$ Hyd. 82-83; 85; 88; 99; 102; 104; 142; 146.

${ }^{1358}$ Hyd. 86; 88; Thompson 1982, 140.
} 
ellentétben Aëtius megjelenéséről és tulajdonságairól nem sokat beszél, mert nem akarja elterelni az olvasó figyelmét a valóban jelentős eseményekről. ${ }^{1359}$

Aëtius esetében új jelenség, hogy több alkalommal is harcolnia kellett a függetlenségre törekvő vagy a saját politikai hatalmát veszélyeztető személyekkel, többek között Anaolsusszal, Bonifatiusszal és Sebastianusszal szemben. ${ }^{1360}$ Kulikowski Aëtius személyén keresztül jut arra a sajátos, de túlságosan általános következtetésre, hogy a barbárok tulajdonképpen nem betolakodók, hanem a Római Birodalom sokadik generációs lakói, akik nem törtek be a birodalom területére, hanem polgárháborúkat vívtak riválisaikkal vagy külföldi szövetségeseikkel, ezáltal nem lehet elég pontosan megfogalmazni, hogy kiket nevezünk barbároknak vagy rómaiaknak. ${ }^{1361}$ Igazi hírnevét Attila 451-es legyőzésének köszönheti, Hydatius viszont nemcsak hogy elhallgatja azt a tényt, hogy sokan vádolták Aëtiust azzal, hogy 452-ben nem tudta megakadályozni a hunok italiai fosztogatását, hanem egyenesen Aëtius és Marcianus sikereiről tudósít a hadjárattal kapcsolatban. Halálának tragikus körülményeit is részletesen bemutatja Hydatius, mert az eset méltánytalansága a központi hatalom további gyengülését és a császári hatalom összeomlását kiválóan illusztrálja. ${ }^{1362}$

Aëtius mellett meg kell említenünk az udvari költőjét, Merobaudest is, akinek irodalmi tevékenységét Hydatius egyértelmüen nagyra tartja, de emellett katonai tevékenységét is kiemeli, mivel leverte az Aracelliben lázadó bagaudák felkelését. ${ }^{1363}$ Burgess szerint ugyanakkor Merobaudes méltatása erősen emlékeztet más, hasonló közhelyekre, az őt dicsérő szavak viszont érthető módon kihatnak Aëtius tevékenységére és még pozitívabb megítélésére is. ${ }^{1364}$

Marcianus trónra lépését Hydatius egyértelmủen pozitív fejleménynek tartja, mivel Theodosius halála után a katonák rögtön megválasztották uralkodónak, ráadásul ehhez Aspar magister militum javaslatára Theodosius nővére, Pulcheria is ragaszkodott és feleségül is ment hozzá. ${ }^{1365}$ Burgess szerint Hydatius egyedül Marcianus titulusát jelöli augustus helyett a princeps kifejezéssel, amely utalhat arra, hogy Hydatius értesült

\footnotetext{
${ }^{1359}$ Drinkwater 1992, 6; Burgess 1988a, 133.

1360 Hyd. 82; 89.

${ }^{1361}$ Kulikowski 2013, 685 .

1362 Hyd. 142; 146; 152.

${ }^{1363}$ Hyd. 120. Hydatius tájékozottságát és talán irigységét is mutatja, hogy utal arra az ércszoborra, amelyet 435. július 30-án a tiszteletére állítottak a római Forum Traianin, vö. Sid. Ap., Carm. 9,277-301. Merobaudes tevékenységéről bővebben: Zos. 4,17; Amm. Marc. 30,5,13; Székely 2018, 103, 16. j.; 106, 34. j.

${ }^{1364}$ Burgess 1988a, 13; 132; Hier., De vir. ill. 122.

1365 Hyd. 139: statim apud Constantinopolim Marcianus a militibus et ab exercitu, instante etiam sorore Theodosii Pulcheria regina, efficitur imperator; qua sibi in coniugium adsumpta regnat in partibus Orientis.
} 
Marcianus hatalomra lépésének nehézségeiröl, vagy éppen ellenkezőleg, egy megkülönböztető címet használt jelentőségének kiemeléséhez, esetleg megpróbált utalni arra a sajátos helyzetre, hogy Marcianus ugyan nem közvetlenül a Theodosius-dinasztiából származik, de házassága révén legitim alapon gyakorolja a hatalmat. ${ }^{1366}$ 452-ben az Italiát fosztogató hunokat Marcianus segédcsapatai tizedelték, így a császár és az égi csapások azonnali békekötésre kényszerítették őket. ${ }^{1367}$

Marcianus hatalmának erejét ugyan nem törte meg, hogy 453-ban meghalt Pulcheria császárné, de az uralkodási évek felsorolásán kívül Hydatius néhány évig semmit sem árul el Marcianus politikai tevékenységéről. 455-től aztán Marcianus egyedüli császár lett (obtinet monarchiam) és hozzájárult a császárrá választott Avitus kinevezéséhez is. Hydatius külön feljegyzést szentel annak a ténynek, hogy Marcianus és Avitus a meggyengült központi hatalom és a barbár támadások ellenére különleges módon egyetértésben kormányozták az egész birodalmat, ${ }^{1368}$ és innentől kezdve mindig egymás mellett említi őket, hiszen mindketten szerepet vállaltak a vandálok 457-es legyőzésében, egymás után veszítették el még az életüket is, ${ }^{1369}$ arról viszont érthető okok miatt nem esik szó, hogy 457-ben Marcianus nevezte ki patriciussá Ricimert. Marcianust összességében mind Hydatius, mind pedig a történészek saját korának egyik legsikeresebb és legjobb császárának tartják, mert nemcsak belpolitikai lépéseivel és vallási kompromisszumok keresésével segítette a keleti területek stabilizálódását, hanem határozott külpolitikájával nyugalmat is tudott teremteni a dunai határvonalon. ${ }^{1370}$

Avitus uralkodását szintén nagyra értékelik a krónikaszerzők, mert őt tartották az egyik legalkalmasabb császárnak arra, hogy megállítsa a barbárok előrenyomulását, ${ }^{1371}$ ráadásul célul is tủzte ki az elveszített területek visszahódítását, ami az egész birodalom érdeke volt, a vandálok legyőzésével pedig biztosítható lett volna Róma gabonaellátása. Avitus Gallia helytartójaként rengeteg birtokkal és kapcsolattal rendelkezett, Petronius Maximus pedig azért őt nevezte ki Gallia magister militumává, mert a kezében volt az egyetlen olyan ütőképes haderő, amelyet szükség esetén a vandálok ellen be lehetett volna

\footnotetext{
1366 Burgess 1988a, 116; Johnson 1993, 61.

${ }^{1367}$ Hyd. 146.

1368 Hyd. 149; 154; 158-159; 162: Marcianus et Avitus concordes principatu Romani utuntur imperii.

${ }^{1369}$ Hyd. 169-170; 176-177.

${ }^{1370}$ Hydatius nem említi, hogy Marcianus a néptelen határtartományokba keleti gótokat, szkireket, rugiakat, szarmatákat, alánokat és hunokat telepített be, arról pedig valószínüleg nem is voltak információi, hogy Palaestinában és Damaszkuszban a szaracénokkal, Egyiptomban pedig a blemmyes törzsekkel kellett harcolnia. Marcianus külpolitikájáról bővebben: Thompson 1950, 58-75.

${ }^{1371}$ Muhlberger 1990, 224.
} 
vetni, ${ }^{1372}$ valószínüleg emiatt bocsátja meg neki Hydatius, hogy Maximus halála után 455. július 9-én a galliai katonák és elökelők kiáltották őt augustusszá Tolosában és Arelatéban. ${ }^{1373}$ Hydatius nem mondja ki nyíltan, hogy Avitus trónra lépését II. Theoderic segítette, talán mert nem volt büszke arra, hogy egy barbár uralkodó támogatására volt szükség a hatalom megszerzéséhez, de Castellanos álláspontjával egyetértve az a tény, hogy Hydatius minimálisra csökkentette a gótok szerepét Avitus kinevezésében, tökéletesen megfelel a Hydatius által képviselt római álláspontnak. ${ }^{1374}$ Hydatius szerint a rómaiak császárrá választották Avitust és ezt Marcianus is elfogadta a birodalom egységének érdekében, ${ }^{1375}$ valójában sem az italiai senatorok nem ismerték el hatalomra lépését, sem pedig Marcianus, aki Eudoxia és lányai fogsága miatt kénytelen volt jó viszonyt ápolni Gaiserickel. Emiatt egyes kutatók túlozva azt állítják, hogy Hydatius Avitus propagandájának esett áldozatul, holott egyértelmüen kirajzolódik a barbárok elleni stratégiája: a vandálok legyőzésével Italia blokádját próbálta megszüntetni, a gótokkal szövetségben pedig igyekezett helyreállítani a szvévek által megszegett békeszerződést, ezért 456-ban Theodericra bízta a szvévek elleni háború vezetését. ${ }^{1376}$

A krónika szerint Avitusnak sikerült legyőznie a vandálokat, valójában Ricimer aratott fölöttük győzelmet Siciliánál és Corsicánál. Avitus jutalmul magister militum praesentalis rangba emelte Ricimert, Italiába visszatérve pedig megfosztotta Avitust a hatalmától, Hydatius viszont minderről csak annyit mond, hogy Avitus elhagyta Italiát és a galliai Arelatébe ment. Avitus 456-os bukását Hydatius azzal indokolja, hogy a gótok megszegték ígéretüket, ${ }^{1377}$ valójában Ricimer az előle menekülő Avitust Placentia mellett legyőzte és 456. október 17-én lemondatta a trónról, de megengedte neki, hogy a város püspöke legyen. Avitus azonban megtudta, hogy a senatus ki akarja végeztetni, ezért tovább menekült, útközben pedig vagy pestis, vagy egy gyilkos keze végzett vele 456 utolsó napjaiban. ${ }^{1378}$ Néhány kutató szerint Hydatius összességében negatívan ítélte meg Avitus szerepét, különösen mert a gótokkal szövetkezett és hagyta, hogy a szvévek huzamosabb

\footnotetext{
1372 Avitus kinevezéséhez hozzájárult az a diplomáciai bravúr is, hogy 451-ben senatorként rá tudta venni a gótokat, hogy a rómaiak oldalán harcoljanak Attila ellen, vö. Klaniczay 2005, 93.

${ }^{1373}$ Hyd. 156: ipso anno in Galliis Avitus Gallus civis ab exercitu Gallicano et ab honoratis primum Tolosa, dehinc apud Arelatum Augustus appellatus Romam pergit et suscipitur.

${ }^{1374}$ Castellanos 2015, 153-154.

1375 Hyd. 159: per Avitum, qui a Romanis et evocatus et susceptus fuerat imperator, legati ad Martianum pro unianimitate mittuntur imperii.

${ }^{1376}$ Hyd. 163; 166; Pawlak 2007, 32.

${ }^{1377}$ Hyd. 169-170; 176: Avitus caret imperio, Gothorum promisso destitutus auxilio, caret et vita.

1378 Avitus halálának körülményeiről bővebben: Greg. Tur. 2,11; Prisc. 32.
} 
ideig fosztogassák a gallaeciai lakosságot, ${ }^{1379}$ ezt azonban cáfolja az a tény, hogy Hydatius igyekszik elhallgatni minden olyan körülményt, amely Avitusra rossz fényt vetne és Ricimer jelentőségét növelné az olvasó szemében. Kétségtelen, hogy Hydatius Avitusábrázolása a gótokkal való folyamatos együttmüködése miatt ${ }^{1380}$ nem lehet annyira pozitív, mint például Marcianusé, de a krónikában nem tükröződik a kortársak azon véleménye, hogy Avitust halála után sokan usurpatornak tekintették és inkább Ricimer érdemeit tartották nagyra.

Hydatius azonban nemcsak Avitus megalázó bukásának körülményeit hallgatja el, hanem mellőzi azoknak a belső hatalmi harcoknak a bemutatását is, amelyek ismeretében az általa sokra becsült római császárok legitimitása még akkor is megkérdőjelezhető lenne, ha az uralkodók képességei és intézkedései nagy reményt adtak az ellenséges barbár népek legyőzésére. Maiorianus 457. április 1-jei és Leo február 7-ei hatalomátvétele például egyszerü tényként szerepel a krónikában, ${ }^{1381}$ Hydatius pedig nem árulja el, hogy egykori parancsnoktársát Ricimer javaslatára nevezték ki nyugatrómai császárrá. Maiorianusról legközelebb csak 459-ben hallunk, amikor legyőzte a gótokat. Hydatius itt is a császár érdemeként tünteti fel a barbárok feletti győzelmet, pedig valójában egykori tiszttársa és a galliai haderő parancsnoka, Aegidius verte vissza Arelaténál Theoderic csapatait, hogy aztán tartós békét (pacis iura) kössenek a római sereg zavartalan elörenyomulása érdekében. ${ }^{1382}$

Hydatius számára azért is lehet jelentős Maiorianus uralkodása, mert ő volt az utolsó császár, aki hajlandó volt lépéseket tenni Hispania megmentéséért. ${ }^{1383}$ A 460 májusában Carthago Nova ellen indított hadjárata ugyan a gondos előkészületek ellenére kudarcot vallott, mert a vandálokat árulók figyelmeztették a római flotta közeledésére, Hydatius ezért igyekszik röviden lezárni az események bemutatását, és csak annyit közöl, hogy amikor Maiorianus terve meghiúsult, visszatért Italiába. Úgy tünik, hogy Gaiseric követek útján békét kért a császártól, valójában Maiorianus egy szerződésben kénytelen volt elismerni a vandálok újabb hódításait. Hydatius Maiorianus bukásával kapcsolatban is csak annyit mond, hogy a császár Galliából visszatérve a birodalom sorsdöntő ügyein fáradozott, de az

\footnotetext{
1379 Burgess 1988a, 121-122; Drinkwater 1992, 6.

${ }^{1380}$ Castellanos 2015, 163.

${ }^{1381}$ Hyd. 178. Valójában Marcianus halála után veje, Anthemius került volna trónra, de az alán származású és arianus hitü magister militum, Aspar befolyásának növelése érdekében egyik tribunusát, Leót támogatta, így Anatolius constantinopolisi patriarcha kénytelen volt őt megkoronázni, vö. Havas - Hegyi - Szabó 2007, 690. 1382 Hyd. 192; Drinkwater 1992, 27.

1383 Collins 2004, 32.
} 
irigykedő Ricimer csellel megölte öt. ${ }^{1384}$ Valójában az italiai Dertonában lázadás tört ki a vandáloktól vereséget szenvedő Maiorianus ellen, ezért Ricimer nyomására 461. augusztus 2-án lemondott a trónról, augusztus 7-én pedig vérhasban vagy Ricimer keze által meghalt. ${ }^{1385}$

Hydatius többször is kiválónak (insignis) nevezi Aegidius comest, aki akkor jelenik meg a krónikában, amikor a vele ellenséges Agrippinus galliai comes 462-ben a rómaiakat elárulva átadta a gótoknak Narbo városát, amely a feltétele volt annak, hogy a Ricimer által császárrá kinevezett Libius Severust a gótok is törvényes uralkodónak tekintsék. Hydatius a többi krónikáshoz képest jóval negatívabb képet fest Agrippinusról, ${ }^{1386}$ valószínűleg azért, hogy Aegidius jelentőségét még inkább ki tudja emelni az olvasók előtt. Amikor a gót Frederic Ricimer biztatására lázadást szervezett Aegidius ellen, ő híveivel együtt legyőzte őket. Hydatius szerint Aegidius hatalmas hírnévnek örvendett, ${ }^{1387}$ amely arra a tényre utal, hogy Aegidius Arelate felszabadítása és keresztény jámborsága miatt valóban rendkívül népszerü lehetett már saját korában is. ${ }^{1388}$

Hydatius szerint 465-ben Aegidius követei átkeltek a vandálokhoz, azt viszont nem árulja el, hogy a követség célja a Gaiserickel való szövetségkötés volt, mert a tervek szerint mialatt ő leszámolt volna a gótokkal, a vandálok megtámadták volna Ricimert Italiában. A követek visszatérése után ${ }^{1389}$ Hydatius szomorúan csak annyit jegyez meg, hogy Aegidius meghalt, ennek körülményeiről viszont igyekszik pontos információkkal szolgálni, hogy hatni tudjon az érzelmekre, és nem hagyja kétségek közt az olvasókat abban a kérdésben sem, hogy valóban veszteséget jelent-e a rómaiak számára Aegidius halála, hiszen végső következtetése szerint a birodalom védelem nélkül maradt és a gótok késlekedés nélkül támadni kezdtek a római területek felé. ${ }^{1390}$ Aegidius vitathatatlanul pozitív értékelését azzal magyarázhatjuk, hogy Aëtius óta ő volt az egyetlen római parancsnok, aki igyekezett szembeszállni a Galliában állomásozó barbár csapatokkal. ${ }^{1391}$

\footnotetext{
1384 Hyd. 195; 204-205: Maiorianum de Galliis Romam redeuntem et Romano imperio vel nomine res necessarias ordinantem Rechimer livore percitus et invidorum consilio fultus fraude interfecit circumventum. 1385 Marc. Com. 461,2.

${ }^{1386}$ Hyd. 212; Castellanos 2015, 186.

1387 Hyd. 214: adversus Egidium commitem utriusque militiae, virum et famma commendatum et deo bonis operibus conplacentem.

1388 Ennek köszönhetően a frankok felajánlották számára a királyi címet, és azt Childeric (458-482) számüzetése idején gyakorolta is, vö. Greg. Tur. 2,12.

${ }^{1389}$ Hyd. 220. A híreket hozó követek útjáról bővebben: Gillett 2003, 68-70.

1390 Hyd. 224: Egidius moritur, alii dicunt insidiis, alii veneno deceptus, quo desistente mox Gothi regiones invadunt quas Romano nomini tuebatur invadunt.

${ }^{1391}$ Burgess 1988a, 133; Collins 1999, 87.
} 
Hydatius a barbárok ellen sikerrel harcoló uralkodók és hadvezérek mellett rendkívül nagy érdeklődést mutat a keleti egyház ügyei és vezetői iránt, amely leginkább annak köszönhető, hogy már a fiatalkori szentföldi zarándoklaton is felfigyelhetett a keleti egyház híres személyiségeire. Míg a Kelet politikai eseményei közül alig olvashatunk valamit a krónikában, jó néhány keleti püspököt bemutat Hydatius, akikkel találkozott a zarándoklaton, vagy akik harcoltak az eretnekmozgalmak ellen. Burgess szerint ez a fokozott érdeklődés egyenesen azzal magyarázható, hogy igyekezett lépést tartani egy olyan terület egyházi életével, ahol még vannak olyan püspökök, akik sikeresen tudják védeni az ortodoxiát, és akiknek a hozzáállása éppen ezért sokkal közelebb áll Hydatius értékrendjéhez, mint saját környezetének lesújtó viselkedése. ${ }^{1392}$ A nyugat egyházi személyiségei közül éppen ezért csak azok szerepelnek a krónikában, akiknek Hydatius felhasználta a mủveit, vagy akik hozzá hasonló elszántsággal harcoltak az eretnek tanításokkal szemben, így az olvasók előtt is világossá válik, hogy a barbár támadások ellenére nyugaton is ki lehet állni sikerrel az ortodoxia ügye mellett. ${ }^{1393}$

Hydatius csodálattal tekint mindkét elődjére, Eusebiusra és Hieronymusra, mivel ők nemcsak történetíróként alkottak maradandót, hanem püspökként és magánemberként is erényes, feddhetetlen életét éltek és védelmezték a katolikus hitet. Hieronymust minden tekintetben rendkívüli (precipuus) embernek tartotta, valószínüleg ezért is gyakorolt életére akkora hatást, amikor kisfiúként láthatta őt a szentföldi zarándoklaton. ${ }^{1394}$ Ez a találkozás kelthette fel először Hydatius érdeklődését Hieronymus élete és müvei iránt, de nagy szerepe lehetett az itt szerzett benyomásoknak abban is, hogy később a vallási élet felé fordult és sokat foglalkozott a keleti egyház eseményeivel. ${ }^{1395}$ Hieronymus kiemelkedő nyelvtudása és munkabírása mellett Hydatius csodálhatta még Damasus pápa titkáraként végzett szolgálatait és az egyiptomi szerzetességben szerzett tapasztalatait is. Hydatius megemlíti Hieronymus eretnekségek ellen írt nagyszerü munkáit és büszkén állapítja meg, hogy az igazság kőkemény kalapácsával semmisítette meg a pelagianusok szektáját. ${ }^{1396}$ Hydatius ezzel a mondattal nemcsak Hieronymus iránti tiszteletét fejezi ki, hanem igazolja olvasói előtt saját tájékozottságát is, hiszen a leszámolás eszközeként említett adamantino

\footnotetext{
1392 Burgess 1988a, 214; 106. Ennek köszönhetően a nyugati egyház képviselőire és a római pápákra vonatkozó információk rendkívül hiányosak, mivel kevésbé keltették fel Hydatius érdeklődését, ráadásul valószínüleg nem is jutott elegendő mennyiségü és pontosságú információhoz velük kapcsolatban, vö. Burgess 1988a, 211.

1393 Burgess 1988a, 217-218.

${ }^{1394}$ Hyd. praef. 1-5; 32-33; 51.

1395 Torres Rodríguez 1956, 767; Burgess 1988a, 14.

1396 Hyd. 51: ad ultimum Pelagiani sectam cum eodem auctore adamantino veritatis malleo contrivit. Adversum hos et adversum alios hereticos extant eius probatissima monimenta.
} 
veritatis malleo felidézi Hieronymus Jeremiás-kommentárjának egy hasonló képét (spirituali percutiendus est clava). ${ }^{1397}$ Hydatius nem tudja, mikor halt meg Hieronymus, ugyanakkor sajnálkozását fejezi ki emiatt az olvasói előtt. ${ }^{1398}$

Augustinus hasonlóképpen a legkiválóbb püspökök közé tartozik, elsősorban azért, mert nagyszerü munkái (studia magnifica) mellett a 411-es carthagói zsinaton legyőzte a donatistákat. ${ }^{1399}$ Bár Augustinus fiatalon a manicheizmus hívei közé tartozott, később nagy sikerrel vette fel a küzdelmet az összes, saját korában népszerü eretnekmozgalommal, ${ }^{1400}$ ahogyan Hydatius is igyekezett jóval szerényebb körülmények között kiállni az ortodoxia védelme mellett. Hippo püspökeként, számos dogmatikai és teológiai munka szerzőjeként a pogányság vádjait is sikerült megcáfolnia, müveiben tárgyalt minden olyan fontos kérdést, amely a korabeli kereszténységet foglalkoztatta. Mivel Augustinus életére is jelentős hatást gyakoroltak a barbárok fosztogatásai és terjeszkedő politikája, a későbbiekben látni fogjuk, hogy Hydatius történelemszemlélete sok hasonlóságot mutat Augustinus felfogásával.

Ambrosius és Martinus Turonensis jótéteményei és csodái mellett Hydatius büszkén számol be arról, hogy mindketten kiálltak az ortodoxia mellett, amikor nem voltak hajlandóak fogadni a segítséget kérő Priscillianust, akit végül eretnekké nyilvánítottak. ${ }^{1401}$ Ambrosiust nem véletlenül tartja Hydatius saját példaképének, hiszen Aemilia és Liguria kormányzójaként igazságosságával kivívta a lakosság szeretetét, Mediolanum püspökeként pedig nemcsak közvetített az arianus és a katolikus közösségek között, hanem mindvégig az ortodoxia érdekeit képviselte a pogányokkal és az eretnekekkel szemben. Széles körü irodalmi tevékenységével korának minden egyházi tanításával foglalkozott műveiben, nagy tudására támaszkodva pedig láttuk, hogy a császári hatalommal szemben is kiállt az egyház függetlenségéért. Hydatius szerint Martinus Turonensis egy sanctus et vir apostolicus, ${ }^{1402}$ mert Gallia első ismert aszkétájaként tanítványi kört alakított ki, 372-es püspökké szentelése után pedig közös tulajdonnal rendelkező szerzetesi közösséget hozott létre. Mivel a katonai karrierről lemondva a szerzetesi és püspöki hivatást választotta, alakja „a szent hitvallók mintaképévé" vált. ${ }^{1403}$ A Hydatius által is hivatkozott Sulpicius Severus 403 körül megírt

\footnotetext{
${ }^{1397}$ Hier., Comm. Jerem. 3,1, in: CSEL 59,151.

1398 Hyd. 97.

1399 Hyd. 45; 90.

1400 Augustinus életmüvét éppen a nagy eretnekségekkel vívott konfliktusa alapján szokás 3 szakaszra osztani: 395-ig a manicheizmus ellen, 415-ig a donatisták ellen, 430-ig pedig a pelagianizmussal szemben lépett fel, vö. Angenendt 2008, 86.

${ }^{1401}$ Hyd. 8; 13.

1402 Hyd. 30.

${ }^{1403}$ Klaniczay 2005, 19; Angenendt 2008, 109.
} 
fiktív és regényes Martinus-életrajzával sikeresen igazolni tudta a nyugati olvasók számára, hogy Galliában is születnek olyan híres szentek, mint Egyiptomban. ${ }^{1404}$

A keleti egyház kiváló (insignes) püspökei közül elsőként Theophilusról, Alexandria patriarchájáról (385-412) olvashatunk, akit Hydatius hatalmas tudású (eruditissimus) szerzőnek tart a húsvéti időrendi számítások (laterculum de pasce observatione) miatt. ${ }^{1405}$ Valószínüleg őt is látta kisfiúként a szentföldi zarándoklaton, jelentőségét pedig úgy is próbálja növelni, hogy nem nevezi meg utódját az alexandriai püspöki székben, ugyanakkor az is elképzelhető, hogy csak nem rendelkezett megfelelő információval erre vonatkozóan. ${ }^{1406}$

Foglalkoztunk már korábban a Constantinopolis élén álló Iohannes Chrysostomus és a nagy politikai befolyással rendelkező Eudoxia közötti nézeteltéréssel, de mivel az Arcadius hatalomra lépése és a Iohannes üldözése ${ }^{1407}$ közötti feljegyzések között számos lacunát találunk, nem tudjuk, hogy Hydatius értesült-e arról a 399-es phrygiai lázadásról, amelyet a keleti gótok robbantottak ki Tribigild katonai parancsnok vezetésével. ${ }^{1408}$ Hydatius azért is becsülhette sokra Iohannes püspöki tevékenységét, mert az ő felszólítására mészároltak le Constantinopolisban csaknem 7 ezer gótot a városi helyőrség tagjai közül, később a többiek elmenekültek és végigrabolták Thracia területét, ez pedig nagyban hozzájárult a már korábban kialakult germánellenes hangulat felerösödéséhez a keleti területeken.

Bár Hydatius kevésbé érdeklődik az aszkéták iránt, mégis említi a kiváló és ékesen szóló (nobilissimus et eloquentissimus) nolai püspököt, Paulinust, aki vir apostolicus-ként dicséretes munkákat is írt. ${ }^{1409}$ Hydatius valószínűleg nemcsak azért fordít nagy figyelmet Paulinus munkásságára, mert szigorú megtartóztatása miatt már kortársai is szentként tisztelték, hanem azért is, mert éppen 409-ben, a barbárok hispaniai betörésekor szentelték

\footnotetext{
${ }^{1404}$ Chadwick 1999, 170. Az életrajz megírásának körülményeiről lásd: Vanyó 1999, 153-155.

1405 Hyd. 5; 31; PG 65,52; Leo, Ep. 121, in: PL 54,1056.

1406 Hyd. 33; 53. Burgess szerint a krónikában tévesen szerepel Theophilus halálának dátuma, vö. Burgess 1988a, 212; valójában Hydatius nem is említi a patriarcha halálát, csak azt, hogy nem tudja, ki állt Alexandria élén Theophilus után.

1407 Hyd. 24; 29.

1408 Arcadius egy gót származású comest, Gainast küldött a felkelés leverésére, de ő is átállt a felkelők oldalára, hogy megkapja magister militumi kinevezését és egy arianus templomot. Gainas és Tribigild tevékenységéről bővebben: Várady 1961, 152-154; 235-237; Wolfram 1988, 148-149; Blockey 2007a, 116118.

1409 Hyd. 72. Paulinus gazdag aquitaniai földbirtokosként 379-ben Campania kormányzója lett, megkeresztelkedése után Hispaniában pappá szentelték, később Italiában Ambrosius papjai között élt, 395-ben viszont lemondott vagyonáról és Nola közelében telepedett le feleségével, Theresiával együtt. Paulinus családi körülményeiről lásd: Székely 2018, 105, 26. j.; életéröl és müveiröl bővebben: Vanyó 2007b, 355-356; Adamik 2009, 814-816.
} 
öt Nola püspökévé, ráadásul széles körü levelezést folytatott Hieronymusszal, Augustinusszal és Martinus Turonensisszel is. ${ }^{1410}$ Hydatius számára Paulinus Nolanus példakép lehet még abból a szempontból is, hogy miután a közéleti szerepléstől visszavonult, egyik barátja, Ausonius megpróbálta visszahívni a politikai életbe, ő azonban kitartott saját döntése mellett és életét teljesen az aszkézisnek szentelte. ${ }^{1411}$

${ }^{1410}$ Vanyó 2004, 393.

${ }^{1411}$ Brown 1999, 55. 


\section{HYDATIUS TÖRTÉNELEMSZEMLÉLETE ÉS SZERZŐI MOTIVÁCIÓI}

\subsection{Isteni gondviselés és apokaliptikus gondolatok}

\subsubsection{Büntetések, előjelek, csodák}

A 4. század végétől egyre többen kezdtek foglalkozni az isteni gondviselés (providentia Dei) kérdésével, amely a keresztény történelemfelfogás egyik legfontosabb tényezőjévé vált. Miután 378-ban a gótok vereséget mértek a rómaiakra, az 5. század elején barbár népek szállták meg Galliát és Hispaniát, 410-ben a gótok elfoglalták Rómát, 429-ben pedig a vandálok saját államot hozhattak létre Észak-Africában, a keresztény történetíróknak tisztázniuk kellett, hogy Isten milyen módon avatkozott bele az emberiség történetébe és ebből kiindulva hogyan valósulhat majd meg az üdvözülés. ${ }^{1412}$ Breisach szerint a rómaiak valójában sohasem tagadták meg az isteni gondviselésbe vetett hitüket, de a császári hatalom gyengülése és a Római Birodalom hanyatlása miatt különösen sokat foglalkoztak az emberiség történetére vonatkozó alapvető kérdésekkel, ezzel magyarázható, hogy jó néhányan a kronológia tanulmányozásába és világtörténeti munkák írásába kezdtek. ${ }^{1413}$

A Hieronymust követő krónikahagyományban általánossá vált az a felfogás, hogy a történelem az isteni akarat egyre inkább kibontakozó megnyilvánulása az emberiség életében, ${ }^{1414}$ ezért a történeti munkák nem pusztán a jelentős múltbeli eseményeket és személyeket összesítették, hanem egyúttal az isteni gondviselés folyamatos megtapasztalását is igyekeztek rögzíteni. ${ }^{1415}$ Hydatius ehhez hasonlóan hitt abban, hogy a Római Birodalmat sújtó csapások és a saját életében megtapasztalt nehézségek az isteni gondviselést és az égi harag megnyilvánulásait jelzik. ${ }^{1416}$ A történelmet az 5. században már

\footnotetext{
${ }^{1412}$ Havas - Takács - Tegyey 2001, 257.

1413 Breisach 2004, 99.

${ }^{1414}$ Már az ószövetségi szerzők is azt vallották, hogy a jövő „Isten személyes akarata szerint” alakul, ezért az nem követ semmilyen természeti törvényt és nem lehet múltbeli eseményekből megjósolni előre, így a kiszámíthatatlanság és a bizonytalanság érzésével párosul, vö. Löwith 1996, 47-48.

1415 Burgess 1988a, 28.

${ }^{1416}$ Már a korábbi időszakban is találunk utalásokat arra vonatkozóan, hogy a különféle előjelek és csapások az istenek bosszúját fejezik ki, vö. Tac., Hist. 1,3.
} 
azért sem lehet az isteni akarattól elválasztva értelmezni, mert a sok szenvedést okozó korabeli eseményeket nem mindig tudták kizárólag emberi és racionális okokkal megmagyarázni, különösen azok a szerzők, akiknek a gondolkodásában püspöki hivatalvállalásuk miatt jelentős szerepet kellett kapnia az isteni gondviselésben és a bibliai próféciák beteljesedésében való hitnek. Ennek tudatában egyetérthetünk Johnsonnal, aki a középkori gondolkodás egyik legnehezebb aspektusának tartja annak megértését, hogy mit jelenthetett a korabeli ember számára a csodás és természetfeletti jelenségek megtapasztalása a mindennapi életben. ${ }^{1417}$

A pusztító és elkerülhetetlen természeti katasztrófákat rendszerint isteni büntetésnek tekintették és összefüggésbe hozták az emberiség erkölcsi állapotával, ${ }^{1418}$ ennek megfelelően az 5. század csapásait is sokan azzal magyarázták, hogy az emberiség számtalan bünt követett el és nem figyelt eléggé az isteni figyelmeztetésekre. Hydatius a többi krónikaszerzőhöz képest különösen nagy érdeklődést mutat a természetfölötti és paranormális jelenségek iránt, a krónikában bemutatott csodákat és előjeleket gyakran próbálja kapcsolatba hozni a bemutatott eseményekkel vagy az égi haraghoz kapcsolódó bibliai látomásokkal. ${ }^{1419}$ Ahogyan Eusebius isteni büntetésként értelmezte a keresztényüldözéseket, amelyek azért következtek be, mert Isten választott népe hütlenné vált és sok bünt követett el, úgy Hydatius is idős korára már annyi igazságtalanságot és szenvedést láthatott saját környezetében, hogy a bemutatott csodajelekkel egyértelmüen próbálta jelezni, az emberiség rossz úton jár, mert megszegte az Isten által kiszabott normákat, ezért büntetésként égi csapásokat kell elviselnie. ${ }^{1420}$

A barbár pusztítások szerepéről Hydatiushoz hasonló elveket vallott Salvianus (400480 k.), aki a lerinumi kolostor papjaként írta meg a De gubernatione Dei című munkáját 440-450 körül. Salvianus szerint a barbár betörések nem az isteni gondviselés hiányát jelzik és nem arra utalnak, hogy Isten nem törődik a világgal, hanem éppen ellenkezőleg, a birodalom hanyatlása Isten igazságos ítélete, amely azt bizonyítja, hogy ő kormányozza a világot. A barbárok pusztításait és a sorscsapásokat az isteni büntetés eszközeként értelmezte, ${ }^{1421}$ de Hydatiushoz hasonlóan rámutatott a keresztény lakosság körében elterjedt romlott erkölcsökre és szokásokra, különösen az egyháziak vagyonszerzésével és

\footnotetext{
${ }^{1417}$ Muhlberger 1990, 214; Johnson 1993, 75.

1418 A római történelem jelentősebb természeti katasztrófáiról, földrengésekről, vulkánkitörésekről, cunamikról, áradásokról és eliszaposodásról lásd: Grüll 2017, 69-87.

1419 Burgess 1988a, 26; Muhlberger 1990, 209; 214; 260.

${ }^{1420}$ Eus., Hist. Ecc. 8,16; Gárdonyi 2006, 22; Muhlberger 1990, 264.

1421 Salv. 1,1-3. Löwith szerint ugyanis „Isten nemcsak azokon keresztül hat, akik engedelmeskednek az akaratának, hanem azokon keresztül is, akik ellenszegülnek neki”, vö. Löwith 1996, 251.
} 
kapzsiságával kapcsolatban Dél-Galliában, Észak-Africában és Hispaniában. Salvianus a Római Birodalom örököseivel állítja szembe az ortodox tanítást nem ismerö, de mégis tiszta lelkű és a keresztény erényeket a rómaiaknál sokszor jobban megtestesítő barbárokat. ${ }^{1422}$ Véleménye szerint a germán törzsek azért törtek be a birodalomba, hogy megbüntessék és istenfélelemre ösztönözzék a romlott római társadalmat, ${ }^{1423}$ vagyis Isten nemcsak az utolsó ítélet alkalmával, hanem a korabeli történelmi események alakításával is igazságot szolgáltat, ${ }^{1424}$ ezáltal a történelemben folyamatosan tapasztalható ,isteni áldás vagy fenyités" a rómaiak nevelési folyamataként is értelmezhető. ${ }^{1425}$

A római világot ért katasztrófákat azonban elsősorban a pogányok értelmezték isteni büntetésként, a keresztények inkább nem értették, hogy ezúttal miért nem mutatkozik meg az isteni segítség. ${ }^{1426}$ Éppen ezért Lactantius Salvianustól eltérően azt gondolja, hogy mivel a történelem középpontjában a keresztény ember áll, a barbár népeknek kell számítaniuk büntetésre, mert megsértették Isten kiválasztott népét, tehát az égi harag valójában a kereszténységet védő igazságszolgáltatás egyik formája. ${ }^{1427}$

A legtöbb kutató egyetért azzal, hogy Hydatius sötét és boldogtalan világban élt, ezért krónikája tele van a kilátástalan jövőre és a bibliai próféciák beteljesedésére vonatkozó utalásokkal. Ezek a próféciák azért kerülhettek az érdeklődés középpontjába, mert úgy tartották, hogy ennek során néhány kiválasztott ember számára megismerhetővé válnak különböző szimbólumok formájában azok a jövőbeli események, amelyeket a Bibliában már megjövendöltek. Az élet hétköznapi rendjét megszakító eseményeket és természeti jelenségeket Isten közbenjárására bekövetkező csodajeleknek tekintették, amelyek vagy előre jeleztek egy későbbi eseményt, vagy megerősítették egy már megtörtént dolog

\footnotetext{
${ }^{1422}$ Salv. 4,54-58; Ladner 1976, 24; Alföldy 2000, 204; Albrecht 2004, 1032; Adamik 2009, 827. A germánok tiszta erkölcseiröl hasonlóan nyilatkozott Tacitus, amikor a züllött és harcolni képtelen rómaiakkal szembeállította az egyszerü, szabad, harcolni képes barbárokat, akiknek az ereje csak növekszik a római belviszályok miatt, vö. Tac., Germ. 18-19; Adamik 2009, 593.

${ }^{1423}$ A népvándorlást éppen ezért szokás „történelmi szükségszerüségnek” is értelmezni, mivel a szabad germán harcosok felülmúlták a hanyatlásnak induló római rabszolgatartó társadalmat, vö. Klaniczay 2005, 88.

${ }^{1424}$ Chadwick 1999, 232; Vanyó 2007b, 350-351. A 6. századi kelta szerzetes, Gildas szintén az isteni büntetés eszközének tartja az angolszászokat, akik barbár pusztítóként érkeztek Britanniába a bünös britek megfékezésére, a 8. századi szerzetes és tudós, Beda pedig azért gondolja jogosnak a britek elleni kegyetlen és kollektív fellépést, mert nem tudták az angolszászokat az igaz hitre téríteni, vö. Breisach 2004, 98.

${ }^{1425}$ Bultmann 1994, 71.

1426 Vanyó 2007b, 340. Az elsősorban Észak-Africában felerősödött vita Augustinus történelemszemléletére gyakorolt hatását a későbbiekben elemezzük.

${ }^{1427}$ Lact., Div. Inst. 7,15; Havas - Takács - Tegyey 2001, 257-258; Adamik 2009, 699. Lactantius életéröl és müveiröl bővebben: Albrecht 2004, 1291-1305; Vanyó 2007a, 434-438; Adamik 2009, 694-704.
} 
jelentőségét, vagyis a világvége várása „a töredékek összeforrasztásának vágyából született."

Burgess szerint Hydatius csodás jelenségek iránti érdeklődése a gallaeciai pogányság hatását mutatja, vagy elképzelhető, hogy ez általában is jellemző volt a gallaeciai kereszténységre, ugyanakkor kizárható a Molé által feltételezett közvetlen kapcsolat Hydatius és a pogányság között. ${ }^{1429} \mathrm{Ha}$ viszont figyelembe vesszük, hogy a keresztények történelemfelfogása szerint az emberiség elörehaladása a Teremtéstől kezdve az isteni akarat részét képezi, akkor azok az alkalmak, amikor Isten saját észrevétlen müködését megszakítva aktívabb szerepet vállal és beavatkozik az események alakulásába, ${ }^{1430}$ kétségtelenül az emberiség iránti szeretetét és saját maga létezését igazolják. A 6. században Gregorius Turonensisnél már kifejezetten azt látjuk, hogy a csodák felsorolását annak az igazolására is használja, hogy az eretnek tanításokkal szemben egyedül az ortodox hit képes valódi csodatételekre. ${ }^{1431}$ Ennek megfelelően Hydatius esetében sem lehet kizárni, hogy a csodajelek felsorolásával Isten mindenütt jelenlévő erejét szeretné igazolni, ${ }^{1432}$ és ezáltal az igaz hit követésére buzdítja az olvasóit, vagyis az ábrázolt természetfölötti jelenségeket az isteni beavatkozás megnyilvánulásainak kell tekintenünk.

Burgess Hydatius és más krónikaszerzők műveit összehasonlítva azt vizsgálta, hogy a természeti jelenségek és a csodajelek iránti nagy érdeklődés vajon a pogány eredetű annalisztikus történetírásra, vagy inkább a keresztény apokaliptikus megközelítésre vezethető vissza. Az 5-6. századi annalisztikus müvek, valamint Eusebius, Hieronymus és Prosper feljegyzéseinek elemzéséből az látszik, hogy a szerzők nem túl sok természeti jelenséget rögzítettek, de azokat is általában azért, mert érdekesnek találták őket és a történeti hagyomány részét képezték, ugyanakkor csak nagyon ritkán alkalmazták azokat konkrét események előjeleként. Marcellinus Comes és Gregorius Turonensis már legalább annyira intenzív érdeklődést mutat a rendkívüli jelenségek iránt, mint maga Hydatius, Orosius viszont mindezektől eltérően egyfajta „apocalyptic dimension” jegyében csak a kereszténység előtti idők illusztrálására és a világban tapasztalható gonoszság bemutatására használta a csodajeleket. ${ }^{1433}$ Mivel a természetfölötti jelenségek iránt nemcsak a

\footnotetext{
${ }^{1428}$ Burgess 1988a, 251; Bauer 1991, 70; Breisach 2004, 101; Wieser 2016, 108.

${ }^{1429}$ Burgess 1988a, 175-176; 198-199; Molé 1975, 103-106.

1430 Burgess 1988a, 187.

${ }^{1431}$ Gurevics 1987, 46. Általánosságban is elmondható, hogy a csoda a katolikus egyház szentjeinek elfogadott monopóliumává válik, és az „absztrakt Istenbe” vetett hitet egyszerü módon teszi megfoghatóvá a hívek számára, vö. Gurevics 1987, 102.

1432 Breisach 2004, 101.

${ }^{1433}$ Burgess 1988a, 169-174.
} 
krónikaszerzők, hanem a hétköznapi emberek is érdeklődtek, szerepeltetésük az olvasó figyelmének megragadására és érdeklődésének felkeltésére is alkalmas volt, ezért nem tekinthetők a római müveltség hanyatlásának bizonyítékaként, jól mutatják viszont, hogy a szerzők gyakran egy kevésbé müvelt, egyszerü közönséghez írták müveiket, ezáltal szükséges volt azok kibővítése meglepő és csodás elemekkel az olvasók szórakoztatására. ${ }^{1434} \mathrm{Ha}$ a csodajelek gyakori szerepeltetését ezek alapján azzal magyarázzuk, hogy alkalmasak voltak az érdeklődő olvasók figyelmének fenntartására is, egyetérthetünk azzal az állásponttal, mely szerint a bonyolult „cálculos astrofísicos” alkalmazása ellenére ${ }^{1435}$ azért nem kapcsolható össze minden előjel konkrétan valamelyik krónikában szereplő eseménnyel, mert azok rögzítésére leginkább „their own collective importance" miatt került sor. ${ }^{1436}$

Ezek után érdemes megvizsgálnunk alaposabban, hogy Hydatius milyen esetekben értelmezte az általa bemutatott eseményeket isteni büntetésként, és mikor hivatkozott bibliai próféciák beteljesedésére, különös tekintettel Dániel jövendöléseire. ${ }^{1437}$ Amikor a barbárok 409 után megszállták és végigrabolták egész Hispaniát, Hydatius szerint beteljesedtek az Úr szavai, amelyet a próféták megjövendöltek, mert az egész világot négy csapás sújtotta: a fegyver, az éhínség, a dögvész és a vadállatok, emiatt az emberi faj megállíthatatlanul sodródott a pusztulása felé. ${ }^{1438}$ A barbárok betörésének ez a drámai és túlságosan részletes leírása feltehetően annak köszönhető, hogy a kialakult helyzetet az Ezékiel által megjövendölt Hierosolyma pusztulásához és az isteni harag megújulásához lehessen hasonlítani. ${ }^{1439}$ Athaulf és Galla Placidia 414-ben megkötött házasságából nem született gyermek, és ebben Dániel jövendölését látták beteljesedni, mely szerint a déli király lánya egybekel az északi királlyal, de egyik utódjuk sem éli túl őket. ${ }^{1440}$ Hydatius talán azért idézi

\footnotetext{
${ }^{1434}$ Gurevics 1987, 48-49. Az alsó társadalmi rétegek szinte kritika nélkül fogadták a természetfölötti jelenségeket, az absztrakt fogalmak befogadására viszont csak szemléletes képek segítségével voltak képesek, ezért a nekik szóló müvekben többnyire az „érzelem fölötte áll az értelemnek”, vö. Gurevics 1987, 94.

${ }^{1435}$ Candelas-Colodrón 2004, 360.

${ }^{1436}$ Burgess 1988a, 168.

1437 Dániel könyvének és Hydatius krónikájának párhuzamos helyeit közli: Cardelle de Hartmann 1994, 155 157; Kitchen 2013, 649-652.

${ }^{1438}$ Hyd. 40: passim in humani generis efferantur interitum, et ita quatuor plagis ferri famis pestilentie bestiarum ubique in toto orbe sevientibus, predicte a domino per prophetas suos adnuntiationes implentur.

${ }^{1439}$ Ez. 5,7-17; 14,12-23; 33,23-29; Jel. 6,8; Dán. 9,27; Mt 24,15; Burgess 1988a, 189. Hieronymus ehhez hasonlóan a Galliát megszálló barbárokat a zsidókat fenyegető asszírokhoz hasonlította, vö. Hier., Ep. 123,15; Zsolt 83,9; Wieser 2016, 96.

${ }^{1440}$ Hyd. 49: Atavulfus apud Narbonam Placidiam duxit uxorem; in quo profetia Danihelis putatur inpleta, ut ait, filiam regis austri sociandam regi aquilonis, nullo tamen eius ex ea semine subsistente; vö. Dán 11,5-6: dél királyának leánya feleségül megy észak királyához, de karjának nem lesz elég ereje, még ivadéka se marad.
} 
majdnem szó szerint Dániel szavait, hogy igazolja olvasói elött a tájékozottságát, ${ }^{1441}$ ugyanakkor a megjegyzés arra is utalhat, hogy helytelenítette a gót király és a római császár lányának házasságát. ${ }^{1442}$

Amikor a vandál Gunderic 428-ban különös kegyetlenséggel (impie elatus) megszerezte Hispalis templomát, Isten büntetéseként megszállta az ördög (dei iudicio demone correptus), és Isidorus szerint még a templom kapujában utolérte a halál, mivel megsértette Vincentiust, a város vértanúját. ${ }^{1443}$ Burgess ennek kapcsán rávilágít arra, hogy Hydatius démonokról alkotott elképzelése mennyire eltért a korabeli keresztény értelmezéstől, ${ }^{1444}$ ami számunkra azt igazolja, hogy Hydatius valójában nem foglalkozott teológiai értelmezésekkel, hanem az isteni büntetést hangsúlyozta az igaz hit védelmében. Ezt támasztja alá az is, hogy Litorius római parancsnok gótoktól elszenvedett 439-es vereségét Hydatius a meggondolatlanságával (inconsultius), halálát pedig a sebesülésével indokolja, és nem említi Isidorus vallási magyarázatát, mely szerint Litoriusnak azért kellett meghalnia, mert a démonok előjelei és a jósok jövendölései megtévesztették. ${ }^{1445}$

Hydatius többször is említi a nyugati világban nagy tiszteletnek örvendő Szent Eulaliát, aki 308-ban a Diocletianus-féle üldözések alatt szenvedett mártírhalált Emeritában. ${ }^{1446}$ Először 429-ben, amikor a Gaiserictől vereséget szenvedő szvév Heremigarius megsértette (iniuria spreverat) Eulaliát, ezért menekülés közben Isten kezétől vezérelve (divino brachio) büntetésként az Anas folyóba vetette magát. Hydatius Eulaliaábrázolása azt mutatja, hogy a szentek figyelmet és tiszteletet követelnek a keresztény hívektől, és ha barbár módon megsértik őket, akkor bosszút állnak a bűnösökön. ${ }^{1447}$

Carthago 439-es elfoglalásakor Gaiseric különös kegyetlenséggel bánt a papsággal, és ahogyan Dániel megjövendölte, a szentek nyughelyeit feldúlta, a katolikus templomokat pedig az arianusok kezére adta. ${ }^{1448}$ Burgess ugyan kételkedik abban, hogy Hydatius valóban

\footnotetext{
${ }^{1441}$ Molé 1974, 311-313; Burgess 1988a, 159.

1442 Más források azt mutatják, hogy ez nem volt kényszerházasság, Athaulf és Galla Placidia kölcsönösen vonzódtak egymáshoz, és mindkettőjüket szépnek és müveltnek tartották kortársaik, vö. Sz. Jónás 1994, 1314; Bubnó 2013, 19. Az esküvői ceremónia részleteiről lásd: Olymp. 24,26; a házasság hátteréről bővebben: Randers-Pehrson 1993, 118; Wolf 1999, 17-18.

1443 Hyd. 79; Isid., Hist. Vand. 73.

${ }^{1444}$ Az általános felfogás szerint a démonok sok bajt és szerencsétlenséget okoznak az emberiség számára, vö. Brown 1972, 53-56; ez alapján Gunderic a démon általi megszállás miatt indított volna támadást, ehelyett viszont azt írja Hydatius, hogy a démont Isten küldte, hogy halállal büntesse a vétkes Gundericet, vö. Burgess 1988a, 209.

1445 Hyd. 108; Isid., Hist. Goth. 24: daemonum signis haruspicumque responsis deceptus.

1446 Collins 1983, 96-100; Burgess 1988a, 209.

${ }^{1447}$ Hyd. 80. A középkori hívek és a szentek kapcsolatáról bővebben: Gurevics 1987, 86-93.

1448 Hyd. 110: rex elatus inpie episcopum clerumque depellit ex ea et iuxta prophetiam Danihelis demutatis ministeriis sanctorum ecclesias catholicas tradidit Arrianis; vö. Dán. 9,27; 11,31.
} 
az Antikrisztussal akarta-e azonosítani Gaiseric alakját, ${ }^{1449}$ mindenesetre az olvasók meghökkentésére és Gaiseric jellemrajzának színesítésére jó alkalmat biztosított ez a megfeleltetés.

Attila seregét italiai fosztogatása miatt isteni büntetésként égi csapások, éhínség és betegség sújtotta, ${ }^{1450}$ így sikerült a rómaiaknak legyőzniük a hunokat, ráadásul Attila 453 tavaszán orrvérzés, agyvérzés vagy mérgezés következtében az életét is elveszítette. ${ }^{1451}$ Isidorus ugyanakkor kettős értelmet ad ennek a hydatiusi gondolatnak, hiszen szerinte éppen a hunok voltak Isten haragjának ostorai (virga furoris dei), akiket Isten büntetésként szabadított rá a bünös világra, hogy tartózkodjanak a vágyaiktól. ${ }^{1452}$

Hydatius rendkívül részletesen számol be Theoderic 456-os bracarai fosztogatásairól, különös tekintettel az egyházi személyekkel, a hívekkel és az épületekkel szemben alkalmazott durvaságra. Tragikusnak tartja, hogy a szentek basilicáit feltörték, az oltárokat ledöntötték, a szüzeket elrabolták, ${ }^{1453}$ a papságot meztelenre vetkőztették, a lakosságot pedig elhurcolták a menedékhelyekről. ${ }^{1454}$ A gótok szvévekkel szemben tanúsított könyörtelensége Hydatius szerint felelevenítette a Hierosolymával kapcsolatos égi büntetéseket. Ha elfogadjuk korábbi feltételezésünket, mely szerint a szvévek nagy része megtartotta az arianus hitet, akkor a gótok kegyetlenkedése valóban elfogadható a szvéveket sújtó büntetésnek, ráadásul azt is megmagyarázza, hogy a katolikusokhoz csatlakozó Rechiariusnak miért csak később, Theoderic fogságában kellett meghalnia. ${ }^{1455}$

462-ben az isauriai földrengés ${ }^{1456}$ Hydatius szerint azért következett be, ${ }^{1457}$ mert a város lakói nem figyeltek az isteni intelmekre, ezért a földrengés teljesen lerombolta a

\footnotetext{
1449 Burgess 1988a, 159.

${ }^{1450}$ Hyd. 146: divinitus partim fame, partim morbo quodam plagis caelestibus feriuntur.

${ }^{1451}$ Iord., Get. 254-258.

1452 Isid., Hist. Goth. 28-29: adflictionibus emendati a saeculi cupiditate et peccato semet ipsos coerceant.

1453 Ezek a laikus nők a klerikusok testvérei vagy lányai lehettek, akik velük együtt éltek és szüzességi fogadalmat tettek, vö. Burgess 1988a, 223-224.

${ }^{1454}$ Hyd. 167: etsi incruenta, fit tamen satis maesta et lacrimabilis eiusdem direptio civitatis. Romanorum magna agitur captivitas captivorum; sanctorum basilicae effractae; altaria sublata atque confracta; virgines dei exim quidem abductae, sed integritate servata; clerus usque ad nuditatem pudoris exutus; promiscui sexus cum parvulis de locis refugii sanctis populus omnis abstractus; iumentorum, pecorum, camellorumque horrore locus sacer impletus; scripta super Hierusalem ex parte caelestis irae renovavit exempla.

1455 Hyd. 168; 171.

${ }^{1456}$ Hyd. 210: Antiochia maior Isauriae inobaudiens monitis salutaribus terra dehiscente demergitur, episcopo tantum ipsius civitatis cum aliquantis qui eum obaudientes timori domini sunt secuti de interitu liberatis, turrium etiam solis cacuminibus extantibus super terram.

${ }^{1457}$ Hyd. 210. Thompson szerint a földrengés valójában 458. szeptember 13-14-én zajlott, és bár 459-ben volt egy másik földmozgás is Antiochiában, Hydatius valószínüleg azért datálja 462-re az eseményt, mert csak utólag hallott róla és nem kapott pontos információt a földrengés dátumáról, vö. Thompson 1982, 292, 52. j.
} 
vidéket, megnyílt a föld a nagyobb Antiochiában, ${ }^{1458}$ a bünös antiochiaiak közül pedig csak azok menekültek meg, akik engedelmesen követték a város püspökét. ${ }^{1459}$

Hydatius jó néhány alkalommal próbált természeti jelenségeket konkrét események előjeleként értelmezni. Mivel saját korához közeledve várakozásainkkal ellentétben egyre több ilyen jellegü feljegyzést készített, ezt a legtöbben Gallaecia zürzavaros helyzetével és a jövőbeli tragédiákra utaló figyelmeztetésekkel magyarázzák. ${ }^{1460}$ Értesülünk például a 402. november 11-én lezajlott napfogyatkozásról, amely feltehetően Hispania északi részén volt látható 7.40 órakor, ${ }^{1461}$ de nem tudjuk, hogy ez minek az előre jelzéséhez kapcsolódik. Elképzelhető, hogy egy 403-404 körüli eseményről van szó, de Hydatius erre az időszakra vonatkozó feljegyzései elvesztek, és mivel nem említi Stilicho 402-ben Alaric gótjai fölött aratott győzelmeit sem, a legvalószínübb, hogy a barbárok 409-es betörését vagy Róma 410es elfoglalását jelezte előre a napfogyatkozás. ${ }^{1462}$

Nem világos, hogy milyen esemény előjeleként szerepel a krónikában, hogy 414-ben Hierosolymában megtalálták az első vértanú (primus martyr), Stephanus ereklyéit, aki a 60as évek üldözéseinek esett áldozatul, ${ }^{1463}$ mindenesetre említése rendkívül jó alkalom arra, hogy Hydatius tájékozottságát ismét igazolja az olvasói előtt, hiszen a mártírok tisztelete a 4. századtól rendkívül divatossá vált Hispaniában. ${ }^{1464}$ Mivel Hydatius Stephanus vértanúságát Krisztus életéhez viszonyítja, akár az is elképzelhető, hogy kedvező előjelként arra a magánéleti fordulatra próbált utalni, amikor elkezdett vallásos életet élni, hiszen megtérésére Muhlberger szerint bő egy évvel később került sor. ${ }^{1465}$

Néhány természeti csapás valószínüleg a gótok 418-as fosztogatásához és letelepedéséhez kapcsolódik. 418. július 19-én, csütörtökön Gallaeciában, a későbbi

\footnotetext{
1458 Thompson úgy látja, hogy Hydatius Keletre vonatkozó földrajzi ismeretei meglehetősen pontatlanok, mert Antiochia városát tévesen nem Syriába, hanem Isauriába helyezi, vö. Thompson 1982, 139; Burgess viszont érthető módon még azon is csodálkozik, hogy a 460-as évek Gallaeciájába egyáltalán bármilyen keleti esemény híre eljuthatott, vö. Burgess 1988a, 225.

${ }^{1459}$ Muhlberger felfigyelt arra, hogy egyes kéziratokban Antiochia pusztulását megelőzi néhány Gallaeciában látható csodajel, a leginkább elfogadott Burgess-féle kéziratban azonban az egyik jelenség az antiochiai földrengés után szerepel, vö. Muhlberger 1990, 215; Hyd. 209; 213b.

1460 Jones $1993,78-79$.

${ }^{1461}$ Hyd. 26; Cons. Const. 402; Chr. Gall. 452, 46; Chr. Gall. 511, 544; Seeck 1921, col. 41; Burgess 1988a, 269.

1462 Thompson 1982, 142.

${ }^{1463}$ Hyd. 50; ApCsel 6,8-8,3.

${ }^{1464}$ A vértanúakták korabeli terjedéséről lásd: Vanyó 2007a, 438-445.

${ }^{1465}$ Muhlberger 1990, 198. Elméletünk helyességét igazolná, ha Hydatius egyházi pályafutásának következő állomását, a 427-es püspökké szentelését is hasonlóan pozitív előjel kísérte volna, azonban éppen a 427. év feljegyzései nem maradtak ránk, így nem tudjuk, hogy egyáltalán beszámolt-e a felszentelés tényéröl az olvasóknak
} 
pusztítás helyszínén ugyanis teljes napfogyatkozás volt 9.30 óra körül, ${ }^{1466}$ Hierosolyma környékét erős földrengés rázta meg 419-ben, ${ }^{1467}$ a galliai Biterraeben 419-ben pedig rettenetes elöjeleket (signa terrifica) látott Paulinus, a város püspöke. ${ }^{1468}$

442 decemberében egy üstökös jelent meg az égen, hogy elöre jelezze az újabb csapást, a dögvészt. ${ }^{1469}$ Hydatius talán itt közvetlenül a 442-443 fordulóján pusztító pestisjárvány terjedését jegyezte fel, de mivel azt állítja, hogy a dögvész csaknem az egész világra kiterjedt, az is elképzelhető, hogy az adott időszakban felhalmozódó problémákra utal. Nagy jelentősége lehet például annak, hogy a galliai partokon vandálok kalózkodtak és szerződésre kényszerítették a rómaiakat, ezekről azonban Hydatius nem számolt be a krónikában. Az előjel éppen ezért inkább arra utalhat, hogy bagaudák fosztogatták a lakosságot, vagy hogy a manicheusok tevékenységükkel rendkívül nagy problémát okoztak az egyházi vezetőknek és magának Hydatiusnak is. ${ }^{1470}$

Hydatius szerint 447. december 23-án, kedden napfogyatkozás volt 13 órakor, nem említi viszont, hogy ebben az évben január 27-én Constantinopolisban földrengést is tapasztaltak. A különös természeti jelenségek minden bizonnyal Rechila 448-ban bekövetkezett halálát és fia, a katolikus Rechiarius trónra lépését jelezték előre, ${ }^{1471}$ Attila viszont ezt égi jelként értelmezve Constantinopolis ellen vonult, amelynek következtében a hunoknak fizetendő subsidium a háromszorosára emelkedett. ${ }^{1472}$

Hydatius rendkívül hosszan mutatja be a 450-451-es gallaeciai földrengések és az ehhez kapcsolódó égi előjelek körülményeit. ${ }^{1473}$ A 450. április 4-én a naplemente utáni északi fények tüzvörös és lándzsa alakú fénycsíkok formájában villogtak és cikáztak az égen. Hydatius felhívja az olvasók figyelmét arra, hogy ezek az elöjelek egy rövidesen bekövetkező eseményre utalnak, a következő feljegyzésben pedig be is számol arról, hogy a hunok a békeszerződést megszegve Gallia fosztogatására indultak. Ezt követően újabb előjelek tüntek fel Galliában: 451. szeptember 26-án holdfogyatkozás következett be, egy

\footnotetext{
1466 Hyd. 56; Marc. Com. 418; Chr. Gall. 452, 82; Burgess 1988a, 269.

${ }^{1467}$ Hyd. 58; Marc. Com. 419.

${ }^{1468}$ Hyd. 65; Chr. Gall. 452, 84.

${ }^{1469}$ Hyd. 118: cometae sidus apparere incipit mense Decembri; quod per menses aliquot visum subsequentis in pestilentia plagae, quae fere in toto orbe diffusa est, praemisit ostentum; Marc. Com. 442.

${ }^{1470}$ Hyd. 120; 122; Székely 2008, 76, 86. j.

${ }^{1471}$ Hyd. 128-129.

1472 Klaniczay 2005, 92.

1473 Hyd. 141: in Gallecia terremotus assidui, signa in caelo plurima ostenduntur, nam pridie non. Aprilis tertia feria post solis occasum ab aquilonis plaga caelum rubens sicut ignis aut sanguis efficitur, intermixtis per igneum ruborem lineis clarioribus in speciem hastarum rutilantium deformatis, a die clauso usque in horam noctis fere tertiam signi durat ostensio, quae mox ingenti exitu perdocetur.
} 
június 18-án megjelenő üstökös pedig 29-én keleten, később nyugaton látszódott. ${ }^{1474}$ Isidorus szerint ezeket a csodajeleket már a csata előtt is lehetett látni, mivel a catalaunumi vereséget jelezték előre, Hydatiusnál viszont valószínűleg Attila italiai hadjáratára utalnak. ${ }^{1475}$ Kevésbé fogadható el Muhlberger álláspontja, aki az előjeleket Theoderic király meggyilkolásával és Thorismund hatalomátvételével hozza kapcsolatba, hiszen nem valószínü, hogy Hydatius katasztrófaként tekintett volna egy gót királyváltásra, ráadásul Theoderic halála az előjelek előtt szerepel a krónikában. ${ }^{1476}$

454-ben egy gallaeciai földrengésröl és az égen hajnalban viaskodó napokról olvashatunk. ${ }^{1477}$ Mivel a következő négy feljegyzésben a római hatalmi viszonyokkal kapcsolatos események szerepelnek, a csodajelek valószínűleg Aëtius és Valentinianus meggyilkolását, illetve Petronius Maximus uzurpációját jelezték előre, amelyek tovább csökkentették az amúgy is gyenge központi hatalom hatékonyságát. 458. május 28-án egy részleges napfogyatkozásról számol be Hydatius, amely valószínűleg 9.20-12.00 óra között zajlott. Ehhez hasonló jelenségröl olvashatunk 464. július 20-án 5.50-8.20 óra között is, amely valószínüleg a szvévek és a gótok közötti szövetségkötést vagy a Hydatius által nagyra becsült Aegidius meggyilkolását jelezte előre. ${ }^{1478}$

462-ben több csodajelről is beszámol Hydatius. Március 2-án, feltehetően előző este 23.40 óra és másnap 3.00 óra között különféle égi jelek tüntek fel Gallaeciában, a naplementekor kukorékoló kakasok és a vérvörös színű telihold valószínűleg Narbo gótok kezére kerülését jelezte előre. ${ }^{1479} 462$ júniusában Gallaeciában juhokat ért villámcsapás, ${ }^{1480}$ ezen kívül Bracarában kettő, az Asturica melletti Legióban ${ }^{1481}$ pedig négy gyermek összekapaszkodva és egymást szorítva halt meg, amelyek feltehetően a gallaeciabeliek és a szvévek között néhány hónap múlva kiújuló zavargásokat jelezték elöre. ${ }^{1482}$

\footnotetext{
${ }^{1474}$ Hyd. 142-143. Az üstökös nyugati megelenésénél a szövegben [...] kal. Aug. szerepel, ezért nem tudjuk pontosan, hogy augusztus Kalendaeja elött hány nappal, vagyis július 16. és augusztus 1. között pontosan mikor történt az esemény. A jelenségek pontos datálásáról bővebben: Burgess 1988a, 92-93.

1475 Isid., Hist. Goth. 26; Hyd. 145-146.

1476 Muhlberger 1990, 216; vö. Hyd. 142; 144.

${ }^{1477}$ Hyd. 151: in Gallecia terraemotus et in sole signum in ortu quasi altero secum concertante monstratur.

${ }^{1478}$ Hyd. 152-155; 184; 221-222; 224; Burgess 1988a, 270-271.

1479 Hyd. 209: pullorum cantu ab occasu solis luna in sanguinem plena convertitur; Burgess 1988a, 179; vö. Hyd. 212.

${ }^{1480}$ Hyd. 213a: mense Iunio in Gallicia coruscatione villae exuste et greges ovium concremati, carnes concise pluviae de caelo mixtae cadunt, duo aduliscentes carne in invicem soledati adhaerentes sunt mortui.

${ }^{1481}$ Legio városa Asturicával közösen müködtetett püspökséget a 3. század végétől, de nem tudjuk pontosan, hogy Hydatius idején még létezett-e ez az együttmüködés, ugyanakkor a gótok 457-es fosztogatásakor Hydatius szerint Asturicában két püspök volt, ezért lehetséges, hogy Legio vezetője is éppen ott tartózkodott, vö. Hyd. 179; Claude 1978, 671, 89-90. j.; Burgess 1988a, 16; 221.

1482 Hyd. 213b: duorum natorum portentum visum; quatuor Legione simile memoratur; vö. Hyd. 216.
} 
467-ben a Galliából visszatérő követek újabb csodajelekről hoztak hírt. Naplementekor két nap jelent meg az égen, Tolosában pedig a talajból feltörö vér hömpölygött a város közepén, ${ }^{1483}$ ami Burgess szerint azt jelképezheti, hogy a gótok központi városából szétáradt Krisztus kegyelmének olaja, amely a barbárok kezében az Antikrisztus vérévé változott. ${ }^{1484}$ Amikor Hydatius arról tudósít, hogy a gótok tanácskozásán a kezükben tartott fegyverek hegye zöld, piros, sárga vagy fekete színű lett, akkor feltehetően Euric király előtt tartottak fényes katonai díszszemlét, ahol egy római megfigyelőt elkápráztatott a kézifegyverek színekben pompázó sokasága, ${ }^{1485}$ amely ,a középkori lovagi hadseregek színes változatosságához" hasonlított. ${ }^{1486}$ A krónikában a legtöbb természetfölötti jelenség Hispanián kívül történik, de számos példát látunk arra is, hogy egy Gallaeciában látható csodajelet egy attól távoli helyen bekövetkező rendkívüli eseménnyel hozott Hydatius összefüggésbe. Mivel a gallaeciai elöjelek aligha utalhatnak Hispanián kívüli eseményekre, egyetérthetünk Muhlberger feltételezésével, mely szerint Hydatius sem gondolhatta komolyan, hogy egymástól távoli helyeket ilyen logikai múvelettel össze lehet kapcsolni. ${ }^{1487}$

Az isteni büntetések, a beteljesedett próféciák és az égi előjelek felsorolása mellett Hydatius néhány alkalommal említi az isteni irgalom jelenlétét és a szentek közbenjárását is, amelyek az emberiség iránti könyörületességet kifejezve képesek voltak megakadályozni vagy enyhíteni a jogosan kiszabott isteni büntetés mértékét. ${ }^{1488}$ A barbárok például 411-ben hosszú fosztogatás után az Úr könyörületességéből (domino miserante) kötöttek békét Hispania lakóival, 451-ben a római és a gót sereg pedig ugyan jelentős veszteségeket szenvedett Attila csapataitól Catalaunumnál, Isten segítségével (divino auxilio) mégis sikerült legyőzniük a hunokat, ráadásul 452-ben az isteni gondviselés jóvoltából égi csapások sújtották a seregeiket, így biztosítva volt Marcianus és Aëtius katonáinak győzelme. ${ }^{1489}$

\footnotetext{
${ }^{1483}$ Hyd. 238: legati de rege Gothorum reversi referunt portenta in Galliis visa aliquanta: in conspectu similem ipsi de continuo paruisse solem alium visum solis occasu; congregatis etiam quodam die concilii sui Gothis tela que habebant in manibus a parte ferri vel acie alia viridi, alia roseo, alia croceo, alia nigro colore naturalem ferri speciem aliquandiu non habuisse mutata; medio Tolose civitatis hisdem diebus e terra sanguinem erupisse totoque diei fluxisse curriculo.

${ }^{1484}$ Burgess 1988a, 182.

1485 Gillett 2003, 76

${ }^{1486}$ A barbár hadijelvények nemzetségek szerinti megoszlása sok hasonlóságot mutat a Notitia Dignitatumban szereplö római alakulatok pajzsdíszítményeivel, vö. Várady 1961, 197.

${ }^{1487}$ Muhlberger 1990, 215.

${ }^{1488}$ A mártírok és a szentek hispaniai kultuszáról lásd: Maldonado 2005, 151-188.

${ }^{1489}$ Hyd. 41; 142; 146.
} 
457-ben az Emerita kifosztására készülö Theoderic Eulalia csodájának köszönhetően elhagyta a várost, ${ }^{1490}$ pár hónappal később pedig hiába ostromolta Coviacum erődítményét, a lakosság Isten segítségével (auxilio dei) mégis ellenállt és legyőzte az ellenséget. 460-ban az Aquae Flaviae városában fogságba esett Hydatius Isten kegyelméböl (miserantis dei gratia) szabadulhatott ki a szvévek fogságából és újra elfoglalhatta hivatalát, 467-ben Leo és Anthemius pedig Isten parancsára (deo ordinante) indította el a vandálok elleni összehangolt támadást Gaiseric fosztogatásainak megállítására. ${ }^{1491}$

Mivel az egyház álláspontja szerint a próféciák és a csodajelek az isteni akaratot jelezték elöre, érthető módon a püspökök nagy része kötelességének érezhette, hogy segítsen az erről szóló hírek terjesztésében. ${ }^{1492}$ A krónika forrásainak vizsgálatakor láttuk, hogy milyen írások és levelek állhattak Hydatius rendelkezésére a természetfölötti jelenségekről szóló részek összeállításakor, azt viszont nem tudjuk pontosan, hogy maga Hydatius milyen mértékben közremüködött az ilyen jellegü információk terjesztésében. Valószínűleg Hydatius a püspöki szokásokat követve, egyfajta munkaköri kötelességként jegyezte fel ezeket a csodajeleket a krónikában, amellyel nemcsak hozzájárult ahhoz, hogy széles körben és az utókor számára is hozzáférhetőek legyenek a bemutatott jelenségek, hanem a történeti események színesítését és az olvasók érdeklődésének fenntartását is biztosította, alkalmazásuk viszont nem jelentheti automatikusan azt, hogy valóban hitt volna ezekben az előjelekben és őszintén rettegett volna az égi harag büntetéseitől.

\subsubsection{Jövőkép és apokaliptikus hiedelmek}

Muhlberger szerint Hydatius müve nemcsak történeti forrásként értékes az utókor számára, hanem irodalmi és történetírói munkaként is nagy jelentőséggel bír. Általánosságban is elmondható, hogy az 5. századi krónikások tudatosan gyüjtötték össze életük fontosabb eseményeit, hogy a közelmúlt értékelésével egyfajta „vision of history”-t jelenítsenek meg az olvasók előtt, ${ }^{1493}$ ugyanakkor túlzásnak tünik Burgess azon következtetése, hogy a pesszimista Hydatius központi témája a közeledő világvége, mivel minden eseményt ennek alárendelve tárgyal munkájában. ${ }^{1494}$ Hydatius a Hieronymust követő krónikahagyományban egyedüliként utalt a Biblia apokaliptikus jövendöléseire, ezért meg kell vizsgálnunk, hogy

\footnotetext{
${ }^{1490}$ Hyd. 175: Theudericus Emeritam depredari moliens beatae Eulaliae martyris terretur ostentis.

${ }^{1491}$ Hyd. 179; 202; 230.

1492 Muhlberger 1990, 209.

1493 Muhlberger 1990, 5.

1494 Burgess 1988a, 192.
} 
valóban hitt-e abban, hogy a világ a végéhez közeledik, és saját korának szenvedései Krisztus második eljövetelét, a parúsziát jelezték elöre.

Ennek tisztázásához Muhlberger rövid áttekintést nyújt arról, hogy milyen okok vezethettek az apokaliptikus irodalom megszületéséhez, amelyek közé a hipotézis szerint Hydatius krónikája is tartozik. ${ }^{1495}$ Ha saját életében sok csapás és igazságtalanság éri a hívő embert, akkor nem érti, miért kell szenvednie Isten ártatlan szolgáinak, ugyanakkor sejti, hogy az emberiség bűnei válthatták ki az égi csapásokat. A hitében kissé megingott, de hüséges keresztény ember ekkor abban bízik, hogy az isteni gondviselés majd véget fog vetni a szenvedéseknek, a bűnösök megkapják méltó büntetésüket, az igazságosság pedig a béke megteremtésével helyreáll. ${ }^{1496} \mathrm{Az}$ apokaliptikus írások a jövőre vonatkozó isteni szándékot próbálják megfejteni a világban tapasztalható csodák és előjelek értelmezésével. Mivel a krónikában utalásokat olvashatunk Dániel próféciáira és a Jelenések Könyvére, első látásra könnyen sorolhatnánk Hydatius művét is az apokaliptikus írások közé. ${ }^{1497}$

Ha választ keresünk arra, hogy Hydatius miért vállalkozott a krónikaírás nehéz feladatára, úgy tünik, még jobban megerösödik bennünk ez a hipotézis. A kutatók nagy része azt gondolja, hogy Hydatius szerint a barbárokat az isteni harag küldte az emberiség megbüntetésére, ezért jelenlétük a próféciák beteljesedésével a világ végének közeledésére utal, Burgess azonban ebből azt a következtetést vonja le, hogy Hydatius nemcsak hitt benne, hanem meg is volt győződve arról, hogy hamarosan vége a világnak, ezért ő volt az első olyan történetíró, aki a „teleological Christian historiographic tradition” keretein belül szembe mert nézni azzal, hogy munkájában a történelem utolsó eseményeiről ad számot. ${ }^{1498}$ Ehhez hasonlóan Pawlak is úgy gondolja, hogy amikor Hydatius látta, hogy a császári hatalom gyengesége miatt a római világ összeomlik, pesszimistává vált és az általa megtapasztalt eseményeket a világ végeként értelmezte. ${ }^{1499}$

Hydatius a krónikát jó néhány nyugtalanító előjel bemutatásával fejezte be. A szokásosnál keményebb esztendő említése, az évszakok összekavarodása ${ }^{1500}$ és az égből

\footnotetext{
1495 Muhlberger 1990, 260.

1496 A zsidó szemlélet szerint Isten a világot közvetlenül és bölcsen irányítja, de ha a kiválasztott nép szembefordul az isteni akarattal, akkor súlyos büntetésben részesül, vö. Breisach 2004, 86. A zsidóság történelemfelfogásáról bővebben: Bultmann 1994, 28-31; a zsidó eszkatológia kezdeteiről lásd: Eliade 2006, 452-456.

${ }^{1497}$ Dániel könyve a Kr. e. 2. században keletkezett, de Dániel ennek nem a szerzője, csak fiktív hőse, a 7-8. fejezet az apokaliptikus irodalom első ismert példája. Az apokrif apokalipszisek jelentőségéről lásd: Vanyó 2007a, 162-167; a fogalom általános értelmezéséről bővebben: Landes 1988, 205-206.

${ }^{1498}$ Burgess 1988a, 154-156.

1499 Pawlak 2007, 36.

${ }^{1500}$ Hyd. 246: durissimus extra solitum hoc eodem tempore annus hiberni, veris, aestatis, autumni in aeris et omnium fructuum permutatione diffunditur.
} 
hulló magvak keserüsége ${ }^{1501}$ azt jelezheti, hogy Gallaeciában felbomlott és elveszett az a megszokott rend, amely a lakosság nyugalmát hosszú időn keresztül biztosította, mivel a szvévek és a gótok gyakran fosztogatták Asturica környékét, a vandálok ellen indított római hadjárat kimenetele pedig a többszöri kudarc miatt még mindig bizonytalan. ${ }^{1502}$ Később istenfélő és keresztény férfiak négy különleges külsejü és fajtájú halat fogtak ki a vízből, ${ }^{1503}$ csodájuk azonban nehezen értelmezhető. ${ }^{1504}$ Valószínűleg Hydatius itt visszautal az előző feljegyzésben említett négy évszakra és ezzel egy teljes esztendő elmúlására, mivel az utána olvasható 365 esztendőnyi időszak Muhlberger szerint azt mutatja, hogy valóban véget ért egy ciklus az emberiség történetében, ${ }^{1505}$ de a megszokott rend összezavarása (permutatione) miatt nem 365 nap, hanem 365 év alkot egy időbeli egységet. Burgess szerint Hydatius biztosan ismerte a 365-ös szám asztrológiai jelentőségét, ${ }^{1506}$ Tranoy azt gondolja, hogy a négy hal a négy világbirodalmat jelképezi, Candelas-Colodrón pedig a Gallaeciában népszerü priscillianista eszmékkel és újszövetségi szöveghelyekkel hozza kapcsolatba a csodajeleket. ${ }^{1507}$

A krónika végén szereplő jelenségek tehát ismételten igazolják Hydatius tájékozottságát és a természetfölötti jelenségek iránti érdeklődését, másrészről viszont még tovább erősíthetik azt a hipotézist, hogy Hydatius tényleg számított a világvége közeledésére, és azért helyezett el jó néhány előjelet a krónika utolsó feljegyzései között, hogy ezzel is figyelmeztesse olvasóit Krisztus második eljövetelére. Pawlak szerint nem is lehetne elképzelni ennél pesszimistább és demoralizálóbb befejezést egy olyan krónikában,

\footnotetext{
${ }^{1501}$ Hyd. 247: in flumine Minio de municipio Lais miliaro ferme quinto capiuntur pisces IIII novi vizu et specie, sicut retulere qui ceperant Christiani et religiosi, Hebraeis et Grecis litteris, Latinis autem aerarum numeris insigniti, ita CCCLXV anni circulum continentes, parvo mensium intervallo haud procul de supradicto municipio in speciem lenticulae viridissimorum, ut herba, quaedam forma granorum plena amaritudine defluxit e caelo; et multa alia ostenta quae memorare prolixum est. Burgess ezeket a magvakat az exodusi manna ellenpéldájának is tartja, vö. Burgess 1988a, 181.

${ }^{1502}$ Hyd. 241; 243-244.

${ }^{1503}$ Hyd. 247. A héber és görög betükkel megjelölt halak emlékeztetnek a szintén 5. századi mythographus, Fulgentius Fabius Planciades kronológiai számítására, mely szerint a Biblia és az ábécé alapján 23 korszaka van a világtörténelemnek, vö. Gesztelyi - Havas 1999, 253.

${ }^{1504}$ Burgess és Tranoy Mommsen szövegében a két csodajelet összekapcsoló mensum szót mensiumra javította, hogy a magvak leírásáról szóló rész úgy kezdődjön, hogy parvo mensium intervallo, mások pedig a pari mensium intervallo kifejezésre hivatkozva az évet 12 egyforma részre osztották fel, vö. Muhlberger 1990, 262.

${ }^{1505}$ Muhlberger 1990, 262. Mivel a „világtörténések periodicitása” is abból a felfogásból alakult ki, hogy a világ menete a természet éves és évszakonkénti váltakozásának megfelelően halad elöre, így az évszakok körforgásáról és a ciklus lezárásáról szóló feljegyzés sajátosan kapcsolódik egymáshoz, vö. Bultmann 1994, 33.

${ }^{1506}$ Hyd. 246. Augustinus egyik írásában említ egy eretnek tanítást, mely szerint Krisztus keresztre feszítése után 365 évvel meg fog szünni a kereszténység, vö. August., De Civ. 18,53,2; Burgess 1988a, 182; Landes $1988,154$.

${ }^{1507}$ Tranoy 1974, 1,61; Candelas-Colodrón 2002b, 759-764.
} 
amelynek szerzője szerint a világ a végéhez közeledik. ${ }^{1508}$ Abban sem kételkedhetünk, hogy Hydatius hallott a manicheizmushoz hasonlóan a khiliazmus tanításáról, ${ }^{1509}$ mely szerint Krisztus második eljövetelével az utolsó ítéletkor az igazhitüek feltámadnak és ezer évig élnek majd a földön Krisztus uralma alatt. ${ }^{1510}$ Burgess ráadásul meggyőzően igazolta, hogy Hydatius ismerte azt az apokrif apokalipszist, ${ }^{1511}$ amely tartalmazta Krisztus Tamás apostolhoz írt levelét. ${ }^{1512} \mathrm{Ez}$ alapján kiszámítható, hogy a világ vége 450 évvel Krisztus mennybemenetele után, a 9. ioboleus végén, ${ }^{1513}$ azaz 482. május 27 -én következik majd be. ${ }^{1514}$

Összességében tehát jó néhány érv szól amellett, hogy Hydatius egyfajta „carácter supersticioso"-ként hitt a közelgő világvégében, ${ }^{1515}$ és ahogyan korábban láttuk, a legtöbb kutató szerint a barbárok pusztításai, a gótok betelepedése és Róma többszöri kifosztása egyaránt apokaliptikus gondolatok felé sodorták Hydatiust is. ${ }^{1516}$ Mindezek ellenére mégis azt mondhatjuk, hogy bár Hydatius ismerte a khiliasztikus eszméket és nem állt tőle távol a világvégére és Krisztus második eljövetelére való készülődés gondolata, a Tamásapokalipszisre vonatkozó utalás csak „una anotación al margen”, ${ }^{1517}$ és valójában a történeti idők folytatását várta.

Muhlberger elismeri, hogy Hydatius sohasem beszél konkrétan a közeledő világvégéröl, míg a legtöbb kortárs exegétikai vagy apologetikus munka éppen ennek említésével próbálja bünbánatra ösztönözni az olvasókat. Burgess szerint Hydatius valószínűleg elvárta olvasóitól, hogy megértsék a krónika apokaliptikus aspektusait, ugyanakkor belátja, hogy nem ezek a „didactic and prophetic matters” jelentik a beszámoló legfontosabb mondanivalóját. ${ }^{1518}$ Ha Hydatius a kereszténység történetének bemutatásával

\footnotetext{
1508 Pawlak 2007, 29.

${ }^{1509}$ Az ebioniták khiliasztikus eszméket is hirdettek, talán Hydatius ezért kapcsolja őket tévesen Nestorius és Eutyches mozgalmához.

1510 Szántó 1983, 100.

${ }^{1511}$ Hydatius kéziratának ezzel kapcsolatos kronológiai jelöléseiről lásd: Burgess 1988a, 160-162.

${ }^{1512}$ A Revelatio Thomae fragmentumához bőséges bibliográfiát kínál: Burgess 1988a, 162, 27. j., a szöveget közli: Burgess 1988a, 258-261. A Tamás-apokalipszis további elemzéséhez lásd: Wright 2003, 27-64.

1513 A vélemények azonban megoszlanak abban, hogy a ioboleusokat Krisztus születésétől vagy feltámadásától kell számítani, vö. Burgess 1988a, 165-166.

${ }^{1514} \mathrm{Ez}$ a dátum összhangban van azzal a Lactantius által is táplált apokaliptikus hagyománnyal, mely szerint a világ története 500 körül ér majd véget, vö. Lact., Div. Inst. 7,14,6-7; 7,25,3; Palmer 2014, 8; a feljegyzés ugyanakkor mutathatja Sulpicius Severus hatását is, vö. Cardelle de Hartmann 1994, 19-20. 1515 Candelas-Colodrón 2004, 358-359.

1516 Ward-Perkins 2005, 171-172; Palmer 2014, 25; López Quiroga - Martínez Tejera 2017, 439; Burgess összegyüjtötte a vonatkozó szerzőket is, vö. Burgess 1988a, 155, 1. j. Az apokaliptikus gondolatok 5. századi elterjedéséhez lásd még: Kitchen 2013, 641-660.

1517 Candelas-Colodrón 2004, 361.

${ }^{1518}$ Muhlberger 1990, 263; Burgess 1988a, 229.
} 
valóban az olvasókat próbálta volna felkészíteni a közelgő világvégére, akkor konkrétan meg kellett volna említenie az ezzel kapcsolatos írásos bizonyítékokat.

A manicheusokkal kapcsolatban már foglalkoztunk Thoribius levelével, amelyben Hydatius és Caeponius segítségét kérte a mozgalom felszámolásához. Ebből a levélből kiderül, hogy Thoribius azért a priscillianusok és a manicheusok szektáját találta a legveszélyesebbnek, mert ők még az Ószövetség érvényességét is megkérdőjelezve igyekeztek népszerüsíteni különböző apokrif iratokat és nem az egyház előírásai szerint tartották az istentiszteleteket. ${ }^{1519}$ Thoribius emiatt arra kérte Hydatiust és a többi püspököt, hogy figyeljenek fel az apokrif iratok veszélyességére és igyekezzenek megállítani azok terjedését, mert a püspökök között nagy népszerüséget szerezve veszélyt jelentenek a katolikus hit egységére. ${ }^{1520}$ Ezek után a felsőbb egyházi utasításokat mindig maradéktalanul követő Hydatius aligha juthatott arra az elhatározásra, hogy mégis érvényesnek tekinti a sokak által ismert, de apokrifnak nyilvánított Tamás-apokalipszis szövegét, hiszen Thoribius éppen az ilyen típusú iratok elutasítására kérte a püspököket. Hiába állítja Burgess, hogy „,in spite of his orthodox pretensions Hydatius had studied and accepted an uncanonical text", ${ }^{1521}$ csak arra vannak bizonyítékaink, hogy Hydatius ismerte az apokrif szöveget.

Az apokalipszis motívuma elsősorban a montanisták és a priscillianusok körében volt rendkívül népszerü, és ha nincs is arra konkrét bizonyítékunk, hogy Gallaeciában széles körben ismerték a Tamás-apokalipszist, ${ }^{1522}$ Hydatius minden bizonnyal a priscillianusok közvetítésével ismerhette meg a szövegét. Burgess ebből rögtön arra következtet, hogy Hydatius igazhitüségét a priscillianusok veszélybe sodorták, mert nemcsak hogy olvasta, hanem a krónikában terjesztette is ezt az eretnek tanítást, ${ }^{1523}$ azt viszont nem veszi figyelembe, hogy csak arra vannak bizonyítékaink, hogy Hydatius ismerte és felhasználta Tamás apokalipszisét. Vanyó az apokrifek jelentőségét vizsgálva felhívja a figyelmünket arra, hogy ezek az egyház által el nem ismert iratok a keresztények „szórakoztató olvasmányaiként" váltak rendkívül népszerüvé, ezért egészen a 4. századig csak az egyházatyák „elutasitó magatartását” figyelhetjük meg velük kapcsolatban, de még az 5. században sem rendelkezett egyetlen zsinati döntés sem a betiltásukról. ${ }^{1524}$ Úgy tünik, hogy

\footnotetext{
1519 Thor., Ep. ad Hyd. et Cep. 4-6, in: PL 54,694-695; López Quiroga - Martínez Tejera 2017, 479.

${ }^{1520}$ Muhlberger 1990, 237. Az apokrif és kánoni iratok fogalmának értelmezéséről lásd: Bauer 1991, 9-11.

${ }^{1521}$ Burgess 1988a, 162.

1522 Chadwick 1976, 110.

1523 Burgess 1988a, 208. Burgess kevésbé elfogadható módon azzal mentegeti Hydatiust, hogy Gallaecia elszigeteltsége miatt kevésbé ismerhette fel az ilyen hiedelmek eretnek voltát, Thoribius korábbi kérését pedig nem vette figyelembe, így nem is volt annyira ortodox, mint amennyire beállítja magát a krónikában. ${ }^{1524}$ Vanyó 2007a, 151-154.
} 
Thoribius figyelmeztetése sem jelentett sokkal többet a korábbi gyakorlatnál, mégis igazolja az apokrif olvasmányok megnövekedett népszerüségét, amelynek eredményeképpen Hydatius is megismerhette Tamás szövegét anélkül, hogy valójában hitt volna benne.

Az apokaliptikus hiedelmek azonban az apokrif iratokon kívül is fontos szerepet töltöttek be az egyház életében. Jó néhány bibliai utalás foglalkozik a parúszia gondolatával, ${ }^{1525}$ Pál apostol leveleiben többször is hivatkozik Krisztus második eljövetelére, ${ }^{1526}$ később Irenaeus, Kelemen és Hippolytus műveiben egyértelmüen kimutatható az eszkatológia hatása, ${ }^{1527}$ az 5. században pedig még Paulinus Nolanust, Gregorius Turonensist, Sulpicius Severust, Ambrosiust, Hieronymust, Quodvultdeust és Gregorius Magnus pápát is foglalkoztatta a parúszia körülményeinek bemutatása. ${ }^{1528}$ Mivel Krisztus második eljövetele a várakozásokkal ellentétben mégsem következett be, a keresztények csalódottsága különböző reakciókat eredményezett. Egyesek még későbbre tolták a parúszia időpontját és a köztes időt azzal magyarázták, hogy a keresztény egyháznak az egyetemes megváltás érdekében még az egész világot meg kell térítenie, ${ }^{1529}$ a másik felfogás szerint a parúszia valójában már Krisztus halálával és feltámadásával megtörtént, a történelem „elérte a célját”, ${ }^{1530}$ éppen ezért felesleges bármilyen eszkatologikus számítás a világ végére vonatkozóan. ${ }^{1531}$ Ennek megfelelően az apokaliptikus gondolkodás a kereszténységen belül gyorsan népszerütlenné vált, ${ }^{1532}$ és egyre inkább a hitetlenek közé sorolták azokat, akik mégis a parúszia bekövetkezésére vártak egy meghatározott időpontban, Constantinus óta pedig már eretneknek tartották a khiliazmus híveit.

Nem véletlen, hogy a legtöbb 5. századi keresztény szerző hiába tekintette az általa megtapasztalt csapásokat az isteni akarat megnyilatkozásának, legtöbbször mégsem fogtak eszkatológiai számításokba és nem tartottak a világvége közeledésétől. Hieronymus például nem is kapcsolta össze saját korának tragédiáit az apokaliptikus próféciákkal, ${ }^{1533}$ Eusebius

\footnotetext{
${ }^{1525}$ Mt 16,28; 24,3-36; Mk 13,4-37; Lk 21,7-36; Jel 1,1; 2 Pét 3,8.

1526 1Kor 7,26-29; 10,11; 1Thess 4,13-5,11; 2Thess 2; Róm 8,35-39; 10,4. Az eszkatológia motívumáról Szent Pál és Szent János esetében bővebben: Bultmann 1994, 51-68; a fogalom általános értelmezéséről lásd: Landes 1988, 205.

${ }^{1527}$ Iren., Haer. 5,28,3; Mal. 228; Hippol., In Dan. 4,24; Burgess 1988a, 164.

1528 A pontos szöveghelyeket közli: Burgess 1988a, 167, 52-53. j.; Palmer 2014, 8-9; Sulpicius Severus világvégevárással kapcsolatos véleményéről bővebben: Wieser 2016, 97-100.

${ }^{1529}$ Breisach 2004, 89; Mk 13,10.

${ }^{1530}$ Bultmann 1994, 55; Eliade 2006, 522-523.

1531 Vanyó 2009, 239.

${ }^{1532}$ A zsidó teológiában azonban továbbra is fontos szerepe maradt a khiliasztikus eszméknek, vö. Gesztelyi Havas 1999, 253.

${ }^{1533}$ Hier., Comm. in Dan., in: PL 25,491-584.
} 
kiemelte, hogy Krisztus tanítása szerint a kereszténységnek nem kell kutatnia, mikor lesz vége a történelemnek, ${ }^{1534}$ Augustinus szerint pedig nem is lehet pontosan kiszámítani a világ végének időpontját. ${ }^{1535}$ Gregorius Turonensis úgy látja, hogy csak a keresztények egy kis része vesztette el minden reményét és ezért hisz a világvége közeledésében, ${ }^{1536}$ Isidorus pedig teljesen közömbösnek tartja, hogy mennyi idő van még hátra az emberiség történetéböl. ${ }^{1537}$

Hozzájuk hasonlóan Hydatius sem végzett számításokat a világvégére vonatkozóan, nem foglalkozott eszkatológiai vagy millenarista kalkulációkkal, és nem vonta be az események ábrázolásához Dániel 4 világbirodalomról szóló látomását sem. ${ }^{1538}$ Muhlberger szerint Hydatius azért nem akarja meghatározni ezt az időpontot, mert túlságosan konzervatív gondolkodású, és feltétel nélkül elfogadja Augustinus útmutatását, helyette inkább népszerü elődeit követve egyszerü felsorolást nyújt a saját korában látott vagy hallott csodajelekről. A természetfölötti jelenségek ábrázolása és a parúsziára vonatkozó utalások azonban nem azt bizonyítják, hogy Hydatius hitt a közeledő világvégében, ahogyan ezt Burgess állítja, ${ }^{1539}$ hanem igazolják a bibliai hagyományhoz való ragaszkodását és az apokaliptikus hiedelmekben való jártasságát. A praefatióban elhelyezett évszámítási táblázatról is azt hihetnénk, hogy a világvége időpontjának kiszámításához szükséges, valójában Hydatius itt is csak a Hieronymus-féle hagyományt követi és a krónika formai követelményeinek való megfelelést biztosítja.

Nem hagyhatjuk figyelmen kívül azt sem, hogy az apokalipszisek szerzői múltjuk és jelenük leírásával saját írói működésüket igyekeznek legitimizálni, mivel azok az olvasók, akik a szerzőhöz hasonló tapasztalatokkal rendelkeznek, hinni fognak abban, hogy a szerző a jövőbeli eseményeket is hasonló megbízhatósággal tudja elmondani számukra. ${ }^{1540}$ Jellemző módon a csodajelek háborús időszakokban mindig megszaporodnak, a próféciák pedig leginkább a hétköznapi emberek történelemértelmezésében játszottak fontos szerepet,

\footnotetext{
${ }^{1534}$ Eus., Chr. praef.; ApCsel 1,6-8; Mt 24,36; Mk 13,32-37.

1535 August., De Civ. 12,11; 18,53; 20,7; Löwith 1996, 222; Palmer 2014, 32. Augustinus 418-ban a salonai Hesychiusnak írt válaszlevelében kifejtette, hogy már Gallienus idején is tévedtek a keresztények, amikor a barbárok gyakori betöréseit a világvégével hozták kapcsolatba, vö. Brown 1999, 61.

1536 Greg. Tur. prol.; Breisach 2004, 102.

1537 Isid., Chr. 122. További szerzők eszkatológiai nézeteiről és számításairól lásd: Vanyó 2009, 245-261; 688-691; Palmer 2014, 35-36.

${ }^{1538}$ Cardelle de Hartmann 1994, 157-158; Candelas-Colodrón 2004, 327.

${ }^{1539}$ Muhlberger 1990, 263; Burgess 1988a, 179.

1540 Bauer 1991, 69.
} 
mivel számukra is érthető formában egyszerüsítették le a történelmi eseményeket. ${ }^{1541}$ Ezek alapján Hydatius a krónikájában bemutatott próféciákat és apokaliptikus motívumokat saját hitelességének megerősítéséhez is használhatta, hogy a kevésbé müvelt olvasók számára megkönnyítse a korszak eseményeinek értelmezését. Hydatius rendkívüli érdeklődését a csodajelek iránt sokan azzal magyarázzák, hogy saját korának zürzavaros helyzetében hajlamos volt apokaliptikusan értelmezni a jelenségeket, ${ }^{1542}$ de ennél sokkal meggyőzőbbnek tünnek azok az érvek, amelyek a rendelkezésére álló tekintélyes forrásanyag kihasználására és az annalisztikus történeti hagyományhoz való ragaszkodásra vonatkoznak.

Burgess szerint a krónikából sugárzó „pessimistic and apocalyptic tone” annak köszönhető, hogy a kisebb helyi sikereket elhomályosították a rómaiak katonai vereségei, a békekövetségek kudarcot vallottak, a korábban győzelmeket elérő hadvezérek ellen merényleteket szerveztek, az eretnekekkel szemben pedig tehetetlennek bizonyult a katolikus egyház. ${ }^{1543}$ Hydatius ugyan valóban elkeseredett Gallaecia siralmas helyzete miatt, de nem beszél a birodalom megsemmisüléséről és katonai vereségéről, ${ }^{1544}$ éppen ellenkezőleg, reménykedve számol be arról, hogy Anthemius és Leo nagyszabású hadjáratot készített elő a barbárokkal szemben. ${ }^{1545} \mathrm{Az}$ isteni gondviseléssel kapcsolatban bemutatott csodajelek leginkább ,the few small rays of lasting optimism”, ${ }^{1546}$ amelyek azt bizonyítják, hogy Isten nem hagyta magára az emberiséget, hanem segít neki túlélni a barbárok okozta zürzavart, Hydatius tehát távol áll a kétségbeeséstől, vagyis „pesimismo no es igual apocalipticismo." ${ }^{1547}$ Hydatius leghevesebb indulatait a gallaeciai sorscsapásokkal kapcsolatban a praefatióban találjuk, mert már itt szeretné felhívni az olvasók figyelmét a krónikában bemutatott események jelentőségére. Ha elfogadjuk Burgess azon feltételezését, hogy Hydatius a krónika bevezetőjét írta meg utoljára, ${ }^{1548}$ akkor magyarázatot kapunk arra is, hogy miért a kezdősorok tünnek a legkomorabb hangvételünek Hydatius beszámolójában.

\footnotetext{
${ }^{1541}$ Grüll 2007, 178-179. Az egész középkorra jellemző, hogy a látomások, a csodákról szóló elbeszélések és a szentek életének leírásai leginkább a lakosság „széles rétegéhez” szóltak, mert többnyire a folklór szintjén keletkeztek és szájhagyomány útján terjedtek, vö. Gurevics 1987, 23-24.

${ }^{1542}$ Burgess 1988a, 178-179.

${ }^{1543}$ Burgess 1988a, 184.

1544 Johnson 1993, 80.

${ }^{1545}$ Hyd. 241.

${ }^{1546}$ Burgess 1988a, 188.

${ }^{1547}$ Candelas-Colodrón 2004, 361.

${ }^{1548}$ Burgess 1988a, 210.
} 
Ebből a pesszimizmusból sokan arra következtetnek, hogy az idős és küzdelmeiben megfáradt szerző a történelmi idők beteljesedését várja, pedig valójában Hydatius egy zürzavaros világban a saját érdeklődésének megfelelően és irodalmi szándékossággal (,intencionalidad literaria”) használ apokaliptikus elemeket, ${ }^{1549}$ hogy azok segítségével az emberiség szenvedését szemléletesen tudja ábrázolni az olvasói elött. Elképzelhető, hogy az isteni gondviseléssel kapcsolatos próféciák mégis Hydatius hitrendszerének elemeivé váltak, de akkor sem vitathatjuk, hogy hatásuk csak néhány elszigetelt esetben mutatkozik meg és nem hatja át az egész krónika eszmevilágát, ez pedig mindenképpen alkalmas az olvasó kíváncsiságának kielégítésére és a figyelem fenntartására. Ha mindezek ellenére feltételezzük, hogy Hydatius a körülötte lévő szenvedéseket megtapasztalva mégis Krisztus második eljövetelét várta, akkor sem lehetett pontos elképzelése arról, hogy hogyan következik be a világvége, hiszen ahogyan korábban láttuk, a krónika struktúráját nem eszerint építette fel. ${ }^{1550}$

A barbár támadások sok történetírót kétségbeesés helyett a múlt eseményeinek összegyüjtésére ösztönöztek, ahogyan ezt tapasztalhattuk Isidorus és Gregorius Turonensis esetében is, ${ }^{1551}$ Hydatius hozzájuk hasonlóan hosszú távra tervezett és nem foglalkozott a világvége közeledésével. A praefatiót például azzal zárja, hogy utódaira hagyja az utolsó napok összegzését. ${ }^{1552}$ Burgess szerint Hydatius azért a consummanda kifejezést használja a hieronymusi subdenda helyett, mert a krónikát a világ végéhez közeledő történelem összefoglalásának szánja, és igazából nem várja el, hogy később folytassák a munkáját. ${ }^{1553}$ Valójában Hydatius ezzel saját tájékozottságát igazolja, mert egy Bibliában gyakran előforduló kifejezést használ, ${ }^{1554}$ ez pedig tovább növelheti a mü tekintélyét az olvasók előtt. Hydatius a krónika utolsó soraiban a nyugtalanító előjelek bemutatását azzal zárja, hogy a többi előjelet hosszú lenne elmesélni. ${ }^{1555}$ Ezzel a megjegyzéssel mintha az idős és megfáradt szerző szintén további mesélésre ösztönözné a későbbi történetírókat, hogy ha lehetőségeik engedik, folytassák a munkáját. ${ }^{1556}$ Ha Hydatius történelemszemlélete valóban apokaliptikus értelmezést kívánna, ahogyan a legtöbb kutató gondolja, akkor miért buzdított

\footnotetext{
1549 Candelas-Colodrón 2004, 327.

${ }^{1550}$ Cardelle de Hartmann 1994, 157-158.

1551 Breisach 2004, 102.

${ }^{1552}$ Hyd. praef. 6: posteris in temporibus quibus offenderint reliquimus consummanda.

1553 Hier., Chr. praef.; Burgess 1988a, 157-158.

${ }^{1554}$ Izaj 10,22-23; 28,22; Dán 9,27; Mt 13,39; 24,3; 28,20.

1555 Hyd. 247: et multa alia ostenta quae memorare prolixum est.

${ }^{1556}$ Egyes kutatók ezt a befejezést is Dániel próféciájával hozták összefüggésbe, vö. Kitchen 2013, 652.
} 
volna többször is a krónika folytatására, amikor a hamarosan bekövetkező világvége miatt várhatóan sem folytatója, sem olvasója nem lenne a történeti feljegyzéseknek.

\subsection{Motivációk a történetírásra}

A keresztény világkrónikákat Croke szerint a középkor végétől kevésbé tartották értékes alkotásoknak, mert lényegesen alacsonyabb színvonalon íródtak, mint a klasszikus időszakban keletkezett történeti müvek. ${ }^{1557}$ Ennek okát sokan abban látják, hogy a klasszikus kor utáni szellemi hanyatlás idején, vagy ahogyan Muhlberger fogalmaz, a „historiographical sterility” korában keletkeztek, ráadásul a szerzői többnyire kompilátorok voltak, akiknek már a bemutatni kívánt anyag összegyüjtése és elrendezése is nagy problémát okozott. Breisach szerint az Eusebius utáni világkrónika müfaja alig változott, a keresztény szerzők pedig „csak kisebb jelentőségü müveket” alkottak. ${ }^{1558}$ Maga Hydatius is úgy nyilatkozik, hogy a krónikaírás egészen saját koráig hanyatlott, ${ }^{1559}$ a kutatók azonban sokáig az ő munkásságát sem tartották jelentősnek.

Az utóbbi évtizedekben mégis megnövekedett az érdeklődés a késő ókori és a középkori történetírás iránt, többek között azért, mert a kutatók egy része belátta, hogy meghatározó hiba volt korábban a fenti érvekre hivatkozva teljes évszázadok történeti munkáit elutasítani. ${ }^{1560}$ A keresztény történetírás iránti hozzáállás javulásához lényegesen hozzájárult az a tény, hogy a hagyományos római történetírás kizárólag római keretek között mozgott és nem vetették össze a római történelem alakulását más államok fejlődésével, ezáltal a Római Birodalom szétesésével párhuzamosan a római történetírás is hanyatlásnak indult. Ettől kezdve már csak a keresztény történetírás volt képes valóban egyetemes történet írására, alkalmazkodva a megváltozott körülményekhez, amelyet a római világ eltűnése, a barbár támadások és a szellemi kultúra hanyatlása idézett elő. ${ }^{1561} \mathrm{~A}$ modern kutatások, amelyek nemcsak a krónikaformára és a társadalmi gondolkodás változására irányulnak, hanem a krónikák szerzőit is alapos vizsgálat alá veszik, abban mindenképpen újszerüek, hogy a krónika müfajához és a mögöttük álló emberhez bizonyos mértékü

\footnotetext{
1557 Croke 1983, 116.

1558 Muhlberger 1990, 5; Breisach 2004, 91.

${ }^{1559}$ Hyd. praef. 5: ad nostri temporis cursum disscriptio defluxit annorum.

${ }^{1560}$ Muhlberger 1990, 3.

${ }^{1561}$ A keresztény szerzők a birodalom határain túlmutató vallási keretek között így meg tudták őrizni a múlt, a jelen és a jövő közötti folytonosságot, vö. Breisach 2004, 84-85; ahogyan ez látható többek között Sulpicius Severus krónikájában is, vö. Wieser 2016, 107.
} 
tisztelettel közelítenek, és elismerik, hogy a szerzők említésre méltó szellemi és irodalmi teljesítményt nyújtottak saját korukban. ${ }^{1562}$ Emiatt érdemes alaposabban megvizsgálnunk azt is, hogy Hydatius életére a körülötte tapasztalt válságjelenségek milyen hatást gyakoroltak és milyen lépésekre ösztönözhették öt saját életében.

Ha a fentiek alapján elfogadjuk, hogy Hydatius valójában nem hitt a közelgő világvégében és inkább a történelem folytatását várta, akkor felmerülhet bennünk a kérdés, hogy mikor és miért készítette történeti munkáját. Hydatius nem utalt arra művében, hogy mikor kezdett a krónika írásába. Nem zárhatjuk ki teljesen, hogy már nagyon korai időponttól kezdve készített történeti feljegyzéseket, de a ránk maradt szöveg írását valószínüleg csak 457-458 után tudta elkezdeni, mert az eseménysor központi részét és tetőpontját a gótok $456-457-e s$ lusitaniai és gallaeciai betörése jelenti. ${ }^{1563}$ Ez alapján általánosan elfogadott az a nézet, amire Hydatius is utal, hogy messze ifjúkorától (extremus et vitae), idős emberként emlékezett vissza múltjára és döntően saját tapasztalatait írta meg a krónikában. ${ }^{1564}$ Kevésbé érthető Burgess érvelése, mely szerint Hydatius tudta, hogy soha többé nem tudja majd újra átnézni az összeállított anyagot, ezért nem szerepel egyetlen jelentős esemény vagy sokatmondó következtetés sem a krónika végén. ${ }^{1565}$

Néhány kutató éppen ezért feltételezi, hogy Hydatius eredetileg csak 456-ig állította össze a krónikát, ${ }^{1566}$ erre utalhat a Szvév Királyság pusztulásával kapcsolatos megjegyzés is, ${ }^{1567}$ a 455-456-os sorsdöntő események miatt viszont később Prosperhez hasonlóan úgy döntött, hogy folytatja a beszámolót és kiegészíti azt mindennapi tapasztalataival, de emellett szól a gótok tevékenységéről szóló beszámoló szemléletváltása ${ }^{1568}$ és a szvévek 456 utáni értékelésében látható változás is. Mindenesetre Hydatius siralmas öregségével (lacrimabile propriae vitae tempus) is magyarázhatóak a kronológiával kapcsolatos pontatlanságok, ${ }^{1569}$ amelyek korrigálására utólag már valószínüleg nem volt ideje vagy egyéb források híján lehetősége sem. Túlzónak tünnek azonban Burgess szavai, amikor Hydatius kronológiáját az „incorrect, inconsistent and idiosyncratic” kifejezésekkel

\footnotetext{
1562 Muhlberger 1990, 4.

1563 Thompson 1982, 140-141.

${ }^{1564}$ López Quiroga - Martínez Tejera 2017, 439.

1565 Hyd. praef. 1; Burgess 1988a, 229.

1566 Cardelle de Hartmann 1994, 64-65; Gillett 2003, 48-49; Arias 2007, 4; Gelarda 2008-2009, 304.

${ }^{1567}$ Hyd. 168. A gondolat ugyanakkor egyszerü átvétel is lehet Hieronymus krónikájából, vö. Hier., Chr. 103b; $121 ; 124$.

1568 Pawlak 2007, 34, 35. j.; López - Rodríguez 1997, 554.

${ }^{1569}$ Hyd. praef. 5.
} 
jellemezte, ráadásul még azt is hozzátette, hogy Hydatiustól, az elszigetelt Gallaecia jelentéktelen püspökétől nem is várhatnánk mást. ${ }^{1570}$

Nem ilyen egyöntetü a kutatók véleménye arról, hogy miért kezdett Hydatius a krónika írásába. Muhlberger azon az állásponton van, hogy mivel Hydatius élete jelentős részét a barbárokkal és az eretnekekkel szembeni küzdelem kísérte végig, idős korára annyira pesszimistává vált, hogy az általa bemutatott szenvedések a körülötte kialakult zürzavaros világ miatt „,apocalyptic interpretation”-t kívánnak. ${ }^{1571}$ Burgess szerint azonban nem véletlen, hogy az apokaliptikus hiedelmek egy történeti munka készítésére, illetve a gallaeciai események és az isteni gondviselés közötti összefüggés bemutatására ösztönözték Hydatiust ahelyett, hogy a világvégi készülődéssel és a bünbánattal kapcsolatos prédikációkat írt volna. ${ }^{1572}$ A parúszia elmaradása miatt ugyan a keresztények érdeklődése az „univerzális eszkatológia” helyett az „egyéni lélek megváltására” irányult, ${ }^{1573}$ azt Burgess sem gondolhatja komolyan, hogy Hydatius azért próbálta a világvége közeledtével Hieronymus munkáját folytatni és Isten teremtményének dicsőítésével olvasóit is bünbánatra ösztönözni, hogy végül saját helyzetét tegye előnyösebbé az esetleges ítéletnapon.

Brunhölzl nem ragaszkodik ennyire az apokaliptikus értelmezéshez, mert szerinte Hydatius számára a történetírás egy természetes reakció lehetett a körülötte megtapasztalt és egyre növekvő zürzavarra. Mivel ez a speciális körülmény motiválta őt arra, hogy feljegyezze saját korának eseményeit, nem lehet véletlen, hogy Hydatius munkáját tartják az egyetlen irodalmi igényü próbálkozásnak, amely ebben a rendkívül nehéz időszakban született. Ezzel egyetértve Sotinel is úgy látja, hogy elszigetelt helyzete és információhiánya ösztönözhette őt arra, hogy lelkiismeretesen összegyüjtse az általa ismert történeti eseményeket. ${ }^{1574}$ Ezek alapján úgy tűnik, hogy Hydatius valódi történetírói motivációját csak akkor tudjuk megérteni, ha megvizsgáljuk azt is, hogyan kapcsolódik munkája a Hieronymust követő krónikahagyományhoz.

\footnotetext{
${ }^{1570}$ Burgess 1988a, 73.

1571 Muhlberger 1990, 194; 266.

1572 Burgess 1993, 9-10.

1573 Bultmann 1994, 64.

${ }^{1574}$ Brunhölzl 1975, 67; Sotinel 2009, 137.
} 


\subsection{Kapcsolódás a krónikahagyományhoz}

Muhlberger igyekszik pontos összefoglalást nyújtani arról, hogy az 5. századi szerzők hogyan viszonyultak a keresztény világkrónika hagyományához és milyen formákat alkalmaztak munkájukban. ${ }^{1575}$ Hieronymus krónikájának végétől, 378-tól számtalan politikai és vallási változás következett be a Római Birodalomban, ezért a hagyomány folytatói erős késztetést érezhettek arra, hogy a változások bemutatásával ábrázolják saját koruk eseményeit. A Hieronymust követő krónikaszerzők tehát már nemcsak az Eusebius által összegyüjtött és a Hieronymus által kiegészített eseményeket terjesztették tovább, hanem igyekeztek megmutatni az olvasóik számára, hogyan kell keresztény szemmel értelmezni a bemutatott történelmi folyamatokat.

Több kutató is utal arra, hogy Hieronymus nemcsak azért vállalkozott Eusebius müvének fordítására, hogy kifejezze csodálatát a nagy jelentőségü munka iránt, hanem azért is, hogy irodalmi szenzációt keltsen a nyugati olvasóközönség előtt, hiszen a latin nyelvü irodalomban korábban még nem létezett hasonló jellegű történeti áttekintés, Hieronymus pedig jó érzékkel felismerte, hogy szükség lenne egy ilyen típusú összefoglaló munkára. ${ }^{1576}$ Hydatiust ugyanezek a szempontok is ösztönözhették az írás elkezdésére, hiszen a munka folytatásának megírásával ő is szenzációt kelthetett saját környezetében, Hieronymus iránti tiszteletére pedig számtalan bizonyítékot találunk a krónikában. Mivel Hieronymus bibliafordításból eredő tekintélyét nem csorbította, hogy történeti munkáját egyre többen elismerték, Hydatius saját írói tevékenységének jelentőségét is megpróbálhatta azzal növelni, hogy saját feljegyzéseit hozzákapcsolta Hieronymus művéhez, amelyet a leghitelesebb keresztény krónikának tartottak az 5. században. ${ }^{1577}$ Hydatius ezzel arról is gondoskodott, hogy Hieronymus művét a későbbiekben még többen megismerjék és másolják, népszerüségét pedig mi sem mutatja jobban, hogy Hispania jó néhány tartományában fennmaradtak a szöveg másolatai. ${ }^{1578}$ Hydatius nemcsak választékos nyelvezete (decore dictorum) és sokoldalú írói tevékenysége (diverso stili opere) miatt

\footnotetext{
1575 Muhlberger 1990, 273-274.

1576 Muhlberger 1990, 19; Kelly 2003, 118.

1577 Muhlberger 1990, 22-23; Kelly 2003, 507.

1578 Hyd. praef: in aliquantis Hispaniarum provinciis conscripta retinetur. Hydatius Hieronymus munkáját egy olyan 382 után készült hispaniai másolatból ismerhette, amelyet valószínúleg Gallaeciában másoltak tovább valamikor az 5. század elején, vö. Burgess 1988a, 24.
} 
csodálja Hieronymust, hanem mert kellő óvatossággal járt el az írás során (certo stili studio declaratur), munkája pedig teljes és pontos ismereteken (certa et plena cognitio) alapult. ${ }^{1579}$

Hydatius Hieronymussal kapcsolatban többször is kiemeli, hogy Eusebius feljegyzéseit görögből latinra fordította és megírta a történet folytatását, vagyis saját beszámolóját hozzákapcsolta (adiectum) elődje munkájához. ${ }^{1580}$ Ezt a hagyományt tiszteletben tartva, a kortárs történetírókhoz hasonlóan ${ }^{1581}$ ő is alkalmazza a Hieronymustól átvett egyszerü eljárást, és még hangsúlyozza is az elődeitől való függést. Büszkén mondja olvasóinak, hogy bevezetővel kiegészítve röviden leírta az eseményeket, ${ }^{1582}$ amelynek során a korábbi mintákat követte, ${ }^{1583}$ vagyis ismert szerzők nyomában, az elődök által kitaposott úton járva vállalkozott a krónikaírás feladatára. ${ }^{1584}$

Az utolsó, Hieronymustól átvett feljegyzés után Hydatius bevezető gondolatai következnek, majd utána szerepel az az éveket összesítő computatio, amely Hieronymus számításait és megfogalmazását alapul véve az Ádámtól eltelt időt fontos személyiségek és események megjelölésével különböző intervallumokra osztja fel. ${ }^{1585}$ Hydatius abban viszont eltér elődjétől, hogy míg a computatio után közvetlenül, egyetlen sor kihagyása nélkül írja meg részletes praefatióját, addig Hieronymus igyekezett a saját maga által írt 325 utáni beszámolót elválasztani az Eusebiustól átmásolt szakasztól. ${ }^{1586}$ Hydatius ezzel azt szeretné érzékeltetni, amit később meg is fogalmaz, hogy tudatlan szolgaként (ignarus servus) és nem egyenrangúan (inpari gressu) követi híres elődeit, ${ }^{1587}$ vagyis tisztában van azzal, hogy saját jelentőségét valójában tiszteletlenség lenne összemérni Hieronymuséval. Minden bizonnyal az olvasót igyekszik magának megnyerni szerénységével, amikor a majdnem pápává választott Hieronymus ${ }^{1588}$ méltatása után saját magát a leghitványabbnak nevezi Isten szolgái között (indignussimus omnium servorum dei), elődeiről pedig egy ellentétes kötőszóval (verum) tér át saját magára. Püspöki kinevezését mintha nem is érdemelte volna

\footnotetext{
${ }^{1579}$ Hyd. praef. 1; praef. 4.

${ }^{1580}$ Hyd. praef. 3-4: de Greco in Latinum scripturae huius interpres a vicesimo anno supradicti imperatoris in quartumdecimum Valentis Augusti annum subditam texit historiam.

${ }^{1581}$ Prosp. 378; Vict. Tunn. praescr.; Ioh. Bicl. praescr.; Greg. Tur. prol. 1,1.

1582 Hier., Chr. 326; Hyd. praef.: comperi et disscripsi brevi antelato praefationis indicio.

${ }^{1583}$ Hyd. praef. 1: in praecedenti opere suo pro capacitate proprii sensus aut verbi ostensum ab his secutus exemplar.

${ }^{1584}$ Hyd. praef. 5: de cognitis etsi in omnibus inpari gressu vestigia subsequeretur, vel vestigiis se substerneret praecessorum, quae fideli suscipiens cordis intuitu, partim ex studio scriptorum, partim ex certo aliquantorum relatu, partim ex cognitione, quam iam lacrimabile propriae vitae tempus offendit, quae subsequuntur adiecimus.

1585 Helm 1956, 250.

1586 Burgess 1988a, 24.

${ }^{1587}$ Hyd., praef.; praef. 5.

${ }^{1588}$ Hier., Ep. 45,3.
} 
meg (inmerito), véletlen isteni ajándéknak tekinti (divino munere), ${ }^{1589}$ és még azt is vállalja az olvasói elött, hogy nem tudja (ignoravit), hogy ki követte Theophilust az alexandriai egyház élén. ${ }^{1590}$ Burgess szerint itt nemcsak szerénységről és az elődőkkel szembeni alázatosságról van szó, hanem Hydatius reális önértékeléséről, mivel valóban tisztában van azzal, hogy életének szükös lehetőségei miatt krónikájával nem tud Eusebius és Hieronymus nyomdokaiba lépni, ${ }^{1591}$ ugyanakkor azok a megjegyzések, amelyekben püspöki kinevezését és fogságból való szabadulását isteni közbenjárásnak tulajdonítja, a szerénységen túl arra is utalnak, hogy Hydatius úgy tekintett magára, mint aki „especially chosen for his office for some special divine purpose", ${ }^{1592}$ vagyis egyfajta isteni küldetést teljesítve joggal tarthat számot az olvasók érdeklődésére és elismerésére.

Mindezek ellenére Hydatius nagyfokú hozzáértést és tájékozottságot tanúsít a történetírás módszereivel kapcsolatban. A praefatio például terjedelme és tartalma miatt más szerzők bevezetőitől eltérően egy teljes értékű történeti bevezetőnek, vagy akár egy önálló munkának is tekinthető. ${ }^{1593}$ Burgesst találó módon egy lelkipásztori levél felépítésére emlékezteti a három részre tagolható gondolatsor, amely az önmegtagadást és más szerzők méltatását éppúgy tartalmazza, mint az elődeihez való kapcsolódás említését és a forrásanyagra vonatkozó megjegyzéseket, rendkívüli hasonlóságot mutatva így a Hydatius által is hivatkozott Eusebius egyháztörténeti munkájának bevezetőjével. ${ }^{1594}$ Hiába nyilatkozik úgy, hogy kevés tapasztalatot szerzett és alig ismeri a müfaji előzményeket, ${ }^{1595}$ az olvasó éppen Hydatius tájékozottságára és körültekintésére figyel fel, amikor értelmének és irodalmi jártasságának korlátairól nyilatkozik, ${ }^{1596}$ vagy amikor magabiztosan szólítja meg az olvasókat, hogy tájékoztatást adjon a krónika témáiról és időkeretéröl. ${ }^{1597}$ Ez a Hieronymusnál is megtapasztalt jelenség a munka nehézségeiről és a fordítás sajátosságairól azonban nem csökkenti a krónika jelentőségét, hanem ellenkezőleg, éppen arról tanúskodik, hogy mindketten tisztában voltak saját munkájuk irodalmi jelentőségével. Hydatius praefatiója még abban is rendkívül különleges, hogy a szerző saját életéről olyan sok információt tartalmaz, hogy ebben még Hieronymus művét is felülmúlta, ez pedig akár arra

\footnotetext{
${ }^{1589}$ Hyd. praef. 1; praef. 6. Azt is tudjuk ugyanakkor, hogy Augustinus óta a váratlan megtéréseket és püspöki kinevezéseket gyakran magyarázták Isten csodás beavatkozásával, vö. Brown 1999, 56.

1590 Hyd. 53.

${ }^{1591}$ Burgess 1988a, 73.

1592 Hyd. praef. 1; 202; Burgess 1988a, 189.

1593 A praefatio kimerítő elemzését lásd: Cardelle de Hartmann 1994, 70-95.

1594 Burgess 1988a, 231-232; Eus., Hist. Ecc. 952; 957.

1595 Hyd. praef. 1: perexiguum informatus studio seculari, multo minus docilis sanctae lectionis volumine salutari sanctorum et eruditissimorum patrum.

${ }^{1596}$ Hyd. praef. 1: suo pro capacitate proprii sensus aut verbi.

${ }^{1597}$ Hyd. praef. 6: continentiam gestorum et temporum qui legis ita discernes.
} 
is utalhat, hogy igyekezett elödjénél még többet nyújtani az olvasók számára. Egyetérthetünk Muhlberger azon állításával, mely szerint a praefatio egy díszes „captatio benevolentiae" ${ }^{1598}$ hiszen fontos szerepe van abban, hogy Hydatius elnyerje az olvasók szimpátiáját és minél szélesebb körben olvassák a munkáját.

Annak ellenére, hogy sok kritika érte Hydatius kronológiáját, a saját korához és szülőföldjéhez közeledve a nehézkes információáramlás ellenére egyre pontosabb datálással találkozunk, az események időbeli sorrendje pedig általában megfelel a valóságnak, ezért elfogadhatjuk, hogy Hydatius lehetőségeihez mérten a legnagyobb pontosságra törekedett a krónika megírásakor, jóllehet vannak olyan szélsőséges megközelítések is, mint Muhlbergeré, aki az összes előforduló hibáért Hydatiust tartja felelősnek, Courtois viszont leginkább a későbbi másolókat okolja a pontatlanságokért. ${ }^{1599}$ Hydatius forrásainak áttekintésekor már láttuk, hogy milyen pontosan igyekezett megjelölni, milyen típusú anyagokat használt munkája során és honnan szerezte információit az események bemutatásához. Amikor Hydatius biztosítja az olvasóit arról, hogy hüséges szívvel (fideli cordis intuitu) vállalkozott a történeti munka megírására, utalhat arra, hogy az elődök hagyományát próbálta követni a krónikaírással, de célozhat arra is, hogy a legjobb tudása szerint hitelesen próbálta rögzíteni az eseményeket, amelyek Gillett szerint biztosan mentesek a propagandisztikus céloktól Gallaecia és Hydatius periférikus helyzete miatt. ${ }^{1600}$ Hydatius történeti bevezetője ilyen szempontból is megfelel a keresztény világkrónikákkal szemben támasztott elvárásoknak, hiszen azok szerzői nagymértékben törekedtek az igazság feltárására, ezért a hagyományokra való hivatkozással és a források viszonylag pontos megjelölésével igyekeztek az olvasók számára megbízható beszámolót nyújtani. ${ }^{1601}$ Burgess találóan fogalmaz, amikor azt állítja, hogy a sokféle forrást használó Hydatius „,can be no more reliable than his sources”, ezért érdemes a feljegyzések valódiságát önmagukban vizsgálni, függetlenül az egész krónika ,general reliability”-jétől. ${ }^{1602}$

Ezek alapján nem fogadhatjuk el Muhlberger állítását, mely szerint elsősorban azért kell felfigyelnünk az 5. századi krónikások, köztük Hydatius müvére, mert ők közremüködtek a Hieronymustól induló krónikahagyomány folytatásában azzal, hogy bemutatták a történelem saját korukra eső részét. Még a krónika jelentőségét sok esetben

\footnotetext{
1598 Muhlberger 1990, 212.

1599 Muhlberger 1990, 287.

${ }^{1600}$ Hyd. praef. 5-6; Gillett 2003, 53.

1601 Breisach 2004, 104. Különösen körültekintően bánik később a forrásokkal Beda, aki szokatlanul pontos forráshivatkozásaival a hitelesség elérése érdekében a dokumentumok pontos értelmezésére törekedett, vö. Beda, praef. Beda életéről és müveiről bővebben: Adamik 2014, 527-558.

1602 Burgess 1988a, 249.
} 
vitató Thompson is egyetért Mommsen véleményével, mely szerint Hydatius igen megbízható és óvatos történetíró, auctor pro aetate diligens et fidei optimae. ${ }^{1603}$ Burgess szerint a legtöbb krónikaszerzőt azzal szokták vádolni, hogy valójában nincs szerkezete a munkájuknak, mert leginkább csak arra ügyeltek, hogy egymás után feljegyezzék a számukra fontos eseményeket. Hydatiusnál ehhez képest egy „dramatic structure” feltételezhető, amely alapján megkülönböztethetünk egymástól egy bevezető szakaszt (introduction) a 379-409 közötti eseményekkel, fokozást vagy bonyodalmat (rising action or complication) a 410-455 közötti résszel, egy csúcspontot (climax) a 456-os katasztrófával, végül a hanyatlást eredményező következményeket (falling action or denovement) a 457-468 közötti beszámolóval. ${ }^{1604} \mathrm{Ha}$ ez az aristotelési felosztás nem is látható ennyire világosan a krónikában, ${ }^{1605}$ nem vitathatjuk, hogy Hydatius a szvévek megszállását és annak következményeit mutatja be a krónika központi témájaként.

Ezzel kapcsolatban érdemes megvizsgálni, hogy Hydatius milyen jellegü történeti munkát írt. Hydatius említi Sulpicius Severus chronicáját, Eusebius és Hieronymus historiáját, de szintén a müfajra vonatkoznak a chronographia historia, az annorum volumen, a successio temporum és a disscriptio annorum kifejezések, ${ }^{1606}$ amelyek ismét igazolják Hydatius nagyfokú hozzáértését és irodalmi tájékozottságát. Burgess azonban nem tud állást foglalni abban, hogy Hydatius krónikája milyen jellegü történeti munka, mivel világi és egyháztörténetről, egyetemes és lokális, spirituális és lelkipásztori célkitűzésekkel jellemzi a szerző törekvéseit. Hasonló sikertelenséggel próbálta Torres Rodríguez meghatározni, hogy Hydatius munkája a világkrónika müfaján belül milyen témában íródott, mivel úgy látja, hogy egyaránt sorolhatjuk azt az egyetemes történetek, az egyháztörténetek, a Hispania-történetek, a meteorológiai történetek, a szerzői önéletrajzok, a babonatörténetek és a néprajztörténetek közé. ${ }^{1607}$ Mivel Hydatius említi Eusebius egyháztörténeti munkáját, Muhlberger rögtön arra következtet, hogy saját müvét nem a világtörténeti krónikák, hanem speciálisan az egyháztörténetek közé sorolja, ${ }^{1608}$ holott tudjuk, hogy Eusebius krónikája és egyháztörténete két különböző munka, Hydatius pedig minden bizonnyal azért az utóbbit említi, mert ezt becsülték legtöbbre saját kortársai. A praefatio végén található felsorolásban és a krónika első felében ugyan valóban nagyobb hangsúlyt kapnak az egyházi témák, ráadásul Hydatius neveltetése és püspöki tevékenysége

\footnotetext{
${ }^{1603}$ Muhlberger 1990, 278; Thompson 1982, 141; Mommsen 1894, 7.

1604 Burgess 1988a, 230.

1605 Arist., Poet. 18,1-2.

${ }^{1606}$ Hyd. 30; praef. 2-5.

${ }^{1607}$ Burgess 1988a, 229; Torres Rodríguez 1956, 237-238.

${ }^{1608}$ Hyd. praef. 2; Muhlberger 1990, 212.
} 
miatt kétségtelenül elkötelezett volt a vallási témák iránt, az események bemutatásakor mégis nagyobb szerepe van a politikai és a katonai ügyeknek, amelyek „building blocks”ként építik fel a legtöbb keresztény világkrónikát. ${ }^{1609}$

Érdemes ugyanakkor azt is megvizsgálnunk, hogy Hieronymus és Hydatius témaválasztása mennyiben különbözik egymástól. Hieronymus elsősorban az eretnekségek ellen irányuló vallási törekvéseket, a császárok és a trónbitorlók politikáját, a háborúkat és a katonai eseményeket, valamint a különböző természeti jelenségeket ábrázolta munkájában. Hydatius átvette ezt a mintát, de a katonai események között szinte kizárólag a barbárok Róma elleni támadásait mutatta be, kevésbé tartotta fontosnak a különböző személyek életrajzára vonatkozó információkat, a természeti jelenségek számát viszont látványosan megnövelte. Jól mutatják ezek a változások, hogy Hydatius a hieronymusi örökséget saját érdeklődése és élethelyzete szerint alakította át, válogatott az ábrázolni kívánt témák között és megváltoztatta az elödöknél látott minták arányait. ${ }^{1610}$

Hydatius sajátos módon kapcsolódik az 5. századi krónikahagyományhoz, mert a hasonlóságok mellett több szempontból el is tért a kortárs történetíróktól, ezzel pedig az lehetett a legfőbb célja, hogy felhívja magára az olvasók figyelmét. Hydatius kortársa, Prosper például csak egy rövid áttekintést szeretne adni a világ történetéröl, ezért Hieronymus munkáját jelentősen átszerkeszti és lerövidíti, hogy érthetőbb és vázlatosabb legyen a történeti összefoglalás. ${ }^{1611}$ Hydatius ezzel ellentétben nem dolgozza át és nem rövidít Hieronymus művén, csak egyszerüen hozzákapcsolja saját feljegyzéseit az eredeti szöveghez, és nem törődik azzal, hogy változtasson elődje munkáján, mert a krónika folytatásával más volt a célja. Prosper a Hieronymustól átvett egyházi és világi eseményeket dogmatikai magyarázatokkal egészítette ki, hogy az egyéni tettek erkölcsi következményeit is ábrázolni tudja művében, Hydatius viszont ettől eltérően saját provinciájának szenvedéseit mutatja be a körülmények pontos ábrázolásával, és ezeknek nem a következményeit emeli ki, hanem inkább az előzményekre, az emberiség politikai és vallási bűneire hivatkozik.

Hydatiust sokan vádolták azzal, hogy nem a megfelelő hangsúllyal tárgyalja az eseményeket, mivel a fontos tényekről gyakran keveset mond vagy el is hallgatja őket, a kevésbé releváns információkat pedig túlzott részletességgel írja le. ${ }^{1612}$ Részben elfogadhatjuk Burgess magyarázatát, mely szerint Hydatius elsősorban azokat az

\footnotetext{
${ }^{1609}$ Hyd. praef. 6; Burgess 1988a, 226.

${ }^{1610}$ Burgess 1988a, 25; 98.

1611 Muhlberger 1990, 272-273.

1612 Thompson 1982, 161.
} 
eseményeket rögzítette, amelyek „on personal criteria” fontosnak minősültek vagy amelyekre vonatkozóan rendelkezett megfelelő forrásokkal, ${ }^{1613}$ ugyanakkor azt a lehetőséget sem zárhatjuk ki, hogy a gallaeciai olvasók érdeklődését is szem előtt tartotta, amikor például rendkívül sok természetfölötti jelenséget tárgyalt munkájában, ráadásul ha olyan eseményeket is be tud mutatni az olvasóknak, amelyeket más források nem rögzítettek, azzal növelheti saját krónikájának jelentőségét is.

\subsection{Válságos idők és Róma küldetése}

Hydatius azt sugallja az olvasók számára, hogy a birodalomnak elsősorban a barbárok betörése miatt kellett nagyon sok szenvedést elviselnie, ezért sem véletlen, hogy a krónikában a 409-es betörés az első jelentős politikai esemény Theodosius 395-ös halála után, amely egyúttal fordulópontot is jelent Hispania történetében. Mivel ezt megelőzően Gallaeciára vonatkozóan sem találunk feljegyzéseket Hydatiusnál, Burgess joggal tekint a 409-es eseményekre a krónika első, bevezető szakaszának záróakkordjaként. ${ }^{1614}$ Gelarda szerint ekkor „ogni equilibrio si rompe”, hiszen politikai, katonai és gazdasági bizonytalanság veszi kezdetét, ráadásul a római császári uralom is véget ér a provinciában, ezért mondhatja Cortázar és Vesga, hogy a barbárok 409-es betörése „egyenlö a római Hispánia halálával."1615

Hydatius viszont semmit sem árul el a barbár betörés előzményeiről, a 406-os galliai invázióról és a polgárháború hispaniai hatásairól, de Muhlberger szerint ez nem véletlen, hiszen Hydatius így próbálja fokozni a betörés nagyságát és váratlan bekövetkezését, hogy az olvasók is legalább annyira meglepődjenek a barbárok robbanásszerü megjelenésén, mint annak idején Hispania lakossága. Burgess a jelenséget azzal magyarázza, hogy Hydatius valószínűleg nem rendelkezett erre vonatkozó forrásokkal, ${ }^{1616}$ az viszont biztosan logikus volt Hydatius számára is, hogy ha a barbárok Galliából törtek be, akkor korábban valahonnan oda is kellett érkezniük. Muhlberger szerint Hydatius Hispania barbár megszállását azért ábrázolja közvetlenül Róma gót kifosztása előtt, mert a hispaniai betörésüket sokkal jelentősebbnek tartja saját életére nézve, mint Róma bukását. ${ }^{1617}$ A két

\footnotetext{
1613 Burgess 1988a, 247.

${ }^{1614}$ Hyd. 34; Burgess 1988a, 232.

1615 Gelarda 2008-2009, 297; Collins 2004, 11; Cortázar - Vesga 2001, 97.

1616 Muhlberger 1990, 218; Burgess 1988a, 234.

${ }^{1617}$ Hyd. 35; Muhlberger 1990, 218.
} 
esemény közül Hydatius valóban többet érzékelhetett a barbár betörés következményeiböl, de az anyag elrendezését azzal az egyszerü ténnyel is magyarázhatjuk, hogy a barbár betörés korábban történt, mint Róma kifosztása, az viszont nem világos, hogy Hydatius miért datálja mindkét eseményt 409-re, holott a gótok 408-as és 409-es hadjárata után Róma elfoglalására 410-ben került sor. Elképzelhető, hogy Hydatius ezzel a szándékos figyelmetlenséggel igyekszik csökkenteni a római események jelentőségét, hogy egyúttal kiemelje a barbár betörés következményeit, ugyanakkor a gallaeciai események jelentőségét az is növeli, hogy Róma megszállásával egy időben, és ahogyan Burgess rámutatott, azonos módon, az ingressus kifejezéssel van ábrázolva mindkét esemény. ${ }^{1618}$

Hydatius krónikáját azért is tekinthetjük a császári hatalom széteséséről szóló elkeseredett beszámolónak, mert szerzőjük már gyerekkorától kezdve a saját bőrén tapasztalta meg a barbár megszállás következményeit. A barbárok 409-es betörésének éppen ezért nemcsak a birodalom és Hispania müködésére nézve voltak súlyos következményei, hanem Hydatius életében is fordulópontot jelent az esemény. Ez a párhuzamosság a későbbiekben is megfigyelhető, hiszen számos példát találunk arra, hogy szülőföldje helyzetének romlásával Hydatius is egyre pesszimistábban látta saját életének alakulását. Hydatius krónikájában azt a folyamatot jeleníti meg, amely során a császári hatalom fokozatosan széthullik és a római közigazgatási rendszer a helyi hatóságokra alapozva már alig tud müködni, vagyis a ,political-administrative frame-work” eltünése és a ,direct territorial control" hiánya miatt mind a városi, mind a vidéki területeken olyan visszafordíthatatlan változások indulnak el, amelyek miatt a korábban integrált igazgatási és gazdasági struktúrával rendelkező Gallaecia is napról napra elszigeteltebb és a birodalmat tekintve periférikus területté válik. ${ }^{1619}$

Nem véletlen, hogy Hydatius többször is kiemelte a bevezetőben, hogy szülőföldje távol esik a római irányítás központjától és szinte a világ végének számít, mivel saját szemével láthatta, hogy a meggyengült császári vezetés Gallaeciát magára hagyta, a római lakosság pedig saját erejéből már képtelen volt megvédeni provinciáját a hódítók fosztogatásaitól. ${ }^{1620}$ Hydatius jól érzékelte azt a folyamatot, amelynek során az 5 . században minél messzebb feküdt egy tartomány a központi irányítástól, annál nagyobb függetlenséget kapott, és így általában a városi hatóságoknak már önállóan kellett dönteniük arról, hogy

\footnotetext{
1618 Burgess 1988a, 233.

1619 López Quiroga - Martínez Tejera 2017, 515; Díaz - Menéndez-Bueyes 2005, 266. A birodalmi adminisztráció hispaniai hanyatlásáról bővebben: Arce 2007, 189-196.

1620 Arias 2007, 50. Hispania demilitarizálódása már a Kr. u. 1. században megkezdődött, a diocletianusi közigazgatási reform és a diocesis-rendszer kialakítása pedig arra ösztönözte a lakosságot, hogy saját erődítményrendszerrel gondoskodjon önmaga biztonságáról, vö. Cortázar - Vesga 2001, 96.
} 
ellenálljanak-e a barbár hódítóknak, vagy saját boldogulásuk érdekében együttmüködjenek velük. ${ }^{1621}$ A császári hatalom csökkenésével és a barbárok terjeszkedésével ez a kérdés egyre nagyobb jelentőséget kapott, és a megszállt területeken sokszor a püspök maradt az egyetlen olyan müködöképes hatóság, amely a római állam képviseletében még valamekkora befolyást gyakorolhatott a helyi lakosságra. ${ }^{1622}$ Bár a periférikus területeken szolgáló püspököknek valóban nem volt okuk szembefordulni az ortodox uralkodóval, azt azonban az egyházon belüli problémák elemzésénél láttuk, hogy a központi segítség elmaradása és a pápától való nagy távolság miatt a püspökök egy része az eretnekségekkel szimpatizált és bizonytalan kimenetelü hatalmi játszmákba kezdett.

A késő császárkorban a római lakosság részéről egyre nagyobb igényként fogalmazódott meg, hogy az uralkodó alapvető feladatának tekintse az alattvalóiról való gondoskodást és a társadalmon belüli béke megteremtését, ${ }^{1623}$ ezért a legtöbb császár törekedett arra, hogy patronusi szerepet vállaljon ne csak Italiában, hanem a birodalom tartományaiban is. ${ }^{1624}$ Hydatius viszont már azt tapasztalja, hogy a központi irányítás gyengeségének súlyos politikai és egyházi következményei vannak, hiszen ahogyan a szétfeszítő erők vizsgálatánál láttuk, a barbár népek egyre nagyobb területtel és önállósággal rendelkeznek, a politikai hatalom pedig már nem tudja védelmezni a katolikus vallást, ezért az eretnek tanítások gyorsan terjednek és az egyházi fegyelmet sem lehet betartatni a püspökökkel. A dogmatikai viták a nyilvánosság előtt, különböző társadalmi rétegek bevonásával és meglehetősen kíméletlen hangnemben zajlottak, ${ }^{1625}$ a császári hatalom pedig egyre erőszakosabb módszerekkel próbálta kezelni a felmerülő problémákat, emiatt jó néhány konfliktus alakult ki a birodalmi irányítás és az egyház vezetői között, ${ }^{1626}$ amely hosszú távon az államhatalom további gyengüléséhez vezetett.

Hydatius már a praefatióban rendkívül pesszimista képet fest az 5. század végi állapotokról, saját korát nyomorúságosnak tartja és úgy látja, hogy a szűk határok közé zárt

\footnotetext{
${ }^{1621}$ Liebeschuetz 2007, 209. Vannak konkrét példák is ilyen típusú döntési dilemmákra Gallia területéről, vö. Greg. Tur. 7,24-31.

1622 Wood 2007b, 504; Koenigsberger 1987, 56.

${ }^{1623}$ Már Augustus korától kezdve a princeps kötelessége volt a pater patriae és a defensor plebis cím birtokában a birodalom teljes lakosságának védelmezése, vö. Alföldy 2000, 103.

${ }^{1624}$ Mivel az egyik legfontosabb birodalmi érdek a tartományi lakosság adóképességének megőrzése volt, a kora császárkorban még igyekeztek megakadályozni a provinciák kirablását és a korrupció elterjedését, a többlépcsős fellebbezési rendszer kiépítésével pedig a lakosság jogbiztonságát próbálták növelni.

$1625 \mathrm{Az}$ 5. század végén teológiai kérdésekkel már nemcsak a császári udvarban, hanem Constantinopolis utcáin is szívesen foglalkoztak a polgárok, ahogyan erről a nyssai Gregorius is meglepödve számolt be a fóvárosba érkezve, vö. Katus 2014, 202.

1626 Kelemen szerint a császár egyházi ügyekben vállalt szerepe valójában csak addig volt fontos, amíg az egyház nem alakította ki saját hierarchikus szervezetét, vö. Kelemen 2007, 14.
} 
Római Birodalom ${ }^{1627}$ a sorscsapások miatt pusztulásra van ítélve. ${ }^{1628}$ Hydatius krónikájában egy olyan világot mutat be, ahol az igazságosságot már régen legyőzték, és a hatalom egyre inkább átkerül Isten ellenségeinek a kezébe, ezért táplál mérhetetlenül nagy ellenszenvet a barbárok és az eretnekek iránt. ${ }^{1629}$ Ehhez hasonlóan Ammianus Marcellinus többször is kiemeli, hogy a besúgók folyamatosan veszélyeztetik a rómaiak biztonságát, Salvianus pedig Hydatiushoz hasonló keserüséggel nyilatkozik a Római Birodalomról, amely a társadalmi feszültségek és a középrétegek lesüllyedése miatt már a végnapjait éli. ${ }^{1630}$

Ezen a ponton érdemes röviden kitérnünk arra, hogy Hydatius korának keresztény és pogány szerzői hogyan gondolkodtak a római állam szerepéről, és ez mennyiben különbözik a hagyományos római történelemfelfogástól. A történelem korszakolásának problémája már Dániel könyvének 4 királyságról szóló próféciájában is megjelenik, ${ }^{1631}$ amelynek allegórikus értelmezése más bibliai részletek segítségével lehetséges: ${ }^{1632}$ Nabukodonozor óbabiloni birodalmának helyét a méd-perzsa, később a makedón állam veszi át, az utolsó, negyedik világbirodalom pedig a korábbiak tulajdonságait egyesítve kemény lesz, mint a vas, és az örökkévalóságig fog tartani. ${ }^{1633}$ Elsőként a Kr. e. 1. században Pompeius Trogus foglalkozott azzal, hogy a birodalmi hatalom az asszíroktól a médekre, majd a perzsákon és a makedónokon keresztül a rómaiakra helyeződött át, vagyis a translatio imperii alapján biztosítható a történelem folytonossága, a Kr. u. 1. században pedig Velleius Paterculus a római történelmet az egyetemes történelem részeként ábrázolta, és az ismeretlen Aemilius Surára hivatkozva azt hirdette, hogy a történelem az egymás után fejlődő és hanyatló

\footnotetext{
${ }^{1627}$ Thompson szerint ez a megjegyzés legfeljebb csak annyit jelenthet, hogy a központi hatalom politikai és katonai szempontból már nem tudta ellenőrizni a barbárok kezére került hispaniai területeket, vö. Thompson 1982, 215; mégsem vethetjük el azonban azt a lehetőséget, hogy Hydatius képes volt reálisan érzékelni, hogy a nyugati birodalomrész kiterjedése drasztikus gyorsasággal csökken.

${ }^{1628}$ Hyd. praef. 6.: omnium miserabilis temporis erumnarum, et conclusi in angustias imperii Romani metas subdidimus ruituras. Hieronymus ehhez hasonlóan a barbárok betörésével magyarázta a római világ pusztulását, vö. Hier., Ep. 16,16.

${ }^{1629}$ Muhlberger 1990, 261.

1630 Adamik 2009, 733; Amm. Marc. 14,1; Salv. 4,30.

${ }^{1631}$ Dán 2,32-35 alapján Nabukodonozor óbabiloni király álmában látott egy szobrot, amelynek feje aranyból, mellkasa és karja ezüstből, hasa bronzból, lába pedig vasból és agyagból készült. Amikor egy kő összetörte a szobrot, minden testrésze porrá vált, a kőböl pedig egy nagy hegy lett, amely betöltötte az egész földet. A különbözö fémekkel való jellemzés később az emberi lét hanyatlásának szimbólumává is vált, vö. Sulp. Sev., Chr. 2,3,3; Bultmann 1994, 35; Wieser 2016, 105. Dániel 4 birodalmának jelentőségéről bővebben: Eliade 2006, 462-466; a 4 birodalom toposzának eredetéröl és modern szakirodalmáról lásd: Grüll 2007, 228-229.

${ }^{1632}$ A szoborbirodalmakat tisztátalan vadállatok is jelképezhetik, a negyedik állat pedig felfalja majd az egész földet, vö. Dán 7,23; 7,7; Jel 12,9; 13,2; ehhez hasonló babiloni, iráni és föníciai példákat lásd: Eliade 2006, 463.

${ }^{1633}$ Breisach 2004, 92; Grüll 2007, 9-11.
} 
világbirodalmakat mutatja be, végső célja pedig az, hogy a Római Birodalom felemelkedésével felváltsa az összes korábbi világbirodalmat. ${ }^{1634}$

A későbbi szerzők többsége Dániel próféciájára hivatkozva világkorszakok felsorakoztatásával határozta meg a történelem egyes fejlődési szintjeit. Órigenés a szőlőmunkásokról szóló példabeszédre hivatkozva 5 szakaszt különített el a világtörténelemben, ${ }^{1635}$ Eusebius a kronológiában alkalmazott 6 határkővel a világ történetét 6 korszakra osztotta fel, ${ }^{1636}$ Tertullianus szerint pedig a Római Birodalom a világvége előtt az utolsó lesz a birodalmak sorában. ${ }^{1637}$ Hieronymus és Ambrosius már úgy gondolta, hogy a római állam olyan békét teremtett a keresztények számára, amely „az eljövendő istenbirodalom földi elözményének" is tekinthetö, Sulpicius Severus pedig a Dániel látomásában szereplő szobor lábait elsőként értelmezte a 395-ben kettéosztott birodalom részeiként. ${ }^{1638}$ Lactantius organikus államfelfogása alapján a birodalmak az emberi élethez hasonlóan születésük és fejlődésük után szükségszerüen elpusztulnak, ${ }^{1639}$ a pogány történetírást képviselő Florus szerint Róma 900 év alatt érte el az emberi élet szakaszaihoz hasonló fázisokon keresztül az öregkort, ${ }^{1640}$ Ammianus Marcellinus viszont úgy véli, hogy a végső öregség állapota nem feltétlenül jelenti a birodalom pusztulását, mert még van remény egy újabb ifjúkor megszületésére. ${ }^{1641}$

Augustinus Hydatiushoz hasonló válságos helyzetben, de néhány évtizeddel korábban, 412-426 között Észak-Africában fejtette ki az államról alkotott felfogását. Mivel a vandálok 407-ben betörtek Galliába, 410-ben pedig a gótok fosztogatták Rómát, a pogányok és a keresztények között vita alakult ki az isteni gondviseléssel kapcsolatban. Augustinus a pogányok vádjaival szemben írt De civitate Dei címü vitairatában úgy látja, hogy a barbár betörések ellenére a kereszténység korában jóval kevesebb katasztrófa történt a Római Birodalom területén, mint korábban. ${ }^{1642}$ Véleménye szerint a történelemben a

\footnotetext{
${ }^{1634}$ Iustin. 28,2; 29,2; 30,4,16; 31,5; Vell. Pat. 1,6,6; Breisach 2004, 71; Albrecht 2004, 843; Németh - Hegyi 2011, 27; Mehl 2011, 116-119.

1635 Mt 20,1-16; Chadwick 1999, 72.

1636 Breisach 2004, 92. Határkövet jelent Ádám, Ábrahám és Mózes működése, a Templom felépítése és újjáépítése, valamint Krisztus születése.

1637 Tertull., Adv. Iud. 8-13; Albrecht 2004, 1252.

1638 Hier., Ep. 123,16; Ambr., Ep. 74; Sulp. Sev., Chr. 2,3,3; Havas 1998, 49-50; Havas - Takács - Tegyey 2001, 261-262; Wieser 2016, 106.

${ }^{1639}$ Lact., Div. Inst. 7,15.

${ }^{1640}$ Florus a királyság korát 400, az ifjú- és felnőttkort 150-150, az öregkort 200 évre becsülte, vö. Flor. 1.

1641 Amm. Marc. 14,6,3; Albrecht 2004, 1139; 1151; Breisach 2004, 82; Adamik 2009, 624. Ammianus Marcellinus életéröl és müveiről bővebben: Mellor 2002, 110-131; Albrecht 2004, 1143-1155; Adamik 2009, 724-734.

1642 Augustinus összefoglalta müvében a pogány és a keresztény Rómáról szóló kritikát mind a történetírói, mind az apologetikus hagyomány tekintetében, ezért ezt tartják minden későbbi keresztény történelemfelfogás
} 
fellendülés és a hanyatlás mindig egymás után következik, az építő és a szétfeszítő erök egyszerre fejtik ki hatásukat, így a birodalomnak nem azért kell elviselnie a külső barbár támadásokat, mert a keresztények elfordultak az ősi római vallástól és elterjesztették hitüket, hanem mert az állam müködése számos területen válságba került. ${ }^{1643}$ Mivel a birodalmi élet központja még mindig Róma, az egyháznak túl kell élnie a válságos időket, a birodalmat ostromló barbárokra pedig nem Isten országának ellenségeként és büntetésként kell tekinteni, hanem érdemes jelenlétüket inkább egy új kihívásnak értelmezni, amely az egyház előtt áll, hogy megtérítse őket a katolikus vallásra. ${ }^{1644}$ Augustinus egyúttal elutasítja azt a felfogást, mely szerint Dániel próféciájára hivatkozva Rómát a negyedik világbirodalommal kellene azonosítani, mivel a birodalmak történelmi küldetésük teljesítése után mindig elpusztulnak, így a római állam sem kerülhetné el sorsát a barbárok megtérítése és az emberiség egyesítése után. ${ }^{1645}$ Mivel Augustinus kozmikus történelemszemlélete szerint tévedés volt összekapcsolni az egyház müködését Róma történetével, a kereszténység fejlődését különválasztja a hanyatló római császárságtól, ${ }^{1646}$ ennek ellenére hisz a birodalom fennmaradásában, ha annak vezetése békére és igazságosságra törekszik.

Augustinus több kísérletet is tett a történelem szakaszolására, de semmilyen korszakolási rendszert sem követett kizárólagosan. ${ }^{1647}$ A Teremtés 6 napjának megfelelően a világ történetét 6 korszakra osztotta fel, de ezek a szakaszok a millenaristák felfogásával szemben nem feltétlenül tartanak ezer évig. ${ }^{1648}$ A 6 aetason át tartó történelem az égi és a földi állam keveredésének leképeződése, az utolsó korszak végén, Krisztus második eljövetelével pedig Isten állama elnyeri az örök boldogságot, a földi állam viszont örök büntetésben részesül. ${ }^{1649}$ A történelem 6 korszaka ugyanakkor a florusi koncepcióhoz

alapjának. Augustinus történelemteológiájának bővebb elemzését lásd: Gecse 1977, 454-457; Löwith 1996, 211-224; Albrecht 2004, 1361-1364; Wieser 2016, 99-100.

1643 August., De Civ. 4,4; 15,5; Neil 2007, 331-332; Vanyó 2007b, 340-344.

1644 August., Ep. 199.

1645 Breisach 2004, 93. Augustinus a gondviselés fogalmát „szekularizálja”, amikor a történelmet már nem örökké tartó ciklikus mozgásnak tekinti, hanem folyamatos változásnak, mivel Isten nemcsak megteremtette a világot, hanem a végét is ő szabta meg, vö. Bultmann 1994, 72; Palmer 2014, 8-9.

1646 Ennek megfelelően Krisztus eljövetele nem a történelmi időkben következik be, mint a khiliasztikusok vagy a millenaristák állítják, tehát egyetlen történelmi katasztrófának sem lehet spirituális jelentése, vö. Eliade 2006, 591-592.

1647 Ezekről bővebben lásd: Albrecht 2004, 1363.

1648 August., De Civ. 18,2; 20,23; 22,30. Az első korszak Ádámtól az özönvízig tart, a további korszakok végét Ábrahám, Dávid, a babiloni fogság és Krisztus születése, illetve második eljövetele és a történelem vége jelenti, vö. Löwith 1996, 222; Zsinka 2012, 12. Augustinus és a millenarizmus viszonyáról lásd: Landes 1988, 156-160; Palmer 2014, 18-19.

1649 August., De Civ. 15,1; Segesváry 1994, 70; Gárdonyi 2006, 23; Adamik 2009, 805-806. A későbbi Beda eszkatologikus magyarázata szerint a 6. aetas végén megérkezik majd az Antikrisztus, a 8. aetas pedig az örök boldogság eljöveteléig tart, vö. Landes 1988, 174-178; Hofmann 1997, 425. 
hasonlóan az emberi élet szakaszainak is megfeleltethető, ${ }^{1650}$ de Illés jóslata alapján elkülöníthetjük a szellemi fejlődés szempontjából a törvények előtti és a törvények alatti szakaszt, illetve az isteni dicsőség korszakát is. ${ }^{1651}$

Hydatius Augustinushoz hasonlóan rendületlenül hisz a világi és az egyházi hatalom erejében, de ahogyan láttuk, nehezen tolerálja a barbárok hódító törekvéseit, és még kevésbé hajlandó a római politikában és az egyházi életben tapasztalható szétfeszítő erőket természetes történelmi jelenségként értelmezni. Elkeseredettségét azzal is magyarázhatjuk, hogy míg Augustinus a béke megteremtését várja a birodalmi vezetéstől, Hydatius a saját tapasztalatai és a korábban vizsgált szétfeszítő erők nagysága miatt már nem lát reális esélyt a pusztulás elkerülésére.

\subsection{A küzdelem formái}

A Hydatiusról kialakult képünk rendkívül egységesnek mondható, hiszen püspökként és történetíróként az egyházi és politikai nézetei is összhangban vannak egymással. A körülötte lévő zürzavarban a régi világ védelmezőjeként tekint saját magára, egy olyan bástyára, amely egész életében kiállt a császári hatalom és a katolikus egyház védelme mellett. ${ }^{1652}$ Koenigsberger szerint az 5. századi római társadalomban a császári hatalom és a katolikus egyház erőviszonyainak megváltozása miatt kialakult egyfajta „dual focus of loyalty”, amely sem a görög-római világra, sem más kultúrákra nem volt jellemző, Gelarda pedig találóan „un eccellente paradigma della simbiosi tra romanità e cattolicesimo”-nak nevezi Hydatiust. ${ }^{1653}$

Burgess kissé leegyszerüsítve azt vallja, hogy Hydatius világképében minden motívum fekete és fehér, így azok ellentétben állnak egymással, ennélfogva történeti beszámolóját tekinthetjük a „Romans and barbarians, emperors and usurpers, orthodox and heretic, good and evil" közötti állandó konfliktussorozatnak is. Bultmann szerint azonban az ember életének velejárója, hogy folyamatosan küzdjön az ellentétes erőkkel, és mivel nemcsak saját és mások cselekedetei, hanem a sors is irányítja a történelmet, néha alulmarad ebben a küzdelemben, emiatt viszont az ember nem mindig választhatja meg saját céljait,

\footnotetext{
${ }^{1650}$ Ez alapján beszélhetünk első és második gyerekkorról, ifjúságról, fiatalkorról, férfikorról és öregkorról.

${ }^{1651}$ Löwith 1996, 222; Breisach 2004, 94.

1652 Muhlberger 1990, 266.

${ }^{1653}$ Koenigsberger 1987, 56; Gelarda 2008-2009, 295.
} 
sem pedig az eszközöket, amelyekkel el tudja érni majd azokat. ${ }^{1654}$ Ahogyan Gallaeciát egyre nagyobb bajok ostromolták és Hydatiusnak is egyre súlyosabb nehézségekkel kellett szembenéznie, még jobban megnőtt ezeknek a konfliktusoknak, céloknak és eszközöknek a szerepe Hydatius világában. Élete nagy részében a barbárok és az eretnekek ellen harcolt, de ennek a küzdelemnek több formáját is nyomon követhetjük a krónika segítségével.

Első lépésként a Gallaeciában állandósult szvév fosztogatások megállításában igyekezett segítséget nyújtani azzal, hogy 431-ben a császári hatalom segítségében bízva követséget vállalt Aëtiushoz. ${ }^{1655}$ Hydatius politikai szerepvállalása jól mutatja, hogy a korabeli egyház milyen fontos szerepet játszott a politikai életben. Gelarda szerint a püspökök a helyi lakosság szószólójaként, ${ }^{1656}$ egyfajta politikai „,key figures” szerepében különösen nagy aktivitást mutattak a diplomáciai életben, szinte automatikusan lettek a megszállt városok irányítói, hogy megszervezzék a lakosság védelmét és tárgyaljanak a barbár seregek vezetőivel, ${ }^{1657}$ megcáfolva ezzel minden olyan hipotézist, amely a gallaeciaiak közömbösségére vonatkozik. Thompson úgy látja, hogy Hydatius elsősorban azért vállalhatta ezt a küldetést, hogy egyházi vezetőként elősegítse a körülötte fokozatosan összeomló világ megmaradását, de talán saját elszigeteltségét is próbálta kompenzálni azzal, hogy a követvállalással bekerül a politikai körforgásba. ${ }^{1658}$ Gelarda ugyan azt állítja, hogy a Hydatius által ábrázolt követségek nem különálló eseményként és egyes személyek tevékenységeként jelennek meg, hanem politikai kontextusban, ebben az esetben mégis feltételezhetjük, hogy Hydatius saját presztízsének erősítésére használta fel a galliai követség bemutatását az olvasói előtt, és elég befolyásosnak érezte magát ahhoz, hogy egy ilyen fontos ügyben személyesen lássa el a követi teendőket. ${ }^{1659}$

Arias szerint a római közigazgatás alapelemei dominánsak maradtak a szvévek által megszállt területeken is, ezért az egyház vezető tagjai gyakran vállaltak diplomáciai szerepet, hogy az egyház magas szintü függetlenségével elősegítsék a rómaiak és a szvévek közötti kapcsolatok müködését. Torres Rodríguez érvei alapján az összes római intézmény közül az egyház állt a legerősebb lábakon, hiszen a vezetői elősegítették, gyakran még át is vállalták a helyi közigazgatás müködtetését, amely a szvévek 411-es letelepedése után

\footnotetext{
${ }^{1654}$ Burgess 1988a, 192; Bultmann 1994, 12.

1655 Hyd. 86; 88.

1656 Gelarda 2008-2009, 302.

${ }^{1657}$ Halsall 2007, 341; Dawson 1938, 105; Candelas-Colodrón 2004, 168-169.

1658 Thompson 1982, 140; Castellanos 2015, 53. Ugyanezt a politikai aktivitást látjuk csaknem két évszázaddal később Isidorus Hispalensis esetében, aki a zavaros hispaniai helyzet miatt avatkozott bele a politikai küzdelmekbe Sisenand király trónralépésekor, vö. Székely 2008, 17.

${ }^{1659}$ Gelarda 2008-2009, 295; Gillett 2003, 50.
} 
fokozatosan felmorzsolódott. ${ }^{1660}$ Emiatt a városok és a helyi közösségek maguk kezdték megszervezni a saját ellenállásukat általában egy jó koordinációs képességekkel rendelkező püspök vezetésével, akinek köszönhetően akár tárgyalásokra és alkudozásokra is sor kerülhetett a szvév hatalommal, sok esetben pedig az ellenállás fokozatosan együttmüködéssé alakulhatott. ${ }^{1661}$ A püspökök a városok vezetöiként bírói jogkörrel is rendelkeztek, személyes tekintélyük és népszerüségük miatt saját illetékességi területükön szinte korlátlan hatalmat gyakoroltak, ez pedig egyfajta kompenzációt jelentett Róma központi erejének meggyengülésével szemben, másrészről viszont a jogi és gazdasági ügyekbe való beleszólásuk, ha eltérő is volt városonként és püspökönként, de az egyház pozícióját erősítette tovább. ${ }^{1662}$ Találóan fogalmaz Liebeschuetz, amikor a püspökök hatalmának 5. századi növekedését azzal indokolja, hogy az egyház vezetői szükségszerüen betagozódtak a helyi „,power vacuum”-ba, ${ }^{1663}$ és defensor civitatis-ként a „civil and religious functions" birtokában gyakran még anyagilag is támogatniuk kellett a városok mindennapi müködését. ${ }^{1664}$

Hydatius esete jól mutatja, hogy a császári és a katonai követek mennyire fontos szerepet játszottak az 5. századi provinciák életében, különösen azokon a területeken, amelyek már barbár megszállás alá kerültek. Hydatius a hispán-római „sentire politico”-t megtestesítve őszintén hisz abban, hogy a diplomácia a békeszerződések és a megállapodások létrehozásának politikai eszközeként nemcsak a pillanatnyi túlélést segítheti elö, hanem hosszú távon is alkalmas lehet a rómaiak és a barbárok közötti problémák megoldásában, vagyis az arisztokrácia „pactista” vonalát képviselve inkább a kommunikációs és diplomáciai eszközökre támaszkodik, mintsem hogy nyers konfrontációra kényszerüljön. ${ }^{1665}$ Hydatius ugyanakkor a tartományi közösség vezetőjeként tisztában lehetett azzal, hogy Gallaecia és bármelyik tartomány nyugalmának biztosítása elsősorban a császári hatóságok és a barbár uralkodó közötti folyamatos kommunikáción múlik, nem pedig egyetlen katonai vagy diplomáciai beavatkozáson, ezért is büszke arra,

\footnotetext{
1660 Arias 2007, 49; Torres Rodríguez 1977, 268. Ezt a folyamatot jogi források is alátámasztják, vö. Burgess 1988a, 127; ugyanakkor maga Hydatius is megerősíti feltételezésünket azzal, hogy hispaniai tisztségviselőt 420-ban említ utoljára Maurocellus vicarius személyében, vö. Hyd. 66.

${ }^{1661}$ Díaz - Menéndez-Bueyes 2005, 294.

1662 Dawson 1938, 48; Carr 2002, 26; Díaz 1986, 362.

1663 Liebeschuetz 2007, 219.

1664 López Quiroga - Martínez Tejera 2017, 524.

1665 Gelarda 2008-2009, 298-299; Candelas-Colodrón 2004, 170.
} 
hogy saját közbenjárásának köszönhetően (sub interventu episcopali) megvalósult a béke a rómaiak és a szvévek között. ${ }^{1666}$

Nem kételkedhetünk abban, hogy Hydatius már fiatalon is elkötelezett volt az ortodoxia iránt, mivel szokatlan módon már rendkívül korán püspökké szentelték, és emiatt is bízhatták rá az Aëtiushoz indított követséget is. Ezért sem meglepő, hogy a küzdelem következő szakaszában, a 440-es években vallási téren próbált segítséget nyújtani az eretnekekkel szembeni harcban, amikor Thoribiusszal együtt fellépett a manicheusok és a priscillianusok ellen. Az a tény, hogy Thoribius Hydatiust és Caeponiust kérte fel a velük szembeni küzdelemre, szintén arra utal, hogy Hydatius híres volt az ortodoxia melletti kiállásáról és igazhitüségéről. ${ }^{1667}$

Azt is tudjuk azonban, hogy Gallaecia püspökségeinek irányítása az 5. században sem lehetett túl egyszerü feladat, mert a többi provinciához képest az itt müködő püspököket az eretnek tanítások népszerüsége miatt kevésbé tudták erős kézzel irányítani, ${ }^{1668}$ sok esetben még a püspöki tanácskozások megtartása és a korábbi zsinati határozatok érvényesítése is akadályba ütközött. ${ }^{1669}$ Másrészről viszont Hydatius felhívja a figyelmünket arra, hogy püspöki kinevezése új lehetőségeket biztosított számára, hiszen vezető egyházi pozíciója révén, különösen a 430-440-es években valószínűleg sokat találkozott gallaeciabeliekkel és szvévekkel, követekkel és utazókkal egyaránt, így eljuthatott hozzá a pápai és a püspöki levelezések egy része, ${ }^{1670}$ amelyek még akkor is jó forrásanyagot jelenthettek egy krónika megírásához, ha Hydatius csak jóval később kezdett bele annak megírásába.

Hydatius láthatóan tudatában volt annak a felelösségnek, amely a püspöki pozícióhoz mint közérdekü hivatali szolgálathoz kapcsolódott, éppen ezért büszkén vállalta az ezzel járó feladatokat. ${ }^{1671}$ Példaként tekintett azokra az egyházatyákra, akik sikeresen vették fel a harcot különböző eretnekmozgalmakkal, és Gallaecia többi püspökétől is ehhez hasonló fegyelmet és lojalitást várt el. A krónikában a szvévek és a rómaiak együttélése egyfajta „permanent conflict” formájában jelenik meg, ugyanakkor tudjuk, hogy leginkább a katolikus papság képviselői müködhettek együtt a szvév hatalommal, segítve ezzel az

\footnotetext{
1666 Gillett 2003, 43-44; 76; Hyd. 91.

${ }^{1667}$ Burgess 1988a, 194; 202.

1668 Burgess feltételezése szerint a priscillianus püspökök magas száma lehetetlenítette el a gallaeciai egyház müködését, vö. Burgess 1988a, 200; López Quiroga - Martínez Tejera 2017, 478-479.

1669 Leo, Ep. 15, praef.; Thor., Ep. 2, in: PL 54,693; Burgess 1988a, 203. Hispania kedvezőtlen vallási helyzetéről bővebben: Chadwick 1976, 11.

${ }^{1670}$ Hyd. praef. 6; Burgess 1988a, 34.

1671 Angenendt 2008, 71.
} 
expanzív törekvéseiket és a császári hatalom fokozatos felmorzsolódását. ${ }^{1672}$ A korábbi példák alapján egyértelmü, hogy Emerita és Arelate városában jó néhány püspök a helyi közösség élére állt és karizmatikus vezetőként segítette a lakosság mindennapjait, Gallaeciában viszont nem hallunk ilyen típusú interakciókról, Hydatius pedig valószínűleg kisebbségben volt vagy talán teljesen magára is maradt az eretnekek elleni küzdelemben. ${ }^{1673}$

Ezek alapján valószínüsíthetjük, hogy Hydatius nemcsak azért részletezi saját püspöki tevékenységét, hogy a többi egyházi vezetőt is hasonló viselkedésre buzdítsa, hanem az olvasók előtt is igazolni szeretné, hogy ő milyen lelkiismeretesen harcol a katolikus hit védelmében és mennyire együttmüködik a felsőbb egyházi utasításokkal, ezáltal igyekszik példaképeihez hasonló sikereket és népszerüséget elérni. Burgess azonban felhívja a figyelmünket két ezzel kapcsolatos problémára. Mivel Hydatius nem mond semmit a vele együtt vizsgálódó Caeponiusról, elképzelhető, hogy ő nem volt annyira elszánt és igazhitü, mint Hydatius, vagy egyszerüen nem akart szembekerülni a priscillianusokkal. Az is különös, hogy Hydatius a felkutatott eretnekekkel szemben semmilyen önálló lépést nem tett, csak az elöírások szerint jelentést küldött Emeritába, talán mert félt a priscillianusok vagy a manicheusok bosszújától. Ezek ismeretében már meg sem lepődünk azon, hogy 447 után nem is említi a priscillianusok mozgalmát, holott korábban láttuk, hogy népszerüségük még ebben az időszakban is nagy problémát jelentett Gallaeciában. Nem tudjuk, hogy 447 után hogyan viszonyultak a szvévek az ortodox római lakossághoz, mindenesetre Aquae Flaviae városában nem látunk nagy püspöki győzelmeket az eretnekség képviselőivel szemben. ${ }^{1674}$ Nincsenek információnk arról sem, hogy Hydatius saját müködési területén akár csak egyetlen alkalommal is konkrét lépéseket tett volna a priscillianusok ellen, de lehet, hogy csak azért nem említi ezeket a krónikában, mert az erre irányuló törekvései meghiúsultak vagy kudarccal végződtek.

A korabeli püspökök biztosan ismerték Augustinusnak a püspökök helyes viselkedésével kapcsolatos véleményét, és minden bizonnyal több esetet is hallottak arról, hogy milyen reakciókat váltott ki a Hispaniába és Africába özönlő barbárok támadása. Utolsó leveleiben azt tanácsolja az africai püspököknek, hogy néhányan maradjanak a helyükön és szolgálják a keresztény híveket, mások pedig inkább meneküljenek el és mentsék a saját életüket, de hogy kinek melyik utat kell választania, az igazságosság kedvéért sorsolással állapítsák meg. ${ }^{1675}$ Augustinus óvatos fogalmazásának az lehet az oka,

\footnotetext{
1672 Barbero - Loring 2005, 164.

${ }^{1673}$ Wood 2007b, 517; Muhlberger 1990, 244.

${ }^{1674}$ Burgess 1988a, 203-204; 223-225.

1675 August., Ep. 228,5, in: CSEL 57,488; Chadwick 1999, 210; Vanyó 2007b, 321.
} 
hogy mindenképpen gondoskodni kívánt a lakosság lelki gondozásáról, de nem akarta kockáztatni azt sem, hogy minden püspököt elveszítsen a vandálok elleni küzdelemben. A levelekböl ugyanakkor az is kiderül, hogy jó néhány püspök azért hagyta el lakóhelyét, mert a híveik behódoltak vagy megsemmisültek a barbárok elleni harcban, más püspökök viszont mindent hátrahagyva elmenekültek és csak saját életük megmentésére törekedtek. Szégyenkezve említi a bracarai Avitus esetét, aki a barbárok támadásakor nem érezte kötelességének, hogy visszatérjen gyülekezetéhez és segítsen megszervezni az ellenállást, de elmarasztalja Orosiust is, aki a barbár invázió elől szintén a tengeren túlra menekült és cserben hagyta a híveit. ${ }^{1676}$ Hydatius említ két asturicai püspököt, akik valószínüleg fontos szerepet játszhattak a helyi közösség életében, mert a gótok elhurcolták őket a város 457-es fosztogatásakor, ugyanakkor alig hallunk olyan esetről, amikor a püspökök saját híveikkel összefogva igyekeztek megvédeni a közösségüket és kiálltak a katolikus hit mellett. ${ }^{1677}$

Hydatius püspöki tevékenységének megítélését tovább árnyalhatjuk azzal, ha megvizsgáljuk, hogy a példaképnek tekintett Eusebius milyen elveket vallott az ortodox tanítással kapcsolatban. Mivel a 320-as években Eusebius még úgy vélte, hogy Arius vitatott tanítása jobban megfelel a vallási hagyományoknak, mint a katolikus hitvallás, a nicaeai zsinaton kezdetben Arius pártjára állt, és a később elfogadott dogmát csak fenntartásokkal tudta elfogadni. Eusebius püspökként sajátos helyzetben volt, mert a keresztény tanítás korábbi hagyományait nagyon jól ismerte, ugyanakkor elkötelezett híve volt Constantinus politikájának, ezért megpróbált mindkét fél számára megfelelni és közvetítő szerepet játszani az arianizmus és az ortodoxia között. ${ }^{1678}$ Hydatius minden bizonnyal jól ismerte Eusebius püspöki tevékenységét és mérsékelten arianus hajlamait, de érthető módon erről semmit sem mond a krónikában, elkeseredéssel tölthette el viszont, hogy Eusebius munkásságát annak ellenére is nagyra tartották, hogy nem mindig az ortodoxiát védelmezte és közvetítő szerepét sem koronázta siker.

Hydatius életének és püspöki müködésének egyik fordulópontja lehetett, amikor 460-ban a szvévek elrabolták és három hónapra bebörtönözték, azt viszont nem árulja el, hogy miért akarták őt a besúgók félreállítani és később milyen okból ellenezték a szabadon bocsátását. ${ }^{1679}$ Ahogyan láttuk, az 5. században a városok mindennapi életének biztosítása és az adminisztratív tevékenységek irányítása egyre inkább a püspökök feladatává vált, ezért

1676 PL 41,805-806. Orosius 414-ben Hippóba utazott Augustinushoz, 415-ben Palaestinában tartózkodott, de amikor 416-ban arról értesült, hogy Hispaniában a vandálok fosztogatni kezdtek, visszatért Hippóba, vö. Székely 2008, 18; Adamik 2009, 807.

1677 Hyd. 179; Pawlak 2007, 35; Thompson 1982, 180.

1678 Athan, De syn. 17; Theodor. 1,5; Vanyó 2007b, 67-69.

${ }^{1679}$ Hyd. 196; 202. 
a barbár vezetők egy város megtámadásakor gyakran a püspökökkel tárgyaltak, a megszállás után pedig velük alakították ki a két nép közötti együttélés feltételeit. ${ }^{1680}$ Ennek tükrében elfogadhatónak tünik Muhlberger magyarázata, mely szerint Hydatius nyilvánosan kiállt a rómaiak érdekek mellett és szimpatizált a birodalmi irányítással, ezért megpróbálták őt eltávolítani a közéletből, ${ }^{1681}$ Torres Rodríguez és Tranoy viszont inkább azt feltételezi, hogy a besúgók arianusok vagy priscillianusok lehettek, ezért vallási okok miatt fordulhattak az ortodox püspök ellen, ${ }^{162}$ különösen mert azt is tudjuk, hogy a priscillianusok gyakran a püspökök egyházon belüli hatalmát is megkérdőjelezték. ${ }^{1683}$ Mivel Hydatius is említi, hogy nem Frumarius vagy a szvévek, hanem a három besúgó kezdeményezte az elfogását, bizonyítékok nélkül is megfontolandó Burgess azon feltevése, hogy a nevük alapján római származású besúgók elkeseredésükben átállhattak a szvévek oldalára, és mivel priscillianusok voltak és Hydatius konkrét lépésekkel vagy csak az igazhitűek bátorításával fellépett ellenük, bosszúból próbálták meg őt félreállítani. ${ }^{1684}$ Mindez azt is megmagyarázná, hogy Hydatius miért utasítja el teljesen a barbárokkal való együttmüködés minden formáját, hiszen ő maga is ennek az interakciónak, vagy ahogyan fogalmaz, besúgásnak esett áldozatul. Ha első látásra úgy tủnik, hogy a krónika domináns témája a barbárok tevékenysége, és az egyházi kérdésekről sokkal kevesebb szó esik, ${ }^{1685}$ mégsem kételkedhetünk abban, hogy Hydatius több évtizedes püspöki müködése alatt a szvévek által megszállt területen történtek olyan egyházi élettel kapcsolatos események, amelyeket érdemes lett volna feljegyezni a krónikában, hacsak nem kényszerült arra Hydatius, hogy félelemből vagy a saját magáról alkotott pozitív kép megőrzése céljából elhallgassa őket.

Bármelyik is lehetett az elfogás valódi oka, Hydatius ekkor saját bőrén tapasztalhatta meg, hogy egyházi vezetőként hiába védelmezi a birodalmi érdekeket és a katolikus hitet, a központi hatalom nem tudja megvédeni őt, és a fosztogató barbárok már a püspöki

\footnotetext{
${ }^{1680}$ Horváth 1999, 48.

1681 Muhlberger 1990, 226. Néhány kutató szerint Hydatius ellenpólusaként fejtette ki tevékenységét Balconius, Bracara püspöke, aki a szvévek oldalára állva igyekezett a rómaiak és a szvévek közötti kapcsolatot békésebb útra terelni, vö. Torres Rodríguez 1977, 93; Arias 2007, 53.

1682 Torres Rodríguez 1956, 783-784; 792-793; Tranoy 1974, 1,16; 2,114. Molé azt állítja, hogy Hydatius senatori származása miatt vonta magára a gótok ellenszenvét, de ezt a feltételezést már korábban elutasítottuk, vö. Molé 1974, 328-329. Megfontolandó viszont Burgess véleménye, mely szerint Hydatius félhetett az asturicai vizsgálat során felkutatott eretnekek bosszújától, vö. Burgess 1988a, 203; López Quiroga és Martínez Tejera viszont annak ellenére gyanakszik vallási okokra, hogy szerintük sincs arra bizonyíték, hogy a besúgók a priscillianusok közé tartoztak volna, vö. López Quiroga - Martínez Tejera 2017, 479.

${ }^{1683}$ López Quiroga - Martínez Tejera 2017, 482.

${ }^{1684}$ Burgess 1988a, 204.

1685 Pawlak 2007, 31.
} 
méltóságot sem tartják tiszteletben. Éppen ezért Hydatius számára ez a fogság szimbolikus jelentőségű abból a szempontból is, hogy már nincs jelentősége annak, hogy Constantinus óta a katolikus püspökök a társadalom kiváltságos rétegét alkották és nagy tisztelet övezte őket, ${ }^{1686}$ hiszen a barbárok betörése és a császári hatalom gyengesége miatt az ősi rend bomlásnak indult, veszélybe sodorva ezzel Hydatius személyes biztonságát és valódi szabadságát is. ${ }^{1687}$ Úgy tünik, hogy Hydatius a krónikában valójában nem az apokaliptikus világvégéről, hanem egy bizonyos világ végéről beszél, ahol a megszokott vallási és társadalmi rend felbomlásával a korábbi vezető réteg számára kérdésessé vált, hogy milyen módon tudja megőrizni társadalmi pozícióját a barbárok uralma alatt. ${ }^{1688}$

Hispaniában ugyanis a szvévek betörése után egyre nagyobb befolyással rendelkezett egy erösen romanizált nemesi réteg, amelynek tagjai vezető pozíciókat kaptak az egyházban és a városok vezetésében. ${ }^{1689}$ Hispania periférikus területeinek kapcsolata a központi irányítással azonban már a 4. század elejétől lazulni kezdett, a helyzeten pedig csak rontott az a körülmény, hogy a gazdasági és politikai szereppel kevésbé rendelkező városok elnéptelenedtek, így a központi hatalom már kevésbé tudott érvényesülni ezeken a területeken. ${ }^{1690}$ Különösen igaz volt ez Gallaeciában, ahol a népesség jelentős része villákba és mezőgazdasági területekre menekült, ezért az állam a közigazgatási rendszer szétesése után már csak látszólag tudta ellenőrizni az itt élő római lakosságot. ${ }^{1691}$ Az egyre rosszabb helyzetben lévő városokkal szemben a vidéki nagybirtokosok gyakran megtagadták az állammal való együttmüködést, és saját hatalmukat féltve inkább vagyonuk gyarapítására és

\footnotetext{
${ }^{1686}$ Muhlberger 1990, 243; Angenendt 2008, 76. A 4. század elejétől a városok vezető rétegéhez tartoztak a püspökök és a papság, akik mentesültek többek között az adófizetés alól, és szélesebb jogkörrel ruházták fel őket, mint a többi egyház képviselöit, vö. Brown 1999, 46.

1687 A városi lakosság valójában már régen elveszítette politikai jogait, véleményüket többnyire utcai zavargásokban tudták csak kifejezni, vö. Foss - Magdalino 1990, 35. Az 5. század végétöl a római városok megmaradását már csak az biztosította, hogy az egyházmegye közigazgatási központjaként a püspökök a maguk köré gyüjtött papokkal együtt ott tartották székhelyüket, vö. Pirenne 1983, 44. A római civitas változásairól és a városi vezetők helyzetéröl lásd: Kornemann 1946; Nörr 1965; Heather 2007c, 455-464.

1688 Brown 1999, 62.

1689 Brown 1999, 71; Angenendt 2008, 165. A városi tanácsokat vezető decuriók a senatorokéhoz hasonló kiváltságos réteget alkottak, de hivatalukkal nem kaptak fizetést, ráadásul számos olyan kiadást is vállalniuk kellett, amely a város müködéséhez, jótékonykodáshoz, az utak és a védmüvek fenntartásához kapcsolódik, vagyis a birodalom teherhordó rétegeként nemcsak irányították, hanem bizonyos mértékben finanszírozták is a városok müködését, vö. Havas - Hegyi - Szabó 2007, 775; 779.

${ }^{1690}$ Hendrik a városok hanyatlásával kapcsolatban két elméletre hívja fel a figyelmünket: Ward-Perkins szerint a katonai és a politikai nehézségek, illetve a barbárok betörései akkora felfordulást okoztak a társadalomban, hogy az tönkretette a birodalmon belüli kommunikációs és kereskedelmi hálózatot, ahogyan látjuk ezt Hydatius esetében is, Kulikowski viszont sokkal szélesebb kiterjedésünek ábrázolja azt a folyamatot, amelynek során a birodalom a külső és belső csapások következtében nyelvi, etnikai és strukturális változáson ment keresztül, vö. Ward-Perkins 2005, 87-88; Hendrik 2015, 6-7.

${ }^{1691}$ Cortázar - Vesga 2001, 91; Halsall 2007, 340.
} 
villáik korszerüsítésére törekedtek, ${ }^{1692}$ bár ez a fajta gazdagság kevésbé volt jellemző Gallaecia vidéki és ,semi-urban” jellegü területeire. ${ }^{1693}$

A nyugati területeken a 4. század végétől lesüllyedt városi középréteg egy része saját helyzetének romlását és az állam védelmi funkcióinak csökkenését érzékelve egy másik menekülési utat választott, és a patrocinium rendszerének kialakításával megpróbálta valamelyik befolyással rendelkező nagybirtokos, magas rangú tisztségviselö, katonai parancsnok vagy egyházi vezető segítségét kérni abban, hogy patronusként védje meg őt a túlságosan magas állami adóztatástól, a barbárok és a kalózok fosztogatásaitól vagy a vallási konfliktusoktól. ${ }^{1694}$ A nagybirtokosok sok esetben a villa köré épített fallal és saját hadseregükkel garantálták azoknak a biztonságát, ${ }^{1695}$ akik a védelemért cserébe átadták a birtokukat, amelynek továbbmüvelésével még megélhetésük is biztosítva volt. Bár az állam számtalan rendelettel próbálta tiltani az így kialakult gyakorlatot, mivel az alkalmas volt a törvények kijátszására és az adófizetés elkerülésére, 415-tól mégis kénytelen volt beletörődni abba, hogy akár egész városok is csoportos védelemért cserébe személyes függő helyzetbe kerüljenek. ${ }^{1696}$ Mindez a lesüllyedt középrétegek helyzetének további romlását eredményezte, hosszú távon pedig gyakran saját tulajdonuk elvesztéséhez, egész vidékek elnéptelenedéséhez és az adóbevételek csökkenése miatt az államapparátus müködésképtelenségéhez vezetett, ${ }^{1697}$ ráadásul a colonusi rendszer elterjedésével olyan

1692 Régészeti bizonyítékok igazolják, hogy az 5. század közepéig a hispaniai villák területén gyakran új mozaikpadlók, bazilikák, mauzóleumok és fürdők épültek, ezáltal a hispaniai gazdaság súlypontja Baeticából a félsziget belső területei felé tolódott, vö. Cortázar - Vesga 2001, 92-93; Chavarría Arnau 2005, 546-547; Grüll 2014, 164-166; López Quiroga - Martínez Tejera 2017, 522-524. A villák fejlesztésének köszönhetően a városokban munka nélkül maradt kézmüvesek is vidékre költöztek és itt segítettek a textíliák, a kerámiák és a fémfeldolgozás megnövekvő igényeit kielégíteni, közülük különösen kiemelkedtek a Mesetában alkotó mozaikkészítő iparosok, vö. Cortázar - Vesga 2001, 93; Halsall 2007, 88. A villagazdaságok korábbi müködéséhez és a fogalom általános értelmezéséhez lásd: Buren 1968; Havas - Németh - Szabó 2001, 461463; Hoffmann 2014, 53-59; a villák 5. századi helyzetéről bővebben: Percival 1992, 156-164; Kulikowski 2010, 133-139; a gallaeciai feltárásokról lásd: Sánchez Pardo 2013, 143-144; López Quiroga - Martínez Tejera 2017, 515-516.

1693 Sánchez Pardo 2013, 155; López Quiroga - Martínez Tejera 2017, 482. A gallaeciai térség „territorial organization"-re vonatkozó helyneveinek vizsgálatát lásd: Díaz 2011, 191-206.

1694 A villákon létrehozott magánkápolnák és templomok a kereszténység új központjaivá váltak és biztosították a hívek vallásgyakorlatát, vö. López Quiroga - Martínez Tejera 2017, 481. Az 5. század második felétől létrehozott vidéki egyházi építmények szerepéről lásd: Sánchez Pardo 2013, 149-150.

1695 A mintavillaként ismert dél-etruriai settefinestrei villaépület, amely egy kiugró mészkőtáblán elhelyezkedve a völgy fölé magasodott, eleve egy „stratégiailag jól védhető helyen” feküdt, vö. Grüll 2017, 168.

${ }^{1696}$ Salv. 5,38; CTh 11,24,6. A patrocinium elterjedése az állam egész müködésére is negatív hatást gyakorolt, Libanius például ezzel magyarázza a városok hanyatlását, a hadsereg pusztulását és a lakosság jólétének megszünését is, vö. Liban., Or. 47,1-16. A fogalom további értelmezéséhez lásd: Hahn 1968; Demandt 1989, 333-337.

${ }^{1697}$ Mivel a városi curialisok egyre nagyobb anyagi terhet viseltek és az adók behajtásáért teljes anyagi felelösséget kellett vállalniuk, a legtöbben nem kiváltságnak, hanem büntetésnek tekintették tisztségüket, 
kényszerintézkedések bevezetésére került sor, amelyek már értelmetlenné tették a szabadok és a nem szabadok közötti jogi különbségtételt is. ${ }^{1698}$

Az így kialakult társadalmi feszültségek és a növekvő szociális problémák gyakran helyi szintű nyugtalansághoz vagy nyílt felkelésekhez vezettek, ahogyan Hydatius is utalt rájuk a galliai és hispaniai rablóbandákba verődött bagaudák vagy az egyház hatalmát is megkérdőjelező circumcelliók esetében. A bagaudák az elszegényedett falusi lakosságot, a colonusokat és a rabszolgák egyes csoportjait lázadásra buzdítva fosztogatták a nagybirtokokat és a közigazgatás központjait jelentő városok ellen fordultak, mert úgy érezték, hogy a barbár támadásokkal szemben nem kaptak megfelelő központi segítséget. ${ }^{1699}$ Salvianus szerint leginkább a törvénytelenségek és az adók behajtásával kapcsolatos túlkapások kényszerítették őket lázadásra, ${ }^{1700}$ bár ez a 4 . század végéig csak kisebb gerillaharcokban nyilvánult meg és a tehetetlen vidéki lakosság fizetés nélkül maradt katonákkal való összekapcsolódására adott lehetőséget. ${ }^{1701} \mathrm{Az}$ 5. század eleji alán-vandálszvév betörés idején már az Alpok térségében a baszkokkal és a Pireneusok lakóival egyesülve fosztogatták Sarus gót seregét, majd az alpesi átkelőhelyek elfoglalása után mozgalmuk központja Armorica tartományára helyeződött át és fokozatosan kiterjedt Gallia és Hispania területeire is. ${ }^{1702}$ Felkelésüket csak átmenetileg sikerült leverni 411-417 között, Armoricában 435-437 között újra fosztogatni kezdtek Tibatto vezetésével, ${ }^{1703}$ későbbi tevékenységükről pedig már Hydatius is beszámol. ${ }^{1704} \mathrm{Az}$ észak-africai circumcelliók felkelése a legnagyobb vidéki szerveződésű ellenállást jelenti a késő császárkorban. A

ráadásul Salvianus szerint a városi lakosság is zsarnokként tekintett rájuk, vö. Salv. 5,18; Alföldy 2000, 188189. A városi curialisok sajátos helyzetéről bővebben: Jones 1964, 2,712-763; Kelemen 2007, 48-50; 90-98; a 4. századi curialisokra vonatkozó rendeleteket közli: Borzsák 1997, 260-262.

1698 Alföldy 2000, 177; 181. Mivel a kisbirtokok eltünésével az államapparátus költségeit fedező bevételek még bizonytalanabbá váltak, a birodalmi vezetés a foglalkozás kötelező örökítésével és bonyolult adórendszerrel próbált megfelelö bevételhez jutni. A késő császárkori adórendszerről és a colonusok jogi helyzetéröl bővebben: Várady 1961, 94-101; Kelemen 2007, 74-78; Ward-Perkins 2007, 336-345; Heather 2007c, 465-468. A colonusokról szóló 4. századi rendeleteket közli: Borzsák 1997, 258-260; a colonatus müködéséről a Lex Manciana alapján lásd: Hoffmann 2014, 69-70; Borzsák 1997, 237-240; a foglalkozás kötelezö örökítéséröl bővebben: Kelemen 2007, 101-111.

1699 Eutrop., Brev. 9,20,3; Alföldy 2000, 171; 197; Cortázar - Vesga 2001, 95. A bagaudák első megmozdulására Diocletianus idején, 283-285 körül került sor, a felkelést végül Maximianus társcsászár verte le.

${ }^{1700}$ Salv. 5,6. Ez alapján a bagaudákat általában a terhek elől menekülő és törvényen kívül helyezkedő embereknek tartották, akik erdős és kevésbé müvelt területekre húzódtak, vö. Klaniczay 2005, 67.

${ }_{1701}$ Amm. Marc. 28,2,10; Collins 2004, 28.

${ }^{1702}$ Szádeczky-Kardoss 1957, 116-122; Várady 1961, 234, 147. j.; Cortázar - Vesga 2001, 95. A bagaudák galliai és hispaniai mozgalmáról bővebben: Thompson 1952, 11-23; Czúth - Szádeczky-Kardoss 1956, 175 180; Arce 2007, 159-166.

${ }^{1703}$ Thompson 1982, 32-35; Randers-Pehrson 1993, 125.

${ }^{1704}$ Hyd. 117; 120; 133; 150. 
hatalmas és önellátásra is képes nagybirtokok idénymunkásaiból szerveződő mozgalom a társadalmi különbségek megszüntetését és egy önálló africai nemzeti egyház létrehozását tűzte ki célul, de a donatizmussal összekapcsolódva nem is annyira a gazdagok, mint inkább a katolikus egyház ellen irányult. ${ }^{1705}$ Ezek a mozgalmak azonban időben és térben egymástól elszigetelten jöttek létre, és nem állt mögöttük egy összehangolt forradalmi ideológia, így csak kisebb szerepük lehetett a római hatalom felbomlásában. ${ }^{1706}$

Az a sajátos tendencia viszont, hogy a lesüllyedt középrétegek elsősorban nem a vagyonosabb földesurakat, hanem a császári hatalmat megtestesítő államapparátust hibáztatták saját helyzetükért, egyértelműen mutatja, hogy a római társadalom jelentős része elidegenedett a császári politikától, emiatt lojalitás helyett közömbösséget tanúsított, vagy egyre gyakrabban ellenségesen viszonyult a római államrendhez. ${ }^{1707}$ Mivel a társadalom alsó rétege már nem tudott hinni abban, hogy a császári hatalom biztosítani tudja számára a pax Romanát, ha nem is felszabadítóként tekintett a barbár megszállókra, de saját boldogulása érdekében gyakran együttmüködött velük, különösen miután egyre világosabbá vált, hogy a megüresedett vidékek újbóli benépesítésére és a hadsereg folyamatos utánpótlására egyaránt a barbárok további betelepítése jelenti az egyetlen reális megoldást. ${ }^{1708} \mathrm{~A}$ római arisztokráciának sok esetben nem is volt más lehetősége, hiszen csak úgy tarthatta meg földjeit és társadalmi kiváltságait, ha együttmüködött a barbár megszállókkal, ezáltal a legtöbben arra törekedtek, hogy a „political revolution”-t ne kísérje „social and economic cataclysm." 1709

Salvianus szerint akkora volt az elégedetlenség a császár hatalmi apparátusával és a birodalmi intézményekkel szemben, hogy a rómaiak közül sokan kifejezetten örömmel fogadták a barbárok érkezését és hozzájuk menekülve inkább barbárnak vallották magukat, csak hogy elkerüljék a rómaiak fennhatóságát és az egyre súlyosabb adóterheket, vagyis véleménye szerint a barbárok nem csapásokat hoztak a birodalomba, hanem éppen tőlük várható az új rend kialakítása a válságban lévő társadalmi rétegek számára is. ${ }^{1710}$ Orosius még akkor is elfogadja a barbárok által felkínált új rendszert, ha érkezésük sok szempontból katasztrofális helyzetet teremtett és átlépett minden eddig megszokott mértéket. ${ }^{1711}$

\footnotetext{
1705 Jedin 1962, 2,1,145; Alföldy 2000, 197. A circumcelliók fosztogatásairól és azonosításáról bővebben: August., Ep. 108,16,18; Lepelley 1980; Shaw 2004, 227-258.

1706 Alföldy 2000, 197-198.

${ }^{1707}$ Koenigsberger 1987, 19-21; Alföldy 2000, 199.

1708 Alföldy 2000, 203.

${ }^{1709}$ Heather 2007b, 31-32.

1710 Salv. 5,8; 5,23; Várady 1961, 164; Mezey 1986, 23; Halsall 2005, 39.

1711 Oros. prol. 15,3.
} 
Találkozunk olyan esettel is, amikor ugyanaz a személy változtatott a barbárokkal kapcsolatos véleményén, Sidonius Apollinaris (430-486k.) például Gallia praefectus praetoriójaként és Augustonemetum püspökeként igyekezett szembeszállni a gót hódítókkal 474-ben. Miután Euric csapatai elfoglalták a várost, ${ }^{1712}$ száműzték Sidoniust, de 477-ben visszatérhetett és a hívek szószólójaként már a gótokkal való megbékélést szorgalmazta. ${ }^{1713}$ A későbbi időszakban még több ehhez hasonló példát látunk a rómaiak és a barbárok közötti együttmüködésre. ${ }^{1714}$

Hydatius azonban Salvianustól, Orosiustól és Sidonius Apollinaristól eltérően sohasem próbálta meg pozitív színben feltüntetni a barbárokat, és egyszer sem hibáztatta a kialakult válságos helyzetért a birodalmi apparátust vagy a császári vezetést. Számára azonban elfogadhatatlan, hogy a korábban kívülállónak és idegennek tartott barbárok egyenrangú partnerként bebocsátást nyerjenek a helyi társadalomba, és ne alárendelt szövetségesként éljenek a birodalom keretei között. Elismerte ugyan, hogy a barbárok betörtek Hispaniába és felülkerekedtek a már rendkívül gyenge római katonaságon, de ez még nem jogosítja fel őket arra, hogy uralkodjanak is a római lakosság fölött. ${ }^{1715}$ Hydatius valószínűleg azt is sérelmezhette, hogy a császári hatalom számára a 4. századtól kezdve egyre inkább azok számítottak megbízható embernek, akik nem ragaszkodtak mindenáron a hagyományos arisztokrácia értékrendjéhez, hanem a birodalom érdekeit szem előtt tartva képesek voltak akár a barbárokkal való együttmüködésre is. ${ }^{1716}$ Burgess a népnevek és a helyi lakosság megjelölésére használt formák vizsgálatával igazolja, hogy Hydatius szemében viszont az igazi római polgár nemcsak pusztán katonai vagy közigazgatási szolgálatot vállal a birodalom területén, hanem nyelvében, kultúrájában és a mindennapokban is képviseli a római eszmét. ${ }^{1717}$

Hydatius éppen ezért ellenségesen tekintett mindazokra, akik hivatali vagy diplomáciai szempontból együttmüködtek a barbár hódítókkal, és határozottan képviselte a két ellentétes társadalom modelljét. ${ }^{1718}$ Nem véletlen, hogy több kutató szerint a Nyugatrómai Birodalom felbomlásában valóban jelentős szerepet játszott a társadalmon belüli „fragmentation”, amelynek következményeképpen a római lakosság jelentős része

\footnotetext{
1712 Ennek részleteiről lásd: Klaniczay 2005, 124.

1713 Sid. Ap., Ep. 8,9,5; Koenigsberger 1987, 15-17; Heather 2007b, 30; Bubnó 2013, 20. Sidonius Apollinaris életéről és müveiről bővebben: Adamik 2009, 830-840.

${ }^{1714}$ Az arelatéi Caesarius (470 k.-543) és a viennai Avitus (450 k.-518) például annak ellenére, hogy katolikus püspökök voltak, jó viszonyt ápoltak a burgund uralkodókkal, vö. Vanyó 2007b, 377.

1715 Johnson 1993, 44.

1716 Brown 1999, 63-64.

1717 Burgess 1988a, 111-112.

${ }^{1718}$ Pawlak 2007, 36.
} 
úgy döntött, hogy a csökkenő hatalommal rendelkező római császár helyett inkább egy germán vezető szolgálatába áll és együttműködik a városokat megszálló barbárokkal. ${ }^{1719}$ Hydatius egyértelmü elutasítását az együttmüködésre vonatkozóan azzal is indokolhatjuk, hogy egész életében túlságosan közelről szemlélte a barbárok jelenlétét és saját bőrén tapasztalta meg ennek súlyos következményeit. ${ }^{1720}$ A császári hatalom már semmilyen védelmet nem tudott nyújtani Gallaecia lakosságának, a gót külpolitika Róma-barát irányvonala nem felelt meg Hydatius politikai elképzeléseinek, ráadásul hiába ítélte már 456-ban pusztulásra a szvévek királyságát, ${ }^{1721}$ a 460-as években még úgy tünhetett számára, hogy a megerösödött hatalommal rendelkező szvévek sohasem fognak eltünni a provinciából.

A kutatók többsége azonban egyetért azzal, hogy a szvévek Gallaeciában való letelepedése semmiképpen sem volt annyira katasztrofális esemény, mint amennyire Hydatius ábrázolja, ${ }^{1722}$ a jelenség emiatt csak ,,a limited local threat"-nek tekinthető az 5. század második feléből. ${ }^{1723}$ Thompson például igazolta, hogy a katolikus egyház igazgatási formái szinte kivétel nélkül megmaradtak a szvévek által megszállt területeken is, ${ }^{1724}$ régészeti leletek pedig azt bizonyítják, hogy a szvévek megjelenése nem akadályozta a Földközi-tengeren érkező importot és nem alakította át lényegesen a kialakult birtokviszonyokat, ${ }^{1725}$ de nem hozott radikális változást a településhálózat elosztásában és összetételében sem. ${ }^{1726}$ Bár az 5. század második felének régészeti leletei a mezőgazdasági tevékenységek visszaeséséről, társadalmi polarizációról és a vagyon koncentrációjáról tanúskodnak, a gallaeciai villák egy részét a Hispania más részein tapasztalható tendenciától eltérően elhagyták, a tengeri kereskedelem pedig leginkább a társadalmi elitre korlátozódott, a kisebb gazdasági központok fokozatosan átalakulva a kora középkori falvak alapját

\footnotetext{
${ }^{1719}$ Heather 2006, 415-425; 432-443; Halsall 2007, 19; Brown 2012, 392-394; Hendrik 2015, 108-109.

1720 Burgess 1988a, 152.

${ }^{1721}$ Pawlak 2007, 35; Hyd. 168.

1722 Arias 2007, 43; López Quiroga - Martínez Tejera 2017, 524.

1723 Goldsworthy 2009, 356.

1724 Thompson 1982, 215.

1725 Ferreira 1993, 198; Van Schoor 1995, 337; Edmondson 1989, 97. A partmenti területeken előkerült régészeti leletek igazolják a kikötőkben végzett aktív halászati és áruforgalmi tevékenységet, egyfajta „,dynamic trade” müködését, vö. López Quiroga - Martínez Tejera 2017, 515; 525-526. Az erre vonatkozó kutatásokról bővebben: Sánchez Pardo 2013, 150-152; a kereskedelemhez és árucseréhez kapcsolódó leleteket lásd: 6. sz. kép; López Quiroga - Martínez Tejera 2017, 160-169; 185-188; 201-204; 255; 269-280.

1726 A központokat jelentő civitasok, az átmenetet képező vicusok és a vidéki villák gallaeciai feltárásáról bővebben: López Quiroga - Martínez Tejera 2017, 520-525.
} 
jelentették, ${ }^{1727}$ ezek a változások azonban nem feltétlenül a szvév hatalom erősödése, hanem inkább az egész birodalmat érintő gazdasági-társadalmi folyamatok és a lakosság krisztianizálódása miatt következtek be. ${ }^{1728}$ Mivel Hydatius rendkívül rövid szavakat használ Remismund uralkodásának megjelölésére, Arias szerint a 460-as évek végére Gallaeciában véget értek a szvévek fosztogató hadjáratai, és már csak ott kellett harcolniuk tovább, ahol nem hódoltak be a szvév ellenőrzésnek. ${ }^{1729}$ Korábban ugyan láttuk, hogy a szvévek elsősorban Bracara, Asturica és Lucus környékét népesítették be, a vidéki területeket pedig döntő részben meghagyták a római lakosságnak, Thompson még azt is igazolta, hogy a szvévek Gallaecia déli részén, a Durius és a Tagus folyók közötti területen 456 után többször is indítottak fosztogató hadjáratokat, ennélfogva nem élhettek nagy számban Aquae Flaviae környékén sem. ${ }^{1730}$

A régészeti feltárások tehát azt mutatják, hogy az 5. század közepén Gallaecia életében egy „,complex but dynamic period” kezdődött, ez viszont nem a római világ végét, hanem a térség gazdasági, politikai és társadalmi átalakulását eredményezte, ráadásul a válságjelenségek Gallaecia központi területeihez képest „,more gradual and less dramatic” fejtették ki hatásukat a vidéki településeken. Mivel nincs bizonyítékunk arra, hogy az 5. századi Gallaeciában bekövetkezett volna egy társadalmi-gazdasági „systematic collapse", ${ }^{1731}$ Hydatius barbárokra vonatkozó sztereotipikus megállapításai nem származhatnak saját mindennapi tapasztalataiból, a központi hatalom gyengesége és a barbárok fosztogatásai miatt felmerülő problémák leginkább csak Hydatius lelki világában és saját életének kudarcai miatt alakulhattak ki.

\subsection{A történetírás végső célja}

Hydatius politikai és egyházi karrierje tehát a kezdeti szakaszban felfelé ívelt, a 450-es évektől viszont a központi vezetés hiánya és a barbár megszállás miatt már nem jutott jelentős szerephez sem a barbárok, sem az eretnekek elleni küzdelemben. Az Aëtiushoz vállalt politikai követség hosszú távon nem eredményezte a barbárok és a rómaiak közötti

\footnotetext{
1727 Sánchez Pardo 2013, 156. A villák elhagyásának lehetséges okairól lásd: López Quiroga - Martínez Tejera 2017, 521-524; a feltárt lakóházak, temetők és istentiszteleti helyek alapján kimutatható változásokról bővebben: López Quiroga - Martínez Tejera 2017, 123; 168-169; 187-188; 226-230; 248-249; 256-265.

${ }^{1728}$ López Quiroga - Martínez Tejera 2017, 520-521.

${ }^{1729}$ Arias 2007, 61.

1730 Thompson 1982, 201.

${ }^{1731}$ Sánchez Pardo 2013, 154; 156; 166.
} 
békés együttélést, az eretnekségek ellen folytatott küzdelemben pedig kezdetben ugyan voltak sikerei, de saját müködési területén nem tudott vagy nem mert fellépni a priscillianizmus követőivel szemben, ráadásul 460-ban még saját szabadsága és élete is veszélybe került. ${ }^{1732}$ Wood szerint ez a fogság mégsem tekinthető az egyház és a barbárok közötti „dramatic confrontation”-nak, inkább egy szimbolikus esemény volt, amely a helyi közösség összeomlásán kívül azt is jelezte, hogy Hydatius végérvényesen kudarcot vallott azokkal a próbálkozásaival, amelyek a szvévek katonai müveleteit és fosztogatásait enyhítették volna. ${ }^{1733}$ Nem véletlen, hogy Hydatius tehetetlennek és Gallaecia elszigetelt helyzete miatt magányosnak érezhette magát, ezért nemcsak szülőföldjéről nyilatkozik lesújtóan, hanem önmagát is Isten tudatlan (ignarus servus) és leghitványabb szolgájának (indignussimus) nevezi, öregségét pedig siralmasnak (lacrimabile) tartja. ${ }^{1734}$

Ebböl a kilátástalan helyzetből jelentett volna kiutat számára a krónikaírás, amelybe láttuk, hogy valószínüleg élete végén, különösebb előkészületek nélkül kezdett bele. A küzdelem tehát a politikai és a vallási szerepvállalás után irodalmi síkon folytatódott, újabb feladattal és elismeréssel kecsegtetve Hydatiust. Nem helytálló Burgess azon kijelentése, hogy „suffered, but he survived”, hiszen Hydatius feltételezésünk szerint nem közömbösen, félelemben és nyugtalanságban élte utolsó éveit, hanem ellenkezőleg, kétségbeejtő helyzete újabb feladatra inspirálta őt ahelyett, hogy a Torres Rodríguez által javasolt „psicosis obsesiva y deprimente" tünetei egyre jobban ránehezedtek volna személyiségére. Nem fogadjuk el Wood kritikáját sem, mely szerint Hydatius „is one not of charismatics”, mert ha nem is tudott már öszintén hinni a diplomáciai eszközök sikerében és megtörték a sorozatos kudarcok, ${ }^{1735}$ mindezek az érzések mégsem a küzdelem feladására, hanem újabb módszerek bevetésére késztették őt, ahogyan az általa nagyra tartott Hieronymus is nemcsak püspökként harcolt az eretnekmozgalmakkal szemben, hanem teológiai és történeti szerzőként is maradandót alkotott.

Általánosan elfogadott vélemény, hogy a történelem bemutatása közcélú tevékenységnek számít, ${ }^{1736}$ ezért a történetírás célja nem lehet pusztán pragmatikus módon a múltbeli események teljeskörü rekonstruálása és a valóság feltárása, ${ }^{1737}$ hanem a szerzők

\footnotetext{
1732 Salvianus lesújtó hangnemben írt arról, hogy az 5. század végén gyakran halálfélelemmel gondoltak a rómaiak arra a lehetőségre, hogy a barbárok fogságába esnek, vö. Salv. 5,21; 7,6; Alföldy 2000, 202.

${ }^{1733}$ Wood 2007b, 516.

${ }^{1734}$ Hyd. praef.; praef. 5.

1735 Burgess 1988a, 191; Wood 2007b, 516; Gelarda 2008-2009, 306.

1736 Breisach 2004, 84; 104; Adamik 2009, 603-604. A történetírás lehetséges céljairól bővebben: Mellor 2002, 196-199.

${ }^{1737}$ Herod. 1,1; Thucyd. 1,22; 2,64; Polyb. 2,56-63.
} 
vagy szórakoztató és érdekes olvasmányt próbálnak nyújtani a közönségnek, ${ }^{1738}$ vagy pedig moralizáló művekben jó és rossz exemplumok felsorolásával az erény követésére buzdítják az olvasóikat. A barbárok 5. századi betörése után azonban a történetíróknak ettől eltérő feladataik is adódhattak, Gregorius Turonensis például a hívek lelkesítését tartotta a történetírás legfőbb céljának, Beda a jó példák felsorolásával nevelö funkciót tulajdonít saját tevékenységének, Sidonius Apollinaris pedig mindig valamilyen aktuális feladat szolgálatába állította a költészetét, szükség esetén például Avitust és Mariorianust magasztalta panegyricusaiban, ${ }^{1739}$ papi pályára lépve pedig versíró hajlamait rejtett formában, leveleinek részeként valósította meg. ${ }^{1740}$ Elfogadhatjuk ugyanakkor Burgess véleményét, mely szerint Hydatius esetében a krónikaírás tevékenysége mögött nem állnak „,apologetic, didactic or rhetorical purposes”, de arra sem törekedett Hydatius, hogy a politikai és vallási válság miatt Sulpicius Severushoz hasonlóan ,hidat verjen a keresztény múlt és jövő közé", ${ }^{1741}$ hanem elsősorban saját érzéseit és tapasztalatait igyekezett az olvasók előtt feltárni az események bemutatásakor.

A krónika bevezetőjében Hydatius valóban arról tájékoztatja olvasóit, hogy korának összes sorscsapását igyekszik bemutatni, amelyek a Római Birodalom és a világ szélén fekvő Gallaecia (intra extremam Galleciam) pusztulásához vezettek. A birodalom hanyatlásának folyamatát Hydatius saját kis világán keresztül, Gallaeciában szerzett tapasztalataira alapozva figyelhette meg, ezért mondja azt Burgess találóan, hogy Hydatius számára Gallaecia „, a microcosm of the rest of the Empire." ${ }^{1742}$ Mivel a krónika műfajában a „történeti és irodalomi igények” egyszerre jelennek meg, az események kronológiai felsorolásán kívül fontos szerepe van „az egyéni élmények rögzítésének” is, ezért a Hieronymust követő krónikahagyományban általánossá vált, hogy a szerzők ösztönösen azt mutatták meg müveikben, hogy saját környezetük eseményeinek tükrében hogyan látták a világtörténelem alakulását. ${ }^{1743}$ Éppen ezért fogadhatjuk el, hogy Hydatiust saját tapasztalatai befolyásolták a történeti események ábrázolásában, még akkor is, ha ezek szubjektivitásuk miatt sohasem válhattak a legfontosabb információforrássá. ${ }^{1744}$

Hydatius ugyan tisztában volt azzal, hogy Hieronymus munkáját akkor követné a leghüségesebben, ha az egyetemes történet eseményeire koncentrálna, mégis az állítja, hogy

\footnotetext{
${ }^{1738}$ Cic., Ad fam. 5,12,4-5; Plin., Ep. 5,8,4.

1739 Sidonius Apollinaris Avitus-propagandájáról lásd: Gillett 2003, 84-112.

${ }^{1740}$ Sid. Ap., Ep. 9,7; 9,16; Adamik 2009, 835-836.

${ }^{1741}$ Burgess 1988a, 191; Wieser 2016, 107-108.

1742 Hyd. praef. 6; Burgess 1988a, 239.

1743 Mezey 1986, 10-11; Muhlberger 1990, 5-6.

1744 Johnson 1993, 21; Pawlak 2007, 36.
} 
szándékosan döntött úgy, hogy Gallaecia helyzetéröl közöl részletes beszámolót. ${ }^{1745}$ Érdeklődése különösen a barbárok 409-es betörése és Róma 410-es ostroma után fordult kifejezetten a helyi események ábrázolása felé, mivel ezen a földön élt és a gallaeciai lakosság szenvedését látta a legsúlyosabbnak saját környezetében. ${ }^{1746}$ Hydatius tehát „,nella strutturazione, nelle intenzioni e soprattutto nei modelli seguiti" az egyetemes történelem rögzítésére alkalmas krónikaformában kezdett írni, de saját korához közeledve egyre inkább a szvévek és a gótok gallaeciai tevékenysége került a figyelem középpontjába, ebből pedig jó néhány kutató arra a helytelen következtetésre jut, hogy a krónika más forrásokhoz képest kevésbé lehet jelentős a római történelem megismerése szempontjából. ${ }^{1747}$ Gillett ugyan elismeri, hogy Hydatius a nyugati területek és a barbár királyságok történetére vonatkozóan kulcsfontosságú eseményekről számolt be, de szerzői hozzáállását mégis „insistently local”nak minősíti, Humphries szerint pedig Hydatius a fontos eseményekkel szemben „perfunctory treatment”-t alkalmaz és leginkább azokra a részletekre fókuszál, amelyek saját életkörülményeit és Gallaecia helyzetét befolyásolják. ${ }^{1748}$ Muhlberger egyenesen felrója Hydatiusnak, hogy sokkal többet mond Gallaecia helyzetéről, mint amennyi valójában szükséges lenne, Burgess viszont éppen azt tartja elképesztőnek, hogy Hydatius gallaeciai püspökként szinte semmit sem árul el a provincia egyházi helyzetéről. ${ }^{1749} \mathrm{~A}$ krónika bevezetőjét ismerve nem vitathatjuk, hogy maga Hydatius is tisztában volt azzal, hogy a távoli Gallaecia sorsa egy átlagos olvasó érdeklődésére nem igazán tarthat számot, éppen ezért első látásra Hydatius krónikája csupán egy periférikus beszámoló lehet a korabeli viszonyokról, vagy ahogyan Burgess fogalmaz, Hydatius ,is a minor bishop in a small out-of-the-way town in the mountains of Gallaecia", ${ }^{1750}$ mivel a provincia korábban sem játszott igazán fontos szerepet Hispania életében. ${ }^{1751}$ Nem véletlen, hogy Hydatius több alkalommal is panaszkodott arról, hogy szülöföldje, Gallaecia nagyon távoli vidéknek számít Hispaniában, mindentől messze van (extremus plage) és szinte a világ szélén fekszik

\footnotetext{
1745 Hyd. praef. 6.

1746 Burgess 1988a, 29; Muhlberger 1990, 194.

${ }^{1747}$ Gelarda 2008-2009, 302; Burgess 1988a, 134.

1748 Gillett 2003, 54; Humphries 2009, 105.

1749 Muhlberger 1990, 214; Burgess 1988a, 225.

${ }^{1750}$ Burgess 1988a, 73; Castellanos 2015, 52.

1751 Muhlberger 1990, 247. Burgess szerint Lemica, Hydatius szülöhelyének neve gyakran szerepelt feliratokon, így feltehetően a korai császárkorban még jelentős városnak számított, vö. Burgess 1988a, 7; Thompson viszont úgy látja, hogy Gallaecia a rómaiak idején is annyira jelentéktelen és mindentől távoli hely volt, mint Hydatius idején, vö. Thompson 1982, 139. A 4. század második felében a katonai csapatok szállítása miatt sor került bizonyos útfelújításokra, ami némileg növelte a tartomány jelentőségét, vö. Díaz - MenéndezBueyes 2005, 279. Gallaecia 3-4. századi perifériára sodródásáról bővebben: Díaz - Menéndez-Bueyes 2005, 266-269. Többek között a fenti szempontok magyarázzák, hogy Észak-Spanyolország és Gallaecia régészeti feltárását az utóbbi évtizedekig miért nem preferálták a kutatók, vö. Sánchez Pardo 2013, 141-142.
} 
(extremam Galleciam), de más szerzők is hasonlóan negatívan nyilatkoztak a tartomány adottságairól. ${ }^{1752}$

Gallaecia hanyatlásának fő okát Hydatius éppen abban látja, hogy mivel a terület a központi irányítástól nagy távolságra fekszik, az egyre gyengébb császári hatalom itt már a 430-as években sem tudott megfelelően érvényesülni, sem a katolikus hit védelmezésében, sem pedig a korábbi római igazgatás fenntartásában. A történészek egyetértenek abban, hogy a szvévek 411-es letelepedése óta Gallaecia a mindennapi müködését tekintve valójában már nem is tartozott a Római Birodalomhoz, ezért Hydatius joggal érezhette, hogy a tartomány lakójaként már nem tudja élvezni a római polgárok számára korábban biztosított jogi és gyakorlati előnyöket. ${ }^{1753}$ Ennélfogva Hydatius szempontjából nemcsak azért van szükség egy erős központi hatalomra, hogy ismét politikai és vallási rend uralkodjon a birodalomban, hanem azért is, hogy megőrizhesse saját társadalmi pozícióját és egzisztenciáját. ${ }^{1754}$ Muhlberger szerint ez csak egyfajta történelemszemlélet, ${ }^{1755}$ valójában ennél sokkal többről, egy sajátos és ambiciózus életfilozófiáról van szó. Az 5. századi állapotokat ismerve ugyanis rendkívüli dolognak számít, ha valaki a kortársak többségétől eltérően nem a közömbösséget választja, hanem hajlandó erőfeszítéseket tenni és akár irodalmi síkon is szembeszállni az ellenfeleivel. Ez alapján világosan látszik, hogy Hydatius számára a Római Birodalom nem egy territoriális egység, hiszen a területén már barbár népek telepedtek le, egyes részei pedig Gallaeciához hasonlóan kicsúsztak a központi irányítás alól. A Római Birodalom ezért inkább egy politikai, kulturális és vallási közösség, amelynek tagjai jó esetben a kötelességüket teljesítve szembeszállnak a barbár és az eretnek elemekkel, és megvédik mindazt a közigazgatási és szellemi egységet, amelyet az egykori Róma jelentett polgárai számára.

Hydatius Gallaecia periférikus helyzetére vonatkozó elkeseredését egy másik szempontból is értelmezhetjük. A krónika megírásával folytatni akarta Eusebius és Hieronymus beszámolóját, de azzal a nehézséggel kellett szembenéznie, hogy elődeitől eltérően Gallaecia elszigetelődése miatt kevés lehetősége van kapcsolatot teremteni a külvilággal, emiatt pedig csak nagyon nehezen, vagy egyáltalán nem tud hozzáférni a

\footnotetext{
${ }^{1752}$ Hyd. praef. 1; praef. 6. Strabón rendkívül barátságtalan, rossz éghajlatú és elszigetelt helynek ábrázolta Gallaeciát, vö. Strab. 3,1,2; 3,3,2; 3,5-8; Augustinus szerint a szintén gallaeciai Orosius Hispania széléről származik, vö. August., Ep. 169,13, in: CSEL 44,621; Vigilius pápa 538-ban azt írta a bracarai Profuturusnak, hogy Gallaecia a világ szélső peremén található, 561-ben pedig a gallaeciai metropolita szerint saját egyháztartománya a világ szélén fekszik, vö. Thompson 1982, 139; Burgess 1988a, 6.

${ }^{1753}$ Burgess 1988a, 99.

${ }^{1754}$ Candelas-Colodrón 2004, 175-176.

1755 Muhlberger 1990, 244.
} 
munka írásához szükséges forrásanyaghoz. ${ }^{1756}$ Gillett szerint ezek hiányát Hydatius úgy próbálta ellensúlyozni, hogy rendkívül sok követségről számolt be krónikájában. ${ }^{1757}$ Bár Hydatiusnak a 427-es püspökké választása után biztosan erősödtek és kiszélesedtek egyházi kapcsolatai, mégsem kapott jó néhány fontos eseményről információt, a szóbeszéd útján vagy követek segítségével érkező hírek pedig gyakran pontatlanok és kevésbé megbízhatóak lehettek a zavaros politikai helyzet miatt. Ezek alapján valószínű, hogy Hydatius élete utolsó két évtizedében egyre kevésbé tudta tartani kapcsolatát a Gallaecián kívüli világgal, ${ }^{1758}$ az okokat Thompson hosszasan és meggyőzően elemezte. Egyrészről Italiából nagyon ritkán juthattak hírek közvetlenül Gallaeciába, többnyire inkább galliai követek és kereskedők segítségével érkezhettek információk Hydatiushoz, ahogyan ő maga is utal erre egy alkalommal. ${ }^{1759}$ Másrészről ezeknek az információknak a hitelessége erősen megkérdőjelezhető, ráadásul ha bizonyos hírek Italiából vagy Constantinopolisból el is értek Hispania keleti partjaihoz, az még egyáltalán nem jelentette azt, hogy azok Gallaeciába is eljutottak és Hydatius is értesült róluk, hiszen a baszkok, a bagaudák és a szvévek annyira elzárták a provinciát a külvilágtól, hogy oda csak a legelszántabb utazók tudtak néhány kivételes esetekben bejutni és híreket szolgáltatni. ${ }^{1760}$

Burgess kiválóan illusztrálja a 450-es évek elején az egyházon belül szétküldött pápai levelek sorsával azt a folyamatot, ${ }^{1761}$ amelynek következtében 451 után még a fontosabb pápai döntésekről és az ephesusi vagy a chalcedoni zsinat határozatairól is alig juthattak át információk Hispania keleti partvidékéről Gallaeciába, a helyzetet pedig csak súlyosbíthatta a gótok 456-os inváziója, így a krónika második felében jelentősen lecsökkent a vallási témákat érintő feljegyzések száma, ${ }^{1762}$ de hasonlóan látványos bizonyítékokat szolgáltatnak a Gallaeciába érkező adatok pontatlanságáról a római pápák regnálásával kapcsolatos tévedések Johnson munkájában. ${ }^{1763}$ Ezek a megfigyelések arra engednek következtetni, hogy bár az utolsó két évtized eseményei közelebb állnak a

\footnotetext{
1756 Burgess 1988a, 33.

1757 Gillett 2003, 53. Gillett annyira jelentősnek tartja Hydatius gallaeciai követségekről szóló feljegyzéseit, hogy azt mintának tekinti az 5. századi nyugatrómai császár és a barbár uralkodók közötti kommunikáció elemzéséhez, vö. Gillett 2003, 74-77.

1758 Muhlberger 1990, 212.

${ }^{1759}$ Hyd. 137. Thompson további példák segítségével igyekszik ezt igazolni, vö. Thompson 1982, 143-144.

${ }^{1760}$ Thompson 1982, 149-150.

${ }^{1761}$ Burgess 1988a, 224-225. Leo pápa 450. május 5-én az arelatéi Ravenniusnak küldött leveleket, vö. Leo, Ep. 67, in: PL 54,886-887; 452. január 27-én arra kérte a galliai püspököket, hogy küldjék azokat tovább Hispaniába a chalcedoni zsinat határozataival együtt, vö. Leo, Ep. 102,5, in: PL 54,988; 454. július 28 -án pedig Gallia és Hispania püspökeinek küldött levelet a 455-ös húsvét időpontjáról, vö. Leo, Ep. 138, in: PL 54,1101-1102; Hydatius azonban csak a legelső levélcsomagot kapta meg, vö. Hyd. 137.

1762 Thompson 1982, 150; Burgess 1988a, 224.

1763 Johnson 1993, 36-37.
} 
krónikaírás időpontjához, az információáramlás nehézsége és a Hydatius rendelkezésére álló források szükössége miatt a korábbiakhoz képest mégis kevésbé megbízható adatokat tartalmaznak. ${ }^{1764}$ Burgess ugyanakkor Aquae Flaviae helyzetét és a forrásokban való említését vizsgálva arra a következtetésre jut, hogy a város mégsem lehetett annyira elszigetelt helyzetben, mint amennyire gondolnánk Hydatius beszámolója alapján, mert valószínűleg rendszeresen kapott információkat valakitől, aki Lucus területén élt és hozzá még eljuthattak a birodalom központjából érkező hírek. ${ }^{1765}$ Mindenesetre ez a fizikai elszigeteltség a Hydatiust hatalmába kerítő félelem, bizonytalanság és pesszimizmus hatására egyfajta „claustrophobically negative atmosphere”-t alakíthatott ki az életében, ez pedig kétségtelenül tetten érhető a krónika feljegyzéseiben. ${ }^{1766}$

Hydatius forrásainak áttekintésekor már említettük, hogy különös módon egyáltalán nem utalt a hispaniai kortársak munkásságára. Nem túl meggyőző ezzel kapcsolatban Muhlberger magyarázata, mely szerint Hydatius azért nem használta Orosiust forrásként, mert müvei nem terjedtek el olyan széles körben az 5. századi Hispaniában, mint Italiában. ${ }^{1767}$ Orosius az augustinusi 6 világkorszak helyett a történelem négyes felosztását használja, és a babilóni, a makedón és az africai (carthagói) korszak után a kereszténység jegyében diadalmaskodó Római Birodalmat is bevonja a szakaszolásba. ${ }^{1768}$ Orosius szerint minden hatalom és államot létrehozó erő Istentől származik, de mivel a birodalmak harcolnak egymás között a hatalomért, jobb, ha a translatio imperii alapján „egyetlen birodalom gyakorolja az uralmat." Orosius felfogása szerint a babilóni és a római állam történelmi jelentőséggel bír, a második és a harmadik birodalom csak átmeneti jellegü, a római állam továbbélése viszont a kereszténység győzelme miatti kegyelem miatt biztosítva van. ${ }^{1769}$ Ezek alapján sokkal valószínűbbnek tűnik, hogy Orosius Hydatiustól eltérő történelemszemlélete miatt nem szerepel a krónikában, ${ }^{170}$ hiszen véleménye szerint a kereszténység megjelenése előtt sokkal több katasztrófa sújtotta az emberiséget, vagyis a római történelem az igaz hit elterjedésével fokozatosan jobbra fordult, a kereszténység végleges győzelme pedig a birodalom szétesését és Krisztus második eljövetelét

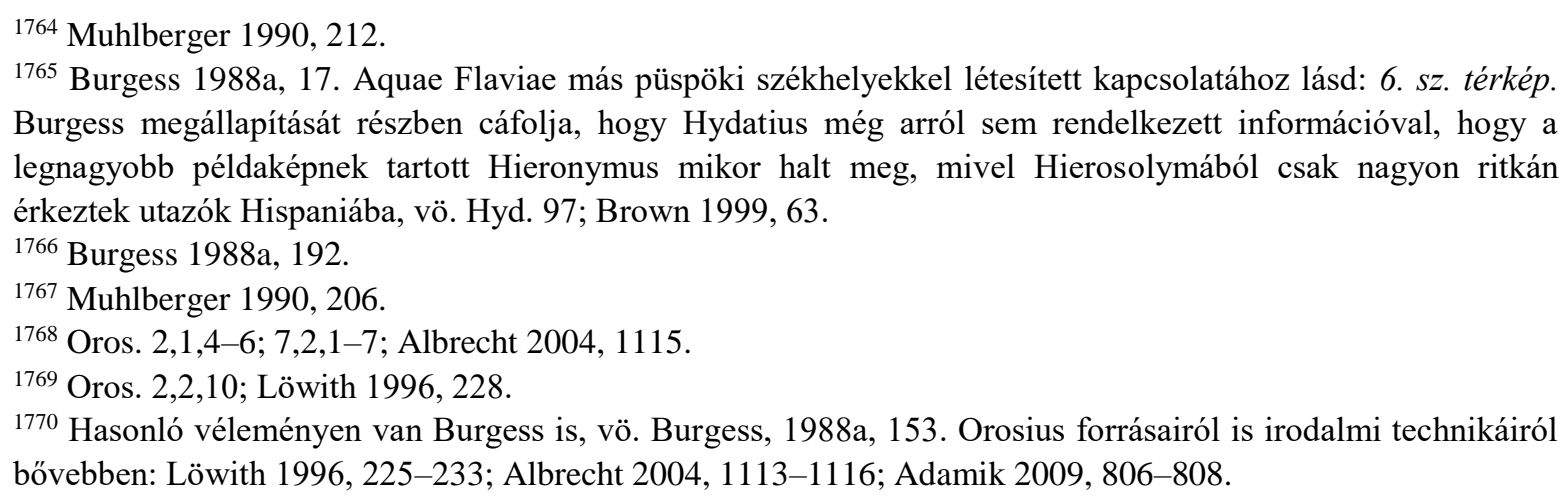
Burgess megállapítását részben cáfolja, hogy Hydatius még arról sem rendelkezett információval, hogy a legnagyobb példaképnek tartott Hieronymus mikor halt meg, mivel Hierosolymából csak nagyon ritkán érkeztek utazók Hispaniába, vö. Hyd. 97; Brown 1999, 63.

1766 Burgess 1988a, 192.

${ }^{1767}$ Muhlberger 1990, 206

1768 Oros. 2,1,4-6; 7,2,1-7; Albrecht 2004, 1115.

1769 Oros. 2,2,10; Löwith 1996, 228.

${ }^{1770}$ Hasonló véleményen van Burgess is, vö. Burgess, 1988a, 153. Orosius forrásairól is irodalmi technikáiról bővebben: Löwith 1996, 225-233; Albrecht 2004, 1113-1116; Adamik 2009, 806-808. 
eredményezi majd. ${ }^{1771}$ Ha tehát a tragikus római eseményeket nem sorscsapásként, hanem Isten folyamatos beavatkozásaként és a bünös emberek büntetéseként értelmezzük, az egymás után ábrázolt események a megváltás történetét fogják megrajzolni. ${ }^{1772}$

Ez a magyarázat azonban nemcsak a késő császárkor történeti eseményeit helyezi lényegesen más megvilágításba, hanem éppen ellentétes Hydatius pesszimista történelemszemléletével, aki a barbárok hódításait és az eretnekség terjedését talán a saját életében szerzett tapasztalatok miatt képtelen volt az üdvösség történeteként értelmezni. ${ }^{1773}$ Orosius szerint a barbárok ugyan hosszú ideig fenyegették és szerencsétlenséget hoztak a hanyatló római világra, ezért talán Hydatiushoz hasonlóan saját életéből kifolyólag is gyülölnie kellene őket, ennek ellenére úgy látja, hogy csak annyi hatalmat ragadtak magukhoz, amennyi Róma szövetségéhez elegendő volt, ráadásul a kereszténységet is felvették, így a római civilizáció birtokában valójában a rómaiak barátjának tekinthetők. ${ }^{1774}$ Orosiusszal szemben azonban többen hangoztatják, hogy érzései nem feltétlenül őszinték és nem a saját álláspontját tükrözik, hiszen Augustinus kérésére írta meg munkáját a pogány vádak cáfolataként, így optimizmusa egyfajta „,an affected attitude.”"1775 Ráadásul míg Hydatius egész életében szenvedett a Gallaeciát megszálló szvévektől, addig Orosius, ahogyan láttuk, a barbárok betörése után mindent hátrahagyva elmenekült és távolról figyelte a hispaniai eseményeket. Orosius mellőzését még azzal is indokolhatjuk, hogy lebecsülte a krónikaírás jelentőségét, Hydatius viszont igyekezett megmutatni, hogy a hagyomány tiszteletben tartásával és néhány merész újítással ebben a müfajban is lehet maradandót alkotni. Hydatius feltehetően saját vetélytársának tekinthette őt, ${ }^{1776}$ és azt gondolta, hogy ha a krónikában nem említi a nevét és ezzel sem járul hozzá Orosius

\footnotetext{
1771 Oros. prol. 13-14; 6,22,5-8; 7,1,1; 7,5,3; Breisach 2004, 95; Vanyó 2007b, 341. Orosius szerint Isten a római polgár megteremtésével és Augustus béketeremtő politikájával Krisztus születését készítette elő, vö. Oros. 3,8,8; 6,1,8; Löwith 1996, 228-229; Albrecht 2004, 1115.

1772 Oros. 2,19; Alonso-Núñez 1993, 197-213; Löwith 1996, 226; Croke 2007, 575; Trambauer 2008, 14.

1773 Orosius a kereszténység történetét két részre osztja, a Teremtéstől Krisztusig, illetve Krisztustól saját koráig, a világtörténetet pedig a Teremtéstöl Róma alapításáig, majd Augustusig és saját koráig tartó periódusokra tagolja, és mindkettőben azonos, hogy saját korát a császárság és a kereszténység diadalaként értelmezi, vö. Gesztelyi - Havas 1999, 255.

${ }^{1774}$ Oros. 1,16,2; 7,41,8; Burgess 1988a, 154, 44. j.; Löwith 1996, 225.

${ }^{1775}$ Burgess 1988a, 190.

1776 Elképzelhetö, hogy Hydatius az Orosiusszal való rivalizálás miatt írta a krónikájában, hogy 406-407 körül rendkívül fiatalon ő is részt vett egy szentföldi zarándoklaton, ahol híres püspökökkel találkozhatott.
} 
népszerüségének terjedéséhez, ${ }^{1777}$ akkor az utókor talán majd őt tartja a gallaeciai történetírónak. ${ }^{1778}$

Hasonló okokkal magyarázhatjuk azt is, hogy miért nem szerepel a krónikában a korai kereszténység egyik legnagyobb költőjének tartott Prudentius, ${ }^{1779}$ aki hivatali és kormányzói feladatok ellátása után visszavonult a közélettől és 8 kötetnyi verse miatt vált rendkívül népszerüvé. ${ }^{1780}$ Költeményeit igyekezett a kereszténység szolgálatába állítani, hogy az igaz hit győzelme ne csak Theodosius rendeleteiben, hanem irodalmi szinten is megvalósulhasson. ${ }^{1781}$ Prudentius költészetében Hieronymus és Orosius véleményéhez hasonlóan az ősi Rómának az az isteni küldetése, hogy a kereszténység terjesztésével és a népek fölötti egység megteremtésével az egész világon érvényesülhessen a jog és az igazságosság. A birodalom története tehát egyben szakrális történelem is, Róma pedig az a szent hely, amely a barbárokkal alkotott egységesség megteremtésével egyre közelebb viszi az emberiséget a történelem beteljesedéshez és Krisztus uralmának megvalósulásához. ${ }^{1782}$ Hydatius szintén az igaz hit győzelmének elősegítése érdekében fogott a krónika írásába, és Prudentiushoz hasonlóan ő is csak élete végén kezdte el irodalmi tevékenységét, de már nem tudott hinni az egységesség megteremtésében és a kereszténység győzelmében, hanem csak a politikai és egyházi téren tapasztalt hütlenség, illetve a barbár hódítások és eretnek tanítások miatt kialakult válság tüneteit tartotta szem elött. Míg Prudentius az 5. század elején reményteljes képet festett Róma történelmi rendeltetéséről és a keresztény világ győzelméről, addig Hydatius fél évszázaddal később már elkeserítően nyilatkozik a birodalom összeomlásáról és inkább meg sem említi a Prudentius által felvázolt Rómaeszményt. ${ }^{1783}$

\footnotetext{
1777 Orosius a középkorban is rendkívül népszerủ szerzőnek számított, ezért sokan úgy tartják, hogy ö teremtette meg a keresztény egyetemes történetírás müfaját, vö. Havas - Takács - Tegyey 2001, 265; Breisach 2004, 95.

1778 Hasonlóképpen meglepö, hogy Hydatius hispaniai püspökként alig foglalkozik a hispaniai egyház kiemelkedő személyiségeivel, Gallaeciából pedig csak egyetlen püspököt, Thoribiust említ, öt is csak valószínüleg azért, hogy kiemelje közös püspöki tevékenységüket, ezek alapján akár azt is feltételezhetjük, hogy Hydatius saját tartományából nemcsak egyedüli történetíróként, hanem kiemelkedő püspökként is szeretné elnyerni az utókor elismerését.

1779 Albrecht szerint Hispania kulturális élete a 2. század elejétől „a babérjain pihent”, és csak az 5. század elején Prudentiusszal tért vissza „a világ színpadára”, vö. Albrecht 2004, 1030.

1780 Prudentius életéröl és müveiröl bővebben: Albrecht 2004, 1088-1099; Vanyó 2007b, 357-361; Adamik 2009, 811-814; PL 59-60; CSEL 61.

${ }^{1781}$ Prudentius emiatt a keresztény költők körében a poeta doctus mintájává vált, vö. Adamik 2009, 814.

1782 Prud., C. Symm. 2,816-819; Dawson 1938, 35-36; Ladner 1976, 23.

1783 Prudentius Hydatiusszal ellentétben büszke arra, hogy a rómaiak erényei milyen naggyá tették a birodalmat, amely a keresztény császárok alatt válhat majd igazán világbirodalommá. A Roma aeternagondolat továbbélése és a krisztianizált nyugat pusztulásának elvetése miatt Prudentius lett a középkor „legtöbbet olvasott és utánzott költője”, vö. Albrecht 2004, 1095-1096.
} 
Érdemes ezen a ponton megemlítenünk néhány későbbi történetírót, akik szintén optimistán szemlélték saját koruk történelmét, és úgy próbálták a birodalom szétesése ellenére éppen Rómán keresztül biztosítani a történelem folytonosságát, ${ }^{1784}$ hogy a kereszténység egyetemessége által egyfajta küldetéstudattal ruházták fel saját népüket a translatio imperii jegyében. Iordanes (490 k.-560 k.) a Getica és a Romana címü történeti munkákban a Hieronymustól átvett genealógiák és az Augustusig tartó uralkodólisták alapján újraírta Róma történetét a város alapításától egészen 551-ig. ${ }^{1785}$ A Római Birodalmat a 4 világbirodalom utolsó egyesítőjének tartotta, és azt vizsgálta, hogy valamilyen módon meg lehetne-e menteni a válságba keveredett és vészjósló eseményeket átélt birodalmat. Iordanes támogatta a kortárs Iustinianusnak a Római Birodalom helyreállítására vonatkozó törekvéseit, a gótokat pedig a közös siker érdekében a rómaiakkal való békés együttélésre buzdította. ${ }^{1786}$ Iordaneshez hasonlóan Cassiodorus is azt vallotta, hogy Róma korábbi hatalmát a germánok testesítették meg, ezért törés nélkül tárgyalja a történelmet a római kezdetektől egészen a gótok koráig, ${ }^{1787}$ ugyanakkor titokban szellemi fegyverekkel próbált harcolni a gót uralommal szemben, ${ }^{1788}$ ahogyan Sidonius Apollinaris is a birodalom hanyatlása ellenére hitt abban, hogy a római egyház és irodalom örökké élni fog. ${ }^{1789}$ Gregorius Turonensis (538-594) Historia Francorum címü munkájában azt hangsúlyozta, ${ }^{1790}$ hogy a Római Birodalom bukása után a frankok vették át a hatalmat azzal az isteni küldetéssel felruházva, hogy megvédjék a katolikus lakosságot a szomszédos arianus királyságok támadásaitól, vagyis a frankok történetét összekapcsolta az üdvösség történetével. ${ }^{1791}$ Hydatius az 5. század második felében már hiába keresett uralkodói példaképeket a Római Birodalom megmentéséért, minden császári politikai törekvés kudarcot vallott, a barbárokkal való békés együttélés pedig szóba sem kerülhetett a küzdelmeket vállaló Hydatius történelemszemléletében. ${ }^{1792}$

\footnotetext{
${ }^{1784}$ Breisach 2004, 98.

${ }^{1785}$ Iordanes életéröl és müveiről bővebben: Adamik 2014, 106-123.

${ }^{1786}$ Kiss 2005, 5-7.

${ }^{1787}$ Breisach 2004, 98. A kérdés további vizsgálatához mindkét szerzőnél lásd: Christensen 2002.

1788 Cassiodorus szerint a barbárok elleni küzdelem csak csendesen, a mindennapokban leplezett módon lehet sikeres, de a régi római műveltség felélesztésével van még remény a szabadság ismételt elérésére, vö. Albrecht 2004, 1211.

1789 Adamik 2009, 839. Sidonius Apollinaris a görög-római kultúra szépségeit és a keresztény eszméket népszerüsítette a barbárok fenyegető müveletlenségével és durvaságával szemben, vö. Sid. Ap., Carm. 4; 12; Adamik 2009, 832; 835.

${ }^{1790}$ Gregorius Turonensis életéről és müveiről bővebben: Adamik 2014, 325-349.

1791 Wallace-Hadrill 1967, 68-69; Brown 1999, 111; Breisach 2004, 98; Adamik 2014, 338.

1792 További szerzőket közöl Róma küldetéséről és a barbárok szerepéről: Ladner 1976, 25-26.
} 
Az 5. századi krónikák egyik legfontosabb sajátosságának tartják, hogy a korábbi, narratív jellegü történeti munkákhoz képest jóval rövidebbek és látszólag egyszerübbek, mert szerzőik az eusebiusi cum summa brevitate elvét követve tömören, a lehető legkevesebb szóval és közvetlen módon próbálták feljegyezni saját koruk eseményeit, ${ }^{1793}$ mint ahogy egyre népszerübbé váltak a korábbi történeti munkák kivonatos és rövidített formái, az epitomék és a breviariumok is. ${ }^{1794}$ A keresztény szerzők éppen ezért egyfajta sermo humilis megalkotására törekedtek, amely nemcsak a munka iránti alázatosságukat fejezte ki, hanem lehetővé tette, hogy a kevésbé művelt közönség is minél szélesebb körben olvashassa beszámolóikat, ${ }^{1795}$ gyakran pedig Orosiushoz hasonlóan kifejezetten a nyilvánosság számára írtak. ${ }^{1796}$

Hydatius a felújított müfaj szerkezeti kereteit ugyan megtartotta, de kortársaival ellentétben rendkívül részletes beszámolót készített, különösen a krónika második felében, ahol már nem igazán tudott használni írott forrásokat. ${ }^{1797}$ Hydatius a terjedelmi határokat kiszélesítve sokszor igen hosszú leírásokat közölt bizonyos eseményekkel kapcsolatban, ${ }^{1798}$ szembefordulva azzal a pogány szerzők által alkalmazott gyakorlattal, mely szerint a formai követelmények megőrzése sokkal fontosabb volt, mint maga a bemutatni kívánt tartalom. ${ }^{1799}$ Hiába láttuk, hogy Hydatius egyedülálló bevezetővel örvendeztette meg az olvasóit, rendkívül körültekintőnek mutatkozott a források kezelésében, hüségesen követte az elődök által nyújtott mintát, ráadásul néhány esetben még a görög szavak használatában is igyekezett tudását megcsillogtatni, mégis úgy tünik, hogy Hydatius nem minden szempontból volt megfelelően felkészülve a krónikaírás nehéz feladatára. Stílusát sokan mesterkéltnek és zavarosnak találták, ami arra utal, hogy ha jómodú családból származott is, nem részesült ilyen jellegü tanulmányokban, de szintén képzettségének korlátait mutatják azok a tárgyi tévedések, amelyeket az eretnekmozgalmak eredetével és tanításával

\footnotetext{
1793 Woods 2009, 369; Helm 1956, 19; Muhlberger 1990, 8.

${ }^{1794}$ Mivel a sok évszázadra visszanyúló római történelem áttekintése egyre nehezebb és követhetetlenebb feladattá vált, szükség volt olyan kanonizált történeti munkákra, amelyekkel a közös egység hangsúlyozása miatt a birodalomba telepített barbár lakosság is azonosulni tud, vö. Breisach 2004, 82; Albrecht 2004, 1038; Horváth 2014, 10. Az első jelentős epitomé Florus, a fontosabb breviariumok pedig Festus és Eutropius nevéhez kapcsolhatók.

${ }^{1795}$ Breisach 2004, 105. Gregorius Turonensis egyenesen elutasította a választékos stílust és a könnyen érthető szemléletes ábrázolásmódra törekedett, vö. Gurevics 1987, 44-46, latinsága ugyanakkor sokak szerint nehézkes és gyakran barbár szófordulatokat tartalmaz, vö. Mezey 1986, 42.

1796 Orosius munkája gondos forráshasználatával, átlátható tagolásával és olvasmányosságával egészen a felvilágosodás koráig rendkívül népszerünek számított, vö. Albrecht 2004, 1115; Croke 2007, 575.

${ }^{1797}$ Az 5-6. század ránk maradt krónikái közül Hydatiusé a leghosszabb, vö. Burgess 1988a, 32.

1798 A későbbi krónikaszerzők nem tartották nagyra, hogy Hydatius másokhoz képest sokkal több információt nyújtott a követségekröl, vö. Gillett 2003, 41.

${ }^{1799}$ Millar 1964, 28.
} 
kapcsolatban megfigyeltünk. ${ }^{1800}$ Burgess szerint Hydatius ugyan kísérletet tett egy stílusában magasabb szintű irodalmi nyelv alkalmazására, de éppen a szöveg túlzott részletességével és bonyolult nyelvezetével magyarázhatjuk, hogy miért merült majdnem teljesen feledésbe Hydatius beszámolója. ${ }^{1801}$ Nem véletlen, hogy csak egyetlen hiányos kézirat maradt fenn a krónikából, Hydatius buzdítása ellenére pedig még a gallaeciaiak közül sem akadt senki, aki folytatta volna a feljegyzéseit. ${ }^{1802}$ Úgy tünik, hogy helytálló volt a praefatio egyik utalása, mely szerint a mindentől távoli Gallaecia sorsa nem igazán számíthat majd nagy érdeklődésre, mert az a tény, hogy Gallaeciából egyetlen kézirat sem került elő, azt valószínűsíti, hogy még itt is alig olvasták a krónikát. ${ }^{1803}$

Hydatius az utolsó, irodalmi küzdelmének kudarcát, egyben végső tragédiáját értelemszerüen már nem érhette meg. Brown találó hasonlata szerint Hydatius a késő császárkor szemtanújaként úgy érezhette, hogy a korszak foglyává vált, ${ }^{1804}$ mert a barbárok és az eretnekek elleni küzdelemben politikai és vallási céljait valójában sohasem tudta elérni, ezáltal nemcsak a szvév besúgók, hanem a saját magával szemben támasztott elvárások fogságába is esett. Kissé szigorú Candelas-Colodrón, amikor azt javasolja, hogy Hydatiust a korábbi kutatásokkal ellentétben ne azonosítsuk az ortodoxia szószólójaként, mert valójában kevés információt közöl teológiai kérdésekröl, de ne is tekintsük őt a császári hatalom elfogult propagandistájának, hiszen leginkább saját helyzetének hiteles ábrázolása miatt döntött úgy, hogy feljegyzi korának történelmi eseményeit. ${ }^{1805}$ Annyit azonban elfogadhatunk, hogy Hydatius korábbi küzdelmeinek kudarca után saját közösségén belül még mindig elismerésre és megbecsülésre vágyott, feltehetően ezért kezdett élete utolsó szakaszában egy olyan történeti munka megírásába, amely aztán a zürzavaros állapotok miatt mégsem keltett szenzációt a barbárok és az eretnekek által ostromlott Gallaeciában.

„Maga a krónika majdnem mindig a krónikás élete”, írja találóan Mezey a középkori krónikákról szóló könyvének bevezetőjében, mivel a krónikaszerzők munkájuk megírásával nemcsak saját korukat, hanem saját életüket is igyekeztek megmenteni az emberiség

\footnotetext{
1800 Burgess 1988a, 13; 200-201; 240-243.

1801 Burgess 1988a, 30; Candelas-Colodrón 2004, 356. Hydatius szóhasználatának klasszikus és vulgáris elemeiről, valamint a krónika nyelvezetének manipulatív használatáról lásd: Cardelle de Hartmann 1994, 161203; Kiss 2006, 3-34.

1802 Ezzel szemben Orosius müvéből csaknem 200 kézirat áll a rendelkezésünkre, és müvét még arabra is lefordították, vö. Albrecht 2004, 1115. Az 5-6. századi világkrónikák további sorsáról rövid összefoglalót közöl: Croke 2007, 579-580.

1803 Muhlberger 1990, 275

1804 Brown 1999, 62.

1805 Candelas-Colodrón 2004, 363-365.
} 
számára. ${ }^{1806}$ Hydatiusnak ugyan nem sikerült elérnie, hogy őt tartsa az utókor Gallaecia leghíresebb történetírójának, de a caesaraugustai Braulio bracarai Fructuosushoz írt levelében már az elegantissimi et doctissimi viri közé sorolta az alakját. ${ }^{1807}$ Adamik kissé általánosítva úgy fogalmaz, hogy az 5 . század közepén ,a római irodalom nem termett nagy tehetségeket”, és akikről tudunk, azok „sem tartoznak a legnagyobbak közé”, mégis érdemes tanulmányozni őket, mert „egy ecsetvonással gazdagithatják a korszakra vonatkozó ismereteinket."1808 Bár túlzásnak tünik, hogy Burgess Hydatius müvét a középkori történetírás első alkotásának tekinti, ${ }^{1809}$ egyedülálló teljesítményét mi sem mutatja jobban, hogy a krónika jelentőségét sokszor vitató Thompson szerint ha nem ismernénk Hydatiust, talán nem is lenne az 5. századi Hispaniának története. ${ }^{1810}$

\footnotetext{
1806 Mezey 1986, 7-8.

${ }^{1807}$ Hydatius életéröl saját munkáján, Leo és Thoribius levelein, valamint Pseudo-Isidorus rövid megjegyzésén kívül csak ez a levél tanúskodik, vö. Braul., Ep. 44, in: PL 80,698-699; Burgess 1988a, 9.

1808 Adamik 2009, 826.

${ }^{1809}$ Burgess 1988a, 2; 240.

1810 Thompson 1982, 137.
} 


\section{ÖSSZEGZÉS}

1. Hydatius jól ismerte a krónikaírás hagyományait és nagyra értékelte elődei történetírói tevékenységét. Tisztában volt a krónikaírás formai és kronológiai követelményeivel, használta Eusebius és Hieronymus datálási módszereit, az uralkodási és consuli évek jelölését, az olimpiászokat és az éveket összesítő computatiót. A hagyománykövetésben a legfontosabb mintát Hieronymus jelentette számára, ezért az ő müvéhez átdolgozás nélkül kapcsolta hozzá saját munkáját. Ahogyan Hieronymus Eusebius krónikájának fordításával és a folytatás megírásával igyekezett csodálatát kifejezni elődje teljesítménye iránt, úgy Hydatius is büszke arra, hogy az elödje által kínált mintát követheti, ugyanakkor reálisan látja, hogy saját munkája valójában nem mérhető össze Hieronymuséval. A praefatióban kortársaitól eltérően nagyfokú hozzáértést tanúsít a történetírás módszereivel és a forráskezeléssel kapcsolatban. A krónika drámai struktúrája azt mutatja, hogy ismerte a műfajra vonatkozó szerkezeti kötöttségeket, a csodajelekre és az apokaliptikus utalásokra vonatkozó megjegyzések pedig igazolják a bibliai és a történeti hagyományhoz való ragaszkodását.

2. Hydatius népszerüségre törekedett és számos módon kísérletet tett az olvasók érdeklődésének felkeltésére. Hieronymus ebben is mintát jelentett számára, mivel Eusebius mủvének latinra fordításával megpróbált irodalmi szenzációt kelteni, a népszerüség érdekében pedig újításokat is bevezetett. Hydatiust Hieronymus iránti tisztelete is motiválta a történetírásra, ugyanakkor annak népszerüségét kihasználva igyekezett saját ismertségét is növelni. Mivel feltehetően a szvévek betörése miatt nem tudott Gallaeciából elutazva magasabb szintủ tanulmányokat végezni, folyamatosan bizonyítani akart saját közösségén belül. Aëtiushoz vállalt követsége és a Thoribius által rábízott nyomozás sikeressége jól mutatja, hogy elismerésre és hírnévre vágyott, saját püspöki tevékenységét pedig azért részletezte olvasói előtt, hogy felfigyeljenek lelkiismeretességére és az ortodoxia melletti kiállására. A barbár fosztogatások túlzó és részletes leírásával megpróbált az olvasók érzelmeire hatni, a bibliai próféciákkal és csodajelekkel kapcsolatos feljegyzések, a bemutatott természeti jelenségek és a Tamás-apokalipszisre való utalás pedig saját érdeklődését és tájékozottságát mutatja, ugyanakkor alkalmas a kevésbé művelt olvasók figyelmének megragadására is. Hydatius élete végén történeti munkájával megpróbált elismerést szerezni saját közösségén belül, és ennek érdekében számos újítást is bevezetett: a hagyományos kronológiai jelölések mellett elsőként alkalmazta a hispaniai aerát, 
szokatlanul hosszú praefatiójában sok életrajzi és forráskezelésre vonatkozó információ is helyet kapott, az olvasók érdeklődését szem előtt tartva más krónikásokhoz képest nagyobb teret biztosított a barbárokkal kapcsolatos katonai eseményeknek és a természeti jelenségeknek, a müfaj terjedelmi határait kiszélesítve pedig bizonyos eseményekkel kapcsolatban rendkívül részletes leírásokat közölt az olvasók kíváncsiságának kielégítésére. Már a praefatióban próbálja elnyerni az olvasók szimpátiáját, amikor saját lehetőségeinek és forrásainak korlátairól nyilatkozik, és bár egyetemes történeti munkát ír, érdeklődése saját korához közeledve egyre inkább Gallaecia eseményei felé fordult. Hydatius kortársa, Orosius valószínűleg azért nem szerepel a krónikában, mert eltérő a történelemszemlélete és lebecsüli a krónikaírás jelentőségét, ráadásul Hydatius feltehetően riválisának tekintette őt, és azt akarta, hogy az utókor saját magát tartsa majd Gallaecia leghíresebb történetírójának.

3. A szvévek a római kormányzattal kötött szerződés alapján telepedtek le Gallaeciában, és nem gyakoroltak a hispán-római lakosság fölött olyan abszolút hatalmat, mint ahogyan Hydatius azt ábrázolja. A barbárok letelepedését más népekkel kötött szerződéshez hasonlóan írásban is rögzíteni kellett, Hydatius viszont azért utalhat mégis a területek sorsolással történő elosztására, mert nem volt büszke arra, hogy a barbárok a központi hatalom engedélyével szállták meg Hispaniát. A szvévek valószínúleg a legitim uralkodóval vagy valamelyik usurpatorral kötött megegyezés alapján katonai szolgálatért cserébe kaptak földeket a letelepedéshez, de az is elképzelhető, hogy csak néhány csoportjuk jutott földhöz alkuszerü megállapodások következtében. A két uralkodó közötti együttmüködésről érmék is tanúskodnak, de ezt igazolja az is, hogy Hermeric két évtizedig nem indított hódító háborúkat római területek felé, 418-419 körül a rómaiak kifejezetten szvévbarát politikát folytattak, Hydatius pedig több alkalommal a korábbi szerződések megújítására utal. A szvévek sohasem foglalták el teljesen Gallaecia területét, nem avatkoztak bele a római intézmények müködésébe, kevésbé tartották szoros ellenőrzés alatt a hispán-római lakosságot, fosztogatásaiknak sohasem voltak vallási okai, de arra sincsenek meggyőző bizonyítékaink, hogy beleszóltak volna a püspökválasztásokba az általuk megszállt területen, vagy hogy szükség lett volna az engedélyükre a krónikában szereplő püspöki vizsgálatok lefolytatásához és a püspökök utazgatásához. Bár Hydatius úgy érezte, hogy a szvévek sohasem fognak eltünni Gallaeciából, régészeti leletek igazolják a birtokviszonyok megmaradását és a kereskedelem folytonosságát, ráadásul a szvévek Aquae Flaviae környéki fosztogatása arra utal, hogy a területen döntő részben hispán-római lakosság élt. 
4. A szvév-római interakciók minősége folyamatosan változott, de Hydatius egyértelmüen elutasította a velük való együttmüködést. A gallaeciabeliek a szvév megszállás kezdetén a biztonságosabb magaslatokra és erödített területekre költöztek, a földmüvesek egy része még megpróbált ellenállni a hódításoknak, de a 431-438 közötti követváltások a két nép közötti együttmüködés elindulását igazolják. Ezeket a megállapodásokat valószínűleg nem mindenki tartotta tiszteletben, a megegyezések pedig sokszor alkuszerüek voltak és csak kisebb csoportokra vonatkoztak. Rechila a hispán-római lakosság egy részével azért müködött együtt, hogy haderejüket és erőforrásaikat igénybe vehesse a szvév hódításokhoz, a katolikus Rechiarius pedig szintén stratégiai okokból, a római lakosság megnyerése miatt tekintett el az erőszakos térítésektől. A szvévek 456-os gótoktól elszenvedett vereségük után sokkal békésebb politikába kezdtek a gallaeciabeliekkel, ugyanakkor a szvév fosztogatások erősödése után sokan együttmüködtek a barbárokkal, vagyis a szvév-római kapcsolatok a körülményektől függően folyamatosan változtak, és nem jellemezhetjük őket általánosságban sem ellenséges, sem békés viszonynak. Hydatius meggyőződéssel hitt abban, hogy a diplomáciai eszközök és saját követvállalása akár hosszú távon is elősegítheti a rómaiak és a barbárok közötti problémák megoldását, ezért teljes mértékben elutasította a barbárokkal való együttmüködést, és nem akarta észrevenni azt az általános tendenciát, hogy a lesüllyedt középrétegek jelentős része a központi segítség elmaradása miatt már elidegenedett a császári politikától és saját érdekeit szem elött tartva inkább elfogadja a barbár megszállók uralmát.

5. Gaiseric vandál király a rómaiakkal való együttmüködés teljes elutasításával törekedett hatalmának megerősítésére. A vandálok a többi barbár néptől eltérően katonai szempontból sem voltak elkötelezettek a birodalom iránt, Africába való átköltözésük után már semmilyen együttmüködést nem tanúsítottak a császári vezetéssel, ráadásul a rómaiaktól átvett közigazgatási intézményeket sem mindig tartották tiszteletben és római tisztségviselőket csak ritkán alkalmaztak a hivatalokban. A vandálok a szvévekkel és a burgundokkal szemben azonnal az arianizmus hívei lettek, semmilyen mértékủ toleranciát nem mutattak az eltérő vallásúak iránt, még más területek arianus közösségeivel sem tartották fenn a kapcsolatot. Gaiseric saját hatalmának szolgálatába állította az arianus hitet, és agresszív valláspolitikával próbálta növelni a vandálok összetartását, politikai és gazdasági érdekek miatt kíméletlen üldözésben részesítette a katolikus egyház vezetőit, a római arisztokrácia egy részét elüzte az elfoglalt földekről és a maradék területek használatáért többszörös adót vetett ki, ezáltal a megszállt területeken a vandálok többnyire elkülönülve éltek a római lakosságtól. Carthago 439-es elfoglalása rendkívül nagy 
pusztítással járt, bár a helyi kulturális élet virágkorát élte Gaiseric uralkodása alatt. Miután a 442-es foedus megkötésével vandál kézre kerültek a legjelentősebb africai területek, Gaiseric Róma gabonaellátását veszélyeztetve kalózok módjára fosztogatta a Földközitenger partvidékét, ezért a történetírók nagy túlzásokkal ábrázolták a vandálok 455-ös római betörését is, 468-ban pedig a keleti és nyugati csapatok összehangolt támadással próbáltak véget vetni tevékenységüknek. Gaiseric nem osztotta meg a hatalmát más vandál vezetőkkel, ezáltal jogköre lényegesen nagyobbnak tűnik, mint a többi germán uralkodónak, Hydatius talán ezért hozta összefüggésbe személyét bibliai próféciákkal, ugyanakkor a 460as években azért nem hallunk a vandálok kegyetlenségéről, mert így a szvév fosztogatások mértéke nagyobbnak látszódhat az olvasók elött.

6. Hydatius mindig kiállt a császári hatalom és az ortodoxia védelme mellett. A barbárokat a történeti hagyományban kialakult negatív sztereotípiáknak megfelelően erőszakos, fosztogató és megbízhatatlan embereknek ábrázolta, a germán invázió mértékét és következményeit is túlzásokkal mutatta be, mert álláspontja szerint a germán népek a hagyományos római rend elpusztítására törekedtek, ugyanakkor igyekszik elhallgatni a rómaiak szerződésszegéseit és kegyetlenségét, amelyek gyakran kiprovokálták a barbárok viselkedését. Kemény kritikával illeti azokat a rómaiakat, akik a császárhoz való lojalitás és a birodalmi rend helyreállítása helyett az árulást választották vagy saját hatalmi törekvéseikhez eszközként használták a barbarizálódott római hadsereget, ellensúlyozásként pedig a római császárokról és hadvezérekről igyekszik pozitív portrékat készíteni az olvasók számára, elhallgatva minden olyan eseményt, amely rossz fényt vetne a példaképként ábrázolt egyházi és politikai vezetők tevékenységére. Hydatius csaknem teljes rálátást biztosít az 5. században népszerü eretnekmozgalmakra, de a tanítások értelmezése helyett azt próbálja megmutatni az olvasóinak, hogy ezek a mozgalmak milyen módon gyengítették az ortodoxia helyzetét és hogyan sodorták válságba a birodalmi irányítást. Nagy hangsúlyt kapnak a krónikában azok az egyházi vezetők, akik hozzá hasonlóan kiálltak az ortodoxia mellett és konkrét lépésekkel is harcoltak az eretnek tanításokkal szemben, a pelagianizmus említését például Hieronymus, a donatizmusét Augustinus ellenük elért sikerei indokolják. Hydatius csodás jelenségek iránti érdeklődése a pogányság és az eretnekség hatását csak annyiban mutathatja, hogy ismerte az ezzel kapcsolatos próféciákat, de nem tartotta azokat az ortodoxiával ellentétesnek. A körülötte lévő zürzavar ellenére rendületlenül hisz a világi és egyházi hatalom erejében, ezért a gallaeciai válság megoldását is tölük várja, ugyanakkor a birodalmat szétfeszítő erőket képtelen természetes történelmi jelenségként értelmezni. Gallaecia válságos helyzete arra ösztönözte őt, hogy több formában is fellépjen a barbárok 
és az eretnekek elleni küzdelemben, ezért lelkesen vállal követséget a szvévek fosztogatása idején, később lelkiismeretesen vesz részt a priscillianusok és a manicheusok ellen indított nyomozásban, mindez pedig megcáfolja több kutató azon feltételezését, hogy a hispánrómaiak teljes közömbösséget mutattak saját helyzetük javításában a barbár megszállások alatt. A 460-as szvév támadáskor a besúgók valószínüleg azért akarták őt eltávolítani a közéletböl, mert túlságosan ismert volt a római érdekek és az ortodoxia melletti elkötelezettségéröl.

7. Hydatius krónikája nem kíván apokaliptikus értelmezést, mert központi témája nem a közeledő világvége. A Hydatius által példaképként említett egyházi és politikai vezetők tevékenységükkel optimális esetben meg tudnák menteni a birodalmat, az égi büntetések és beteljesedett próféciák mellett pedig jelentős szerep jut az isteni könyörületesség és segítség ábrázolásának is, ráadásul mivel az egyházi személyiségekhez hasonlóan elutasította az eszkatologikus számításokat, Hydatius számára is közömbös lehetett, hogy mennyi idő van még hátra az esetleges világvégéig. Bár feltehetően a priscillianusok közvetítésével megismerte Tamás apokalipszisét, a krónikában sohasem említette konkrétan a közeledő világvégét, és Thoribius levélben is figyelmeztette a püspököket az apokrif iratok veszélyességére, ezért Hydatius minden bizonnyal engedelmeskedett a felsőbb egyházi utasításoknak. A krónikában szereplő természetfölötti jelenségek és csodajelek nem mindig kapcsolhatók konkrét eseményekhez, alkalmazásukat leginkább Hydatius érdeklődésével és az olvasók szórakoztatásával magyarázhatjuk, vagyis irodalmi eszközként a figyelem fenntartására használja a csodás és természetfölötti jelenségeket, apokaliptikus utalásai csak azt igazolják, hogy ragaszkodik a bibliai hagyományokhoz, az évszámítási táblázat közlése pedig a formai követelményeknek való megfelelés miatt vált szükségessé. Hydatius a múlt eseményeinek összegyüjtésével a történelmi idők folytatását várta, olvasóit pedig a krónika folytatására buzdította, ha viszont valóban a közeledő világvégére készült volna, egyik tényezőnek sem lenne létjogosultsága.

8. Hydatius a gallaeciai közösség megbecsült tagja volt, de élete végén elveszítette népszerüségét és külső kapcsolatait is. Hydatiust valószínűleg vallásos nevelésének és közösségen belüli megbecsültségének köszönhetően választották rendkívül fiatalon Aquae Flaviae püspökévé. Az egyházi vezetők diplomáciai tekintélyét kihasználva saját felelősségének tudatában a helyi lakosság szószólójaként vállalkozott a 431-es követségre, amellyel saját elszigeteltségét is kompenzálva bekapcsolódhatott volna a politikai életbe, sikeres békekötés esetén pedig tovább növelhette volna egyházon belüli befolyását. Hydatius már fiatalon ismert lehetett az ortodoxia melletti elkötelezettségéről, ezért őt kérte 
fel Thoribius és Leo pápa az eretnekekkel szembeni vizsgálatra, ugyanakkor nem tudunk Hydatius önálló püspöki intézkedéseiről a többségében priscillianus Gallaeciában, talán mert nézetei miatt megfélemlítették és elrabolták, vagy próbálkozásai kudarccal végződtek. Bár püspökké választása után biztosan kibővültek egyházi kapcsolatai, a 456 utáni zavaros politikai helyzet miatt egyre kevésbé tudta tartani Gallaecián kívüli kapcsolatait és alig juthatott hozzá megbízható forrásokhoz. Utolsó éveinek kétségbeejtő helyzete krónikaírásra ösztönözte Hydatiust, amely korábbi küzdelmeinek kudarca után végre hosszú távon is elismerést hozhatott volna számára, de szövegének túlzott részletessége és bonyolult nyelvezete miatt nem szerzett népszerüséget. 


\section{MELLÉKLETEK}

\section{Kronológiai listák}

\section{Római császárok}

I. Constantinus

Maxentius

Licinius

II. Maximinus

II. Constantinus

I. Constans

II. Constantius

Magnentius (usurpator)

Gallus (usurpator)

Iulianus

Iovianus

I. Valentinianus

Valens

Procopius (usurpator)

Gratianus

II. Valentinianus

I. Theodosius

Magnus Maximus (usurpator)

Eugenius (usurpator)

\section{Nyugatrómai császárok}

Honorius

III. Constantius

Iohannes (usurpator)

III. Valentinianus

Petronius Maximus (usurpator)

Avitus

Maiorianus

Libius Severus

Anthemius

Olybrius

\section{Keletrómai császárok}

Arcadius

II. Theodosius

Marcianus

I. Leo

\author{
306. július 25 . $\quad-337$. május 22 . \\ 306. október 28 . - 312. október 28. \\ 308. november 11 . - 324. szeptember 18. \\ 311. május. $1 . \quad-313$. július/augusztus \\ 337. május 22 . $\quad-340$. április \\ 337. május 22 . $\quad-350$. január 18. \\ 337. május 22 . $\quad-361$. november 3. \\ 350. január 18 . - 353. augusztus 11 . \\ 351. március 15 . $\quad-354$ \\ 360. február $\quad-363$. június 26. \\ 363. június $26 . \quad-364$. február 17. \\ 364. február 26 . $\quad-375$. november 17. \\ 364. március 28 . - 378. augusztus 9. \\ 365. szeptember 26. - 366. május 27. \\ 367. augusztus 4 . $\quad-383$. augusztus 25. \\ 375. november 17 . - 392. május 15 . \\ 379. január $19 . \quad$ - 395. január 17. \\ 383. augusztus $\quad-388$. augusztus 28 . \\ 392. augusztus 22 . - 394. szeptember 6 .
}

395. január $17 . \quad-$ 408. május 1 .

408. május $1 . \quad-450$. július 28 .

450. augusztus 25 . - 457. január 26 .

457. február $7 . \quad-474$. január 18. 


\section{Vizigót királyok}

$\begin{array}{lll}\text { Athanaric } & 364 / 365 & -381 \text {. január } 11 . \\ \text { Alaric } & 395 & -410 \\ \text { Athaulf } & 410 & -415 \text {. augusztus } 15 . \\ \text { Sigeric } & 415 & -415 \text {. augusztus } 22 . \\ \text { Vallia } & 415 & -418 \\ \text { I. Theoderic } & 418 & -451 \text {. június } 20 . \\ \text { Thorismund } & 451 & -453 \\ \text { II. Theoderic } & 453 & -466 \\ \text { Euric } & 466 & -484 \text {. december } 28 .\end{array}$

\section{Vandál királyok}

Godigisel

$359-406$

Gunderic

$406 / 407-428$

Gaiseric

428

- 477. január 25 .

\section{Szvév királyok}

Hermeneric

Heremigarius

Rechila

Rechiarius

Aioulf (D)

Framtane (É)

Maldras (D)

Rechimund (É)

Frumarius (D)

Remismund

II. Hermeneric
409

427

438

448

456

456

457

457

460

465

469
$-438$

$-429$

$-448$

- 456. december

- 457. június

$-457$

- 460. február

$-464$

$-464$

$-469$

$-485$

\section{Római pápák}

I. Iulius

Liberius

II. Felix (ellenpápa)

I. Damasus

Ursicinus (ellenpápa)

Siricius

I. Anastasius

I. Innocentius

Zosimus

Eulalius (ellenpápa)

I. Bonifatius

I. Coelestinus

III. Sixtus

I. Leo

Hilarius

Simplicius
337. február 6. - 352. április 12 .

352. május $17 . \quad-366$. szeptember 24.

$355-365$. november 22.

366. október 1 . - 384. december 11 .

366. október $1 . \quad-367$. november 16.

384. december 11 . - 399. november 26.

399. november 27 . - 401. december 19.

401. december 22 . - 417. március 12 .

417. március 18 . - 418. december 26.

418. december 27 . - 419. április 29.

418. december 29 . - 422. szeptember 4.

422. szeptember 10. - 432. július 27 .

432. július 31. - 440. augusztus 19.

440. szeptember 29. - 461. november 10.

461. november 19 . - 468. február 29.

468. március 3 . - 483. március 10. 


\section{Constantinopolisi patriarchák}

Nicomediai Eusebius

$339-341$

I. Paulus

$341-342$

I. Macedonius

$342-346$

I. Paulus

$346-350$

I. Macedonius

$351-360$

Antiochiai Eudoxius

$360-370$

Florentius

363

Demophilus

$370-380$

Euagrius

$370 / 379$

I. Maximus

380

Gregorius Nazianzenus $\quad 380-381$

Nectarius

$381-397$

Iohannes Chrysostomus

$398-404$

$404-405$

$406-425$

Atticus

$426-427$

I. Sisinnius

$428-431$

Nestorius

$431-434$

Maximianus

$434-446$

Proclus

$446-449$

Flavianus

$449-458$

Anatolius

$458-471$

\section{Hierosolymai patriarchák}

I. Macarius

III. Maximus

I. Cyrillus

II: Iohannes

Praulius

Iuvenalis

I. Anastasius
$325-333$

$333-348$

$350-386$

$386-417$

$417-422$

$422-458$

$458-478$

\section{Alexandriai patriarchák}

I. Athanasius

$328-339$

Cappadociai Gregorius

I. Athanasius

$339-346$

II. Petrus

$346-373$

I. Timotheus

$373-380$

$380-385$

I. Theophilus

$385-412$

I. Cyrillus

$412-444$

I. Dioscorus

$444-451$

Proterius

$451-457$

II. Timotheus Aelurus

$457-460$

III. Timotheus Salofaciolus $460-475$ 


\section{Antiochiai patriarchák}

$\begin{array}{ll}\text { Antiochiai Stephanus } & 342-344 \\ \text { Leontius } & 344-358 \\ \text { Eudoxius } & 358-359 \\ \text { Anianus } & 359 \\ \text { Meletius } & 360-361 \\ \text { Euzoius } & 361-378 \\ \text { Meletius } & 362-381 \\ \text { II. Paulinus } & 362-388 \\ \text { Antiochiai Dorotheus } & 378-381 \\ \text { I. Flavianus } & 381-404 \\ \text { Euagrius } & 388-393 \\ \text { Porphyrus } & 404-412 \\ \text { Alexander } & 412-417 \\ \text { Theodotus } & 417-428 \\ \text { I. Iohannes } & 428-442 \\ \text { II. Domnus } & 442-451 \\ \text { II. Maximus } & 451-455 \\ \text { I. Basilius } & 456-458 \\ \text { Acacius } & 458-461 \\ \text { Martyrius } & 461-469\end{array}$

\section{Földrajzi nevek mutatója}

A Chronica szövegében és a jegyzetekben előforduló földrajzi nevek közül csak azokat közöljük, amelyek kevésbé ismertek és a mai alakjuk különbözik a latin elnevezésüktől. A Hydatiusnál előforduló helynevek és vidékek áttekintéséhez lásd: 1-2. sz. térkép.

Agrigentum [Agrigento]

Alexandria [Al Iskandariyah]

Ambianum [Amiens]

Anas [Guadiana]

Ancyra [Ankara]

Antiochia [Antakya]

Aquae Celenae [Caldas de Reis]

Aquae Flaviae [Chaves]

Aquileia [Aglar]

Aquitania [Gascogne]

Arausio [Orange]

Arelate [Arles]

Argontoratum [Strasbourg]

Ariminium [Rimini]

Asturica [Astorga]

Augustodunum [Autun]

Augustonemetum [Clermont-Ferrand]
Aunona [Tui]

Auregens [Orense]

Aurelianum [Orléans]

Avaricum [Bourges]

Baetis [Guadalquivir]

Baleares [Baleári-szigetek]

Barcilona [Barcelona]

Biterrae [Béziers]

Bracara Augusta [Braga]

Brixia [Brescia]

Burdigala [Bordeaux]

Burentinus [Busento]

Byzacena [Tunézia]

Caesaraugusta [Zaragoza]

Caesarea [Cherchell]

Caesarea Maritima [Kesarije]

Caesarodunum [Tours] 
Calagurris [Calahorra]

Carthago Nova [Cartagena]

Casae Nigrae [Negrine]

Catalaunum [Châlons-sur-Marne]

Cauca [Coca]

Chalcedon [Kadiköy]

Conimbrica [Condeixa-a-Velha]

Consentia [Cosenza

Constantinopolis [Isztambul]

Corduba [Córdoba]

Coviacum [Valencia de Don Juan]

Cyrus [Kurus]

Danuvius [Duna]

Dertona [Tortona]

Diospolis [Lydda]

Dorylaeum [Eskişehir]

Durius [Duero]

Edessa [Urfa]

Elvira [Granada]

Emerita [Mérida]

Ephesus [Efes]

Erbasis [Nerbasis]

Faesulae [Fiesola]

Frigidus [Vipala]

Gades [Cádiz]

Hadrianopolis [Edirne]

Hasta [Asti]

Heraclea [Marmaraereğlisi]

Hierosolyma [Jeruzsálem]

Hippo Regius [Annaba]

Hispalis [Sevilla]

Iberus [Ebro]

Ilerda [Lérida]

Isauria [Bozkir]

Laodicea [Latakia]

Legio [León]

Lemica [Nocelo da Pena]

Lerinum [Lérins]

Liris [Garigliano]

Lucentum [Alicante]

Lucus [Lugo]

Martylis [Mertola]

Mediolanum [Milánó]

Meseta [Meseta Central]

Mettis [Metz]

Mileve [Mila]

Moguntiacum [Mainz]

Mopsuestia [Yakapinar]

Morinorum Castellum [Cassel]

\author{
Narbo [Narbonne] \\ Nasianzus [Aksaray] \\ Neapolis [Nápoly] \\ Nemetacum [Arras] \\ Nicaea [Iznik] \\ Nicomedia [Izmit] \\ Novimagus [Noyon] \\ Ossonuba [Faro] \\ Palentia [Palencia] \\ Pamplona [Iruña] \\ Panormus [Palermo] \\ Philippopolis [Plovdiv] \\ Pictavium [Poitiers] \\ Placentia [Piacenza] \\ Poetovium [Ptuj] \\ Pollentia [Pollenzo] \\ Ponte Vetera [Pontevedra] \\ Portus Cale [Porto] \\ Promunturium Mercurii [Bon-fok] \\ Remi [Reims] \\ Rhenus [Rajna] \\ Rhodanus [Rhone] \\ Salamis [Famaguszta] \\ Salona [Solin] \\ Samosata [Samsat] \\ Scallabis [Santarém] \\ Scyllaceum [Scylletium] \\ Serdica [Szófia] \\ Singillium [Genil] \\ Spira [Speyer] \\ Tagus folyó [Tajo] \\ Tarraco [Tarragona] \\ Tarsus [Tarsus] \\ Tauromenion [Taormina] \\ Thagaste [Souk Arrhas'an] \\ Thessalonice [Szaloniki] \\ Ticinum [Pavia] \\ Toletum [Toledo] \\ Tolosa [Toulouse] \\ Treveri [Trier] \\ Tricassis [Troyes] \\ Tude [Tui] \\ Turnacum [Tournai] \\ Turoni [Tours] \\ Tyriasso [Turiazo] \\ Ulixippona [Lisszabon] \\ Urbicus [Orbigo] \\ Utriculum [Otricoli] \\ Vienna [Vienne]
}




\section{Térképek}
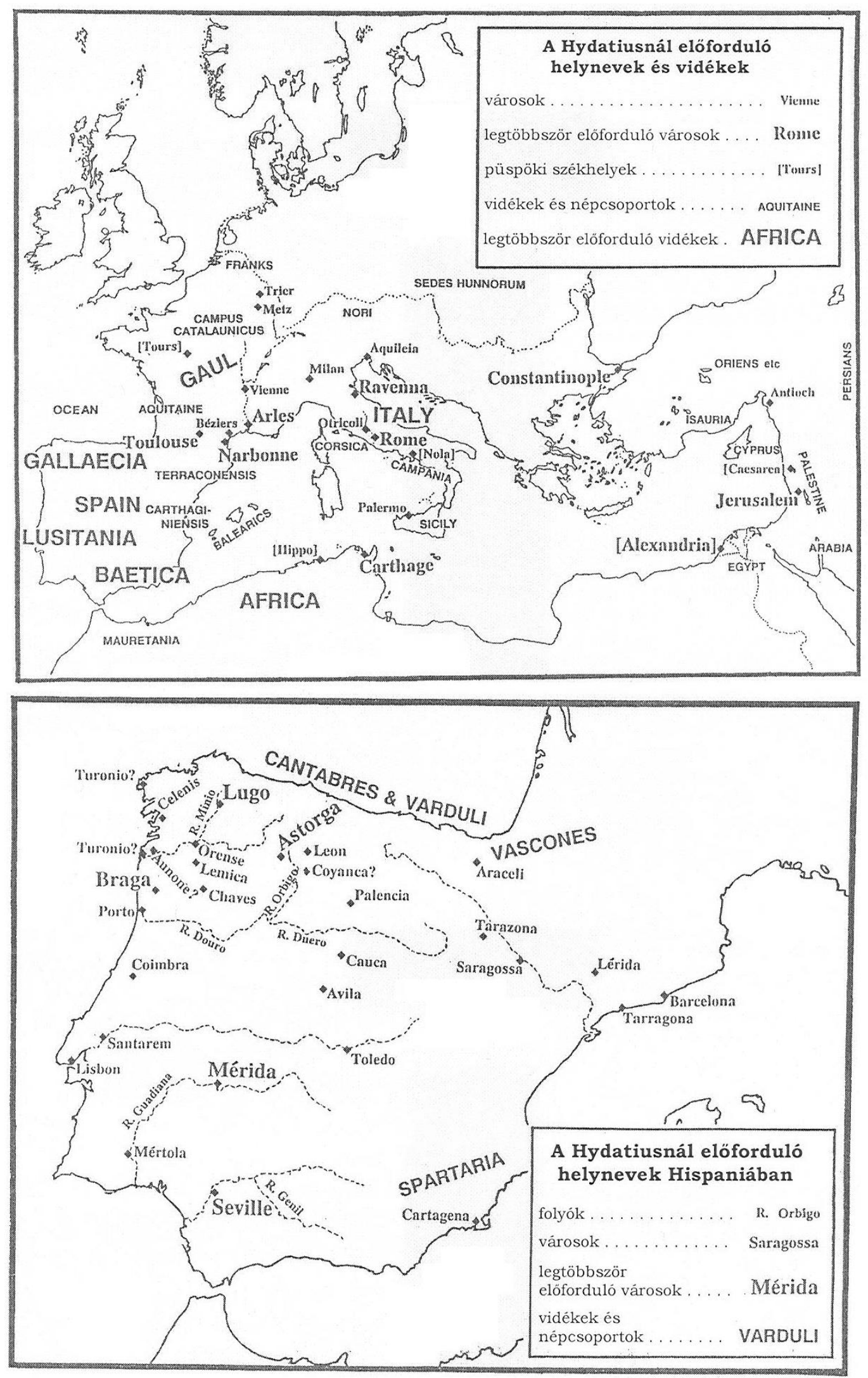

1-2. sz. térkép: A Hydatiusnál előforduló helynevek és vidékek Hispaniában (saját szerkesztés Muhlberger 1990, 218; 246. alapján) 


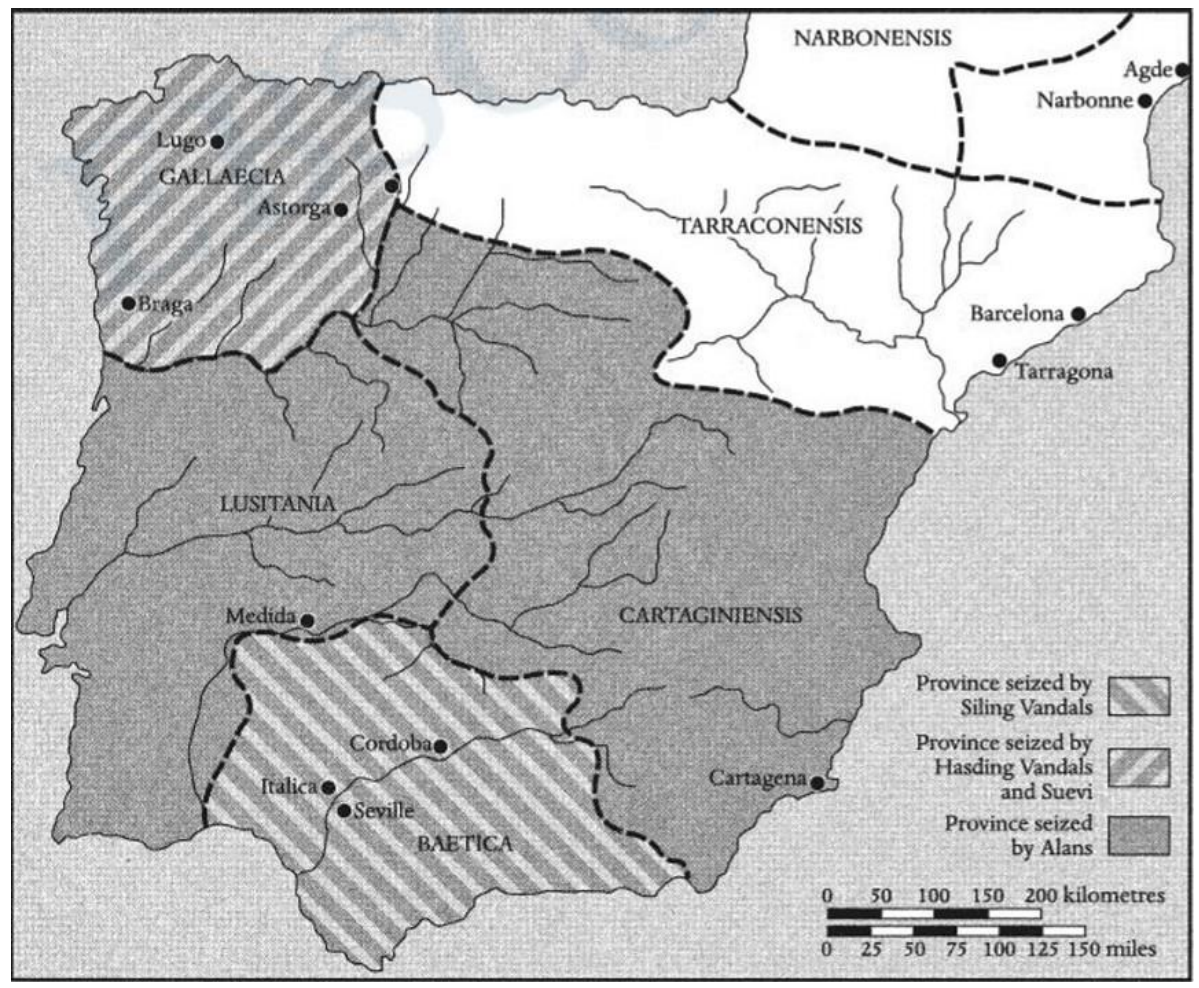

3. sz. térkép: Hispania felosztása 411-ben (In: Heather 2006, 209, fig. 9.)

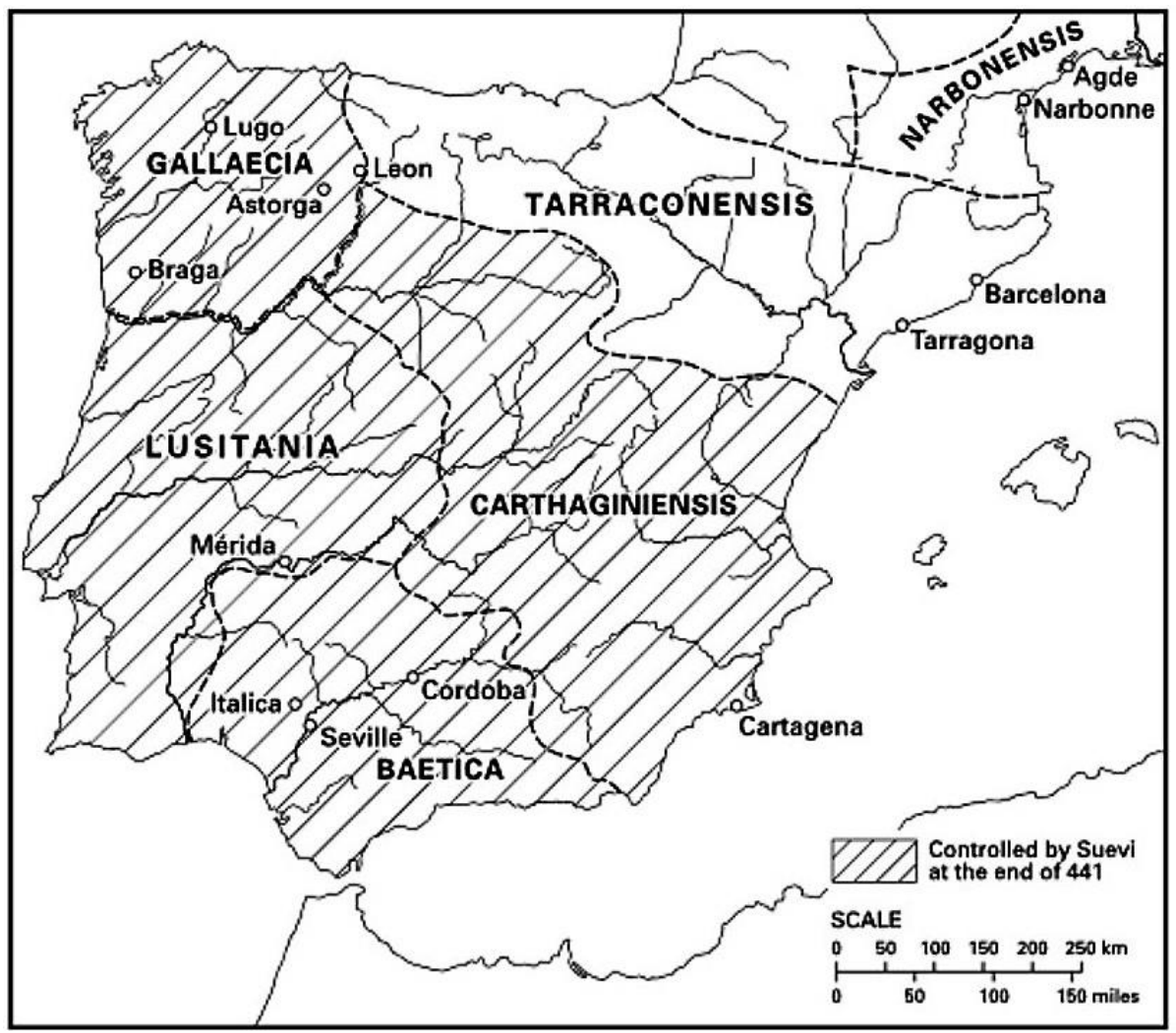

4. sz. térkép: Szvév ellenőrzés alatt álló területek 441-ben (In: Heather 2007b, 12, fig. 3.) 


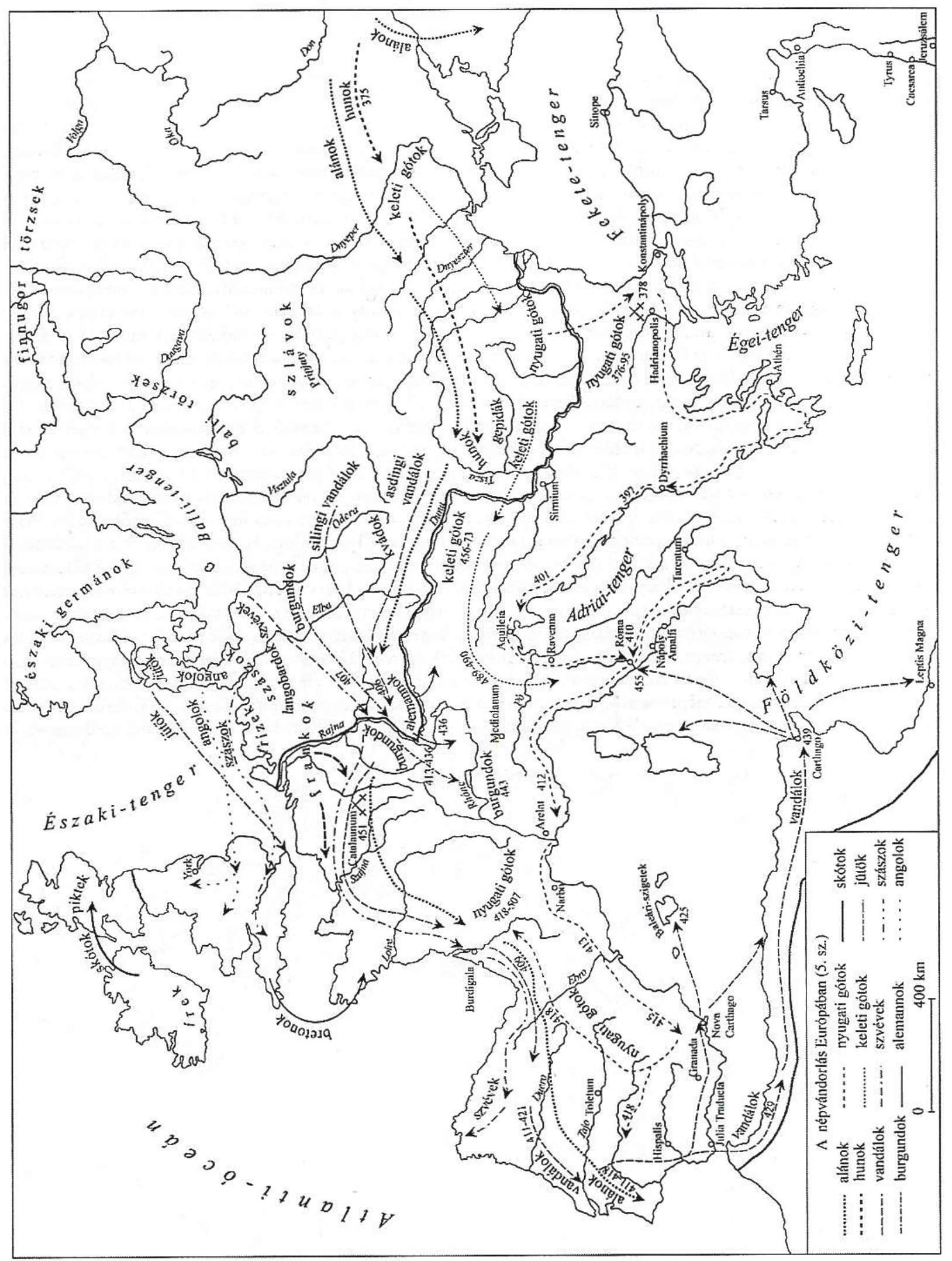

5. sz. térkép: Az 5. századi európai népvándorlás

(In: Szántó 2007, 13.) 


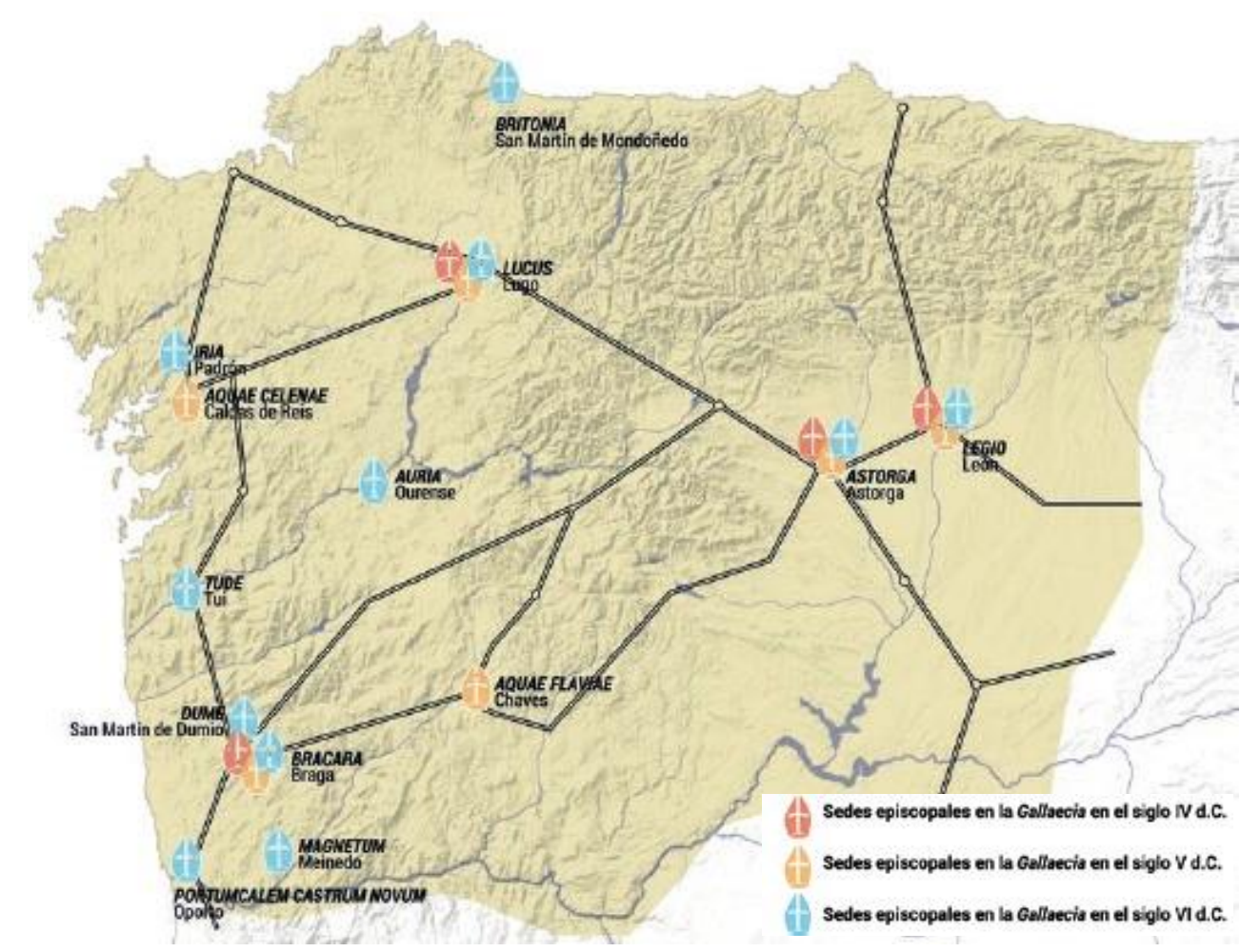

6. sz. térkép: Püspöki székhelyek és kapcsolatok a 4-6. századi Gallaeciában (In: López Quiroga - Martínez Tejera 2017, 126, fig. 26.)

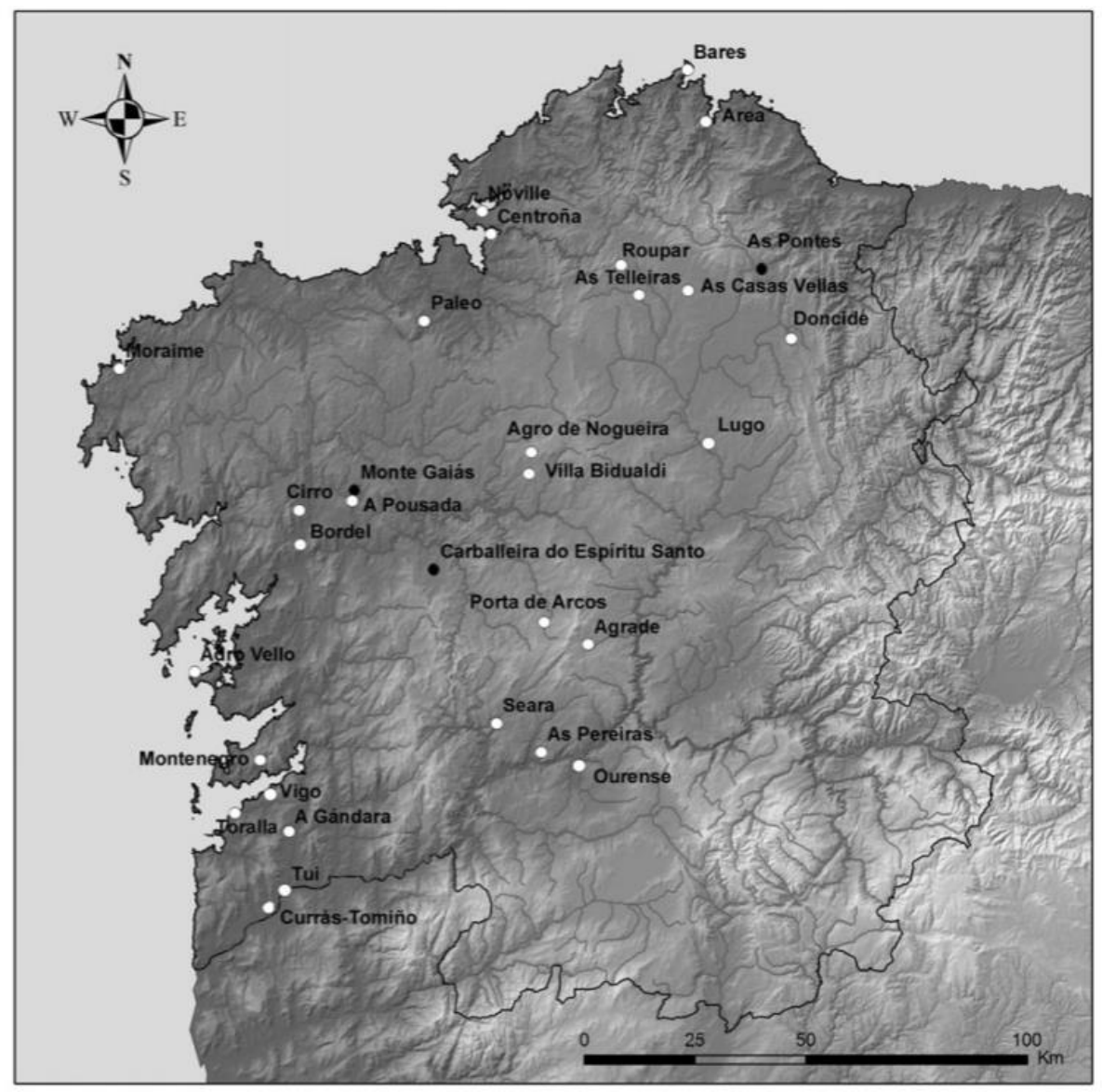

7. sz. térkép: A szvév letelepedés központi helyei (०) és a mezőgazdasági termelés színterei $(\bullet)$

(In: Sánchez Pardo 2013, 145, fig. 2.) 


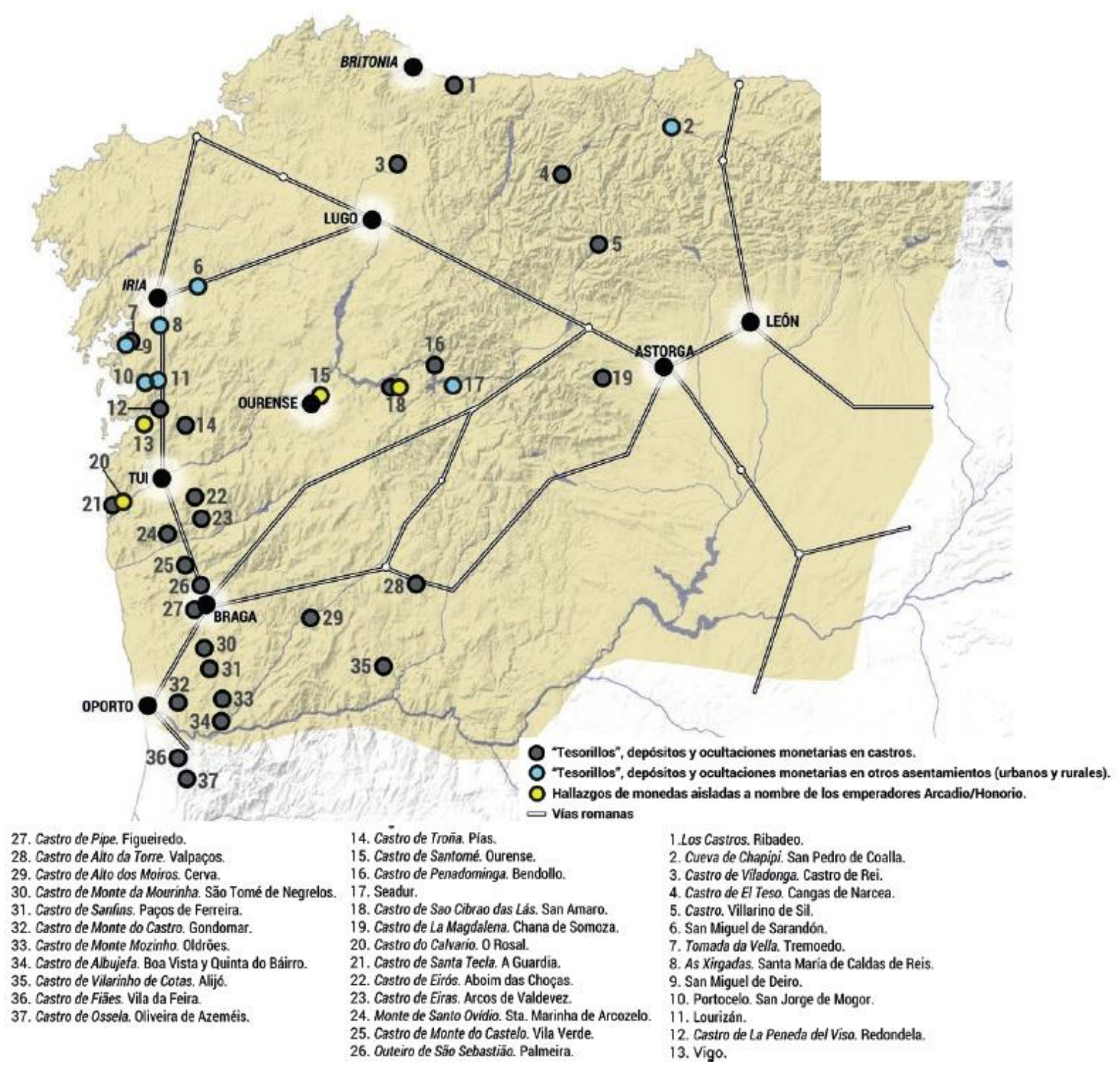

8. sz. térkép: Numizmatikai lelöhelyek a 4-5. századi Gallaeciában

(In: López Quiroga - Martínez Tejera 2017, 209, fig. 52.) 


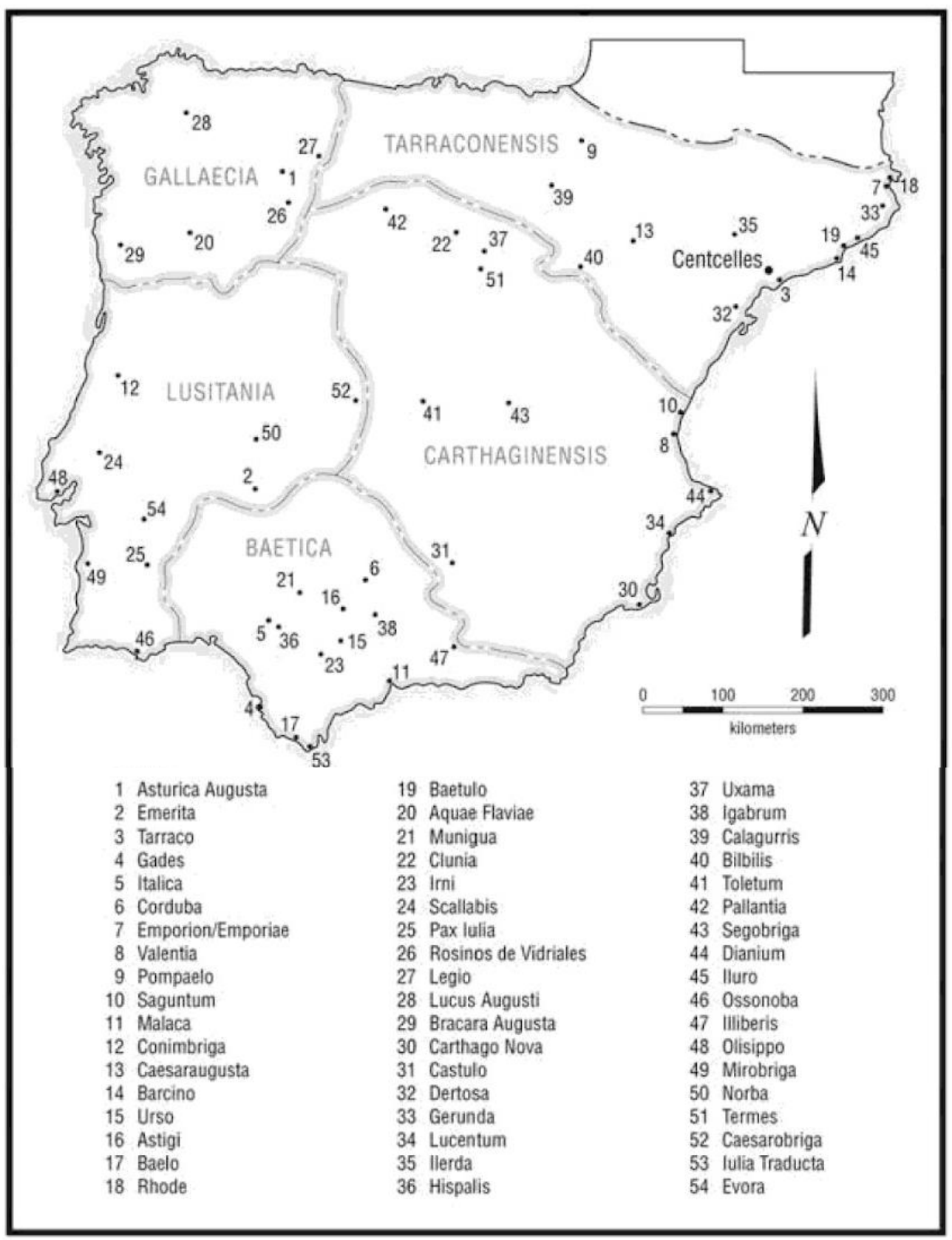

9. sz. térkép: Hispania közigazgatási rendszere Diocletianus idején (In: Kulikowski 2010, xxi.) 


\section{Képek}

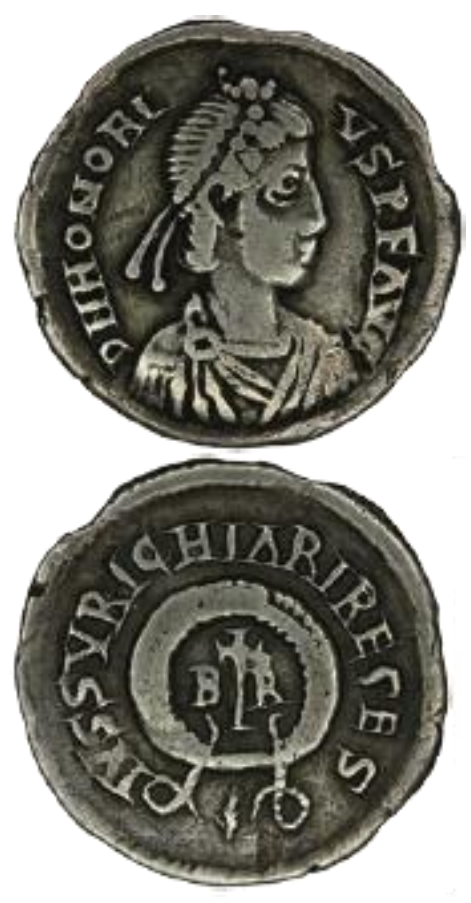

1. sz. kép: Rechiarius bracarai siliqua-ja (In: López Quiroga - Martínez Tejera 2017, 37, fig. 17.)
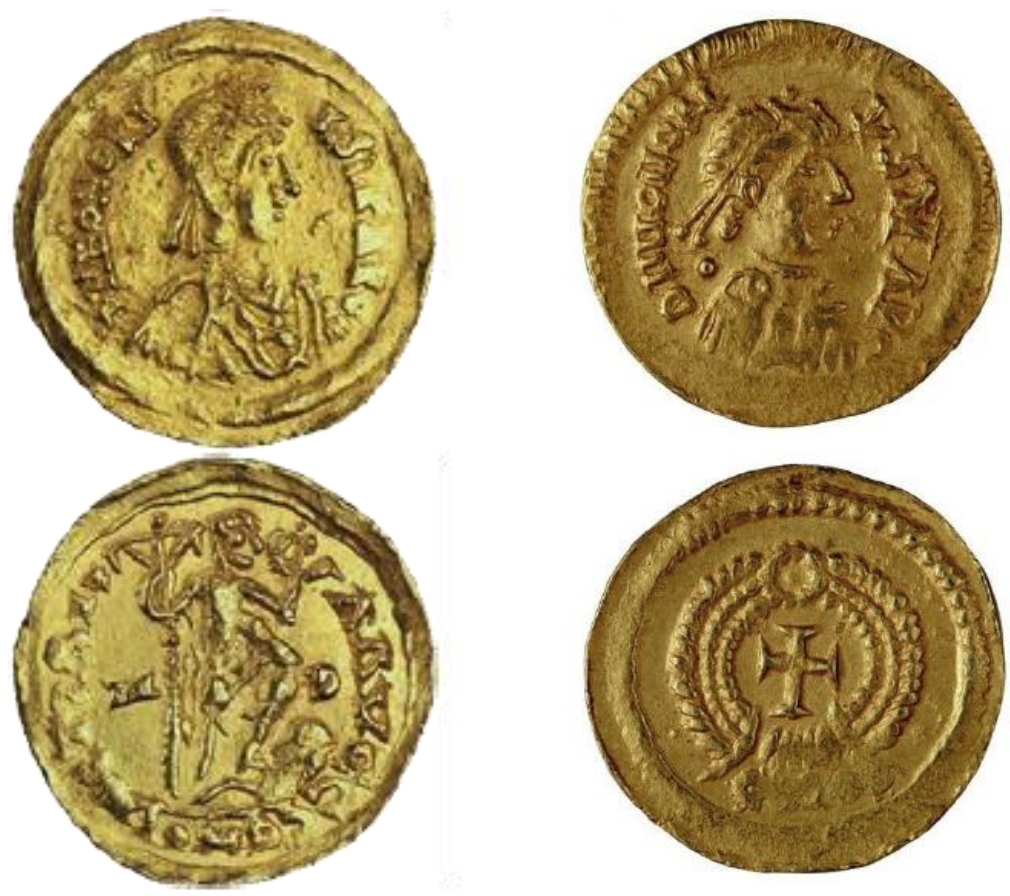

2. sz. kép: Honorius nevével veretett solidus és tremissis (In: López Quiroga - Martínez Tejera 2017, 37, fig. 16; 70, no. 39.) 

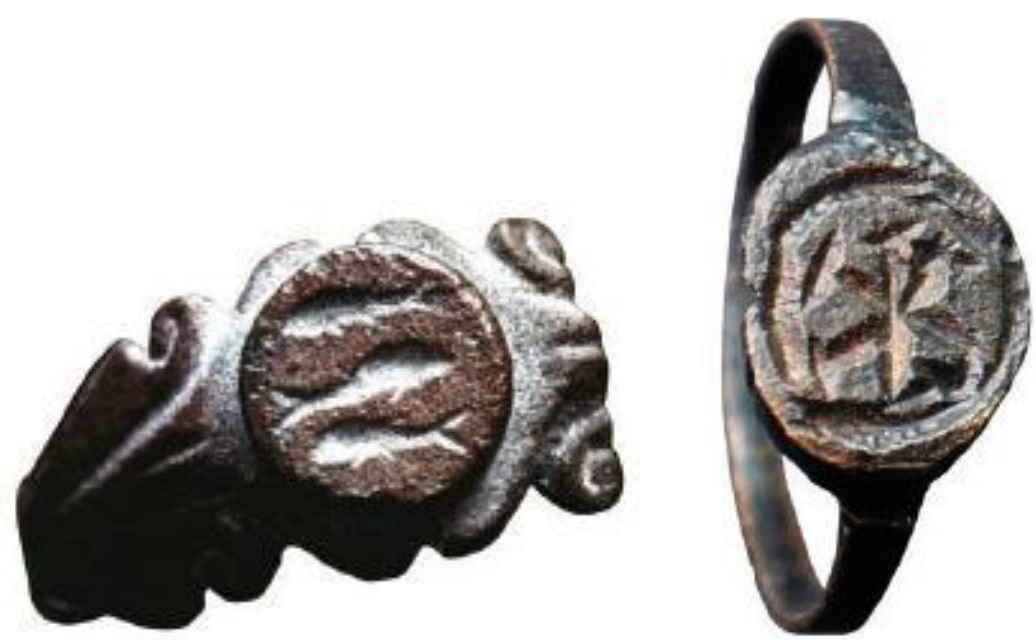

3. sz. kép: A lucusi ezüst- és az asturicai bronzgyürü

(In: López Quiroga - Martínez Tejera 2017, 161, no. 98; 163, no. 100.)
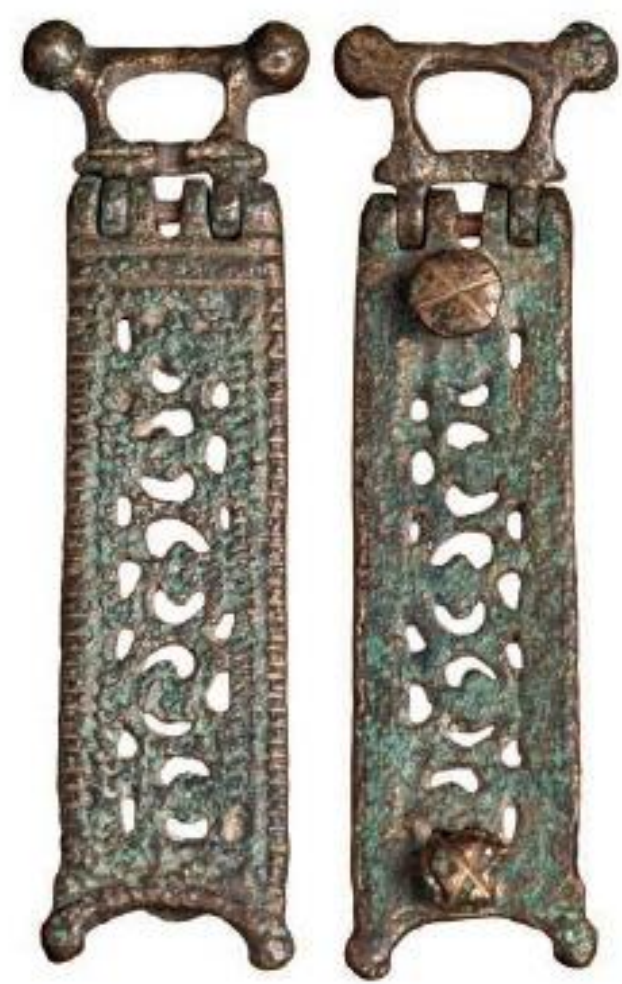

4. sz. kép: 4. századi bronz övcsat Penadomingából (In: López Quiroga - Martínez Tejera 2017, 256, no. 173.) 


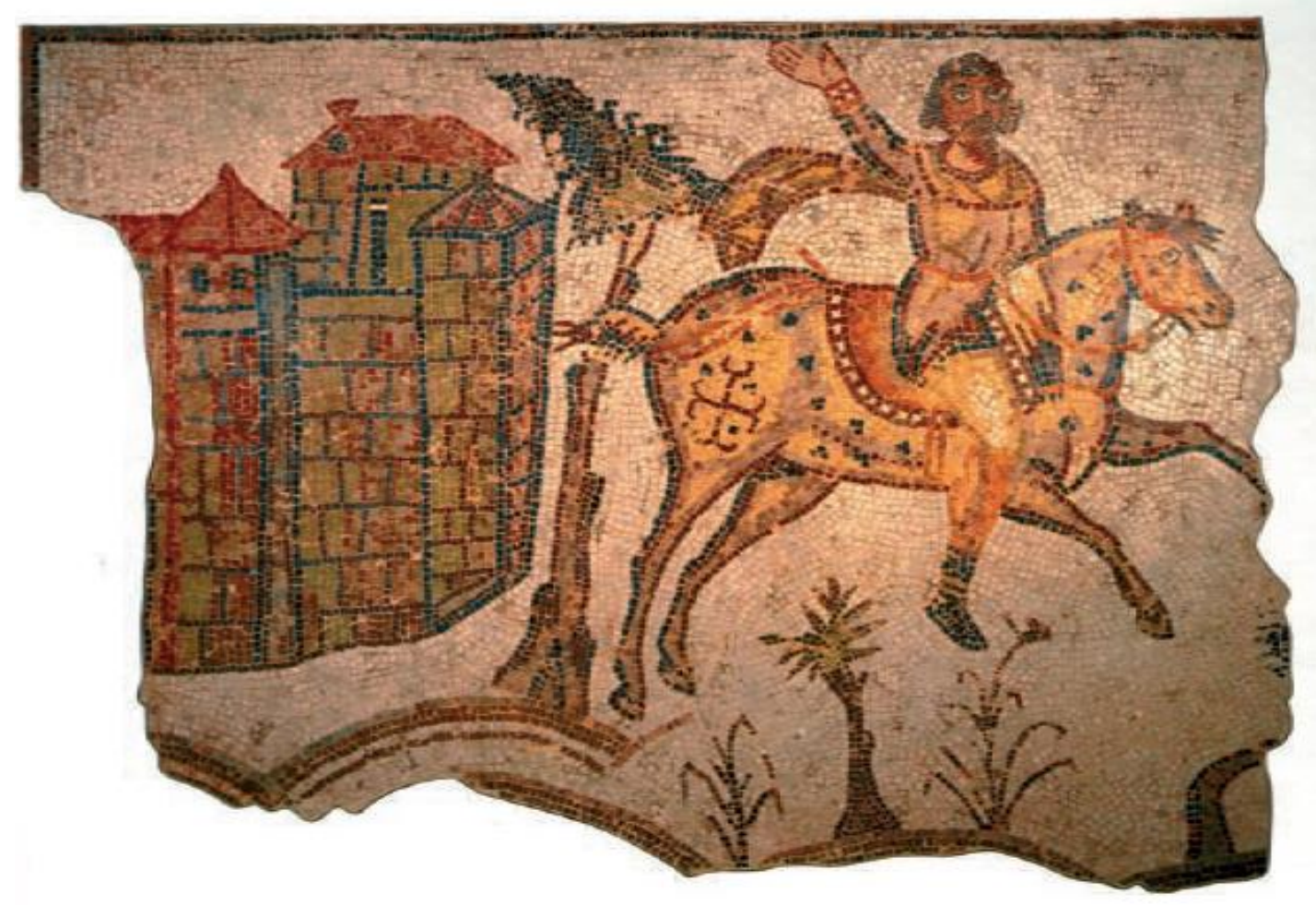

5. sz. kép: Vadászjelenetet ábrázoló mozaik Borj Jedid területéről (In: Rummel 2008, 177, abb. 4.)
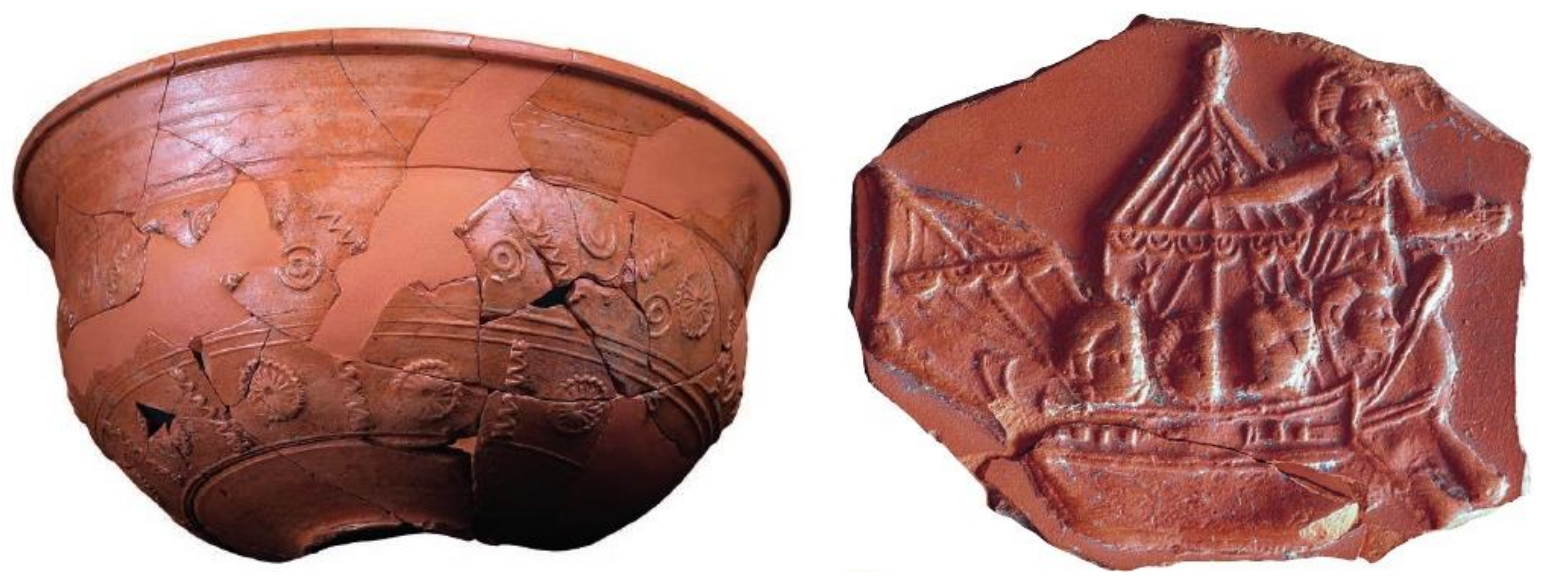

6. sz. kép: 4-5. századi étel- vagy víztároló edénytöredékek Lucusból (In: López Quiroga - Martínez Tejera 2017, 166, no. 105; 167, no. 107.) 


\section{Felhasznált irodalom}

\section{Rövidítések}

$\boldsymbol{A C O}=$ Acta Conciliorum Oecumenicorum iussu atque mandato Societatis Scientiarum Argentoratensis. Vols. 1-24. Eds. E. Schwartz - J. Straub. Berlin, 1914-1984; $1995^{2}$. $\boldsymbol{A N R \boldsymbol { W }}=$ Aufstieg und Niedergang der Römischen Welt. Vol. I. Eds. H. Temporini - W. Haase. Berlin-New York, 1972.

CSEL $=$ Corpus Scriptorum Ecclesiasticorum Latinorum. Wien, 1866-1886.

Mansi $=$ Sacrorum Conciliorum Nova et Amplissima Collectio. Vols. 1-31. Ed. J. D. Mansi. Firenze-Venezia, 1759-1798; Paris, 1899-1927²; Graz, 1961-1962³ .

MGH AA CM = Monumenta Germaniae Historica, Auctores Antiquissimi IX.; XI.; XIII.; Chronica minora IV-VII saec. 1.; 2.; 3. Ed. Th. Mommsen. Berlin, 1892; 1894; 1898; Munich, $1981^{2}$.

$\boldsymbol{P G}=$ Patrologiae Graecae cursus completus. Vols. 1-161. Ed. J. P. Migne. Paris, 18571866.

$\boldsymbol{P L}=$ Patrologiae Latinae cursus completus. Vols. 1-222. Ed. J. P. Migne. Paris, 1844$1865,1878-1890^{2}$.

PLRE $=$ The Prosopography of the Later Roman Empire. Vols. II-III. Eds. A. H. M. Jones J. R. Martindale - J. Morris. Cambridge, 1980-1992.

$\boldsymbol{R} \boldsymbol{E}=$ Paulys Realencyclopädie der classischen Altertumswissenschaft. Hrsg. G. Wissowa et al. Stuttgart, 1894-1986.

\section{Források}

Amm. Marc. $=$ Ammiani Marcellini rerum gestarum libri qui supersunt. Vols. I-II. Ed. W. Seyfarth. Berlin, 1978. = Ammianus Marcellinus: Róma története. Ford. Szepesy Gy. Budapest, 1993.

August., De Civ. = Augustin, De civitate Dei. Ed. T. E. Page. Cambridge, 1966. = Aurelius Augustinus püspöknek a pogányok ellen Isten városáról írt 22 könyve. Ford. Földváry A. Vols. I-II. Budapest, 1942-1943, 2005². = Az Isten államáról (részletek). Ford. Hoffmann Zs. In: Róma: Egy világbirodalom politikai, erkölcsi és történelmi eszméi I. Antik államelméleti antológia. Agatha IV. Szerk. Havas L. et al. Debrecen, 1998, 447457.

Beda, Chr. = Bedae chronica maiora et minora. In: MGH AA XIII., CM 3. Ed. Th. Mommsen. Berlin, 1898, 223-356.

Biblia $=$ Ó- és Újszövetségi Szentírás. Szerk. E. Beck. Budapest, 2016.

Cass. = Cassiodori Senatoris chronica ad a. DXIX. In: MGH AA XI., CM 2. Ed. Th. Mommsen. Berlin, 1894, 109-162. 
Chr. Gall. 452 = Chronica Gallica a. CCCCLII et DXI. In: MGH AA IX., CM 1. Ed. Th. Mommsen. Berlin, 1892, 615-665. = The Gallic Chronicle of 452: A New Critical Edition with a Brief Introduction. Transl. R. Burgess. In: Society and Culture in Late Antique Gaul. Eds. R. W. Mathisen - D. Shanzer. Aldershot, 2001, 52-84.

Chr. Gall. 511 = Chronica Gallica a. CCCCLII et DXI. In: MGH AA IX., CM 1. Ed. Th. Mommsen. Berlin, 1892, 615-665. = The Gallic Chronicle of 511: A New Critical Edition with a Brief Introduction. Transl. R. Burgess. In: Society and Culture in Late Antique Gaul. Eds. R. W. Mathisen - D. Shanzer. Aldershot, 2001, 85-99.

$\boldsymbol{C I}=$ Codex Iustinianus. In: Corpus Iuris Civilis. Vol. II. Ed. P. Krüger. Dublin-Zürich, 1967.

$\boldsymbol{C T h}=$ Codex Theodosianus. Ed. P. Krüger. Berlin, 1923.

Cons. Const. $=$ Consularia Constantinopolitana ad a. CCCXCV ecum additamcnto Hydatii ad a. CCCCLXVIII: accedunt consularia chronici paschalis. In: MGH AA IX., CM 1. Ed. Th. Mommsen. Berlin, 1892, 196-248. = The Consularia Constantinopolitana. In: The Chronicle of Hydatius and the Consularia Constantinopolitana. Transl. R. W. Burgess. Oxford, 1993, 215-245.

Cons. Ital. $=$ Consularia Italica. In: MGH AA IX., CM 1. Ed. Th. Mommsen. Berlin, 1892, 249-340.

Eus., Chr. = Eusebii chronicorum libri duo. Vols. I-II. Ed. A. Schoene. Dublin-Zurich, 1967.

Eus., Hist. Ecc. = Eusebii historia ecclesiastica. Vols. I-X. Ed. E. Schwartz. Berlin, 19031909. = Euszebiosz egyháztörténete. Ford. Baán I. Ókeresztény Írók 4. Szerk. Vanyó L. Budapest, 1983.

Gildas = De excidio et conquestu Britanniae. In: MGH AA XIII., CM 3. Ed. Th. Mommsen. Berlin, 1898, 1-85.

Greg. Tur. = Gregorii episcopi Turonensis libri historiarum X. In: MGH Script. Rer. Merov. I/1. Ed. W. Arndt. Hannover, 1885. = Gregory of Tours: The History of the Franks. Transl. L. Thorpe. London, 1977.

Hier., Chr. = Die Chronik des Hieronymus. Ed. R. Helm. Berlin, 1956.

Hier., Ep. = Hieronymi epistulae. In: CSEL 54-56. Ed. I. Hilberg. Vienna, 1910-1918.

Hyd. = Hydatii Lemici continuatio chronicorum Hieronymianorum ad a. CCCCLXVIII. In: MGH AA XI., CM 2. Ed. Th. Mommsen. Berlin, 1894, 1-36. = Hydatii Limici Chronica Subdita. In: The Chronicle of Hydatius and the Consularia Constantinopolitana. Transl. R. W. Burgess. Oxford, 1993, 69-123. = Püspöki tudósítás Hispaniából. Hydatius: Chronica. Ford. Széll G. In: Késő római szöveggyüjtemény. Szerk. Székely M. - Illés I. Á. Szeged, 2013, 347-400.

Ioh. Bicl. = Iohannis abbatis Biclarensis chronica a. DLXVII-DXC. In: MGH AA XI., CM 2. Ed. Th. Mommsen. Berlin, 1894, 207-220. = John of Biclaro: Chronicle. In: Conquerors and Chroniclers of Early Medieval Spain. Ed. and transl. K. B. Wolf. Liverpool, 1990. = Horváth E.: Iohannes Biclarensis krónikája. Aetas 23/1 (2008), $116-127$. 
Iord., Get. = Iordanis Getica. In: MGH AA V/1. Ed. Th. Mommsen. Berlin, 1882, 53-138. = Iordanes: Getica. A gótok eredete és tettei. Ford. Kiss M. et al. Pécs, 2005, 43-105.

Iord., Rom. = Iordanis Romana. In: MGH AA V/1. Ed. Th. Mommsen. Berlin, 1882. = Az idök rövid összefoglalása, avagy a római nép eredete és tettei. Ford. Horváth Sz. Kaposvár-Pécs, 2014.

Isid., Chr. = Isidori Iunioris episcopi Hispalensis chronica maiora ed. primum a. DCXV chronicorum epitome ed. a. DCXXVII. In: MGH AA XI., CM 2. Ed. Th. Mommsen. Berlin, 1894, 391-506.

Isid., Etym. = Isidori Hispalensis etymologiae. Ed. W. M. Lindsay. Oxford, 1911. = The Etymologies of Isidore of Seville. Eds. S. A. Barney et al. Cambridge, 2006.

Isid., Hist. Goth., Vand., Suev. = Isidori Iunioris episcopi Hispalensis historia Gothorum, Wandalorum et Sueborum ad a. DCXXIV. In: MGH AA XI., CM 2. Ed. Th. Mommsen. Berlin, 1894, 241-390. = Las historias de los godos, vandalos y suevos de Isidoro de Sevilla. Ed. and transl. C. Rodriguez Alonso. Leon, 1975. = Sevillai Izidor: A gótok, vandálok és szvévek története. Ford. Székely M. Szeged, 2008, 27-66.

Isid., Vir. ill. = Isidori De viris illustribus. In: PL 83, 1081-1106. = El De viris illustribus de Isidoro de Sevilla. Ed. C. Codoñer Merino. Salamanca, 1964.

Leo, Ep. = S. Leonis Magni epistulae contra Eutychis haeresim. Series theologica 15, 20. Ed. C. Silva-Tarouca. Rome, 1934-1935.

Mal. = Ioannis Malalae chronographia. Corpus Fontium Historiae Byzantinae 35. Ed. J. Thurn. Berlin-New York, 2000.

Mar. Avent. = Marii episcopi Aventicensis chronica a. CCCCLV-DLXXXI. In: MGH AA XI., CM 2. Ed. Th. Mommsen. Berlin, 1894, 225-240.

Marc. Com. = Marcellini v. c. comitis chronicon ad a. DXVIII continuatum ad a. DXXXIV. In: MGH AA XI., CM 2. Ed. Th. Mommsen. Berlin, 1894, 37-108. = The Chronicle of Marcellinus. Transl. B. Croke. Sydney, 1995.

Not. Dig. = Notitia Dignitatum. Ed. O. Seeck. Berlin, 1867; repr. Frankfurt, 1962. = Borhy L. (szerk.): Notitia utraque cum Orientis tum Occidentis ultra Arcadii Honoriique Caesarum tempora. Budapest, 2003.

Oros. = Pauli Orosii historiarum adversum paganos libri VII. Ed. C. Zangemeister. In: CSEL 5. Berlin, 1882. = Orose: Histoires contre les païnes. Transl. M.-P. ArnaudLindet. Paris, 1990-1991.

Prisc.$=$ Priskos. Ed. C. Müller. In: FHG, 1868. = The Fragmentary Classicizing Historians of the Later Roman Empire. Eunapius, Olympiodorus, Priscus and Malchus. Ed. R. C. Blockley. 1981-1983.

Proc. $=$ Procopius: Bellum Gothicum. In: Procopii Caesariensis opera omnia . Eds. J. Haury - G. Wirth. Leipzig, 1962-1964; repr. Munich, 2001.

Prosp. = Prosperi Tironis epitome chronicon ed. primum a. CCCCXXXIII. continuata ad a. CCCLV. In: MGH AA IX., CM 1. Ed. Th. Mommsen. Berlin, 1892, 341-500.

Salv. = Salvianus: De gubernatione Dei. In: Salvien de Marseille: Oeuvres, Du gouvernement de Dieu. Ed. G. Lagarrigue. Paris, 1975. 
Sid. Ap., Ep. et Carm. = Gai Sollii Apollinaris Sidonii epistulae et carmina. In: MGH AA VIII. Ed. Ch. Luetjohann. Berlin, 1887, 1-264.

Socr. = Socrates: Historia Ecclesiastica. In: PG 67. Ed. J. P. Migne. = Szókratész egyháztörténete. Ford. Baán I. Ókeresztény Írók 9. Szerk. Vanyó L. Budapest, 1984.

Sozom. $=$ Sosomenos: Historia Ecclesiastica. Eds. J. Bidez - C. Hansen. Berlin, 1960.

Sulp. Sev., Chr. = Sulpicii Severi chronicorum libri. Ed. C. Halm. In: CSEL 1. Vienna, 1866, 3-105.

Theodor. $=$ Theodorus Lector: Epitome historiae tripartitae. In: PG 86a, 158-165.

Theoph. = Theophanes: Chronicon. In: PG 108, 55-1009.

Vict. Aquit. = Victori Aquitani cursus paschalis a. CCCCLVII. In: MGH AA IX., CM 1. Ed. Th. Mommsen. Berlin, 1892, 666-756.

Vict. Tunn. = Victoris Tonnennensis episcopi chronica a. CCCCXLIV-DLXVII. In: MGH AA XI., CM 2. Ed. Th. Mommsen. Berlin, 1894, 178-206. = Tunnunai Victor: Chronica (444-565). Ford. Széll G. Documenta Historica 80. Szeged, 2008, 13-50.

Vict. Vit. = Victoris Vitensis Historia persecutionis Africanae provinciae sub Geiserico et Hunirico regibus Wandalorum. In: MGH AA III/1. Ed. C. Halm. Berlin, 1879, 1-58.

Zos. = Zosimos: Historia nova. Ed. F. I. Paschoud. Paris, 1971.

\section{Monográfiák és tanulmányok}

Adamik 2009 = Adamik T.: Római irodalom a kezdetektől a Nyugatrómai Birodalom bukásáig. Pozsony, 2009.

Adamik 2014 = Adamik T.: Latin irodalom a kora középkorban (6-8. század). A keresztény Európa születése. Pozsony, 2014.

Adriányi 2001 = Adriányi G.: Az egyháztörténet kézikönyve. Szent István kézikönyvek 5. Budapest, 2001.

Aguzzi 2017 = Aguzzi, S. D.: Israel, the Church, and Millenarianism. A Way beyond Replacement Theology. New York, 2017.

Albrecht 2004 = Albrecht, M. von: A római irodalom története. Vols. I-II. Ford. Tar I. Budapest, 2004.

Alföldi 1963 = Alföldi, M. R.: Die Konstantinische Goldprägung. Untersuchungen zu ihrer Bedeutung für Kaiserpolitik und Hofkunst. Mainz, 1963.

Alföldi 2005 = Alföldi A.: Keresztény császárok, pogány Róma. Máriabesnyő-Gödöllö, 2005.

Alföldi 2006 = Alföldi A.: A késörómai birodalom válaszúton: Valentinianus és a senatus összeütközése. Máriabesnyő-Gödöllö, 2006.

Alföldy 2000 = Alföldy G.: Római társadalomtörténet. Ford. Borhy L. Budapest, 2000.

Alföldy 2007 = Alföldy G.: Spain. In: The Cambridge Ancient History. Vol. 11: The High Empire, AD 70-192. Eds. A. K. Bowman - P. Garnsey - D. Rathbone. Cambridge, 2007, 444-461. 
Allen 2007 = Allen, P.: The Definition and Enforcement of Orthodoxy. In: The Cambridge Ancient History. Vol. 14: Late Antiquity: Empire and Successors, AD 425-600. Eds. A. Cameron - B. Ward-Perkins - M. Whitby. Cambridge, 2007, 811-834.

Allen - Mayer 2000 = Allen, P. - Mayer, W.: John Chrysostom. London, 2000.

Alonso-Núñez 1993 = Alonso-Núñez, J.-M.: Die Auslegung der Geschichte bei Paulus Orosius. Die Abfolge der Weltreiche, die Idee der Roma Aeterna und die Goten. Wiener Studien 106 (1993), 197-213.

Althaner 1947 = Althaner, B.: Ókeresztény irodalomtörténet. Ford. Hermann I. Budapest, 1947.

Andel 1976 = Andel, G. K.: The Christian Concept of History in the Chronicle of Sulpicius Severus. Amsterdam, 1976.

Anderle 1999 = Anderle Á.: Spanyolország története. Budapest 1999.

Angenendt 2008 = Angenendt, A.: A kora középkor: A nyugati kereszténység 400-tól 900ig. Budapest, 2008.

Angi 1999 = Angi J. et al.: Európa a korai középkorban (3-11. század). Szerk. Orosz I. Debrecen, 1999.

Arce 1997 = Arce J.: Otium et negotium. The Great Estates, 4th-7th century. In: The Transformation of the Roman World, AD 400-900. Eds. L. Webster - M. Brown. Los Angeles, 1997, 19-32.

Arce 2002 = Arce, J.: Los vándalos en Hispania, 409-429 AD. Antiquité tardive: revue internationale d'histoire et d'archéologie 10 (2002), 75-85.

Arce 2005 = Arce, J.: Spain and the African Provinces in Late Antiquity. In: Hispania in Late Antiquity: Current Perspectives. Eds. K. Bowes - M. Kulikowski. LeidenBoston, 2005, 341-361.

Arce 2007 = Arce, J.: Bárbaros y Romanos en Hispania, 400-507 AD. Madrid, 2007.

Arias 2007 = Arias, J. C.: Identity and Interactions: The Suevi and the Hispano-Romans. Virginia, 2007.

Augusto 2016 = Augusto, D. P.: Exim in Gallaeciam Priscillianistarum Haeresis Invasit. The Success of Priscillianism in Gallaecia Following the Trials at Trier. Klio 98/2 (2016), 634-652.

Ayres $2004=$ Ayres, L.: Nicaea and its Legacy. An Approach to Fourth-Century Trinitarian Theology. New York, 2004.

Baán 1997 = Baán I.: Justinianus császár teológiája. Varia Byzantina II. Budapest, 1997.

Baldus 1984 = Baldus, H. R.: Theodosius der Grosse und die Revolte des Magnus Maximus. Chiron 14 (1984), 175-192.

Barbero - Loring 2005 = Barbero, A. - Loring, M. I.: The Formation of the Sueve and Visigothic Kingdoms in Spain. In: The New Cambridge Medieval History. Vol. 1.: c. 500-c. 700. Ed. P. Fouracre. Cambridge, 2005, 162-192.

Barnes 1981 = Barnes, T. D.: Constantine and Eusebius. Cambridge, 1981.

Barnes 1993 = Barnes, T. D.: Athanasius and Constantius. Theology and Politics in the Constantinian Empire. Cambridge-London, 1993. 
Barnes - Williams 1993 = Barnes, M. R. - Williams, D. H. (eds.): Arianism after Arius. Edinburgh, 1993.

Bauer 1991 = Bauer, J. B.: Az újszövetségi apokrifek. Ford. Vanyó L. Budapest, 1991.

Benevolo 1994 = Benevolo, L.: A város Európa történetében. Ford. Ordasi Zs. Budapest, 1994.

Benoit - Simon 1998 = Benoit, A. - Simon, M.: La Judaïsme et le Christianisme antique. Paris, 1998.

Berndt - Steinacher 2014 = Berndt, G. M. - Steinacher, R. (eds): Arianism. Roman Heresy and Barbarian Creed. Farnham, 2014.

Bevan - Gray 2009 = Bevan, G. A. - Gray, P. T. R.: The Trial of Eutyches. A New Interpretation. Byzantinische Zeitschrift 101 (2009), 617-657.

Bleicken 1978 = Bleicken, J.: Verfassungs- und Sozialgeschichte des Römischen Kaiserreiches. Paderborn, 1978.

Blockey 2007a = Blockey, R. C.: The Dynasty ot Theodosius. In: The Cambridge Ancient History. Vol. 13: The Late Empire, AD 337-425. Eds. A. Cameron - P. Garnsey. Cambridge, 2007, 111-137.

Blockey 2007b = Blockley, R. C.: Warfare and Diplomacy. In: The Cambridge Ancient History. Vol. 13: The Late Empire, AD 337-425. Eds. A. Cameron - P. Garnsey. Cambridge, 2007, 411-436.

Bonner 2018 = Bonner, A.: The Myth of Pelagianism. Oxford, 2018.

Borzsák 1997 = Borzsák I. (szerk.): Római történeti chrestomathia. Budapest, 1997.

Bowes - Kulikowski 2005 = Bowes, K. - Kulikowski, M. (eds.): Hispania in Late Antiquity: Current Perspectives. Leiden-Boston, 2005.

Brandt 2007 = Brandt, H.: Nagy Konstantin, az elsö keresztény uralkodó. Ford. Bíró K. Budapest, 2007.

Breisach 2004 = Breisach, E.: Historiográfia. Ford. Baics G. Budapest, 2004.

Brestian 2011 = Brestian, S. de: Vascones and Visigoths: Creation and Transformation of Identity in Northern Spain in Late Antiquity. In: Romans, Barbarians and the Transformation of the Roman World. Cultural Interaction and the Creation of Identity in Late Antiquity. Eds. R. W. Mathisen - D. Shanzer. Burlington, 2011, 283-298.

Brincken 1957 = Brincken, A-D.: Studien zur lateinischen Weltchronistik bis in der Zeitalter Ottos von Freising. Düsseldorf, 1957.

Brown 1969 = Brown, P.: The Diffusion of Manichaeism in the Roman Empire. Journal of Roman Studies 59 (1969), 92-103.

Brown 1972 = Brown, P.: Religion and Society in the Age of Saint Augustine. London, 1972.

Brown 1999 = Brown, P.: Az európai kereszténység kialakulása 200-1000. Ford. Pálosfalvi T. Budapest, 1999.

Brown 2012 = Brown, P.: Through the Eye of a Needle: Wealth, the Fall of Rome, and the Making of Christianity in the West, 350-550 AD. Princeton, 2012.

Brunhölzl 1975 = Brunhölzl, F.: Geschichte der lateinischen Literatur des Mittelalters. Vol. I. München, 1975. 
Bubnó 2013 = Bubnó H.: Rómaiak vagy barbárok? Akkulturáció és kultúramegőrzés a barbár államokban, különös tekintettel az afrikai Vandál Királyságra. Orpheus Noster 5/2 (2013), 15-29.

Bultmann 1994 = Bultmann, R.: Történelem és eszkatológia. Ford. Bánki D. Budapest, 1994.

Buren 1968 = Buren, A. W. van: Villa. RE 8A,2, 1968, cols. 2142-2159.

Burgess 1988a = Burgess, R. W.: Hydatius: A Late Roman Chronicler in Post-Roman Spain. An Historiographical Study and New Critical Edition of the Chronicle. D. Phil. thesis. Oxford, 1988.

Burgess 1988b = Burgess, R. W.: A New Reading for Hydatius Chronicle 177 and the Defeat of the Huns in Italy. Phoenix 42 (1988), 357-363.

Burgess 1992 = Burgess, R. W.: From Gallia Romana to Gallia Gothica: the view from Spain. In: Fifth-century Gaul: A Crisis of Identity? Eds. J. Drinkwater - H. Elton. Cambridge, 1992, 19-27.

Burgess 1993 = Burgess, R. W.: The Chronicle of Hydatius and the Consularia Constantinopolitana. Oxford, 1993.

Burgess 1996 = Burgess, R. W.: Hydatius and the Final Frontier: The Fall of the Roman Empire and the End of the World. In: Shifting Frontiers in Late Antiquity. Eds. R. W. Mathisen - H. S. Sivan. Aldershot, 1996, 321-332.

Burgess 1999 = Burgess, R. W.: Studies in Eusebian and Post-Eusebian Chronography. Stuttgart, 1999.

Burns 1992 = Burns, T. S.: The Settlement of 418. In: Fifth-century Gaul: A Crisis of Identity? Eds. J. Drinkwater - H. Elton. Cambridge, 1992, 53-63.

Burns 1994 = Burns, T. S.: Barbarians within the Gates of Rome. A Study of Roman Military Policy and the Barbarians, ca. 375-425 AD. Indianapolis, 1994.

Burns 2003 = Burns, T. S.: Rome and the Barbarians 100 BC-AD 400. Baltimore, 2003.

Burrus 1995 = Burrus, V.: The Making of a Heretic. Gender, Authority and the Priscillianist Controversy. Berkeley-Los Angeles-Oxford, 1995.

Bury 1923 = Bury, J. B.: History of the Later Roman Empire. Vols. I-II. London, 1923.

Cameron 1982 = Cameron, A.: Byzantine Africa: The Literary Evidence. Excavations at Carthage 7 (1982), 29-62.

Cameron 1993 = Cameron, A.: The Mediterranean World in Late Antiquity AD 395-600. London-New York, 1993.

Cameron 2007a $=$ Cameron, A.: The Reign of Constantine, AD 306-337. In: The Cambridge Ancient History. Vol. 12: The Crisis of Empire, AD 193-337. Eds. A. K. Bowman - P. Garnsey - A. Cameron. Cambridge, 2007, 90-109.

Cameron 2007b $=$ Cameron, A.: Vandal and Byzantine Africa. In: The Cambridge Ancient History. Vol. 14: Late Antiquity: Empire and Successors, AD 425-600. Eds. A. Cameron - B. Ward-Perkins - M. Whitby. Cambridge, 2007, 552-569.

Campos 1984 = Campos, J.: Idacio, obispo de Chaves, su Cronicón. Salamanca, 1984.

Candelas-Colodrón 2002a = Candelas-Colodrón, C.: Hidacio, Obispo de Chaves: Iglesia, territorio y poder en el siglo V. Gallaecia 21 (2002), 287-294. 
Candelas-Colodrón 2002b = Candelas-Colodrón, C.: Una hipótesis para la interpretación del Prodigium de la pesca del Miño en el Cronicón de Hidacio. In: Actas del III Congreso Hispánico de Latín Medieval, 26-29 de septiembre de 2001. Vol. 2. León, 2002, 759-764.

Candelas-Colodrón 2004 = Candelas-Colodrón, C.: Análisis de la figura de Hidacio de Chaves a través de los condicionantes socioeconómicos, politicos y culturales de la Gallaecia del siglo V. El Cronicón. Coruña, 2004.

Cardelle de Hartmann 1994 = Cardelle de Hartmann, C.: Philologische Studien zur Chronik des Hydatius von Chaves. Palingenesia 47. Stuttgart, 1994.

Cardelle de Hartmann 1998 = Cardelle de Hartmann, C.: Ortodoxos y priscilianistas en la época sueva. In: Suevos-Schwaben. Das Königreich der Sueben auf der Ibersichen Halbinsel (411-585). Coloquio Interdisciplinar. Universidade do Minho, Braga, 4-6 March 1996. Eds. E. Koller - H. Laitenberger. Tübingen, 1998, 81-104.

Cardelle de Hartmann 2002 = Cardelle de Hartmann, C. (ed.): Victor Tunnunensis, Iohannes Biclarensis: Chronicon cum reliquiis ex Consularibus Caesaraugustanis Chronicon. In: CCSL 173A. Turnhout, 2002.

Carr 2002 = Carr, K. E. Vandals to Visigoths: Rural Settlement Patterns in Early Medieval Spain. Michigan, 2002.

Caspar 1926 = Caspar, E.: Die älteste römische Bischofsliste. Berlin, 1926.

Castellanos - Viso 2005 = Castellanos, S. - Viso, I. M.: The Local Articulation of Central Power in the North of the Iberian Peninsula. Early Medieval Europe 13/1 (2005), 142.

Castellanos 2015 = Castellanos, S.: En el final de Roma (455-480). Madrid, 2015.

Chadwick $1976=$ Chadwick, H.: Priscillian of Avila. The Occult and the Charismatic in the Early Church. Oxford, 1976.

Chadwick 1999 = Chadwick, H.: A korai egyház. Ford. Ertsey K. - Tornai Sz. Budapest, 1999.

Chadwick 2007 = Chadwick, H.: Orthodoxy and Heresy from the death of Constantine to the eve of the first council of Ephesus. In: The Cambridge Ancient History. Vol. 13: The Late Empire, AD 337-425. Eds. A. Cameron - P. Garnsey. Cambridge, 2007, 561-600.

Charles-Edwards 2007 = Charles-Edwards, T. M.: Law in Western Kingdoms between the Fifth and the Seventh Century. In: The Cambridge Ancient History. Vol. 14: Late Antiquity: Empire and Successors, AD 425-600. Eds. A. Cameron - B. Ward-Perkins - M. Whitby. Cambridge, 2007, 260-287.

Chavarría Arnau 2005 = Chavarría Arnau, A.: Villas in Hispania during the Fourth and Fifth Centuries. In: Hispania in Late Antiquity: Current Perspectives. Eds. K. Bowes M. Kulikowski. Leiden-Boston, 2005, 519-552.

Christensen 2002 = Christensen, A. S.: Cassiodorus, Jordanes and the History of the Goths. Studies in a Migration Myth. Copenhagen, 2002.

Cichorius 1932 = Cichorius, C.: Annales. RE 1,2, 1932, cols. 2248-2256.

Claude 1970 = Claude, D.: Geschichte der Westgoten. Stuttgart-Berlin, 1970. 
Claude 1978 = Claude, D.: Prosopographie des Spanischen Suebenreiches. Francia 6 (1978), 647-676.

Clover 1972 = Clover, F. M.: Geiseric and Attila. Historia 22 (1972), 104-117.

Clover 1993 = Clover, F. M.: The Late Roman West and the Vandals. Aldershot, 1993.

Collins 1983 = Collins, R.: The Basques in Aquitaine and Navarre: Problems of Frontier Government. In: War and Society in the Middle Ages: Essays in Honour of J. O. Prestwitch. Eds. J. Gillingham - J. C. Holt. Cambridge, 1983, 3-17.

Collins 1992 = Collins, R.: Law, Culture and Regionalism in Early Medieval Spain. Aldershot, 1992.

Collins 1999 = Collins, R.: Early Medieval Europe 300-1000. New York, 1999.

Collins 2004 = Collins, R.: Visigothic Spain 409-711. Oxford, 2004.

Collins 2007 = Collins, R.: The Western Kingdoms. In: The Cambridge Ancient History. Vol. 14: Late Antiquity: Empire and Successors, AD 425-600. Eds. A. Cameron - B. Ward-Perkins - M. Whitby. Cambridge, 2007, 112-134.

Conant 2004 = Conant, J.: Literacy and Private Documentation in Vandal North Africa: The Case of the Albertini Tablets. Ashgate, 2004, 199-224.

Corcoran 1997 = Corcoran, J. A.: Augustinus Contra Donatistas. Donaldson, 1997.

Cortázar - Vesga 2001 = Cortázar, F. G. de - Vesga, J. M. G.: Spanyolország története. Ford. Lakatos Zs. - Renteria A. Budapest, 2001.

Courtois 1951 = Courtois, C.: Auteurs et Scribes. Remarques sur la Chronique d'Hydace. Byzantion 21 (1951), 23-54.

Courtois 1955 = Courtois, C: Les Vandales et l'Afrique. Paris, 1955.

Croke 1983 = Croke, B.: The Origins of the Christian World Chronicle. In: History and Historians in Late Antiquity. Eds. B. Croke - A. M. Emmett. Oxford, 1983, 116-131.

Croke 1992 = Croke, B.: Christian Chronicles and Byzantine History, Fifth-Sixth Centuries. Aldershot, 1992.

Croke 2007 = Croke, B.: Late Antique Historiography, 250-650 CE. In: A Companion to Greek and Roman Historiography. Ed. J. Marincola. Oxford, 2007, 567-581.

Curran 2007 = Curran, J.: From Jovian to Theodosius. In: The Cambridge Ancient History. Vol. 13: The Late Empire, AD 337-425. Eds. A. Cameron - P. Garnsey. Cambridge, 2007, 78-110.

Czúth - Szádeczky-Kardoss 1956 = Czúth B. - Szádeczky-Kardoss S.: A bagauda mozgalmak Hispaniában. Antik Tanulmányok 3 (1956), 175-180.

Czúth 1979 = Czúth B.: Geiserich és vandáljai Rómában. Acta Antiqua et Archaeologica, Suppl. II. Szeged, 1979, 25-32.

Dahn 1911 = Dahn, F.: Die Könige der Germanen . Leipzig, 1911.

Daniel-Rops 1957 = Daniel-Rops, H.: Histoire de l'Église du Christ. Vol. I. Paris, 1957.

Dawson 1938 = Dawson, C.: Európa születése. Ford. Németh A. Budapest, 1938.

Deane 1963 = Deane, H. A.: The Political and Social Ideas of St. Augustine. New York, 1963.

Degrassi 1952 = Degrassi, A.: I fasti consolari dell'impero romano dal 30 a.C. al 613 d.C. Roma, 1952. 
Demandt 1989 = Demandt, A.: Die Spätantike. Römische Geschichte von Diocletian bis Justinian 284-565. München, 1989.

Demandt 2013 = Demandt, A.: Zeitenwende. Aufsätze zur Spätantike. Berlin, 2013.

D'Emilio 2015 = D'Emilio, J. (ed).: Culture and Society in Medieval Galicia. A Cultural Crossroads at the Edge of Europe. Boston, 2015.

Denzinger - Umberg 1942 = Denzinger, H. - Umberg., J.: Enchiridion Symbolorum. Freiburg, 1942.

Díaz 1986 = Díaz, P. C.: La modalidad del asentamiento suevo y sus consecuencias. Studia Zamorensia 7 (1986), 353-365.

Díaz 1993 = Díaz, P. C.: El alcance de la ocupación sueva de Gallaecia y el problema de la germanización. In: Galicia: da romanidade á xermanización, problemashistóricos e culturais. Hom. F. Bouza Álvarez. Santiago de Compostela, 1993, 209-226.

Díaz 2000a = Díaz, P. C.: El reino Suevo de Hispania y su sede en Bracara. In: Sedes Regiae. Eds. G. Ripoll - J. M. Gurt. Barcelona, 2000a, 403-423.

Díaz 2000b = Díaz, P. C.: City and Territory in Hispania in Late Antiquity. In: Towns and their Territories between Late Antiquity and the Early Middle Ages. Eds. G. P. Brogiolo - N. Gauthier - N. Christie. Leiden, 2000, 3-35.

Díaz 2011 = Díaz, P. C.: El Reino Suevo (411-585). Madrid, 2011.

Díaz - Menéndez-Bueyes 2005 = Díaz, P. C. - Menéndez-Bueyes, L. R.: The Cantabrian Basin in the Fourth and Fifth Centuries: From Imperial Province to Periphery. In: Hispania in Late Antiquity: Current Perspectives. Eds. K. Bowes - M. Kulikowski. Leiden-Boston, 2005, 265-297.

Diego - Béjar 1992 = Diego Núñez, M. Á. de - Béjar Trancón, M. B.: Reseña histórica del reino suevo. In: Anuario. Instituto de Estudios Zamoranos Florián de Ocampo. 1992, $597-614$.

Drake 1992 = Drake, H. A.: The Church, Society and Political Power. In: The Cambridge History of Christianity. Vol. 2: Constantine to c. 600. Eds. A. Casiday - F. W. Norris. Cambridge, 2007, 403-430.

Drinkwater 1992 = Drinkwater, J.: The Bacaudae of fifth-century Gaul. In: Fifth-century Gaul: A Crisis of Identity? Eds. J. Drinkwater - H. Elton. Cambridge, 1992, 208-217.

Duby 1978 = Duby, G.: Emberek és struktúrák a középkorban. Ford. Vekerdi L. Budapest, 1978.

Dvornik 1966 = Dvornik, F.: Byzanz und der Römische Primat. Stuttgart, 1966.

Edmondson 1989 = Edmondson, J. C.: Mining in the Later Roman Empire and Beyond: Continuity or Disruption? The Journal of Roman Studies 79 (1989), 84-102.

Edwards 2007 = Edwards, M.: Synods and Councils. In: The Cambridge History of Christianity. Vol. 2: Constantine to c. 600. Eds. A. Casiday - F. W. Norris. Cambridge, 2007, 367-385.

Eliade 2006 = Eliade, M.: Vallási hiedelmek és eszmék története. Ford. Saly N. Budapest, 2006.

Elliott 1996 = Elliott, T. G.: The Christianity of Constantine the Great. Scranton, 1996. 
Ensslin 1953 = Ensslin, W.: Die Religionspolitik des Kaisers Theodosius der Große. München, 1953.

Escribano 2005 = Escribano, V.: Heresy and Orthodoxy in Fourth-Century Hispania: Arianism and Priscillianism. In: Hispania in Late Antiquity: Current Perspectives. Eds. K. Bowes - M. Kulikowski. Leiden-Boston, 2005, 121-149.

Falluomini 2015 = Falluomini, C.: The Gothic Version of the Gospels and Pauline Epistles. Cultural Background, Transmission and Character. Berlin, 2015.

Ferreira 1993 = Ferreira de Almeida, C. A.: Arqueoloxía tardorromana e germánica no NW peninsular. In: Galicia: da romanidade á xermanización, problemashistóricos e culturais. Hom. F. Bouza Álvarez. Santiago de Compostela, 1993, 191-200.

Ferreiro 1987 = Ferreiro, A.: The Sueves in the Chronica of John of Biclaro. Latomus: Revue d'études latines 46/1 (1987), 200-203.

Ferreiro 1998 = Ferreiro, A.: Sueves and Martin of Braga: Historiography and Future Research Projects. In: Suevos-Schwaben. Das Königreich der Sueben auf der Ibersichen Halbinsel (411-585). Coloquio Interdisciplinar. Universidade do Minho, Braga, 4-6 March 1996. Eds. E. Koller - H. Laitenberger. Tübingen, 1998, 37-62.

Fliche - Martin 1947 = Fliche, A. - Martin, V.: Histoire de l'Église des origines jusqu'à nos jours. Vol. IV. Paris, 1947.

Foss - Magdalino 1990 = Foss, C. - Magdalino, P.: Róma és Bizánc. Ford. Zsolt A. Budapest, 1990, 8-19.

Fraser 1972 = Fraser, P. M.: Ptolemaic Alexandria . Oxford, 1972.

Frassetto $2003=$ Frassetto, M.: Encyclopedia of Barbarian Europe. Society in Transformation. Oxford, 2003.

Frend 1972 = Frend, W. H. C.: The Rise of the Monophysite Movement. Chapters in the History of the Church in the Fifth and Sixth Centuries. Cambridge, 1972.

Frend 2004 = Frend, W. H. C.: From Donatist Opposition to Byzantine Loyalism: The Cult of Martyrs in North Africa 350-650. In: Vandals, Romans and Berbers. New Perspectives on Late Antique North Africa. Ed. A. H. Merrills. London-New York, 2004, 259-270.

Frenyó 2002 = Frenyó Z.: Krisztológiai és antropológiai kérdések az ókeresztény gondolkodásban. Budapest, 2002.

García Villada 1932 = García Villada, Z.: Historia Eclesiástica de España. Vol. I. Madrid, 1932.

Gárdonyi 2006 = Gárdonyi M.: Bevezetés a katolikus egyház történetébe. Budapest, 2006.

Gecse 1977 = Gecse G.: Történelem és kereszténység. Egyház- és dogmatörténeti tanulmányok. Budapest, 1977.

Gelarda 2008-2009 = Gelarda, I.: Guerre e Diplomazia in Iberia nel Chronicon del vescovo Idazio. Hormos. Ricerche di Storia Antica 1 (2008-2009), 294-306.

Gelzer 1964 = Gelzer, H.: Sextus Julius Africanus und die Byzantinische Chronographie. Vols. I-II. New York, 1964.

Gerberding 2005 = Gerberding, R.: The Later Roman Empire. In: The New Cambridge Medieval History. Vol. 1: c. 500-c. 700. Ed. P. Fouracre. Cambridge, 2005, 13-34. 
Gesztelyi - Havas 1999 = Gesztelyi T. - Havas L.: A római kronológia. In: Bevezetés az ókortudományba III. Agatha VI. Szerk. Havas L. - Tegyey I. Debrecen, 1999, 235272.

Gibbon 1983 = Gibbon, E.: The Decline and Fall of the Roman Empire. Vols. I-III. New York, 1983.

Gillett 2003 = Gillett, A.: Envoys and Political Communication in the Late Antique West 411-533. Cambridge, 2003.

Gluschanin 1989 = Gluschanin, E. P.: Die Politik Theodosius' I und die Hintergründe des sogenannten Anti-germanismus im Oströmischen Reich. Historia 38 (1989), 233-234.

Goetz 1980 = Goetz, H.-W.: Die Geschichtstheologie des Orosius. Darmstadt, 1980, 71-79.

Goffart 1980 = Goffart, W.: Barbarians and Romans, AD 418-584. The Techniques of Accomodation. Princeton, 1980.

Goffart 2006 = Goffart, W.: Barbarian Tides: The Migration Age and the Later Roman Empire. Philadelphia, 2006.

Goldsworthy 2004 = Goldsworthy, A.: A római hadsereg története. Ford. Endreffy L. Pécs, 2004.

Goldsworthy 2009 = Goldsworthy, A.: How Rome Fell. Death of a Superpower. New Heaven, 2009.

Goltz 2007 = Goltz, A.: Marcellinus Comes und das 'Ende' des Weströmischen Reiches im Jahr 476. In: Continuity and Change. Studies in Late Antique Historiography. Electrum 13. Eds. D. Brodka - M. Stachura. Kraków, 2007, 39-59.

Greatrex - Elton 2015 = Greatrex, G. - Elton, H. (eds.): Shifting Genres in Late Antiquity. Ashgate, 2015.

Grillmeier 1987 = Grillmeier, A.: Reception and Contradiction. The Development of the Discussion about Chalcedon from 451 to the Beginning of the Reign of Justinian. Christ in Christian Tradition II: From the Council of Chalcedon (451) to Gregory the Great (590-604). Part 1. Transl. P. Allen - J. Cawte. London-Oxford, 1987.

Grumel 1958 = Grumel, V.: La chronoclogie. Traité d'études byzantines. Vol. I. Paris, 1958.

Grüll 1998 = Grüll T.: Az európai müvelödés története I. Ókor, középkor, reneszánsz, reformáció. Budapest, 1998.

Grüll 2007 = Grüll T.: Az utolsó birodalom. Az Imperium Romanum természetrajza . Budapest, 2007.

Grüll $2016=$ Grüll T.: A globalizáció és multikulturalizmus kérdései a Római Birodalomban. Korall 63 (2016), 69-83.

Grüll 2017 = Grüll T.: A Római Birodalom gazdasága. Budapest, 2017.

Grützmacher 1901 = Grützmacher, G.: Hieronymus: Eine biographische Studie von alten Kirchengeschichte. Vols. I-III. Leipzig, 1901.

Guenée 1973 = Guenée, B.: Histoires, annales, chroniques. Essai sur les genres historiques au Moyen Age. Annales 28 (1973), 997-1016.

Gurevics 1987 = Gurevics, A. J.: A középkori népi kultúra. Ford. Kövér Gy. - F. Nagy G. Budapest, 1987. 
Hahn 1968 = Hahn I.: Das bäuerliche Patrocinium in Ost und West. Klio 50 (1968), 261276.

Hall 2007 = Hall, S. G.: The Organization of the Church. In: The Cambridge Ancient History. Vol. 14: Late Antiquity: Empire and Successors, AD 425-600. Eds. A. Cameron - B. Ward-Perkins - M. Whitby. Cambridge, 2007, 731-744.

Halsall 1999 = Halsall, G.: Movers and Shakers: the Barbarians and the Fall of Rome. Early Medieval Europe 8 (1999), 131-145.

Halsall 2005 = Halsall, G.: The Barbarian Invasions. In: The New Cambridge Medieval History. Vol. 1: c. 500-c. 700. Ed. P. Fouracre. Cambridge, 2005, 35-55.

Halsall 2007 = Halsall, G.: Barbarian Migrations and the Roman West 376-568. Cambridge, 2007.

Hanson 1988 = Hanson, R. P. C.: The Search Christian Doctrine of God. The Arian Controversy, 318-381. Edinburgh, 1988.

Havas 1998 = Havas L. et al.: Róma: Egy világbirodalom politikai, erkölcsi és történelmi eszméi I-II. Antik államelméleti antológia. Agatha IV. Debrecen, 1998.

Havas - Hegyi - Szabó 2007 = Havas L. - Hegyi W. Gy. - Szabó E.: Római történelem. Budapest, 2007.

Havas - Németh - Szabó 2001 = Havas L. - Németh Gy. - Szabó E.: Római történeti kézikönyv. Budapest, 2001.

Havas - Takács - Tegyey 2001 = Havas L. - Takács L. - Tegyey I.: A római irodalom története. In: Bevezetés az ókortudományba IV. Agatha VII. Szerk. Havas L. - Tegyey I. Debrecen, 2001, 101-387.

Havas - Vilmos - Szabó 1999 = Havas L. - Vilmos L. - Szabó E.: Az ókori Róma története. In: Bevezetés az ókortudományba III. Agatha VI. Szerk. Havas L. - Tegyey I. Debrecen, 1999, 63-218.

Heather 1994 = Heather, P.: Goths and Romans 332-489. Oxford, 1994.

Heather 1995 = Heather, P.: The Huns and the End of the Roman Empire in Western Europe. English Historical Review 110 (1995), 4-41.

Heather 1996 = Heather, P.: The Goths. Oxford, 1996.

Heather 2006 = Heather, P.: The Fall of the Roman Empire: A New History of Rome and the Barbarians. New York, 2006.

Heather 2007a = Heather, P.: Goths and Huns, c. 320-425. In: The Cambridge Ancient History. Vol. 13: The Late Empire, AD 337-425. Eds. A. Cameron - P. Garnsey. Cambridge, 2007, 487-515.

Heather 2007b $=$ Heather, P.: The Western Empire, 425-476. In: The Cambridge Ancient History. Vol. 14: Late Antiquity: Empire and Successors, AD 425-600. Eds. A. Cameron - B. Ward-Perkins - M. Whitby. Cambridge, 2007, 1-32.

Heather 2007c $=$ Heather, P.: State, Lordship and Community in the West, c. AD 400-600. In: The Cambridge Ancient History. Vol. 14: Late Antiquity: Empire and Successors, $A D$ 425-600. Eds. A. Cameron - B. Ward-Perkins - M. Whitby. Cambridge, 2007, 437-468. 
Heather 2010 = Heather, P.: Empires and Barbarians. The Fall of Rome and the Birth of Europe. Oxford, 2010.

Heather - Matthews 1991 = Heather, P. - Matthews, J.: The Goths in the Fourth Century. Liverpool, 1991.

Heine $2010=$ Heine, R. E.: Origen. Scholarship in the Service of the Church. Oxford, 2010.

Helm 1923 = Helm, R.: Eusebius' Chronik und ihre Tabellenform. Abhandlungen der Berliner Akademie, Phil.-Hist. Kl., no. 4. Berlin, 1923.

Helm 1927 = Helm, R.: Hieronymus und Eutrop. Rheinisches Museum für Philologie 76 (1927), 138-170; 254-306.

Helm 1956 = Helm, R. (ed.): Die Chronik des Hieronymus. Berlin, 1956.

Hendrik 2015 = Hendrik, W. D.: The Afterlife of the Roman City. Architecture and Ceremony in Late Antiquity and the Early Middle Ages. Cambridge, 2015.

Heussi 2000 = Heussi, K.: Az egyháztörténet kézikönyve. Ford. Magyar I. Budapest, 2000.

Hofmann 1997 = Hofmann, H.: Weltchroniken. In: Neues Handbuch der Literaturwissenschaft IV: Spätantike. Eds. L. J. Engels - H. Hofmann. Wiesbaden, 1997, 418-427.

Hoffmann 2014 = Hoffmann Zs.: Mezőgazdaság és agrárviszonyok az ókori Rómában. A köztársaság és a principatus kora. Szeged, 2014.

Honoré 1998 = Honoré, T.: Law in the Crisis of Empire 379-455 AD. The Theodosian Dynasty and its Quaestors. Oxford, 1998.

Hoover 2018 = Hoover, J. A.: The Donatist Church in an Apocalyptic Age. Oxford, 2018.

Horváth 1993 = Horváth E.: A nyugati gót történetírás emlékei. Isidorus Hispalensis és Johannes Biclarensis történeti művei. Aetas 9/1 (1993), 14-27.

Horváth 1999 = Horváth E.: Az arianizmus és a barbár államalakulatok. Studia Miskolcinensia 3 (1999), 45-52.

Horváth 2004 = Horváth E.: Priscillianus esete Maximus császárral és Ambrus püspökkel. Publicationes Universitatis Miskolciensis. Sectio Philosophica 9/3 (2004), 67-81.

Horváth 2006 = Horváth E.: The Role of Arianism in the Vandal Kingdom. In: Religion, Ritual and Mythology: Aspects of Identity Formation in Europe. Ed. J. Carvalho. Pisa, 2006, 171-181.

Horváth 2014 = Horváth Sz.: Iordanes: Romana. Az idök rövid összefoglalása, avagy a római nép eredete és tettei. Kaposvár-Pécs, 2014.

Hughes 2012 = Hughes, I.: Aetius, Attila's Nemesis. Philadelphia, 2012.

Hummer 1998 = Hummer, H. J.: The Fluidity of Barbarian Identity: The Ethnogenesis of Alemanni and Suebi, AD 200-500. Early Medieval Europe 7/1 (1998), 1-27.

Humphries 1996 = Humphries, M.: Chronicle and Chronology. Prosper Aquitaine, his Methods and the Development of Early Medieval Chronography. Early Medieval Europe 5 (1996), 155-175.

Humphries 2009 = Humphries, M.: The Shapes and Shaping of the Late Antique World: Global and Local Perspectives. In: A Companion to Late Antiquity. Ed. P. Rousseau. Oxford, 2009, 97-109. 
Hunt 2007 = Hunt, D.: The Church as a Public Institution. In: The Cambridge Ancient History. Vol. 13: The Late Empire, AD 337-425. Eds. A. Cameron - P. Garnsey. Cambridge, 2007, 238-276.

Hwang 2009 = Hwang, A.: Intrepid Lover of Perfect Grace. The Life and Thought of Prosper of Aquitaine. Washington, 2009.

Inglebert 2001 = Inglebert, H.: Interpretatio Christiana. Les Mutations des Savoirs (Cosmographie, Géographie, Ethnographie, Histoire) dans l'Antiquité Chrétienne (30-630 aprés JC). Paris, 2001.

James 1980 = James, E. (ed.): Visigothic Spain: New Approaches. Oxford, 1980.

James 2014 = James, E.: Europe's Barbarians AD 200-600. London-New York, 2014.

Jedin 1962 = Jedin, H. (ed.): Handbuch der Kirchengeschichte. Vols. I-II. Freiburg, 1962.

Jedin 1998 = Jedin, H.: A zsinatok története. Ford. Viz L. Budapest, 1998.

Jedin - Dolan 1980 = Jedin, H. - Dolan, J. (eds.): The Imperial Church from Constantine to the early Middle Ages. History of the Church II. Transl. A. Biggs. New York, 1980.

Johnson 1993 = Johnson, G.: The Chronicles of Spain. Queensland, 1993.

Jones 1964 = Jones, A. H. M.: The Later Roman Empire. Vols. I-II. Oxford, 1964.

Katus 2014 = Katus L.: Európa története a középkorban. Pécs, 2014.

Kelemen 2007 = Kelemen M.: A birodalom kormányzása. A Késö-római Birodalom közszolgálata. Acta Wenzeliana 5. Budapest, 2007.

Kelly 2003 = Kelly, J. N. D.: Szent Jeromos élete, irásai és vitái. Ford. Nemes K. Budapest, 2003.

King 1990 = King, A.: Roman Gaul and Germany. London, 1990.

Kiss 2006 = Kiss S.: Les Documents Latins du haut Moyen âge et la Naissance du Français. Vol. I: La chronique d'Hydatius. Series Linguistica 10. Debrecen, 2006.

Kiss 2008 = Kiss M.: Gót vezéregyéniségek a késő Római Birodalomban. Getica-kutatások. Pécs, 2008.

Kitchen 2013 = Kitchen, T. E.: Apocalyptic Perceptions of the Roman Empire in the Fifth Century AD. In: Abendländische Apokalyptik. Kompendium zur Genealogie der Endzeit. Eds. V. Wieser et al. Berlin, 2013, 641-660.

Klaniczay 2005 = Klaniczay G. (szerk.): Európa ezer éve: a középkor. Vol. I. Budapest, 2005.

Koenigsberger 1987 = Koenigsberger, H. G.: Medieval Europe 400-1500. London-New York, 1987.

Kofsky 2000 = Kofsky, A.: Eusebius of Caesarea against paganism. Leiden, 2000.

Kornemann 1946 = Kornemann, E.: Civitas. RE Suppl. 1, 1946, cols. 300-317.

Kosiński 2007 = Kosiński, R.: The Life of Nestorius as seen in Greek and Oriental Sources. In: Continuity and Change. Studies in Late Antique Historiography. Electrum 13. Eds. D. Brodka - M. Stachura. Kraków, 2007, 155-170.

Kulikowski 2000 = Kulikowski, M.: Barbarians in Gaul, Usurpers in Britain. Britannia 31 (2000), 325-345. 
Kulikowski 2005 = Kulikowski, M.: Cities and Government in Late Antique Hispania: Recent Advances and Future Research. In: Hispania in Late Antiquity: Current Perspectives. Eds. K. Bowes - M. Kulikowski. Leiden-Boston, 2005, 31-70.

Kulikowski 2010 = Kulikowski, M.: Late Roman Spain and its Cities. Baltimore-London, 2010.

Kulikowski 2013 = Kulikowski, M.: The Archeology of War and the 5th c. 'Invasions'. In: War and Warfare in Late Antiquity. Current Perspectives. Late Antique Archaeology 8. Eds. A. Sarantis - N. Christie. Leiden-Boston, 2013, 683-701.

Ladner 1976 = Ladner, G. B.: On Roman Attitudes toward Barbarians in Late Antiquity. Viator 7 (1976), 1-26.

Landes 1988 = Landes, R.: Lest the Millennium be Fulfilled. Apocalyptic Expectations and the Pattern of Western Chronography 100-800 CE. In: The Use and Abuse of Eschatology in the Middle Ages. Eds. W. Verbeke - D. Verhelts - A. Welkenhuysen. Leuven, 1988, 137-211.

Lafont 1998 = Lafont, G.: A katolikus egyház teológiatörténete. Ford. Mártonffy M. Budapest, 1998.

Lepelley 1980 = Lepelley, C.: Iuvenes et circoncelliones. Les derniers sacrifices humains de l'Afrique romaine. Antiquités Africaines 15 (1980), 261-271.

Liebeschuetz 2007 = Liebeschuetz, J. H. W. C.: Administration and Politics in the Cities of the Fifth to the mid Seventh Century, 425-640. In: The Cambridge Ancient History. Vol. 14: Late Antiquity: Empire and Successors, AD 425-600. Eds. A. Cameron - B. Ward-Perkins - M. Whitby. Cambridge, 2007, 207-237.

Lieu 2007 = Lieu, S. N. C.: Christianity and Manichaeism. In: The Cambridge History of Christianity. Vol. 2: Constantine to c. 600. Eds. A. Casiday - F. W. Norris. Cambridge, 2007, 279-295.

Livermore 1971 = Livermore, H. V.: The Origins of Spain and Portugal. London, 1971.

López Pereira 1998 = López Pereira, J. E.: La Galicia sueva vista por los escritores indígenas contemporáneos. In: Suevos-Schwaben. Das Königreich der Sueben auf der Ibersichen Halbinsel (411-585). Coloquio Interdisciplinar. Universidade do Minho, Braga, 4-6 March 1996. Eds. E. Koller - H. Laitenberger. Tübingen, 1998, 21-36.

López Quiroga - Martínez Tejera 2017 = López Quiroga, J. - Martínez Tejera, A. M. (eds.): In Tempore Sueborum. El Tiempo de los Suevos en la Gallaecia (411-585). El Primer Reino Medieval de Occidente. Catálogo de Exposición. Transl. C. Ilie. Ourense, 2017.

In: https://www.scribd.com/document/387581132/Catalogo-In-Tempore-Sueborum; http://www.academia.edu/37321555/IN_TEMPORE_SUEBORUM. The time_of_the_Su evi_in_Gallaecia_411-585_AD_Exhibition_Catalogue_English_(2018.12.30.)

López - Rodríguez 1997 = López, Q. J. - Rodríguez, L. M.: De los Romanos a los Bárbaros: la instalación de los Suevos y sus consecuencias sobre la organización territorial en el Norte de Portugal (411-469). Studi Medievali 38/3 (1997), 529-560. 
López Sánchez 2005 = López Sánchez, F.: Coinage, Iconography and the Changing Political Geography of Fifth-Century Hispania. In: Hispania in Late Antiquity: Current Perspectives. Eds. K. Bowes - M. Kulikowski. Leiden-Boston, 2005, 487-518.

Lortz 1962 = Lortz, J.: Geschichte der Kirche in Ideengeschichtlicher Betrachtung. Vols. III. Münster, 1962.

Löhr 2007 = Löhr, W.: Western Christianities. In: The Cambridge History of Christianity. Vol. 2: Constantine to c. 600. Eds. A. Casiday - F. W. Norris. Cambridge, 2007, 9-51.

Löwith 1996 = Löwith, K.: Világtörténelem és üdvtörténet. A történelemfilozófia teológiai gyökerei. Ford. Boros G.-Miklós T. Budapest, 1996.

Lyman 2007 = Lyman, J. R.: Heresiology: The Invention of 'Heresy' and 'Schism'. In: The Cambridge History of Christianity. Vol. 2: Constantine to c. 600. Eds. A. Casiday - F. W. Norris. Cambridge, 2007, 296-316.

Maldonado 2005 = Maldonado, P. C.: Angelorum participes: The Cult of the Saints in Late Antique Spain. In: Hispania in Late Antiquity: Current Perspectives. Eds. K. Bowes M. Kulikowski. Leiden-Boston, 2005, 151-188.

Man 2009 = Man, J.: Attila. The Barbarian King Who Challenged Rome. New York, 2009.

Marincola 2007 = Marincola, J. (ed.): A Companion to Greek and Roman Historiography. Oxford, 2007.

Marton 2004 = Marton J.: A keresztény ókor. Marosvásárhely, 2004.

Martyn 2008 = Martyn, J. R. C.: Arians and Vandals of the 4th-6th centuries. Cambridge, 2008.

Matthews 1975 = Matthews, J.: Western Aristocracies and Imperial Court AD 364-425. New York-Oxford, 1975.

Matthews 2005 = Matthews, G. B.: Augustine. Oxford, 2005.

McEvoy 2013 = McEvoy, M. A.: Child Emperor Rule in the Late Roman West, AD 367455. Oxford, 2013.

McLynn 1994 = McLynn, N. B.: Ambrose of Milan. Church and Court in a Christian Capital. Berkeley, 1994.

Mehl 2011 = Mehl, A.: Roman Historiography. An Introduction to its Basic Aspects and Development. Transl. H.-F. Mueller. Oxford, 2011.

Mellor 2002 = Mellor, R.: The Roman Historians. New York, 2002.

Merrills 2004 = Merrills, A. H. (ed.): Vandals, Romans and Berbers. New Perspectives on Late Antique North Africa. London-New York, 2004.

Merrills - Miles 2010 = Merrills, A. H. - Miles, R.: The Vandals. Oxford, 2010.

Metcalf 1993 = Metcalf, D. M.: The Coinage of the First and Second Suevic Kingdoms. In: Galicia: da romanidade á xermanización, problemashistóricos e culturais. Hom. F. Bouza Álvarez. Santiago de Compostela, 1993, 355-365.

Meyendorff 2001 = Meyendorff, J.: Birodalmi egység és keresztény szakadások. Az egyház 450-680 között. Varia Byzantina IV. Ford. Utry G. Budapest, 2001.

Meyendorff 2003 = Meyendorff, J.: Krisztus az ortodox teológiában. Ford. Imrényi T. et al. Budapest, 2003. 
Mezey 1986 = Mezey L. (szerk.): Róma utódai. Szemelvények középkori krónikákból. Budapest, 1986.

Millar 1964 = Millar, F.: A Study on Cassius Dio. Oxford, 1964.

Mócsy 1974 = Mócsy A.: Pannonia a késői császárkorban. Apollo Könyvtár 4. Budapest, 1974.

Mócsy 1987 = Mócsy A.: A dunai-balkáni térség romanizációja. Világtörténet 9/3 (1987), 317.

Molé 1974 = Molé, C.: Uno storico del V secolo: il vescovo Idazio. Siculorum Gymnasium 27 (1974), 279-351.

Molé 1975 = Molé, C.: Uno storico del V secolo: il vescovo Idazio. Parte II. Siculorum Gymnasium 28 (1975), 58-139.

Mommaerts - Kelley 1992 = Mommaerts, T. S. - Kelley, D. H.: The Anicii of Gaul and Rome. In: Fifth-century Gaul: A Crisis of Identity? Eds. J. Drinkwater - H. Elton. Cambridge, 1992, 111-121.

Mommsen 1894 = Mommsen, Th. (ed.): Hydatii Lemici continuatio chronicorum Hieronymianorum. In: MGH AA XI., CM 2. Berlin, 1894, 1-36.

Mommsen 1909 = Mommsen, Th.: Über die Quellen der Chronik des Hieronymus. Gesammelte Schriften 7. Berlin, 1909.

Moreira 1993 = Moreira, D. A.: A propósito da toponímia germânica: esboço provisório de duas consideraçoes. In: Galicia: da romanidade á xermanización, problemashistóricos e culturais. Hom. F. Bouza Álvarez. Santiago de Compostela, 1993, 399-404.

Moss 1973 = Moss, J. R.: The Effects of the Policies of Aetius on the History of Western Europe. Historia 22 (1973), 711-731.

Mosshammer 1979 = Mosshammer, A. A.: The Chronicle of Eusebius and Greek Chronographic Tradition. Lewisburg, 1979.

Muhlberger 1984 = Muhlberger, S.: Heroic Kings and Unruly Generals: The „Copenhagen” Continuation of Prosper Reconsidered. Florilegium 6 (1984), 50-95.

Muhlberger 1990 = Muhlberger, S.: The Fifth-Century Chroniclers. Prosper, Hydatius and the Gallic Chronicler of 452. Leeds, 1990.

Nautin 1984-1985 = Nautin, P.: L'Introduction d'Hydace à sa continuation de la Chronique d'Eusèbe et Jérôme. Revue d'Histoire des Textes 14-15 (1984-1985), 143-153.

Neil 2007 = Neil, B.: Towards Defining a Christian Culture: The Christian Transformation of Classical Literature. In: The Cambridge History of Christianity. Vol. 2: Constantine to c. 600. Eds. A. Casiday - F. W. Norris. Cambridge, 2007, 317-342.

Németh - Hegyi 2011 = Németh Gy. - Hegyi W. Gy.: Görög-római történelem . Budapest, 2011.

Neugebauer 1981 = Neugebauer, O.: On the 'Spanish Era'. Chiron 11 (1981), 371-380.

Neumann 1917 = Neumann, K. J.: Foedus. RE 6,2, 1917, cols. 2818-2827.

Nörr 1965 = Nörr, D.: Imperium und Polis in der hohen Prinzipatszeit. Gymnasium 72 (1965), 485-499.

Nsiri 2018 = Nsiri, M.-A.: Genséric fossoyeur de la Romanitas africaine? Lybian Studies 49 (2018), 93-119. 
Olajos 1999 = Olajos T.: A görög kronológia. In: Bevezetés az ókortudományba III. Agatha VI. Szerk. Havas L. - Tegyey I. Debrecen, 1999, 219-234.

Oost 1968 = Oost, S.: Galla Placidia Augusta: A Biographical Essay. Chicago, 1968.

Palmer 2014 = Palmer, J. T.: The Apocalypse in the Early Middle Ages. Cambridge, 2014.

Pawlak 2007 = Pawlak, M.: Hydace et le Désordre de son Temps. In: Continuity and Change. Studies in Late Antique Historiography. Electrum 13. Eds. D. Brodka - M. Stachura. Kraków, 2007, 29-37.

Percival 1992 = Percival, J.: The Fifth-Century Villa: New Life or Death Postponed? In: Fifth-century Gaul: A Crisis of Identity? Eds. J. Drinkwater - H. Elton. Cambridge, 1992, 156-164.

Pfeiffer 1968 = Pfeiffer, R.: History of Classical Scholarship from Beginnings to the End of the Hellenistic Age. Oxford, 1968.

Piel 1936 = Piel, J. M.: Os nomes germánicos na toponimia portuguesa. Boletim de Filología II. Lisbon, 1936.

Piganiol 1964 = Piganiol, A.: Le Sac de Rome: Vue d'Ensemble. Paris, 1964.

Pilhofer 1990 = Pilhofer, P.: Presbyteron Kreitton. Der Altersbeweis der Jüdischen und Christlichen Apologeten und seine Vorgeschichte. Tübingen, 1990.

Pirenne 1983 = Pirenne, H.: A középkori gazdaság és társadalom története. Ford. Gyáros E. Budapest, 1983.

Pitts 1989 = Pitts, L. F.: Relations between Rome and the German Kings on the Middle Danube in the First to Fourth Centuries AD. The Journal of Roman Studies 79 (1989), 45-58.

Pohl 1997 = Pohl, W. (ed.): Kingdoms of the Empire. The Integration of Barbarians in Late Antiquity. The Transformation of he Roman World. Vol. I. Leiden-New York-Köln, 1997.

Pohl 2004 = Pohl, W.: The Vandals: Fragments of a Narrative. In: Vandals, Romans and Berbers. New Perspectives on Late Antique North Africa. Ed. A. H. Merrills. LondonNew York, 2004, 31-48.

Pohl $2018=$ Pohl, W.: The Military Transformation of the Roman World. In: In Tempore Sueborum. El Tiempo de los Suevos en la Gallaecia (411-585). El Primer Reino Medieval de Occidente. Volumen de Estudios. Eds. J. López Quiroga - A. M. Martínez Tejera, A. M. Ourense, 2018, 1-12. [ms.]

Prete 1961 = Prete, S.: Pelagio e il Pelagianismo. Brescia, 1961.

Quasten 1951-1955 = Quasten, J.: Patrology. Vols. I-III. Westminster, 1951-1955.

Randers-Pehrson 1993 = Randers-Pehrson, J. D.: Barbarians and Romans. The Birth Struggle of Europe, AD 400-700. Norman-London, 1993.

Rebenich 2002 = Rebenich, S.: Jerome. London-New York, 2002.

Rees 1998 = Rees, B. R.: Pelagius. Life and Letters. Woodbridge, 1998.

Regenbogen 1966 = Regenbogen, O.: Pinax. RE 20,2, 1966, cols. 1409-1482.

Reinhart 1952 = Reinhart, W.: Historia general del reino hispánico de los Suevos. Madrid, 1952. 
Reynolds 2011 = Reynolds, J.: Defending Rome: The Masters of the Soldiers. Bloomington, 2011.

Riché 2016 = Riché, P.: Oktatás és müvelödés a barbár Nyugaton (6-8. század). Ford. Ádám A. - Sághy M. Budapest, 2016.

Ridings 1995 = Ridings, D.: The Attic Moses. The Dependency Theme is Some Early Christian Writers. Göteborg, 1995.

Roberto 2007 = Roberto, U.: Die Einheit der Menschheit und die Chronographiae von Iulius Africanus. In: Continuity and Change. Studies in Late Antique Historiography. Electrum 13. Eds. D. Brodka - M. Stachura. Kraków, 2007, 15-28.

Rummel 2008 = Rummel, P. von: Where Have all the Vandals Gone? Migration, Ansiedlung und Identität der Vandalen im Spiegel archäologischer Quellen aus Nordafrika. In: Das Reich der Vandalen und seine (Vor-)Geschichten. Eds. G. M. Berndt - R. Steinacher. Wien, 2008, 151-174.

Russell 1996 = Russell, J. C.: The Germanization of Early Medieval Christianity. A Sociohistorical Approach to Religious Transformation. Oxford, 1996.

Sachs 1932 = Sachs, G.: Die germanischen Ortsnamen in Spanien und Portugal. LeipzigJena, 1932.

Sághy 2007 = Sághy M.: Isten barátai. Aszkézis és hatalom a IV. században. In: Hatalom, legitimáció, ideológia. Történeti tanulmányok. Szerk. Gedő É. - Horváth E. Budapest, 2007, 7-20.

Sánchez Pardo 2013 = Sánchez Pardo, J. C.: Power and Rural Landscapes in Early Medieval Galicia (400-900 AD). Towards a Re-Incorporation of the Archaeology into the Historical Narrative. Early Medieval Europe 21/2 (2013), 140-168.

Sáry 2009 = Sáry P.: Pogány birodalomból keresztény birodalom. A Római Birodalom kereszténnyé válása a Codex Theodosianus tükrében. Budapest, 2009.

Schmidt 1938 = Schmidt, L.: Geschichte der Deutschen Stämme bis zum Ausgang der Völkerwanderung. Die Westgermanen. München, 1938.

Schmidt 1953 = Schmidt, L.: Histoire des Vandales. Paris, 1953.

Schmidt 1970a = Schmidt, L.: Geschichte der Wandalen. München, 1970.

Schmidt 1970b = Schmidt, L.: Die Westgermanen. München, 1970.

Schmidt - Nicholas $2017=$ Schmidt, T. C. - Nicholas, N.: Hippolytus of Rome: Commentary on Daniel and Chronicon. Piscataway, 2017.

Schön 1933 = Schön, E.: Fasti. RE 6,2, 1933, cols. 2023-2046.

Schönfeld 1958 = Schönfeld, M.: Laeti. RE 12,1, 1958, cols. 446-448.

Schulten 1960 = Schulten, A.: Dediticii. RE 4,2, 1960, cols. 2359-2363.

Schulz 1993 = Schulz, R.: Die Entwicklung des Römischen Völkerrechts im vierten und fünften Jahrhundert n. Chr. Stuttgart, 1993.

Schütz 1937 = Schütz A.: Dogmatika. Vol. II. Budapest, 1937.

Schwarz 2004 = Schwarz, A.: The Settlement of the Vandals in North Africa. In: Vandals, Romans and Berbers. New Perspectives on Late Antique North Africa. Ed. A. H. Merrills. London-New York, 2004, 49-58. 
Schwarz 2011 = Schwarz, A.: Visigothic Settlement, Hospitalitas and Army Payment Reconsidered. In: Romans, Barbarians and the Transformation of the Roman World. Cultural Interaction and the Creation of Identity in Late Antiquity. Eds. R. W. Mathisen - D. Shanzer. Burlington, 2011, 265-270.

Seeck 1921 = Seeck, O.: Hydatius. RE 9,1, 1921, cols. 40-43.

Segesváry 1994 = Segesváry L. (szerk.): Az egyháztörténelem alapvonalai. Debrecen, 1994, $58-86$.

Shaw 2004 = Shaw, B. D.: Who were the Circumcellions? In: Vandals, Romans and Berbers. New Perspectives on Late Antique North Africa. Ed. A. H. Merrills. LondonNew York, 2004, 227-258.

Simonetti 1986 = Simonetti, M.: La produzione letteraria latina fra Romani e barbari (sec. V-VIII). Roma, 1986.

Sivan 1987 = Sivan, H.: On Foederati, Hospitalitas, and the Settlement of the Goths in AD 418. American Journal of Philology 108/4 (1987), 759-772.

Sivan 2011 = Sivan, H.: Galla Placidia. The Last Roman Empress. Oxford, 2011.

Snaedal 2015 = Snaedal, M.: Attila. Studia Etymologica Cracoviensa 20/3 (2015), 211-219.

Sotinel 2009 = Sotinel, C.: Information and Political Power. In: A Companion to Late Antiquity. Ed. P. Rousseau. Oxford, 2009, 125-138.

Southern 1987 = Southern, R. W.: A nyugati társadalom és az egyház a középkorban. Ford. Jászay G. Budapest, 1987.

Spät 1997 = Spät E.: Egy eretnek püspök ábrázolása az V. században. Ókortudományi Értesítő 1/1 (1997), 21-27.

Spät 1998 = Spät E.: Priscillianus tanai az egyházatyák tükrében. Antik Tanulmányok 42/1-2 (1998), 137-152.

Stein 1949 = Stein, E.: Histoire du Bas-Empire. Vols. I-II. Paris, 1949.

Stevens 1993 = Stevens, W. M.: Cycles of Time. Calendrical and Astronomical Reckonings in Early Science. In: Time and Process. Eds. J. T. Fraser - L. Rowell. Madison, 1993, $27-51$.

Stevenson 1987 = Stevenson, J.: A New Eusebius: Documents Illustrating the History of the Church to $A D$ 337. London, 1987.

Szádeczky-Kardoss $1957=$ Szádeczky-Kardoss S.: Bagaudák az Alpokban. Antik Tanulmányok 4 (1957), 116-122.

Szádeczky-Kardoss 1961 = Szádeczky-Kardoss S.: Zur Interpretation zweier HydatiusStellen. Helikon 1/1 (1961), 148-152.

Szántó 1983 = Szántó K.: A katolikus egyház története. Vol. I. Budapest, 1983.

Szántó 2007 = Szántó R. (szerk.): Középkori egyetemes történelem: térképvázlatok gyüjteménye. Szeged-Miskolc, 2007.

Székely 2002 = Székely M.: Apuntes sobre el nacimiento de la Historia de los Vándalos de Isidoro de Sevilla. Acta Hispanica 7 (2002), 7-16.

Székely 2003 = Székely M.: Theodosius amator pacis generisque Gothorum. Theodosius gót politikájáról. Aetas 18/3-4 (2003), 24-32. 
Székely 2008 = Székely M. (ford.): Sevillai Izidor: A gótok, vandálok és szvévek története. Szeged, 2008.

Székely 2017 = Székely M.: Theodosius and the Goths. Chronica 17 (2017), 79-90.

Székely 2018 = Székely M. (ford.): Pacatus: Theodosius császár dicsőítése. Ókor 17/1 (2018), 101-107.

Széll 2005 = Széll G. (ford.): Hydatius: Chronica (379-469). Documenta Historica 68. Szeged, 2005.

Széll 2007 = Széll G.: Hydatius, az V. század gallaeciai krónikása. In: Panégyris. Szerk. Mészáros T. - Jutai P. Budapest, 2007, 53-56.

Széll 2008a = Széll G.: Az 5-6. századi világkrónikák forrásai. In: Enumeratio. Szerk. Jutai P. - Tóth I. Budapest, 2008, 38-43.

Széll 2008b = Széll G. (ford.): Tunnunai Victor: Chronica (444-565). Documenta Historica 80. Szeged, 2008b.

Széll 2011a = Széll G.: A monofiziták helyzete a Trák-dinasztia idején. In: Corollarium. Tanulmányok a hatvanöt éves Tar Ibolya tiszteletére. AAASzeged Suppl. XIII. Szerk. Czerovszki M. - Nagyillés J. Szeged, 2011, 288-293.

Széll 2011b = Széll G.: Iustinianus és Theodora sajátos küzdelme a monofizitákkal. In: Imperium sine fine: Tanulmányok Róma császárkori történelméröl. Szerk. Székely M. - Illés I. Á. Belvedere Meridionale 23/3 (2011), 79-87.

Széll 2012 = Széll G.: Justinian and Theodora's Peculiar Struggle with the Monophysites. Acta Ant. Hung. 52/1 (2012), 1-8.

Széll 2013 = Széll G.: Püspöki tudósítás Hispaniából. Hydatius: Chronica. In: Késő római szöveggyüjtemény. Szerk. Székely M. - Illés I. Á. Szeged, 2013, 347-400.

Széll 2015a = Széll G.: Propter potentiorem principalitatem: The beginnings of the Primacy of the Church of Rome. In: Sapiens Ubique Civis. Proceedings of International Conference on Classical Studies (Szeged, Hungary, 2013). Antiquitas, Byzantium, Renascentia XIII. Eds. Nagyillés J. et al. Budapest, 2015, 243-253.

Széll 2015b = Széll G.: A hispaniai Szvév Királyság felemelkedése (409-456). In: Tanulmányok a hetven éves Wojtilla Gyula tiszteletére. AAASzeged Suppl. XIV. Szerk. Székely M. - Illés I. Á. Szeged, 2015, 113-124.

Széll 2017 = Széll G.: The Crisis of the Kingdom of the Suebi: Relations with the Visigoths and the Romans (456-468). Eds. Székely M. - Illés I. Á. Chronica 17 (2017), 91-99.

Széll 2019 = Széll G.: Eretnekség és igazhitüség az 5. századi Gallaeciában. Szerk. Székely M. - Priskin Gy. Belvedere Meridionale 31/1 (2019). [megjelenés alatt]

Sz. Jónás 1994 = Sz. Jónás I.: Barbár királyok. Budapest, 1994.

Tengsröm 1964 = Tengsröm, E.: Donatisten und Katholiken. Gothenburg, 1964.

Thompson 1950 = Thompson, E. A.: The Foreign Policies of Theodosius II and Marcian. Hermathena 76 (1950), 58-75.

Thompson 1952 = Thompson, E. A.: Peasant Revolts in Late Roman Gaul and Spain. Past and Present 2 (1952), 11-23.

Thompson 1963 = Thompson, E. A.: The Barbarian Kingdoms in Spain and Gaul. Nottingham Medieval Studies 2 (1963), 3-33. 
Thompson 1965 = Thompson, E. A.: The Early Germans. Oxford, 1965.

Thompson 1966 = Thompson, E. A.: The Visigoths in the Time of Ulfila. Oxford, 1966.

Thompson 1980 = Thompson, E. A.: The Conversion of the Spanish Suevi to Catholicism. In: Visigothic Spain: New Approaches. Ed. E. James. Oxford, 1980, 77-92.

Thompson 1982 = Thompson, E. A.: Romans and Barbarians: The Decline of the Western Empire. Madison, 1982.

Timkó 1971 = Timkó I.: Keleti kereszténység, keleti egyházak. Budapest, 1971.

Todd 2004 = Todd, M.: The Early Germans. Oxford, 2004.

Todd 2007a = Todd, M.: The Germanic Peoples and Germanic Society. In: The Cambridge Ancient History. Vol. 12: The Crisis of Empire, AD 193-337. Eds. A. K. Bowman - P. Garnsey - A. Cameron. Cambridge, 2007, 440-460.

Todd 2007b = Todd, M.: The Germanic Peoples. In: The Cambridge Ancient History. Vol . 13: The Late Empire, AD 337-425. Eds. A. Cameron - P. Garnsey. Cambridge, 2007, 461-486.

Torres López 1940 = Torres López, M.: El Reino Suevo de España. In: España Visigoda. Vol. 3. Ed. R. Menéndez-Pidal. Madrid, 1940.

Torres Rodríguez 1956 = Torres Rodríguez, C.: El cronicon de Hidacio: Consideraciones. Compostellanum 1 (1956), 765-801.

Torres Rodríguez 1977 = Torres Rodríguez, C.: El reino de los suevos (or Galicia sueva). La Coruña, 1977.

Török 1999 = Török J.: Egyetemes egyháztörténelem. Vol. I. Budapest, 1999.

Trambauer 2008 = Trambauer, M.: Gescheiterte Reichsbildungen im Frühmittelalter. Die hispanischen Sueben und die Rugier. Wien, 2008.

Tranoy 1974 = Tranoy, A.: Hydace: Chronique. Vols. I-II. Sources Chrétiennes 218-219. Paris, 1974.

Van Schoor 1995 = Van Schoor, M. L.: The Barbarians in the West: An Archaeological Appraisal of the Suevic Kingdom in the Northwest of Iberia. In: Archaeological and Historical Aspects of West-European Societies: Album Amicorum André Van Doorselaer. Ed. M. Lodewijckx. Leuven, 1995, 333-339.

Vanyó 1999 = Vanyó L.: A III-IV. század szentjei. Budapest, 1999.

Vanyó 2004 = Vanyó L.: Ókeresztény írók lexikona. Budapest, 2004.

Vanyó 2007a = Vanyó L.: Az ókeresztény egyház irodalma I: Az elsö három század. Budapest, 2007.

Vanyó 2007b = Vanyó L.: Az ókeresztény egyház irodalma II: A 4-8. század. Budapest, 2007.

Vanyó 2009 = Vanyó L.: Bevezetés az ókeresztény kor dogmatörténetébe. Budapest, 2009.

Várady 1961 = Várady L.: Későrómai hadügyek és társadalmi alapjaik. A Római Birodalom utolsó évszázada (376-476). Budapest, 1961.

Vilella 1999 = Vilella, J.: Idacio, un cronista de su tempo. Compostellanum 44 (1999), 3954.

Vives 1963 = Vives, J. (ed.): Concilios Visigóticos e Hispano-romanos. Barcelona-Madrid, 1963. 
Wallace-Hadrill 1961 = Wallace-Hadrill, D. S.: Eusebius of Caesarea . Westminster, 1961.

Wallace-Hadrill 1967 = Wallace-Hadrill, J. M.: The Barbarian West. The Early Middle Ages 400-1000. New York, 1967.

Wallraff - Mecella 2009 = Wallraff, M. - Mecella, L. (eds).: Die Kestoi des Julius Africanus und ihre Überlieferung. Berlin-New York, 2009.

Ward-Perkins 2005 = Ward-Perkins, B.: The Fall of Rome and the End of Civilization. Oxford, 2005.

Ward-Perkins $2007=$ Ward-Perkins, B.: Land, Labour and Settlement. In: The Cambridge Ancient History. Vol. 14: Late Antiquity: Empire and Successors, AD 425-600. Eds. A. Cameron - B. Ward-Perkins - M. Whitby. Cambridge, 2007, 315-345.

Waxman 1960 = Waxman, M.: A History of Jewish Literature. Vols. I-V. New York, 1960.

Whately 2012 = Whately, C.: Jordanes, the Battle of the Catalaunian Plains and Constantinople. Dialogues d'histoire ancienne, suppl. 8 (2012), 57-70.

Whitby 2007 = Whitby, M.: The Army, c. 420-602. In: The Cambridge Ancient History. Vol. 14: Late Antiquity: Empire and Successors, AD 425-600. Eds. A. Cameron - B. Ward-Perkins - M. Whitby. Cambridge, 2007, 288-314.

Wieser 2016 = Wieser, V.: Sulpicius Severus Krónikája és a 4. századi világvégevárás. Ford. Barabás G. Világtörténet 38/1 (2016), 87-118.

Wiik 2008 = Wiik, K.: Az európai népek eredete. Ford. Kádár Gy. Budapest, 2008.

Williams 2006 = Williams, M. H.: The Monk and the Book. Jerome and the Making of Christian Scholarship. Chicago, 2006.

Williams 2017 = Williams, S.: The Politics of Heresy in Ambrose of Milan. Community and Consensus in Late Antique Christianity. Cambridge, 2017.

Williams - Friell 2014 = Williams, S. - Friell, G.: The Rome That Did Not Fall. The Survival of the East in the Fifth Century. New York, 2014.

Wolf 1999 = Wolf, K. B. (ed. and transl.): Conquerors and Chroniclers of Early Medieval Spain. Liverpool, 1999.

Wolfram 1988 = Wolfram, H.: History of the Goths. California, 1988.

Wolfram 1990 = Wolfram, H.: Die Goten. Von den Anfängen bis zur Mitte des sechsten Jahrhunderts. Entwurf einer historischen Ethnographie. München, 1990.

Wolfram 1997 = Wolfram, H.: The Roman Empire and Its Germanic Peoples. Berkeley, 1997.

Wood $2005=$ Wood, I. N.: Christianisation and the Dissemination of Christian Teaching. In: The New Cambridge Medieval History. Vol. 1: c. 500-c. 700. Ed. P. Fouracre. Cambridge, 2005, 710-734.

Wood 2007a $=$ Wood, I. N.: The Barbarian Invasions and First Settlements. In: The Cambridge Ancient History. Vol. 13: The Late Empire, AD 337-425. Eds. A. Cameron - P. Garnsey. Cambridge, 2007, 516-537.

Wood 2007b $=$ Wood, I. N.: The North-Western Provinces. In: The Cambridge Ancient History. Vol. 14: Late Antiquity: Empire and Successors, AD 425-600. Eds. A. Cameron - B. Ward-Perkins - M. Whitby. Cambridge, 2007, 497-524.

Wood 2013 = Wood, I. N.: The Modern Origins of the Early Middle Ages. Oxford, 2013. 
Woods 2009 = Woods, D.: Late Antique Historiography: A Brief History of Time. In: $A$ Companion to Late Antiquity. Ed. P. Rousseau. Oxford, 2009, 357-372.

Wright 2003 = Wright, C. D.: The Apocalypse of Thomas: Some New Latin Texts and their Significance for the Old English Versions. In: Apocryphal Texts and Traditions in Anglo-Saxon England. Eds. K. Powell - D. Scragg. Cambridge, 2003, $27-64$.

Ziegler 1972 = Ziegler, K. H.: Das Völkerrecht der Römischen Republik. ANRW 1,2, 1972, 68-114.

Zimmermann 2002 = Zimmermann, H.: A középkori pápaság. A középkori pápák története a historiográfia tükrében. Ford. Bagi D. Budapest, 2002.

Zsinka 2012 = Zsinka L.: A latin keresztény Európa születése. Grotius-tanulmányok. Budapest, 2012, 1-30. 